\title{
SOLUÇÃO CONSENSUAL DE CONFLITOS SANITÁRIOS NA ESFERA ADMINISTRATIVA
}

\author{
Dissertação de Mestrado
}

Orientador: Professor Doutor Thiago Marrara de Matos

FACULDADE DE DIREITO DA UNIVERSIDADE DE SÃO PAULO SÃO PAULO 
UNIVERSIDADE DE SÃO PAULO

FACULDADE DE DIREITO

\section{SOLUÇÃO CONSENSUAL DE CONFLITOS SANITÁRIOS NA ESFERA ADMINISTRATIVA}

\section{NATALIA PASQUINI MORETTI}

Dissertação apresentada à Banca Examinadora da Faculdade de Direito da Universidade de São Paulo, como exigência para obtenção do título de Mestre em Direito, sob a orientação do Professor Doutor Thiago Marrara de Matos. 


\section{FOLHA DE AVALIAÇÃO}

Natalia Pasquini Moretti

Dissertação apresentada à Faculdade de Direito da Universidade de São Paulo para obtenção do título de Mestre em Direito Área de Concentração: Direito do Estado

\section{Banca Examinadora}

Professor Dr.:

Instituição: Assinatura:

Professor Dr.:

Instituição: Assinatura:

Professor Dr.:

Instituição: Assinatura: 


\section{AGRADECIMENTOS}

O encerramento desta dissertação marca o fim de parte de um projeto de vida, construído diariamente ao longo de três anos, no curso do qual várias pessoas estiveram ao meu lado, mostrando-se de notável importância. A elas, não poderia deixar de prestar os meus sinceros agradecimentos.

Ao Professor Doutor Thiago Marrara de Matos, pelo privilégio de ser sua orientanda, por toda confiança em mim depositada e, principalmente, por contribuir para o amadurecimento das ideias que nortearam a elaboração deste trabalho, cumprindo de forma brilhante o seu papel de orientador.

Aos professores do Programa de Pós-graduação em Direito da Faculdade de Direito da Universidade de São Paulo, em especial àqueles com quem tive contato nas disciplinas do curso de mestrado, agradeço os valiosos ensinamentos transmitidos: Professora Maria Sylvia Zanella Di Pietro, Professora Odete Medauar, Professor Doutor Fernando Dias Menezes de Almeida, Professor Doutor Gustavo Henrique Justino de Oliveira e Professor Doutor Floriano de Azevedo Marques Neto.

À Professora Pós-Doutora e Livre-Docente em Saúde Pública pela Universidade de São Paulo Sueli Gandolfi Dallari e ao Professor Doutor Fernando Mussa Abujamra Aith, do Departamento de Medicina Preventiva da Faculdade de Medicina da Universidade de São Paulo, que me permitiram ter uma visão mais profunda sobre a importância da “democracia sanitária” para a construção de uma sociedade mais justa e fraterna.

Agradeço com todo meu amor à minha mãe, Elaine Silvia Pasquini, ao meu pai, Luiz Augusto Moretti, ao meu irmão, Sandro Pasquini Moretti e à minha cunhada, Fabiana Fernandes Pera Moretti e aos meus avós Olga Pasquini e Agenor Volpini, que mesmo sem entenderem ao certo as minhas escolhas, sempre me apoiaram em todos os meus objetivos.

Agradeço, especialmente, ao meu noivo, Eduardo Prozzi Honorato, que acompanhou de perto a elaboração deste trabalho, me apoiando em todos os momentos, com imenso carinho. $\mathrm{O}$ amor que compartilhamos me fortalece e me encoraja para novos projetos em comum.

Aos meus colegas de ingresso no mestrado: Fernando Moreno Machado, Bruno Cunha, Gabriel Mundim, Thiago Stuchi, que em pouco tempo se transformaram em amigos, agradeço pela colaboração mútua e convívio durante o período de pesquisa, nas 
aulas e, especialmente, nos Seminários de Pesquisa em Direito Administrativo, realizados anualmente em Ribeirão Preto, desde 2011.

Aos meus primos Fernanda Moré e Marcelo Telichevsky Ferreira pela alegria e pelo presente que me proporcionaram com a chegada da Joana e, agora, do Henrique.

À querida amiga Juliana Finardi Pires, pela cuidadosa revisão do texto.

Às queridas amigas Carolina de Campos Gonzaga, Mariuscha Karen Caixeta, Silvia Follain, Maria Araújo, Cibele Bordin, Lúcia da Silva Medeiros, Jane Eire de Souza Lopes e Roberta Silva de Carvalho, pela motivação.

Ao caro amigo e Advogado da União Luiz Carlos de Freitas, com quem tive a oportunidade de trabalhar em parceria na Procuradoria Regional da União da $3^{\text {a }}$ Região, nesse período, agradeço o convívio e o grande incentivo para o desenvolvimento das atividades de pesquisa.

Aos demais colegas da Procuradoria Regional da União da $3^{\text {a }}$ Região que me apoiaram e incentivaram durante o período de pesquisa e redação do trabalho, em especial, Marco Antônio Perez de Oliveira, Patrícia Torres Barreto Costa Carvalho; Juliana Lopes da Cruz, Nilma de Castro Abe, Luiz Fabrício Thaumaturgo Vergueiro, Homero Andretta Júnior, Tércio Issami Tokano, Gustavo Henrique Pinheiro de Amorim e Kaoru Ogata.

Agradeço à Escola da Advocacia-Geral da União, por incentivar o aprimoramento e a capacitação pessoal de seus membros colaborando, assim, para a conclusão deste trabalho.

A todos, muito obrigada. 


\section{RESUMO}

Este trabalho tem por objeto examinar a atuação administrativa consensual, com enfoque na solução de conflitos sobre prestações materiais de saúde na esfera administrativa. A Constituição Federal de 1988 reconhece expressamente a saúde como direito fundamental de todos e determina ser dever do Estado garanti-lo, mediante políticas sociais e econômicas que visem à promoção, proteção e recuperação da saúde. Para alcançar os fins estatuídos pelo constituinte, diversas políticas públicas têm sido elaboradas e executadas. Porém, tendo em vista que grande parte da população não tem acesso às ações e serviços de saúde, o trabalho se propõe a indicar possíveis alternativas para enfrentar esta problemática brasileira. Para construir uma concepção dogmática adequada à compreensão do direito à saúde e de suas repercussões jurídicas, a dissertação analisa a teoria dos direitos fundamentais, explicitando as variadas funções que o direito à saúde pode exercer conforme o caso concreto. A função positiva do direito à saúde é destacada neste estudo, sobretudo, sua importância no Estado Social na promoção da igualdade material. Na sequência, o trabalho se dedica ao estudo do Sistema Único de Saúde (SUS), com base na estrutura delineada pela Constituição para conduzir a elaboração e a execução de políticas sanitárias. Em seguida, o tema da participação popular na Administração Pública é examinado como vetor do caráter Democrático do Estado, analisando seus pressupostos, instrumentos e, ainda, suas formas de expressão no âmbito do Sistema Único de Saúde (SUS). Por fim, o texto explora o modelo de Administração consensual no Brasil, especialmente no tocante à atividade de dirimir controvérsias na via administrativa, buscando identificar se, e em quais casos, esta atuação configura um autêntico módulo convencional. Feito o recorte temático proposto como linha de pesquisa, o trabalho examina instrumentos pró-consensuais institucionalizados para a solução de conflitos em matéria de saúde na via administrativa, apontando caminhos voltados à realização do direito fundamental à saúde e aos objetivos do Estado previstos na Constituição Federal.

Palavras-chave: direito fundamental à saúde; políticas públicas; participação popular na Administração Pública; Sistema Único de Saúde (SUS); soluções consensuais. 


\begin{abstract}
This essay intends to examine the consensual administrative action, approaching to the conflict resolution regarding to medical supplies as well as healthcare services in the administrative process. The Federal Constitution of 1988 expressly recognizes health as a fundamental right and State's guarantee duty, through social and economic policies, which has the propose of health promotion, protection and recovery. In order to realize the constitutional aims, a lot of public policies have been developed and implemented. However, considering that great amount of the population does not have access to healthcare actions and services, the study has the purpose of identifying possible alternatives to deal with this Brazilian issue. In order to develop an appropriate dogmatic understanding related to right to health and its legal repercussions, this essay analyzes the fundamental rights theory, explaining the various right to health functions that could be used according to the case. The right to health's positive function is highlighted in this essay, mainly, its importance to the Social State regarding to substantive equality promotion. Afterwards, this essay studies the Brazilian healthcare system (so-called Sistema Único de Saúde, or simply SUS), based on the structure outlined by the Constitution related to development and performance of public health policies. Then, the public participation theme in Public Administration is analyzed as a Democratic State conductor, going through its assumptions, instruments, and also its way of expression in the Brazilian healthcare system (SUS). Finally, the study explores the Brazilian consensual administrative model, especially in relation to conflict resolution activity in the administrative process, with the view to identify if, and in which cases, this action consist on a genuine conventional mechanism. In the conclusion, the analyze focuses on institutional mechanisms in favor of conflicts resolution by consensus regarding to heath in the administrative process, pointing out possible ways which conduces to right of heath effectiveness and achievements related to the objectives stated in the Federal Constitution.
\end{abstract}

Keywords: fundamental right to health, public policies; public participation in Public Administration; Brazilian healthcare system (SUS); consensual resolutions. 


\section{SUMÁRIO}

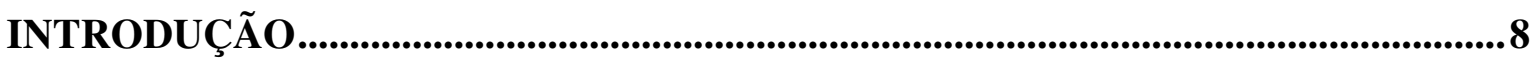

CAPÍTULO 1 - O DIRIEITO À SAÚDE...............................................................................20

1.1. A SAÚdE COMO OBJETO DE CONHECIMENTO do DiREITO SANITÁRIO.........................20

1.2. FUNDAMENTAÇÃO JURÍDICO-POLÍTICA DOS DIREITOS SOCIAIS E DO DIREITO À SAÚDE

1.3. A SAÚdE NO BRASIL ANTES DA CONSTITUIÇÃO FEDERAL DE 1988 E AS ORIGENS DO

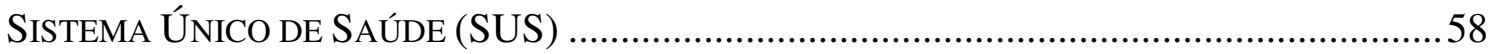

CAPÍTULO 2 - O DIREITO À SAÚDE NA CONSTITUIÇÃO FEDERAL DE 1988...

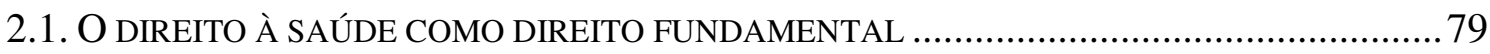

2.2. O DiREITO À SAÚdE NA CONSTITUIÇÃo FEDERAL DE 1988 ........................................93

2.3. COMPETÊNCIAS CONSTITUCIONAIS EM MATÉRIA DE SAÚDE .................................... 114

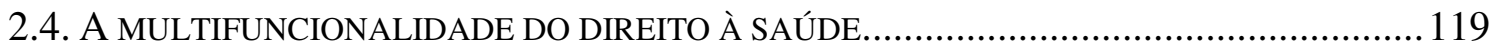

2.5. EFICÁCIA E EFETIVIDADE NO DIREITO À SAÚDE ........................................................ 139

2.5.1. Teoria do mínimo existencial ............................................................................ 150

2.5.2. Restrições ao direito à saúde ........................................................................ 162

CAPÍTULO 3 - O SISTEMA ÚNICO DE SAÚdE E AS POLÍTICAS PÚBLICAS DE

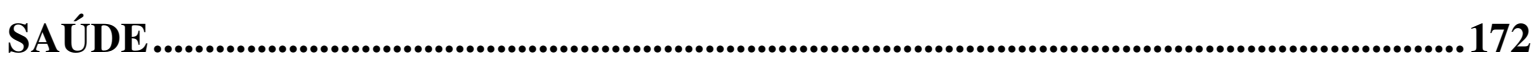

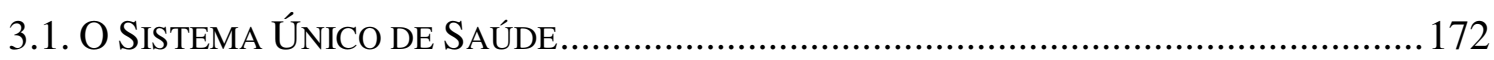

3.1.1. Organização e funcionamento (Lei n. 8.080/90 e Lei n. 8.142/90) ................. 172

3.1.2. Objetivos e Princípios..................................................................................... 188

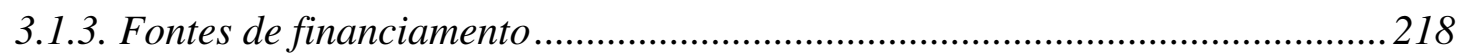

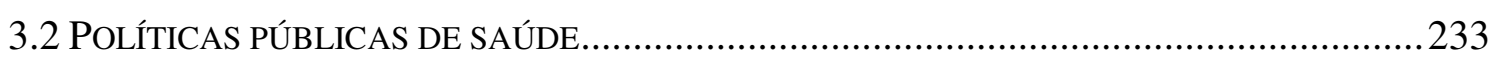

\section{CAPÍTULO 4 - PARTICIPAÇÃO POPULAR NA ADMINISTRAÇÃO PÚBLICA}

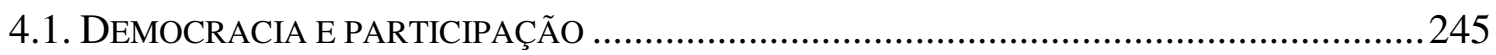

4.2. INSTRUMENTOS DE PARTICIPAÇÃO POPULAR NA ADMINISTRAÇÃO PÚBLICA.............259

4.3. PRESSUPOSTOS DA PARTICIPAÇÃO POPULAR NA AdMINISTRAÇÃO PÚBliCA .............285 
4.3.1. Educação

4.3.2. Acesso à informação.

4.3.3. Processo administrativo conforme os princípios do Estado Democrático de Direito 299

4.4. PARTICIPAÇÃo POPUlAR NO SiSTEMA ÚNICO DE SAÚdE (SUS). 308

\section{CAPÍTULO 5 - SOLUÇÃO CONSENSUAL DE CONFLITOS SANITÁRIOS NA} ESFERA ADMINISTRATIVA

5.1. A ADMINISTRAÇÃO PÚBLICA BELICOSA E O PROCESSO ADMINISTRATIVO COMO INSTRUMENTO PACIFICADOR DE CONFLITOS.

5.2. OS MÓDULOS CONVENCIONAIS E A IMPLEMENTAÇÃO DO DIREITO FUNDAMENTAL À SAÚDE

5.3. MECANISMOS DE SOLUÇÃO CONSENSUAL DE CONFLITOS RELATIVOS AO DIREITO À SAÚDE NA ESFERA ADMINISTRATIVA.

5.3.1. Os instrumentos pró-consensuais procedimentais instituídos pela Coordenação das Demandas Estratégicas do SUS (CODES), da Secretaria de Estado da Saúde de São Paulo (SES/SP), e pela Procuradoria Geral do Estado de São Paulo (PGE/SP)

5.3.2. Os instrumentos pró-consensuais procedimentais instituídos pela Secretaria de Estado da Saúde de São Paulo (SES/SP) e pelos Juizados Especiais da Fazenda Pública (JEFAZ).

5.3.3. Os instrumentos pró-consensuais procedimentais instituídos pelo Comitê Interinstitucional de Resolução Administrativa de Demandas da Saúde (CIRADS)..

5.4. A COMPLEMENTARIEDADE DO MODELO DE ADMINISTRAÇÃO CONSENSUAL.

AS VIRTUDES E OS RISCOS DESTE MODELO

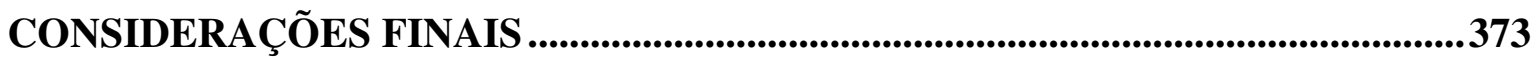

REFERÊNCIAS BIBLIOGRÁFICAS.........................................................................387

ANEXOS .404 


\section{INTRODUÇÃO}

A saúde é um bem jurídico fundado na dignidade da pessoa humana e indissociavelmente ligado à vida, o bem jurídico mais importante que existe. $\mathrm{O}$ conceito amplo formulado na Constituição da Organização Mundial de Saúde consagra que "a saúde é um estado de completo bem-estar físico, mental e social, e não somente a ausência de doenças ou enfermidades".

O processo de afirmação histórica dos Direitos Humanos trouxe relevantes avanços para a humanidade, particularmente o fortalecimento da noção de Estado de Direito e da garantia dos direitos fundamentais. Com a Declaração Universal dos Direitos Humanos, de 1948, por consenso geral, a saúde foi reconhecida como um valor essencial às pessoas, merecendo um tratamento especial do sistema normativo.

No Brasil, somente a partir da promulgação da Constituição Federal de 1988 a saúde foi afirmada como um direito fundamental social, como se infere da leitura do artigo $6^{\circ}$. O regime jurídico-constitucional do direito à saúde assegura a aplicabilidade imediata da norma, fundada no disposto no artigo $5^{\circ}$, parágrafo $1^{\circ}$, da Constituição Federal. Ademais, o direito fundamental à saúde é dotado de eficácia normativa reforçada, constituindo limitação material ao exercício do poder de reforma constitucional (artigo 60, parágrafo $4^{\circ}$, inciso IV).

Embora a saúde tenha sido consagrada na Constituição Federal como direito fundamental, gerando, assim, a legítima pretensão em face do Estado quanto à sua efetividade, é certo que grande parte da população brasileira está alijada do exercício de tal direito. O resultado da pesquisa realizada pela Confederação Nacional da Indústria (CNI) e pelo Instituto Brasileiro de Opinião Pública e Estatística (IBOPE) ${ }^{1}$, publicada em janeiro de $2012^{2}$, demonstra que os fundamentos da República Federativa do Brasil ${ }^{3}$ e seus principais objetivos ${ }^{4}$ estão dissociados da triste realidade da saúde pública brasileira. ${ }^{5}$

\footnotetext{
${ }^{1}$ Pesquisa CNI - IBOPE: retratos da sociedade brasileira: saúde pública. Brasília: CNI, 2012.

2 A pesquisa "Retratos da Sociedade Brasileira: saúde pública", consta na íntegra como anexo I a esta dissertação. Suas especificações técnicas são as seguintes: o período de campo compreendeu os dias 16 a 20 de setembro de 2011; foi realizada com eleitores de 16 (dezesseis) anos ou mais da área em estudo; o universo de eleitores foi estratificado, sendo cada um dos estratos composto por um Estado-membro da Federação, exceto os estados do Acre, Amapá e Roraima, que juntos compõem apenas um estrato; nos casos em que o Estado possui Região Metropolitana, seu universo foi estratificado em Região Metropolitana e Interior; o modelo de amostragem utilizado foi o de conglomerados em 3 (três) estágios; foram realizadas 2200 (duas mil e duzentas) entrevistas pessoais, com utilização de questionário elaborado conforme os
} 
Os principais dados dessa pesquisa indicam que, numa análise geral, a população brasileira reprova as ações e serviços públicos de saúde ${ }^{6}: 61 \%$ (sessenta e um por cento) dos entrevistados consideram o serviço público de saúde no país "péssimo" ou "ruim",; $54 \%$ (cinquenta e quatro por cento), consideram o serviço público de saúde de sua cidade "péssimo" ou "ruim" 8 ; $85 \%$ (oitenta e cinco por cento), não perceberam avanços no sistema público de saúde no país nos últimos três anos ${ }^{9}$; e $95 \%$ (noventa e cinco por cento), reconhecem ser necessário destinar mais recursos para a saúde. ${ }^{10}$

objetivos da pesquisa, em 141 (cento e quarenta e um) Municípios; o intervalo de confiança estimado é de 95\% (noventa e cinco por cento) e a margem de erro máxima estimada é de 2 (dois) pontos percentuais para mais ou para menos sobre os resultados encontrados no total da amostra; e houve controle de qualidade nos questionários. Pesquisa CNI - IBOPE: retratos da sociedade brasileira: saúde pública. Brasília: CNI, 2012, p.66-67.

${ }^{3}$ Nos termos do artigo $1^{\circ}$ da Constituição Federal de 1988, incisos II e III, a República Federativa do Brasil, constituída como Estado Democrático de Direito, tem como fundamentos, dentre outros, a cidadania e a dignidade da pessoa humana, in verbis: "Art. $1^{\circ}$ A República Federativa do Brasil, formada pela união indissolúvel dos Estados e Municípios e do Distrito Federal, constitui-se em Estado Democrático de Direito e tem como fundamentos: I - a soberania; II - a cidadania; III - a dignidade da pessoa humana; IV - os valores sociais do trabalho e da livre iniciativa; V - o pluralismo político."

${ }^{4} \mathrm{O}$ artigo $3^{\circ}$ da Constituição Federal prescreve o seguinte: "Art. $3^{\circ}$ Constituem objetivos fundamentais da República Federativa do Brasil: I - construir uma sociedade livre, justa e solidária; II - garantir o desenvolvimento nacional; III - erradicar a pobreza e a marginalização e reduzir as desigualdades sociais e regionais; IV - promover o bem de todos, sem preconceitos de origem, raça, sexo, cor, idade e quaisquer outras formas de discriminação."

${ }^{5}$ Esta pesquisa indica que um em cada três trabalhadores, nos últimos 12 (doze) meses, perdeu pelo menos um dia de trabalho por motivos relacionados à saúde e, no mesmo período, 7\% (sete por cento) dos trabalhadores perderam pelo menos um dia de trabalho devido a acidente de trabalho. Entre os entrevistados, 67\% (sessenta e sete por cento) têm ou tiveram um trabalho remunerado nos últimos 12 (doze) meses. Dentre esses, $35 \%$ (trinta e cinco por cento) perderam pelo menos um dia de trabalho no último ano por razões de saúde. Quanto aos últimos 30 (dias), a pesquisa demonstra que 14\% (quatorze por cento) dos trabalhadores deixaram de realizar suas atividades laborais devido a algum problema relacionado à sua saúde. Pesquisa CNI - IBOPE: retratos da sociedade brasileira: saúde pública. Brasília: CNI, 2012, p.12 e 39-41.

${ }^{6}$ Apesar disso, $48 \%$ (quarenta e oito por cento) dos brasileiros que utilizaram serviço na rede pública de saúde nos últimos 12 (doze) meses consideraram-no "ótimo" ou "bom", enquanto para $22 \%$ (vinte e dois por cento) foi "ruim" ou "péssimo". A mesma pesquisa revelou que os serviços privados de saúde receberam melhor avaliação. Para os entrevistados que utilizaram algum serviço de saúde na rede privada para si próprio, nos últimos 12 (doze) meses, 63\% (sessenta e três por cento) consideraram o atendimento "ótimo" ou "bom" e $16 \%$ julgaram-no como "péssimo" ou "ruim". Pesquisa CNI - IBOPE: retratos da sociedade brasileira: saúde pública. Brasília: CNI, 2012, p. 10 e 23.

${ }^{7}$ Sobre a qualidade do sistema público de saúde no Brasil, apenas $1 \%$ (um por cento) da população a avalia como "ótima", $9 \%$ (nove por cento) como "boa", $28 \%$ (vinte e oito por cento) a avalia como regular, $22 \%$ (vinte e dois por cento) como ruim e 39\% (trinta e nove por cento) a considera péssima. Pesquisa CNI IBOPE: retratos da sociedade brasileira: saúde pública. Brasília: CNI, 2012, p. 13.

${ }^{8}$ A avaliação da evolução do sistema público de saúde na cidade dos entrevistados, nos últimos três anos, varia conforme a região em que residem. Enquanto na Região Sul do país 26\% (vinte e seis por cento) dos entrevistados considera que a qualidade do sistema de saúde melhorou, na Região Nordeste $48 \%$ (quarenta e oito por cento) acredita que a qualidade do sistema público de saúde se agravou neste período. O sistema público é considerado pior pelos residentes nos municípios com mais de 100 (cem) mil habitantes ou nas capitais, em comparação com os residentes de municípios menores ou no interior. Pesquisa CNI - IBOPE: retratos da sociedade brasileira: saúde pública. Brasília: CNI, 2012, p. 13-15.

${ }^{9}$ Este percentual resulta da soma de $42 \%$ (quarenta e dois por cento) dos entrevistados, para os quais não houve mudança no sistema público de saúde brasileiro, e de $43 \%$ (quarenta e três por cento) dos entrevistados 
A gravidade deste quadro é ainda maior se levarmos em conta que $73 \%$ (setenta e três por cento $)^{11}$ da população brasileira ${ }^{12}$ dependem exclusivamente das ações e serviços fornecidos pelo Sistema Único de Saúde. ${ }^{13}$ Tendo em consideração a última estatística apresentada pelo Instituto Brasileiro de Geografia e Estatística, são aproximadamente 141 milhões de brasileiros que necessitam da rede pública para a proteção, a promoção e a recuperação de sua saúde ${ }^{14}$ e não conseguem receber atendimento médico ou hospitalar com boa qualidade e em tempo razoável. ${ }^{15}$

que consideram ter se agravado a situação do serviço público de saúde no Brasil nos últimos 3 (três) anos. Apenas $14 \%$ (quatorze por cento) dos entrevistados acreditam que o sistema público de saúde no país se tornou melhor nos últimos três anos. Pesquisa CNI - IBOPE: retratos da sociedade brasileira: saúde pública. Brasília: CNI, 2012, p. 9, 14 e 22.

${ }^{10}$ Pesquisa CNI - IBOPE: retratos da sociedade brasileira: saúde pública. Brasília: CNI, 2012. p. 9-11.

${ }^{11}$ Os dados levantados pela Confederação Nacional da Indústria (CNI) e pelo Instituto Brasileiro de Opinião Pública e Estatística (IBOPE) indicam que apenas $27 \%$ da população brasileira têm planos de saúde. O percentual de pessoas que contratam plano de saúde ou convênio é maior na medida em que aumenta a renda familiar. Das famílias com renda até um salário mínimo, apenas 7\% (sete por cento) dos entrevistados têm plano de saúde ou convênio. Para o grupo em que a renda familiar é de cinco a dez salários mínimos, este percentual passa para $52 \%$ (cinquenta e dois por cento) e alcança $83 \%$ (oitenta e três por cento) dos entrevistados cuja renda familiar supera a 10 (dez) salários mínimos. Pesquisa CNI - IBOPE: retratos da sociedade brasileira: saúde pública. Brasília: CNI, 2012, p.14 e 17.

${ }^{12}$ Segundo pesquisa realizada pelo Instituto Brasileiro de Geografia e Estatística (IBGE) publicada no dia 31/08/2012 no Diário Oficial da União e encaminhada para o Tribunal de Contas da União, a população residente no Brasil foi estimada em 193.946.886 (cento e noventa e três milhões novecentos e quarenta e seis mil oitocentos e oitenta e seis), tendo como referência $1^{\circ}$ de julho de 2012. Disponível no site do IBGE na Internet: <http://www.ibge.gov.br/>. Consulta em 23/03/2013.

${ }^{13}$ Das pessoas entrevistadas que têm plano de saúde, apenas $1 \%$ (um por cento) utiliza somente ou principalmente o serviço público, ao passo que $91 \%$ (noventa e um por cento) utilizam somente ou principalmente o serviço privado. A rede privada é utilizada de forma exclusiva por apenas $10 \%$ (dez por cento) dos entrevistados. De acordo com esta pesquisa, $62 \%$ (sessenta e dois por cento) dos entrevistados avaliam os hospitais privados incontestavelmente melhores do que os públicos e $86 \%$ (oitenta e seis por cento) dos entrevistados concordam, ainda que parcialmente, com esta afirmativa. Considerando apenas os entrevistados que utilizaram hospital público e/ou privado nos últimos 12 (doze) meses, a nota média atribuída aos hospitais públicos é de 5,7 (cinco inteiros e sete décimos) enquanto que a dos hospitais privados é de 8,1 (oito inteiros e um décimo). Os entrevistados atribuíram notas de 0 (zero) a 10 (dez) a onze itens dos hospitais públicos e privados, quais sejam: material hospitalar e medicamentos; condição de limpeza/manutenção; roupas, toalhas e roupa de cama, facilidade de acesso ao hospital; segurança; disponibilidade de medicamentos; relação do hospital com os pacientes/parentes; infraestrutura e equipamentos médicos; alimentação oferecida; tempo médio para a realização de exames; e tempo de espera para atendimento/internação. Dos entrevistados que utilizam apenas o serviço privado, 97\% (noventa e sete por cento) possuem plano de saúde ou convênio. Pesquisa CNI - IBOPE: retratos da sociedade brasileira: saúde pública. Brasília: CNI, 2012, p. 9, 18, 24-26 e 35.

${ }^{14}$ Os dados são semelhantes às informações colhidas pela Agência Nacional de Saúde Suplementar (ANS) em 2012, de que apenas quarenta e oito milhões seiscentos e sessenta mil brasileiros têm acesso a plano de assistência médico-hospitalar. Beneficiários de planos de saúde mais conscientes de seus direitos. Disponível em: <http://www.ans.gov.br>. Consulta em 02 de março de 2013.

15 Dentre os problemas do sistema público de saúde, para 55\% (cinquenta e cinco por cento) dos entrevistados, o principal consiste na dificuldade de conseguir atendimento médico. $\mathrm{O}$ tempo de espera para marcar a consulta ou o exame, ou para sua realização é o motivo de maior reclamação dos brasileiros quanto à saúde pública de sua cidade. Em seguida, $10 \%$ (dez por cento) dos entrevistados indicam a falta equipamentos e investimentos na rede pública de saúde e $9 \%$ (nove por cento) se queixam da falta de 
Em relação ao acesso às ações e serviços de saúde, as principais iniciativas sugeridas pela população para melhorar os serviços de saúde na rede pública são: o aumento do número de médicos ${ }^{16} 17$ e o aperfeiçoamento da infraestrutura das unidades de saúde, mencionados por $57 \%$ (cinquenta e sete por cento) e por $54 \%$ (cinquenta e quatro por cento) dos entrevistados, respectivamente. ${ }^{18}$

É verdade que a avaliação dos serviços públicos de saúde não é negativa em todos os aspectos ${ }^{19}$. O resultado da avaliação dos entrevistados que conheciam as ações e os

médicos. Pesquisa CNI - IBOPE: retratos da sociedade brasileira: saúde pública. Brasília: CNI, 2012, p.10 e 29-30.

${ }^{16}$ Conforme a pesquisa Demografia Médica no Brasil, publicada em fevereiro de 2013 pelo Conselho Federal de Medicina, enquanto em 1970 havia apenas 58.994 (cinquenta e oito mil novecentos e noventa e quatro) médicos em atividade no Brasil, o número de registros em outubro de 2012 atingiu 388.015 (trezentos e oitenta e oito mil e quinze). O expressivo crescimento da categoria de 1970 a 2012 foi de $557,72 \%$ (quinhentos e cinquenta e sete inteiros e setenta e dois décimos por cento), ao passo que a população brasileira cresceu apenas $101,84 \%$ (cento e um inteiros e oitenta e quatro décimos por cento), totalizando 193.867.971 habitantes. O atual número de médicos em atividade no Brasil se aproxima de 400.00 (quatrocentos mil) e alcança a razão de 2 (dois) médicos por grupo de 1.000 (mil) habitantes, um aumento de $73,92 \%$ (setenta e três inteiros e noventa e dois décimos por cento) em relação a 1980, quando esta proporção era de 1,15 (um inteiro e quinze décimos). Contudo, a distribuição geográfica de médicos registrados no país é bastante desigual se considerarmos as regiões do país, os Estados, suas capitais e as demais cidades. Enquanto nas Regiões Norte e Nordeste o índice de médico por mil habitantes equivale praticamente à metade da média nacional (de 1,01 e de 1,2, respectivamente), na Região Sudeste o índice é de 2,67 (dois inteiros e sessenta e sete décimos), na Região Sul é de 2,09 (dois inteiros e nove décimos), e na Região Centro-Oeste é de 2,05 (dois inteiros e cinco décimos). Com base no cadastrado do Cadastro Nacional de Estabelecimentos de Saúde (CNES) há 287.693 (duzentos e oitenta e sete mil seiscentos e noventa e três) médicos cadastrados, enquanto que o número de médicos registrados no Conselho Federal de Medicina é de 388.015 (trezentos e oitenta e oito mil e quinze). A diferença está relacionada às inconsistências daquele cadastro, sobretudo em relação ao setor privado, e com o fato de que parte dos médicos não atua em estabelecimentos de saúde, mas em universidades, na indústria farmacêutica, na promoção da saúde, em setores administrativos, dentre outros. Dos 287.693 médicos cadastrados no CNES, 215.640 médicos atuam no Sistema Único de Saúde, em serviços públicos municipais, estaduais e federais, o que representa $55,50 \%$ (cinquenta e cinco inteiros e cinquenta décimos por cento) do total de 388.015 médicos ativos registrados no CONSELHO FEDERAL DE MEDICINA. Demografia Médica no Brasil: cenários e indicadores de distribuição, v. 2. SCHEFFER, Mário (coordenador). CASSENOTE, Alex; BIANCARELLI, Aureliano (pesquisadores). São Paulo: Conselho Regional de Medicina do Estado de São Paulo, 2013.

${ }_{17}$ A Constituição Federal proíbe, como regra, a acumulação remunerada de cargos públicos (CF, art. 37, XVI). Porém, excepcionalmente, se houver compatibilidade de horários, dentre outros, permite a cumulatividade de dois cargos ou empregos privativos de profissionais de saúde, com profissões regulamentadas, assim entendidos os médicos, enfermeiros e auxiliares de enfermagem. (CF, art. 37, inciso XVI, alínea "c"). A finalidade dessa norma constitucional é contribuir para que seja suprida a carência de profissionais que prestam serviços na área da saúde pública, viabilizando que sejam desempenhadas atribuições relativas a mais de um cargo, in verbis: "Art. 37. A administração pública direta e indireta de qualquer dos Poderes da União, dos Estados, do Distrito Federal e dos Municípios obedecerá aos princípios de legalidade, impessoalidade, moralidade, publicidade e eficiência e, também, ao seguinte: (...) XVI - é vedada a acumulação remunerada de cargos públicos, exceto, quando houver compatibilidade de horários, observado em qualquer caso o disposto no inciso XI: (...) c) a de dois cargos ou empregos privativos de profissionais de saúde, com profissões regulamentadas"

${ }^{18}$ Pesquisa CNI- IBOPE: retratos da sociedade brasileira: saúde pública. Brasília: CNI, 2012, p.11 e 32.

${ }^{19}$ A pesquisa em análise demonstra que a maioria da população aprova a qualidade dos medicamentos genéricos, visto que 54\% (cinquenta e quatro por cento) dos entrevistados concordam totalmente que o medicamento genérico é tão bom quanto o medicamento de marca e $28 \%$ (vinte e oito por cento) concordam 
programas de governo foi satisfatório, visto que receberam, em média, a nota 6,6 (seis inteiros e seis décimos), em uma escala de 0 (zero) a $10(\mathrm{dez}){ }^{20} \mathrm{O}$ programa relativo à Campanha de Vacinação foi o melhor avaliado pela população, com nota média de 8,8 (oito inteiros e oito décimos). Por sua vez, o programa Brasil unido contra a dengue ${ }^{21}$ recebeu nota 7,9 (sete inteiros e nove décimos). Ao programa Farmácia Popular ${ }^{22}$ foi atribuída nota 7,4 (sete inteiros e quatro décimos). O Serviço de Atendimento Móvel de Urgência (SAMU 192) ${ }^{23}$ recebeu nota 7,2 (sete inteiros e dois décimos). Ao Programa

em parte com essa afirmação. Pesquisa CNI - IBOPE: retratos da sociedade brasileira: saúde pública. Brasília: CNI, 2012, p. 37.

${ }^{20}$ Dos seis programas governamentais apresentados, dois são conhecidos por quase todos os entrevistados: Campanhas de Vacinação e Combate à Dengue. De outro lado, 5\% (cinco por cento) dos entrevistados não quiseram ou não souberam responder sobre a Farmácia Popular, 8\% (oito por cento) não quiseram ou não souberam responder acerca do SAMU 192, 10\% (dez por cento) não quiseram ou não souberam avaliar o Programa Estratégia Saúde da Família e 16\% (dezesseis por cento) não souberam ou não quiseram atribuir uma nota à UPA 24h. Pesquisa CNI - IBOPE: retratos da sociedade brasileira: saúde pública. Brasília: CNI, 2012, p. 16.

${ }^{21} \mathrm{O}$ combate à dengue foi instituído como programa em razão da gravidade desta moléstia no campo da saúde pública mundial. O Ministério da Saúde apresentou as Diretrizes Nacionais para Prevenção e Controle da Dengue, visando auxiliar os estados e os municípios na organização de suas atividades de prevenção e controle, contribuindo para evitar a ocorrência de óbitos e reduzir o impacto das epidemias de dengue. O desafio é dar sustentabilidade e continuidade a esses resultados, tendo como meta uma taxa de letalidade por dengue menor que 1\%. A cartilha da saúde de 2012, do Ministério da Saúde, aponta, até a semana epidemiológica 17, uma redução do número de casos de casos de $52 \%$ em 2009, comparado ao mesmo período de 2008. BRASIL. Ministério da Saúde. Secretaria de Vigilância em Saúde. Departamento de Vigilância Epidemiológica. Diretrizes nacionais para prevenção e controle de epidemias de dengue. Brasília: Ministério da Saúde, 2009.

${ }^{22}$ O Programa "farmácia popular" foi criado em 2004 pelo governo federal considerando o dever do Estado de garantir os meios indispensáveis à prevenção, à promoção e à recuperação da saúde, a necessidade de oferecer alternativas de acesso à assistência farmacêutica, com vistas à promoção da integralidade do atendimento à saúde e a meta de assegurar medicamentos essenciais para o tratamento dos agravos com maior incidência na população (hipertensão arterial, diabetes mellitus, contracepção, incontinência, dislipidemia, asma, rinite, osteoporose e glaucoma), mediante redução de seu custo para os pacientes. $\mathrm{O}$ programa possui uma rede própria de Farmácias Populares e parceria com farmácias e drogarias da rede privada, denominada "Aqui tem Farmácia Popular". A Lei no 10.858/2004 autorizou a Fundação Oswaldo Cruz - Fiocruz, a disponibilizar medicamentos, produtos básicos e essenciais à saúde da população a baixo custo, mediante ressarcimento. A finalidade do programa é a diminuição do impacto dos preços dos medicamentos no orçamento familiar a partir do sistema de pagamento conjunto, em que o poder público custeia cerca de $90 \%$ do valor do medicamento e o cidadão arca com o restante. O Decreto $\mathrm{n}^{\circ} 5.090 / 04$ regulamentou e instituiu o programa "Farmácia Popular do Brasil". A Portaria n 971, de 15 de maio de 2012 prevê as normas operacionais do Programa Farmácia Popular do Brasil (PFPB), que disciplinam a instalação de Farmácias Populares em parceria com Estados, Distrito Federal, Municípios e instituições, bem como com a rede privada de farmácias e drogarias. Disponível em: < http://portal.saude.gov.br>. Acesso em 05/02/2013. ${ }^{23} \mathrm{O}$ Serviço de Atendimento Móvel às Urgências integra a Política Nacional de Atenção às Urgências, que deve ser feita em todos os níveis do Sistema Único de Saúde, organizando a assistência desde as unidades básicas, equipes de saúde da família, até os cuidados pós-hospitalares na convalescença, recuperação e reabilitação. O serviço abrange o transporte de pacientes em ambulâncias, Unidades de Suporte Avançado e de Suporte Básico de Vida, orientadas por Centrais de Regulação Médica de Urgência, conforme o caso concreto. A regulamentação infralegal do Serviço de Atendimento Móvel às Urgências é dada pelas Portarias GM n $n^{\circ} 1828$, de 02/09/2004, no 2420, de 09/11/2004, no 1863, de 29/09/2003, no 1864, de 29/09/2003, 2072, de 30/10/2003, 2048, de 05/11/2002 e 2657, de 16/12/2004. BRASIL. Ministério da Saúde. Política Nacional 


\section{Estratégia Saúde da Família ${ }^{24}$ (antigo Programa Saúde da Família) ${ }^{25}$ os entrevistados}

atribuíram nota 7,0 (sete) e, por fim, a UPA 24h (Unidades de Pronto-Atendimento, vinte e quatro horas por dia) foi avaliada com nota 6,6 (seis inteiros e seis décimos). ${ }^{26}$

Por conta de políticas públicas e dos programas acima mencionados, houve sensível diminuição da mortalidade infantil ${ }^{27} 28$ e aumento da expectativa de vida dos brasileiros ${ }^{29}$.

de Atenção às Urgências. Ministério da Saúde. 3 ed. Série E. Legislação de Saúde. Brasília: Editora do Ministério da Saúde, 2006. Disponível em: <http://bvsms.saude.gov.br>. Acesso em 05/02/2013.

${ }^{24}$ Atualmente denominado "Estratégia da Saúde da Família", o Programa Saúde da Família (PSF) no Brasil teve origem com a criação do Programa de Agentes Comunitários de Saúde (PACS) em 1991, como parte do processo de reforma do setor da saúde, desde a promulgação da Constituição de 1988, visando aumentar a acessibilidade ao sistema de saúde e incrementar as ações de prevenção e promoção da saúde. Em 1994, o Ministério da Saúde lançou o PSF como política nacional de atenção primária, com caráter organizativo e substitutivo ao modelo tradicional de assistência baseada em profissionais médicos especialistas focais. $\mathrm{O}$ Programa Saúde da Família consolidou-se como estratégia prioritária para a reorganização da Atenção Básica no Brasil (Portaria $\mathrm{n}^{\circ}$ 648, de 28 de março de 2006), que tem como um de seus fundamentos o acesso universal e contínuo a serviços de saúde de qualidade, reafirmando os princípios básicos do Sistema Único de Saúde: universalização, equidade, descentralização, integralidade e participação da comunidade - mediante o cadastramento e a vinculação dos usuários. Em 2011, a portaria GM nº 2.488/2011 revogou a portaria GM N ${ }^{\circ}$ 648/2006 e demais disposições em contrário ao estabelecer a revisão de diretrizes e normas para a organização da Atenção Básica e aprovar a Política Nacional de Atenção Básica para a Estratégia Saúde da Família (ESF) e para o Programa de Agentes Comunitários de Saúde (PACS). A Estratégia de Saúde da Família visa criar um novo modelo de assistência à saúde, que supere o modelo tradicional, calcado na supervalorização das práticas da assistência curativa por médicos especialistas, em geral nos hospitais, que induz ao excesso de procedimentos tecnológicos e medicamentosos e, sobretudo, na fragmentação do cuidado. A família passa a ser o objeto de atenção no ambiente em que vive, permitindo uma compreensão ampliada do processo saúde/doença. O programa inclui ações de promoção da saúde, prevenção, recuperação, reabilitação de doenças e agravos mais frequentes. No âmbito da reorganização dos serviços de saúde, a estratégia da saúde da família pretende consolidar um novo modelo que valorize as ações de promoção e proteção da saúde, prevenção das doenças e atenção integral. Como consequência de um processo voltado à humanização do Sistema Único de Saúde, o programa tem como ponto positivo a valorização dos aspectos que influenciam a saúde das pessoas fora do ambiente hospitalar. Em dez anos houve expressiva ampliação da cobertura populacional de agentes comunitários de saúde e de equipes de saúde da família. Em 2001, os percentuais da população brasileira atendida eram de 46,6\% e 25,4\%. Em 2010, estes índices passaram para $63,7 \%$ e 53,1\%, respectivamente. Disponível em: <http://dab.saude.gov.br/>. Acesso em 17/07/2012.

${ }^{25}$ Com relação aos agentes comunitários de saúde e agentes de combate às endemias, os parágrafos $4^{\circ} \mathrm{e} 5^{\circ}$ do artigo 198 da Constituição Federal estabelecem o seguinte: "Art. 198. As ações e serviços públicos de saúde integram uma rede regionalizada e hierarquizada e constituem um sistema único, organizado de acordo com as seguintes diretrizes: (...) $\S 4^{\circ}$ Os gestores locais do sistema único de saúde poderão admitir agentes comunitários de saúde e agentes de combate às endemias por meio de processo seletivo público, de acordo com a natureza e complexidade de suas atribuições e requisitos específicos para sua atuação. § $5^{\circ}$ Lei federal disporá sobre o regime jurídico, o piso salarial profissional nacional, as diretrizes para os Planos de Carreira e a regulamentação das atividades de agente comunitário de saúde e agente de combate às endemias, competindo à União, nos termos da lei, prestar assistência financeira complementar aos Estados, ao Distrito Federal e aos Municípios, para o cumprimento do referido piso salarial." Tendo em vista a regulamentação do parágrafo $5^{\circ}$, do artigo 198 , da Constituição Federal, foi editada a Lei $\mathrm{n}^{\circ} 11.350 / 2006$, que disciplina $\mathrm{o}$ regime jurídico e as atividades de Agente Comunitário de Saúde e de Agente de Combate às Endemias.

${ }^{26}$ Pesquisa CNI- IBOPE: retratos da sociedade brasileira: saúde pública. Brasília: CNI, 2012, p. 9 e 16.

${ }^{27}$ O Relatório do Fundo das Nações Unidas para a Infância indica que houve no Brasil uma queda de $73 \%$ (setenta e três por cento) na taxa de mortalidade infantil (crianças de até cinco anos), em apenas duas décadas, índice bem maior do que a média global, que foi de pouco mais de $40 \%$ (quarenta por cento). Em 1990, a taxa de mortalidade infantil no Brasil era de 58 (cinquenta e oito) em cada 1000 (mil) crianças nascidas vivas. Em 2010 o índice passou para 17. Apesar da significativa melhora no quadro, o Brasil ainda 
Aliado a essas mudanças fáticas, também houve significativo progresso normativo com a disciplina do direito à saúde na Constituição Federal de 1988 e na legislação infraconstitucional posteriormente editada.

Porém, quanto vale a saúde dos brasileiros?

O Instituto de Pesquisa Econômica Aplicada (IPEA) apurou que o gasto com a saúde no Brasil era de 1,8\% do Produto Interno Bruto (PIB) em 1995 e passou para 3,77\% do PIB em 2012, o que é pouco se comparado ao nível médio internacional de investimento na área da saúde, que é de aproximadamente $7 \%$ do Produto Interno Bruto (PIB).$^{30} \mathrm{O}$ IPEA também verificou que, enquanto nos países desenvolvidos os cidadãos custeiam um terço dos gastos com a saúde pública, no Brasil os contribuintes pagam $56 \%$ do que se dispende nessa área, situação semelhante apenas a de trinta dos cento e noventa e três países-membros da Organização das Nações Unidas ${ }^{31}$.

deve adotar estratégias para diminuir a mortalidade infantil. O Brasil está na $107^{\text {a }}$ posição na tabela mundial acerca de morte de crianças. Nas Américas, Cuba e Canadá apresentam o melhor índice, com apenas 6 mortes por mil crianças nascidas vivas. No ranking mundial, Cingapura, Eslovênia, Suécia e Finlândia apresentam os menores números de mortalidade infantil (menos de 3 por mil crianças nascidas vivas). Nas Américas, Haiti (70 por mil) e Bolívia (51 por mil) apresentam o maior índice de mortalidade infantil, enquanto Serra Leoa, Somália, Mali e Chade possuem os piores índices globais. Disponível em: $<$ http://www.apromiserenewed.org>. Consulta em: 25/03/2013.

${ }^{28} \mathrm{O}$ declínio da mortalidade infantil no Brasil é uma conquista significativa que, segundo o Portal da Saúde do Ministério da Saúde é resultado de diversas medidas, a saber: o aumento da cobertura vacinal da população, o uso da terapia de reidratação oral, o aumento da cobertura do pré-natal, a ampliação dos serviços de saúde, a redução contínua da fecundidade, a melhoria das condições ambientais, o aumento do grau de escolaridade das mães e o crescimento do aleitamento materno. Disponível em: $<$ http://portal.saude.gov.br>. Consulta em 25/03/2013.

${ }^{29}$ De acordo com os dados do Instituto Brasileiro de Geografia e Estatística, o número médio de anos que a população brasileira espera viver apresenta crescente ascensão. Em 1960, a expectativa de vida no Brasil era de 62,5 anos e, em 2011, passou a ser de 74,08 anos (74 anos e 29 dias). Assim, ao longo de 51 anos, a esperança de vida ao nascer no Brasil, foi incrementada em 11,58 anos. Em relação ao índice de 2010 (73,76 anos), houve um aumento de 0,31 anos (3 meses e 22 dias). Disponível em: <http://www.ibge.gov.br>. Consulta em 25/03/2013.

${ }^{30}$ Segundo o Ministério da Saúde, o gasto total per capita, em 2010, com ações e serviços públicos de saúde foi de R\$ 752,83 (setecentos e cinquenta e dois reais e oitenta e três centavos). Fonte: Ministério da Saúde/Secretaria Executiva/Área de Economia da Saúde e Desenvolvimento/Sistema de informações sobre Orçamentos Públicos em Saúde- SIOPS (Gasto Estadual e Municipal); SPO/SE e Fundo Nacional de SaúdeFNS (Gasto Federal). Disponível em: <http://www2.datasus.gov.br>. Consulta em 20/03/2013.

${ }^{31}$ A saúde é um dos fatores levados em conta na apuração, pela Organização das Nações Unidas (ONU), do Índice de Desenvolvimento Humano (IDH). Assim, é compreensível que o Brasil ocupe a $84^{\mathrm{a}}$ posição, conforme a lista divulgada em novembro de 2011 pela ONU, com a classificação do IDH de seus quase 200 países-membros. Entre os países latino-americanos, a Argentina e o Uruguai ocupam os primeiros lugares e o Brasil está em $14^{\circ}$, atrás das ilhas caribenhas Antígua e Barbuda, Trinidad e Tobago, Dominica e Santa Lúcia. Notícia publicada em 21/05/2012. O Estado de São Paulo: a saúde é precária. Disponível em: $<$ http://www.ipea.gov.br>. Consulta em 17/07/2012. 
Apesar de a sociedade brasileira pagar uma carga tributária elevada ${ }^{32}$ se comparada com a de outros países latino-americanos e de membros da Organização para a Cooperação e Desenvolvimento Econômico-OCDE ${ }^{33}$, a avaliação da situação da saúde pública no Brasil indica que a população continua a ter dificuldade de acesso às ações e serviços públicos de saúde e que o atendimento prestado é ineficiente e, muitas vezes, ineficaz.

O Estado Social deve desempenhar um conjunto de atribuições relevantes na área da saúde, como financiador, regulador e provedor de ações e serviços voltados à efetividade ao direito à saúde. A importância dessas atividades afigura-se ainda maior em países caracterizados por profundas desigualdades socioeconômicas entre seus cidadãos, como no Brasil ${ }^{34}$, onde as políticas públicas são indispensáveis para realizar os objetivos sociais que o Estado Democrático de Direito se comprometeu a promover.

Por certo, as soluções para os problemas sociais que o País atravessa não se limitam ao campo da política, envolvendo também aspectos jurídicos que o Direito Administrativo deve se preocupar em resolver.

A matéria suscita diversos questionamentos que se buscará responder ao longo do trabalho, tais como: qual o conteúdo e a extensão do direito à saúde? Quais as posições jurídicas decorrentes de sua consagração constitucional para os titulares e para os destinatários desse direito fundamental? Quais instrumentos jurídicos podem ser utilizados pelo indivíduo para assegurar o recebimento de prestações materiais de saúde de forma

\footnotetext{
${ }^{32}$ Segundo o relatório anual "Estatísticas sobre Receita na América Latina", divulgado em 13 de novembro de 2012 pela Organização para a Cooperação e Desenvolvimento Econômico (OCDE), no Brasil, em 2010, a arrecadação de tributos alcançou 32,4\% (trinta e dois inteiros e quatro décimos por cento) do Produto Interno Bruto (PIB). Em 1990 a relação entre a receita tributária e o PIB era de 28,2\% (vinte e oito inteiros e dois décimos por cento). A carga tributária brasileira está muito acima da média latino-americana e em 2010 superou a de 17 (dezessete) países da OCDE, entre eles Austrália, Canadá, Japão, Nova Zelândia, Espanha, Suíça e Estados Unidos. Carga Tributária no Brasil. 2011. Fonte: <http://www.fazenda.gov.br>. Consulta em 24/03/2013.

${ }^{33}$ A Organização para a Cooperação e Desenvolvimento Econômico (OCDE) é um órgão internacional e intergovernamental, composto por 34 (trinta e quatro) países membros, com sede em Paris, França. Fundada em 14 de dezembro de 1961, a OCDE sucedeu a Organização para a Cooperação Econômica Europeia, criada em 16 de abril de 1948. Por meio a OCDE, os representantes se reúnem para trocar informações e alinhar políticas com o objetivo de potencializar seu crescimento econômico e colaborar com o desenvolvimento de todos os demais países membros. O Brasil não é membro da OCDE, porém participa do programa de engajamento ampliado, que lhe permite participar de Comitês da Organização. Carga Tributária no Brasil - 2011. Disponível em: <http://www.fazenda.gov.br>. Consulta em 24/03/2013.

${ }^{34}$ Sobre o impacto da desigualdade extrema persistente sobre o Estado de Direito, confira: VIEIRA, Oscar Vilhena. A desigualdade e a subversão do Estado de Direito. In: Estado de direito e o desafio do desenvolvimento. Dimitri Dimoulis, Oscar Vilhena Vieira (organizadores). São Paulo: Saraiva, p.207-232, 2011.
} 
eficaz? Como a Administração pode melhorar o acesso das pessoas às ações e aos serviços públicos de saúde?

Com efeito, as respostas a essas indagações dependem de uma investigação aprofundada sobre o regime jurídico-constitucional do direito à saúde, bem como da legislação que o regulamenta. A partir daí será possível estabelecer os contornos e cada uma das funções que o direito à saúde pode assumir na realidade jurídica.

O interesse da pesquisa se coloca na discussão sobre a função do Executivo de solucionar consensualmente controvérsias atinentes às demandas por prestações materiais de saúde na esfera administrativa.

A atualidade do tema está ligada à nova era da Administração Pública instaurada pela Constituição Federal de 1988, centrada na figura do cidadão e na realização dos direitos sociais, que pressupõem prestações do Estado.

O estabelecimento de princípios regentes da atividade administrativa em seu artigo 37, caput, ampliou a concepção de legalidade a que a Administração está sujeita e gerou importantes reflexos nas relações entre a Administração Pública prestadora e os cidadãos.

Além da finalidade de limitação ao exercício do poder e garantia de direitos dos cidadãos perante o Estado, o Direito Administrativo disciplina as relações jurídicas entre Administração e cidadãos. Na perspectiva de um Direito Administrativo constitucionalizado, cabe questionar qual é o papel da Administração frente às inúmeras demandas para a concretização do direito à saúde em sua dimensão positiva? A Administração Pública pode buscar soluções de conflitos sobre prestações materiais de saúde mediante consenso dos cidadãos?

Portanto, o foco da pesquisa pressupõe o reconhecimento da conflituosidade existente entre os cidadãos e a Administração Pública quanto ao direito à saúde em sua dimensão positiva, atinente ao direito a prestações materiais, e o dever da Administração de tratar esses conflitos de forma compatível com o Estado Democrático e Social de Direito em que está inserida. Interessam, pois, as discussões sobre a participação administrativa, o dever de realização de justiça na via administrativa e o processo administrativo, notadamente na sua função de garantia de direitos dos cidadãos.

O enfoque do agir da Administração Pública em relação à efetivação do direito fundamental à saúde exige o desenvolvimento de uma teoria e uma dogmática que 
ofereçam soluções às dificuldades relativas à sua concretização material no tempo presente.

O primeiro capítulo do trabalho examina a saúde como objeto do Direito Sanitário, em seus diversos aspectos, destacando-a como bem jurídico de primordial importância que merece a proteção especial do Direito Positivo. Também é estudada a proteção conferida à saúde pelas Constituições do Brasil anteriores à Constituição Federal de 1988, com a recordação necessária da História da saúde pública, até a estruturação e consolidação do Sistema Único de Saúde (SUS). Todos esses elementos são importantes para uma análise evolutiva e a correta compreensão do significado e dos reflexos decorrentes da afirmação da saúde como direito fundamental na Constituição Federal de 1988.

O segundo capítulo traça as caraterísticas do regime jurídico-constitucional do direito fundamental à saúde, com base na Constituição Federal de 1988. De início é abordado o regime jurídico dos direitos fundamentais, particularmente dos direitos fundamentais sociais e a questão das competências em matéria de saúde. A partir daí, o estudo passa a delimitar os direitos e deveres que emergem do direito à saúde para o Estado e para os indivíduos.

Na sequência, será objeto de estudo a problemática da efetividade do direito à saúde, analisando-se a questão da eficácia e aplicabilidade da norma definidora desse direito fundamental, bem como da determinação do conteúdo do direito à saúde e do seu núcleo essencial.

O terceiro capítulo da dissertação tem por escopo o exame da estrutura normativa do Sistema Único de Saúde (SUS), os objetivos para os quais foi instituído, seus princípios reitores e as normas sobre o financiamento deste sistema, à luz da Lei Complementar n. 141/2012, que regulamentou a Emenda Constitucional n. 29/2000. O estudo parte do modelo jurídico-constitucional para, em seguida, abordar os principais aspectos da legislação estruturante e das normas operacionais que regem o funcionamento do Sistema Único de Saúde (SUS).

Ainda neste capítulo é analisado o tema do planejamento estatal ante aos objetivos traçados na Constituição Federal de 1988, o reconhecimento do direito fundamental à saúde e o correlato dever do Estado de dar-lhe efetividade, mediante políticas econômicas e sociais. O foco deste item será discutir os principais aspectos relativos à atividade planejadora do Estado e às políticas públicas de saúde. 
O quarto capítulo do trabalho trata da participação do cidadão na Administração Pública, especialmente em relação ao "Sistema Único de Saúde", examinando se e, em caso positivo, em qual medida a Administração atua conforme o vetor democrático do Estado, permitindo que a comunidade efetivamente participe do processo de tomada de decisão acerca da elaboração, execução e fiscalização das políticas públicas de saúde, conforme determina a diretriz constitucional.

A existência de problemas graves relativos ao acesso às ações e aos serviços oferecidos no âmbito do Sistema Único de Saúde, bem como as demandas crescentes para o atendimento de diversificadas prestações materiais de saúde conduziram a um expressivo crescimento do número de ações judiciais que envolvem prestações materiais na área da saúde no Brasil ${ }^{35}$, conforme constatado na pesquisa do Fórum Nacional do Judiciário para a Saúde ${ }^{36}$ do Conselho Nacional de Justiça.

Diante da crise quanto à concretização dos deveres estatais na área da saúde e a necessidade de fazer um corte metodológico para o estudo do tema proposto, o quinto capítulo deste trabalho destina-se ao estudo dos mecanismos de solução consensual de conflitos de saúde entre os indivíduos e a Administração, na via administrativa. O foco do estudo consiste na discussão acerca do dever que incumbe à Administração democrática de tornar efetivo o direito fundamental à saúde, sobretudo em relação à sua dimensão positiva, no tocante ao direito a prestações materiais.

A partir de um panorama sobre o modelo consensual da Administração e com base na classificação dogmática dos módulos convencionais, passa-se ao estudo dos mecanismos pró-consensuais institucionalizados para solução de conflitos sanitários na esfera administrativa.

\footnotetext{
${ }^{35}$ Há 240.980 (duzentos e quarenta mil novecentos e oitenta) processos sobre saúde na Justiça brasileira. Na maior parte das ações os pedidos consistem no fornecimento de medicamentos e tratamentos pelo Sistema Único de Saúde (SUS), disponibilização de vagas em hospitais públicos, e realização de intervenções cirúrgicas ou procedimentos por usuários de seguros e planos privados. Apesar do estudo não ter sido concluído (ainda faltam informações dos tribunais de Justiça da Paraíba, Pernambuco e Amazonas), é possível verificar que o Tribunal de Justiça do Rio Grande do Sul concentra quase metade de todas as ações sobre saúde do país (113.953), o Tribunal de Justiça de São Paulo possui 44.690 ações e o Tribunal de Justiça do Rio de Janeiro 25.234 ações. Disponível em: <http://www.conjur.com.br>. Consulta em 25/03/2013.

${ }^{36}$ Criado em 2010, o Fórum do Judiciário para a Saúde tem a proposta de avaliar e monitorar as demandas de saúde observadas nos tribunais, de forma a encontrar alternativas que levem à resolução destes conflitos e à agilidade de tais demandas judiciais. O Fórum está reunindo, neste encontro, representantes de todos os seus comitês gestores, juntamente com integrantes de secretarias estaduais e ministério da Saúde. Disponível em: $<$ http://www.cnj.jus.br>. Consulta em: 18 de junho de 2013.
} 
O tema da solução consensual de conflitos sanitários entre os indivíduos e o Estado comporta problemas complexos de difícil equacionamento. Sem pretender resolvê-los, a presente dissertação busca desenvolver linhas de raciocínio e contribuir para o estudo do modelo de Administração consensual, no concernente à atividade de dirimir controvérsias acerca do direito fundamental à saúde, em sua dimensão positiva, na via administrativa.

Embora o marco inicial da reflexão tenha um lugar definido- os conflitos por prestações materiais de saúde entre cidadãos e a Administração Pública-, os objetivos apontam na direção do paradigma emergente - o oferecimento de instrumentos próconsensuais procedimentais para a concretização do direito à saúde na via administrativa, de forma democrática, eficiente, equânime e justa. 


\section{CAPÍTULO 1 - O DIRIEITO À SAÚDE}

O estudo dos mecanismos de solução de conflitos na área da saúde coloca ao jurista o desafio primeiro de delinear alguns elementos conceituais relativos à matéria, possibilitando a compreensão do tema sobre o qual se pretende discorrer e, principalmente, a sedimentação de conceitos jurídico-filosóficos que alicerçam a doutrina dedicada ao tema do direito à saúde.

O primeiro item deste capítulo tece uma reflexão sobre a saúde como objeto de conhecimento do Direito Sanitário, considerando os fatores que a influenciam, e busca estabelecer uma concepção de saúde com base nos instrumentos jurídico-normativos que a protegem, compatível com a realidade e as necessidades do Século XXI.

O estudo da saúde como direito impõe, preliminarmente, o exame de elementos históricos relevantes ao Direito Internacional dos Direitos Humanos. É neste cenário que se examina a dinâmica relação entre o movimento de internacionalização dos Direitos Humanos e seus impactos no Direito interno, com foco na proteção do direito à saúde.

Na sequência, é abordada a proteção conferida à saúde pelas Constituições do Brasil anteriores à Constituição Federal de 1988, com a recordação necessária da história da saúde pública, até a estruturação e consolidação do Sistema Único de Saúde (SUS).

\subsection{A saúde como objeto de conhecimento do Direito Sanitário}

As tarefas do jurista no contexto atual envolvem a identificação da historicidade e da utilidade dos institutos e das práticas, bem como o mapeamento dos antagonismos existentes ${ }^{37}$, para que se possa compreender o propósito de sua dimensão, numa concepção material da justiça. ${ }^{38}$

37 SUNDFELD adota a teoria dos antagonismos entre Direito Administrativo dos Clips X Direito Administrativo dos negócios, como a matriz atual de análise em que deve se basear o jurista para descobrir as novas concreções do Direito Administrativo. Na visão de SUNDFELD, atualmente, não basta o estudo da moldagem dos institutos ou do direito de princípios, sendo necessário ao administrativista, antes de tudo, investigar a existência de antagonismos em cada caso, enxergando "institutos flexíveis, compatíveis com o inclassificável, o experimentalismo responsável, a acomodação de contrários”, para que esse ramo do Direito possa ser designado como Direito Administrativo do desenvolvimento. SUNDFELD, Carlos Ari. Direito Administrativo para céticos. São Paulo: Malheiros, 2012, p. 85-92.

38 Segundo BITTAR e ALMEIDA, a justiça funciona, enquanto valor que orienta a construção históricodialética dos direitos, como fundamento e propósito para as expectativas sociais em torno do direito. Embora 
O jurista, enquanto técnico do Direito, pode formular e colocar a disposição da sociedade mecanismos concretos que viabilizem a realização de interesses consagrados na ordem jurídica. Isto porque, o Direito ${ }^{39}$ não é um fim em si mesmo, mas instrumento de realização de determinados valores escolhidos como importantes pela sociedade e de limitação do poder do Estado. ${ }^{40}$ É o arcabouço coercitivo e normativo de regência da conduta humana social, que encontra seu fundamento histórico e finalidade na realização da justiça. ${ }^{41} 42$

Se a razão de existir do Direito ${ }^{43}$ e a finalidade de operar na vida social consiste em promover justiça, o Direito deve ser o veículo para realizá-la. ${ }^{44}$ Do contrário, o Direito se

a justiça seja de difícil contorno conceitual, asseguram que, ainda assim, pode ser considerada um valor essencialmente humano e profundamente necessário às realizações do convívio humano, porque nela reside a semente da igualdade. BITTAR, Eduardo Carlos Bianca; ALMEIDA, Guilherme Assis de. Curso de Filosofia do Direito. 4.ed. São Paulo: Atlas, 2005, p.448.

${ }^{39}$ Como afirma AITH ao tratar da ciência jurídica nas sociedades modernas, o Direito se apresenta de forma multifacetada, porém sempre como instrumento de promoção da justiça social. O que torna o Direito uma ciência é a forma de sua implementação prática, pois é sua aplicação que lhe dá a dimensão social que possui. Assim, quanto mais eficaz for a implementação do Direito, melhor atenderá o seu papel de transformação da realidade social em prol do desenvolvimento humano. AITH, Fernando. Curso de Direito Sanitário: a proteção do Direito à Saúde no Brasil. São Paulo: Quartier Latin, 2007, p. 41.

${ }^{40}$ Para ROUSSEAU, com a passagem do estado natural para o estado civil, a conduta humana deixou de ser instintiva para ser de justiça, somada à moralidade. $\mathrm{O}$ homem perdeu a liberdade natural e o direito limitado às suas forças para ganhar a liberdade civil, que é a liberdade limitada pela vontade geral e a posse (direito do primeiro ocupante). Foi estabelecido o direito de propriedade, porém o direito de cada particular sobre sua parte no solo está sempre subordinado ao direito da comunidade sobre o todo. ROUSSEAU sustenta que a base de todo o sistema social em vez de destruir a igualdade natural a substitui por uma igualdade moral, considerando todos os homens iguais por convenção e por direito. ROUSSEAU, Jean Jacques. Contrato Social. Versão original: 1762. Tradução de Rolando Roque da Silva. Edição eletrônica: Ridendo Castigat Moraes. Livro I, 2002, p.9-35. Disponível em: <http://www.cfh.ufsc.br>. Consulta em: 9/09/2013.

${ }^{41}$ A preocupação de identificação do Direito com a Justiça deixou de ser objeto de estudo do direito como reflexo do positivismo científico do século XIX e do surgimento do positivismo jurídico como movimento de pensamento, segundo o qual aquilo que não pode ser provado racionalmente, não pode ser conhecido e que somente importa ao jurista o estudo do Direito Positivo. O positivismo normativo de Hans Kelsen defende o isolamento do método jurídico para garantir autonomia ao direito, como ciência. Para Hans Kelsen, discutir sobre justiça é tarefa da ética, ciência que se ocupa de estudar normas morais e que, portanto, se incumbe de detectar o certo, o errado, o justo e o injusto. É com base na quebra da relação ser/dever ser que Hans Kelsen opera a distinção entre o que é jurídico (fenômeno jurídico puro) e o que não é jurídico (cultural, ético, metafísico, religioso, sociológico, antropológico e histórico). BITTAR, Eduardo Carlos Bianca; ALMEIDA, Guilherme Assis de. Curso de Filosofia do Direito. 4.ed. São Paulo: Atlas, 2005, p.343-346.

${ }^{42}$ A justiça não é coercível, pois tem natureza de norma moral, e não jurídica. As normas jurídicas, por sua vez, absorvem conteúdos de normas de justiça, funcionando como forma de proscrever socialmente comportamentos que sejam considerados injustos. O estudo do direito relacionado à justiça é objeto de estudo da filosofia do Direito (jusnaturalistas). Para BITTAR e ALMEIDA, "a Filosofia do Direito é um saber crítico a respeito das construções jurídicas erigidas pela Ciência do Direito e pela própria práxis do Direito. Mais que isso, é sua tarefa buscar os fundamentos do Direito, seja para certificar-se de sua natureza, seja para criticar o assento sobre o qual se fundam as estruturas do raciocínio jurídico, provocando, por vezes, fissuras no edifício que por sobre as mesmas se ergue." BITTAR, Eduardo Carlos Bianca; ALMEIDA, Guilherme Assis de. Curso de Filosofia do Direito. 4.ed. São Paulo: Atlas, 2005, p.50.

${ }^{43}$ Assim como as demais ciências humanas ou sociais, as ciências jurídicas são normativas, pois atribuem grande valor à construção racional da realidade. As ciências normativas apresentam como característica 
torna um fenômeno sem sentido. A função técnico-instrumental do Direito é, portanto, servir ao convívio social justo ${ }^{45}$, dirigido ao atendimento do bem comum do conjunto dos $\operatorname{cidadãos}^{46}$, o que supõe a eliminação da desigualdade social no concernente às condições de uma vida digna, entendida esta como o respeito aos direitos fundamentais. ${ }^{47}$

A compreensão do Direito Sanitário envolve tanto a consideração da discussão filosófica, que permite afirmar a saúde como direito, quanto dos instrumentos adjetivos aptos a assegurar a efetividade dos objetivos constitucionais específicos desta matéria. A superação da classificação alternativa entre ciência pura e ciência aplicada faz com que o Direito Sanitário represente uma mudança de paradigma no campo do Direito.

O Direito Sanitário pode ser definido como o ramo do Direito que tem por objeto a disciplina das ações e serviços públicos e privados de interesse à saúde no País ${ }^{48}$, tendo como principais finalidades a redução dos riscos de doença e outros agravos à saúde, bem como o estabelecimento de condições que assegurem o acesso universal e igualitário às ações e serviços para a promoção, a proteção e a recuperação da saúde. ${ }^{49}$

A consolidação do Direito Sanitário no Brasil encontra sua origem na Constituição Federal de 1988, que expressamente define a saúde como direito fundamental (artigo $6^{\circ}$ ) e dedica uma Seção especificamente para o tratamento da saúde em seu Título VIII, que trata

principal a possibilidade de revisão de suas conclusões, porque a definição de seus valores depende da moralidade e dos costumes de uma sociedade, variáveis ao longo do tempo e conforme as peculiaridades do caso concreto. As ciências jurídicas estão presas às necessidades que as tornam saberes parciais sobre fenômenos sociais, além de fenômenos normativos sobre fenômenos sociais. BITTAR, Eduardo Carlos Bianca; ALMEIDA, Guilherme Assis de. Curso de Filosofia do Direito. 4.ed. São Paulo: Atlas, 2005, p.4446.

44 BITTAR, Eduardo Carlos Bianca; ALMEIDA, Guilherme Assis de. Curso de Filosofia do Direito. 4.ed. São Paulo: Atlas, 2005, p. 447-448.

45 BITTAR, Eduardo Carlos Bianca; ALMEIDA, Guilherme Assis de. Curso de Filosofia do Direito. 4.ed. São Paulo: Atlas, 2005, p. 257.

${ }^{46}$ No Livro I do "Contrato Social”, escrito em 1762, Jean Jacques Rousseau investiga o motivo de o homem ter nascido livre e, por todos os lados, estar preso. Afirma que o fundamento do Estado e da sociedade civil é uma deliberação conjunta, um pacto estabelecido entre os homens que supõe, neste ato, unanimidade para unir e dirigir as forças particulares existentes, transformada numa força maior organizada para a realização da igualdade, governada pela ideia de bem comum. O contrato surge como condição para garantir a liberdade natural de cada um e meio pelo qual cada homem coloca toda sua autoridade sob o comando supremo da vontade geral. O contrato é base de toda autoridade legítima entre os homens e a restrição à liberdade dos cidadãos em relação ao Estado somente se justifica se o poder for exercido em favor daqueles. ROUSSEAU, Jean Jacques. Contrato Social. Versão original: 1762. Tradução de Rolando Roque da Silva. Edição eletrônica: Ridendo Castigat Moraes. Livro I, 2002, p.9-35.

${ }^{47}$ COMPARATO, Fábio Konder. Rumo à justiça. São Paulo: Saraiva, 2010, p.392.

${ }^{48}$ AITH, Fernando. Curso de Direito Sanitário: a proteção do Direito à Saúde no Brasil. São Paulo: Quartier Latin. 2007, p. 83.

${ }^{49}$ De acordo com o disposto no artigo 196 da Constituição Federal: "Art. 196. A saúde é direito de todos e dever do Estado, garantido mediante políticas sociais e econômicas que visem à redução do risco de doença e de outros agravos e ao acesso universal e igualitário às ações e serviços para sua promoção, proteção e recuperação." 
da Ordem Social (Capítulo II, Seção II, artigos 196 a 200). O reconhecimento expresso da saúde como direito fundamental e dever do Estado ampliou a regulação estatal sobre as ações e serviços de interesse à saúde, gerando uma intensa produção legislativa e a edição de atos administrativos que repercutem sobre a efetivação do direito à saúde.

Ante as especificidades que o diferenciam dos demais ramos do Direito e o conjunto de princípios e normas próprias, inerentes ao seu domínio, DALLARI ${ }^{50}$ e AITH defendem que o Direito Sanitário adquiriu conteúdo sólido o suficiente para que seja considerado de forma autônoma, sem perder de vista suas interfaces com os outros ramos da ciência jurídica, eis que compõe uma parte do todo. ${ }^{51}$ Neste campo de interação de disciplinas, importa destacar alguns temas relevantes que evidenciam a interface entre o Direito Sanitário e o Direito Administrativo ${ }^{52}$ : a constante tensão existente entre os interesses da saúde pública (autoridade) e direitos individuais (liberdade); os diferentes modelos de prestação de serviços públicos de saúde no Brasil; o processo administrativo como instrumento para a garantia de direitos; as novas tecnologias em saúde etc.

A saúde passou a ser objeto de interesse do Direito, inicialmente, a partir da noção de que há uma saúde pública a ser protegida. A noção de saúde influi sobre o conteúdo e a aplicação do Direito Sanitário e deve ser compreendida a partir de uma perspectiva histórico-dinâmica que evolui até sua afirmação como direito fundamental.

O termo "saúde" é polissêmico, significando o estado geral de bem-estar de uma população, a atividade estatal relativa à prestação de serviços públicos de saúde ${ }^{53}$, o campo

\footnotetext{
${ }^{50}$ De acordo com DALLARI, o Direito Sanitário pode ser definido como um subcampo autônomo do conhecimento científico, dotado de leis próprias, derivadas dos agentes e instituições que o caracterizam. DALLARI, Sueli Gandolfi. Direito Sanitário: fundamentos, teoria e efetivação. In: Direito Sanitário: saúde e direito, um diálogo possível. AITH, Fernando; SATURNINO, Luciana Tarbes Mattana; DINIZ, Maria Gabriela Araújo; MONTEIRO, Tammy Claret (organizadores). Belo Horizonte: ESP-MG, p. 62-63, 2010.

${ }^{51}$ AITH, Fernando. Curso de Direito Sanitário: a proteção do direito à saúde no Brasil. São Paulo: Quartier Latin, 2007, p. 78-83.

52 Conforme MELLO, o "Direito Administrativo é o ramo do Direito Público que disciplina a função administrativa, bem como pessoas e órgãos que a exercem.” MELLO, Celso Antônio Bandeira de. Curso de Direito Administrativo. 27. ed. São Paulo: Malheiros, 2010, p.37.

53 A promoção da saúde, segundo REY, compreende a "ação desenvolvida através de um conjunto de medidas individuais e coletivas que têm por objetivo aumentar a capacidade das pessoas sãs de manter e melhorar sua saúde e bem-estar. Essas medidas devem: a) levar os indivíduos a desenvolver hábitos de vida sadios e a combaterem os comportamentos nocivos à saúde; b) incitar as coletividades a sanearem o ambiente físico e social de modo a sustentarem as opções pessoais favoráveis à saúde; c) pressionar as autoridades e organismos decisórios da sociedade para que se empenhem em proporcionar as condições gerais básicas favoráveis ao bem-estar físico, mental e social dos cidadãos (...)" REY, Luís. Dicionário de termos técnicos de medicina e saúde. 2.ed. Rio de Janeiro: Guanabara Koogan, 2008, p. 798.
} 
de atividade humana caracterizada pela especialização profissional e institucional, e também a ciência organizada na disciplina denominada "Direito Sanitário". 54

No século IV A.C., ápice da democracia grega, as palavras que mais se aproximavam do termo "saúde" eram dietética e ginástica. Para os Gregos, a ideia de saúde estava associada a comer de forma adequada (dietética) e a fazer exercícios físicos (ginástica). A ideia de saúde tinha um sentido positivo, de bem-estar e felicidade.

A noção de saúde relacionada à prevenção de doenças surgiu durante a Idade Média, entre os séculos $\mathrm{V}$ e $\mathrm{XV}^{55}$, época em que a assistência pública, abrangente da assistência social e da assistência médica dependia da solidariedade da vizinhança, pois o Estado atuava apenas de forma subsidiária à ação da comunidade local.

No século XVII foi desenvolvida uma linha de pensamento que passou a conceituar saúde no sentido negativo, como ausência de doenças. ${ }^{56}$ No final do século XIX e na primeira metade do século XX, auge da Revolução Industrial, houve um debate entre as duas correntes que procuravam definir um conceito de saúde: de um lado, os grupos excluídos do processo de produção por máquinas, que viviam em situação de miserabilidade, sustentavam existir ligação direta entre a noção de saúde e as condições sociais, o meio ambiente, a alimentação, o trabalho e a moradia; de outro lado, a saúde era conceituada como ausência de doenças por grupos que observavam o emprego adequado das drogas desenvolvidas para o tratamento de doenças, bem como a cura de muitas pessoas. ${ }^{57}$

\footnotetext{
${ }^{54}$ AITH, Fernando. Curso de Direito Sanitário: a proteção do Direito à Saúde no Brasil. São Paulo: Quartier Latin, 2007, p. 50-51.

${ }^{55}$ A história da medicina registra importante evolução na compreensão do diagnóstico de doenças na Europa, durante o Renascimento, com a ascensão da investigação experimental, especialmente pela dissecação de corpos e os estudos de anatomia, que desafiaram as tradições aceitas a partir de evidências científicas. Porém, segundo BERTOLLI FILHO tal fato não gerou benefícios diretos na saúde das pessoas, pois tinham medo de se submeter aos tratamentos, em geral baseados em purgantes e sangrias, e preferiam buscar a cura espiritual ou remédios recomendados por curandeiros. Sobre a história da saúde pública no Brasil, conferir: BERTOLLI FILHO, Cláudio. História da Saúde Pública no Brasil. 3. ed. São Paulo: Ática, 1999, p.5-6.

${ }^{56}$ DALLARI afirma que a origem de tal corrente pode ser encontrada nos trabalhos do filósofo francês Descartes que, ao equiparar o corpo humano a uma máquina, acreditou que seria possível descobrir como conservar a saúde. DALLARI, Sueli Gandolfi. O conteúdo do direito à saúde. In: O Direito achado na rua: introdução crítica ao direito à saúde. COSTA, Alexandre Bernardino; SOUSA JÚNIOR, José Geraldo; DELDUQUE, Maria Célia; OLIVEIRA, Mariana Siqueira de Carvalho; DALLARI, Sueli Gandolfi (organizadores), v.4. Brasília: CEAD/UnB, p.93, 2009.

${ }^{57}$ DALLARI, Sueli Gandolfi. O conteúdo do direito à saúde. In: O Direito achado na rua: introdução crítica ao direito à saúde. COSTA, Alexandre Bernardino; SOUSA JÚNIOR, José Geraldo; DELDUQUE, Maria Célia; OLIVEIRA, Mariana Siqueira de Carvalho; DALLARI, Sueli Gandolfi (organizadores), v.4. Brasília: CEAD/UnB, p.94, 2009.
} 
Além de significar a ausência de doenças ou enfermidades, a concepção atual de saúde $^{58}$ envolve o estado de completo bem-estar físico, psíquico e social, necessário para assegurar condições de uma vida digna e com qualidade. Assim, tanto o sentido positivo, quanto o sentido negativo estão abrangidos pela atual concepção de saúde. ${ }^{59}$

O estado de saúde depende, ao mesmo tempo, de aspectos individuais (físicos e psicológicos), coletivos, culturais, políticos, sociais, religiosos e econômicos, e da relação direta e dinâmica entre o indivíduo e o ambiente social em que vive. ${ }^{60} \mathrm{E}$ não são apenas os elementos próximos da realidade concreta do indivíduo que influenciam sua condição de saúde, mas também fatores que dependem da organização sociopolítica e econômica dos Estados. $^{6162}$

${ }^{58}$ Do ponto de vista clínico, STEDMAN assim define a saúde: "1. O estado do organismo quando funciona de modo ideal, sem qualquer evidência de doença ou anormalidade. 2. Estado de equilíbrio dinâmico em que a capacidade de um indivíduo ou de um grupo de lidar com todas as circunstâncias de vida encontra-se num nível ótimo. 3. Estado caracterizado por integridade anatômica, fisiológica e psicológica, capacidade de desempenhar pessoalmente um papel na família, no trabalho e na comunidade, capacidade de lidar com estresses físicos, biológicos, psicológicos e sociais, sensação de bem-estar, e ausência de risco de doença e morte prematura." STEDMAN. Dicionário Médico. 27 ed. Rio de Janeiro: Guanabara Koogan, tradução de Stedman's Medical Dictionary, sob a supervisão de Maria de Fátima Azevedo, 2003, p. 701.

${ }^{59}$ É interessante observar que a Portaria n. 104, de 25 de janeiro de 2011, do Ministério da Saúde, dentre outras matérias, define as terminologias adotadas em legislação nacional, conforme o disposto no Regulamento Sanitário Internacional 2005, apresentando os conceitos de "doença", "agravo", "evento", "emergência de Saúde Pública de Importância Nacional" e "emergência de Saúde Pública de Importância Internacional". Assim, nos termos do artigo $1^{\circ}$, incisos I a V, desta portaria: "I - Doença: significa uma enfermidade ou estado clínico, independentemente de origem ou fonte, que represente ou possa representar um dano significativo para os seres humanos; II - Agravo: significa qualquer dano à integridade física, mental e social dos indivíduos provocado por circunstâncias nocivas, como acidentes, intoxicações, abuso de drogas, e lesões auto ou heteroinfligidas; III - Evento: significa manifestação de doença ou uma ocorrência que apresente potencial para causar doença; IV - Emergência de Saúde Pública de Importância Nacional ESPIN: é um evento que apresente risco de propagação ou disseminação de doenças para mais de uma Unidade Federada - Estados e Distrito Federal - com priorização das doenças de notificação imediata e outros eventos de saúde pública, independentemente da natureza ou origem, depois de avaliação de risco, e que possa necessitar de resposta nacional imediata; e V - Emergência de Saúde Pública de Importância Internacional - ESPII: é evento extraordinário que constitui risco para a saúde pública de outros países por meio da propagação internacional de doenças e que potencialmente requerem uma resposta internacional coordenada."

${ }^{60}$ Nesta perspectiva, AITH afirma que o estado equilibrado de saúde do indivíduo pode ser verificado por meio do "sentimento de autossatisfação e da harmonia com os outros". AITH, Fernando. AITH, Fernando. A emergência do Direito Sanitário como um novo campo do Direito. In: Estudos de Direito Sanitário: a produção normativa e saúde. ROMERO, Luiz Carlos; DELDUQUE, Maria Célia (organizadores). Brasília: Senado Federal: Subsecretaria de Edições Técnicas, p.15, 2011.

${ }^{61}$ DALLARI, Sueli Gandolfi. O conteúdo do direito à saúde. In: O Direito achado na rua: introdução crítica ao direito à saúde. COSTA, Alexandre Bernardino; SOUSA JÚNIOR, José Geraldo; DELDUQUE, Maria Célia; OLIVEIRA, Mariana Siqueira de Carvalho; DALLARI, Sueli Gandolfi (organizadores), v.4. Brasília: CEAD/UnB, p.93, 2009.

${ }^{62}$ De acordo com AITH, a saúde representa, concomitantemente, os reflexos: (i) do comportamento individual, que será considerado, em grande parte, responsável pela preservação de sua saúde; (ii) das influências que o ambiente social produz sobre o indivíduo; e (iii) da sorte, fator aleatório sobre a saúde. AITH, Fernando. A emergência do Direito Sanitário como um novo campo do Direito. In Estudos de Direito 
É indiscutível que as características individuais apresentam grande relevância para o estado de saúde de uma pessoa: hábitos sedentários e a má alimentação, por exemplo, bastam para aumentar as possibilidades de causar obesidade e hipertensão. A herança genética também está associada à saúde dos indivíduos, podendo influenciar na aquisição ou desenvolvimento de doenças determinadas pela mutação de um gene. Tais situações revelam a face individual da saúde, embora também possam ter traços que as ligariam à organização sociopolítica em que estão integradas. Assim, como exemplifica DALLARI, o arranjo genético pode ter sido resultado do fato de gerações anteriores terem vivido em ambientes contaminados. ${ }^{63}$

A face coletiva da saúde fica evidenciada pela obrigatoriedade de vacinação de grande número de pessoas para garantir proteção imunológica a uma determinada população e, também, com a campanha de combate à dengue que impõe à generalidade de moradores de certa região a adoção de cuidados para não permitir o acúmulo de água parada, evitando, assim, a proliferação do mosquito Aedes aegypti. Sob uma perspectiva ainda mais abrangente, a utilização racional da água potável e o abastecimento de veículos automotores com álcool como combustível são recomendações que valem para todos, de todos os países. Outro exemplo do aspecto coletivo da saúde se depreende da notícia recentemente divuldada pela Agência Internacional para Pesquisa sobre Câncer (IARC), da Organização Mundial de $S_{a u ́ d e}{ }^{64}$, que concluiu haver evidências científicas de que a poluição é carcinogênica para as pessoas de todas as regiões do mundo, divulgando que,

Sanitário: a produção normativa e saúde. ROMERO, Luiz Carlos; DELDUQUE, Maria Célia (organizadores). Brasília: Senado Federal: Subsecretaria de Edições Técnicas, p. 16, 2011.

${ }^{63}$ DALLARI, Sueli Gandolfi. O conteúdo do direito à saúde. In: O Direito achado na rua: introdução crítica ao direito à saúde. COSTA, Alexandre Bernardino; SOUSA JÚNIOR, José Geraldo; DELDUQUE, Maria Célia; OLIVEIRA, Mariana Siqueira de Carvalho; DALLARI, Sueli Gandolfi (organizadores), v.4. Brasília: CEAD/UnB, p.93, 2009.

${ }^{64}$ Os principais médicos especialistas do mundo foram convocados pelo Programa de Monografias da Agência Internacional para Pesquisa sobre Câncer (IARC), da Organização Mundial de Saúde para estudar se a exposição das pessoas à poluição causa câncer. Os estudos foram baseados em minuciosa revisão da literatura científica recente (mais de mil artigos científicos dos cinco continentes) e em grandes estudos epidemiológicos realizados na América do Sul, América do Norte, Europa e Ásia. Já era sabido que a poluição do ar é um grave problema de saúde e que poderia aumentar os riscos de uma ampla gama de doenças, sobretudo respiratórias e cardíacas. Contudo, os novos estudos realizados pelos principais especialistas do mundo concluíram que a poluição do ar não é apenas um risco para a saúde em geral, mas é também carcinogênica para humanos. Nos termos do relatório apresentado, há provas suficientes de que a exposição à poluição causa câncer de pulmão e também aumenta o risco de câncer de bexiga. Muito embora a composição da poluição do ar e os níveis de exposição das pessoas possam variar drasticamente em cada um dos locais do mundo, as conclusões deste estudo se aplicam a todas as regiões do mundo. "IARC: Outdoor air pollution a leading environmental cause of cancer deaths". O artigo foi divulgado no site da Organização das Nações Unidas na Internet e está disponível em: <http://www.who.int/>. Consulta em: 24/10/2013. 
em 2010, 223.000 (duzentas e vinte e três mil) mortes por câncer de pulmão em todo o mundo, foram causadas pela poluição do $\operatorname{ar}^{65}$. Portanto, é estreme de dúvidas que a saúde também deve ser considerada a partir de uma perspectiva coletiva.

A face cultural da saúde, por sua vez, mostra conexão com os hábitos de saúde adotados por um grupo de pessoas em relação, por exemplo, aos cuidados de higiene dos alimentos e da periodicidade de limpeza das caixas d'água de suas residências.

Os aspectos associados à religião podem gerar conflitos quanto à definição do conteúdo e da forma de proteção do direito à saúde, considerando a diversidade de crenças existentes na sociedade brasileira. Assim, por exemplo, surgem discussões sobre o aborto, inclusive de fetos anencéfalos, e a transfusão de sangue em Testemunhas de Jeová.

Os aspectos econômicos também apresentam estreita relação com a saúde, na medida em que o tratamento de saúde (medicamentos, exames, cirurgias, dentre outros) envolve custos. Além disso, a maior parte das doenças e iniquidades em saúde decorrem das condições em que as pessoas nascem, vivem, crescem, trabalham e envelhecem, ou seja, dos "determinantes sociais da saúde", expressão que abrange elementos sociais, econômicos, políticos, culturais e ambientais da saúde. ${ }^{66}{ }^{67}$ As políticas necessárias para a implementação de ações sobre os determinantes sociais da saúde demandam ações intersetoriais, que beneficiam a sociedade como um todo e geram reflexos no estado de saúde de uma determinada população. ${ }^{68} 69$ ${ }^{65}$ IARC Scientific Publication n. 161. Air Pollution and Cancer. STRAIF, Kurt; COHEN, Aaron; SAMET,
Jonathan (editores), eISBN 978-92-832-2161-6. Disponível em: <http://www.iarc.fr>. Consulta em:
$17 / 10 / 2013$.
${ }^{66}$ Segundo o documento de discussão da Conferência Mundial sobre Determinantes Sociais da Saúde
(“conferência mundial”), realizada no Rio de Janeiro, entre 19 e 21 de outubro de 2011 , os determinantes
mais importantes são aqueles que estratificam a sociedade, como a distribuição de renda, a discriminação e a
existência de estruturas políticas ou de governança que reforcem as iniquidades relativas ao poderio
econômico. Tais mecanismos estruturais que influenciam a posição social ocupada pelos indivíduos são a
causa mais profunda das iniquidades em saúde. As discrepâncias atribuíveis a esses mecanismos moldam a
saúde dos indivíduos através de determinantes intermediários, como as condições de moradia e psicossociais,
fatores comportamentais e biológicos, além do próprio sistema de saúde. Diminuindo diferenças: a prática
das políticas sobre determinantes sociais da saúde. Documento de discussão. Conferência Mundial sobre
Determinantes Sociais da Saúde. Rio de Janeiro/Brasil. 19-21 out. 2011. Genebra: Organização Mundial da
Saúde. Tradução: Cristiano Botafogo. Disponível em: <http://www.who.int>. Consulta em 26/10/2013.
67 No mesmo sentido, como observa AITH, a saúde não depende apenas de fatores biológicos, pois os
denominados fatores estruturais do indivíduo (em itálico no original), definidos pela sua condição social e
econômica, possuem influência determinante sobre o estado de saúde das pessoas. AITH, Fernando. A
emergência do Direito Sanitário como um novo campo do Direito. In: Estudos de Direito Sanitário: a
produção normativa e saúde. ROMERO, Luiz Carlos; DELDUQUE, Maria Célia (organizadores). Brasília:
Senado Federal: Subsecretaria de Edições Técnicas, p.16, 2011.
68 Nesta Conferência, a Organização Mundial de Saúde recomendou aos países que implementem ações sobre
os determinantes sociais da saúde e redução das iniquidades em saúde por meio de intervenções a ser 
A necessidade de atuação conjunta dos Estados para a melhoria das condições de saúde de suas populações revela a dimensão sócio-política da saúde. Como exemplo, cumpre mencionar a necessidade de cooperação entre os Estados para extinguir os focos de contaminação do vírus da gripe aviária em seus territórios, evitando que o vírus se propague e seja capaz de provocar uma epidemia de gripe. Não é suficiente que um Estado promova ações de controle da gripe aviária, tornando herméticas suas fronteiras, pois o vírus influenza, hospedado por aves, pode infectar mamíferos que venham a ingressar no território nacional.

Da mesma forma, não basta que uma pessoa tome todos os cuidados necessários para evitar focos de dengue em sua residência se os seus vizinhos também não adotarem medidas preventivas, pois permanecerá na situação de risco de ser picada pelo mosquito e contrair a dengue. Do mesmo modo, não é possível às pessoas comuns detectarem que alguns produtos industrializados expostos à venda estão contaminados, sendo imperiosa a existência de um órgão que realize a fiscalização da qualidade desses alimentos. ${ }^{70}$

realizadas sobre cinco dimensões principais: 1.1. Governança para o enfrentamento das causas mais profundas das iniquidades em saúde: implementando ações sobre os determinantes sociais da saúde; 1.2. Promoção da participação: lideranças comunitárias para a ação sobre os determinantes sociais; 1.3. O papel do setor, incluindo os programas de saúde pública, na redução das iniquidades em saúde; 1.4. Ações globais sobre os determinantes sociais: alinhando prioridades e grupos de interesse; 1.5. Monitoramento do progresso: medir e analisar para informar as políticas sobre determinantes sociais. ORGANIZAÇÃO MUNDIAL DA SAÚDE. Diminuindo diferenças: a prática das políticas sobre determinantes sociais da saúde. Documento de discussão. Conferência Mundial sobre Determinantes Sociais da Saúde. Rio de Janeiro, 19-21 out. 2011. Genebra: Organização Mundial da Saúde. Tradução: Cristiano Botafogo. Disponível em: $<$ http://www.who.int>. Consulta em 26/10/2013.

69 No mesmo sentido, a Declaração de Alma-Ata, de 1978, produzida na Conferência Internacional sobre Cuidados Primários de Saúde, relacionou a noção de "intersetorialidade" com os determinantes sociais da saúde, destacando o fato de que a proteção da saúde não se exaure em medidas de cunho estritamente sanitários, mas depende de uma atuação de todos os setores relativos ao desenvolvimento humano e social. O item VII da Declaração de Alma-Ata estabelece o seguinte: "VII) Os cuidados primários de saúde: 1 Refletem, e a partir delas evoluem, as condições econômicas e as características socioculturais e políticas do país e de suas comunidades, e se baseiam na aplicação dos resultados relevantes da pesquisa social, biomédica e de serviços de saúde e da experiência em saúde pública. 2 - Têm em vista os principais problemas de saúde da comunidade, proporcionando serviços de proteção, cura e reabilitação, conforme as necessidades. 3 - Incluem pelo menos: educação, no tocante a problemas prevalecentes de saúde e aos métodos para sua prevenção e controle, promoção da distribuição de alimentos e da nutrição apropriada, previsão adequada de água de boa qualidade e saneamento básico, cuidados de saúde materno-infantil, inclusive planejamento familiar, imunização contra as principais doenças infecciosas, prevenção e controle de doenças localmente endêmicas, tratamento apropriado de doenças e lesões comuns e fornecimento de medicamentos essenciais. 4 - Envolvem, além do setor saúde, todos os setores e aspectos correlatos do desenvolvimento nacional e comunitário, mormente a agricultura, a pecuária, a produção de alimentos, a indústria, a educação, a habitação, as obras públicas, as comunicações e outros setores. (...)”

${ }^{70}$ DALLARI, Sueli Gandolfi. O conteúdo do direito à saúde. In: O Direito achado na rua: introdução crítica ao direito à saúde. COSTA, Alexandre Bernardino; SOUSA JÚNIOR, José Geraldo; DELDUQUE, Maria Célia; OLIVEIRA, Mariana Siqueira de Carvalho; DALLARI, Sueli Gandolfi (organizadores), v.4. Brasília: CEAD/UnB, p.94-95, 2009. 
Nessas situações fica clara a tensão existente entre a autoridade e as liberdades individuais. Com efeito, para assegurar a proteção da saúde pública por vezes é necessário proibir, restringir ou condicionar o exercício de determinados direitos, o que se faz por meio do poder de polícia. Esta limitação à liberdade individual tem por escopo a garantia da própria liberdade e dos direitos das pessoas e encontra fundamento na supremacia do interesse público sobre o particular. Assim, por exemplo: a obrigação imposta às pessoas de se vacinarem visa garantir a imunização da população; e a exigência de tratamento compulsório, o isolamento ou a quarentena objetiva prevenir a ocorrência de epidemia.

Contudo, cumpre observar que o poder de polícia é limitado pelo princípio da legalidade, o que impede a Administração Pública de impor obrigações ou proibições não previstas em lei, visto que se trata de limitar o exercício de direitos individuais. De acordo com DI PIETRO, o poder de polícia pode ser conceituado como "a atividade do Estado consistente em limitar o exercício dos direitos individuais em benefício do interesse público". 71

No século XXI, os elementos relacionados à organização da sociedade internacional influenciam com mais força o estado de saúde das pessoas. ${ }^{72}$ A multiplicação dos deslocamentos geográficos dos indivíduos devido às catástrofes naturais, guerras ou outros motivos favorecem a propagação de doenças infecciosas e podem condicionar modos de vida insalubres. A degradação do meio-ambiente provocada por atividades econômicas, a urbanização e o crescimento desordenado das megalópoles também provocam o crescimento exponencial dos riscos sanitários. Todos esses fatores tornam evidente que as medidas para a promoção e a proteção da saúde devem ser desenvolvidas além das fronteiras dos países, sendo imperiosa a superação de problemas políticos e jurídicos.

A despeito do desenvolvimento extraordinário da ciência e do incremento de mecanismos de cooperação internacional para regulamentar a proteção da saúde individual e coletiva em âmbito interno e internacional, vivenciamos situações graves decorrentes da

\footnotetext{
${ }^{71}$ DI PIETRO, Maria Sylvia Zanella. Direito Administrativo. 23.ed. São Paulo: Atlas, 2010, p. 114-117.

72 DALLARI, Sueli Gandolfi. O conteúdo do direito à saúde. In: O Direito achado na rua: introdução crítica ao direito à saúde. COSTA, Alexandre Bernardino; SOUSA JÚNIOR, José Geraldo; DELDUQUE, Maria Célia; OLIVEIRA, Mariana Siqueira de Carvalho; DALLARI, Sueli Gandolfi (organizadores), v.4. Brasília: CEAD/UnB, p.95, 2009.
} 
persistência de epidemias ${ }^{73}$ e do surgimento de novas doenças de difícil controle que, por vezes, ocorrem em razão da primazia de interesses econômicos em relação aos direitos sociais. ${ }^{74}$

Portanto, a complexa noção de saúde depende da reunião de todos esses fatores e apenas pode ser compreendida num determinado ambiente social, respeitando-se as diversas representações de saúde que nele existam. ${ }^{75}$

Somente em um Estado Democrático a comunidade poderá participar da elaboração destas decisões, que deverão ser construídas a partir de consensos sociais, com a finalidade de proteção e promoção da saúde. ${ }^{76}$ Daí a importância da educação dos indivíduos para a cidadania, com garantia de acesso às informações de interesse à saúde, como pressuposto para que possam ser promovidos debates, com a participação da sociedade, voltados à determinação do conteúdo normativo de saúde e à tomada de decisões relacionadas à temática da saúde pública.

\subsection{Fundamentação jurídico-política dos direitos sociais e do direito à saúde}

O estudo da saúde como um direito, especificamente um direito fundamental social consagrado pela Constituição Federal de 1988, recomenda a pesquisa dos principais fatos que contribuíram, ao longo da História, para que fosse conquistado, bem como dos instrumentos que asseguram sua proteção.

\footnotetext{
${ }^{73}$ Para ilustrar, vale citar o surto de Febre Aftosa que ocorreu no Paraguai, em 2011. Logo após o Paraguai ter notificado a Organização Mundial da Saúde Animal sobre um foco da doença em bovinos no seu território, o governo brasileiro proibiu a entrada de animais suscetíveis à febre aftosa e seus produtos em todo País e, ainda, orientou que os estados de Mato Grosso do Sul, Paraná, Santa Catarina e Rio Grande do Sul reforçassem as atividades de fiscalização e vigilâncias nas fronteiras internacionais, para impedir a reintrodução do vírus no Brasil e possibilitar a detecção precoce de qualquer sinal clínico da doença. Notícia disponível no Portal Brasil: <http://www.brasil.gov.br/>. Consulta em 15/10/2013.

${ }^{74} \mathrm{Na}$ visão de VENTURA, não se pode admitir que os interesses econômicos de Estados ou empresas prefiram aos direitos sociais, especialmente ao direito à saúde. Para a subsistência da espécie humana, defende a necessidade de que todas as ações em matéria econômica sejam precedidas de análise quanto as suas consequências no plano dos direitos humanos. VENTURA, Deisy de Freitas Lima. Uma visão internacional do direito à saúde. In: O Direito achado na rua: introdução crítica ao direito à saúde. COSTA, Alexandre Bernardino; SOUSA JÚNIOR, José Geraldo; DELDUQUE, Maria Célia; OLIVEIRA, Mariana Siqueira de Carvalho; DALLARI, Sueli Gandolfi (organizadores), v.4. Brasília: CEAD/UnB, p.85, 2009.

75 AITH, Fernando. A emergência do Direito Sanitário como um novo campo do Direito. In: Estudos de Direito Sanitário: a produção normativa e saúde. ROMERO, Luiz Carlos; DELDUQUE, Maria Célia (organizadores). Brasília: Senado Federal: Subsecretaria de Edições Técnicas, p. 17, 2011.

76 AITH, Fernando. A emergência do Direito Sanitário como um novo campo do Direito. In: Estudos de Direito Sanitário: a produção normativa e saúde. ROMERO, Luiz Carlos; DELDUQUE, Maria Célia (organizadores). Brasília: Senado Federal: Subsecretaria de Edições Técnicas, p. 37-38, 2011.
} 
O estudo histórico-dialético dos direitos sociais guarda relação com os chamados direitos de liberdade, afirmados pela primeira vez no final do século XVIII, na Declaração de Direitos do Estado da Virgínia, de 12 de junho de 1776, e estabelecida em 4 de julho do mesmo ano, anteriormente à independência das treze colônias inglesas da América do Norte. Em seguida, os novos Estados independentes seguiram o exemplo da Virgínia e anteriormente à adoção de suas constituições políticas editaram declarações de direitos. ${ }^{77}$

O Estado Contemporâneo em sua primeira forma substancial, de origem liberalburguesa, surgiu a partir da reivindicação de que o Estado se sujeitasse ao Direito e respeitasse as liberdades individuais. O movimento dos colonos ingleses ${ }^{78}$ na América do Norte $^{79}$ e a insurreição do povo na França foram manifestações do propósito de se estabelecer limites ao uso do poder pelos governantes. ${ }^{80}$

Neste cenário de agitações sociais e políticas intensas e do movimento radical de libertação das rédeas econômicas e estruturais da Revolução Francesa ${ }^{81}$, foi promulgada a

${ }^{77}$ FERREIRA FILHO, Manoel Gonçalves. Direitos Humanos fundamentais. 14. ed. São Paulo: Saraiva, 2012, p. 37-38.

${ }^{78}$ Como precedente histórico, FERREIRA FILHO destaca a Magna Carta, de 21 de junho de 1215, peça fundamental da constituição inglesa e de todo o constitucionalismo que, embora tenha sido outorgada por João sem Terra, é um pacto resultante do acordo entre esse rei e os barões insatisfeitos, apoiados pela burguesia de cidades como Londres. Segundo FERREIRA FILHO, apesar dessa Carta não tem por finalidade a afirmação de direitos do Homem, mas sim dos direitos dos ingleses, decorrentes da law of the land, ela enumera prerrogativas asseguradas a todos os súditos da monarquia, o que importa numa clara limitação do poder, e define garantias específicas para a hipótese de violação dos mesmos. A Magna Carta indica a judiciabilidade como um dos princípios do Estado de Direito, pois exige decisão judicial relativamente à prisão do homem livre, estabelecendo em seu item 39 que sem o julgamento legal dos seus pares, de conformidade com a lei da terra (law of land), nenhum homem livre será detido ou preso, ou despojado de seus bens, exilado ou prejudicado de qualquer maneira que seja. FERREIRA FILHO afirma que a Magna Carta foi confirmada e reconfirmada por monarcas, em diversos documentos outros, ante a reivindicação pelo Parlamento desses direitos fundamentais. Cita, por exemplo, a petition of Rigths, de 7 de junho de 1828, que reclama, dentre outros, o julgamento pelos pares para a privação da liberdade ou da propriedade, e o Bill of Rigths, de 13 de fevereiro de 1689, o qual afirma a independência do Parlamento, avançando no estabelecimento da separação dos Poderes. FERREIRA FILHO, Manoel Gonçalves. Direitos Humanos fundamentais. 14. ed. São Paulo: Saraiva, 2012, p. 29-30.

${ }^{79}$ Os ingleses levaram para a América do Norte as ideias representadas pelas expressões: rule of law, due processo of law e equal protection of the law. Segundo FERREIRA FILHO, rule of law significa a sujeição de todos, inclusive das autoridades, ao império do Direito, como limitação do poder num sistema de direito não escrito. O rule of law é expressão do sistema do Common Law, que inclui o direito judiciário inglês, o qual se desenvolveu a partir do século XII, com a consolidação do direito consuetudinário (law of the land). $\mathrm{O}$ due processo of law fez com que o direito evoluísse com racionalidade e preservação da liberdade. A utilização dessas fórmulas pelos tribunais americanos contribuiu para o desenvolvimento da doutrina dos direitos fundamentais nos séculos XIX e XX. FERREIRA FILHO, Manoel Gonçalves. Direitos Humanos fundamentais. 14. ed. São Paulo: Saraiva, 2012, p. 30-31.

${ }^{80}$ FERREIRA FILHO, Manoel Gonçalves. Direitos Humanos fundamentais. 14. ed. São Paulo: Saraiva, 2012, p. 19.

${ }^{81}$ A teoria de ROUSSEAU se desenvolveu como preceptora do movimento revolucionário francês, que culminou com a queda da Bastilha em 14 de julho de 1789. Para ROUSSEAU, com a passagem do estado natural para o estado civil, a conduta humana deixou de ser instintiva para ser de justiça, somada à 
Declaração dos Direitos do Homem e do Cidadão, em 26 de agosto de 1789, na França ${ }^{82}$, sintetizada num preâmbulo e dezessete artigos. Nessa declaração, foram solenemente consagrados os direitos de liberdade como direitos naturais, inalienáveis, invioláveis e imprescritíveis. Diversamente das antecedentes declarações de ingleses e americanos, a Declaração dos Direitos do Homem e do Cidadão estabeleceu como titulares todos os homens, indistintamente..$^{83} 84$

Assim, a despeito do pioneirismo da Declaração de Direitos do Povo da Virgínia, de 1776, foi a Declaração dos Direitos do Homem e do Cidadão, de 1789, a fonte de inspiração de outras constituições ${ }^{85}{ }^{86} \mathrm{e}$ declarações de direitos, devido à clareza de suas fórmulas ${ }^{87}$ e à universalidade formal e abstrata própria do jusnaturalismo do século XVIII.

moralidade. Os homens perderam a liberdade natural e o direito limitado às suas forças para ganhar a liberdade civil, que é a liberdade limitada pela vontade geral e a posse. A base de todo o sistema social em vez de destruir a igualdade natural a substitui por uma igualdade moral, considerando todos os homens iguais por convenção e por direito. ROUSSEAU, Jean Jacques. Contrato Social. Livro I, p.9-35. Disponível em: $<$ http://www.cfh.ufsc.br>. Acesso em 05/06/2013.

${ }^{82} \mathrm{Na}$ França, a primeira Constituição foi estabelecida em 1791, somente após a Declaração dos Direitos do Homem e do Cidadão. Até os dias atuais, a Declaração dos Direitos do Homem e do Cidadão permanece em vigor na França, com fundamento no preâmbulo da Constituição de 1958, integrando o chamado "bloco de constitucionalidade". FERREIRA FILHO explica que, por razões de economia de tempo e trabalho, posteriormente se passou a estabelecer num documento único a declaração de Direitos (o pacto social) e a Constituição (o pacto político). FERREIRA FILHO, Manoel Gonçalves. Direitos Humanos fundamentais. 14. ed. São Paulo: Saraiva, 2012, p. 23-24.

${ }^{83}$ BONAVIDES, Paulo. Curso de Direito Constitucional. 22.ed. São Paulo: Malheiros, 2008, p. 562.

${ }^{84}$ Naquele momento histórico de consolidação do Estado de Direito conforme os princípios do liberalismo, para que tais direitos fossem oponíveis ao rei, BARROS afirma que a burguesia os concebeu como naturais de todas as pessoas e, por isso, universais, incondicionais, imprescritíveis e inalienáveis, independentemente de qualquer condição pessoal ou social. BARROS, Sérgio Resende de. A difusão dos Direitos Humanos Fundamentais. In: Direitos fundamentais coletivos e difusos: questões sobre a fundamentalidade. KIM, Richard Pae; BARROS, Sérgio Resende de; KOSATA, Fausto Kozo Matsumoto (coordenadores). São Paulo: Editora Verbatim, p. 37-38, 2012.

85 A Constituição francesa de 24 de junho de 1793 reafirmou os direitos humanos já reconhecidos pela Declaração dos Direitos do Homem e do Cidadão, de 26 de agosto de 1789, e estabeleceu outros, como o direito social aos socorros públicos, previsto em seu artigo 21: "Art. 21. Les secours publics sont une dette sacrée. La société doit la subsistance aux citoyens malheureux, soit em leur procurant du travail, soit em assurant les moyens d'exister à ceux qui sont hors d'état de travailler". Disponível em: <http://www.elysee.fr>. Consulta em: 08 de maio de 2013. Conforme a tradução de Manoel Gonçalves Ferreira Filho, "Art. 21. Os socorros públicos são uma dívida sagrada. A sociedade deve a subsistência aos cidadãos infelizes, quer seja procurando-lhes trabalho, quer seja assegurando os meios de existência àqueles que são impossibilitados de trabalhar." FERREIRA FILHO, Manoel Gonçalves. Direitos Humanos fundamentais. 14. ed. São Paulo: Saraiva, 2012, p. 63.

86 A influência da Declaração dos Direitos do Homem e do Cidadão também é evidente no constitucionalismo brasileiro desde a primeira Constituição, de 1824, que, adotando as ideias do liberalismo, criou um Estado monárquico, constitucional e representativo (art. $3^{\circ}$ ), estabeleceu a separação dos Poderes (arts. $9^{\circ}$ e 10) e a realização de eleições (arts. 12 e 90 a 97), e consagrou direitos civis e políticos aos cidadãos brasileiros, que ao Estado incumbia assegurar (art. 179).

${ }^{87}$ FERREIRA FILHO, Manoel Gonçalves. Direitos Humanos fundamentais. 14. ed. São Paulo: Saraiva, 2012, p. 38 . 
O avanço gerado pelo liberalismo econômico e político, a postura abstencionista do Estado, a reivindicação pelo sufrágio universal ${ }^{88}$ e as regras decorrentes das Revoluções Americana e Francesa, geraram a deterioração do quadro social, sobretudo nos Estados mais desenvolvidos da Europa ocidental, como a Grã-Bretanha e a França ${ }^{89}$, e um pouco mais tarde nos Estados Unidos. Este processo de desenvolvimento capitalista provocou concentração de renda na burguesia e o acirramento da luta de classes sociais. ${ }^{90}$

O lema da Revolução francesa do século XVIII exprimiu em três princípios nucleares o conteúdo dos direitos fundamentais, estabelecendo até mesmo a sequência histórica de sua gradativa institucionalização nas constituições dos Estados: liberdade, igualdade e fraternidade. ${ }^{91} 92$

Os direitos de liberdade têm por titular o indivíduo e consistem em faculdades de resistência ou de oposição perante o Estado, apresentando como característica a subjetividade. Na ordem dos valores políticos, os direitos de liberdade evidenciam a separação entre a Sociedade e o Estado. ${ }^{93}$

Ante a necessidade de corrigir as desigualdades sociais marcantes no século XIX, foram introduzidos novos direitos fundamentais no constitucionalismo das diversas formas de Estado social, baseados na ideologia antiliberal do século XX: os direitos sociais, econômicos e culturais, bem como os direitos coletivos, conhecidos como direitos de segunda dimensão ${ }^{94}$. Tais direitos vieram a complementar a primeira dimensão dos direitos

88 A reivindicação pelo sufrágio universal vinha ao encontro dos princípios da Revolução de 1789 , especialmente do princípio da isonomia, e tornou-se mais intensa na medida em que maior número de trabalhadores adquiria direitos políticos (voto e elegibilidade) devido à redução do censo exigido para tanto. Os movimentos ou partidos que buscavam o voto desses "novos cidadãos" representaram um fator político de peso no sentido da reforma política e social. FERREIRA FILHO, Manoel Gonçalves. Direitos Humanos fundamentais. 14. ed. São Paulo: Saraiva, 2012, p.61.

${ }^{89}$ Em 4 de novembro de 1948 foi promulgada a Constituição francesa, que reconheceu os direitos humanos, dedicando um capítulo para enuncia-los. Nesta época, a Europa ainda vivenciava graves conflitos sociais, sobretudo em Paris, onde havia movimentos de trabalhadores e desempregados. FERREIRA FILHO, Manoel Gonçalves. Direitos Humanos fundamentais. 14. ed. São Paulo: Saraiva, 2012, p. 63-64.

${ }^{90}$ Neste contexto, FERREIRA FILHO relata o surgimento da Questão Social, que envolve a marginalização da classe trabalhadora, a ausência de proteção corporativa, a omissão do poder político, a menor necessidade de mão de obra devido às novas máquinas e as condições insalubres e periculosas de trabalho. FERREIRA FILHO, Manoel Gonçalves. Direitos Humanos fundamentais. 14. ed. São Paulo: Saraiva, 2012, p. 59-61. ${ }^{91}$ BONAVIDES, Paulo. Curso de Direito Constitucional. 22.ed. São Paulo: Malheiros, 2008, p. 562-564.

92 AITH afirma que "a fraternidade ou solidariedade se expressa como o conjunto de regras voltadas a um escopo comum de progresso e melhoria da qualidade de vida de todos aqueles que compõem o grupo social, determinando que um dos grandes objetivos do ser humano é possuir uma sociedade que ofereça a todos os seus integrantes a igualdade material”. AITH, Fernando. Curso de Direito Sanitário: a proteção do Direito à Saúde no Brasil. São Paulo: Quartier Latin. 2007, p. 68.

${ }^{93}$ BONAVIDES, Paulo. Curso de Direito Constitucional. 22.ed. São Paulo: Malheiros, 2008, p. 563-564.

${ }^{94}$ BONAVIDES, Paulo. Curso de Direito Constitucional. 22.ed. São Paulo: Malheiros, 2008, p. 564-565. 
fundamentais, impondo ao Estado o dever de promover ações ou serviços com o objetivo de assegurar a igualdade material entre os cidadãos.

O primeiro texto constitucional que reconheceu os direitos sociais e econômicos foi a Constituição mexicana, de $1917^{95}$, seguida pela Constituição alemã de 1919, promulgada pela Assembleia Constituinte em Weimar, que se tornou memorável por estabelecer um novo modelo concernente aos direitos e deveres fundamentais dos alemães. A Constituição alemã de 1919 foi copiada por outras Constituições editadas na Europa e pelo mundo afora, como a Constituição brasileira de 1934, que foi a pioneira no constitucionalismo pátrio a enunciar uma Ordem Econômica e Social (Título IV). ${ }^{96} 97$

No início do século XIX já não havia dúvida de que a saúde da população estava relacionada às suas condições de vida e que os comportamentos humanos podem se constituir em ameaça à saúde do povo e, consequentemente, à segurança do Estado. Contudo, o reconhecimento da necessidade de proteção da saúde para a manutenção das relações harmoniosas entre todos os países, somente foi reforçada após o flagelo da Segunda Guerra Mundial. ${ }^{98}$

Em face das monstruosas violações de direitos humanos cometidas pelo nazismo e da crença de que parte dessas violações poderia ser prevenida se houvesse um sistema de proteção desses direitos na esfera internacional, emerge a necessidade de reconstrução do valor dos direitos humanos, como paradigma ético a orientar a ordem internacional. ${ }^{99} 100$

\footnotetext{
95 FERREIRA FILHO critica o entendimento de que a Constituição mexicana de 1917 seja considerada o marco consagrador dos direitos econômicos e sociais, pois esta Carta não espelha a segunda geração dos direitos fundamentais nem teve grande repercussão na América Latina. Observa que esta Carta apresenta o nacionalismo, a reforma agrária, a hostilidade em relação ao poder econômico e um elenco dos direitos do trabalhador sem garantir propriamente o direito ao trabalho. FERREIRA FILHO sustenta que a Parte XIII do Tratado de Versalhes, de 28 de junho de 1919, pelo qual foram definidas as condições de paz entre os Aliados e a Alemanha, teve maior importância para a consagração dos direitos dos trabalhadores, considerados fundamentais e obrigatórios para todos os Estados signatários do referido Tratado. FERREIRA FILHO, Manoel Gonçalves. Direitos Humanos fundamentais. 14. ed. São Paulo: Saraiva, 2012, p. 64-65.

96 FERREIRA FILHO, Manoel Gonçalves. Direitos Humanos fundamentais. 14. ed. São Paulo: Saraiva, 2012 , p. 67.

97 No mesmo sentido, a Declaração Soviética dos Direitos do Povo Trabalhador e Explorado, de 1918, atribuiu aos trabalhadores a titularidade de direitos e garantias, atribuindo ao Estado o dever de promoção para a construção de uma sociedade igualitária. A Constituição soviética de 1936 consolidou esses direitos fundamentais, estabelecendo, expressamente, direitos trabalhistas, direito à educação, direito ao amparo material aos idosos e direito a serviços médicos gratuitos.

98 DALLARI, Sueli Gandolfi. Direito Sanitário: fundamentos, teoria e efetivação. In: Direito Sanitário: saúde e direito, um diálogo possível. AITH, Fernando; SATURNINO, Luciana Tarbes Mattana; DINIZ, Maria Gabriela Araújo; MONTEIRO, Tammy Claret (organizadores). Belo Horizonte: ESP-MG, p.49, 2010.

99 Para aprofundar o estudo da proteção internacional dos direitos humanos, conferir: PIOVESAN, Flávia. Temas de Direitos Humanos. 6.ed. São Paulo: Saraiva, 2013, sobretudo os capítulos 1, 2 e 3.
} 
Neste cenário, foi fortalecida a noção de que proteger os direitos humanos consistia em tema de interesse internacional, da qual decorreram duas importantes consequências: a revisão da noção tradicional de soberania absoluta dos Estados, que passou a sofrer um processo de relativização, na medida que se admite o monitoramento e a responsabilização no plano nacional, nos casos de violação dos direitos humanos; e a sedimentação do entendimento de que o indivíduo deve ter direitos protegidos na esfera internacional, na condição de sujeito de Direito. ${ }^{101}$

A partir do pós-guerra, em 1945, e inspirada por estas concepções, a Organização das Nações Unidas ${ }^{102}$ (ONU) foi criada ${ }^{103}$ em decorrência do interesse dos Estados que

100 Sobre o aspecto terminológico é preciso observar que as expressões "direitos humanos" e "direitos fundamentais" não são equivalentes. Embora ambas se refiram a direitos atribuídos às pessoas pelo simples fato de pertencerem ao gênero humano, não sendo, portanto, noções incompatíveis, elas apresentam significado diverso em parte, pois os direitos humanos guardam relação com os direitos da pessoa humana reconhecidos pela ordem jurídica internacional, ao passo que os direitos fundamentais são concebidos como os direitos reconhecidos e positivados na ordem jurídica interna. Neste sentido, SARLET observa que os direitos humanos compreendem os direitos reconhecidos em documentos de direito internacional, ao ser humano como tal, independentemente de seu vínculo com determinada ordem constitucional, e que aspiram validade universal, para todos os povos e em todos os lugares, revelando um caráter supranacional e universal, enquanto os direitos fundamentais se referem aos direitos consolidados na esfera do direito constitucional positivo de determinado Estado e, assim, possuem contornos mais precisos e restritos. Afirma, ainda, que em sua vertente histórica, tanto os direitos humanos, como os direitos fundamentais, têm suas raízes no reconhecimento, pelo direito positivo, de um conjunto de direitos anteriormente concebidos como direitos naturais da pessoa humana, que assumem uma dimensão anterior à existência do Estado. SARLET, Ingo Wolfgang; MARINONI, Guilherme; MITIDIERO, Daniel. Curso de Direito Constitucional. 2. ed. São Paulo: Editora Revista dos Tribunais, 2013, p. 259-263. BARROS adverte que direitos humanos e direitos fundamentais são institutos que não devem ser separados, uma vez que todos os direitos humanos são fundamentais para a construção e a preservação da humanidade. BARROS realça que a expressão "direitos do homem" era utilizada em sentido amplo para se referir aos direitos fundamentais de ambos os gêneros da espécie humana (masculino e feminino), mas foi considerada discriminatória pelas mulheres, tendo se passado a utilizar "direitos humanos". BARROS, Sérgio Resende de. A difusão dos Direitos Humanos Fundamentais: In: Direitos fundamentais coletivos e difusos: questões sobre a fundamentalidade. KIM, Richard Pae; BARROS, Sérgio Resende de; KOSATA, Fausto Kozo Matsumoto (coordenadores). São Paulo: Editora Verbatim, p. 37-39, 2012.

${ }^{101}$ PIOVESAN, Flávia. Temas de Direitos Humanos. 6.ed. São Paulo: Saraiva, 2013, p.47.

102 PORTELA explica que a Organização das Nações Unidas (ONU) representa um marco no desenvolvimento do Direito Internacional, porque é um organismo de caráter universal, aberto à discussão de qualquer tema que transcenda as fronteiras dos entes estatais ou que possa ser objeto de cooperação internacional. Todos os Estados do mundo que aceitarem as obrigações contidas na Carta das Nações Unidas e que, a juízo da Organização, estejam aptos e dispostos a cumpri-las, podem ser membros da ONU. A admissão de Estados na ONU é decidida por sua Assembleia Geral, mediante recomendação do Conselho de Segurança da entidade. A ONU sucedeu a Liga das Nações, também conhecida como Sociedade das Nações (SDN), que existiu entre 1919 e 1947 e tinha sede em Genebra. A entidade tinha vocação universal e baseava-se em princípios como a segurança coletiva, a igualdade entre os Estados, a proscrição da guerra, a solução pacífica das controvérsias e a observância dos tratados. Contudo, a Liga das Nações fracassou frente à intensificação de tensões que levou à II Guerra Mundial, a adoção da regra da unanimidade para aprovação das principais decisões da entidade e a não-participação de Estados importantes, como os Estados Unidos da América. PORTELA, Paulo Henrique Gonçalves. Direito Internacional Público e Privado. 3. ed. Bahia: JusPODIVM. 2011, p. 241- 243. 
venceram o conflito em reorganizar o mundo com o auxílio de uma organização baseada na igualdade soberana entre os Estados e dirigida, prioritariamente, à manutenção da paz e da segurança internacional.

Dentre os objetivos da Organização das Nações Unidas, previstos no artigo $1^{\circ}$ da Carta das Nações Unidas ${ }^{104}$, cumpre destacar a cooperação internacional para resolver problemas de caráter econômico, social, cultural ou humanitário dos Estados, e para promover e estimular o respeito aos direitos humanos e às liberdades fundamentais de todos, sem distinção de raça, sexo, língua ou religião.

Ao tratar da Cooperação internacional Econômica e Social, a Carta das Nações Unidas orienta as Nações a perseguirem condições de estabilidade e bem-estar indispensáveis às relações pacíficas, com esteio no princípio da igualdade de direitos e autodeterminação dos povos. Prevê o dever da Organização das Nações Unidas de criar condições para: alcançar os níveis mais altos de vida, trabalho efetivo e condições de progresso e desenvolvimento econômico e social; solucionar problemas internacionais econômicos, sociais, sanitários e conexos; a cooperação internacional de caráter cultural e educacional; e o respeito universal e efetivo dos direitos humanos e das liberdades fundamentais. ${ }^{105}$

${ }^{103}$ A Carta das Nações Unidas para a criação da ONU foi firmada em 26 de junho de 1945, por ocasião da Conferência de São Francisco. As atividades da ONU tiveram início em 24 de outubro de 1945. Sediada em Nova Iorque (EUA) e em Genebra (Suíça), a ONU conta com diversas sedes, órgãos e representações distribuídas ao redor do mundo. PORTELA, Paulo Henrique Gonçalves. Direito Internacional Público e Privado. 3 ed. Bahia: JusPODIVM. 2011, p. 241.

104 “ARTIGO 1 - Os propósitos das Nações unidas são: 1. Manter a paz e a segurança internacionais e, para esse fim: tomar, coletivamente, medidas efetivas para evitar ameaças à paz e reprimir os atos de agressão ou outra qualquer ruptura da paz e chegar, por meios pacíficos e de conformidade com os princípios da justiça e do direito internacional, a um ajuste ou solução das controvérsias ou situações que possam levar a uma perturbação da paz; 2. Desenvolver relações amistosas entre as nações, baseadas no respeito ao princípio de igualdade de direitos e de autodeterminação dos povos, e tomar outras medidas apropriadas ao fortalecimento da paz universal; 3. Conseguir uma cooperação internacional para resolver os problemas internacionais de caráter econômico, social, cultural ou humanitário, e para promover e estimular o respeito aos direitos humanos e às liberdades fundamentais para todos, sem distinção de raça, sexo, língua ou religião; e 4. Ser um centro destinado a harmonizar a ação das nações para a consecução desses objetivos comuns."

105 “ARTIGO 55 - Com o fim de criar condições de estabilidade e bem estar, necessárias às relações pacíficas e amistosas entre as Nações, baseadas no respeito ao princípio da igualdade de direitos e da autodeterminação dos povos, as Nações Unidas favorecerão: a) níveis mais altos de vida, trabalho efetivo e condições de progresso e desenvolvimento econômico e social; b) a solução dos problemas internacionais econômicos, sociais, sanitários e conexos; a cooperação internacional, de caráter cultural e educacional; e c) o respeito universal e efetivo dos direitos humanos e das liberdades fundamentais para todos, sem distinção de raça, sexo, língua ou religião." 
Para a realização de suas metas, a Carta das Nações Unidas ${ }^{106}$ prescreve que sejam criados organismos especializados, por acordos entre os Estados, com competências específicas nos campos econômico, social, cultural, educacional, sanitário e outros conexos. Embora compartilhem os símbolos, princípios e missões da Organização das Nações Unidas, tais instituições possuem personalidade jurídica própria ${ }^{107}$, e, somadas, formam o Sistema das Nações Unidas. ${ }^{108}$

Dentre os organismos especializados da Organização das Nações Unidas, importa destacar a Organização Mundial de Saúde (OMS), criada com a finalidade precípua de instituir padrões mínimos de cuidados à saúde em todo o mundo, para garantir o direito à saúde a todas as pessoas. A Organização Mundial de Saúde é a entidade responsável por coordenar as negociações e ações internacionais sobre saúde, formatar a agenda de pesquisa sobre esta matéria, estabelecer normas, propor políticas públicas de saúde e monitorar as condições sanitárias no mundo. Da mesma forma, a Organização Mundial de Saúde exerce atividades concernentes ao saneamento básico, à nutrição, a higiene, aos medicamentos e ao ensino na área de saúde, dentre outros. ${ }^{109}$

A Constituição da Organização Mundial de Saúde ${ }^{110}$, produzida na cidade de Nova Iorque em 22 de julho de 1946, representou notável progresso ao conceituar a saúde como

\footnotetext{
106“ARTIGO 57 - 1. As várias entidades especializadas, criadas por acordos intergovernamentais e com amplas responsabilidades internacionais, definidas em seus instrumentos básicos, nos campos econômico, social, cultural, educacional, sanitário e conexos, serão vinculadas às Nações Unidas, de conformidade com as disposições do Artigo 63. 2. Tais entidades assim vinculadas às Nações Unidas serão designadas, daqui por diante, como entidades especializadas."

${ }^{107}$ No caso da Organização Mundial da Saúde, o artigo 66 de sua Constituição prevê o seguinte: "Artigo 66. A Organização gozará no território de cada Estado membro da capacidade jurídica que seja necessária para alcançar os seus fins e para o desempenho das suas funções."

108 PORTELA, Paulo Henrique Gonçalves. Direito Internacional Público e Privado. 3. ed. Bahia: JusPODIVM, 2011, p. 249-250.

109 PORTELA, Paulo Henrique Gonçalves. Direito Internacional Público e Privado. 3. ed. Bahia: JusPODIVM, 2011, p. 250.

${ }^{110} \mathrm{O}$ texto original prevê o seguinte: "Constitution of the World Health Organization. The States Parties to this Constitution declare, in conformity with the Charter of the United Nations, that the following principles are basic to the happiness, harmonious relations and security of all peoples: Health is a state of complete physical, mental and social well-being and not merely the absence of disease or infirmity. The enjoyment of the highest attainable standard of health is one of the fundamental rights of every human being without distinction of race, religion, political belief, economic or social condition. The health of all peoples is fundamental to the attainment of peace and security and is dependent upon the fullest co-operation of individuals and States. The achievement of any State in the promotion and protection of health is of value to all. Unequal development in different countries in the promotion of health and control of disease, especially communicable disease, is a common danger. Healthy development of the child is of basic importance; the ability to live harmoniously in a changing total environment is essential to such development. The extension to all peoples of the benefits of medical, psychological and related knowledge is essential to the fullest attainment of health. Informed opinion and active co-operation on the part of the public are of the utmost importance in the improvement of the health of the people. Governments have a responsibility for the health
} 
o "o estado de completo bem-estar físico, mental e social, e não somente a ausência de doenças ou enfermidades", consagrando a importância dos aspectos individual e coletivo da saúde, e da relação harmoniosa do indivíduo com o ambiente em que está socialmente inserido. Além desse conceito preciso, referencial à elaboração de normas em matéria de saúde, esse documento internacional salienta a simultaneidade da existência de deveres por parte dos Estados e também de direitos e deveres das pessoas. ${ }^{111}$

O preâmbulo da Constituição da Organização Mundial de Saúde ${ }^{112}$ exalta a saúde, ao mesmo tempo, nas acepções de direito fundamental ${ }^{113}$, bem coletivo ${ }^{114}$ e bem jurídico de desenvolvimento ${ }^{115}$

of their peoples which can be fulfilled only by the provision of adequate health and social measures." Disponível em: <http://apps.who.int>. Consulta em 05/11/2013. Em tradução livre: Constituição da Organização Mundial de Saúde. Os Estados Partes desta Constituição declaram, em conformidade com a Carta das Nações Unidas, que os seguintes princípios são fundamentais para a felicidade, as relações harmoniosas e a segurança de todos os povos: Saúde é um estado de completo bem-estar físico, mental e social e não apenas a ausência de doença ou enfermidade. O gozo do mais alto nível possível de saúde é um dos direitos fundamentais de todo ser humano, sem distinção de raça, religião, convicção política, condição econômica ou social. A saúde de todos os povos é fundamental para a consecução da paz e da segurança e depende da cooperação máxima dos indivíduos e dos Estados. A realização da promoção e proteção da saúde por qualquer Estado tem valor para todos. Desenvolvimento desigual nos diferentes países na promoção da saúde e controle de doenças, especialmente doenças transmissíveis, é um perigo comum. Desenvolvimento saudável da criança é de fundamental importância; a capacidade de viver harmoniosamente em um ambiente de total mudança é essencial para tal desenvolvimento. A extensão a todos os povos os benefícios dos conhecimentos médicos, psicológicos e outros relacionados, é essencial para a realização plena da saúde. Opinião informada e ativa cooperação por parte do público são da maior importância na melhoria da saúde das pessoas. Os governos têm a responsabilidade pela saúde de seus povos, que somente pode ser cumprida através de prestações adequadas de saúde e políticas sociais.

${ }^{111}$ Conforme DALLARI e NUNES JÚNIOR, a saúde é um fenômeno polifacético, sendo imprescindível a ampla cooperação de Estados e indivíduos para resguardar o bem-estar de cada um. Neste sentido, apontam a transmissibilidade de parte considerável das doenças e as pandemias que se originam num determinado país e ganham contornos planetários. DALLARI, Sueli Gandolfi e NUNES JÚNIOR, Vidal Serrano. Direito Sanitário. São Paulo: Editora Verbatim, 2010, p. 8-9.

112 "Os Estados Membros desta Constituição declaram, em conformidade com a Carta das Nações Unidas, que os seguintes princípios são basilares para a felicidade dos povos, para as suas relações harmoniosas e para a sua segurança: A saúde é um estado de completo bem-estar físico, mental e social, e não consiste apenas na ausência de doença ou de enfermidade. Gozar do melhor estado de saúde que é possível atingir constitui um dos direitos fundamentais de todo o ser humano, sem distinção de raça, de religião, de credo político, de condição econômica ou social. A saúde de todos os povos é essencial para conseguir a paz e a segurança e depende da mais estreita cooperação dos indivíduos e dos Estados. Os resultados conseguidos por cada Estado na promoção e proteção da saúde são de valor para todos. O desigual desenvolvimento em diferentes países no que respeita à promoção de saúde e combate às doenças, especialmente contagiosas, constitui um perigo comum. O desenvolvimento saudável da criança é de importância basilar; a aptidão para viver harmoniosamente num meio variável é essencial a tal desenvolvimento. A extensão a todos os povos dos benefícios dos conhecimentos médicos, psicológicos e afins é essencial para atingir o mais elevado grau de saúde. Uma opinião pública esclarecida e uma cooperação ativa da parte do público são de uma importância capital para o melhoramento da saúde dos povos. Os Governos têm responsabilidade pela saúde dos seus povos, a qual só pode ser assumida pelo estabelecimento de medidas sanitárias e sociais adequadas. Aceitando estes princípios com o fim de cooperar entre si e com os outros para promover e proteger a saúde de todos os povos, as partes contratantes concordam com a presente Constituição e estabelecem a 
No concernente à acepção da saúde como bem jurídico de desenvolvimento, cumpre mencionar a discussão existente acerca da proteção das patentes de medicamentos, sobre a qual a doutrina não chegou a um consenso. Há, em suma, dois pontos de vista sobre as patentes: como óbice à universalização do acesso aos medicamentos; e como incentivo ao investimento econômico em pesquisa científica, à inovação e à garantia de qualidade. Por uma abordagem, o direito à saúde deveria prevalecer sobre o direito de propriedade intelectual, a fim de que os medicamentos se tornassem acessíveis ao grande público. Para os defensores desta posição, a redução dos custos com a saúde consiste no interesse público a ser protegido em detrimento dos interesses econômicos da indústria farmacêutica. ${ }^{116} 117$ De outo lado, há quem defensa a necessidade de proteção da propriedade intelectual como garantia da continuidade do fornecimento de medicamentos

Organização Mundial da Saúde como um organismo especializado, nos termos do artigo 57 da Carta das Nações Unidas."

${ }^{113}$ A saúde como direito fundamental está prevista no preâmbulo da Constituição da Organização Mundial de Saúde ao consagrar o direito fundamental do ser humano de gozar do melhor estado de saúde que é possível alcançar, independentemente de raça, religião, preferência política, condição econômica ou social.

${ }^{114}$ A saúde enquanto bem coletivo está prevista no preâmbulo da Constituição da Organização Mundial de Saúde ao reconhecer a essencialidade da saúde de todos os povos para conseguir a paz e a segurança mundiais, alertando para o perigo comum decorrente da desigualdade de desenvolvimento dos diferentes países no tocante à promoção de saúde e ao combate às doenças, especialmente contagiosas e, ainda, a importância da cooperação dos indivíduos e dos Estados para alcançar melhores resultados na promoção e proteção da saúde.

${ }_{115}$ Na perspectiva de um bem jurídico de desenvolvimento, a saúde está inserida no preâmbulo da Constituição da Organização Mundial de Saúde ao prever a importância universal dos resultados conseguidos por cada Estado na promoção e proteção da saúde e os perigos decorrentes do desigual desenvolvimento dos países na promoção de saúde e combate às doenças, especialmente contagiosas. Para a mais ampla realização do direito à saúde, estabelece a necessidade de difusão a todos os povos dos benefícios do conhecimento científico (médico, psicológico e afins) conseguidos por cada Estado na área da saúde.

${ }^{116}$ Para PIOVESAN, os contornos do direito de propriedade intelectual devem ser definidos considerando sua função social e a necessária proteção dos direitos sociais, econômicos e culturais, transitando, assim, de um paradigma liberal individualista e protetivo exclusivamente dos direitos do autor à sua produção científica para um paradigma coletivista, que contemple as dimensões sociais do direito à propriedade intelectual e à propriedade industrial. Afirma que não há, em regra, conflito entre os direitos do autor e os direitos sociais de toda uma coletividade, mas, sim, entre os direitos de exploração comercial (por vezes abusiva) e os direitos sociais da coletividade. PIOVESAN, Flávia. Temas de Direitos Humanos. 6.ed. São Paulo: Saraiva, 2013, p.199-222.

${ }^{117}$ Para DALLARI, não se pode olvidar o fato de que os medicamentos constituem insumo terapêutico de primeira necessidade para os cuidados com a saúde da população e que a concessão de uma patente farmacêutica ao mesmo tempo em que representa estímulo ao progresso científico e tecnológico e garantia ao direito de propriedade de seus titulares, gera preocupações quanto ao abuso desse direito e suas consequências para a saúde da população que não tem recursos para adquirir medicamentos. DALLARI, Sueli Gandolfi. O conteúdo do direito à saúde. In: O Direito achado na rua: introdução crítica ao direito à saúde. COSTA, Alexandre Bernardino; SOUSA JÚNIOR, José Geraldo; DELDUQUE, Maria Célia; OLIVEIRA, Mariana Siqueira de Carvalho; DALLARI, Sueli Gandolfi (organizadores), v.4. Brasília: CEAD/UnB, p.95, 2009. 
inovadores, de elevada qualidade, segurança e eficácia, especialmente para a proteção da saúde a médio e longo prazo, a nível nacional e internacional. ${ }^{118} 119$

O preâmbulo da Constituição da Organização Mundial de Saúde dispõe, também, que a preservação do bem-estar de cada um depende da farta cooperação entre Estados e indivíduos. No tocante aos Estados, prevê que o dever para com a saúde das pessoas envolve a promoção de medidas sociais e sanitárias adequadas, a apresentação de informações e esclarecimentos em matéria de saúde. Aos indivíduos, por sua vez, cabe adotar cuidados de higiene, sanitários e ambientais, e cooperar ativamente para a melhoria da saúde de todos. ${ }^{120}$

A Organização Mundial de Saúde tem por finalidade a harmonização das normas sanitárias nacionais e o avanço da normatização sanitária internacional ${ }^{121}$, para que todos os povos possam alcançar o nível de saúde mais elevado possível. ${ }^{122}$ Constam da Constituição da Organização Mundial de Saúde as funções dessa organização ${ }^{123}$, a

${ }^{118}$ Esta é a posição sustentada por MACHADO e RAPOSO. Para aprofundar os estudos sobre este tema, conferir: MACHADO, Jónatas E.M.; RAPOSO, Vera Lúcia. Direito à saúde e qualidade dos medicamentos: proteção dos dados de ensaios clínicos numa perspectiva de direito brasileiro, comparado e internacional. Coimbra: Almedina, 2010.

${ }^{119}$ Segundo BARROSO, a propriedade industrial pode consistir em um óbice a uma eficiente proteção da saúde, porém para que haja restrição a um direito fundamental (propriedade industrial) em favor da realização de uma meta coletiva (proteção da saúde), é necessário que esta corresponda aos valores políticos fundamentais que a Constituição consagra. Em face do confronto entre o interesse público primário consistente na garantia de um direito fundamental (propriedade industrial) e o interesse público primário consubstanciado em uma meta coletiva (proteção da saúde), a solução a ser dada pelo intérprete deverá observar, sobretudo, dois parâmetros: razão pública e dignidade humana. BARROSO explica que a razão pública consiste no emprego de elementos constitucionais essenciais e princípios consensuais de justiça encontrados num ambiente de pluralismo político, ao passo que o princípio da dignidade humana significa, em seu núcleo, que cada indivíduo deve ser tratado como um fim em si mesmo e não como meio para a realização de metas coletivas ou de outras metas individuais. Por consequência, se a concretização de determinada política represente importante meta coletiva, mas implique em violação da dignidade humana, ainda que de uma única pessoa, conclui que tal política deve ser preterida. BARROSO, Luís Roberto. Curso de Direito Constitucional contemporâneo: os conceitos fundamentais e a construção do novo modelo. São Paulo: Saraiva, 2009, p. 71-72.

${ }^{120}$ Nos termos em que prescreve o preâmbulo: "uma opinião pública esclarecida e uma cooperação ativa da parte do público são de suma importância capital para o melhoramento da saúde dos povos".

${ }^{121}$ VENTURA, Deisy de Freitas Lima. Uma visão internacional do direito à saúde. In: O Direito achado na rua: introdução crítica ao direito à saúde. COSTA, Alexandre Bernardino; SOUSA JÚNIOR, José Geraldo; DELDUQUE, Maria Célia; OLIVEIRA, Mariana Siqueira de Carvalho; DALlARI, Sueli Gandolfi (organizadores), v.4. Brasília: CEAD/UnB, p.83, 2009.

${ }^{122}$ Nos termos do artigo 1 da Constituição da OMS, "Artigo 1. O objetivo da Organização Mundial da Saúde (daqui em diante denominada Organização) será a aquisição, por todos os povos, do nível de saúde mais elevado que for possível."

123 "Artigo 2. Para conseguir o seu objetivo, as funções da Organização serão: a) Atuar como autoridade diretoria e coordenadora dos trabalhos internacionais no domínio da saúde; b) Estabelecer e manter colaboração efetiva com as Nações Unidas, organismos especializados, administrações sanitárias governamentais, grupos profissionais e outras organizações que se julgue apropriado; c) Auxiliar os Governos, a seu pedido, a melhorar os serviços de saúde; d) Fornecer a assistência técnica apropriada e, em 
possibilidade de todos os Estados serem admitidos na qualidade de membro ${ }^{124}$, a garantia de seu funcionamento pela Assembleia Mundial da Saúde, Conselho Executivo e Secretariado ${ }^{125}$, a forma de composição e as atribuições de cada um de seus órgãos ${ }^{126}$.

Uma das atribuições mais importantes da Organização Mundial de Saúde consiste na aplicação do Regulamento Sanitário Internacional (RSI) elaborado em 1951, revisado em 2005 e vigente a partir de 15 de junho de $2007 .{ }^{127}$

Atualmente, devido ao desenvolvimento dos fluxos migratórios e dos meios de transporte há um compartilhamento dos riscos sanitários decorrentes de acidentes nucleares (como Chernobil) e da propagação de doenças (como o HIV, a febre Ebola, a gripe aviária, dentre outras). Por estes fatores, o Regulamento Sanitário Internacional (RSI) deve ser constantemente revisado, especialmente para: prever a notificação obrigatória de "novas

caso de urgência, a ajuda necessária, a pedido dos Governos ou com o seu consentimento; e) Prestar ou ajudar a prestar, a pedido das Nações Unidas, serviços sanitários e facilidades a grupos especiais, tais como populações de territórios sob tutela; f) Estabelecer e manter os serviços administrativos e técnicos julgados necessários, compreendendo os serviços de epidemiologia e de estatística; g) Estimular e aperfeiçoar os trabalhos para eliminar doenças epidêmicas, endêmicas e outras; h) Promover, em cooperação com outros organismos especializados, quando for necessário, a prevenção de danos por acidente; i) Promover, em cooperação com outros organismos especializados, quando for necessário, o melhoramento da alimentação, da habitação, do saneamento, do recreio, das condições econômicas e de trabalho e de outros fatores de higiene do meio ambiente; j) Promover a cooperação entre os grupos científicos e profissionais que contribuem para o progresso da saúde; k) Propor convenções, acordos e regulamentos e fazer recomendações respeitantes a assuntos internacionais de saúde e desempenhar as funções que neles sejam atribuídas à Organização, quando compatíveis com os seus fins; 1) Promover a saúde e o bem-estar da mãe e da criança e favorecer a aptidão para viver harmoniosamente num meio variável; m) Favorecer todas as atividades no campo da saúde mental, especialmente as que afetam a harmonia das relações humanas; n) Promover e orientar a investigação no domínio da saúde; o) Promover o melhoramento das normas de ensino e de formação prática do pessoal sanitário, médico e de profissões afins; p) Estudar e relatar, em cooperação com outros organismos especializados, quando for necessário, as técnicas administrativas e sociais referentes à saúde pública e aos cuidados médicos sob os pontos de vista preventivo e curativo, incluindo os serviços hospitalares e a segurança social; q) Fornecer informações, pareceres e assistência no domínio da saúde; r) Ajudar a formar entre todos os povos uma opinião pública esclarecida sobre assuntos de saúde; s) Estabelecer e rever, conforme for necessário, a nomenclatura internacional das doenças, das causas de morte e dos métodos de saúde pública; t) Estabelecer normas para métodos de diagnóstico, conforme for necessário;

u) Desenvolver, estabelecer e promover normas internacionais com respeito aos alimentos, aos produtos biológicos, farmacêuticos e semelhantes; v) Dum modo geral, tomar as medidas necessárias para alcançar os fins da Organização."

124 "Artigo 3. A qualidade de membro da Organização é acessível a todos os Estados."

125 “Artigo 9. O funcionamento da Organização é assegurado por: a) A Assembleia Mundial da Saúde (daqui em diante denominada Assembleia da Saúde); b) O Conselho Executivo (daqui em diante denominado Conselho); c) O Secretariado."

${ }^{126}$ Os artigos 10 a 23 da Constituição da OMS tratam da Assembleia Mundial da Saúde, os artigos 24 a 29 do Conselho Executivo e, por sua vez, os artigos 30 a 37 do Secretariado.

127 VENTURA, Deisy de Freitas Lima. Uma visão internacional do direito à saúde. In: O Direito achado na rua: introdução crítica ao direito à saúde. COSTA, Alexandre Bernardino; SOUSA JÚNIOR, José Geraldo; DELDUQUE, Maria Célia; OLIVEIRA, Mariana Siqueira de Carvalho; DALLARI, Sueli Gandolfi (organizadores), v.4. Brasília: CEAD/UnB, p.83-84, 2009. 
enfermidades"; orientar os Estados-membros a adotarem medidas de controle do transporte internacional de pessoas e de mercadorias; e divulgar informações sobre as doenças.

A Organização Mundial de Saúde atua em conjunto com outros organismos vinculados à Organização das Nações Unidas (ONU), especialmente as organizações de caráter regional, como a Organização Pan-Americana de Saúde (OPAS) ${ }^{128}$, contribuindo para a cooperação entre os Estados no combate às epidemias e na melhoria dos indicadores relativos à saúde em grande parte da esfera terrestre. ${ }^{129}$

A Declaração Universal dos Direitos Humanos, adotada e proclamada ${ }^{130}$ em 10 de dezembro de $1948^{131}$, introduziu a chamada concepção contemporânea de direitos humanos $^{132}$, marcada pela universalidade e indivisibilidade destes direitos. Universalidade porque a condição de pessoa é o único requisito para a titularidade de direitos humanos, cujo fundamento é a dignidade humana. Indivisibilidade porque, pioneiramente, foram reunidos os catálogos dos direitos civis e políticos e dos direitos econômicos, sociais e culturais, formando uma unidade interdependente e inter-relacionada. Ao conjugar direitos civis e políticos e direitos econômicos, sociais e culturais, a Declaração combinou o valor da liberdade ao valor da igualdade e, assim, sedimentou que os direitos humanos constituem uma unidade indivisível. ${ }^{133}$

${ }^{128}$ A Organização Pan-Americana de Saúde é o escritório regional para as Américas da Organização Mundial de Saúde, cuja finalidade é contribuir para a reorganização e reorientação do setor de saúde, por meio da descentralização e da participação social. Sobre a Organização Pan-Americana de Saúde, conferir: OPASOMS. Organização Pan-Americana da Saúde. Brasília: Organização Pan-Americana da Saúde, 2011.

${ }^{129}$ VENTURA, Deisy de Freitas Lima. Uma visão internacional do direito à saúde. In: O Direito achado na rua: introdução crítica ao direito à saúde. COSTA, Alexandre Bernardino; SOUSA JÚNIOR, José Geraldo; DELDUQUE, Maria Célia; OLIVEIRA, Mariana Siqueira de Carvalho; DALLARI, Sueli Gandolfi (organizadores). v. 4. Brasília: CEAD/UnB, p.84, 2009.

${ }^{130}$ A Declaração Universal dos Direitos Humanos foi aprovada pela Resolução n. 217 A (III), da Assembleia Geral da Organização das Nações Unidas (ONU), em 10 de dezembro de 1948, pela aprovação unânime de quarenta e oito Estados e oito abstenções. PIOVESAN, Flávia. Temas de Direitos Humanos. 6.ed. São Paulo: Saraiva, 2013. p.48. Por meio da Resolução n 217 A (III) da Assembleia Geral das Nações Unidas.

${ }^{131}$ Nesta mesma data a Declaração Universal dos Direitos Humanos foi assinada pelo Brasil.

132 Considerando a historicidade dos direitos, a concepção contemporânea introduzida pela Declaração Universal dos Direitos Humanos, de 1948, foi reiterada pela Declaração de Direitos humanos de Viena, de 1993, que prevê, em seu parágrafo $5^{\circ}$ : "Todos os direitos humanos são universais, interdependentes e interrelacionados. A comunidade internacional deve tratar os direitos humanos globalmente, de forma justa e equitativa, em pé de igualdade e com a mesma ênfase". A Declaração de Viena afirma também a interdependência entre os valores dos direitos humanos, democracia e desenvolvimento. PIOVESAN, Flávia. Temas de Direitos Humanos. 6.ed. São Paulo: Saraiva, 2013, p. 199-202.

${ }^{133}$ Sobre o critério metodológico que classifica os direitos humanos em gerações, PIOVESAN expõe seu entendimento no sentido de que uma geração de direitos não substitui a outra, mas com ela interage, na medida em que se acolhe a ideia da cumulação e fortalecimento dos direitos humanos consagrados, todos essencialmente complementares e em constante dinâmica de interação. Logo, apresentando os direitos humanos como uma unidade indivisível, revela-se esvaziado o direito à liberdade, quando não assegurado o 
A equivocada ideia de que direitos civis e políticos merecem reconhecimento e observância, enquanto direitos econômicos, sociais e culturais não merecem respeito há de ser definitivamente afastada com base na indivisibilidade dos direitos humanos. Sob a óptica normativa internacional, PIOVESAN afirma estar superada a concepção ideológica de que os direitos econômicos, sociais e culturais não seriam reivindicáveis, porquanto são autênticos direitos fundamentais, que demandam séria e responsável observância "como direitos e não como caridade, generosidade ou compaixão". ${ }^{134}$

A Declaração Universal dos Direitos Humanos estabeleceu como objeto da mais alta inspiração, comum de todos os povos e nações, a promoção, o reconhecimento e a observância universal e efetiva aos direitos humanos pelos Estados membros. ${ }^{135}{ }^{136} \mathrm{~A}$ Declaração consiste, pois, em parâmetro fundamental e código de atuação para os Estados integrantes da comunidade internacional, que podem ser merecedores de reprovação internacional caso a descumpram sistematicamente. ${ }^{137}$

A saúde foi reconhecida na Declaração Universal dos Direitos Humanos como um direito decorrente do direito à vida ${ }^{138}$. Segundo a Declaração de 1948, os contornos do direito à saúde compreendem: um padrão de vida capaz de assegurar, à pessoa e a sua família, saúde e bem estar, inclusive alimentação, vestuário, habitação, cuidados médicos e os serviços sociais indispensáveis; o direito à segurança em caso de desemprego, doença, invalidez, viuvez, velhice ou outros casos de perda dos meios de subsistência fora de seu

direito à igualdade e, por sua vez, revela-se esvaziado o direito à igualdade, quando não assegurada a liberdade. PIOVESAN, Flávia. Temas de Direitos Humanos. 6.ed. São Paulo: Saraiva, 2013, p. 50-51.

${ }^{134}$ PIOVESAN, Flávia. Temas de Direitos Humanos. 6.ed. São Paulo: Saraiva, 2013, p. 151.

135 “A Assembleia Geral proclama: A presente Declaração Universal dos Direitos Humanos como o ideal comum a ser atingido por todos os povos e todas as nações, com o objetivo de que cada indivíduo e cada órgão da sociedade, tendo sempre em mente esta Declaração, se esforce, através do ensino e da educação, por promover o respeito a esses direitos e liberdades, e, pela adoção de medidas progressivas de caráter nacional e internacional, por assegurar o seu reconhecimento e a sua observância universal e efetiva, tanto entre os povos dos próprios Estados-Membros, quanto entre os povos dos territórios sob sua jurisdição."

${ }^{136}$ Conforme PIOVESAN, os Estados não fizeram reserva aos princípios nem às disposições da Declaração Universal dos Direitos Humanos, consolidando-a como consenso sobre os valores de cunho universal a serem observados por todos os Estados. PIOVESAN, Flávia. Temas de Direitos Humanos. 6.ed. São Paulo: Saraiva, 2013, p.45-46.

137 A partir de sua aprovação, a Declaração Universal dos Direitos Humanos tem exercido forte influência tanto na ordem internacional, como nas ordens nacionais. Em âmbito internacional, a Declaração orienta as ações da Organização das Nações Unidas e serve de inspiração para novos tratados internacionais voltados à proteção dos direitos humanos. Já no âmbito dos Estados, as previsões da Declaração também exercem uma significativa influência nas Constituições nacionais e nas legislações locais e, em muitos casos, nas decisões judiciais. PIOVESAN, Flávia. Temas de Direitos Humanos. 6.ed. São Paulo: Saraiva, 2013, p.52.

138 "Artigo $3^{\circ}$ Toda pessoa tem direito à vida, à liberdade e à segurança pessoal." 
controle; o direito a cuidados e assistência especiais à maternidade e à infância ${ }^{139}$; o direito a exigir do Estado a implementação dos direitos sociais indispensáveis à sua dignidade e ao desenvolvimento de sua personalidade ${ }^{140}$; o direito a condições justas de trabalho, inclusive de remuneração que assegure à pessoa e à sua família uma existência digna e, se necessário, outros meios de proteção social. ${ }^{141}$

Desde que a Declaração Universal dos Direitos Humanos foi aprovada, introduzindo a concepção contemporânea de direitos humanos e a consciência ética sobre a essencialidade de protegê-los, instaurou-se uma discussão acerca de qual seria a maneira mais eficaz para assegurar a observância dos direitos nela previstos em todos os Estados. Prevaleceu a posição de que a Declaração deveria ser "juridicizada" em tratados internacionais, que fossem juridicamente obrigatórios e vinculantes no âmbito do Direito Internacional. ${ }^{142} 143$

139 O artigo 25 da Declaração Universal dos Direitos do Homem dispõe: "Artigo 25. §1. Toda pessoa tem direito a um padrão de vida capaz de assegurar a si e a sua família saúde e bem-estar, inclusive alimentação, vestuário, habitação, cuidados médicos e os serviços sociais indispensáveis, e direito à segurança em caso de desemprego, doença, invalidez, viuvez, velhice ou outros casos de perda dos meios de subsistência em circunstâncias fora de seu controle. §2. A maternidade e a infância têm direito a cuidados e assistência especiais. Todas as crianças, nascidas dentro ou fora de matrimônio, gozarão da mesma proteção social."

140 "Artigo 22. Toda pessoa, como membro da sociedade, tem direito à segurança social e à realização, pelo esforço nacional, pela cooperação internacional de acordo com a organização e recursos de cada Estado, dos direitos econômicos, sociais e culturais indispensáveis à sua dignidade e ao livre desenvolvimento da sua personalidade."

141 "Artigo 23. §1. Toda pessoa tem direito ao trabalho, à livre escolha de emprego, a condições justas e favoráveis de trabalho e à proteção contra o desemprego. §2. Toda pessoa, sem qualquer distinção, tem direito a igual remuneração por igual trabalho. §3. Toda pessoa que trabalha tem direito a uma remuneração justa e satisfatória, que lhe assegure, assim como à sua família, uma existência compatível com a dignidade humana, e a que se acrescentarão, se necessário, outros meios de proteção social. §4. Toda pessoa tem direito a organizar sindicatos e a neles ingressar para a proteção de seus interesses."

${ }^{142}$ PIOVESAN, Flávia. Temas de Direitos Humanos. 6.ed. São Paulo: Saraiva, 2013, p.52 e 152.

${ }^{143}$ O Pacto Internacional sobre Direitos Econômicos, Sociais e Culturais (PIDESC) apresenta uma sistemática particular de monitoramento da implementação dos direitos em seus artigos 16 a 23, que inclui o mecanismo dos relatórios a serem encaminhados pelos Estados Partes por etapas. Tais relatórios devem consignar as medidas legislativas, administrativas e judicias adotadas pelo Estado Parte visando assegurar a observância dos direitos reconhecidos pelo Pacto e o progresso realizado. Além disso, poderão indicar os fatores e as dificuldades no processo de implementação das obrigações decorrentes do Pacto. Diversamente do Pacto Internacional sobre Direitos Civis e Políticos (PIDCP), o Pacto Internacional sobre Direitos Econômicos, Sociais e Culturais (PIDESC) não contempla o mecanismo de comunicação interestatal, mediante o qual um Estado Parte pode alegar ter ocorrido violação por outro Estado Parte aos direitos enunciados no tratado. O Pacto Internacional sobre Direitos Econômicos, Sociais e Culturais (PIDESC) também não estabelecia o direito de petição, porém em 10 de dezembro de 2008 foi adotado o Protocolo facultativo ao Pacto Internacional de Direitos Econômicos, Sociais e Culturais (PIDESC), que prevê a competência do Comitê de Direitos Econômicos, Sociais e Culturais para receber e apreciar as comunicações de uma violação, por um dos Estados Partes, de qualquer um dos direitos econômicos, sociais e culturais enunciados no Pacto (artigo $1^{\circ}$ ) e introduz os seguintes mecanismos: petições de indivíduos ou grupos de indivíduos que entendam ser vítimas de violação de qualquer um dos direitos econômicos, sociais e culturais por um Estado-parte (artigo $2^{\circ}$ ); medidas de urgência (artigo $5^{\circ}$ ); resolução amigável (artigo $7^{\circ}$ ); comunicações interestatais (artigo $10^{\circ}$ ); visita no território do Estado Parte para fins de investigação da 
Nesse sentido, o processo de "juridicização" da Declaração teve início em 1949 e foi concluído em 1966, com a aprovação de dois distintos tratados internacionais no âmbito das Nações Unidas - o Pacto Internacional dos Direitos Civis e Políticos (PIDCP) e o Pacto Internacional sobre Direitos Econômicos, Sociais e Culturais (PIDESC), que consagraram com maior detalhamento os direitos constantes da Declaração Universal dos Direitos Humanos, através de preceitos juridicamente obrigatórios e vinculantes.

A elaboração desses dois pactos já revela a importância de ambas as categorias de direitos $^{144}$, bem como a existência de resistências por parte dos Estados em conferir-lhes igual proteção, sobretudo porque enquanto os direitos civis e políticos devem ser assegurados prontamente pelos Estados, visto que são autoaplicáveis, os direitos sociais, econômicos e culturais, nos termos em que concebidos pelo Pacto ${ }^{145}$, estão condicionados à atuação dos Estados, que têm a incumbência de adotar todas as medidas, até o máximo de seus recursos disponíveis, com vistas a realizar de forma progressiva esses direitos, tão rapidamente quanto possível. ${ }^{146}$

alegada violação grave e sistemática desses direitos por um dos Estados Parte (artigo $11^{\circ}$ ); e medidas de proteção aos indivíduos que façam as comunicações previstas nesse Protocolo (artigo $13^{\circ}$ ). Este Protocolo entrou em vigor na ordem jurídica internacional em 5 de maio de 2013, após a ratificação de dez Estados Partes (artigo $11^{\circ}$ ). Apesar do Protocolo facultativo ao Pacto Internacional de Direitos Econômicos, Sociais e Culturais (PIDESC) ser apoiado pela comunidade internacional desde a última Conferência Mundial de Direitos Humanos em Viena (1993) e das manifestações sociais favoráveis à sua ratificação, até 31 de outubro de 2013 o Brasil não o adotou. O texto completo deste Protocolo consta do site da Organização das Nações Unidas (ONU) na Internet. Disponível em: <http://www.onu.org.br>. Consulta em: 31/10/2013.

144 Tal ideia foi inserida no Preâmbulo do Pacto internacional sobre Direitos Civis e Políticos (PIDCP): "Reconhecendo que, em conformidade com a Declaração Universal dos Direitos do Homem, o ideal do ser humano livre, no gozo das liberdades civis e políticas e liberto do temor e da miséria, não pode ser realizado a menos que se criem condições que permitam a cada um gozar de seus direitos civis e políticos, assim como de seus direitos econômicos, sociais e culturais (...)" E foi repetida no Preâmbulo do Pacto Internacional sobre Direitos Econômicos, Sociais e Culturais (PIDESC), de forma quase idêntica: "Reconhecendo que, em conformidade com a Declaração Universal dos Direitos do Homem, o ideal do ser humano livre, liberto do temor e da miséria, não pode ser realizado a menos que se criem condições que permitam a cada um gozar de seus direitos econômicos, sociais e culturais, assim como de seus direitos civis e políticos, Considerando que a Carta das nações Unidas impõe aos Estados a obrigação de promover o respeito universal e efetivo dos direitos e das liberdades do homem (...)"

${ }^{145}$ Os parágrafos $1^{\circ}$ e $2^{\circ}$, do artigo $2^{\circ}$, do Pacto Internacional sobre Direitos Econômicos, Sociais e Culturais (PIDESC) dispõem o seguinte: "1. Cada Estados Partes do presente Pacto comprometem-se a adotar medidas, tanto por esforço próprio como pela assistência e cooperação internacionais, principalmente nos planos econômico e técnico, até o máximo de seus recursos disponíveis, que visem assegurar, progressivamente, por todos os meios apropriados, o pleno exercício e dos direitos reconhecidos no presente Pacto, incluindo, em particular, a adoção de medidas legislativa. 2. Os Estados Partes do presente pacto comprometem-se a garantir que os direitos nele enunciados se exercerão sem discriminação alguma por motivo de raça, cor, sexo, língua, religião, opinião política ou de outra natureza, origem nacional ou social, situação econômica, nascimento ou qualquer outra situação.”

146 PIOVESAN, Flávia. Temas de Direitos Humanos. 6.ed. São Paulo: Saraiva, 2013, p.152-153. 
O Pacto Internacional sobre Direitos Econômicos, Sociais e Culturais (PIDESC) ${ }^{147}$, foi incorporado ao ordenamento jurídico nacional por meio do Decreto n. 591, de 6 de julho de 1992 e entrou em vigor para o Brasil em 24 de abril de 1992. Este pacto apresenta em seu artigo 12 um conteúdo amplo do direito à saúde, que compreende: 1.1. A face individual do direito de toda pessoa de desfrutar do mais alto nível possível de saúde física e mental; 1.2. A face coletiva do direito, presente em ações preventivas de enfermidades epidêmicas e endêmicas; e 1.3. O dever de atuação dos Estados-partes no sentido de implementar medidas para o fim de assegurar a plena efetividade desse direito. ${ }^{148}$

O Comitê de Direitos Econômicos, Sociais e Culturais (CDESC) ${ }^{149}$, órgão das Nações Unidas criado em 1985, elaborou recomendações gerais, que desenvolvem o conteúdo jurídico dos direitos sociais previstos no Pacto Internacional sobre Direitos Econômicos, Sociais e Culturais, visando prestar assistência aos Estados e avaliar o cumprimento de suas obrigações como signatários do Pacto Internacional sobre Direitos Econômicos, Sociais e Culturais (PIDESC). ${ }^{150} \mathrm{O}$ documento denominado "Recomendação

147 O Pacto Internacional sobre Direitos Econômicos, Sociais e Culturais (PIDESC) foi adotado pela XXI Sessão da Assembleia-Geral das Nações Unidas, em 19 de dezembro de 1966. Até 2011 o PIDESC contemplava a adesão de 160 Estados-partes.

148 O Pacto Internacional de Direitos Econômicos, Sociais e Culturais (PIDESC), de 1966, estabelece o seguinte: "Artigo 12. 1. Os Estados Partes no presente Pacto reconhecem o direito de todas as pessoas de gozar do melhor estado de saúde física e mental possível de atingir. 2. As medidas que os Estados Partes no presente Pacto tomarem com vista a assegurar o pleno exercício deste direito deverão compreender as medidas necessárias para assegurar: a) A diminuição da mortinatalidade e da mortalidade infantil, bem como o são desenvolvimento da criança; b) O melhoramento de todos os aspectos de higiene do meio ambiente e da higiene industrial; c) A profilaxia, tratamento e controle das doenças epidêmicas, endêmicas, profissionais e outras; d) A criação de condições próprias a assegurar a todas as pessoas serviços médicos e ajuda médica em caso de doença."

${ }^{149}$ O Comitê de Direitos Econômicos, Sociais e Culturais (CDESC) é órgão subsidiário do Conselho Econômico e Social, formado por 18 expertos em matéria de direitos humanos, eleitos pelo Conselho para um mandato de quatro anos. A função primordial do Comitê é supervisionar a aplicação do Pacto Internacional sobre Direitos Econômicos, Sociais e Culturais (PIDESC), como determinam seus artigos 16, 17 e 18. Com base nos relatórios remetidos pelos Estados Partes e pelos organismos especializados, o Comitê de Direitos Econômicos, Sociais e Culturais (CDESC) poderá emitir orientações, observações finais e recomendações gerais. As recomendações gerais consistem na interpretação do Comitê de Direitos Econômicos, Sociais e Culturais (CDESC) sobre os dispositivos do Pacto Internacional sobre Direitos Econômicos, Sociais e Culturais (PIDESC), cumprindo o papel de uma "jurisprudência" do órgão, conquanto nenhuma das ações do Comitê tenha efeito vinculante para os Estados.

${ }^{150}$ Segundo o artigo 17 do Pacto Internacional sobre Direitos Econômicos, Sociais e Culturais (PIDESC), os Estados Partes devem apresentar seus relatórios no prazo de dois anos a partir da entrada em vigor do Pacto e, posteriormente, a cada cinco anos. A apresentação dos relatórios pelos Estados objetiva assegurar a avaliação pelo Estado de sua situação em relação aos direitos econômicos, culturais e sociais, para que possa: (i) verificar se houve progressos no cumprimento do Pacto Internacional sobre Direitos Econômicos, Sociais e Culturais (PIDESC); (ii) elaborar políticas públicas conforme o Pacto Internacional sobre Direitos Econômicos, Sociais e Culturais (PIDESC); e (iii) viabilizar o conhecimento da população acerca das políticas dos Estados relacionadas à aplicação do Pacto, estimulando, assim, a participação social na aplicação, formulação e monitoramento dessas políticas. 
Geral n. 14", de 2000, elaborado por este Comitê, trata do direito de toda pessoa desfrutar do mais alto nível possível de saúde física e mental.

A Recomendação Geral n. 14, do Comitê de Direitos Econômicos, Sociais e Culturais (CDESC) $)^{151}$ das Nações Unidas, contém elementos que contribuem para a compreensão do conteúdo do "direito ao melhor nível possível de saúde física e mental possível de atingir" e das obrigações estatais no campo da saúde. ${ }^{152}$ Para a adoção de medidas e a verificação do cumprimento dos deveres do Estado relativos ao direito à saúde é imprescindível que os atores envolvidos em tais ações saibam o que significa esse direito, o que deve ser feito e o que não deve ser feito para materializa-lo. Assim, a sociedade civil, o próprio Estado e os sistemas de proteção dos Direitos Humanos podem exercer a tarefa de monitorar e avaliar se os poderes públicos cumprem as obrigações que satisfaçam ao menos os níveis essenciais mínimos do direito à saúde. ${ }^{153} 154$

O parágrafo $1^{\circ}$, do artigo $2^{\circ}$, do Pacto Internacional sobre Direitos Econômicos, Sociais e Culturais (PIDESC) ${ }^{155}$ prevê a progressividade relativa ao pleno exercício dos

151 O Comitê de Direitos Econômicos, Sociais e Culturais (CDESC) é órgão subsidiário do Conselho Econômico e Social, formado por 18 expertos em matéria de direitos humanos, eleitos pelo Conselho para um mandato de quatro anos. A função primordial do Comitê é supervisionar a aplicação do Pacto Internacional sobre Direitos Econômicos, Sociais e Culturais (PIDESC), como determinam seus artigos 16, 17 e 18. Com base nos relatórios remetidos pelos Estados Partes e pelos organismos especializados, o Comitê de Direitos Econômicos, Sociais e Culturais (CDESC) poderá emitir orientações, observações finais e recomendações gerais. As recomendações gerais consistem na interpretação do Comitê de Direitos Econômicos, Sociais e Culturais (CDESC) sobre os dispositivos do Pacto Internacional sobre Direitos Econômicos, Sociais e Culturais (PIDESC), cumprindo o papel de uma "jurisprudência" do órgão, conquanto nenhuma das ações do Comitê tenha efeito vinculante para os Estados.

152 A Recomendação n. 14, de 2000, ao tratar do direito ao desfrute do mais alto nível possível de saúde (artigo 12 do Pacto Internacional sobre Direitos Econômicos, Sociais e Culturais) afirma o seguinte: "La salud es un derecho humano fundamental e indispensable para el ejercicio de los demás derechos humanos. Todo ser humano tiene derecho al disfrute del más alto nivel posible de salud que le permita vivir dignamente. La efectividad del derecho a la salud se puede alcanzar mediante numerosos procedimientos complementarios, como la formulación de políticas en materia de salud, la aplicación de los programas de salud elaborados por la Organización Mundial de la Salud (OMS) o la adopción de instrumentos jurídicos concretos. Además, el derecho a la salud abarca determinados componentes aplicables en virtud de la ley."

153 Segundo PIOVESAN, a jurisprudência internacional do Comitê de Direitos Econômicos, Sociais e Culturais (CDESC) sedimentou o entendimento de que os Estados tem o dever de observar do mínimo essencial concernente aos direitos sociais (minimum core obligation), com base no princípio maior da dignidade humana, que é o núcleo dos direitos humanos, demandando absoluta urgência e prioridade. Para a implementação dos direitos sociais, o Comitê adota os seguintes critérios: acessibilidade; disponibilidade; adequação; qualidade; e aceitabilidade cultural. PIOVESAN, Flávia. Temas de Direitos Humanos. 6.ed. São Paulo: Saraiva, 2013, p.157.

154 Sobre o tema conferir: OLIVEIRA, Aline Albuquerque Sant'Anna de. Direito à Saúde: conteúdo, essencialidade e monitoramento. In: Revista CEJ, Brasília, ano XIV, v. 48, janeiro/março, p. 92-100, 2010.

155 “Art. $2^{\circ}$, parágrafo $1^{\circ}$. Cada Estado Membro no presente Pacto compromete-se a adotar medidas, tanto por esforço próprio como pela assistência e cooperação internacionais, principalmente nos planos econômico e técnico, até o máximo de seus recursos disponíveis, que visem a assegurar, progressivamente, por todos os 
direitos econômicos, sociais e culturais. A realização progressiva do direito à saúde, assim como dos demais direitos reconhecidos nesse Pacto, não significa que estejam esvaziadas as obrigações dos Estados Partes.

Ao contrário, aos Estados Partes são atribuídas obrigações concretas de avançar da forma mais rápida e eficaz possível na plena concretização do artigo 12 deste Pacto ${ }^{156}{ }^{157} \mathrm{e}$ de não implementarem medidas que importem em retrocesso quanto ao respeito, à proteção e à realização do direito à saúde. ${ }^{158}$

Além disso, no campo da saúde há obrigações que exigem o cumprimento imediato pelos Estados, voltadas à plena realização do direito à saúde. Assim, embora cada Estado comprometa-se a adotar medidas até o máximo de seus recursos disponíveis, que visem a assegurar, progressivamente, por todos os meios apropriados, o respeito, a proteção e a concretização do direito de toda pessoa a desfrutar do mais alto nível possível de saúde física e mental, "as obrigações essenciais" estão excetuadas deste comando, pois implicam na adoção imediata de determinadas medidas, independentemente de seus recursos financeiros, pelos poderes públicos dos Estados. ${ }^{159}$

meios apropriados, o pleno exercício dos direitos reconhecidos no presente Pacto, incluindo, em particular, a adoção de medidas legislativas."

156 O Pacto Internacional de Direitos Econômicos, Sociais e Culturais (PIDESC), de 1966, estabelece o seguinte: "Artigo 12. 1. Os Estados Partes no presente Pacto reconhecem o direito de todas as pessoas de gozar do melhor estado de saúde física e mental possível de atingir. 2. As medidas que os Estados Partes no presente Pacto tomarem com vista a assegurar o pleno exercício deste direito deverão compreender as medidas necessárias para assegurar: a) A diminuição da mortinatalidade e da mortalidade infantil, bem como o são desenvolvimento da criança; b) O melhoramento de todos os aspectos de higiene do meio ambiente e da higiene industrial; c) A profilaxia, tratamento e controlo das doenças epidêmicas, endêmicas, profissionais e outras; d) A criação de condições próprias a assegurar a todas as pessoas serviços médicos e ajuda médica em caso de doença."

${ }^{157}$ Neste sentido, a Recomendação Geral n. 14, de 2000, do Comitê de Direitos Econômicos, Sociais e Culturais (CDESC) assim dispõe: "31. La realización progresiva del derecho a la salud a lo largo de un determinado período no debe interpretarse en el sentido de que priva de todo contenido significativo las obligaciones de los Estados Partes. Antes al contrario, la realización progresiva significa que los Estados Partes tienen la obligación concreta y constante de avanzar lo más expedita y eficazmente posible hacia la plena realización del artículo 12."

${ }^{158}$ A Recomendação Geral n. 14, de 2000, do Comitê de Direitos Econômicos, Sociais e Culturais (CDESC) prevê: "32. Al igual que en el caso de los demás derechos enunciados en el Pacto, existe una flerte presunción de que no son permisibles las medidas regresivas adoptadas en relación con el derecho a la salud. Si se adoptan cualesquiera medidas deliberadamente regresivas, corresponde al Estado Parte demostrar que se han aplicado tras el examen más exhaustivo de todas las alternativas posibles y que esas medidas están debidamente justificadas por referencia a la totalidad de los derechos enunciados en el Pacto en relación con la plena utilización de los recursos máximos disponibles del Estado Parte."

${ }^{159}$ As obrigações essenciais aos Estados Partes estabelecidas pelo Comitê de Direitos Econômicos, Sociais e Culturais (CDESC) compreendem: (i) garantir o direito de acesso a bens, instalações e serviços de saúde sem discriminação alguma, em especial em relação aos grupos vulneráveis ou marginalizados; (ii) assegurar o acesso a uma alimentação essencial mínima, nutritivamente adequada e segura e assegurar que ninguém padeça de fome; (iii) garantir o acesso à habitação, condições sanitárias adequadas e água limpa e potável; (iv) fornecer medicamentos essenciais, segundo as orientações periódicas da Organização Mundial de Saúde; 
Segundo a Recomendação Geral n. 14, de $2000^{160}$, o direito à saúde não deve ser compreendido como o direito de estar sadio. Seu conteúdo normativo abrange direitos e liberdades. Os direitos garantem aos indivíduos a possibilidade de exigir do Estado a realização de ações para sua efetiva concretização e um sistema de proteção que assegure às pessoas igualdade de condições para desfrutar do mais alto nível de saúde possível. Por sua vez, as liberdades individuais se referem ao direito de controlar sua própria saúde e seu corpo, a de não ser submetido a tratamentos ou experimentos médicos sem prévio consentimento.

De acordo com o Comitê de Direitos Econômicos, Sociais e Culturais (CDESC), o direito à saúde não se refere apenas ao direito à atenção sanitária oportuna e apropriada, mas também aos principais fatores determinantes da saúde, como o acesso à água potável, condições sanitárias e habitação adequada, condições sadias de trabalho e meio ambiente, acesso à educação e informação sobre questões relacionadas à saúde, inclusive a saúde sexual e a reprodutiva. Além disso, um aspecto importante que está inserido na própria compreensão do que seja o direito à saúde consiste na participação da população no processo de adoção de decisões públicas nessa temática, nos planos comunitário, nacional e internacional. ${ }^{161}$ A participação social é reforçada em relação à prestação de serviços de

(v) zelar pela distribuição equitativa de bens, instalações e serviços de saúde; e (vi) adotar e aplicar, a partir de estudos epidemiológicos, uma estratégia e plano de ação nacional de saúde pública para fazer frente às preocupações em matéria de saúde de toda a população. A estratégia e o plano de ação deverão ser elaborados e periodicamente revisados, num processo participativo e transparente, que estabeleça o direito a indicadores de saúde, mediante a instituição de sistemas de informação, e bases de referência da saúde que permitam monitorar eficazmente os progressos realizados (item 43 da Recomendação Geral n. 14, de 2000). Há também obrigações específicas, definidas como prioritárias: a) zelar pela atenção à saúde materna e infantil; b) proporcionar imunização contra as principais enfermidades infecciosas; c) adotar medidas para prevenir, tratar e combater as enfermidades epidêmicas e endêmicas; d) estimular políticas educacionais que tenham como objeto o acesso à informação sobre os principais problemas em saúde da comunidade; e) proporcionar capacitação adequada ao pessoal do setor da saúde, incluída a educação em matéria de saúde e direitos humanos (item 44 da Recomendação Geral n. 14, de 2000).

160 "1. Contenido normativo del artículo 12 (...) 8. El derecho a la salud no debe entenderse como un derecho a estar sano. El derecho a la salud entraña libertades y derechos. Entre las libertades figura el derecho a controlar su salud y su cuerpo, con inclusión de la libertad sexual y genésica, y el derecho a no padecer injerencias, como el derecho a no ser sometido a torturas ni a tratamientos y experimentos médicos no consensuales. En cambio, entre los derechos figura el relativo a un sistema de protección de la salud que brinde a las personas oportunidades iguales para disfrutar del más alto nivel posible de salud."

${ }^{161}$ Segundo a Recomendação Geral n. 14, de 2000: “1. Contenido normativo del artículo 12 (...) 11 . El Comité interpreta el derecho a la salud, definido en el apartado 1 del artículo 12, como un derecho inclusivo que no sólo abarca la atención de salud oportuna y apropiada sino también los principales factores determinantes de la salud, como el acceso al agua limpia potable y a condiciones sanitarias adecuadas, el suministro adecuado de alimentos sanos, una nutrición adecuada, una vivienda adecuada, condiciones sanas en el trabajo y el medio ambiente, y acceso a la educación e información sobre cuestiones relacionadas con la salud, incluida la salud sexual y reproductiva. Otro aspecto importante es la participación de la población en 
saúde preventivos e curativos, à organização do setor de saúde, ao sistema de seguro e, especialmente, para as decisões políticas relativas ao direito à saúde a serem tomadas nos planos comunitário e nacional. ${ }^{162}$

Com o objetivo de conferir maior precisão ao conteúdo do direito à saúde, o Comitê de Direitos Econômicos, Sociais e Culturais (CDESC) estabeleceu na Recomendação Geral n. 14, de 2000, quatro elementos essenciais e inter-relacionados cuja aplicação depende das condições prevalentes em cada Estado-Parte: disponibilidade ${ }^{163}$; acessibilidade $^{164}$; aceitabilidade ${ }^{165}$ e qualidade. ${ }^{166}$

Portanto, o direito à saúde pode ser compreendido como o direito ao desfrute de uma ampla gama de bens, serviços e condições necessárias para se alcançar o mais alto

todo el proceso de adopción de decisiones sobre las cuestiones relacionadas con la salud en los planos comunitario, nacional e internacional."

162 "Artículo 12 (...) Otro aspecto importante es la mejora y el fomento de la participación de la población en la prestación de servicios médicos preventivos y curativos, como la organización del sector de la salud, el sistema de seguros y, en particular, la participación en las decisiones políticas relativas al derecho a la salud, adoptadas en los planos comunitario y nacional."

${ }^{163}$ A disponibilidade significa que cada Estado deve contar com número suficiente de instalações, bens e serviços públicos de saúde, assim como de políticas públicas e programas de ação. A natureza dos estabelecimentos, bens e serviços dependerá de diversos fatores em particular do nível de desenvolvimento do Estado. Os serviços referidos também incluem aqueles que se ocupam dos determinantes básicos da saúde, como água limpa e potável, e condições sanitárias adequadas, hospitais, clínicas e demais instalações relacionados à saúde, profissionais da saúde capacitados e bem remunerados, bem como medicamentos essenciais, definidos no Programa de ação sobre medicamentos essenciais da Organização Mundial de Saúde (OMS), disponibilizados pelo Estado.

${ }^{164} \mathrm{~A}$ acessibilidade é definida como o dever assumido pelos Estados de que as instalações, bens e serviços de saúde sejam acessíveis a todos, sem discriminação alguma. A acessibilidade apresenta quatro dimensões: (I) não discriminação: estabelecimentos, bens e serviços de saúde devem ser acessíveis de fato e de direito aos setores mais marginalizados e vulneráveis da população; (II) acessibilidade física: os estabelecimentos, bens e serviços de saúde devem estar ao alcance geográfico de todos os setores da população, em especial dos grupos vulneráveis ou marginalizados, das minorias étnicas e populações indígenas, mulheres, crianças e adolescentes, idosos, pessoas com deficiência e com AIDS. Incluem-se também as pessoas que vivem em localidades de difícil acesso e nas zonas rurais; (III) acessibilidade econômica: os estabelecimentos, bens e serviços de saúde devem estar ao alcance de todos. Caso os serviços de atenção à saúde e os serviços relativos aos determinantes básicos da saúde sejam pagos, deverão atender ao princípio da equidade para que os serviços de saúde, públicos ou privados, estejam ao alcance de todos, incluídos os grupos socialmente desfavorecidos; (IV) acesso à informação: compreende o direito de solicitar, receber e difundir informações e ideias sobre questões relacionadas à saúde. Contudo, os dados pessoais relativos à saúde devem ser tratados com confidencialidade.

${ }^{165}$ A aceitabilidade significa que os estabelecimentos de saúde, bens e serviços devem respeitar a ética médica e os padrões culturais dos indivíduos. Todos os serviços de saúde devem ser projetados para respeitar a confidencialidade e melhorar a saúde das pessoas que estejam sendo tratadas.

${ }^{166}$ A qualidade é entendida como a adequação das instalações, bens e serviços sob o ponto de vista científico e médico. O pessoal médico deve ser qualificado, os medicamentos de boa qualidade, os equipamentos hospitalares cientificamente aprovados e em boas condições, além de estarem disponíveis água potável e saneamento básico adequado. 
nível possível de saúde, consideradas as condições biológicas e socioeconômicas da pessoa, bem como os recursos financeiros do Estado. ${ }^{167}$

Cumpre preciso observar que tanto os direitos sociais como os direitos civis e políticos implicam em obrigações de conteúdo positivo e negativo por parte do Estado, não sendo acertada a visão simplista de que os direitos civis e políticos demandariam mera abstenção estatal (obrigação de conteúdo negativo), enquanto os direitos sociais demandariam apenas prestações de conteúdo positivo. ${ }^{168}{ }^{169} \mathrm{~A}$ título de exemplo é interessante mencionar o aparato de segurança do Estado e a organização de vias públicas para garantir o exercício de direitos de liberdade, e, ainda, o custo de todo o aparato eleitoral que viabiliza o exercício de direitos políticos. Assim, os direitos civis e políticos não acarretam ao Estado tão-somente a obrigação de não intervenção, mas também implicam em ações de conteúdo positivo que permitam sua implementação.

Ao lado do sistema normativo global de proteção dos direitos humanos no âmbito da Organização das Nações Unidas ${ }^{170}$, integrado por instrumentos de alcance geral ${ }^{171} \mathrm{e}$ instrumentos de alcance específico ${ }^{172}$, há um sistema normativo regional que amplia e fortalece esta proteção, voltado à internalização dos direitos humanos no plano regional, particularmente na Europa, América ${ }^{173}$ e África.

A partir da promulgação da Constituição Federal de 1988 teve início a interação do Direito Internacional e do Direito interno, fortalecendo a sistemática de proteção dos

167 Conforme a Recomendação Geral n. 14, de 2000: “1. Contenido normativo del artículo 12 (...) 9 . El concepto del "más alto nivel posible de salud", a que se hace referencia en el párrafo 1 del artículo 12, tiene en cuenta tanto las condiciones biológicas y socioeconómicas esenciales de la persona como los recursos con que cuenta el Estado. Existen varios aspectos que no pueden abordarse únicamente desde el punto de vista de la relación entre el Estado y los individuos; en particular, un Estado no puede garantizar la buena salud ni puede brindar protección contra todas las causas posibles de la mala salud del ser humano. Así, los factores genéticos, la propensión individual a una afección y la adopción de estilos de vida malsanos o arriesgados suelen desempeñar un papel importante en lo que respecta a la salud de la persona. Por lo tanto, el derecho a la salud debe entenderse como un derecho al disfrute de toda una gama de facilidades, bienes, servicios y condiciones necesarios para alcanzar el más alto nivel posible de salud."

${ }^{168}$ PIOVESAN, Flávia. Temas de Direitos Humanos. 6.ed. São Paulo: Saraiva, 2013, p.153.

$169 \mathrm{O}$ estudo desta questão será retomado no capítulo 2 , no subitem 2.4 , relativo à multifuncionalidade do direito à saúde.

170 Tendo em vista o fortalecimento da efetividade dos direitos sociais, econômicos e culturais, a Declaração de Viena de 1993 recomenda a aplicação de um sistema de indicadores voltado a aferir o progresso alcançado na realização desses direitos. PIOVESAN, Flávia. Temas de Direitos Humanos. 6.ed. São Paulo: Saraiva, 2013, p. 156.

${ }^{171}$ Como, por exemplo, o Pacto Internacional dos Direitos Civis e Políticos (PIDCP) e o Pacto Internacional sobre Direitos Econômicos, Sociais e Culturais (PIDESC), de 1966.

${ }^{172}$ Como as Convenções Internacionais que buscam combater específicas violações de direitos humanos como, por exemplo, a tortura, a discriminação contra mulheres e a discriminação racial.

173 No contexto Americano, um exemplo é o Protocolo à Convenção Americana referente aos Direitos Econômicos, Sociais e Culturais (Protocolo de San Salvador), em 21 de agosto de 1996. 
direitos humanos. ${ }^{174} 175$ Dentre os importantes tratados internacionais de direitos humanos que foram ratificados e, assim, incorporados ao direito brasileiro, cumpre destacar: o Pacto Internacional dos Direitos Civis e Políticos (PIDCP), em 6 de julho de 1992 ${ }^{176}$; o Pacto Internacional sobre Direitos Econômicos, Sociais e Culturais (PIDESC), em 6 de julho de 1992 ${ }^{177}$; a Convenção Americana de Direitos Humanos, em 25 de setembro de 1992 ${ }^{178}$; o Protocolo à Convenção Americana referente aos Direitos Econômicos, Sociais e Culturais (Protocolo de San Salvador), em 21 de agosto de $1996^{179}$; e a Convenção sobre os Direitos das Pessoas com Deficiência e seu protocolo facultativo, em $1^{\circ}$ de agosto de $2008^{180}$.

$\mathrm{Na}$ esfera nacional de proteção do direito à saúde há uma pluralidade de ordens normativas vigentes (local, regional, federal e nacional) aplicáveis de forma justaposta. Do exame dessas normas é possível verificar a permeabilidade das normas jurídicas internacionais, que ocorre de forma explícita, pela internacionalização de instrumentos internacionais de proteção da saúde, e de forma implícita, com a absorção de interesses originariamente tutelados em normas estrangeiras no processo legislativo nacional.

\footnotetext{
${ }^{174} \mathrm{O}$ marco inicial do processo de incorporação de tratados internacionais de direitos humanos pelo Direito brasileiro ocorreu em 28 de setembro de 1989, com o depósito da carta de Ratificação da Convenção contra a Tortura e Outros Tratamentos Cruéis, Desumanos ou Degradantes (aprovada pelo Congresso Nacional por meio do Decreto Legislativo $n^{\circ}$ 04, de 23 de maio de 1989), adotada pela Resolução 39/46, da Assembleia Geral das Nações Unidas, em 10 de dezembro de 1984.

175 As inovações introduzidas pela Constituição Federal de 1988, especialmente a inclusão da "prevalência dos direitos humanos" como princípio orientador das relações internacionais em que a República Federativa do Brasil faça parte $\left(\mathrm{CF}\right.$, art. $4^{\circ}$, II) e o princípio da dignidade da pessoa humana como fundamento do Estado $\left(\mathrm{CF}\right.$, art. $1^{\mathrm{o}}$, III) foram importantes fatores para a ratificação desses tratados internacionais pelo Estado brasileiro. PIOVESAN acrescenta a tais fatores a necessidade do Estado brasileiro reorganizar sua agenda internacional, de modo condizente com as transformações internas decorrentes do processo de democratização e o objetivo de compor uma imagem mais positiva do Estado brasileiro como respeitador e garantidor dos direitos humanos no cenário internacional. PIOVESAN, Flávia. Temas de Direitos Humanos. 6.ed. São Paulo: Saraiva, 2013, p.56.

${ }^{176}$ O Pacto Internacional dos Direitos Civis e Políticos (PIDCP) foi promulgado pelo Decreto n. 592, de 6 de julho de 1992.

177 O Pacto Internacional sobre Direitos Econômicos, Sociais e Culturais (PIDESC) foi promulgado pelo Decreto n. 591, de 6 de julho de 1992.

178 A Convenção Americana sobre Direitos Humanos (Pacto de São José da Costa Rica), foi promulgada pelo Decreto n. 678, de 6 de novembro de 1992.

$179 \mathrm{O}$ Protocolo à Convenção Americana sobre Direitos Humanos (Protocolo de San Salvador), foi promulgada pelo Decreto n. 3.321, de 30 de dezembro de 1999. O protocolo de San Salvador, da Organização dos Estados Americanos (OEA) faz parte do sistema regional interamericano de proteção dos direitos humanos. O Protocolo de San Salvador acolhe a concepção de que cabe aos Estados investir o máximo de recursos disponíveis para alcançar a plena efetividade dos direitos econômicos, sociais e culturais, tanto mediante esforços internos, quanto por meio da cooperação internacional. Este Protocolo permite o recurso ao direito de petição a instâncias internacionais para a proteção de dois dos direitos nele previstos, a saber: o direito à educação e os direitos sindicais (artigo 19, parágrafo $6^{\circ}$ ). PIOVESAN, Flávia. Temas de Direitos Humanos. 6.ed. São Paulo: Saraiva, 2013, p.164.

180 A Convenção sobre os Direitos das Pessoas com Deficiência e seu protocolo facultativo foram promulgados pelo Decreto n. 6.949, de 25 de agosto de 2009.
} 
No tocante à permeabilidade explícita, para que um tratado internacional vigore no Brasil é imperioso o atendimento de três requisitos: ser negociado e assinado pelo Poder Executivo, que detém competência privativa para "celebrar tratados, convenções e atos internacionais, sujeitos a referendo do Congresso Nacional" (artigo 84, inciso VIII, da Constituição Federal); ser aprovado pelo Congresso Nacional a quem cabe "resolver definitivamente sobre tratados, acordos ou atos internacionais que acarretem encargos ou compromissos gravosos ao patrimônio nacional" (artigo 49, inciso I, da Constituição Federal); e que o Poder Executivo o ratifique junto ao Estado depositário, indicado no próprio tratado, o promulgue por meio de Decreto e o publique. ${ }^{181}$

A Constituição Federal de 1988, após apresentar a extensa lista de direitos e garantias fundamentais no artigo $5^{\circ}$ (incisos I a LXXVIII), prevê no parágrafo $2^{\circ}$ deste dispositivo que os direitos e garantias expressos na Constituição “(...) não excluem outros decorrentes do regime e dos princípios por ela adotados, ou dos tratados internacionais em que a República Federativa do Brasil seja parte". ${ }^{182}$ Com esteio neste dispositivo constitucional é possível organizar três grupos de direitos fundamentais: (i) direitos expressos na Constituição; (ii) direitos implícitos na Constituição, decorrentes do regime e dos princípios adotados no texto constitucional; e (iii) direitos expressos nos tratados internacionais de que o Brasil seja signatário. ${ }^{183}$

Em relação ao terceiro grupo de direitos, incorporados à ordem-jurídica brasileira por força de tratados internacionais subscritos pelo Brasil, é importante distinguir os direitos enunciados em tratados internacionais de proteção de direitos humanos e os direitos enunciados nos demais tratados comuns. Enquanto aqueles tratados apresentam um caráter especial, na medida em que suas normas fundadas na dignidade da pessoa humana

\footnotetext{
$181 \mathrm{O}$ conjunto de regras relativas à saúde pública, oriundas de fonte internacional (tratados ou acordos internacionais bilaterais ou multilaterais) devidamente incorporados à ordem jurídica brasileira compreende o Direito Internacional Sanitário. VENTURA, Deisy de Freitas Lima. Uma visão internacional do direito à saúde. In: O Direito achado na rua: introdução crítica ao direito à saúde. COSTA, Alexandre Bernardino; SOUSA JÚNIOR, José Geraldo; DELDUQUE, Maria Célia; OLIVEIRA, Mariana Siqueira de Carvalho; DALLARI, Sueli Gandolfi (organizadores), v.4. Brasília: CEAD/UnB, p.80, 2009.

182 “Art. $5^{\circ}$ Todos são iguais perante a lei, sem distinção de qualquer natureza, garantindo-se aos brasileiros e aos estrangeiros residentes no País a inviolabilidade do direito à vida, à liberdade, à igualdade, à segurança e à propriedade, nos termos seguintes: (...) $§ 2^{\circ}$ - Os direitos e garantias expressos nesta Constituição não excluem outros decorrentes do regime e dos princípios por ela adotados, ou dos tratados internacionais em que a República Federativa do Brasil seja parte."

183 PIOVESAN, Flávia. Temas de Direitos Humanos. 6.ed. São Paulo: Saraiva, 2013, p.57.
} 
objetivam enriquecer a proteção dos direitos dos indivíduos em face dos poderes do Estado, estes buscam relações de equilíbrio e reciprocidade entre Estados-partes. ${ }^{184}$

Via de consequência, quanto à posição hierárquica das normas há duas situações: em relação aos direitos previstos em tratados que não versem sobre direitos humanos, nos termos do artigo 102, III, "b”, da Constituição Federal ${ }^{185}$, suas normas terão hierarquia infraconstitucional. De outro lado, os tratados internacionais versem sobre direitos humanos detêm hierarquia de normas constitucionais. A extensão do regime jurídicoconstitucional das normas definidoras dos direitos e garantias fundamentais aos tratados internacionais sobre direitos humanos decorre dos princípios da prevalência dos direitos humanos e da máxima efetividade das normas constitucionais referentes a direitos e garantias fundamentais, bem como da natureza materialmente constitucional dessas normas (parágrafo $2^{\circ}$, do artigo $5^{\circ}$, da Constituição Federal), que compõem a noção conceitual de bloco de constitucionalidade. ${ }^{186}$

Além de apresentarem hierarquia constitucional, as normas previstas em tratados internacionais que versem sobre direitos humanos são imediatamente aplicáveis, por força do disposto no parágrafo $1^{\circ}$, do artigo $5^{\circ}$, da Constituição Federal. ${ }^{187}$ Assim, a partir da ratificação desses tratados internacionais os efeitos se irradiam concomitantemente na ordem jurídica internacional e na ordem jurídica interna. ${ }^{188}$

De acordo com o parágrafo $3^{\circ}$, do artigo $5^{\circ}$, da Constituição Federal ${ }^{189}$, inserido pela Emenda Constitucional $n^{\circ} 45 / 2004$, os tratados internacionais concernentes a direitos humanos de que o Brasil faça parte devem ser integrados pela ordem jurídica do País por meio de aprovação, em dois turnos de votação em cada Casa do Congresso Nacional, pelo quorum qualificado de três quintos dos votos dos seus membros, que é justamente o

${ }^{184}$ PIOVESAN, Flávia. Temas de Direitos Humanos. 6.ed. São Paulo: Saraiva, 2013, p.56-59.

185 Art. 102. Compete ao Supremo Tribunal Federal, precipuamente, a guarda da Constituição, cabendo-lhe: (...) III - julgar, mediante recurso extraordinário, as causas decididas em única ou última instância, quando a decisão recorrida: (...) b) declarar a inconstitucionalidade de tratado ou lei federal;"

186 PIOVESAN, Flávia. Temas de Direitos Humanos. 6.ed. São Paulo: Saraiva, 2013, p.57-61.

187 “Art. $5^{\circ}$ Todos são iguais perante a lei, sem distinção de qualquer natureza, garantindo-se aos brasileiros e aos estrangeiros residentes no País a inviolabilidade do direito à vida, à liberdade, à igualdade, à segurança e à propriedade, nos termos seguintes: (...) $\S 1^{\circ}$ - As normas definidoras dos direitos e garantias fundamentais têm aplicação imediata."

${ }^{188}$ PIOVESAN, Flávia. Temas de Direitos Humanos. 6.ed. São Paulo: Saraiva, 2013, p.60.

189 “Art. $5^{\circ}$ Todos são iguais perante a lei, sem distinção de qualquer natureza, garantindo-se aos brasileiros e aos estrangeiros residentes no País a inviolabilidade do direito à vida, à liberdade, à igualdade, à segurança e à propriedade, nos termos seguintes (...) $\S 3^{\circ}$ - Os tratados e convenções internacionais sobre direitos humanos que forem aprovados, em cada Casa do Congresso Nacional, em dois turnos, por três quintos dos votos dos respectivos membros, serão equivalentes às emendas constitucionais." 
procedimento rigoroso estabelecido para a aprovação de emenda à Constituição, nos termos do artigo 60, parágrafo $2^{\circ}$, da Constituição Federal ${ }^{190}$. Desta maneira, os tratados internacionais de proteção de direitos humanos que já são materialmente constitucionais, com base no parágrafo $2^{\circ}$, do artigo $5^{\circ}$, da Constituição Federal, para que sejam também formalmente constitucionais, a partir da vigência da Emenda Constitucional $n^{\circ}$ 45/2004, devem obedecer ao procedimento previsto no parágrafo $3^{\circ}$, do artigo $5^{\circ}$, da Constituição. ${ }^{191}$

Uma questão que é preciso esclarecer diz respeito aos tratados internacionais concernentes a direitos humanos aprovados anteriormente à Emenda Constitucional $\mathrm{n}$. 45/2004 (EC n.45/04). Tais tratados se revestem de caráter material e formalmente constitucional, porquanto definem direitos fundamentais (Título II da Constituição Federal - "Dos Direitos e Garantias Fundamentais") e foram recepcionadas pelo Direito brasileiro, ampliando e expandindo, sob esta perspectiva, o bloco de constitucionalidade. ${ }^{192}$

A definição da posição hierárquica que ocupam os tratados internacionais concernentes a direitos humanos incorporados à ordem jurídico-constitucional brasileira, antes e depois da Emenda Constitucional no 45/2004 é relevante para se definir qual será o impacto desses tratados internacionais. Três situações podem ocorrer: (i) coincidência das normas com o direito assegurado na Constituição; (ii) integração, complementação e ampliação do universo de direitos constitucionalmente previstos; e (iii) contrariedade a preceito do Direito interno.

Na primeira situação, o Direito interno se inspira e utiliza como paradigma o Direito Internacional dos Direitos Humanos para produzir normas aplicáveis em âmbito nacional. Na segunda situação, o Direito interno recepciona os direitos consagrados em tratados internacionais de direitos humanos subscritos pelo País, conferindo-lhes a mesma condição hierárquica das normas constitucionais. Assim, é possível que seja ampliado ou

\footnotetext{
190 De acordo com o artigo 60, caput, e parágrafo $2^{\circ}$, da Constituição Federal: “Art. 60. A Constituição poderá ser emendada mediante proposta: (...) $\S 2^{\circ}$ - A proposta será discutida e votada em cada Casa do Congresso Nacional, em dois turnos, considerando-se aprovada se obtiver, em ambos, três quintos dos votos dos respectivos membros."

${ }^{191}$ Os primeiros tratados internacionais de direitos humanos aprovados conforme o parágrafo $3^{\circ}$, do artigo $5^{\circ}$, da Constituição Federal foram a Convenção sobre os Direitos das Pessoas com Deficiência e seu protocolo facultativo, em $1^{\text {o }}$ de agosto de 2008, por meio do Decreto Legislativo n. 186, de 10 de julho de 2008.

192 PIOVESAN adota esta posição por quatro argumentos: (i) a interpretação sistemática dos parágrafos $2^{\circ} \mathrm{e}$ $3^{\circ}$ do artigo $5^{\circ}$, da Constituição Federal, pois a EC 45/04 não revogou o parágrafo $2^{\circ}$ deste dispositivo; (ii) a racionalidade material e a lógica que devem orientar a hermenêutica dos direitos humanos; (iii) a necessidade de evitar interpretações que indiquem anacronismo do sistema jurídico; e (vi) a teoria geral da recepção do Direito brasileiro. PIOVESAN, Flávia. Temas de Direitos Humanos. 6.ed. São Paulo: Saraiva, 2013, p. 62.
} 
complementado o elenco de direitos fundamentais ou, ainda, melhor definidos os contornos desses direitos. Na terceira situação, a incorporação ao Direito interno de tratados internacionais que versem sobre direitos humanos, recebidos com a hierarquia de norma constitucional, devido ao seu caráter especial em relação aos demais atos normativos internacionais, tem o condão de paralisar a eficácia jurídica de toda e qualquer disciplina normativa infraconstitucional com ela conflitante. ${ }^{193} 194$

A saúde está definida como direito humano em diversos tratados internacionais subscritos pelo Brasil, tendo status de norma constitucional, com base no disposto no artigo $5^{\circ}$, parágrafo $2^{\circ}$ da Constituição Federal de $1988^{195}$. Nesse sentido, o conteúdo abrangente dos tratados internacionais que versam sobre o direito à saúde de que o Brasil é parte, asseguram direitos e deveres às pessoas e vinculam o Estado brasileiro a adotar medidas voltadas a garantir sua plena efetividade. A Constituição Federal de 1988 e a legislação infraconstitucional em matéria de saúde tiveram como referência o Direito Internacional dos Direitos Humanos. Neste caso, ocorre a interação das normas conforme a segunda hipótese anteriormente descrita, pois os tratados internacionais incorporados à ordem jurídica pátria ampliam o conteúdo do direito à saúde e servem como reforço à sua proteção pelo Direito Interno. A título de exemplo, cabe mencionar o preceito do artigo 11

\footnotetext{
${ }^{193}$ Neste sentido é o voto do Ministro Gilmar Mendes no Recurso Extraordinário (RE) n. 466.343, julgado pelo Plenário do Supremo Tribunal Federal, no qual foi Relator o Ministro Cezar Peluso (DJe 05.06.2009). O acórdão proferido no RE n. 466.343 reconheceu a ilegitimidade da legislação infraconstitucional que trata da prisão civil do depositário infiel face à internacionalização do Pacto Internacional dos Direitos Civis e Políticos e da Convenção Americana sobre Direitos Humanos (Pacto de San José da Costa Rica). No julgamento em referência, o Ministro Celso de Mello concluiu que embora o Pacto de San José da Costa Rica tenha sido ratificado pelo Brasil antes da EC n. 45/2004, por consistir em tratado internacional de direitos humanos, se reveste de caráter materialmente constitucional, compondo, sob esta dimensão, o bloco de constitucionalidade.

194 De acordo com MARINONI, o sistema jurídico-constitucional brasileiro admite o controle da compatibilidade da lei com os tratados internacionais de direitos humanos mediante ação direta ou por meio do controle difuso. A ação direta perante o Supremo Tribunal Federal seria cabível desde que tenham sido aprovados posteriormente a EC n. 45/2004, de acordo com o disposto no parágrafo $3^{\circ}$ do artigo $5^{\circ}$ da Constituição Federal. Além disso, afirma que os tratados internacionais de direitos humanos podem ser objeto de controle difuso de constitucionalidade e de convencionalidade em relação às normas infraconstitucionais do Direito Interno. SARLET, Ingo Wolfgang; MARINONI, Guilherme; MITIDIERO, Daniel. Curso de Direito Constitucional. 2. ed. São Paulo: Editora Revista dos Tribunais, 2013, p. 1264-1268. Cumpre acrescentar que também seria possível o controle concentrado na hipótese em que o tratado internacional de direitos humanos tenha sido adotado anteriormente a Emenda Constitucional n. 45/2004, por força do entendimento adotado no acórdão proferido no RE 466.343, STF, Pleno, Rel. Min.Cezar Peluso, DJe 05.06.2009.

195 “Art. $5^{\circ}$ Todos são iguais perante a lei, sem distinção de qualquer natureza, garantindo-se aos brasileiros e aos estrangeiros residentes no País a inviolabilidade do direito à vida, à liberdade, à igualdade, à segurança e à propriedade, nos termos seguintes: (...) $§ 2^{\circ}$ - Os direitos e garantias expressos nesta Constituição não excluem outros decorrentes do regime e dos princípios por ela adotados, ou dos tratados internacionais em que a República Federativa do Brasil seja parte."
} 
do Pacto Internacional dos Direitos Econômicos, Sociais e Culturais, que estabelece o direito de toda pessoa a um nível de vida adequado para si próprio e para sua família.

Segundo o Ministério das Relações Exteriores ${ }^{196}$, o Brasil é signatário de 19 (dezenove) tratados multilaterais ${ }^{197}{ }^{198}$ e de 190 (cento e noventa) tratados bilaterais ${ }^{199}$ ${ }^{200}$ relativos especificamente à proteção, promoção e recuperação da saúde da população brasileira. Além dos tratados, há outros compromissos internacionais ${ }^{201}{ }^{202}$ pelos quais o Estado assume o dever de atender metas para melhorar o estado de saúde da população. ${ }^{203}$

196 A lista dos acordos internacionais multilaterais e bilaterais firmados pelo Brasil pode ser consultada no site oficial da Divisão de Assuntos Internacionais do Ministério das Relações Exteriores, assim como também pode ser consultado o inteiro teor de quase a totalidade desses documentos. Disponível em: $<$ http://dao-mre.serpro.gov.br>.

${ }^{197}$ A consulta está atualizada até 16 de outubro de 2013. Disponível em: <http://dao-mre.serpro.gov.br>.

${ }^{198}$ Dentre os tratados multilaterais de que o Brasil é signatário, vale destacar a Convenção-Quadro para o Controle do Tabaco, primeiro tratado internacional da história da Organização Mundial de Saúde, adotado em 21 de maio de 2003 e vigente desde 27 de fevereiro de 2005. O Brasil assinou a Convenção-Quadro para o Controle do Tabaco em 16 de junho de 2003, a qual foi ratificada em 3 de novembro de 2005 e entrou em vigor no dia $1^{\circ}$ de fevereiro de 2006. Até 16 de outubro de 2013, 177 países aderiram à Convenção-Quadro para o Controle do Tabaco. Disponível em: <http://www.who.int>. Consulta em 16/10/2013.

199 A consulta está atualizada até 16 de outubro de 2013. Disponível em: <http://dao-mre.serpro.gov.br>.

${ }^{200}$ Um dos principais parceiros do Brasil em cooperação internacional na área de saúde é Cuba. Apenas em 2012 foram celebrados 5 (cinco) ajustes complementares a acordos de cooperação científica, técnica e tecnológica entre os governos brasileiro e cubano, que estão em vigor, com as seguintes finalidades: 1. Prestar apoio técnico para a expansão e consolidação da rede cubana de bancos de leite humano; 2 . Implementar o projeto de fortalecimento da organização da pesquisa clínica sobre câncer; 3. Implementar o projeto de estabelecimento das substâncias de referência para o controle da qualidade dos medicamentos; e 4. Implementar a fase 3 do projeto de fortalecimento da odontologia no Brasil e em Cuba (2 ajustes). Disponível em: <http://dao-mre.serpro.gov.br>.

201 A Declaração de Alma-Ata, formulada por ocasião da Conferência Internacional sobre Cuidados Primários de Saúde, em Alma-Ata, na antiga Rússia, atual Cazaquistão, entre 6 e 12 de setembro de 1978, foi destacada a importância dos cuidados primários à saúde, tendo sido estabelecido em seu item I o seguinte: "A Conferência reafirma enfaticamente que a saúde - estado de completo bem-estar físico, mental e social, e não simplesmente a ausência de doença ou enfermidade - é um direito humano fundamental, e que a consecução do mais alto nível possível de saúde é a mais importante meta social mundial, cuja realização requer a ação de muitos outros setores sociais e econômicos, além do setor da saúde." Segundo REY, foi verificada a necessidade de uma solução urgente para a promoção de saúde na nova ordem econômica internacional. Assim, os eixos definidos na Declaração de Alma-Ata para a obtenção de um estado de saúde para todos por volta do ano 2000 foram: educação; fornecimento de alimentos; água potável segura; saúde materna e infantil, inclusive com planejamento familiar; imunizações; prevenção e controle das doenças endêmicas; tratamento apropriado das afecções e lesões comuns; e fornecimento dos medicamentos essenciais. Após dezoito anos da realização da Conferência de Alma-Ata, o Fórum Mundial da Saúde da Organização Mundial da Saúde, realizado em 1996, concluiu que apesar dos progressos alcançados na área de saúde, persistem grandes desigualdades entre países industrializados e países em desenvolvimento quanto às condições de saneamento básico e extensão dos cuidados de saúde à população pobre, o que impõe a ampliação do acesso às ações e serviços de saúde para todos, em nível mundial. REY, Luís. Dicionário de termos técnicos de medicina e saúde. 2.ed. Reimpressão. Rio de Janeiro: Guanabara Koogan, 2008, p. 39 e 797.

202 A "Cúpula do Milênio das Nações Unidas", realizada em setembro de 2000, reuniu lideres mundiais de 189 países para firmar um compromisso com os direitos humanos e a democracia, estabelecendo um conjunto de metas bem delimitadas quanto ao tempo, visando a combater a pobreza, a fome, as doenças, o analfabetismo, a degradação do meio ambiente e a discriminação contra a mulher. Foram apresentados então os "Objetivos de Desenvolvimento do Milênio", com os respectivos indicadores sociais. No que se refere às nações das Américas, em 2003, todos os países da região reuniram-se em uma conferência em Brasília, onde 
A permeabilidade implícita, por sua vez, se refere à influência do direito internacional da saúde na ordem jurídica nacional sem que haja a internalização das normas de regulação da saúde da forma tradicional.

Ao longo do processo histórico-dialético, o direito à saúde foi reconhecido, tanto no Direito Internacional, com a proveitosa universalização dos direitos humanos ${ }^{204}$, como no Direito Interno, com a sua positivação como direito fundamental social na Constituição Federal de 1988, o qual será objeto de detido exame, após a necessária retrospectiva do processo histórico de sua conquista. ${ }^{205}$

\subsection{A saúde no Brasil antes da Constituição Federal de 1988 e as origens do Sistema Único de Saúde (SUS)}

A organização política e social do Estado brasileiro passou por diferentes fases ${ }^{206}$ desde o Diploma Constitucional do Império de 25 de março de 1824, originado por ato de

foi feita a "Declaração de Brasília", que é uma chamada à ação e à execução do que está expresso nos Objetivos da Declaração do Milênio. Os oito objetivos gerais, que deverão ser atendidos até o final de 2015, são os seguintes: 1- erradicar a extrema pobreza e a fome; 2- atingir o ensino primário para todos; 3promover a igualdade entre os sexos e a autonomia das mulheres; 4- reduzir a mortalidade na infância; 5 melhorar a saúde materna; 6- combater o HIV/AIDS, a malária e outras doenças; 7- garantir a sustentabilidade ambiental e 8- estabelecer uma parceria mundial para o desenvolvimento. Dentre esses objetivos, os relacionados nos itens "4", "5", e "6" referem-se diretamente à área de saúde e os demais trazem repercussões importantes à promoção da saúde da população.

${ }^{203}$ O Brasil não firmou recentemente novos tratados multilaterais para a melhoria das condições de saúde da população. Foram estabelecidos tão somente dois memorandos de entendimento sobre cooperação trilateral nas áreas de saúde e medicina (vigente desde 17/10/2007) e em ciência, tecnologia e inovação (vigente desde 15/04/2010) entre o governo do Brasil, da Índia e da África do Sul. Neste sentido, VENTURA observa que após a globalização econômica não houve continuidade na assinatura de novos acordos internacionais voltados à proteção da saúde, diversamente do que ocorreu após a Segunda Guerra Mundial, época que houve intensa cooperação internacional para a regulação na área da saúde como consequência da criação da Organização Mundial de Saúde. VENTURA, Deisy de Freitas Lima. Uma visão internacional do direito à saúde. In: O Direito achado na rua: introdução crítica ao direito à saúde. COSTA, Alexandre Bernardino; SOUSA JÚNIOR, José Geraldo; DELDUQUE, Maria Célia; OLIVEIRA, Mariana Siqueira de Carvalho; DALLARI, Sueli Gandolfi (organizadores), v.4. Brasília: CEAD/UnB, p.80, 2009.

${ }^{204}$ No tocante à posição do Brasil em relação ao sistema internacional de proteção dos direitos humanos, PIOVESAN afirma que somente após o processo de democratização deflagrado em 1985, o Estado brasileiro passou a ratificar relevantes tratados internacionais de direitos humanos. PIOVESAN, Flávia. Temas de Direitos Humanos. 6.ed. São Paulo: Saraiva, 2013, p.54.

${ }^{205}$ Conforme BOBBIO, os direitos humanos, apesar de terem sido considerados naturais desse o início, não foram dados de uma vez por todas nem conjuntamente. A defesa do homem do Poder, de toda forma de Poder, pelos bens supremos da vida, da liberdade e da segurança social é uma história de tempos longos. BOBBIO, Norberto. A era dos direitos. Tradução de Carlos Nelson Coutinho, nova ed. Rio de Janeiro: Elsevier, 2004, p.201-212.

${ }^{206}$ BULOS observa que no constitucionalismo pátrio apenas quatro das constituições foram democráticas e, assim, livremente votadas e promulgadas por Assembleias Constituintes (1891, 1934. 1946 e 1988), ao passo que as demais foram ilegitimamente outorgadas (1824, 1937 e 1967, com a reforma empreendida pela 
D. Pedro I, após a dissolução da Assembleia Constituinte, convocada em 1823, até a promulgação da Constituição Republicana de 1988. Neste longo período, houve transformações substanciais na história do Brasil, que refletiram na própria concepção do Estado $^{207} \mathrm{e}$, consequentemente, no tratamento jurídico-constitucional conferido aos direitos sociais e, particularmente, ao direito à saúde. ${ }^{208}$

A vinda da família Real portuguesa ao Brasil ${ }^{209}$, em 1808, provocou alterações na administração pública colonial, inclusive na área da saúde, visto que até então era proibido o ensino superior nas colônias. ${ }^{210} 211$ A cidade do Rio de Janeiro passou a ser o centro das atenções sanitárias, pois sediava provisoriamente a Corte portuguesa e o principal porto do

Emenda Constitucional n. 1/69). Acrescenta que além dessas Constituições, o Brasil teve mais duas de natureza provisória, provenientes de governos revolucionários, que foram instituídas pelos Decretos n. 1, de 15 de novembro de 1889 e n. 19.398, de 11 de novembro de 1930. BULOS, Uadi Lammêgo. Constituição Federal Anotada. 10. ed. São Paulo: Saraiva, 2012, p. 32.

${ }^{207}$ Num breve panorama, em 15 de novembro de 1889, ocorreu a proclamação da República por Marechal Deodoro da Fonseca e iniciou-se a República Velha. Foi então promulgada a primeira Constituição republicana, de 24 de fevereiro de 1891. Este regime terminou em 1930, com a chegada de Getúlio Vargas ao poder. Em seguida, com a ruptura da concepção liberal de Estado, foi promulgada a Constituição de 1934, que positivou em seu texto os direitos sociais e implantou o modelo cooperativo de federalismo. Em 1964 o general Castelo Branco assumiu a Presidência do país e iniciou-se o Regime Militar que, a pretexto de combater a desordem e a corrupção, suprimiu direitos individuais, como a liberdade de manifestação do pensamento (censura dos meios de comunicação) e a liberdade de associação (extinguiu partidos políticos) e criou o bipartidarismo entre a Aliança Renovadora Nacional (ARENA) e o Movimento Democrático Brasileiro (MDB). Posteriormente ao fïm do regime militar, em meio ao processo de redemocratização do país, deputados federais e senadores se reuniram em Assembleia Nacional Constituinte e promulgaram a Constituição Federal de 1988, conhecida como Constituição "cidadã”, tanto pela intensa participação popular na elaboração do seu texto, quanto pelo reconhecimento dos direitos e garantias fundamentais.

${ }^{208}$ Sobre a saúde no Brasil anterior à Constituição Federal de 1988, conferir: SILVA, Francisco Livanildo da. O Direito à Saúde e a Política Nacional de Atenção Oncológica: Uma análise a partir da crescente judicialização dos medicamentos antineoplásicos. Dissertação (mestrado). Universidade Federal do Rio Grande do Norte. Natal, 2012.

${ }^{209}$ Segundo BERTOLLI FILHO, os principais obstáculos ao estabelecimento dos colonizadores em terras brasileiras eram os conflitos com os indígenas, as dificuldades materiais da vida na região e, sobretudo, as diversas enfermidades graves que ceifavam muitas vidas. Por conta disso, o Conselho Ultramarino português criou no século XVI os cargos de físico-mor e cirurgião-mor para zelar pela saúde da população sob domínio lusitano. Contudo, tais funções permaneceram por longos períodos sem ocupantes, devido ao desinteresse dos médicos pelos baixos salários e pelo medo dos perigos que enfrentariam no Brasil. BERTOLLI FILHO, Cláudio. História da Saúde Pública no Brasil. 3. ed. São Paulo: Ática, 1999, p.5-6.

${ }^{210}$ Em 1746, na área do território dos atuais estados de São Paulo, Paraná, Mato Grosso, Mato Grosso do Sul e Goiás, havia apenas seis médicos graduados em universidades europeias. Neste período, a população rica e pobre preferia utilizar os remédios recomendados pelos curandeiros negros ou indígenas do que recorrer aos médicos formados na Europa, que eram "raros e caros". BERTOLLI FILHO, Cláudio. História da Saúde Pública no Brasil. 3. ed. São Paulo: Ática, 1999, p.5-6.

${ }^{211}$ No Brasil, até a metade do século XVIII a administração portuguesa não se preocupou em organizar o espaço social visando o combate às causas das doenças no Brasil. Não há registros da relação entre saúde e sociedade nas instituições médicas ou no aparelho do Estado anteriormente ao século XIX. BRASIL. Conselho Nacional de Secretários de Saúde. Sistema Único de Saúde. Coleção Para Entender a Gestão do SUS, v. 1, Brasília: CONASS, 2011, p.10. 
país. Dom João VI pretendia exibir uma nova imagem da região, definida pelos europeus como território de barbárie e escravidão ${ }^{212}$. Assim, por ordem real, foram fundadas as academias médico-cirúrgicas do Rio de Janeiro (1813) e da Bahia (1815), que logo se transformaram nas duas primeiras escolas de medicina do país. ${ }^{213}$

Em 7 de setembro de 1822, com a proclamação da independência por D. Pedro I, o Brasil deixou de ser uma colônia e tornou-se independente de Portugal. A Constituição de 1824 prescrevia em seu último título, as disposições gerais e as garantias dos direitos civis e políticos dos cidadãos brasileiros. Embora o direito à saúde não tenha sido reconhecido de forma autônoma, a previsão de segurança individual como base dos direitos civis e políticos assegurava, indiretamente, a saúde das pessoas, dentre outras formas: proibindo o trabalho, cultura, indústria ou comércio que violasse a segurança ou a saúde dos cidadãos; proscrevendo penas cruéis; determinando que as cadeias fossem seguras, limpas e bem arejadas; e garantindo os socorros públicos. ${ }^{214}$

Em 1829, por ordem de dom Pedro I e para atender ao pedido feito por membros da elite nacional, foi criada a Imperial Academia de Medicina, reunindo os principais clínicos que atuavam no Rio de Janeiro. Esta academia funcionou como órgão consultivo do imperador nas questões relativas à saúde pública nacional. Nessa época, também foi criada a Junta de Higiene Pública com o objetivo de cuidar da saúde da população. Porém, em razão da fragilidade das medidas sanitárias adotadas, não alcançou sua finalidade. A população lutava por conta própria contra doenças e a morte. ${ }^{215}$

Em 15 de novembro de 1889, a proclamação da República derrubou a monarquia constitucional do Império do Brasil, instaurando a forma republicana de governo, baseada

${ }^{212}$ BERTOLLI FILHO, Cláudio. História da Saúde Pública no Brasil. 3. ed. São Paulo: Ática, 1999, p.8.

${ }^{213}$ BRASIL. Conselho Nacional de Secretários de Saúde. Sistema Único de Saúde. Coleção Para Entender a Gestão do SUS, v. 1. Brasília: CONASS, 2011, p. 10.

214 "TITULO $8^{\circ}$. Das Disposições Geraes, e Garantias dos Direitos Civis, e Politicos dos Cidadãos Brazileiros. (...) Art. 179. A inviolabilidade dos Direitos Civis, e Politicos dos Cidadãos Brazileiros, que tem por base a liberdade, a segurança individual, e a propriedade, é garantida pela Constituição do Imperio, pela maneira seguinte. (...) XIX. Desde já ficam abolidos os açoites, a tortura, a marca de ferro quente, e todas as mais penas crueis. (...) XXI. As Cadêas serão seguras, limpas, o bem arejadas, havendo diversas casas para separação dos Réos, conforme suas circumstancias, e natureza dos seus crimes. (...) XXIV. Nenhum genero de trabalho, de cultura, industria, ou commercio póde ser prohibido, uma vez que não se opponha aos costumes publicos, à segurança, e saude dos Cidadãos. (...) XXXI. A Constituição tambem garante os soccorros publicos". (Redação conforme o original)

215 As Santas Casas de Misericórdia fundadas nos principais núcleos populacionais brasileiros faziam o atendimento hospitalar da maioria da população. A primeira foi fundada na Vila de Santos, em 1543. Todavia, como em suas enfermarias os pacientes com doenças de todos os tipos permaneciam juntos e também dividiam leitos, as famílias dos doentes evitavam interna-los com receio de que logo morressem. BERTOLLI FILHO, Cláudio. História da Saúde Pública no Brasil. 3. ed. São Paulo: Ática, 1999, p.8-11. 
na ideia de trazer desenvolvimento, em sentido amplo, para o País. A modernização da economia e das relações de trabalho no Brasil se mostrava necessária e urgente, visto que somente em 13 de maio de 1888 foi abolida a escravisão. ${ }^{216}$

A Constituição de $1891^{217}$, devido ao seu caráter eminentemente liberal, não contemplava direitos sociais, tendo se limitado a estabelecer a inviolabilidade dos direitos concernentes à "segurança individual" 218 e uma cláusula de abertura a outros direitos e garantias não expressos no texto constitucional, decorrentes da forma de governo e dos princípios que consigna. ${ }^{219}$ Se é certo que os Estados poderiam estabelecer ações e serviços de saúde, como o saneamento básico, com fundamento na norma de competência que autorizava o exercício de todo e qualquer poder que não fosse vedado por norma prevista no texto constitucional, ${ }^{220}$ o fato é que a atuação estatal se limitava às medidas de contenção de surtos epidêmicos. $^{221}$

Nesse contexto, a medicina social foi concebida como medida educativa para a prevenção de doenças, sobretudo no espaço social urbano ${ }^{222}$ e assumiu o papel de guia do Estado para assuntos sanitários, com o objetivo de melhorar a saúde individual e coletiva e, por consequência, contribuir para o projeto de modernização do país. ${ }^{223}$

Contudo, a desorganização dos serviços de saúde nos primeiros anos da República facilitou a proliferação de novas ondas epidêmicas no país. ${ }^{224}$ Entre 1890 e 1900, o quadro

\footnotetext{
${ }^{216}$ BERTOLLI FILHO, Cláudio. História da Saúde Pública no Brasil. 3. ed. São Paulo: Ática, 1999, p.12.

${ }^{217}$ NASCIMENTO explica que as leis trabalhistas surgiram na Europa e tiveram tímidos reflexos no Brasil, insuficientes para provocar a ação do governo e a estruturação do direito operário. Conta que somente com o advento da Emenda Constitucional de 7 de setembro de 1926 foi prevista a atribuição para que o Congresso Nacional legislasse sobre a estruturação do direito do trabalho. NASCIMENTO, Amauri Mascaro. Curso de Direito do Trabalho: história e teoria geral do direito do trabalho: relações individuais e coletivas do trabalho. 19. ed. São Paulo: Saraiva, 2004, p. 66-68.

218 “Art. 72 - A Constituição assegura a brasileiros e a estrangeiros residentes no País a inviolabilidade dos direitos concernentes à liberdade, à segurança individual e à propriedade, nos termos seguintes: (...)”

219 “Art. 78 - A especificação das garantias e direitos expressos na Constituição não exclui outras garantias e direitos não enumerados, mas resultantes da forma de governo que ela estabelece e dos princípios que consigna."

220 “Art. 65 - É facultado aos Estados: 1. celebrar entre si ajustes e convenções sem caráter político (art. 48, $n^{\circ}$. 16);.$^{\circ}$ em geral, todo e qualquer poder ou direito, que lhes não for negado por cláusula expressa ou implicitamente contida nas cláusulas expressas da Constituição".

${ }^{221}$ BERTOLLI FILHO, Cláudio. História da Saúde Pública no Brasil. 3. ed. São Paulo: Ática, 1999, p.13-14.

${ }^{222}$ Sobre o tema, conferir: MACHADO, Roberto; LOUREIRO, Ângela; LUZ, Rogério; MURICY, Kátia. Danação da norma: a medicina social e constituição da psiquiatria no Brasil. Rio de Janeiro: Edições Graal, 1978.

${ }^{223}$ BERTOLLI FILHO, Cláudio. História da Saúde Pública no Brasil. 3. ed. São Paulo: Ática, 1999, p.12.

${ }^{224}$ BERTOLLI FILHO, Cláudio. História da Saúde Pública no Brasil. 3. ed. São Paulo: Ática, 1999, p.13.
} 
sanitário era grave devido às epidemias de varíola ${ }^{225} 226$, febre amarela, febre tifoide, cólera e peste bubônica que se alastraram no Rio de Janeiro e nas principais cidades brasileiras.

As consequências provocadas por conta das epidemias, sobretudo da peste bubônica, se estenderam às relações econômicas do Brasil. Nos negócios realizados pela via marítima não era permitido o acesso de navios brasileiros aos portos de outros países. Além disso, os comerciantes estrangeiros não tinham interesse em atracar seus navios de carga ou de passageiros, no Porto do Rio de Janeiro. ${ }^{227} 228$

${ }^{225}$ Em 31 de outubro de 1904 o Congresso Nacional aprovou uma lei que tornava obrigatória a vacinação contra a varíola, atendendo ao pedido de Oswaldo Cruz. SOUSA e PIVA afirmam que embora o objetivo da campanha fosse positivo, a medida foi aplicada de forma autoritária e violenta. Em alguns casos, os agentes sanitários invadiam os domicílios acompanhados por policiais e vacinavam as pessoas à força. $\mathrm{O}$ povo reagiu contra o processo de vacinação porque nunca havia passado por um processo semelhante e desconhecia a composição e a qualidade do material utilizado na imunização, bem como seus efeitos. Esse clima de incompreensão gerou a chamada "Revolta da Vacina". SOUZA, Vagner Pereira de; PIVA, Teresa Cristina de Carvalho. A Peste Bubônica no Rio de Janeiro e o Instituto Soroterápico Federal. In: Scientiarum Historia IV. Rio de Janeiro: Congresso de Historia das Ciências e das Técnicas e Epistemologia, p. 705, 2011. Disponível em: < http://www.hcte.ufrj.br>. Consulta em 10/12/2013.

${ }^{226}$ A "Revolta da Vacina", ocorrida em 1904, demonstra o inconformismo da população brasileira em relação às medidas sanitárias impostas pelo Estado contra a epidemia de varíola que assolou a cidade do Rio de Janeiro, à época a capital da República. Segundo a Fundação Nacional de Saúde (FUNASA), em apenas cinco meses foram internadas 1.800 (mil e oitocentas) pessoas no Hospital São Sebastião em razão da varíola, embora houvesse lei anterior determinando a imunização compulsória de crianças contra a doença, pois a norma não era cumprida. Diante da gravidade da situação, o Executivo encaminhou ao Congresso Nacional um projeto de lei reinstaurando a obrigatoriedade da vacinação antivariólica nas seguintes condições: antes dos seis meses de idade; para todos os militares; e a cada sete anos. Neste instrumento normativo foi estabelecida a necessidade de apresentação de atestado de imunização aos candidatos a quaisquer cargos ou funções públicas, a quem pretendesse casar, viajar ou matricular-se em escola e, também, atribuía poderes à polícia sanitária para obrigar os moradores de determinada área de foco a se imunizarem e previa a imposição de multa e outras penalidades a quem se recusasse a ser imunizado. As pessoas deveriam ser submetidas à observação médica em local apropriado, pagando as despesas de estadia. Descontente com essas medidas, a população formou um grupo de oposição a Oswaldo Cruz. Deste grupo, foi criada a Liga Contra a Vacinação Obrigatória. O movimento de revolta da população contra o governo durou seis meses. Em 13 de novembro de 1904 houve choques com a polícia, greves, quebra-quebra e tiroteios. Após três dias de guerra urbana, o governo decretou estado de sítio. O levante popular foi controlado e o governo determinou a suspenção da obrigatoriedade da vacina. BRASIL. FUNASA. 100 anos de saúde pública. FUNASA em revista. Ministério da Saúde, n. 1, p. 4-5, Janeiro de 2004. Disponível no site da Fundação Nacional da Saúde, em: <http://www.funasa.gov.br>. Consulta em 11/04/2013.

${ }^{227}$ A peste bubônica é uma das doenças mais graves da história da humanidade, devido ao elevado número de óbitos provocados pelas epidemias ocorridas no continente europeu, tendo sido a mais grave no século XIV. A doença chegou ao Brasil, na cidade de Santos, São Paulo, em outubro de 1899. Naquela época, o porto de Santos era o segundo em importância no país e o principal escoadouro da produção de café. Após apenas três meses, a peste se disseminou e chegou à Capital Federal. O Rio de Janeiro, no início do século XX, era uma cidade cujas características contribuíram para que a doença se espalhasse: crescimento populacional, intensa atividade comercial e precária estrutura de armazenamento de alimentos, de saneamento e esgoto, o qual servia como esconderijo e provedor de alimentos aos ratos. O Porto do Rio de Janeiro tinha destaque como distribuidor de produtos importados para o restante do Brasil, além de ser parada obrigatória para a navegação de cabotagem que ligava o Norte ao Sul do País. A partir da identificação de diversas epidemias no Rio de Janeiro surgiu a necessidade de criação de órgãos destinados a controlá-las e combatê-las. Embora o número de óbitos provocados pela peste bubônica seja bem menor do que os da varíola e da febre amarela, os entraves econômicos que a presença da peste gerava ao Brasil fizeram com que a doença fosse inserida na lista das doenças a serem combatidas. 
Diante dessa situação de calamidade, médicos higienistas foram investidos em altos cargos da estrutura da Administração Pública, mediante o compromisso de estabelecer estratégias para promover a saúde nos locais indicados pelos políticos. ${ }^{229} \mathrm{O}$ Estado passou a realizar campanhas sanitárias e a organizar serviços de saúde para o controle de epidemias. Foram divulgadas regras básicas de higiene e tornou-se obrigatório o isolamento de pessoas acometidas por moléstias infecto-contagiosas e de doentes mentais. ${ }^{230} 231$

A participação do Estado na área da saúde deixou de ser episódica e passou a abranger todas as classes sociais. A incorporação de conhecimentos clínicos e epidemiológicos às práticas de proteção da saúde levaram os governos republicanos a elaborar planos de combate às enfermidades que reduziam e prejudicavam a vida produtiva

${ }^{228}$ Diante desses fatos e com o suporte administrativo e econômico dados pelo governo federal, foi criada a Diretoria Geral de Saúde Pública (DGSP), cujo diretor passou a ser Oswaldo Cruz, em março de 1903, com a missão de acabar com as três principais epidemias da cidade: febre amarela, varíola e peste bubônica. Com apoio do Prefeito da cidade e do engenheiro Pereira Passos, Oswaldo Cruz comandou uma reforma urbanística e sanitária. A principal ação de Oswaldo Cruz para o combate da peste foi a criação de uma turma formada por 50 (cinquenta) homens, apelidados de "ratoeiros", que deveriam sair às ruas comprando os ratos caçados pela população e entregar pelo menos 5 (cinco) ratos por dia ao Desinfectório Central. O salário era de 60 (sessenta) réis por mês e os ratos que fossem capturados a mais, importariam em bonificações, o que incentivava os "ratoeiros" a ampliarem a captura dos roedores. Durante os primeiros meses em que esteve em vigor, a caça aos ratos apresentou os resultados satisfatórios, tendo sido incinerados 24.441 roedores, de 20 de setembro até 31 de dezembro de 1903. Em virtude do problema causado por pessoas que passaram a criar ratos para a obtenção de lucro com a venda dos animais ao governo, a experiência de extermínio dos ratos foi reformulada em meados de 1904. A compra e venda dos animais foi suspensa e eles passaram a ser exterminados por envenenamento, com gases tóxicos aplicados nas galerias subterrâneas de água e esgoto, e caçados nos lugares mais insalubres da cidade, sem, todavia, se pagar pelos animais abatidos. A partir de 1907 houve uma diminuição natural do número de óbitos por peste bubônica e nos anos seguintes a moléstia foi extinta. SOUZA, Vagner Pereira de; PIVA, Teresa Cristina de Carvalho. A Peste Bubônica no Rio de Janeiro e o Instituto Soroterápico Federal. In: Scientiarum Historia IV, Congresso de Historia das Ciências e das Técnicas e Epistemologia, Rio de Janeiro, p.701-707, 2011.

${ }^{229}$ BERTOLLI FILHO, Cláudio. História da Saúde Pública no Brasil. 3. ed. São Paulo: Ática, 1999, p.13-14. ${ }^{230}$ BERTOLLI FILHO, Cláudio. História da Saúde Pública no Brasil. 3. ed. São Paulo: Ática, 1999, p.14.

231 As medidas sanitárias colocadas em prática, de forma autoritária, no final do século XIX e início do século XX, foram importantes para o controle e combate às doenças. No final do século XIX foram criados os primeiros laboratórios de pesquisas médico-epidemiológicos no Brasil, voltados à produção de vacinas e ao estudo de patologias, quais sejam: o Instituto Bacteriológico de São Paulo (posteriormente denominado Instituto Adolfo Lutz); o Instituto Vacinogênico (posteriormente nomeado de Instituto Biológico); e o Instituto Soroterápico Federal. SOUSA e PIVA afirmam que Oswaldo Cruz dirigiu o Instituto Soroterápico Federal (conhecido como laboratórios de Manguinhos) a partir de 2002, cuja principal finalidade por ocasião de sua inauguração consistia na fabricação do soro para combater a Peste Bubônica no Rio de Janeiro. O instituto manteve este nome até 1907, quando foi alterado para Instituto de Patologia Federal. Em 1908 Oswaldo Cruz recebeu uma importante premiação na Exposição de Demografia e Higiene de Berlim e o Instituto recebeu seu nome. Atualmente designada Fundação Oswaldo Cruz, continua em funcionamento, contribuindo com a produção de vacinas e de medicamentos, bem como na formação ampla de profissionais em todas as áreas destinadas à Saúde Pública. SOUZA, Vagner Pereira de; PIVA, Teresa Cristina de Carvalho. A Peste Bubônica no Rio de Janeiro e o Instituto Soroterápico Federal. In: Scientiarum Historia IV, Congresso de Historia das Ciências e das Técnicas e Epistemologia, Rio de Janeiro, p.701-707, 2011. 
da população. ${ }^{232}$ A continuidade da intervenção estatal e o conjunto de ações promovidas em diversas áreas para a melhoria das condições de saúde da população indicam a criação das primeiras políticas de saúde no Brasil.

Durante a República Velha houve um movimento ativo de Reforma Sanitária liderado por médicos higienistas, que alcançou importantes resultados, dos quais se destacam: a criação do Departamento Nacional de Saúde Pública (DNSP), em 1920; e o estabelecimento de bases para a criação de um Sistema Nacional de Saúde, caracterizado pela concentração e pela verticalização das ações no governo central.

A institucionalização da saúde pública ocorreu na era Vargas, com a instalação, em novembro de 1930, do Ministério da Educação e da Saúde Pública. O novo ministério determinou a reorganização dos serviços sanitários do país, para garantir que a burocracia federal pudesse controlá-los, numa estratégia decorrente do centralismo políticoadministrativo imposto por Getúlio Vargas. A remodelação dos serviços sanitários no Brasil exprimia o compromisso do Estado de zelar pelo estado de saúde da população, porém os serviços disponibilizados eram limitados ao tratamento de algumas enfermidades específicas como tracoma e lepra, sem atender as necessidades das pessoas com outras doenças, como a tuberculose nem prestar assistência às mulheres grávidas. ${ }^{233}$

Em caso de enfermidade ou acidente de trabalho, os operários procuravam socorro nos hospitais filantrópicos, que prestavam atendimento médico-hospitalar gratuitamente. A única exceção, no período anterior a 1930, era o Instituto Previdenciário dos Trabalhadores das Estradas de Ferro sediadas em São Paulo, criado em 1923, por meio da Lei Elói Chaves. Aos ferroviários era assegurado o direito de aposentadoria por tempo de serviço ou por invalidez, o tratamento médico, os medicamentos, o auxílio para o funeral e ainda o direito de pensão aos herdeiros do segurado, mediante o desconto mensal de $3 \%$ do salário dos funcionários e $1 \%$ da renda bruta das empresas. ${ }^{234}$

O modelo de serviços contidos na Lei Elói Chaves foi utilizado por Getúlio Vargas para a criação das Caixas de Aposentadorias e Pensões (CAPs) ${ }^{235}$, que posteriormente

\footnotetext{
${ }^{232}$ BERTOLLI FILHO, Cláudio. História da Saúde Pública no Brasil. 3. ed. São Paulo: Ática, 1999, p.14-15. ${ }^{233}$ BERTOLLI FILHO, Cláudio. História da Saúde Pública no Brasil. 3. ed. São Paulo: Ática, 1999, p.30-32. ${ }^{234}$ BERTOLLI FILHO, Cláudio. História da Saúde Pública no Brasil. 3. ed. São Paulo: Ática, 1999, p.32-33.

${ }^{235}$ É interessante observar que embora grande parte das Caixas de Aposentadorias e Pensões tenha sido extinta, a Caixa de Assistência dos Funcionários do Banco do Brasil (CASSI) permanece ativa. Fundada em 27 de janeiro de 1944, por um grupo de funcionários do BB, com o objetivo de ressarcir suas despesas de saúde, atualmente a Caixa de Assistência dos Funcionários do Banco do Brasil é uma das maiores instituições administradoras de planos de saúde do País, dos quais são titulares seus funcionários e familiares.
} 
foram substituídas pelo Instituto de Aposentadorias e Pensões (IAP), a diversas categorias profissionais. Os trabalhadores organizavam associações de auxílio mútuo que, sob a tutela do Estado, garantiam assistência médica e benefícios àqueles trabalhadores ou aos seus dependentes, sem dispender recursos públicos. ${ }^{236}$

Os serviços prestados pelas caixas eram limitados ao atendimento nos casos de menor complexidade, deixando à margem uma parcela de operários acometidos de doenças mais graves como, por exemplo, os tuberculosos. A situação era ainda pior aos trabalhadores que não possuíam carteira de trabalho, e por esse motivo não tinham a possibilidade de contribuir para a caixa de sua categoria profissional, pois quando adoeciam somente podiam pedir ajuda às entidades filantrópicas, nas quais eram tratados como indigentes. $^{237}$

A contínua organização dos operários, facilitada pelo desenvolvimento dos meios de comunicação, levou-os a reivindicar que o Estado se responsabilizasse pela execução de ações e serviços destinados a eliminar, diminuir ou prevenir riscos relativos às condições de saúde no trabalho. ${ }^{238}$

A Constituição de 1934, influenciada pelas primeiras constituições do Estado Liberal, estabeleceu os direitos sociais e as normas definidoras de metas e tarefas do Estado em matéria social. Dentre os direitos sociais, previu o direito à assistência médica e sanitária aos trabalhadores e à gestante, assegurando a esta descanso antes e depois do parto, sem prejuízo do salário e do emprego, o direito ao salário mínimo, a limitação da jornada de trabalho a oito horas, e a proibição de trabalho em indústrias insalubres a menores de 18 anos e às mulheres. ${ }^{239}$ Garantiu os direitos à assistência judiciária gratuita, o

\footnotetext{
${ }^{236}$ BRASIL. Conselho Nacional de Secretários de Saúde. Sistema Único de Saúde. Coleção Para Entender a Gestão do SUS, v. 1. Brasília: CONASS, 2011, p.14.

${ }^{237}$ BERTOLLI FILHO, Cláudio. História da Saúde Pública no Brasil. 3. ed. São Paulo: Ática, 1999, p.33.

${ }^{238}$ Sobre a origem do Direito Sanitário e suas interfaces com outros ramos do direito, conferir: DALLARI, Sueli Gandolfi; NUNES JÚNIOR. Vidal Serrano. Direito sanitário. São Paulo: Editora Verbatim, 2010, p. 7 32. Acerca da correlação entre Direito Sanitário e Direito do Trabalho, conferir: ROCHA, Julio Cesar de Sá da. Direito da Saúde: direito sanitário na perspectiva dos interesses difusos e coletivos. 2. ed. São Paulo: Atlas, 2011, p. 30-31.

239 “Art. 121. A lei promoverá o amparo da produção e estabelecerá as condições do trabalho, na cidade e nos campos, tendo em vista a proteção social do trabalhador e os interesses econômicos do País. $\S 1^{\circ}-\mathrm{A}$ legislação do trabalho observará os seguintes preceitos, além de outros que colimem melhorar as condições do trabalhador: a) proibição de diferença de salário para um mesmo trabalho, por motivo de idade, sexo, nacionalidade ou estado civil; b) salário mínimo, capaz de satisfazer, conforme as condições de cada região, às necessidades normais do trabalhador; c) trabalho diário não excedente de oito horas, reduzíveis, mas só prorrogáveis nos casos previstos em lei; d) proibição de trabalho a menores de 14 anos; de trabalho noturno a menores de 16 e em indústrias insalubres, a menores de 18 anos e a mulheres; e) repouso hebdomadário, de preferência aos domingos; f) férias anuais remuneradas; g) indenização ao trabalhador dispensado sem justa
} 
direito ao trabalho e à assistência social aos que estivessem em situação de indigência ${ }^{240}$, além de afirmar a existência digna como objetivo da ordem econômica ${ }^{241}$ e dispor sobre assistência social e saúde pública, proteção à maternidade e à infância ${ }^{242}$ e o direito à educação $^{243}$. Ademais, a Constituição determinou que a competência material para cuidar da saúde cabia concorrentemente à União e aos Estados. ${ }^{244}$

A Constituição do Estado Novo, de 1937, em matéria de competência, definiu caber privativamente à União o poder de legislar sobre normas fundamentais de "defesa e proteção da saúde, especialmente da saúde da criança"245. Ainda sobre competência legislativa, estabeleceu caber aos Estados, independente de autorização, a competência suplementar para editar normas sobre "assistência pública, obras de higiene popular, casas de saúde, clínicas, estações de clima e fontes medicinais"246 ou caso não haja legislação federal, atribuiu aos Estados a competência legislativa plena. No tocante à competência material para a infância e juventude, determinou ao Estado a adoção de medidas para

causa; h) assistência médica e sanitária ao trabalhador e à gestante, assegurando a esta descanso antes e depois do parto, sem prejuízo do salário e do emprego, e instituição de previdência, mediante contribuição igual da União, do empregador e do empregado, a favor da velhice, da invalidez, da maternidade e nos casos de acidentes de trabalho ou de morte; i) regulamentação do exercício de todas as profissões; j) reconhecimento das convenções coletivas, de trabalho. (...) $§ 5^{\circ}$ - A União promoverá, em cooperação com os Estados, a organização de colônias agrícolas, para onde serão encaminhados os habitantes de zonas empobrecidas, que o desejarem, e os sem trabalho. (...) $\S 8^{\circ}$ - Nos acidentes do trabalho em obras públicas da União, dos Estados e dos Municípios, a indenização será feita pela folha de pagamento, dentro de quinze dias depois da sentença, da qual não se admitirá recurso ex-offício.”

240 "Art. 113 - A Constituição assegura a brasileiros e a estrangeiros residentes no País a inviolabilidade dos direitos concernentes à liberdade, à subsistência, à segurança individual e à propriedade, nos termos seguintes: (...) 32) A União e os Estados concederão aos necessitados assistência judiciária, criando, para esse efeito, órgãos especiais assegurando, a isenção de emolumentos, custas, taxas e selos. (...) 34) A todos cabe o direito de prover à própria subsistência e à de sua família, mediante trabalho honesto. O Poder Público deve amparar, na forma da lei, os que estejam em indigência”.

241 "Art. 115 - A ordem econômica deve ser organizada conforme os princípios da Justiça e as necessidades da vida nacional, de modo que possibilite a todos existência digna. Dentro desses limites, é garantida a liberdade econômica. Parágrafo único - Os Poderes Públicos verificarão, periodicamente, o padrão de vida nas várias regiões da País."

242 “Art. 141 - É obrigatório, em todo o território nacional, o amparo à maternidade e à infância, para o que a União, os Estados e os Municípios destinarão um por cento das respectivas rendas tributárias."

243 "Art. 149 - A educação é direito de todos e deve ser ministrada pela família e pelos Poderes Públicos, cumprindo a estes proporcioná-la a brasileiros e a estrangeiros domiciliados no País, de modo que possibilite eficientes fatores da vida moral e econômica da Nação, e desenvolva num espírito brasileiro a consciência da solidariedade humana.

244 O artigo 10, inciso II, da Constituição de 1934 dispunha: "Art. 10 - Compete concorrentemente à União e aos Estados: (...) II - cuidar da saúde e assistência públicas;”.

245 “Art. 16 - Compete privativamente à União o poder de legislar sobre as seguintes matérias: (...) XXVII normas fundamentais da defesa e proteção da saúde, especialmente da saúde da criança."

246 “Art. 18 - Independentemente de autorização, os Estados podem legislar, no caso de haver lei federal sobre a matéria, para suprir-lhes as deficiências ou atender às peculiaridades locais, desde que não dispensem ou diminuam es exigências da lei federal, ou, em não havendo lei federal e até que esta regule, sobre os seguintes assuntos: (...) c) assistência pública, obras de higiene popular, casas de saúde, clínicas, estações de clima e fontes medicinais;" 
assegurar-lhes condições físicas e morais para uma vida saudável e o desenvolvimento harmonioso de suas faculdades. ${ }^{247}$ A Constituição de 1937 estabeleceu o dever de educação dos filhos ${ }^{248}$, a proteção da infância e da juventude ${ }^{249}$, a gratuidade e obrigatoriedade do ensino primário ${ }^{250}$, o dever social do trabalho e o direito à subsistência mediante o trabalho. ${ }^{251}$ Por fim, ampliou o rol de direitos assegurados na Constituição de 1934 aos trabalhadores. ${ }^{252}$

247 “Art. 127 - A infância e a juventude devem ser objeto de cuidados e garantias especiais por parte do Estado, que tomará todas as medidas destinadas a assegurar-lhes condições físicas e morais de vida sã e de harmonioso desenvolvimento das suas faculdades. O abandono moral, intelectual ou físico da infância e da juventude importará falta grave dos responsáveis por sua guarda e educação, e cria ao Estado o dever de provê-las do conforto e dos cuidados indispensáveis à preservação física e moral. Aos pais miseráveis assiste o direito de invocar o auxílio e proteção do Estado para a subsistência e educação da sua prole."

248 “Art. 125 - A educação integral da prole é o primeiro dever e o direito natural dos pais. O Estado não será estranho a esse dever, colaborando, de maneira principal ou subsidiária, para facilitar a sua execução ou suprir as deficiências e lacunas da educação particular."

249،“Art. 127 - A infância e a juventude devem ser objeto de cuidados e garantias especiais por parte do Estado, que tomará todas as medidas destinadas a assegurar-lhes condições físicas e morais de vida sã e de harmonioso desenvolvimento das suas faculdades. O abandono moral, intelectual ou físico da infância e da juventude importará falta grave dos responsáveis por sua guarda e educação, e cria ao Estado o dever de provê-las do conforto e dos cuidados indispensáveis à preservação física e moral. Aos pais miseráveis assiste o direito de invocar o auxílio e proteção do Estado para a subsistência e educação da sua prole."

250 "Art. 130 - O ensino primário é obrigatório e gratuito. A gratuidade, porém, não exclui o dever de solidariedade dos menos para com os mais necessitados; assim, por ocasião da matrícula, será exigida aos que não alegarem, ou notoriamente não puderem alegar escassez de recursos, uma contribuição módica e mensal para a caixa escolar."

251 "Art. 136 - O trabalho é um dever social. O trabalho intelectual, técnico e manual tem direito a proteção e solicitude especiais do Estado. A todos é garantido o direito de subsistir mediante o seu trabalho honesto e este, como meio de subsistência do indivíduo, constitui um bem que é dever do Estado proteger, assegurando-lhe condições favoráveis e meios de defesa."

252 "Art. 137 - A legislação do trabalho observará, além de outros, os seguintes preceitos: a) os contratos coletivos de trabalho concluídos pelas associações, legalmente reconhecidas, de empregadores, trabalhadores, artistas e especialistas, serão aplicados a todos os empregados, trabalhadores, artistas e especialistas que elas representam; b) os contratos coletivos de trabalho deverão estipular obrigatoriamente a sua duração, a importância e as modalidades do salário, a disciplina interior e o horário do trabalho; c) a modalidade do salário será a mais apropriada às exigências do operário e da empresa; d) o operário terá direito ao repouso semanal aos domingos e, nos limites das exigências técnicas da empresa, aos feriados civis e religiosos, de acordo com a tradição local; e) depois de um ano de serviço ininterrupto em uma empresa de trabalho contínuo, o operário terá direito a uma licença anual remunerada; f) nas empresas de trabalho contínuo, a cessação das relações de trabalho, a que o trabalhador não haja dado motivo, e quando a lei não lhe garanta, a estabilidade no emprego, cria-lhe o direito a uma indenização proporcional aos anos de serviço; g) nas empresas de trabalho contínuo, a mudança de proprietário não rescinde o contrato de trabalho, conservando os empregados, para com o novo empregador, os direitos que tinham em relação ao antigo; h) salário mínimo, capaz de satisfazer, de acordo com as condições de cada região, as necessidades normais do trabalho; i) dia de trabalho de oito horas, que poderá ser reduzido, e somente suscetível de aumento nos casos previstos em lei; j) o trabalho à noite, a não ser nos casos em que é efetuado periodicamente por turnos, será retribuído com remuneração superior à do diurno; k) proibição de trabalho a menores de catorze anos; de trabalho noturno a menores de dezesseis, e, em indústrias insalubres, a menores de dezoito anos e a mulheres; 1) assistência médica e higiênica ao trabalhador e à gestante, assegurado a esta, sem prejuízo do salário, um período de repouso antes e depois do parto; $\mathrm{m}$ ) a instituição de seguros de velhice, de invalidez, de vida e para os casos de acidentes do trabalho; $n$ ) as associações de trabalhadores têm o dever de prestar aos seus associados auxílio ou assistência, no referente às práticas administrativas ou judiciais relativas aos seguros de acidentes do trabalho e aos seguros sociais." 
A partir da instalação do Estado Novo, o Ministério da Educação e da Saúde reforçou as campanhas de educação na área da saúde, buscando ensinar à população hábitos de higiene para evitar a disseminação de doenças, principalmente as infectocontagiosas. Para que fossem compreensíveis à grande parte da população brasileira analfabeta, os cartazes e folhetos continham ilustrações coloridas e baseavam-se em modernas técnicas pedagógicas e de comunicação. ${ }^{253}$

Apesar da expressiva diminuição de mortes por doenças epidêmicas, houve expansão das doenças de massa (endêmicas), entre elas a esquistossomose, a doença de Chagas, a tuberculose, as doenças sexualmente transmissíveis e a hanseníase. O Brasil permanecia como um dos países com as piores condições de saúde pública do continente. Tal situação foi amplamente noticiada pela imprensa em 1942 a partir do resultado dos exames médicos da maior parte dos cerca de cem mil homens adultos que haviam sido convocados pelo Exército para participar como pracinhas na Força Expedicionária Brasileira, e estavam com a saúde comprometida. ${ }^{254}$

A Constituição de 1946, representativa do constitucionalismo do período posterior à Segunda Guerra Mundial e consentânea à evolução anterior, assegurava, dentre outros, os direitos dos necessitados à assistência judiciária ${ }^{255}$ e estabelecia a justiça social como objetivo da ordem econômica, além de garantir o direito ao trabalho ${ }^{256}$, à assistência à maternidade e à infância ${ }^{257}$ e o direito à educação ${ }^{258}$. Esta Constituição estabeleceu a competência da União para editar normas gerais em matéria de defesa e proteção da saúde ${ }^{259}$, atribuindo aos Estados a competência legislativa suplementar. ${ }^{260}$ Em relação aos direitos dos trabalhadores manteve as normas fixadas na Constituição de 1937, que

\footnotetext{
${ }^{253}$ BERTOLLI FILHO, Cláudio. História da Saúde Pública no Brasil. 3. ed. São Paulo: Ática, 1999, p.34-35. ${ }^{254}$ BERTOLLI FILHO, Cláudio. História da Saúde Pública no Brasil. 3. ed. São Paulo: Ática, 1999, p.36-37. 255 “Art. 141 - A Constituição assegura aos brasileiros e aos estrangeiros residentes no País a inviolabilidade dos direitos concernentes à vida, à liberdade, à segurança individual e à propriedade, nos termos seguintes: (...) § 35 - O Poder Público, na forma que a lei estabelecer, concederá assistência judiciária aos necessitados."

256 "Art. 145 - A ordem econômica deve ser organizada conforme os princípios da justiça social, conciliando a liberdade de iniciativa com a valorização do trabalho humano. Parágrafo único - A todos é assegurado trabalho que possibilite existência digna. O trabalho é obrigação social."

257 “Art. 164 - É obrigatória, em todo o território nacional, a assistência à maternidade, à infância e à adolescência. A lei instituirá o amparo de famílias de prole numerosa."

258 “Art. 166 - A educação é direito de todos e será dada no lar e na escola. Deve inspirar-se nos princípios de liberdade e nos ideais de solidariedade humana".

259“'Art. $5^{\circ}$. Compete à União: (...) XV - legislar sobre: (...) b) normas gerais de direito financeiro; de seguro e previdência social; de defesa e proteção da saúde; e de regime penitenciário;”.

260 "Art. $6^{\circ}$ - A competência federal para legislar sobre as matérias do art. $5^{\circ}, \mathrm{n}^{\circ} \quad \mathrm{XV}$, letras b, e, d, f, h, j, l, o e r, não exclui a legislação estadual supletiva ou complementar".
} 
estabeleciam condições de saúde, segurança, assistência sanitária e higiênica, dentre outros direitos trabalhistas. ${ }^{261}$ Tais direitos também foram assegurados na Consolidação das Leis do Trabalho, editada em 1943.

Embora Getúlio Vargas declarasse caber ao Estado preservar a saúde da população, o poder público era omisso e não prestava assistência médica aos brasileiros. Os movimentos sociais reivindicavam que os governantes cumprissem as promessas de melhorar as condições de saúde, de trabalho e previdenciárias da população.

Em maio de 1953 foi criado o Ministério da Saúde, porém a pasta contava com verbas irrisórias, insuficientes para organizar políticas sanitárias eficientes para a melhoria do estado de saúde da população. Em 1960 foi sancionada a Lei Orgânica da Previdência Social, visando aperfeiçoar o sistema. ${ }^{262}$

A população brasileira estava assolada pela fome e mortalidade infantil. ${ }^{263}$ Vários intelectuais brasileiros passaram a defender a saúde como fenômeno dependente do grau de nutrição da população e a propalar o dever do Estado não apenas de tratar os doentes, mas também de garantir a alimentação necessária à população carente. As críticas ao governo ganharam maior força a partir de 1955, com a criação das Ligas Camponesas no Nordeste, lideradas por Francisco Julião.

Apesar disso, os protestos comandados pelas Ligas Camponesas eram contidos com violência, sob a alegação de que defendiam os ideais comunistas e a Reforma Agrária. Nesse quadro conflituoso, a atividade de médicos e epidemiólogos passou a ser vista como uma prática social capacitada para alcançar, através de canais políticos, a melhoria do estado de saúde da população. A convergência de interesses da comunidade médica e da população conferiu maior relevância às questões sanitárias na pauta de reivindicações. ${ }^{264}$

\footnotetext{
261 “Art. 157 - A legislação do trabalho e a da previdência social obedecerão nos seguintes preceitos, além de outros que visem a melhoria da condição dos trabalhadores: (...) VIII - higiene e segurança do trabalho; IX proibição de trabalho a menores de quatorze anos; em indústrias insalubres, a mulheres e a menores, de dezoito anos; e de trabalho noturno a menores de dezoito anos, respeitadas, em qualquer caso, as condições estabelecidas em lei e as exceções admitidas pelo Juiz competente; X - direito da gestante a descanso antes e depois do parto, sem prejuízo do emprego nem do salário; (...) XIV - assistência sanitária, inclusive hospitalar e médica preventiva, ao trabalhador e à gestante; XV - assistência aos desempregados;".

262 BERTOLLI FILHO, Cláudio. História da Saúde Pública no Brasil. 3. ed. São Paulo: Ática, 1999, p.39-44.

263 Naquela época, Josué de Castro, médico pernambucano de renome internacional, foi um dos principais atores nos debates sobre a fome. Como deputado federal entre 1955 e 1963, ele sustentava que não cabia ao Estado simplesmente o dever de doar alimentos aos pobres, deveria assegurar condições de trabalho e salário que permitissem a todo brasileiro garantir a própria alimentação e a da família. BERTOLLI FILHO, Cláudio. História da Saúde Pública no Brasil. 3. ed. São Paulo: Ática, 1999, p. 46-47.

${ }^{264}$ BERTOLLI FILHO, Cláudio. História da Saúde Pública no Brasil. 3. ed. São Paulo: Ática, 1999, p.46-48.
} 
O conjunto de eventos ocorridos no Brasil em 31 de março de 1964 culminou com um golpe de Estado, liderado pelos chefes das Forças Armadas, no dia $1^{\circ}$ de abril de 1964, que derrubou o governo do presidente João Goulart, acarretando profundas modificações na organização política e na vida econômica e social do País. Os militares impuseram ao País um regime ditatorial, punindo todos os indivíduos e instituições que se mostrassem contrários ao movimento designado como Revolução de $1964^{265}$, inclusive todos os lideres políticos, sindicais e religiosos que lutavam pela melhoria das condições de saúde do povo, alegando a necessidade de combater o avanço do comunismo e da corrupção, bem como garantir a segurança nacional. ${ }^{266} 267$

Após o golpe de Estado em 1964, a Constituição de 1967, que materializava o regime militar, previu caber à União a competência legislativa para estabelecer planos nacionais de saúde ${ }^{268}$ e assegurou autonomia administrativa aos Municípios para organizarem os serviços públicos locais. ${ }^{269}$ Esta Constituição atribuía ao poder público o dever de incentivar a pesquisa, o ensino científico e tecnológico ${ }^{270}$ e manteve o conteúdo

\footnotetext{
${ }^{265}$ Os generais presidentes promoveram alterações estruturais na Administração Pública para garantir maior centralização do poder, privilegiando a autonomia do Executivo e restringindo as atribuições dos poderes Legislativo e Judiciário. Em nome da política de "segurança e desenvolvimento", aumentaram as verbas destinadas aos ministérios militares, dos Transportes e da Indústria e Comércio, ao passo que o orçamento do Ministério da Saúde, que havia aumentado até a primeira metade da década de 60, decresceu até o final da ditadura. O regime militar durou até 1985 quando Tancredo Neves foi indiretamente eleito o primeiro presidente civil do Brasil. BERTOLLI FILHO, Cláudio. História da Saúde Pública no Brasil. 3. ed. São Paulo: Ática, 1999, p.49-513.

${ }^{266}$ BERTOLLI FILHO afirma que dentre os perseguidos estavam Josué de Castro e Francisco Julião, que tiveram seus direitos políticos cassados. BERTOLLI FILHO, Cláudio. História da Saúde Pública no Brasil. 3. ed. São Paulo: Ática, 1999, p. 49.

${ }^{267}$ O modelo de modernização implementado pelo regime militar em 1964 representava a exacerbação das relações assimétricas de poder do Estado em relação à sociedade. Num primeiro momento, houve pesados mecanismos repressivos contra os opositores e a extinção dos órgãos de representatividade e, num segundo momento, foi oficializada uma democracia de fachada, baseada no artificial sistema bipartidário. FALEIROS, Vicente de Paula; SILVA, Jacinta de Fátima Senna; VASCONCELLOS, Luiz Carlos Fadel de; e SILVEIRA, Rosa Maria Godoy. FALEIROS, Vicente de Paula; SILVA, Jacinta de Fátima Senna; VASCONCELLOS, Luiz Carlos Fadel de; e SILVEIRA, Rosa Maria Godoy. A construção do SUS: histórias da Reforma Sanitária e do processo participativo. Brasília: Ministério da Saúde, 2006, p.36.

${ }^{268} \mathrm{O}$ artigo $8^{\circ}$ estabelecia em seu inciso XIV: “Art. $8^{\circ}$. Compete à União: (...) XIV - estabelecer e executar planos nacionais de educação e de saúde, bem como planos regionais de desenvolvimento". Aos Estados foi assegurada competência legislativa suplementar para editar normas sobre a execução dos serviços federais, nos termos do parágrafo único e inciso XVII, alínea "a", desse dispositivo: "Parágrafo único. A competência da União não exclui a dos Estados para legislar supletivamente sôbre as matérias das alíneas $c, d, e, n, q$, e $v$ do item XVII, respeitada a lei federal." O inciso XVII, por sua vez, dispunha sobre a competência da União para: "XVII - legislar sôbre: a) cumprimento da Constituição e execução dos serviços federais;"

269 “Art. 15. A autonomia municipal será assegurada: (...) II - pela administração própria, no que respeite ao seu peculiar interêsse, especialmente quanto: (...) b) à organização dos serviços públicos locais."

270 O artigo 179 da Constituição do Brasil de 1967 prescrevia a liberdade da pesquisa e do ensino das ciências e determinava ao poder público que incentivasse tais atividades, da seguinte forma: “Art. 179. As ciências, as
} 
social das Constituições anteriores. Assegurou os direitos dos necessitados à assistência judiciária ${ }^{271}$ e o direito à educação ${ }^{272} \mathrm{e}$, ainda, previu a justiça social como objetivo da ordem econômica e a valorização do trabalho como condição da dignidade humana ${ }^{273}$. Aos trabalhadores foram reconhecidos, dentre outros ${ }^{274}$, o direito à assistência sanitária, hospitalar e médica preventiva. ${ }^{275} 276$ O sistema público de saúde então vigente podia ser considerado como contributivo, por atender somente aqueles que pagavam contribuições

letras e as artes são livres, ressalvado o disposto no parágrafo $8^{\circ}$ do artigo 153. Parágrafo único. O Poder Público incentivará a pesquisa e o ensino científico e tecnológico."

271 “Art. 150 - A Constituição assegura aos brasileiros e aos estrangeiros residentes no País a inviolabilidade dos direitos concernentes à vida, à liberdade, à segurança e à propriedade, nos termos seguintes: (...) § 32 Será concedida assistência Judiciária aos necessitados, na forma da lei.

272 “Art. 168 - A educação é direito de todos e será dada no lar e na escola; assegurada a igualdade de oportunidade, deve inspirar-se no princípio da unidade nacional e nos ideais de liberdade e de solidariedade humana."

273 "Art. 157 - A ordem econômica tem por fim realizar a justiça social, com base nos seguintes princípios: (...) II - valorização do trabalho como condição da dignidade humana".

${ }^{274}$ Em 1966, aproveitando o momento de dificuldades financeiras das antigas caixas de aposentadorias e institutos de aposentadorias e pensões, o governo criou o Instituto Nacional de Previdência Social (INPS), subordinado ao Ministério do Trabalho, unificando todos os órgãos previdenciários que funcionavam desde 1930. O Artigo 165 da Constituição de 1967 estabeleceu em seus incisos XVI, XIX e XX as regras sobre os benefícios previdenciários e acidentários, bem como a necessidade de existência da correspondente fonte de custeio para a criação, majoração ou extensão de benefício, nos seguintes termos: Art. 165. A Constituição assegura aos trabalhadores os seguintes direitos, além de outros que, nos têrmos da lei, visem à melhoria de sua condição social (...) XVI - previdência social nos casos de doença, velhice, invalidez e morte, segurodesemprêgo, seguro contra acidentes do trabalho e proteção da maternidade, mediante contribuição da União, do empregador e do empregado; (...) XIX - aposentadoria para a mulher, aos trinta anos de trabalho, com salário integral; e XX - a aposentadoria para o professor após 30 anos e, para a professora, após 25 anos de efetivo exercício em funções de magistério, com salário integral (Redação dada pela Emenda Constitucional n. 18, de 1981). Parágrafo único. Nenhuma prestação de serviço de assistência ou de benefício compreendidos na previdência social será criada, majorada ou estendida, sem a correspondente fonte de custeio total."

275 “Art. 165. A Constituição assegura aos trabalhadores os seguintes direitos, além de outros que, nos têrmos da lei, visem à melhoria de sua condição social: (...) IX - higiene e segurança no trabalho; X - proibição de trabalho, em indústrias insalubres, a mulheres e menores de dezoito anos, de trabalho noturno a menores de dezoito anos e de qualquer trabalho a menores de doze anos; XI - descanso remunerado da gestante, antes e depois do parto, sem prejuízo do emprêgo e do salário; (...) XV - assistência sanitária, hospitalar e médica preventiva; XVI - previdência social nos casos de doença, velhice, invalidez e morte, seguro-desemprêgo, seguro contra acidentes do trabalho e proteção da maternidade, mediante contribuição da União, do empregador e do empregado; (...) XVIII - colônias de férias e clínicas de repouso, recuperação e convalescença, mantidas pela União, conforme dispuser a lei; (...)”

$276 \mathrm{O}$ direito à assistência médica e hospitalar também foi assegurado ao civil, ex-combatente da Segunda Guerra Mundial, que efetivamente tenha participado em operações bélicas da Força Expedicionária Brasileira e fosse carente de recursos, conforme dispõe o artigo 197, alínea "d" da Constituição do Brasil de 1967: "Art. 197. Ao civil, ex-combatente da Segunda Guerra Mundial, que tenha participado efetivamente em operações bélicas da Força Expedicionária Brasileira, da Marinha, da Fôrça Aérea Brasileira, da Marinha Mercante ou de Fôrça do Exército, são assegurados os seguintes direitos: (...) d) assistência médica, hospitalar e educacional, se carente de recursos." 
ao Estado. Cabia às entidades filantrópicas e assistenciais prestar serviços de saúde as pessoas desprovidas de recursos financeiros. ${ }^{277}$

Em 1974 foi criado o Ministério da Previdência e Assistência Social (MPAS) com o propósito de garantir a saúde dos segurados, suprir a incapacidade gerencial do Instituto Nacional de Previdência Social (INPS) ${ }^{278}$ em relação ao sistema previdenciário, além de estancar os mecanismos de fraudes dos hospitais e clínicas privadas para receber verbas do Instituto Nacional de Previdência Social (INPS). Em 1975 foi criado o Sistema Nacional de Saúde com o fim de reduzir custos e tornar eficazes as ações de saúde em todo o país. ${ }^{279}$

Nesta época, cabia ao Instituto Nacional de Assistência Médica da Previdência Social (INAMPS), órgão vinculado ao Ministério da Previdência Social, gerir os serviços médico-hospitalares prestados aos trabalhadores. O Ministério da Saúde tinha atribuição para planejar e implementar os programas de combate às endemias, vigilância epidemiológica, vigilância sanitária, nutrição e gestão dos hospitais federais. No âmbito federal havia dois órgãos competentes para cuidar de assuntos relativos à saúde no Brasil, inexistindo impedimento à criação de programas regionais administrados pelos Estados e Municípios que objetivassem prestar idênticos serviços à mesma parcela da população. ${ }^{280}$

Os serviços de saúde prestados aos trabalhadores que contribuíam para o sistema público previdenciário não eram prestados diretamente pelo poder público, mas sim por prestadores de serviços da iniciativa privada ${ }^{281}$, devido à estrutura precária e ao reduzido número de hospitais públicos. ${ }^{282} \mathrm{O}$ sistema de saúde vigente durante o período militar era

277 A Emenda Constitucional $n^{\circ} 1 / 1969$, ainda que tenha modificado a localização no texto constitucional, manteve os direitos sociais e as normas definidoras dos fins e metas do Estado previstos na Constituição Federal de 1967.

${ }^{278} \mathrm{Na}$ esfera pública estava estabelecido um sistema dual de atendimento à saúde, no qual cabia ao INPS o tratamento individual de doentes, e ao Ministério da Saúde cabia, pelo menos em teoria, elaborar e executar programas sanitários e assistir a população em casos de epidemias. BERTOLLI FILHO, Cláudio. História da Saúde Pública no Brasil. 3. ed. São Paulo: Ática, 1999, p.54.

${ }^{279}$ BERTOLLI FILHO, Cláudio. História da Saúde Pública no Brasil. 3. ed. São Paulo: Ática, 1999.p.56.

${ }^{280}$ FALEIROS, Vicente de Paula; SILVA, Jacinta de Fátima Senna; VASCONCELLOS, Luiz Carlos Fadel de; e SILVEIRA, Rosa Maria Godoy. A construção do SUS: histórias da Reforma Sanitária e do processo participativo. Brasília: Ministério da Saúde, 2006, p. 36-40.

281 A Constituição de 1967, em seu artigo 170, caput, estabelecia ao Estado o dever de estimular e apoiar a exploração de atividades econômicas pelas empresas privadas, de forma que a atuação estatal apenas suplementava os serviços médico-hospitalares prestados pela iniciativa privada: “Art. 170. Às emprêsas privadas compete, preferencialmente, com o estímulo e o apoio do Estado, organizar e explorar as atividades econômicas".

282 Apesar do discurso oficial no sentido de que a saúde constituía importante fator de produtividade, desenvolvimento e investimento econômico e do compromisso assumido pelo Ministério da Saúde de realizar programas de saúde e saneamento, conforme previsto no II Plano Nacional de Desenvolvimento, de 1975, a situação da saúde pública era de abandono. A saúde era considerada somente em seu aspecto individual e não como fenômeno coletivo. Os parcos recursos destinados à área da saúde eram desviados para o pagamento de 
caracterizado pela centralização político-administrativa federal e superioridade financeira das instituições previdenciárias, o que possibilitou um vigoroso aumento do número de leitos e a construção de hospitais particulares. ${ }^{283}$ Tal modelo de saúde, baseado no tratamento das doenças consideradas individualmente e na conduta curativa, foi estruturado principalmente em hospitais privados, tendo ficado conhecido como "médico privatista hospitalocêntrico" 284 .

Nas décadas de 70 e 80 houve grande volume de investimento de capital estrangeiro na área de serviços médico-hospitalares privados e na indústria farmacêutica, os quais se mostraram negócios lucrativos. A classe média, em especial beneficiada pelo "milagre econômico", contratava os serviços médico-hospitalares prestados por companhias de seguro-saúde ${ }^{285}$, garantindo atendimento eficiente mediante o pagamento de mensalidades, que eram inacessíveis aos trabalhadores em geral. ${ }^{286}$

Os laboratórios farmacêuticos estrangeiros determinavam os preços e a qualidade dos medicamentos vendidos no Brasil. Por meio do Decreto n. 68.806, de 25 de junho de 1971, o governo instituiu a Central de Medicamentos (CEME), destinada a promover e organizar o fornecimento de medicamentos de uso humano àqueles que, por suas condições econômicas, não pudessem adquiri-los ${ }^{287}$. Criada para regular a produção e distribuição de medicamentos dos laboratórios subordinados ou vinculados aos Ministérios da Marinha, do Exército, da Aeronáutica, do Trabalho e Previdência Social e da Saúde, ampliando e aperfeiçoando a assistência farmacêutica, em condições adequadas à capacidade aquisitiva dos beneficiários em todo o território nacional ${ }^{288}$, a Central de

serviços prestados por hospitais particulares e utilizados em campanhas de vacinação, sem que houvesse significativo investimento nos sistemas de distribuição de água tratada e coleta de esgotos, que são fundamentais à prevenção de enfermidades. BERTOLLI FILHO, Cláudio. História da Saúde Pública no Brasil. 3. ed. São Paulo: Ática, 1999, p. 52.

283 BRASIL. Conselho Nacional de Secretários de Saúde. Sistema Único de Saúde. Coleção Para Entender a Gestão do SUS, v. 1. Brasília: CONASS, 2011, p. 24-26.

${ }^{284}$ BRASIL. SUS: avanços e desafios. Brasília: CONASS, 2007c, p. 23.

285 A companhia de seguro-saúde pioneira foi a Golden Cross - Assistência Internacional de Saúde, fundada em 1971, e seguida por outros grupos internacionais, especialmente após 1983.

${ }^{286}$ BERTOLLI FILHO, Cláudio. História da Saúde Pública no Brasil. 3. ed. São Paulo: Ática, 1999, p.58-59. ${ }^{287} \mathrm{O}$ artigo $1^{\circ}$ do Decreto n. 68.806, de 25 de junho de 1971 assim dispunha: “Art. $1^{\circ}$ É instituída a Central de Medicamentos (CEME), órgão da Presidência da República, destinado a promover e organizar o fornecimento, por preços acessíveis, de medicamentos de uso humano àqueles que, por suas condições econômicas, não puderem adquiri-los."

${ }^{288}$ Os artigos $2^{\circ}$ e $3^{\circ}$ do Decreto n. 68.806, de 25 de junho de 1971 estabeleciam o seguinte: Art. $2^{\circ}$ A CEME funcionará como órgão de deliberação coletiva, regulador da produção e distribuição de medicamentos dos laboratórios farmacêuticos, subordinados ou vinculados aos Ministérios da Marinha, do Exército, da Aeronáutica, do Trabalho e Previdência Social e da Saúde. 
Medicamentos (CEME) perdeu a concorrência para os laboratórios privados e não conseguiu regular o mercado ${ }^{289}$, dominado pelos grandes grupos farmacêuticos multinacionais, nem fixar os preços dos medicamentos. ${ }^{290} 291$

A ausência de planejamento e a descontinuidade dos programas de saúde fizeram com que a lamentável situação do quadro sanitário da década de $70^{292}$, não se alterasse nos

Art. $3^{\text {o }}$ À CEME competirá, mantidos os programas de fabricação e distribuição de produtos dos mencionados laboratórios, bem como de compra de produtos à indústria privada, estabelecer um programa de cooperação e coordenação daqueles órgãos com o objetivo de ampliar e aperfeiçoar, em todo o território nacional, a assistência farmacêutica, em condições adequadas à capacidade aquisitiva dos beneficiários."

289 Naquela época, segundo BERTOLLI FILHO, diversos medicamentos ineficazes (em 1976, foram estimados em cinco mil) e até mesmo já proibidos em outros países passaram a ser vendidos no Brasil. BERTOLLI FILHO, Cláudio. História da Saúde Pública no Brasil. 3. ed. São Paulo: Ática, 1999, p.59.

${ }^{290}$ A CEME foi desativada pelo Decreto n. 2.283, de 24 de junho de 1997, cujo artigo $1^{\circ}$ estabeleceu: “Art. $1^{\circ}$ Fica extinto o Instituto Nacional de Alimentação e Nutrição - INAN e desativada a Central de Medicamentos - CEME criados, respectivamente, pela Lei $\mathrm{n}^{\circ}$ 5.829, de 30 de novembro de 1972 , e pelo Decreto $\mathrm{n}^{\circ} 68.806$, de 25 de junho de 1971 ”.

291 Atualmente, tais funções são desempenhadas pela Câmara de Regulação do Mercado de Medicamentos CMED, criada pela Lei n. 10.742, de 6 de outubro de 2003, que, nos termos de seu artigo $1^{\circ}$, “(...) estabelece normas de regulação do setor farmacêutico, com a finalidade de promover assistência farmacêutica à população, por meio de mecanismos que estimulem a oferta de medicamentos e a competitividade do setor". $\mathrm{O}$ artigo $5^{\circ}$ desta lei estabelece: "Art. $5^{\circ}$ Fica criada a Câmara de Regulação do Mercado de Medicamentos CMED, do Conselho de Governo, que tem por objetivos a adoção, implementação e coordenação de atividades relativas à regulação econômica do mercado de medicamentos, voltados a promover a assistência farmacêutica à população, por meio de mecanismos que estimulem a oferta de medicamentos e a competitividade do setor." Em seguida, o artigo $6^{\circ}$ fixa, de forma exemplificativa, as atribuições da Câmara de Regulação do Mercado de Medicamentos - CMED, quais sejam: "Art. $6^{\circ}$ Compete à CMED, dentre outros atos necessários à consecução dos objetivos a que se destina esta Lei: I - definir diretrizes e procedimentos relativos à regulação econômica do mercado de medicamentos; II - estabelecer critérios para fixação e ajuste de preços de medicamentos; III - definir, com clareza, os critérios para a fixação dos preços dos produtos novos e novas apresentações de medicamentos, nos termos do art. $7^{\circ}$; IV - decidir pela exclusão de grupos, classes, subclasses de medicamentos e produtos farmacêuticos da incidência de critérios de estabelecimento ou ajuste de preços, bem como decidir pela eventual reinclusão de grupos, classes, subclasses de medicamentos e produtos farmacêuticos à incidência de critérios de determinação ou ajuste de preços, nos termos desta Lei; V - estabelecer critérios para fixação de margens de comercialização de medicamentos a serem observados pelos representantes, distribuidores, farmácias e drogarias, inclusive das margens de farmácias voltadas especificamente ao atendimento privativo de unidade hospitalar ou de qualquer outra equivalente de assistência médica; VI - coordenar ações dos órgãos componentes da CMED voltadas à implementação dos objetivos previstos no art. 5\%; VII - sugerir a adoção, pelos órgãos competentes, de diretrizes e procedimentos voltados à implementação da política de acesso a medicamentos; VIII - propor a adoção de legislações e regulamentações referentes à regulação econômica do mercado de medicamentos; IX - opinar sobre regulamentações que envolvam tributação de medicamentos; X - assegurar o efetivo repasse aos preços dos medicamentos de qualquer alteração da carga tributária; XI - sugerir a celebração de acordos e convênios internacionais relativos ao setor de medicamentos; XII - monitorar, para os fins desta Lei, o mercado de medicamentos, podendo, para tanto, requisitar informações sobre produção, insumos, matérias-primas, vendas e quaisquer outros dados que julgar necessários ao exercício desta competência, em poder de pessoas de direito público ou privado; XIII - zelar pela proteção dos interesses do consumidor de medicamentos; XIV - decidir sobre a aplicação de penalidades previstas nesta Lei e, relativamente ao mercado de medicamentos, aquelas previstas na Lei n. 8.078, de 11 de setembro de 1990, sem prejuízo das competências dos demais órgãos do Sistema Nacional de Defesa do Consumidor; XV elaborar seu regimento interno."

${ }^{292}$ Houve um aumento de enfermidades como a dengue, a meningite e a malária, mas autoridades do regime militar recorriam à censura para impedir que os meios de comunicação advertissem a população sobre as ameaças epidêmicas dessas doenças. Somente em 1974 as autoridades responsáveis pelo setor de saúde 
anos $80 .{ }^{293}$ Ao tempo da grave crise econômica do regime militar, a sociedade passou a promover mobilizações para eleger diretamente o presidente da República, exigindo direitos democráticos, como a liberdade de manifestação do pensamento e de associação.

A partir de discussões no meio acadêmico, de encontros em seminários e nas agremiações de profissionais que atuavam na área da saúde, foi concebida a noção de medicina social, que pretendia aliar a produção do conhecimento e a prática para desenvolver um programa público de saúde. Desta forma, defendia-se que a saúde fosse considerada em seu aspecto individual e coletivo, considerando as peculiaridades demográficas e endêmicas de todo o território nacional, pois seu desenvolvimento estava atrelado ao atendimento das necessidades regionais de cada grupo de pessoas. Também foi muito criticada a organização centralizada dos serviços de saúde do sistema vigente durante o regime militar.

Os moradores das periferias dos grandes centros urbanos criaram os Conselhos Populares de Saúde, com a assessoria de padres e médicos sanitaristas, visando obter melhores condições de saneamento básico e a construção de hospitais e centros de saúde próximos às suas residências. No mesmo sentido, os profissionais da área da saúde organizaram o chamado "Movimento pela Reforma Sanitária", que se desenvolveu a partir do final dos anos 70, com a Associação Brasileira de Pós-graduação em Saúde Coletiva (ABRASCO) e o Centro Brasileiro de Estudos da Saúde (CEBES), buscando melhorias no sistema público de saúde e no exercício de suas profissões.

O Movimento pela Reforma Sanitária buscava garantir o acesso universal da população às ações e aos serviços de saúde, tanto de caráter preventivo, como curativo e promocional, por meio de um novo sistema de saúde, com financiamento público. A prestação de serviços de saúde não deveria estar condicionada a pagamento ou contribuição específica, como no modelo anterior, em que os assalariados contribuíam para o Instituto Nacional do Seguro Social (INSS). No documento intitulado "Pelo direito universal à saúde", esse movimento destacou a imprescindibilidade da atuação estatal para

admitiram a epidemia de meningite, que já se alastrava pelas principais cidades brasileiras desde 1971, minimizando a gravidade do quadro sanitário com o argumento de que outros países também estariam sendo assolados pela doença. Para conter a enfermidade e o pânico que tomava conta da população, foi realizada uma campanha de vacinação até 1977. BERTOLLI FILHO, Cláudio. História da Saúde Pública no Brasil. 3. ed. São Paulo: Ática, 1999, p. 52-53.

${ }^{293}$ BERTOLLI FILHO, Cláudio. História da Saúde Pública no Brasil. 3. ed. São Paulo: Ática, 1999, p.60-61. 
garantir ações e serviços públicos de saúde à população, afirmando que o acesso à assistência médico-sanitária é "direito do cidadão e dever do Estado". 294295

O Movimento pela Reforma Sanitária tornou-se largamente conhecido e apresentou suas reivindicações na $8^{\text {a }}$ Conferência Nacional de Saúde, ocorrida em $1986 .{ }^{296}$ A forte pressão política desse movimento resultou na criação da Comissão Nacional de Reforma Sanitária que, em 1987, entregou um relatório final, baseado em suas deliberações, à Comissão de Seguridade Social da Assembleia Nacional Constituinte. A participação ativa do Movimento pela Reforma Sanitária na Assembleia Nacional Constituinte se justificava na medida em que tinha por objetivo a inserção no texto constitucional de instrumentos que garantissem a participação social no processo de formulação, execução e fiscalização das políticas públicas de saúde. ${ }^{297}$

As propostas da Comissão Nacional de Reforma Sanitária foram acolhidas em sua maior parte e inseridas na Constituição Federal de $1988^{298}$, estabelecendo, assim, um novo modelo de saúde pública no país, como buscava o Movimento pela Reforma Sanitária.

A afirmação do direito fundamental à saúde na Constituição Federal de 1988 e a criação do Sistema Único de Saúde (SUS) decorreram da evolução dos sistemas de proteção antes instituídos em nível ordinário: o Sistema Nacional de Saúde, criado pela Lei n 6.229/1975 e o Sistema Unificado e Descentralizado de Saúde (SUDS), em 1987, que por consolidar a política de Ações Integradas de Saúde (AIS), de 1983, teve grande importância para o processo de descentralização da saúde.

A Constituição Federal de 1988 concebeu de forma originária um sistema público de saúde, estabelecendo, em seu artigo 198, caput $^{299}$, que "as ações e serviços públicos de

\footnotetext{
${ }^{294}$ BERTOLLI FILHO, Cláudio. História da Saúde Pública no Brasil. 3. ed. São Paulo: Ática, 1999, p.62-63. ${ }^{295} \mathrm{Na}$ mesma linha, a Declaração de Alma-Ata, de 1978, reconheceu a necessidade de se garantir o acesso de todos aos serviços públicos de saúde, independentemente de qualquer pagamento. Como já visto, esta declaração foi elaborada na Conferência Internacional sobre Cuidados Primários em Saúde, realizada na cidade de Alma-Ata, antiga Rússia e atual Cazaquistão, entre 6 e 12 de setembro de 1978.

${ }^{296}$ Os setores conservadores da área previdenciária apresentaram resistência às propostas desse movimento, sob o argumento de que a universalização consistia numa tentativa de apropriação do patrimônio dos trabalhadores e que haveria dificuldade na somatória de atribuições do Instituto Nacional de Assistência Médica da Previdência Social (INAMPS) com as do Ministério da Saúde. Contudo, esse entendimento foi rechaçado diante das conclusões apresentadas nesta Conferência, que obteve numerosa participação da população, representada por 1.000 delegados escolhidos a partir de pré-conferências realizadas em diversos municípios, fato este que a diferenciava das Conferências até então realizadas, formadas por delegados escolhidos pelo Ministro da Saúde ou autoridades da República.

${ }^{297}$ FALEIROS, Vicente de Paula; SILVA, Jacinta de Fátima Senna; VASCONCELLOS, Luiz Carlos Fadel de; e SILVEIRA, Rosa Maria Godoy. A construção do SUS: histórias da Reforma Sanitária e do processo participativo. Brasília: Ministério da Saúde, 2006, p. 85-87.

${ }^{298}$ BERTOLLI FILHO, Cláudio. História da Saúde Pública no Brasil. 3. ed. São Paulo: Ática, 1999, p.63.
} 
saúde integram um rede regionalizada e hierarquizada e constituem um sistema único (...)", que é justamente o Sistema Único de Saúde (SUS).

A partir da estruturação constitucional do Sistema Único de Saúde (SUS) e em cumprimento ao mandamento constitucional de regular, fiscalizar e controlar as ações e os serviços de saúde, o Poder Legislativo vêm elaborando uma série de leis, das quais se destacam: a Lei ${ }^{\circ}$ 8.080, de 19 de setembro de 1990 e a Lei n. 8.142, de 28 de dezembro de 1990. A rigor, essas leis nacionais, que têm o caráter de norma geral, deveriam estar reunidas num único texto normativo, cujo conjunto se denomina Lei Orgânica da Saúde (LOS). Contudo, por razões políticas, a Lei Orgânica da Saúde (LOS), composta por essas duas leis, auxilia a definição das balizas do direito à saúde, estrutura o Sistema Único de Saúde (SUS), explicita seus objetivos, princípios e atribuições, organiza seu funcionamento, prevê a participação dos serviços privados na prestação de assistência à saúde e disciplina a forma de participação da comunidade na gestão da saúde.

A Lei Orgânica da Saúde (Lei nº 8.080, de 19 de setembro de 1990 e a Lei n. 8.142, de 28 de dezembro de 1990) pode ser considerada uma Lei-quadro, que tem por fim esclarecer o papel de cada uma das esferas da Federação no tocante à proteção e à defesa da saúde e a orientar a produção de diversas normas jurídicas do Direito Sanitário. ${ }^{300}$ Cabe ao Chefe do Poder Executivo da União, dos Estados e dos Municípios editar normas complementares à Lei Orgânica da Saúde, para sua fiel execução, com fundamento no artigo 84, IV, da Constituição Federal. ${ }^{301} 302$

Por fim, importa observar que, com a edição da Lei $n^{\circ}$ 8.689, de 27 de julho de 1993, que dispõe sobre a extinção do Instituto Nacional de Assistência Médica da Previdência Social (INAMPS), foi dado fim ao antigo que estabelecia tratamento

299 “Art. 198. As ações e serviços públicos de saúde integram uma rede regionalizada e hierarquizada e constituem um sistema único, organizado de acordo com as seguintes diretrizes: I - descentralização, com direção única em cada esfera de governo; II - atendimento integral, com prioridade para as atividades preventivas, sem prejuízo dos serviços assistenciais; III - participação da comunidade."

${ }^{300}$ AITH, Fernando. Curso de Direito Sanitário: a proteção do Direito à Saúde no Brasil. São Paulo: Quartier Latin, 2007, p. 284-285.

301 “Art. 84. Compete privativamente ao Presidente da República: (...) IV - sancionar, promulgar e fazer publicar as leis, bem como expedir decretos e regulamentos para sua fiel execução".

302 De acordo com DI PIETRO, o poder regulamentar é uma das formas de expressão da função normativa do Poder Executivo, sendo ato de competência privativa do Chefe do Poder Executivo. Doutrinariamente há dois tipos de regulamento: o regulamento de execução e o regulamento independente ou autônomo. O regulamento autônomo ou independente pode ser definido como o que inova na ordem jurídica, pois estabelece normas sobre matérias não disciplinadas em lei. Porém, o Direito brasileiro somente agasalha o regulamento de execução, hierarquicamente subordinado a uma lei prévia. DI PIETRO, Maria Sylvia Zanella. Direito Administrativo. 23. ed. São Paulo: Atlas, 2010, p.90-92. 
diferenciado à assistência médica contributiva prestada aos assalariados e à assistência médica prestada aos indigentes pelas entidades filantrópicas (assistencialista). Como será estudado a seguir ${ }^{303}$, o Sistema Único de Saúde (SUS) consiste em um modelo de ruptura com essa prática discriminatória, tendo propiciado a reordenação das ações e serviços públicos de saúde no País.

${ }^{303}$ Conferir o capítulo 3 . 


\section{CAPÍTUlo 2 - O DIREITO À SAÚde NA CONSTITUIÇÃo FEDERAL DE 1988}

Neste capítulo do trabalho serão delineadas as principais caraterísticas que envolvem o reconhecimento do direito à saúde como direito fundamental no contexto da Constituição Federal de 1988. De início é abordado o regime jurídico dos direitos fundamentais, particularmente dos direitos fundamentais sociais. No segundo item, será analisada a disciplina da saúde no ordenamento jurídico-constitucional e as competências em matéria de saúde. A partir daí, o desafio será avançar no estudo das múltiplas funções do direito à saúde, isto é, a delimitação dos direitos e deveres que emergem do direito à saúde para o Estado, para os indivíduos e para a sociedade.

Na sequência, será objeto de estudo a problemática político-jurídica da efetividade dos direitos sociais, em especial do direito à saúde. Para tanto, será necessário analisar a questão da eficácia e aplicabilidade da norma definidora deste direito fundamental. Em seguida, são traçados delineamentos sobre a determinação do conteúdo do direito à saúde e do seu núcleo essencial. Por fim, serão analisadas algumas questões relevantes sobre as restrições ao direito à saúde, a par dos fundamentos da teoria da reserva do possível.

\subsection{O direito à saúde como direito fundamental}

A consagração do direito à saúde na Constituição Federal de $1988^{304}$, na esteira de um amplo e aberto rol de direitos fundamentais, representa um importante marco no direito constitucional brasileiro, resultado de reivindicações dos movimentos sociais e expressão de um conjunto de valores e escolhas políticas essenciais, em torno das quais se agregam as forças hegemônicas da comunidade. ${ }^{305}$ Dentre os valores e as opções políticas de fundo

\footnotetext{
304 De acordo com CANOTILHO: "Constituição é uma ordenação sistemática e racional da comunidade política, plasmada num documento escrito, mediante o qual se garantem os direitos fundamentais e se organiza, de acordo com o princípio da divisão de poderes, o poder político". CANOTILHO, Joaquim José Gomes. Direito Constitucional. 6 ed. Coimbra: Editora Almedina. 1993, p. 12.

${ }^{305}$ CANOTILHO, Joaquim José Gomes. Direito Constitucional. 6. ed. Coimbra: Editora Almedina, 1993, p. 65-67.
} 
da Constituição, o ser humano é o fundamento primeiro $^{306}$ e a finalidade ${ }^{307}$ que deve ser perseguida pelo Estado Social e Democrático de Direito 308309

A definição expressa dos fins públicos caracteriza a noção de Constituição dirigente $^{310311}$, a qual vincula de forma direta os indivíduos e os Poderes Legislativo, Executivo e Judiciário.

${ }^{306} \mathrm{O}$ artigo $1^{\circ}$ da Constituição Federal dispõe: “Art. $1^{\circ}$ A República Federativa do Brasil, formada pela união indissolúvel dos Estados e Municípios e do Distrito Federal, constitui-se em Estado Democrático de Direito e tem como fundamentos: I - a soberania; II - a cidadania; III - a dignidade da pessoa humana; IV - os valores sociais do trabalho e da livre iniciativa; V - o pluralismo político."

${ }^{307}$ A ideia de constitucionalismo dirigente pode ser extraída da intelecção do artigo $3^{\circ}$ da Constituição Federal de 1988 que consagra as finalidades a serem alcançadas pela República Federativa do Brasil: "Art. $3^{\circ}$ Constituem objetivos fundamentais da República Federativa do Brasil: I - construir uma sociedade livre, justa e solidária; II - garantir o desenvolvimento nacional; III - erradicar a pobreza e a marginalização e reduzir as desigualdades sociais e regionais; IV - promover o bem de todos, sem preconceitos de origem, raça, sexo, cor, idade e quaisquer outras formas de discriminação." A enunciação das tarefas do Estado não se esgota, simplesmente, neste artigo $3^{\circ}$, que deve ser compreendido em conjunto com os artigos $1^{\circ}, 2^{\circ}$ e $4^{\circ}$ e, ainda, com outras metas específicas, como por exemplo, o acesso universal e igualitário às ações e serviços para a promoção, a proteção e a recuperação da saúde (CF, artigo 196).

${ }^{308} \mathrm{~A}$ força normativa da Constituição, como fim e intencionalidade de criar normas jurídicas, é um fenômeno superveniente ao regime militar e que somente se consolidou após a redemocratização do país e a promulgação da Constituição de 1988. BARROSO, Luís Roberto. Curso de Direito Constitucional contemporâneo: os conceitos fundamentais e a construção do novo modelo. São Paulo: Saraiva, 2009, p. 8487.

${ }^{309}$ Conforme PIRES, o Estado brasileiro reafirmou no texto constitucional os postulados da liberdade e da igualdade e se comprometeu, pela primeira vez, com a fraternidade. PIRES, Luís Manuel Fonseca. O Estado Social e Democrático e o Serviço Público: um breve ensaio sobre liberdade, igualdade e fraternidade. Belo Horizonte: Fórum, 2011, p. 95.

${ }^{310}$ De acordo com CANOTILHO, a noção de Constituição dirigente está relacionada à imposição de tarefas e programas que os poderes públicos devem concretizar, além da definição dos princípios materiais estruturantes. No Brasil, CANOTILHO apresentou reflexão crítica contextualizada sobre a dimensão política da "constituição dirigente", associada à ideia de Estado de direito humanista e normativo, bem como ao projeto de modernidade política. Para o doutrinador português, a teoria da constituição dirigente é uma proposta de conformação normativa da política e o suporte para o desenvolvimento do projeto de modernidade, que deve ser sucessivamente implementado, combatendo a três violências ("triângulo dialético"), através da categoria político-estatal: (i) a falta de segurança e de liberdade, impondo a ordem e o direito (o Estado de direito contra a violência física e o arbítrio); (ii) a desigualdade política, alicerçando liberdade e democracia (Estado democrático); e (iii) a pobreza, mediante esquemas de socialidade. Segundo CANOTILHO, quando o Estado ainda não venceu o combate às três violências - física, política e social não se compreende nem o eclipse do Estado de Direito, Democrático e Social nem a dissolução da sua valência normativa (o constitucionalismo dirigente, democrático e social). Neste sentido, a constituição dirigente desempenhará uma função de compreensão incontornável relativamente às tarefas do Estado Social e também dos instrumentos (métodos) para a prossecução destas tarefas (políticas públicas de ensino, trabalho, saúde, segurança social). CANOTILHO, Joaquim José. O Estado adjetivado e a teoria da Constituição. In: Revista da Procuradoria-Geral do Estado. Procuradoria-Geral do Estado do Rio Grande do Sul, v. 25, n. 56, p.25-40, 2012.

311 BARROSO afirma que a concepção da ideia de Constituição dirigente pelo doutrinador português CANOTILHO foi objeto de sua tese de doutoramento, publicada em 1982, intitulada de "Constituição dirigente e vinculação do legislador", que teria sido posteriormente reformulada após a apresentação de críticas diversas. BARROSO esclarece que a noção de Constituição dirigente contida nesse estudo se aplicava à Constituição portuguesa de 1976, a qual trazia em si um projeto específico de poder, de inspiração socialista. Assim, afirma que não se pode, a rigor, atribuir à expressão "Constituição dirigente" o mesmo sentido em Portugal e no Brasil. BARROSO, Luís Roberto. Curso de Direito Constitucional contemporâneo: os conceitos fundamentais e a construção do novo modelo. São Paulo: Saraiva, 2009, p. 215-216. 
A Constituição desempenha papel importantíssimo na sujeição do Estado à ordem jurídico-constitucional que o precede, pois como norma jurídica anterior a ele, o submete às normas que por si próprio crie. $\mathrm{O}$ Estado é criado e regido pela Constituição e, em consequência disso, todo seu funcionamento haverá de atender às disposições constitucionais. Desta maneira todos os órgãos do Estado e todas as manifestações de sua atividade, estão submetidas à ordem jurídico-constitucional. ${ }^{312}$

No Brasil, somente após o regime militar, com a promulgação da Constituição de 1988 e a consolidação e aprofundamento da democratização do país, o direito constitucional brasileiro tornou-se o centro formal, material e axiológico da ordem jurídica e os direitos fundamentais ganharam margem para concretização. A partir desse novo patamar houve a constitucionalização dos direitos fundamentais e a consagração da teoria da efetividade da Constituição.

Ao longo do século XX, o Estado percorreu uma trajetória pendular. No início, ao Estado liberal eram atribuídas funções mínimas e o constitucionalismo caracterizava-se essencialmente pela primazia de aspectos concernentes a organização do Estado e a proteção de um elenco limitado de direitos civis e políticos. O Estado tornou-se social após o primeiro quarto do século, expandindo seu papel para a superação das desigualdades nos planos econômico e social. O constitucionalismo social inseriu no rol de direitos reconhecidos como fundamentais, além dos direitos civis e políticos (direitos de liberdade), os direitos sociais (ligados à promoção da igualdade material). Os questionamentos sobre a eficiência do Estado social para gerar e distribuir riquezas e prestar serviços públicos levaram ao discurso de retorno ao modelo liberal, denominado, então, neoliberalismo, que passou a ser o modelo em diversos países ocidentais a partir da década de 80, como um contra-ataque ao privatismo, em busca do espaço perdido devido à ampliação das tarefas do Estado. Segundo BARROSO, os fundamentos do Estado neoliberal consistem nos seguintes: desestatização; concentração na atividade de regulação da economia, adbicando da intervenção econômica direta; redução de determinadas proteções sociais; abertura de mercado; e inserção internacional dos países, sobretudo através do comércio. ${ }^{313} 314$

\footnotetext{
312 SUNDFELD, Carlos Ari. Fundamentos de Direito Público. 4 ed. São Paulo: Malheiros. 2009, p.41-42.

313 Para BARROSO, embora o Estado contemporâneo ainda seja o protagonista da história da humanidade, seja no plano internacional, seja no plano doméstico, o Estado chegou ao novo século e ao novo milênio marcado pela formação de blocos políticos e econômicos, pela redefinição do conceito de soberania e pelo aparente esvaziamento de seu poder ante a globalização. BARROSO, Luís Roberto. Curso de Direito
} 
Desde as suas origens até os dias de hoje, o constitucionalismo é uma doutrina de limitação do poder do Estado, decorrente da separação de poderes constituídos e da afirmação dos direitos fundamentais. ${ }^{315}$

O Estado brasileiro não é liberal, é Social, e do Estado Social não se espera apenas que se abstenha de interferir na esfera privada das pessoas. Ao contrário, ao menos no plano ideal, o Estado torna-se instrumento da sociedade para a redução das desigualdades sociais, a contenção do abuso do poder econômico e a prestação de serviços públicos para a população. Desta forma, o espaço público foi significativamente ampliado, tomado pela atividade econômica do Estado e pela intensificação de sua atuação legislativa e regulamentar, bem como pelas atividades de planejamento e fomento a segmentos considerados estratégicos.

É na perspectiva do constitucionalismo social, voltado à garantia e efetividade dos direitos fundamentais ${ }^{316}$ que será analisado o regime jurídico dos direitos fundamentais e o direito à saúde na Constituição Federal de 1988.

A primeira dificuldade que se coloca na aproximação da temática dos direitos fundamentais é clarear o significado do adjetivo fundamental, porque indica uma qualidade do direito da qual decorrem variadas posições subjetivas correspondentes. Assim, há que se

Constitucional contemporâneo: os conceitos fundamentais e a construção do novo modelo. São Paulo: Saraiva, 2009, p.68-69.

${ }^{314}$ A partir da significativa redução da participação do setor público na formação bruta do capital fixo no País em relação à participação do setor privado, especialmente a partir da década de 1990, MENEZES DE ALMEIDA explica seus reflexos sobre o Direito administrativo: “(...) sua consequência evidente foi o abandono de um modelo de organização administrativa com base em instrumentos que permitissem a exploração de atividades econômicas e a realização de investimentos diretamente pelo Estado, ou por entidades a ele vinculadas, adotando-se, em seu lugar, um modelo que contempla mecanismos pelos quais o Estado fixa as diretrizes, estimula e controla a atuação dos agentes privados. Desse modo, sobretudo na última década, é cada vez mais frequente falar-se em instrumentos de parcerias com o setor privado e em agências reguladoras; e cada vez menos frequente falar-se em empresas públicas e sociedades de economia mista (salvo para cuidar de sua privatização)." MENEZES DE ALMEIDA, Fernando Dias. Considerações sobre a "Regulação" no Direito Positivo Brasileiro. In: Revista de Direito Público da Economia (RDPE). Belo Horizonte, ano 3, v. 12, p. 69-94, outubro/dezembro 2005.

315 A Declaração dos Direitos do Homem e do Cidadão, de 1789, estabelece o seguinte: “Art. 16. Toda sociedade na qual não está assegurada a garantia dos direitos nem determinada a separação dos poderes, não tem Constituição".

316 No tocante à terminologia constitucional adequada para identificar o objeto do presente trabalho, será adotada a expressão "direitos fundamentais", tal como prevista pelo legislador constituinte para identificar o gênero dos direitos reconhecidos no Título II da Constituição Federal de 1988. A ausência de consenso na doutrina e na jurisprudência quanto ao conceito e à terminologia adequada para o tratamento dos direitos fundamentais resulta na utilização, dentre outras, das expressões "direitos humanos", "direitos subjetivos públicos", "liberdades públicas", "direitos individuais", "liberdades fundamentais" e "direitos humanos fundamentais". Salvo quanto aos direitos humanos, as demais categorias de direitos são menos amplas do que o conjunto de direitos representado pelos direitos fundamentais. No mesmo sentido, MIRANDA afirma preferir utilizar a expressão "direitos fundamentais". MIRANDA, Jorge. Manual de Direito Constitucional. Parte IV: Direitos Fundamentais. 3.ed. Coimbra: Coimbra Editora. 2000, p. 51-52. 
começar examinando o que significa para alguns direitos subjetivos serem designados fundamentais em confronto com outros que seriam, então, direitos não fundamentais?

Em sentido jurídico-constitucional, a qualificação de determinados direitos como fundamentais significa que, na perspectiva do constituinte, tais bens jurídicos foram considerados relevantes e, portanto, merecedores de um regime jurídico qualificado, reforçado e diferenciado em relação aos demais direitos, ainda que também estejam previstos em norma constitucional.

Embora seja possível trazer à colação diversas definições acerca dos direitos fundamentais, qualquer uma delas que pretenda abranger de forma definitiva e completa $\mathrm{o}$ conteúdo dos direitos fundamentais é, de certo modo, dissociada da realidade de cada ordem constitucional especificamente considerada ${ }^{317}$. Um conceito adequado dos direitos fundamentais somente pode ser formulado com relação a um sistema constitucional concreto. $^{318}$

Os direitos fundamentais constituem um conjunto integrado de direitos, resultante de uma evolução contínua. Porém, é possível estabelecer uma graduação dos direitos fundamentais entre principais e operacionais, sendo ambos igualmente necessários para a construção e a preservação da humanidade. Os direitos fundamentais principais não são executáveis por si mesmos, dada a sua própria abstração, como o direito à vida, à liberdade, à igualdade, à fraternidade, à felicidade e à segurança. Os direitos fundamentais operacionais, por sua vez, se baseiam nos principais para instrumentalizá-los em situações concretas. Assim, o direito à saúde é operacional do direito à vida e ambos são principais do direito de ter acesso a medicamentos, que lhes é operacional. ${ }^{319}$

\footnotetext{
317 SARLET cita como exemplo o direito à saúde, previsto como fundamental na Constituição Federal de 1988, que não é considerado fundamental na Constituição espanhola de 1978, pois naquele sistema constitucional não é assegurado ao direito à saúde o regime jurídico equivalente ao dos direitos fundamentais típicos. SARLET, Ingo Wolfgang; MARINONI, Guilherme; MITIDIERO, Daniel. Curso de Direito Constitucional. 2. ed. São Paulo: Editora Revista dos Tribunais, 2013, p.280-281.

318 Para SARLET, à luz da ordem constitucional brasileira, os direitos fundamentais podem ser definidos como “(...) todas as posições jurídicas concernentes às pessoas (naturais ou jurídicas, consideradas na perspectiva individual ou transindividual) que, do ponto de vista do direito constitucional positivo, foram, expressa ou implicitamente, integradas à constituição e retiradas da esfera de disponibilidade dos poderes constituídos, bem como todas as posições jurídicas que, por seu conteúdo e significado, possam lhes ser equiparadas, tendo, ou não, assento na constituição formal.” SARLET, Ingo Wolfgang; MARINONI, Guilherme; MITIDIERO, Daniel. Curso de Direito Constitucional. 2. ed. São Paulo: Editora Revista dos Tribunais, 2013, p.281.

319 BARROS, Sérgio Resende de. A difusão dos Direitos Humanos Fundamentais. In: Direitos fundamentais coletivos e difusos: questões sobre a fundamentalidade. KIM, Richard Pae; BARROS, Sérgio Resende de; KOSATA, Fausto Kozo Matsumoto (coordenadores). São Paulo: Editora Verbatim, p. 38-39, 2012.
} 
Dos direitos fundamentais decorrem posições jurídicas protegidas no direito constitucional dos Estados. A fundamentalidade apresenta um sentido formal e um sentido material. A fundamentalidade formal decorre da previsão expressa desses direitos no texto constitucional. A Constituição Federal de 1988, logo em seu Título II, afirmou os "direitos e garantias fundamentais", como gênero abrangente de cinco espécies de direitos, assim denominadas: "direitos e deveres individuais e coletivos" (capítulo I); "direitos sociais" (capítulo II); “nacionalidade” (capítulo III); “direitos políticos” (capítulo IV); e "partidos políticos" (capítulo V). ${ }^{320} 321$

Em consequência da fundamentalidade formal desses direitos, a própria Constituição Federal estabelece um regime jurídico composto, em especial, por três características: (i) como integrantes da Constituição, os direitos fundamentais estão situados no ápice da estrutura escalonada do ordenamento jurídico, gozando da superioridade hierárquica das normas constitucionais; (ii) na qualidade de normas constitucionais, a modificação destes direitos está sujeita a limites formais (pois o procedimento de emenda à Constituição é mais rigoroso do que o procedimento legislativo

320 O Título II da Constituição Federal é denominado "Dos Direitos e Garantias Fundamentais" e abrange cinco capítulos. O capítulo I estabelece os direitos e deveres individuais e coletivos (artigo $5^{\circ}$, incisos I a LXXVIII) e disciplina o regime jurídico dos direitos e garantias fundamentais (artigo $5^{\circ}$, parágrafos $1^{\circ}$ a $4^{\circ}$ ). O capítulo II define os direitos sociais (artigos $6^{\circ}$ a 11). O capítulo III dispõe sobre a nacionalidade (artigos 12 a 14). O capítulo IV estabelece os direitos políticos (artigos 15 a 16) e, por fim, o capítulo V prevê as normas de regência dos partidos políticos (artigo 17).

321 A classificação concebida pelo legislador constituinte de 1988 deve ser analisada de forma crítica, especialmente pela doutrina constitucionalista. Neste sentido, SARLET destaca que direitos típicos de primeira geração (ou dimensão) foram indevidamente incluídos no elenco destinado aos direitos de segunda geração (direitos sociais), como o direito de associação sindical (artigo $8^{\circ}$ ) e o direito de greve (artigo $9^{\circ}$ ). Contudo, em relação ao direito à saúde, o constituinte o inseriu corretamente no rol dos direitos sociais, considerando a natureza do bem jurídico que protege. Há uma presunção em favor da fundamentalidade também material desses direitos. SARLET, Ingo Wolfgang; MARINONI, Guilherme; MITIDIERO, Daniel. Curso de Direito Constitucional. 2. ed. São Paulo: Editora Revista dos Tribunais, 2013, p.278-291. 
ordinário) e materiais (cláusulas pétreas) ${ }^{322}$; e (iii) são normas imediatamente aplicáveis, por força do disposto no artigo $5^{\circ}$, parágrafo $1^{\circ}$ da Constituição Federal..$^{323} 324$

Além do extenso catálogo de direitos fundamentais adotados pela Constituição Federal de 1988, sob um critério formal, o legislador constituinte reconheceu a existência de outros direitos aos quais, sob um critério material, também se deve atribuir o caráter de fundamentalidade. ${ }^{325}$ De conseguinte, estabeleceu no parágrafo $2^{\circ}$, do artigo $5^{\text {o326 }}$, uma cláusula que permite a abertura material da Constituição para outros direitos fundamentais que se encontrem em tratados e convenções internacionais sobre direitos humanos de que o Brasil seja signatário e sejam aprovados com o mesmo procedimento rigoroso das emendas constitucionais $^{327}$, bem como que estejam implícitos ou decorram do regime e dos princípios adotados pela própria Constituição.

\footnotetext{
322 BONAVIDES utiliza a expressão "garantia constitucional qualificada ou de primeiro grau" para se referir àquelas que estabelecem a inalterabilidade do preceito tanto por via legislativa ordinária como por via constituinte derivada. As garantias constitucionais de primeiro grau se apresentam tão rígidas que não admitem sequer seja objeto de deliberação a proposta de emenda sobre a matéria constante da cláusula constitucional de exclusão do poder de modificação. Tais garantias circundam direitos, princípios e valores da Constituição, cuja alteração ou supressão fere o núcleo, a essência e a razão de ser da própria lei suprema, Como exemplo, menciona aquelas expressamente estampadas no artigo 60 , parágrafo $4^{\circ}$, da Constituição Federal, bem como aquelas que decorrem de limitações tácitas impostas ao poder de reforma constitucional. De outro lado, define como "garantia constitucional simples ou de segundo grau" aquela que resguarda o preceito unicamente da ação do legislador ordinário, sem privar o legislador constituinte da faculdade de emendar a Constituição, conferindo, assim, um círculo menor de proteção à matéria. BONAVIDES, Paulo. Curso de Direito Constitucional. 22.ed. São Paulo: Malheiros, 2008, p. 548-550.

323 “Art. $5^{\circ}$ Todos são iguais perante a lei, sem distinção de qualquer natureza, garantindo-se aos brasileiros e aos estrangeiros residentes no País a inviolabilidade do direito à vida, à liberdade, à igualdade, à segurança $\mathrm{e}$ à propriedade, nos termos seguintes: (...) $\S 1^{\circ}$ - As normas definidoras dos direitos e garantias fundamentais têm aplicação imediata".

324 SARLET, Ingo Wolfgang; MARINONI, Guilherme; MITIDIERO, Daniel. Curso de Direito Constitucional. 2. ed. São Paulo: Editora Revista dos Tribunais, 2013, p.279.

${ }^{325}$ Nesse sentido, o Supremo Tribunal Federal decidiu que o princípio da anterioridade tributária era um direito intangível, embora não previsto no rol de direitos do artigo $5^{\circ}$ da Constituição Federal, pois permitir novas e sucessivas emendas constitucionais que alargassem o conteúdo das exceções expressamente previstas no parágrafo $1^{\circ}$, do artigo 150 , da Constituição Federal, esvaziaria o conteúdo do princípio e da garantia constitucional que ele encerra. (STF, DJU, 18 mar. 1994, ADIn 939/DF, Rel. Min. Sydney Sanches).

326 "Art. $5^{\circ}$ Todos são iguais perante a lei, sem distinção de qualquer natureza, garantindo-se aos brasileiros e aos estrangeiros residentes no País a inviolabilidade do direito à vida, à liberdade, à igualdade, à segurança e à propriedade, nos termos seguintes: (...) $\S 2^{\circ}$ - Os direitos e garantias expressos nesta Constituição não excluem outros decorrentes do regime e dos princípios por ela adotados, ou dos tratados internacionais em que a República Federativa do Brasil seja parte."

${ }^{327}$ A Emenda Constitucional no 45 , de 2004 acrescentou, dentre outros dispositivos, o parágrafo $3^{\circ}$ ao artigo $5^{\circ}$ da Constituição Federal, que assim dispõe: "Art. $5^{\circ}$ Todos são iguais perante a lei, sem distinção de qualquer natureza, garantindo-se aos brasileiros e aos estrangeiros residentes no País a inviolabilidade do direito à vida, à liberdade, à igualdade, à segurança e à propriedade, nos termos seguintes: (...) $\S 3^{\circ} \mathrm{Os}$ tratados e convenções internacionais sobre direitos humanos que forem aprovados, em cada Casa do Congresso Nacional, em dois turnos, por três quintos dos votos dos respectivos membros, serão equivalentes às emendas constitucionais."
} 
Assim, em sentido material, é possível afirmar que a fundamentalidade decorre do conteúdo e da importância dos direitos, isto é, da circunstância do bem protegido representar uma decisão política relevante sobre a estrutura normativa básica do Estado e da sociedade, especialmente no tocante à posição ocupada pelo indivíduo. ${ }^{328} 329330$

O direito à saúde é formal e materialmente fundamental. Em sentido formal, a fundamentalidade decorre de sua previsão no Título II da Constituição Federal, assim como os demais direitos fundamentais. Em sentido material, a fundamentalidade deste direito decorre de um consenso sobre a extraordinária relevância da proteção, promoção e recuperação da saúde para a manutenção da vida com dignidade ${ }^{331}$, bem como de uma concepção de justiça.

Assentado que o elenco de direitos caracterizados pela fundamentalidade não se limitam àqueles em sentido formal, que constam enunciados expressamente no texto constitucional, uma questão que se coloca consiste em saber se os direitos materialmente fundamentais desfrutam ou não da proteção absoluta conferida pela cláusula pétrea contida no parágrafo $4^{\circ}$ do artigo 60, da Constituição Federal e, ainda, de uma maneira mais ampla, do regime jurídico dos direitos fundamentais.

A resposta a esta indagação remete à premissa de que a positivação dos direitos fundamentais resulta de processos de reivindicação nascidos no âmbito de movimentos sociais e ao longo da história das civilizações. Assim, a doutrina associou a evolução dos direitos fundamentais a três "gerações" 332 ou "dimensões" de direitos, havendo também

328 SARLET, Ingo Wolfgang; MARINONI, Guilherme; MITIDIERO, Daniel. Curso de Direito Constitucional. 2. ed. São Paulo: Editora Revista dos Tribunais, 2013, p.279-280.

329 BARROSO explica que a fundamentalidade material tem relação com o conteúdo do direito e o seu propósito para a realização da dignidade humana, diversamente da fundamentalidade formal, que decorre do fato de a Constituição haver positivado determinado direito como fundamental. BARROSO, Luís Roberto. Curso de Direito Constitucional contemporâneo: os conceitos fundamentais e a construção do novo modelo. São Paulo: Saraiva, 2009, p. 178-181.

${ }^{330}$ Segundo BONAVIDES, do ponto de vista material, os direitos fundamentais variam segundo os valores ideológicos, os princípios consagrados na Constituição e a modalidade de Estado. BONAVIDES, Paulo. Curso de Direito Constitucional. 22.ed. São Paulo: Malheiros, 2008, p.360-361.

${ }^{331}$ Ainda que haja discussão acerca dos limites e da forma pela qual deve ser assegurado o direito à saúde, não há dúvidas sobre a importância de protegê-lo.

${ }^{332}$ Quanto à questão terminológica é necessário registrar que em razão do uso da expressão "gerações" poder ensejar compreensão equivocada no sentido de substituição de uma geração por outra, há doutrinadores que mais recentemente prefiram utilizar o termo "dimensões" dos direitos fundamentais, entendimento que optamos por seguir. BONAVIDES, Paulo. Curso de Direito Constitucional. 22.ed. São Paulo: Malheiros, 2008, p.579-593 e SARLET, Ingo Wolfgang; MARINONI, Guilherme; MITIDIERO, Daniel. Curso de Direito Constitucional. 2. ed. São Paulo: Editora Revista dos Tribunais, 2013, p. 270. 
doutrinadores que defendam a existência de uma quarta e até mesmo de uma quinta "geração" ou "dimensão" de direitos humanos e fundamentais. ${ }^{333}$

Cada uma dessas dimensões não surge de forma dissociada da anterior e a sucessão temporal não gera a perda de eficácia de um conjunto de direitos por outro. Ao contrário, as dimensões são mutuamente conexas, e servem de fundamento à estruturação, sedimentação e ampliação do rol dos direitos fundamentais já conquistados em um determinado Estado. ${ }^{334}$

Atualmente, apesar desta classificação dos direitos fundamentais assumir primordialmente função didática, é interessante observar, de forma breve, a diferenciação entre a natureza e o objeto dos direitos enquadrados em cada um das dimensões e o cunho essencialmente dinâmico e dialético da trajetória evolutiva de reconhecimento dos direitos fundamentais, para que se possa situar a questão do direito à saúde e da democracia participativa, a serem estudadas neste trabalho.

Os direitos fundamentais da primeira dimensão, decorrentes do pensamento liberalburguês do século XVIII ${ }^{335}$, são fortemente individualistas. Concebidos como direitos do indivíduo frente ao Estado, especificamente como direitos de defesa, demarcam uma esfera de não intervenção estatal e uma esfera de autonomia individual em face do poder estatal. Nesta categoria se enquadram aos bens fundamentais de proteção das pessoas contra a autoridade do Estado, assumindo relevo os direitos à vida, à liberdade, à propriedade e à igualdade perante a lei e, posteriormente, as liberdades de expressão coletiva, os direitos de participação política. ${ }^{336} 337$

Os direitos da segunda dimensão foram fruto dos movimentos reivindicatórios do século XIX, provocados pelos graves problemas sociais e econômicos decorrentes da

\footnotetext{
${ }^{333}$ Conferir, por todos, BONAVIDES, Paulo. Curso de Direito Constitucional. 22.ed. São Paulo: Malheiros, 2008, p.560-593.

${ }^{334}$ Sobre o tema, conferir: BOBBIO, Norberto. A era dos direitos. Tradução de Carlos Nelson Coutinho, nova ed. Rio de Janeiro: Elsevier, 2004; e BONAVIDES, Paulo. Curso de Direito Constitucional. 22.ed. São Paulo: Malheiros, 2008, p.560-662.

335 Como explica BONAVIDES, o extenso rol de direitos fundamentais compreendidos como direitos individuais ou direitos da liberdade decorreu da necessidade discriminativa verificada pela doutrina constitucional, que à época se achava em estado de tensão com o Estado liberal. BONAVIDES, Paulo. Curso de Direito Constitucional. 22.ed. São Paulo: Malheiros, 2008, p. 543.

336 SARLET, Ingo Wolfgang; MARINONI, Guilherme; MITIDIERO, Daniel. Curso de Direito Constitucional, 2. ed. São Paulo: Editora Revista dos Tribunais, 2013, p. 272-273.

337 Como aponta BONAVIDES, a primeira dimensão de direitos fundamentais é formada por direitos da liberdade que têm por titular o indivíduo e consistem em direitos de resistência ou de oposição perante o Estado. Tal categoria abrange, em suma, os direitos civis e políticos, que em sua maioria, correspondem à fase inaugural do constitucionalismo no Ocidente. BONAVIDES, Paulo. Curso de Direito Constitucional. 22.ed. São Paulo: Malheiros, 2008, p. 562-564.
} 
industrialização e da constatação de que liberdade e igualdade formal não eram suficientes para propiciar seu efetivo gozo. São os direitos sociais, econômicos e culturais, bem como os direitos coletivos e de coletividades, marcados pela relação estreita com a igualdade material. ${ }^{338}$ A característica distintiva dos direitos de segunda dimensão é seu cunho positivo, pois asseguram ao indivíduo direito a determinadas prestações sociais (materiais) por parte do Estado, que compensem as desigualdades substanciais entre as pessoas, especialmente em relação aos direitos sociais básicos como a saúde, educação, previdência e assistência social. Este catálogo de direitos foi proclamado nas Declarações solenes das Constituições marxistas e também de maneira clássica no constitucionalismo da socialdemocracia, contudo, somente no século XX, especialmente nas constituições posteriores à Segunda Guerra Mundial, que estes novos direitos fundamentais foram consagrados num número significativo de constituições.

Os direitos sociais são, pois, complementares aos direitos de liberdade e condicionam o exercício destes direitos, pois os direitos de liberdade somente podem ser assegurados se estiver garantido, a cada um, as condições minimamente adequadas de bem-estar, que permitam uma vida digna e com certa qualidade. ${ }^{339}$

É preciso enfatizar que os direitos fundamentais não foram reconhecidos e protegidos pelo direito positivo constitucional de cada um dos países num bloco fechado e exaustivo dos direitos de cada uma das dimensões, mas num processo dinâmico e dialético, de reconhecimento parcial e progressivo, eventualmente entrecortado de recuos, conforme o respectivo modelo de sociedade. ${ }^{340}$ Dessa forma, o Estado de Direito liberal reconheceu determinados direitos sociais, assim como o Estado Social veio a assegurar direitos de liberdade que não eram garantidos anteriormente (como o direito de greve, por exemplo). Portanto, a diferença entre os direitos fundamentais de primeira dimensão (direitos de liberdade) e os direitos de segunda dimensão (direitos sociais) não está no momento histórico em que tais direitos foram positivados, mas sim nas repercussões jurídicas que acarretam.

A terceira dimensão, vinculada à ideia de solidariedade e fraternidade, abarca direitos universais, de alto teor humanístico, que tendem a se consolidar no final do século

338 SARLET, Ingo Wolfgang; MARINONI, Guilherme; MITIDIERO, Daniel. Curso de Direito Constitucional. 2. ed. São Paulo: Editora Revista dos Tribunais, 2013, p. 273-274.

${ }^{339}$ Neste sentido, conferir: BOBBIO, Norberto. A era dos direitos. Tradução de Carlos Nelson Coutinho, nova ed. Rio de Janeiro: Elsevier, 2004, p. 206-207.

${ }^{340}$ BONAVIDES, Paulo. Curso de Direito Constitucional. 22.ed. São Paulo: Malheiros, 2008, p. 562-563. 
$\mathrm{XX}$, enquanto direitos do gênero humano ou de titularidade transindividual (de natureza coletiva em sentido amplo) ${ }^{341}$, tais como: os direitos ao desenvolvimento, ao meio ambiente, à comunicação e ao patrimônio comum da humanidade. ${ }^{342}$

A quarta dimensão, admitida por alguns autores como BONAVIDES ${ }^{343}$, resulta da universalização dos direitos fundamentais e consubstancia a derradeira fase de institucionalização do Estado Social. São direitos de quarta dimensão os direitos à democracia, no caso, a democracia direta, à informação e ao pluralismo.

$\mathrm{Na}$ visão de BONAVIDES há também uma quinta dimensão dos direitos fundamentais, que diz respeito à paz, elevada de forma autônoma e paradigmática, à posição de direito fundamental que encabeça esta nova dimensão. Para BONAVIDES, a paz, antes concebida como direito de terceira dimensão, relacionada à fraternidade, é erguida à categoria de direito positivo, porquanto representa um direito supremo da humanidade. $^{344} 345$

Sedimentadas as dimensões de direitos fundamentais conforme a construção dogmática sistematizada, é necessário responder o questionamento sobre a possibilidade de extensão da máxima proteção da cláusula pétrea e de todo o regime jurídico dos direitos formal e materialmente fundamentais.

No que diz com a primeira questão, do ponto de vista hermenêutico é possível extrair duas respostas. De um lado, segundo a literalidade da expressão "direitos e garantias individuais" presente no artigo 60 , parágrafo $4^{\circ}$, inciso IV, o enunciado se

341 SARLET, Ingo Wolfgang; MARINONI, Guilherme; MITIDIERO, Daniel. Curso de Direito Constitucional. 2. ed. São Paulo: Editora Revista dos Tribunais, 2013, p.274-275.

342 BONAVIDES, Paulo. Curso de Direito Constitucional, São Paulo: Malheiros. 22. ed., 2008, p. 569-570.

343 Para BONAVIDES, os direitos da quarta dimensão não se limitam a atingir o auge da objetividade dos direitos da segunda e da terceira geração, como absorvem a subjetividade dos direitos da primeira dimensão. Tais direitos sobrevivem e ficam enriquecidos em sua feição principal, objetiva, podendo, doravante, irradiarse com maior eficácia normativa a todos os direitos da sociedade e do ordenamento jurídico. Em razão disso, BONAVIDES afirma que, na democracia globalizada, o homem configura presença moral da cidadania, é a corrente de convergência de todos os interesses do sistema, sendo imprescindível que o cidadão legitimado fiscalize o cumprimento dos direitos constitucionais enunciados (direitos de quatro dimensões), em moldes compatíveis com a natureza e o exercício da democracia direta. Por fim, afirma que "os direitos de quarta dimensão compendiam o futuro da cidadania e o porvir da liberdade de todos os povos. Tão-somente com eles será legítima e possível a globalização política”. BONAVIDES, Paulo. Curso de Direito Constitucional. 22.ed. São Paulo: Malheiros, 2008, p.570-572.

344 Sob a ótica de BONAVIDES, a paz deve ser o axioma da democracia participativa, com seus instrumentos, teoria e valores de igualdade e justiça social, já consolidada na ordem jurídica brasileira. BONAVIDES, Paulo. Curso de Direito Constitucional. 22.ed. São Paulo: Malheiros, 2008, p.579-593.

${ }^{345}$ Cumpre observar que a Constituição Federal de 1988 consagra a paz como princípio fundamental a reger o Brasil em suas relações internacionais: "Art. 4 Art. $4^{\circ}$ A República Federativa do Brasil rege-se nas suas relações internacionais pelos seguintes princípios: VI - defesa da paz;” 
limitaria a abranger os direitos e garantias analiticamente catalogados no artigo $5^{\circ}$ da Constituição Federal. De outro lado, prevalece em grande parte da doutrina contemporânea o entendimento de que o constituinte originário empregou a espécie pelo gênero, em consequência do que a máxima proteção conferida pela cláusula pétrea do inciso IV do parágrafo $4^{\circ}$, do artigo 60, da Constituição Federal abrange todos os direitos e garantias fundamentais, sediados ou não no Título II da Constituição Federal, considerando a norma geral inclusiva prevista no artigo 5º , parágrafo $2^{\circ}$, da Constituição Federal. 346347348

No tocante aos demais elementos do regime jurídico-constitucional reforçado dos direitos formalmente fundamentais, prevalece a mesma interpretação favorável à sua aplicação equivalente aos direitos materialmente fundamentais, pelas seguintes razões: (i) a literalidade do artigo $5^{\circ}$, parágrafo $2^{\circ}$, da Constituição Federal que menciona, de forma genérica, os "direitos e garantias expressos nesta Constituição", sem delimitar sua posição no texto; (ii) o inequívoco compromisso da Constituição Federal com a efetividade dos direitos sociais, inseridos no título concernente aos direitos fundamentais; (iii) a regra do artigo $7^{\circ}$, cujos incisos definem direitos fundamentais dos trabalhadores, prevê expressamente em seu caput cláusula de abertura para outros direitos similares ("São direitos dos trabalhadores urbanos e rurais, além de outros que visem à melhoria de sua condição social”); e (iv) o entendimento de que tanto o rol dos direitos sociais do artigo $6^{\circ}$, quanto o rol dos direitos dos trabalhadores contidos no artigo $7^{\circ}$ são meramente exemplificativos, de sorte que ambos podem ser considerados como "cláusulas especiais de abertura" 349

\footnotetext{
${ }^{346}$ Nesse sentido, BONAVIDES defende que a latitude e densidade normativa da expressão "direitos e garantias individuais" abrange os direitos fundamentais, notadamente os direitos sociais, pois segundo a nova hermenêutica constitucional, a construção material sólida desses direitos é o pressuposto de maior relevância para fazer eficaz a dignidade da pessoa humana, fundamento do Estado de Direito. Sem a concretização desses direitos não seria possível construir jamais uma "Sociedade livre, justa e solidária", que foi contemplada como um dos objetivos da República Federativa do Brasil (CF, artigo $3^{\circ}$ ) nem reduzir as desigualdades sociais, que foi, ao mesmo tempo, positivada como princípio da ordem econômica e um dos objetivos fundamentais de nosso ordenamento jurídico (CF, artigo 170, VII e artigo $3^{\circ}$ ). BONAVIDES, Paulo. Curso de Direito Constitucional. 22.ed. São Paulo: Malheiros, 2008, p. 651-662.

${ }^{347}$ BARROSO, com semelhante ponto de vista, afirma que é o princípio da dignidade da pessoa humana, erigido como fundamento do Estado constitucional brasileiro (CF, art. $1^{\circ}$, III) e integrante da identidade política, ética e jurídica da Constituição que estabelece uma limitação implícita ao poder de reforma, que se propaga a todos os direitos materialmente fundamentais. BARROSO, Luís Roberto. Curso de Direito Constitucional contemporâneo: os conceitos fundamentais e a construção do novo modelo. São Paulo: Saraiva, 2009, p. 178-181.

348 SARLET, Ingo Wolfgang; MARINONI, Guilherme; MITIDIERO, Daniel. Curso de Direito Constitucional. 2. ed. São Paulo: Editora Revista dos Tribunais, 2013, p.283-284.

349 SARLET, Ingo Wolfgang; MARINONI, Guilherme; MITIDIERO, Daniel. Curso de Direito Constitucional. 2. ed. São Paulo: Editora Revista dos Tribunais, 2013, p.283-284.
} 
Assim, e conforme a posição adotada, o regime jurídico dos direitos fundamentais, tanto em sentido formal como em sentido material, é caracterizado, principalmente, pelos seguintes aspectos: (i) consistem em direitos subjetivos; (ii) possuem hierarquia normativa superior dentro do Estado que os institui, pois refletem a opção constitucional por uma determinada ordem de valores; (iii) são fortemente vinculados à dignidade humana ${ }^{350} 351$; (iv) se dirigem a todas as pessoas pelo fato de serem pessoas, enquanto gênero e independentemente de grupo, classe ou raça a que pertençam ${ }^{352}$; (v) são intangíveis, pois abrigados pela cláusula constitucional de rigidez absoluta, notadamente por traduzirem decisões fundamentais do constituinte originário; e (vi) possuem aplicabilidade direta e imediata, conforme interpretação conjugada do disposto nos parágrafos $1^{\circ}$ e $2^{\circ}$ do artigo $5^{\circ}$ da Constituição Federal ${ }^{353}$.

${ }^{350}$ Conforme DALLARI e NUNES JÚNIOR, a característica mais marcante dos direitos fundamentais é a finalidade de concretização da dignidade da pessoa humana, prevista como objetivo fundamental da República Federativa do Brasil, no artigo $1^{\circ}$, inciso III, da Constituição Federal. Tanto os direitos de liberdade (civis e políticos), quanto os direitos sociais (sociais, econômicos e culturais) estão fortemente vinculados com a dignidade da pessoa humana, o que confere unidade valorativa ao sistema de direitos fundamentais. Da análise do conteúdo dos direitos incorporados pela Constituição de 1988 com caráter de fundamentalidade, é possível identificar três objetivos essenciais, caudatários da dignidade humana, quais sejam: a preservação da liberdade do indivíduo; a inserção do indivíduo no contexto político (democracia política); e sua inserção no contexto econômico e social (democracia econômica e social). DALLARI, Sueli Gandolfi; NUNES JÚNIOR. Vidal Serrano. Direito sanitário. São Paulo: Editora Verbatim, 2010, p. 36-38.

${ }^{351}$ Para SARLET, embora não se trate de um direito fundamental autônomo, o princípio da dignidade da pessoa humana desempenha relevante função como elemento referencial para a aplicação e interpretação dos direitos fundamentais (mas não apenas destes) e como fundamento para a dedução de direitos fundamentais decorrentes. SARLET, Ingo Wolfgang; MARINONI, Guilherme; MITIDIERO, Daniel. Curso de Direito Constitucional. 2. ed. São Paulo: Editora Revista dos Tribunais, 2013, p.293.

352 A Constituição Federal de 1988, que serve de base para o presente estudo, não prevê expressamente o princípio da universalidade no tocante à titularidade dos direitos fundamentais, haja vista que a teor do disposto no seu artigo $5^{\circ}$, caput, os titulares dos direitos e garantias fundamentais são os brasileiros e estrangeiros residentes no país, permitindo que se conclua, numa interpretação literal e restritiva, que os estrangeiros não residentes não seriam titulares desses direitos. Contudo, como observa SARLET, doutrina e jurisprudência acabaram por consagrar, também no direito brasileiro, o princípio da universalidade, que, embora vinculado ao princípio da igualdade, com este não se confunde. Por força do princípio da universalidade a titularidade dos direitos fundamentais é atribuída a todas as pessoas, o que não significa a impossibilidade de haver diferenças a serem consideradas, inclusive em alguns casos, por força do próprio princípio da igualdade, além das exceções expressamente previstas pela Constituição Federal como, por exemplo, os direitos reconhecidos aos brasileiros natos em detrimento dos naturalizados. SARLET invoca a função interpretativa do princípio da universalidade para concluir que pelo menos todos os direitos fundados diretamente na dignidade da pessoa humana são extensivos aos estrangeiros. Acrescenta, ainda, que a recusa da titularidade de direitos fundamentais aos estrangeiros não residentes no país, salvo nas hipóteses excepcionadas pelo legislador constituinte, violaria o disposto no artigo $4^{\circ}$, inciso II, da Constituição Federal, que estabelece o dever do Brasil atuar no plano de suas relações internacionais pautado pelo princípio da "prevalência dos direitos humanos" SARLET, Ingo Wolfgang. A titularidade simultaneamente individual e transindividual dos direitos sociais analisada à luz do exemplo do direito à proteção e promoção da saúde. In: O CNJ e os desafios da efetivação do direito à saúde. NOBRE, Milton Augusto de Brito Nobre; SILVA, Ricardo Augusto Dias da (coordenadores). Belo Horizonte: Fórum, p.120-126, 2011.

${ }^{353}$ A Constituição Federal dispõe em seu artigo $5^{\circ}$, parágrafos $1^{\circ}$ e $2^{\circ}$ : "Art. $5^{\circ}$ Todos são iguais perante a lei, sem distinção de qualquer natureza, garantindo-se aos brasileiros e aos estrangeiros residentes no País a 
Além desses aspectos relativos ao regime jurídico dos direitos fundamentais, há cinco características específicas aplicáveis aos direitos sociais (econômicos, sociais e culturais) em razão de suas particularidades, a saber: (i) a conexão com tarefas e incumbências positivas do Estado e demais entidades públicas e privadas (dimensão positiva); (ii) a ampla participação social, (Constituição Federal, artigo 198, inciso III); (iii) a dependência das circunstâncias sociais, políticas e econômicas; (iv) a adequação das prestações e dos custos; (v) a vedação ao retrocesso; (v) a adequação das formas de tutela. $^{354}$

Sob o prisma internacional, há outros cinco princípios próprios dos direitos sociais, produzidos especialmente pelo Comitê de Direitos Econômicos. Sociais e Culturais (CDESC), quais sejam: (i) o princípio da observância do mínimo essencial; (ii) o princípio da aplicação progressiva ${ }^{355}$; (iii) o princípio da inversão do ônus da prova ${ }^{356}$; (iv) o princípio da participação, transparência e responsabilidade ${ }^{357}$; e (v) o princípio da cooperação internacional. ${ }^{358} 359$

inviolabilidade do direito à vida, à liberdade, à igualdade, à segurança e à propriedade, nos termos seguintes: (...) $\S 1^{\circ}$ - As normas definidoras dos direitos e garantias fundamentais têm aplicação imediata. $\S 2^{\circ}-$ Os direitos e garantias expressos nesta Constituição não excluem outros decorrentes do regime e dos princípios por ela adotados, ou dos tratados internacionais em que a República Federativa do Brasil seja parte."

${ }^{354}$ Embora este conjunto de características tenha sido elaborado pelo doutrinador português Jorge Miranda, da análise de cada uma delas verifica-se a possibilidade de aplicação ao direito constitucional brasileiro em relação aos direitos sociais. Tais características serão estudadas na sequência, ao longo do presente capítulo. Para conferir a obra de doutrina mencionada: MIRANDA, Jorge. Manual de Direito Constitucional. Parte IV: Direitos Fundamentais. 3.ed. Coimbra: Coimbra Editora, 2000, p.147.

${ }^{355} \mathrm{O}$ parágrafo $1^{\circ}$, do artigo $2^{\circ}$, do Pacto Internacional sobre Direitos Econômicos, Sociais e Culturais (PIDESC) prevê a progressividade relativa ao pleno exercício dos direitos econômicos, sociais e culturais, estabelecendo o seguinte: "cada Estado Membro no presente Pacto compromete-se a adotar medidas, tanto por esforço próprio como pela assistência e cooperação internacionais, principalmente nos planos econômico e técnico, até o máximo de seus recursos disponíveis, que visem a assegurar, progressivamente, por todos os meios apropriados, o pleno exercício dos direitos reconhecidos no presente Pacto, incluindo, em particular, a adoção de medidas legislativas." Assim, é garantido o núcleo essencial dos direitos sociais já realizado e efetivado, consistindo em óbice à atividade do legislador. Segundo PIOVESAN, do princípio da aplicação progressiva dos direitos sociais decorre o dever dos Estados de alocar o máximo de recursos disponíveis para a implementação de tais direitos, a proibição do retrocesso social e a proibição da inação estatal. PIOVESAN, Flávia. Temas de Direitos Humanos. 6.ed. São Paulo: Saraiva, 2013, p. 159.

356 O princípio da inversão do ônus da prova também emerge do princípio da aplicação progressiva dos direitos sociais (parágrafo $1^{\circ}$, do artigo $2^{\circ}$, do PIDESC) e significa que incumbe ao Estado o ônus da prova quanto à existência de motivos de força maior que justifiquem sua inação ou sua ação insuficiente para a proteção desses direitos, devendo buscar suporte internacional para assegurar a acessibilidade da população a tais direitos. PIOVESAN, Flávia. Temas de Direitos Humanos. 6.ed. São Paulo: Saraiva, 2013, p.159.

${ }^{357}$ A democracia participativa é imprescindível para a formulação e a implementação de políticas públicas em matéria de direitos sociais. Os princípios da participação, transparência e responsabilidade devem permear essas políticas públicas. De acordo com PIOVESAN, devido ao princípio da participação, é fundamental promover o direito à participação em âmbito local e internacional, especialmente "(...) nas instituições financeiras internacionais, de forma a ampliar a participação da sociedade civil internacional e 


\title{
2.2. O direito à saúde na Constituição Federal de 1988
}

\author{
A saúde foi reconhecida como direito ${ }^{360}$ fundamental $^{361}$ social pela Constituição
}

Federal de 1988, em seu artigo $6^{\circ}$, onde estão concentrados os direitos sociais básicos à

fortalecer a participação dos países em desenvolvimento". PIOVESAN, Flávia. Temas de Direitos Humanos. 6.ed. São Paulo: Saraiva, 2013, p. 160-161.

358 Para além das obrigações de respeitar, proteger e implementar direitos sociais em âmbito interno, o princípio da cooperação internacional impõe aos Estados a obrigação de contribuir para a realização desses direitos numa ordem global, fundada na solidariedade. Este princípio esta previsto no parágrafo $1^{\circ}$ do artigo $2^{\circ}$ do Pacto Internacional sobre Direitos Econômicos, Sociais e Culturais (PIDESC) que estabelece: "cada Estado Membro no presente Pacto compromete-se a adotar medidas, tanto por esforço próprio como pela assistência e cooperação internacionais, principalmente nos planos econômico e técnico, até o máximo de seus recursos disponíveis, que visem a assegurar, progressivamente, por todos os meios apropriados, o pleno exercício dos direitos reconhecidos no presente Pacto, incluindo, em particular, a adoção de medidas legislativas.". No mesmo sentido, o Protocolo de San Salvador em matéria de direitos econômicos, sociais e culturais prevê, em seu artigo $1^{\circ}$, que "Os Estados Partes neste Protocolo Adicional à Convenção Americana sobre Direitos Humanos comprometem-se a adotar as medidas necessárias, tanto de ordem interna como por meio da cooperação entre os Estados, especialmente econômica e técnica, até o máximo dos recursos disponíveis e levando em conta seu grau de desenvolvimento, a fim de conseguir, progressivamente e de acordo com a legislação interna, a plena efetividade dos direitos reconhecidos neste Protocolo."

359 PIOVESAN, Flávia. Temas de Direitos Humanos. 6.ed. São Paulo: Saraiva, 2013, p. 156-163. Os princípios em apreço serão estudados no presente capítulo, motivo pelo qual não se fará neste momento um comentário específico a respeito de cada um eles.

${ }^{360}$ AMARAL critica o emprego da terminologia "direito à saúde", sob o argumento de que é impossível se garantir às pessoas um estado "saudável" cuja permanência ao longo do tempo vai de encontro à finitude da espécie humana. AMARAL prefere utilizar a expressão "direito a cuidados de saúde", abrangente de um conjunto de medidas voltadas a garantir condições de saúde, sem se limitar a procedimentos médicos ou a tratamentos farmacêuticos. Saúde Direito de todos, saúde direito de cada um: reflexões para a transição da práxis judiciária. In: O CNJ e os desafios da efetivação do direito à saúde. NOBRE, Milton Augusto de Brito; SILVA, Ricardo Augusto Dias de (Coord.). Belo Horizonte: Fórum, p.81, 2011. Não obstante a razoabilidade do argumento, nesta dissertação será utilizada a expressão "direito à saúde", visto que a mesma foi expressamente prevista na Constituição Federal, em seus artigos $6^{\circ}$ e 196 a 200, dentre outros, na Lei n. 8.080/90, e está consagrada na doutrina e jurisprudência pátrias.

361 Segundo DA SILVA, a primeira Constituição a reconhecer a saúde como fundamental direito do indivíduo e interesse da coletividade foi a Constituição Italiana, promulgada em 22 de dezembro de 1947, e posteriormente, a Constituição portuguesa, aprovada em 2 de abril de 1976, teria estabelecido uma formulação universal mais precisa, melhor do que a Constituição espanhola, em vigor desde 29 de dezembro de 1978. Em todas estas constituições afirma que o direito à saúde foi relacionado com a seguridade social, assim como a Constituição brasileira de 1988. DA SILVA, José Afonso. Curso de Direito Constitucional Positivo. 16. ed. São Paulo: Malheiros. 1999, p.312. Nos termos do artigo 32 da Constituição da República Italiana: “Art. 32. La Repubblica tutela la salute come fondamentale diritto dell'individuo e interesse della collettività, e garantisce cure gratuite agli indigenti. Nessuno può essere obbligato a un determinato trattamento sanitario se non per disposizione di legge. La legge non può in nessun caso violare i limiti imposti dal rispetto della persona umana." Por seu turno, a Constituição portuguesa prevê em seu artigo 64, no capítulo sobre direitos e deveres sociais, o seguinte: "Art. 64. Saúde. 1. Todos têm direito à protecção da saúde e o dever de a defender e promover. 2. O direito à protecção da saúde é realizado: a) Através de um serviço nacional de saúde universal e geral e, tendo em conta as condições económicas e sociais dos cidadãos, tendencialmente gratuito; b) Pela criação de condições econômicas, sociais, culturais e ambientais que garantam, designadamente, a protecção da infância, da juventude e da velhice, e pela melhoria sistemática das condições de vida e de trabalho, bem como pela promoção da cultura física e desportiva, escolar e popular, e ainda pelo desenvolvimento da educação sanitária do povo e de práticas de vida saudável. 3. Para assegurar o direito à protecção da saúde, incumbe prioritariamente ao Estado: a) Garantir o acesso de todos os cidadãos, independentemente da sua condição económica, aos cuidados da medicina 
educação, à alimentação ${ }^{362}$, ao trabalho, à moradia ${ }^{363}$, ao lazer, à segurança, à previdência social, à proteção à maternidade e à infância, e assistência aos desamparados ${ }^{364}$. A inserção pioneira deste catálogo de direitos sociais no título dos direitos fundamentais (Capítulo II, do Título II) ${ }^{365}$, considerado o regime jurídico-constitucional dos direitos fundamentais, assegura aos direitos sociais um espaço destacado na agenda política e jurídica do país, relacionado à evolução das funções do Estado.

Com o reconhecimento da fundamentalidade do direito à saúde pela Constituição Federal, todos os Poderes do Estado estão vinculados, desde logo, a adotar as medidas necessárias à concretização dos comandos constitucionais. Há que se discutir sobre as funções e os instrumentos do Legislativo, do Judiciário e do Executivo para o cumprimento dessa missão. Neste trabalho interessa examinar a atividade desenvolvida pelo Executivo em relação à proteção, à promoção e à recuperação da saúde da população e, em especial, sua função de dirimir controvérsias sobre prestações materiais em saúde.

A adequada compreensão do direito à saúde deve ser feita a partir de uma análise conjunta e sistemática dos princípios que lhe dão fundamento, das normas constitucionais,

preventiva, curativa e de reabilitação; b) Garantir uma racional e eficiente cobertura de todo o país em recursos humanos e unidades de saúde; c) Orientar a sua acção para a socialização dos custos dos cuidados médicos e medicamentosos; d) Disciplinar e fiscalizar as formas empresariais e privadas da medicina, articulando-as com o serviço nacional de saúde, por forma a assegurar, nas instituições de saúde públicas e privadas, adequados padrões de eficiência e de qualidade; e) Disciplinar e controlar a produção, a distribuição, a comercialização e o uso dos produtos químicos, biológicos e farmacêuticos e outros meios de tratamento e diagnóstico; f) Estabelecer políticas de prevenção e tratamento da toxicodependência. 4. O serviço nacional de saúde tem gestão descentralizada e participada." Por fim, a Constituição espanhola prevê dentre os princípios reitores da política social e econômica, em seu artigo 43, o reconhecimento do direito à saúde, nos seguintes termos: “Art. 43. 1. Se reconoce el derecho a la protección de la salud. 2. Compete a los poderes públicos organizar y tutelar la salud pública a través de medidas preventivas y de las prestaciones y servicios necesarios. La ley establecerá los derechos y deberes de todos al respecto. 3. Los poderes públicos fomentarán la educación sanitaria, la educación física y el deporte. Asimismo facilitarán la adecuada utilización del ocio."

$362 \mathrm{O}$ direito à alimentação foi incorporado ao texto original da Constituição Federal de 1988 por meio da Emenda Constitucional n. 64, de 4 de fevereiro de 2010.

$363 \mathrm{O}$ direito à moradia foi incorporado ao texto original da Constituição Federal de 1988 por meio da Emenda Constitucional n. 26, de 14 de fevereiro de 2000.

364 “Art. $6^{\circ}$ São direitos sociais a educação, a saúde, a alimentação, o trabalho, a moradia, o lazer, a segurança, a previdência social, a proteção à maternidade e à infância, a assistência aos desamparados, na forma desta Constituição".

365 As Constituições do Brasil, a partir da Constituição de 1934, reconheceram alguns direitos sociais, sediados num título que compreendia disposições sobre a ordem econômica e social. A Constituição Federal de 1988 foi a primeira a reconhecer a saúde como direito fundamental, trazendo um capítulo próprio que trata "Dos Direitos Sociais" (Capítulo II) em seu Título II, denominado "Dos Direitos e Garantias Fundamentais", deixando para disciplinar a ordem social somente no Título VIII ("Da Ordem Social”), no qual estabeleceu seus princípios e aspectos organizacionais. 
da legislação infraconstitucional e, ainda, dos atos normativos pertinentes que o conformam e estejam direta ou indiretamente relacionadas à sua efetividade. ${ }^{366}$

Contudo, o estudo verticalizado do regime jurídico-constitucional do direito à saúde não pode olvidar a interconexão que há entre a proteção da saúde individual e coletiva com outros direitos. Para exemplificar essa interdependência do direito à saúde com outros direitos fundamentais, vale citar dentre estes: os demais direitos sociais básicos ${ }^{367}$; os direitos sociais dos trabalhadores ${ }^{368}$; direito à vida ${ }^{369}$; os direitos do consumidor $^{370}$, a proteção à família, à maternidade, à infância, à adolescência e à velhice e o amparo às crianças e adolescentes carentes ${ }^{371} \mathrm{e}$, ainda, o direito ao meio ambiente ecologicamente equilibrado. ${ }^{372}$

Nesse sentido, é preciso enfatizar que o direito à saúde também é assegurado com a proteção conferida a outros direitos garantidos pela ordem constitucional pátria e, de forma análoga, a salvaguarda desses direitos também é assegurada com a proteção da saúde. De conseguinte, a implementação do direito à saúde não é tarefa exclusiva da Pasta da Saúde, pois depende da efetividade de políticas públicas que envolvam diferentes setores e tenham como alvo a melhoria do estado de saúde da população.

De início, o Preâmbulo ${ }^{373}$ da Constituição Federal revela o forte compromisso com a justiça social, assumindo como missão e fim do Estado Democrático a concretização dos direitos sociais, dentre os quais está o direito à saúde. O comprometimento do Estado brasileiro é reforçado pelo princípio da dignidade da pessoa humana, elemento referencial

\footnotetext{
${ }^{366}$ Em princípio, será estudado neste subitem o direito à saúde à luz da Constituição Federal de 1988 e ao longo deste trabalho será analisada a legislação infraconstitucional e infralegal que o minudencia, relacionada ao estudo dos mecanismos de consensualização na esfera administrativa de conflitos na área da saúde. Contudo, conforme a relevância, desde logo será feita a referência aos atos normativos concernentes à temática abordada.

367 Artigo $6^{\circ}$ da Constituição Federal.

368 Artigos $7^{\circ}$ a 11 da Constituição Federal.

${ }^{369}$ Artigo 5 ${ }^{\circ}$, caput, da Constituição Federal.

${ }^{370}$ Artigo $5^{\circ}$, inciso XXXII e artigo 170, inciso V, ambos da Constituição Federal. As normas de proteção e defesa do consumidor estão previstos na Lei n. 8.078, de 11 de setembro de 1990, conhecida como "Código de Defesa do Consumidor".

371 Artigo 203, incisos I e II, da Constituição Federal.

372 Artigo 225, da Constituição Federal.

373 Diz o preâmbulo constitucional: "Nós, representantes do povo brasileiro, reunidos em Assembleia Nacional Constituinte para instituir um Estado Democrático, destinado a assegurar o exercício dos direitos sociais e individuais, a liberdade, a segurança, o bem-estar, o desenvolvimento, a igualdade e a justiça como valores supremos de uma sociedade fraterna, pluralista e sem preconceitos, fundada na harmonia social e comprometida, na ordem interna e internacional, com a solução pacífica das controvérsias, promulgamos, sob a proteção de Deus, a seguinte CONSTITUIÇÃO DA REPÚBLICA FEDERATIVA DO BRASIL."
} 
para interpretação e aplicação de outros direitos ${ }^{374}$, positivado como fundamento do Estado Democrático de Direito, no artigo $1^{\circ}$, inciso III, da Constituição Federal. ${ }^{375}$

A meta de alcançar a justiça social guarda compatibilidade com os objetivos fundamentais da República Federativa do Brasil, previstos no artigo $3^{\circ}$ da Constituição Federal $^{376}$, que estabelece como linhas mestras, dentre outras, a construção de uma sociedade livre, justa e solidária, a erradicação da pobreza e da marginalização, bem como a redução das desigualdades sociais e regionais.

Em sintonia com este ideário, o artigo 170, caput, da Constituição Federal ${ }^{377}$, determina como fundamentos da ordem econômica a valorização do trabalho humano e a livre iniciativa, a qual está vinculada à garantia de uma existência digna para todos, conforme os ditames da justiça social. Dentre os princípios da ordem econômica, cumpre dar realce à redução das desigualdades regionais e sociais, prevista no inciso VII deste artigo, fundamento do Estado e finalidade da ordem econômica.

Por sua vez, no Título VIII da Constituição Federal ("Da Ordem Social”), composto por oito capítulos, o constituinte estabeleceu como disposição geral, em seu artigo 193, caput (Capítulo I) ${ }^{378}$, que o primado do trabalho é base da ordem social, cujas finalidades são o bem-estar e a justiça sociais. ${ }^{379}$

374 SARLET, Ingo Wolfgang; MARINONI, Guilherme; MITIDIERO, Daniel. Curso de Direito Constitucional. 2. ed. São Paulo: Editora Revista dos Tribunais, 2013, p.293.

375 “Art. $1^{\circ}$ A República Federativa do Brasil, formada pela união indissolúvel dos Estados e Municípios e do Distrito Federal, constitui-se em Estado Democrático de Direito e tem como fundamentos: (...) III - a dignidade da pessoa humana".

376 "Art. $3^{\circ}$ Constituem objetivos fundamentais da República Federativa do Brasil: I - construir uma sociedade livre, justa e solidária; II - garantir o desenvolvimento nacional; III - erradicar a pobreza e a marginalização e reduzir as desigualdades sociais e regionais; IV - promover o bem de todos, sem preconceitos de origem, raça, sexo, cor, idade e quaisquer outras formas de discriminação."

377 “Art. 170. A ordem econômica, fundada na valorização do trabalho humano e na livre iniciativa, tem por fim assegurar a todos existência digna, conforme os ditames da justiça social, observados os seguintes princípios: I - soberania nacional; II - propriedade privada; III - função social da propriedade; IV - livre concorrência; V - defesa do consumidor; VI - defesa do meio ambiente, inclusive mediante tratamento diferenciado conforme o impacto ambiental dos produtos e serviços e de seus processos de elaboração e prestação; VII - redução das desigualdades regionais e sociais; VIII - busca do pleno emprego; IX tratamento favorecido para as empresas de pequeno porte constituídas sob as leis brasileiras e que tenham sua sede e administração no País. Parágrafo único. É assegurado a todos o livre exercício de qualquer atividade econômica, independentemente de autorização de órgãos públicos, salvo nos casos previstos em lei."

378 O art. 193, caput, da Constituição Federal dispõe: “Art. 193. A ordem social tem como base o primado do trabalho, e como objetivo o bem-estar e a justiça sociais."

379 Conforme BASTOS e MARTINS, o constituinte reiterou os objetivos que, devido à sua importância, considerou necessários serem permanentemente perseguidos, além de torná-los amplamente conhecidos da sociedade e do Governo. BASTOS, Celso Ribeiro; MARTINS, Ives Gandra. Comentários à Constituição do Brasil: promulgada em 5 de outubro de 1988, v.8: arts. 193 a 232. 2.ed. São Paulo: Saraiva, 2000, p. 4. 
Os objetivos da ordem social estabelecidos no texto constitucional consistem no fundamento do "Estado do Bem-Estar Social", que se obriga a remover as mais profundas injustiças sociais para produzir as condições reais indispensáveis ao exercício dos direitos sociais, concretizando, assim, a igualdade material. ${ }^{380}$

O Capítulo II do Título VIII da Constituição Federal ("Da Ordem Social”) é intitulado "Da Seguridade Social", definida no artigo 194, caput ${ }^{381}$, como um conjunto integrado de ações do Estado e da sociedade destinadas a assegurar os direitos à saúde, à previdência e à assistência social, todos correlacionados. O parágrafo único do artigo $194^{382}$ estabelece competir ao Poder Público, nos termos da lei, organizar a seguridade social, baseado em determinados objetivos.

A organização da seguridade social é matéria de competência da União, visto que a Constituição Federal determina expressamente caber à União a competência para legislar sobre seguridade social, em seu artigo 22, inciso XXIII. ${ }^{383} 384$ O parágrafo único do artigo 22 da Constituição Federal ${ }^{385}$ estabelece a possibilidade de lei complementar delegar competências legislativas privativas da União aos Estados em relação a questões específicas das matérias relacionadas neste artigo, dentre as quais está inserida a seguridade social. ${ }^{386}$

${ }^{380}$ BONAVIDES, Paulo. Curso de Direito Constitucional. 22.ed. São Paulo: Malheiros, 2008, p. 378-379. 381 "Art. 194. A seguridade social compreende um conjunto integrado de ações de iniciativa dos Poderes Públicos e da sociedade, destinadas a assegurar os direitos relativos à saúde, à previdência e à assistência social."

382 “Art. 194. (...) Parágrafo único. Compete ao Poder Público, nos termos da lei, organizar a seguridade social, com base nos seguintes objetivos: (...)"

$383 \mathrm{O}$ artigo 22, inciso XXIII da Constituição Federal dispõe: "Art. 22. Compete privativamente à União legislar sobre: (...) XXIII - seguridade social;"

${ }^{384}$ Conforme visão crítica apresentada por ALMEIDA, algumas das competências legislativas privativas da União, previstas no artigo 22 da Constituição Federal poderiam ter sido transferidas com vantagem para a órbita das competências concorrentes, ou para a órbita da competência privativa de outros entes federativos. ALMEIDA cita, entre outras matérias, a seguridade social, prevista no artigo 22, inciso XXIII, em relação a qual teria sido mais adequado partilhar o poder de legislação entre os diversos centros de poder. Nestes termos, explica que em todo o campo da seguridade social os Poderes Públicos devem somar esforços, numa ação integrada, parecendo ser mais apropriado reduzir a participação da União à edição de normas gerais. De conseguinte, conclui que a legislação sobre seguridade social seria melhor situada no artigo 24 da Constituição Federal. ALMEIDA, Fernanda Dias Menezes de. Competências na Constituição de 1988. 3. ed. São Paulo: Atlas, 2005, p. 84-90 e 101-103.

385 Art. 22. Compete privativamente à União legislar sobre: (...) XXIII - seguridade social; (...) Parágrafo único. Lei complementar poderá autorizar os Estados a legislar sobre questões específicas das matérias relacionadas neste artigo."

386 Sobre o parágrafo único do artigo 22, da Constituição Federal, como bem observa ALMEIDA, a repartição de competências é assunto cardeal na Federação e deveria se resolver no âmbito da própria Constituição. Assim, na perspectiva de ALMEIDA, caberia ao constituinte dispor sobre "o que compete a cada entidade federativa e o que pode ser competência comum, esclarecendo, nesse último caso, em que medida e de que forma se exercerá essa competência". Como nota ALMEIDA, os Estados não devem esperar 
Os direitos sociais relativos à Seguridade Social em sentido amplo compreendem, portanto, os direitos à saúde, à previdência e à assistência social, que consistem em direitos fundamentais de segunda dimensão, marcados pela necessidade de prestações materiais (ações e serviços) do Estado, e da atuação conjunta da sociedade, para a garantia de melhores condições de vida às pessoas.

O direito à saúde foi inserido na Seção II, do capítulo sobre a seguridade social (Capítulo II) e teve seus contornos definidos de forma não exaustiva nos artigos 196 a 200 da Constituição Federal de 1988, que estabelecem disposições organizatórias, atribuições e princípios segundo os quais deve ser concretizada a estrutura institucional para sua implementação. A afirmação detalhada desse conjunto de elementos originariamente no texto constitucional e a própria criação do Sistema Único de Saúde, permitem que se sustente que, além do direito fundamental à saúde, a organização e o funcionamento do Sistema Único de Saúde consistem em garantia institucional fundamental, como se analisará mais adiante neste capítulo.

O artigo 196 da Constituição Federal ${ }^{387}$, em sua primeira parte, reforça a norma definidora do direito fundamental, afirmando a saúde como direito de todos, consequentemente, de titularidade universal. Em seguida, o constituinte torna explícito que além de um direito fundamental, a tutela da saúde é assegurada por um dever fundamental: “a saúde é direito de todos e dever do Estado (...)". Assim, a tutela e a efetivação do direito à saúde dependem do cumprimento de deveres conexos que tem origem e amparo na própria Constituição Federal.

receber poderes do legislador federal por três razões: trata-se de mera faculdade aberta ao legislador federal, que não pode ser obrigado a fazer uso dela; a delegação de competência deve se operar por lei complementar, cuja aprovação depende de quórum qualificado, que é sempre mais difícil de alcançar; e há uma limitação de ordem material expressa que limita o campo da delegação apenas sobre "questões específicas" das matérias relacionadas no artigo 22. Além disso, ALMEIDA lamenta o fato de o constituinte ter perdido a oportunidade de estabelecer, de forma expressa, no texto constitucional a possibilidade de delegação desigual de competências aos Estados, em atenção às disparidades regionais, visando uma desejável flexibilização do federalismo simétrico brasileiro. ALMEIDA, Fernanda Dias Menezes de. Competências na Constituição de 1988. 3.ed. São Paulo: Atlas, 2005, p. 107-112.

387 “Art. 196. A saúde é direito de todos e dever do Estado, garantido mediante políticas sociais e econômicas que visem à redução do risco de doença e de outros agravos e ao acesso universal e igualitário às ações e serviços para sua promoção, proteção e recuperação". 
A doutrina discute a questão da universalidade de acesso às ações e serviços públicos de saúde implicar ou não em gratuidade, ou seja, se é necessário contribuir financeiramente para ter acesso a estas ações e serviços públicos essenciais. ${ }^{388}$

O artigo 196 da Constituição deixa claro que as ações e os serviços públicos de saúde devem ser gratuitos, o que é essencial para a sua universalidade. Conforme relata o Conselho Nacional de Secretários de Saúde, embora prevista como princípio estruturante do Sistema Único de Saúde (SUS), a universalidade do mundo dos fatos (real) diverge da universalidade buscada pelos sanitaristas e movimentos sociais e consagrada na Constituição (universalidade ideal), muitas vezes porque a política pública tanto é pensada para atender as demandas dos setores mais pobres da população, como também as demandas setorizadas dos setores mais ricos, por meio dos serviços de maiores $\operatorname{custos}^{389}$, a exigência de contribuição para as classes média e alta usufruírem de tais ações e serviços não importaria em equidade e solidariedade. ${ }^{390} \mathrm{O}$ desafio que se coloca consiste em

${ }^{388}$ Para SARLET, o princípio da universalidade não significa, de modo cogente, um princípio de gratuidade de acesso, porque a garantia do direito à saúde para todos e em igualdade de condições, como expressamente enunciado no artigo 196 da Constituição Federal, não se confunde com um acesso totalmente gratuito, como ocorre com os benefícios no âmbito da assistência social. Na visão de SARLET, o que a Constituição assegura é que todas as pessoas tenham, em princípio, as mesmas condições de acessar o sistema público de saúde, mas não que tenham um direito subjetivo definitivo a qualquer prestação fornecida pelo Estado ou mesmo a qualquer prestação voltada à proteção de sua saúde. SARLET argumenta que a própria Constituição autoriza a existência de sistemas privados de prestação de serviços de saúde e consigna que há entendimento doutrinário no sentido de que o particular que contribui para plano privado não poderá ser atendido pelo SUS. Neste sentido, sustenta que o princípio da proporcionalidade deve ser considerado para se avaliar se é proporcional e razoável para que um particular que disponha de recursos para custear um bom plano de saúde privado possa acessar, sem qualquer tipo de limitação, o sistema público de saúde nas mesmas condições que alguém que não esteja apto a prover com os próprios recursos a sua saúde pessoal. Em arremate, advoga que no contexto de uma sociedade acentuadamente desigual, não se afigura correto o argumento simplista de que quem contribui com o pagamento de impostos já paga o acesso à saúde pública, pois a questão da efetiva necessidade deve ser levada a sério, juntamente com princípios da solidariedade e da igualdade material. SARLET, Ingo Wolfgang; MARINONI, Guilherme; MITIDIERO, Daniel. Curso de Direito Constitucional. 2. ed. São Paulo: Editora Revista dos Tribunais, 2013, p.591-592. Em sentido diverso, MIRANDA defende que não deve haver diferenciação entre os usuários do sistema público de saúde que, a partir do financiamento público, deve atender a todos de forma indiscriminada e independente de qualquer contraprestação específica, conforme idealizado pelo movimento da "Reforma Sanitária". MIRANDA, Ciro Carvalho. Dissertação (mestrado). Fornecimento Gratuito de Medicamento pelo Poder Público e Protocolos Clínicos: poder regulamentar do Ministério da Saúde e adequação do exercício do direito fundamental. Instituto Brasiliense de Direito Público. Brasília, 2010, p. 20. No mesmo sentido, AITH afirma que as ações e serviços de saúde serão universais e gratuitos, vez que contam com a solidariedade nacional, devendo o financiamento observar as normas contidas no artigo 195 da Constituição. Destaca o grande salto de humanismo dado pela Constituição de 1988 ao definir a universalidade das ações e serviços públicos de saúde, tornando-os serviços públicos gratuitos, não contributivos. AITH, Fernando. Curso de Direito Sanitário: a proteção do Direito à Saúde no Brasil. São Paulo: Quartier Latin, 2007, p. 220-223.

${ }^{389}$ BRASIL. SUS: avanços e desafios. Brasília: CONASS, 2007c, p. 48-62.

${ }^{390}$ Nos dias atuais, aproximadamente $27 \%$ (vinte e sete por cento) da população brasileira utiliza os serviços privados de saúde, abrangidos pelo sistema suplementar, sendo certo que essas pessoas também utilizam o 
garantir a efetiva participação popular na elaboração das políticas públicas para que as ações e serviços públicos prestados no âmbito do Sistema Único de Saúde (SUS) espelhem as verdadeiras demandas sociais em matéria de saúde.

Após definir o dever fundamental dos poderes públicos em relação à tutela do direito fundamental à saúde, a norma constitucional em exame define a forma mediante a qual deve ser cumprida esta tarefa: políticas públicas permanentes, que tenham por objetivos específicos a redução do "risco de doença e de outros agravos", bem como a garantia de "acesso universal e igualitário às ações e serviços", para a "promoção, proteção e recuperação" da saúde da população. ${ }^{391}$ Logo, além da tutela do direito individual, o direito à saúde inclui um conjunto de medidas e atividades de cunho coletivo, dirigidas à proteção do conjunto dos cidadãos.

Com efeito, o Estado recebe instrumentos jurídicos eficazes para que possa cumprir o seu dever constitucional de garantir a saúde da população: políticas sociais e econômicas. Tais políticas contribuem ao mesmo tempo para o desenvolvimento econômico e social do País e devem ser norteadas pelos objetivos gerais da República Federativa do Brasil, insculpidos no artigo $3^{\circ}$ da Constituição Federal: "construir uma sociedade livre, justa e solidária"; "garantir o desenvolvimento nacional"; "reduzir as desigualdades sociais e regionais"; e "promover o bem de todos".

A concepção de saúde consolidada pela Constituição de 1988 segue a orientação defendida pela Organização Mundial de Saúde (OMS), na qual se aproximam as noções de saúde e qualidade de vida. Nesta perspectiva, a saúde é considerada não apenas a ausência de doenças, mas o estado de completo bem-estar físico, mental e social do indivíduo. ${ }^{392}$

$\mathrm{O}$ direito fundamental à saúde consagrado no artigo $6^{\circ}$ da Constituição Federal ganha contornos mais precisos em nível normativo-constitucional no artigo 196 (norma constitucional de princípio programático), que o define como direito subjetivo, de todos,

SUS, especialmente em relação aos serviços de alta complexidade, que possuem custos operacionais elevados e não tão rentáveis para as operadoras de planos de saúde ou seguro saúde.

${ }^{391}$ Neste sentido, a Lei n. 8.080, de 19 de setembro de 1990 dispõe no parágrafo $1^{\circ}$ do artigo $2^{\circ}$ como o Estado deve se desincumbir do dever de assegurar a saúde: "Art. $2^{\circ}$ A saúde é um direito fundamental do ser humano, devendo o Estado prover as condições indispensáveis ao seu pleno exercício. $\S 1^{\circ} \mathrm{O}$ dever do Estado de garantir a saúde consiste na formulação e execução de políticas econômicas e sociais que visem à redução de riscos de doenças e de outros agravos e no estabelecimento de condições que assegurem acesso universal e igualitário às ações e aos serviços para a sua promoção, proteção e recuperação.”

${ }^{392}$ Segundo a definição da Organização Mundial da Saúde (OMS), de 1946, a saúde é "o completo bem-estar físico, mental e social e não somente a ausência de doenças ou enfermidades", e ainda reconhece a saúde como um dos direitos fundamentais de todo ser humano, independente de sua condição social e econômica ou sua crença religiosa ou política, afirmando a importância de uma política sanitária. 
em decorrência do fato de pertencerem ao gênero humano, e atribui ao Estado uma alargada série de deveres na área da saúde abrangentes de aspectos: (i) curativos, pela garantia de acesso a meios que possam recuperar a saúde com a cura ou, pelo menos, com a melhoria da qualidade de vida; (ii) preventivos, por meio da efetivação de medidas que tenham por fim evitar o surgimento de doenças, inclusive pelo contágio ("redução do risco de doença" e "proteção"); e (iii) promocionais, relacionados às ações que tenham por escopo melhorar as condições de vida e de saúde das pessoas.

Dessa forma, a noção de saúde consagrada pela Constituição Federal de 1988 está em harmonia com o dever de efetivação progressiva do direito à saúde, bem assim com a garantia do mais alto nível de saúde física e mental possível de atingir, como prescreve o artigo 12, 1, do Pacto Internacional de Direitos Econômicos, Sociais e Culturais (PIDESC). ${ }^{393}$

Embora a Constituição Federal tenha atribuído a titularidade dos direitos e garantias fundamentais aos brasileiros e aos estrangeiros residentes no país, conforme prevê seu artigo $5^{\circ}$, caput $^{394}$, o direito constitucional brasileiro também consagrou os princípios da universalidade de direitos e deveres fundamentais e da dignidade da pessoa humana ${ }^{395}$, que devem ser interpretados de forma combinada ${ }^{396}$. Em relação ao direito à saúde, o caráter de universalidade foi expressamente reconhecido no artigo 196 da Constituição Federal ${ }^{397}$, configurando-se em exceção à regra do artigo $5^{\circ}$, caput. Por isto, o direito fundamental à saúde é reconhecido aos brasileiros e estrangeiros, independentemente da efetiva residência em território brasileiro, visto que está relacionado aos direitos à vida, à integridade física e psíquica, bem como à dignidade humana. 398399400

\footnotetext{
393 O artigo 12, parágrafo $1^{\circ}$, do Pacto Internacional de Direitos Econômicos, Sociais e Culturais (PIDESC) assim prescreve: "Artigo 12. $1^{\circ}$. Os Estados Partes no presente pacto reconhecem o direito de todas as pessoas de gozar do melhor estado de saúde física e mental possível de atingir."

${ }^{394} \mathrm{O}$ artigo $5^{\circ}$, caput, da Constituição Federal estabelece o seguinte: “Art. $5^{\circ}$ Todos são iguais perante a lei, sem distinção de qualquer natureza, garantindo-se aos brasileiros e aos estrangeiros residentes no País a inviolabilidade do direito à vida, à liberdade, à igualdade, à segurança e à propriedade, nos termos seguintes:" 395 Nos termos do artigo $1^{\text {o }}$, inciso III, da Constituição Federal: "Art. $1^{\circ}$ A República Federativa do Brasil, formada pela união indissolúvel dos Estados e Municípios e do Distrito Federal, constitui-se em Estado Democrático de Direito e tem como fundamentos: (...) III - a dignidade da pessoa humana;”

396 SARLET, Ingo Wolfgang; MARINONI, Guilherme; MITIDIERO, Daniel. Curso de Direito Constitucional. 2. ed. São Paulo: Editora Revista dos Tribunais, 2013, p.315-320.

397 “Art. 196. A saúde é direito de todos e dever do Estado, garantido mediante políticas sociais e econômicas que visem à redução do risco de doença e de outros agravos e ao acesso universal e igualitário às ações e serviços para sua promoção, proteção e recuperação."

${ }^{398}$ Cumpre notar que embora os princípios da universalidade e da isonomia sejam correlatos, são princípios que não se confundem. O fato de o direito à saúde ser reconhecido a todos, não impede que seja atribuído tratamento diferenciado às pessoas, seja por disposição constitucional expressa ou por força da aplicação do
} 
O artigo 197 da Constituição Federal ${ }^{401}$ define as a ações e serviços de saúde como de relevância pública, indicando que a saúde se sobressai dentre os serviços que o Estado deve prestar, por uma ampla gama de medidas.

Dentre as funções do Estado aptas à "proteção, a promoção e recuperação" da saúde, MÂNICA destaca: (i) a formulação e o planejamento de políticas públicas; (ii) o

próprio princípio da igualdade. Assim, por exemplo, às pessoas em situação de maior vulnerabilidade social, como crianças, idosos e mulheres grávidas, em razão dessas particularidades, pode ser aplicado tratamento distinto. Neste sentido: SARLET, Ingo Wolfgang; MARINONI, Guilherme; MITIDIERO, Daniel. Curso de Direito Constitucional. 2. ed. São Paulo: Editora Revista dos Tribunais, 2013, p.316.

399 O Supremo Tribunal Federal já consolidou posicionamento no sentido de que mesmo o estrangeiro não residente no Brasil dispõe de garantias constitucionais voltadas a assegurar direitos fundamentais, desde que sejam destinadas a produzir efeitos em território pátrio, na medida em que são direitos de todos os seres humanos, inerentes à dignidade humana, pouco importando que o estrangeiro resida no Brasil ou não. Antes da promulgação da Constituição Federal de 1988, o Supremo Tribunal Federal, no julgamento do Recurso Extraordinário n. 44621/SP, admitiu o cabimento de mandado de segurança para a proteção do direito de propriedade de estrangeiro não residente no país, sob o argumento de que a interpretação literal da norma constitucional que restringia sua titularidade aos brasileiros e estrangeiros residentes no território nacional não teria razão de perdurar no plano do direito moderno, visto que direitos humanos são reconhecidos universalmente. (STF, RE 44621/SP, da relatoria do Ministro Cândido Motta Filho. $1^{\mathrm{a}}$ Turma. DJ 26/10/1960, v. 439-02, p. 880). Após a promulgação da Constituição de 1988, o Supremo Tribunal Federal reiterou esse entendimento no julgamento do Habeas Corpus n. 97147/MT ( $2^{\text {a }}$ Turma. Julgado em 04/08/2009, relatoria para o acórdão do Ministro Cezar Peluso), no julgamento do Habeas Corpus n. 94.016/SP ( $2^{\text {a }}$ Turma, relatoria do Ministro Celso de Mello, julgado em 16/09/2008, DJ 27.2.2009) e no julgamento do Habeas Corpus n. 94477/PR, relatado pelo Ministro Gilmar Mendes ( $2^{\mathrm{a}}$ Turma, julgamento concluído em 06/09/2011).

${ }^{400}$ Neste sentido, no contexto atual, as políticas públicas de saúde apresentam caráter inclusivo para atender também aos estrangeiros não residentes no Brasil, favorecendo um sistema de saúde pública equânime e universal. Com base nos diagnósticos de gestores de municípios situados na região fronteiriça nacional, ao longo dos $15.719 \mathrm{~km}$, foi constatado que houve um aumento do fluxo de circulação dessas populações em busca de melhores serviços de saúde. Assim, foi instituído um Projeto da Secretaria de Atenção à Saúde do Ministério da Saúde, pela Portaria GM 1.120, de 06/07/2005, do Ministério da Saúde, denominado "Sistema Integrado de Saúde das Fronteiras" (SIS-Fronteiras), com o objetivo de fortalecer e melhorar os sistemas locais de saúde dos 121 municípios fronteiriços brasileiros, integrando as ações e serviços para o atendimento de uma população de cerca de três milhões de habitantes. O Projeto compreende três fases de execução, a serem realizadas em cada município fronteiriço, quais sejam: Fase I - Realização do Diagnóstico Local de Saúde quali-quantitativo e elaboração do Plano Operacional; Fase II - Qualificação da Gestão, de serviços e ações, e implementação da Rede de Saúde nos municípios fronteiriços; e Fase III- Implantação de Serviços e ações nos municípios fronteiriços, conforme Diagnóstico local, definido no Plano Operacional. O programa também tem por meta estimular a implantação de ações e acordos bilaterais ou multilaterais entre os países que compartilham fronteiras entre si, por intermédio um diagnóstico homogêneo da situação de saúde além dos limites da fronteira geopolítica brasileira, como já foram estabelecidos entre Brasil e Argentina, Brasil e Paraguai, Brasil e Uruguai e Brasil e Bolívia. As informações estão disponíveis em: $<$ http://portal.saude.gov.br>. Consulta em: 28/10/2013. Para aprofundar o assunto, conferir: SOUZA, Maria de Lourdes de; FERREIRA, Luiz Alberto Peregrino Ferreira; REZENDE, Vanessa Murta; BRANCO, Marisa Lucena Branco (organizadores). A saúde e a inclusão social nas fronteiras. Florianópolis: Fundação Boiteux, 2008. Disponível na biblioteca virtual em saúde: <http://bvsms.saude.gov.br>. Consulta em 28/10/2013.

401 “Art. 197. São de relevância pública as ações e serviços de saúde, cabendo ao Poder Público dispor, nos termos da lei, sobre sua regulamentação, fiscalização e controle, devendo sua execução ser feita diretamente ou através de terceiros e, também, por pessoa física ou jurídica de direito privado." 
financiamento das atividades públicas e incentivo às atividades privadas; (iii) a regulação de todo o setor; e (iv) a prestação dos serviços. ${ }^{402}$

Assim como em relação aos demais direitos sociais, o Estado é o sujeito passivo principal do direito à saúde, cabendo-lhe desenvolver um conjunto de medidas normativas e administrativas voltadas a assegurar a tutela do direito à saúde. Este dispositivo estabelece a edição de uma legislação ${ }^{403}$ que regulamente, fiscalize e controle tais ações e serviços de saúde.

Conquanto seja dever do Estado a concretização do direito à saúde, o constituinte admite que a execução das ações e serviços de saúde seja feita diretamente ou de forma suplementar, por intermédio de terceiros, instituições conveniadas ou contratadas, e, também, por pessoas físicas ou pessoas jurídicas de direito privado, nos termos do caput, do artigo 197 da Constituição Federal. 404405

O artigo 198 da Constituição Federal ${ }^{406}$ é dedicado à definição de regras acerca dos investimentos estatais na área da saúde e à instituição de um sistema único, caracterizado pela hierarquia ${ }^{407}$ e regionalização ${ }^{408}$ das ações e serviços de saúde ${ }^{409}$, organizado com

402 MÂNICA, Fernando Borges. A complementaridade da participação privada no SUS. In: Revista Brasileira de Direito da Saúde, v. 2. Brasília: CMB, p. 34-54, jan./jul. 2012.

${ }^{403}$ Segundo BASTOS e MARTINS, a lei a que se refere o constituinte e lei ordinária, pois se trata de matéria atribuída à competência privativa da União, relativa à edição de normas gerais e, no que concerne às normas gerais, somente é necessário lei complementar em caso de existência de previsão neste sentido no texto constitucional, como mencionado no artigo 146 da Constituição Federal. BASTOS, Celso Ribeiro; MARTINS, Ives Gandra. Comentários à Constituição do Brasil: promulgada em 5 de outubro de 1988, v.8: arts. 193 a 232. 2.ed. São Paulo: Saraiva, 2000, p. 143.

404 “Art. 197. São de relevância pública as ações e serviços de saúde, cabendo ao Poder Público dispor, nos termos da lei, sobre sua regulamentação, fiscalização e controle, devendo sua execução ser feita diretamente ou através de terceiros e, também, por pessoa física ou jurídica de direito privado."

405 Para BASTOS e MARTINS, as pessoas jurídicas de direito privado somente poderão prestar serviços ao Estado na seara da saúde mediante prévio procedimento licitatório, exceto em caso de emergência. Conforme BASTOS e MARTINS, o constituinte reiterou os objetivos que, devido à sua importância, considerou necessários serem permanentemente perseguidos, além de torná-los amplamente conhecidos da sociedade e do Governo. BASTOS, Celso Ribeiro; MARTINS, Ives Gandra. Comentários à Constituição do Brasil: promulgada em 5 de outubro de 1988, v.8: arts. 193 a 232. 2.ed. São Paulo: Saraiva, 2000, p. 144.

406 “Art. 198. As ações e serviços públicos de saúde integram uma rede regionalizada e hierarquizada e constituem um sistema único, organizado de acordo com as seguintes diretrizes: I - descentralização, com direção única em cada esfera de governo; II - atendimento integral, com prioridade para as atividades preventivas, sem prejuízo dos serviços assistenciais; III - participação da comunidade."

407 A hierarquia significa a necessidade de organização das ações e dos serviços públicos de saúde em distintos níveis de complexidade, para que haja racionalização do sistema e otimização de seus custos. DALLARI, Sueli Gandolfi; NUNES JÚNIOR. Vidal Serrano. Direito sanitário. São Paulo: Editora Verbatim, 2010 , p.83.

408 A regionalização indica que é imprescindível a organização das ações e serviços de saúde por circunscrições territoriais, que devem levar em consideração o dinamismo e a complexidade do sistema, que exige constante redefinição e aprimoramento. DALLARI, Sueli Gandolfi; NUNES JÚNIOR. Vidal Serrano. Direito sanitário. São Paulo: Editora Verbatim, 2010, p. 83. 
base nos seguintes alicerces: (i) descentralização, com direção única em cada esfera de governo; (ii) atendimento integral; (iii) prioridade para as atividades preventivas, sem prejuízo dos serviços assistenciais; e (iv) participação da comunidade.

A concepção deste sistema originalmente pela Constituição, denominado "Sistema Único de Saúde", com a definição de normas relativas à estrutura e às diretrizes que orientam seu funcionamento, significa uma autêntica garantia institucional aos indivíduos, associada aos valores sociais que demandam a adoção de medidas concretas pelo Estado a fim de cumprir o seu dever constitucional de assegurar o direito fundamental à saúde. Segundo BONAVIDES, tal disposição organizatória reflete a dimensão objetiva do direito e consiste em garantia contra arbitrariedades estatais. ${ }^{410}$ Sob o prisma do Estado, conforme ALMEIDA, a organização do Sistema Único de Saúde é competência material da União, relativa ao planejamento e racionalização permanente das ações e serviços de saúde. ${ }^{411}$

A garantia institucional do Sistema Único de Saúde importa, simultaneamente, o dever do Estado de estabelecer um complexo normativo para a concretização do direito à saúde, respeitando os princípios e valores da ordem jurídico-constitucional estabelecida, como também a proibição do Estado de reduzir a garantia constitucional assegurada pela Constituição Federal à própria existência e à organização do Sistema Único de Saúde

\footnotetext{
${ }^{409}$ A regionalização e a hierarquização implicam a integração dos entes federativos ao sistema de saúde. A hierarquia consiste na subordinação de todos às regras fixadas pela União, garantindo-se a descentralização, com direção única em cada uma das esferas de governo. BASTOS, Celso Ribeiro; MARTINS, Ives Gandra. Comentários à Constituição do Brasil: promulgada em 5 de outubro de 1988, v.8: arts. 193 a 232. 2.ed. São Paulo: Saraiva, 2000, p.147-148.

${ }^{410}$ BONAVIDES dá ênfase à importância das garantias institucionais como abertura de caminho para a universalização concreta dos direitos fundamentais. Conforme afirmou, enquanto a primeira geração de direitos fundamentais consistia principalmente no estabelecimento das garantias fundamentais da liberdade, a partir da segunda geração tais direitos passaram a compreender, além daquelas garantias, também os critérios objetivos de valores, bem como os princípios que animam a Constituição Federal, projetando-lhe uma unidade de ordenação valorativa. Assim, das prescrições de direitos fundamentais de segunda geração decorrem tanto direitos subjetivos como direitos objetivos. A dimensão objetiva desses direitos, relacionados às disposições organizatórias, consistem em garantias contra atos de arbítrio do Estado. BONAVIDES, Paulo. Curso de Direito Constitucional. 22. ed. São Paulo: Malheiros, 2008, p. 565-569.

${ }^{411}$ Além das competências materiais atribuídas expressamente à União no artigo 21 da Constituição Federal, como "planejar e promover a defesa permanente contra as calamidades públicas, especialmente as secas e as inundações" (inciso XVIII), o texto constitucional estabelece outras. Dentre tais temas, a Constituição Federal defere à União a competência material para organizar o Sistema Único de Saúde, nos termos do artigo 198, caput, da Constituição Federal, pois é tema de planejamento, relacionado à tomada de decisões, visando racionalizar, de forma contínua e permanente, a ação política global. Neste sentido, conferir: ALMEIDA, Fernanda Dias Menezes de. Competências na Constituição de 1988. 3. ed. São Paulo: Atlas, 2005, p.90-96.
} 
(SUS), vedando-se quaisquer medidas que importem em retrocesso, inação ou insuficiente proteção a este direito. ${ }^{412} 413$

A unicidade do sistema significa que todos os meios de ação (ações, serviços, equipamentos etc.) e recursos públicos ${ }^{414}$ (materiais e humanos) compõe um arranjo integrado e harmônico voltado à concretização da atenção integral à saúde e ao atendimento da população. Ademais, um dos principais traços característicos da ideia de sistema é a cooperação dos entes da Federação para a realização das políticas sanitárias, que devem atuar de forma coordenada e articulada, compartilhando suas capacidades para se desincumbirem das tarefas fixadas no texto constitucional quanto à garantia do direito à saúde da população. ${ }^{415}$

A diretriz de descentralização administrativa do Sistema Único de Saúde (SUS) significa a distribuição da capacidade de organização das ações e serviços de saúde entre as entidades federativas, ao contrário do cenário anterior à Constituição de 1988. Naquela ordem jurídico-constitucional a União concentrava a gestão administrativa de políticas públicas de saúde. Atualmente deve existir para cada esfera de governo apenas uma direção, visando melhorar o desempenho e facilitar a fiscalização das ações e serviços públicos de saúde.

\footnotetext{
${ }^{412}$ Segundo a posição adotada, a garantia institucional relativa ao Sistema Único de Saúde consiste numa garantia constitucional "qualificada", como define BONAVIDES face à garantia constitucional "simples", porquanto protege a inalterabilidade do preceito tanto por via legislativa ordinária como por via constituinte derivada, decorrente do poder de reforma constitucional. A garantia constitucional qualificada é tão rígida que não admite seja sequer objeto de deliberação a proposta de emenda tendente a abolir a matéria constante da cláusula constitucional de exclusão, tal qual prevê o artigo 60, parágrafo $4^{\circ}$, alínea "d". A garantia constitucional "simples", ao contrário da garantia constitucional qualificada, recai unicamente contra a ação do legislador ordinário, sem afetar o poder de emenda do legislador constituinte, dotado de competência para exercer o poder de emenda. BONAVIDES, Paulo. Curso de Direito Constitucional. 22 ed. São Paulo: Malheiros, 2008, p. 548-550.

${ }^{413}$ No mesmo sentido, SARLET e FIGUEIREDO defendem que a garantia institucional fundamental ao Sistema Único de Saúde se sujeita à proteção estabelecida para as demais normas jusfundamentais, inclusive no que tange à sua inserção entre os limites materiais à reforma constitucional, estando, assim, salvaguardada pela tutela constitucional protetiva. SARLET, Ingo Wolfgang; FIGUEIREDO, Mariana Filchtiner. Algumas considerações sobre o direito fundamental à proteção e promoção da saúde aos 20 anos da Constituição Federal de 1988. In: Revista de Direito do Consumidor n. 67, p. 125-172, 2008.

${ }^{414} \mathrm{O}$ artigo 198, parágrafo único, da Constituição Federal prevê: "O sistema único de saúde será financiado, nos termos do art. 195, com recursos do orçamento da seguridade social, da União, dos Estados, do Distrito Federal e dos Municípios, além de outras fontes".

${ }^{415}$ Conforme DALLARI e NUNES JÚNIOR, "a definição de organização da saúde em forma de sistema, abrangendo os recursos e ações de todos os entes da Federação, abre, deste modo, um hiato na organização federativa do poder, pois, ao invés de autonomia de cada um dos entes, estipula-se a integração automática de todos eles a um sistema, para o qual devem concorrer com ações e recursos, de maneira a se lograr um conjunto integrado e harmônico apto a realizar os elevados objetivos que lhe foram atribuídos pela Constituição". DALLARI, Sueli Gandolfi; NUNES JÚNIOR. Vidal Serrano. Direito sanitário. São Paulo: Editora Verbatim, 2010, p.80.
} 
A integralidade do atendimento reflete a noção de um conjunto harmônico e pleno das ações e serviços de saúde, de forma que sejam simultaneamente articulados para compreender os aspectos preventivo, curativo e promocional, em âmbito local, regional e nacional, abrangente dos diferentes níveis de complexidade. Importa realçar que as ações preventivas na área da saúde foram indicadas como prioritárias, nos termos do disposto no artigo 198, inciso II, da Constituição Federal.

O dever do Estado de realizar medidas de natureza preventiva, reparadora e promocional da saúde para o atendimento adequado da população não significa que o direito subjetivo à saúde seja absoluto, ilimitado e abrangente de qualquer prestação em face do Estado. ${ }^{416}$ No século XX, o campo da saúde foi marcado por significativos progressos científicos, que implicaram em relevante aumento no custo da assistência à saúde ${ }^{417}$, dos quais se destacam: a descoberta de novos tratamentos; o desenvolvimento de máquinas modernas para a realização de exames, que possibilitam, inclusive, a detecção precoce de doenças; a investigação e a criação de medicamentos e vacinas que permitem a cura, aliviam a dor, aumentam a longevidade e/ou melhoram a qualidade de vida daqueles que a eles têm acesso; e a descoberta de novos procedimentos cirúrgicos minimamente invasivos. Porém, a escassez de recursos públicos investidos na área da saúde não permite que os indivíduos sejam coletivamente beneficiados por tais avanços tecnológicos, geralmente de custo expressivo.

O que está assegurado às pessoas, como titulares do direito subjetivo à saúde, é o oferecimento de prestações materiais delimitadas pelo Estado, conforme as políticas públicas elaboradas pelo Legislativo e implementadas pelo Executivo, com esteio nos princípios e normas definidos na Constituição Federal e na Lei n. 8.080/90. Portanto, em princípio, o reconhecimento do direito subjetivo à saúde, em seu status positivo, conduz à

\footnotetext{
416 Nas palavras de MARRARA e NUNES, “(...) a interpretação mais equilibrada, sob o ponto de vista lógico e teleológico do art. 196, conduz à conclusão de que o direito à saúde gera um direito a prestações básicas e vitais, e não a quaisquer prestações que possam ter por resultado direto ou indireto, próximo ou remoto, uma melhoria do bem-estar individual". MARRARA, Thiago e NUNES, Lydia Neves Bastos Telles. Reflexões sobre o controle das políticas de saúde e de medicamentos. In Direito à vida e à saúde: impactos orçamentário e judicial. BLIACHERIENE, Ana Carla; DOS SANTOS, José Sebastião. São Paulo: Atlas, p. 84-85, 2010.

417 Como observa MÂNICA, ao contrário do que ocorre em outros setores, o avanço tecnológico na área da saúde não importa em redução de custos. MÂNICA, Fernando Borges. Participação privada na prestação de serviços públicos de saúde. Tese (doutorado). Curso de Pós-Graduação em Direito. Universidade de São Paulo. São Paulo, 2009, p.4.
} 
conclusão de que há um direito (individual ou mesmo coletivo, conforme o caso) limitado e condicionado a prestações estatais, denominado de direito subjetivo derivado. ${ }^{418}$

O planejamento é pressuposto para a concretização da integralidade do Sistema Único de Saúde. Tal dispositivo realça o dever do Estado dedica-se prioritariamente às atividades preventivas, sem prejuízo dos serviços de assistência à saúde.

A diretriz constitucional de participação da comunidade indica que o Sistema Único de Saúde (SUS) deverá contemplar mecanismos de participação direta e permanente da população na formulação, gestão e implementação de ações e serviços públicos de saúde. ${ }^{419}$ Sem prejuízo de retomar o estudo deste tema em capítulo específico deste trabalho, cumpre observar brevemente que a participação da comunidade foi prevista como princípio na Lei n. 8.080/90 ${ }^{420}$ e está disciplinada pela Lei n. 8.142/90 $0^{421}$, que determina a criação de duas instâncias colegiadas que contem com a participação social efetiva, em

${ }^{418}$ Neste sentido a Ministra Ellen Gracie decidiu de forma monocrática o seguinte: “(...) a gestão da política nacional de saúde, que é feita de forma regionalizada, busca uma maior racionalização entre o custo e o benefício dos tratamentos que devem ser fornecidos gratuitamente, a fim de atingir o maior número possível de beneficiários. (...) a norma do art. 196 da Constituição da República, que assegura o direito à saúde, refere-se, em princípio, à efetivação de políticas públicas que alcancem a população como um todo, assegurando-lhe acesso universal e igualitário, e não a situações individualizadas. A responsabilidade do Estado em fornecer os recursos necessários à reabilitação da saúde de seus cidadãos não pode vir a inviabilizar o sistema público de saúde. No presente caso, ao se deferir o custeio do medicamento em questão em prol do impetrante, está-se diminuindo a possibilidade de serem oferecidos serviços de saúde básicos ao restante da coletividade." (STF, SS n. 3073/RN. Julgado em 09/02/2007. Ministra Ellen Gracie Presidente. DJ n. 32, de 14/02/2007).

${ }^{419}$ O artigo 198, inciso III da Constituição Federal prevê que a participação da comunidade como uma das diretrizes do Sistema Único de Saúde: "Art. 198. As ações e serviços públicos de saúde integram uma rede regionalizada e hierarquizada e constituem um sistema único, organizado de acordo com as seguintes diretrizes: (...) III - participação da comunidade.”

420 "Art. $7^{\circ}$ As ações e serviços públicos de saúde e os serviços privados contratados ou conveniados que integram o Sistema Único de Saúde (SUS), são desenvolvidos de acordo com as diretrizes previstas no art. 198 da Constituição Federal, obedecendo ainda aos seguintes princípios: (...) III - participação da comunidade".

${ }^{421}$ Nos termos do artigo $1^{\circ}$, da Lei n. 8.142/90: “Art. $1^{\circ}$ O Sistema Único de Saúde (SUS), de que trata a Lei $\mathrm{n}^{\circ}$ 8.080, de 19 de setembro de 1990, contará, em cada esfera de governo, sem prejuízo das funções do Poder Legislativo, com as seguintes instâncias colegiadas: I - a Conferência de Saúde; e II - o Conselho de Saúde. (...) $\S 1^{\circ}$ A Conferência de Saúde reunir-se-á a cada quatro anos com a representação dos vários segmentos sociais, para avaliar a situação de saúde e propor as diretrizes para a formulação da política de saúde nos níveis correspondentes, convocada pelo Poder Executivo ou, extraordinariamente, por esta ou pelo Conselho de Saúde. $\S 2^{\circ}$ O Conselho de Saúde, em caráter permanente e deliberativo, órgão colegiado composto por representantes do governo, prestadores de serviço, profissionais de saúde e usuários, atua na formulação de estratégias e no controle da execução da política de saúde na instância correspondente, inclusive nos aspectos econômicos e financeiros, cujas decisões serão homologadas pelo chefe do poder legalmente constituído em cada esfera do governo. $\S 3^{\circ}$ O Conselho Nacional de Secretários de Saúde (CONASS) e o Conselho Nacional de Secretários Municipais de Saúde (CONASEMS) terão representação no Conselho Nacional de Saúde. $\S 4^{\circ}$ A representação dos usuários nos Conselhos de Saúde e Conferências será paritária em relação ao conjunto dos demais segmentos. (...)" 
cada uma das esferas de governo (federal, estadual, distrital e municipal), a saber: a conferência de saúde e o conselho de saúde.

Nos termos do que prescreve o artigo 199, caput, da Constituição Federal ${ }^{422}$, a assistência à saúde é livre à iniciativa privada, em caráter de complementariedade ao Sistema Único de Saúde e regida de acordo com os princípios e diretrizes deste sistema. ${ }^{423}$ Cumpre observar que a Recomendação Geral n. 14, de 2000, do Comitê de Direitos Econômicos Sociais e Culturais (CDESC) das Nações Unidas adverte aos Estados o dever de assegurar que a privatização ou terceirização de serviços e instalações de saúde não importem em risco à acessibilidade universal e à qualidade das ações e serviços de saúde. ${ }^{424}$

A Constituição Federal estabelece expressamente no parágrafo primeiro do artigo $199^{425}$ que a participação da iniciativa privada no Sistema Único de Saúde (SUS) se dará de forma complementar. A Lei n. 8.080/90, no parágrafo segundo de seu artigo $4^{\mathrm{o} 426}$, repete a previsão relativa ao caráter complementar da participação da iniciativa privada no

422 “Art. 199. A assistência à saúde é livre à iniciativa privada. $\S 1^{\circ}$ - As instituições privadas poderão participar de forma complementar do sistema único de saúde, segundo diretrizes deste, mediante contrato de direito público ou convênio, tendo preferência as entidades filantrópicas e as sem fins lucrativos. $\S 2^{\circ}-E^{\circ}$ vedada a destinação de recursos públicos para auxílios ou subvenções às instituições privadas com fins lucrativos. $\S 3^{\circ}-$ É vedada a participação direta ou indireta de empresas ou capitais estrangeiros na assistência à saúde no País, salvo nos casos previstos em lei. $\S 4^{\circ}$ - A lei disporá sobre as condições e os requisitos que facilitem a remoção de órgãos, tecidos e substâncias humanas para fins de transplante, pesquisa e tratamento, bem como a coleta, processamento e transfusão de sangue e seus derivados, sendo vedado todo tipo de comercialização."

${ }^{423}$ Para aprofundar o estudo do tema, conferir: OLIVEIRA, Gustavo Justino de; Mânica, Fernando Borges. Parcerias na saúde: reflexões sobre a Emenda Constitucional n. 51/2006 e a Lei Federal n. 11.350/2006. Belo Horizonte: Editora Fórum. 2009.

424 “35. Las obligaciones de proteger incluyen, entre otras, las obligaciones de los Estados de adoptar leyes u otras medidas para velar por el acceso igual a la atención de la salud y los servicios relacionados con la salud proporcionados por terceros; velar por que la privatización del sector de la salud no represente una amenaza para la disponibilidad, accesibilidad, aceptabilidad y calidad de los servicios de atención de la salud; controlar la comercialización de equipo médico y medicamentos por terceros, y asegurar que los facultativos y otros profesionales de la salud reúnan las condiciones necesarias de educación, experiencia y deontología. Los Estados también tienen la obligación de velar por que las prácticas sociales o tradicionales nocivas no afecten al acceso a la atención anterior y posterior al parto ni a la planificación de la familia; impedir que terceros induzcan a la mujer a someterse a prácticas tradicionales, por ejemplo a la mutilación de los órganos genitales femeninos; y de adoptar medidas para proteger a todos los grupos vulnerables o marginados de la sociedad, en particular las mujeres, los niños, los adolescentes y las personas mayores, teniendo en cuenta los actos de violencia desde la perspectiva de género. Los Estados deben velar asimismo por que terceros no limiten el acceso de las personas a la información y los servicios relacionados con la salud."

425 “Art. 199. A assistência à saúde é livre à iniciativa privada. $§ 1^{\circ}$ - As instituições privadas poderão participar de forma complementar do sistema único de saúde, segundo diretrizes deste, mediante contrato de direito público ou convênio, tendo preferência as entidades filantrópicas e as sem fins lucrativos."

426 "Art. $4^{\circ} \mathrm{O}$ conjunto de ações e serviços de saúde, prestados por órgãos e instituições públicas federais, estaduais e municipais, da Administração direta e indireta e das fundações mantidas pelo Poder Público, constitui o Sistema Único de Saúde (SUS). (...) § $2^{\circ}$ A iniciativa privada poderá participar do Sistema Único de Saúde (SUS), em caráter complementar." 
Sistema Único de Saúde. Por sua vez, o artigo 24 da Lei n. 8.080/90427 dispõe que a participação privada está vinculada aos casos em que houver insuficiência de ações e serviços públicos de saúde.

No tocante às instituições privadas que pretendam atuar junto ao Sistema Único de Saúde, o constituinte manda que se dê preferência às entidades filantrópicas e às entidades sem fins lucrativos. Tal preferência é reiterada no parágrafo $2^{\circ}$ do artigo $199^{428}$, que proíbe a destinação de recursos públicos para auxílios ou subvenções às instituições privadas que tenham fins lucrativos. A integração da entidade ao Sistema Único de Saúde (SUS) deve ser gerada por convênio ou contrato administrativo. ${ }^{429}$

A complementariedade da participação da iniciativa privada no Sistema Único de Saúde (SUS) gera controvérsias na doutrina sobre a extensão. De acordo com DALLARI e NUNES JÚNIOR devem existir unidades públicas de atendimento e a participação da iniciativa privada no Sistema Único de Saúde significa prestar serviços de saúde, de forma residual, somente para suprir as necessidades de atendimento. ${ }^{430}$ No mesmo sentido, MARQUES NETO afirma que a participação privada na prestação de serviços de saúde está relacionada à ideia de subsidiariedade, pois a iniciativa privada apenas deve prestar serviços públicos de saúde para suprir deficiências ou insuficiências da rede pública de saúde em fazê-lo diretamente. ${ }^{431}$

Em sentido diverso, MÂNICA afirma que não se pode extrair da Constituição Federal o entendimento de que a participação de entidades de natureza pública deve ser preferencial. Na sua ótica, o objetivo de máxima efetivação dos direitos fundamentais, a maior eficiência na garantia do direito à saúde por meio da prestação de serviços públicos pela iniciativa privada e a ausência de limitação à esfera de atuação estatal direta,

\footnotetext{
${ }^{427}$ Inserido no Capítulo II da Lei n. 8.080/90, que trata “Da Participação Complementar", o artigo 24 assim dispõe: "Art. 24. Quando as suas disponibilidades forem insuficientes para garantir a cobertura assistencial à população de uma determinada área, o Sistema Único de Saúde (SUS) poderá recorrer aos serviços ofertados pela iniciativa privada. Parágrafo único. A participação complementar dos serviços privados será formalizada mediante contrato ou convênio, observadas, a respeito, as normas de direito público."

428 “Art. 199. A assistência à saúde é livre à iniciativa privada. (...) § $2^{\circ}$ - É vedada a destinação de recursos públicos para auxílios ou subvenções às instituições privadas com fins lucrativos."

${ }^{429}$ Para um estudo aprofundado a respeito da teoria do contrato administrativo, conferir: MENEZES DE ALMEIDA, Fernando Dias. Contrato Administrativo. São Paulo: Quartier Latin, 2012.

${ }^{430}$ DALLARI, Sueli Gandolfi; NUNES JÚNIOR. Vidal Serrano. Direito sanitário. São Paulo: Editora Verbatim, 2010, p.96.

${ }^{431}$ MARQUES NETO, Floriano de Azevedo. Público e privado no setor de saúde. In: Revista de Direito Público da Economia-RDPE, Belo Horizonte, ano 3, n.9, p.105-154, jan./mar. 2005.
} 
justificam que a atuação privada compreenda todas as atividades voltadas à prevenção de doenças e à promoção, proteção e recuperação da saúde. ${ }^{432}$

É verdade que a cobertura assistencial universal e integral à saúde atualmente prestada direta ou indiretamente pelo Estado, como estabelece a Constituição Federal, não é suficiente em quantidade de oferta nem em qualidade das ações e serviços para o atendimento da população brasileira. Também é possível afirmar que: (i) o Brasil não investe recursos suficientes para sustentar um sistema público de saúde; (ii) todas as pessoas podem ser atendidas pelo sistema público (universalidade); (iii) não há delimitação (no plano constitucional) dos serviços a serem disponibilizados no âmbito do sistema público; e (iv) o conceito de saúde adotado é amplo e aproxima-se de metas subjetivas e intangíveis como qualidade de vida e felicidade. ${ }^{433}$

No entanto, o constituinte definiu expressamente que a participação da iniciativa privada no Sistema Único de Saúde (SUS) deve ocorrer de forma complementar. Além disso, é possível extrair da Constituição Federal, da legislação em matéria de saúde e dos atos infralegais que regulamentam as ações e os serviços de saúde, balizas mais precisas sobre o conteúdo do direito à saúde (no caso, o status positivo). E no contexto da democracia participativa, sobretudo na área da saúde, cabe à população tomar parte da definição dos contornos desse direito, de como e quanto quer (e pode) gastar com as políticas de saúde.

Assim, acompanhamos a posição de que a complementaridade da participação privada nos serviços de saúde significa que a Constituição Federal autoriza a delegação de serviços públicos de saúde a particulares, a ser instrumentalizada por meio de ajustes

\footnotetext{
${ }^{432}$ MÂNICA afirma que a complementaridade da participação privada na prestação de serviços públicos de saúde (delegação de serviço público) deve ocorrer por mecanismos jurídicos que garantam ao sistema controle e fiscalização sob o serviço e assegurem ao prestador privado segurança jurídica e financeira a sua prestação. Diz que não há vedação constitucional à participação privada na ampla gama de serviços de saúde. Assim, com base no artigo 197 do texto constitucional, cada ente federativo, no exercício de sua competência para a organização administrativa dos serviços públicos, pode definir qual é o melhor modelo, dentre aqueles legalmente admitidos, voltado à prestação das ações e dos serviços de saúde a todos aqueles que dele necessitarem. Para MÂNICA, é juridicamente possível a delegação de serviços públicos de saúde a particulares, instrumentalizada por meio de ajustes que tenham como objeto: "(i) um serviço ou um grupo de serviços internos relacionados à atividade-fim de uma entidade ou órgão público prestador de serviços de saúde; (ii) a prestação de serviços por uma unidade privada dotada de infra-estrutura apta ao desenvolvimento das atividades ajustadas; ou (iii) toda a gestão de uma unidade pública de saúde - incluindo, obviamente, atividades-fim, atividades-meio e atividades acessórias." MÂNICA, Fernando Borges. A complementaridade da participação privada no SUS. In: Revista Brasileira de Direito da Saúde, v.2, Brasília: CMB, p. 34-54, jan./jul. 2012.

${ }^{433}$ Os argumentos foram apresentados por Mânica para sustentar sua posição. MÂNICA, Fernando Borges. A complementaridade da participação privada no SUS. In: Revista Brasileira de Direito da Saúde. Volume 2. Brasília: CMB, p. 34-54, jan./jul. 2012.
} 
celebrados com a iniciativa privada, desde que o Estado não possa, diretamente, atender as demandas para a promoção, a proteção e a recuperação da saúde, nos moldes em que prevê o ordenamento jurídico.

De outro lado, a atuação da iniciativa privada fora do Sistema Único de Saúde (atuação suplementar) está submetida ao regime jurídico de Direito Privado, cabendo ao Estado, nos termos do artigo 174 da Constituição Federal ${ }^{434}$, as funções de fiscalização, incentivo e planejamento, como "agente normativo e regulador da atividade econômica". Os entes privados podem prestar assistência à saúde nos distintos níveis de complexidade. Cumpre observar que qualquer atividade de saúde, nos termos do artigo 197 da Constituição Federal, possui relevância pública, devendo sujeitar-se ao controle do Poder Público. Neste sentido, a Lei $\mathrm{n}^{\circ}$ 9.656, de 3 de junho de 1998, regula a atuação dos planos privados de assistência à saúde ${ }^{435}$, colocando-os sob a supervisão e controle da Agência Nacional de Saúde Suplementar (ANS).

A regulação $0^{436}$ assumiu um forte impacto sobre serviços públicos e atividades econômicas, dada a impossibilidade de o Estado satisfazer a todas as necessidades públicas, cabendo-lhe o estabelecimento de regras de conduta para disciplinar a atuação dos particulares e o controle sobre o atendimento dessas necessidades pelos agentes privados.

\footnotetext{
${ }^{434} \mathrm{O}$ artigo 174 assim prescreve: "Art. 174. Como agente normativo e regulador da atividade econômica, o Estado exercerá, na forma da lei, as funções de fiscalização, incentivo e planejamento, sendo este determinante para o setor público e indicativo para o setor privado."

${ }^{435}$ A Lei n. 9.656/98, com a redação atribuída pela Medida Provisória n. 2.177-44, de 2001, prevê em seu artigo $1^{\circ}$ o conjunto de pessoas jurídicas submetidas a esta lei, apresenta os conceitos de "plano privado de assistência à saúde", "operadora de plano de assistência à saúde" e "carteira" e, ainda, determina, em seu parágrafo $1^{\circ}$, os planos, serviços e contratos sujeitos à regulação da Agência Nacional de Saúde Suplementar - ANS, assim como, em seu parágrafo $2^{\circ}$, as cooperativas, entidades e empresas que também se sujeitam às normas e à fiscalização da sobredita autarquia.

${ }^{436}$ MENEZES DE ALMEIDA desenvolve a questão do conteúdo contemporâneo da regulação, como atividade da Administração, com fundamento no disposto nos artigos 21, XI, 174 e 177, §2 $2^{\circ}$, III, todos da Constituição Federal e na análise das leis de criação das agências reguladoras. Segundo MENEZES DE ALMEIDA, "[a regulação] importa, seja pela edição de normas, seja de atos de mera execução, as funções de (i) planejamento; (ii) incentivo (fomento); e (iii) fiscalização (controle). Caso a regulação envolva exercício de poder normativo, tal poder há de se resumir a: (i) edição de normas para tratar de assuntos interna corporis do órgão regulador; (ii) edição de normas para explicitar conceitos e definir parâmetros técnicos aplicáveis à matéria regulada; e (iii) edição de normas infralegais e, nos casos em que couber regulamento, infra-regulamentares, concretizando, assim, a previsão de normas superiores.” MENEZES DE ALMEIDA, Fernando Dias. Considerações sobre a "Regulação" no Direito Positivo Brasileiro. In: Revista de Direito Público da Economia (RDPE). Belo Horizonte, ano 3, n. 12, edição digital, outubro/dezembro 2005.
} 
No que concerne à atividade econômica em sentido estrito de prestação de assistência suplementar à saúde, cabe à Agência Nacional de Saúde Suplementar (ANS) ${ }^{437}$ a promoção e a defesa do interesse público relativos ao desenvolvimento de ações de saúde no País. ${ }^{438}$ Dentre o extenso rol de funções atribuídas à Agência Nacional de Saúde Suplementar (ANS) na Lei n. 9.961, de 28 de janeiro de 2000, encontram-se: estabelecer critérios para aferição e controle da qualidade dos serviços oferecidos pelas operadoras de planos privados de assistência à saúde; estabelecer normas e procedimentos para concessão, manutenção e cancelamento de registro dos produtos das operadoras de planos privados de assistência à saúde; autorizar o registro e o funcionamento das operadoras de planos privados de assistência à saúde; fiscalizar as atividades das operadoras de planos privados de assistência à saúde e o zelo pelo cumprimento das normas atinentes ao seu funcionamento; controlar a avaliação dos aspectos concernentes à garantia de acesso, manutenção e qualidade dos serviços prestados, direta ou indiretamente, pelas operadoras de planos privados de assistência à saúde; e aplicar as penalidades pelo descumprimento da Lei $\mathrm{n}^{0}$ 9.656, de 1998 (dispõe sobre planos e seguros privados de assistência à saúde), e de sua regulamentação. ${ }^{439} 440$

${ }^{437}$ Nos termos do artigo $1^{\circ}$, caput, da Lei n. 9.961, de 28 de janeiro de 2000: "Art. $1^{\circ}$ É criada a Agência Nacional de Saúde Suplementar - ANS, autarquia sob o regime especial, vinculada ao Ministério da Saúde, com sede e foro na cidade do Rio de Janeiro - RJ, prazo de duração indeterminado e atuação em todo o território nacional, como órgão de regulação, normatização, controle e fiscalização das atividades que garantam a assistência suplementar à saúde".

$438 \mathrm{O}$ artigo $3^{\circ}$, caput, da Lei n. 9.961, de 28 de janeiro de 2000 assim estabelece: "Art. $3^{\circ}$ A ANS terá por finalidade institucional promover a defesa do interesse público na assistência suplementar à saúde, regulando as operadoras setoriais, inclusive quanto às suas relações com prestadores e consumidores, contribuindo para o desenvolvimento das ações de saúde no País."

${ }^{439}$ Assim dispõe o artigo $4^{\circ}$, da Lei n. 9.961/2000: “Art. $4^{\circ}$ Compete à ANS: (...) XV - estabelecer critérios de aferição e controle da qualidade dos serviços oferecidos pelas operadoras de planos privados de assistência à saúde, sejam eles próprios, referenciados, contratados ou conveniados; XVI - estabelecer normas, rotinas e procedimentos para concessão, manutenção e cancelamento de registro dos produtos das operadoras de planos privados de assistência à saúde; (...) XXII - autorizar o registro e o funcionamento das operadoras de planos privados de assistência à saúde, bem assim sua cisão, fusão, incorporação, alteração ou transferência do controle societário, sem prejuízo do disposto na Lei no 8.884, de 11 de junho de 1994; (Redação dada pela Medida Provisória n $\mathrm{n}^{\circ}$ 2.177-44, de 2001); XXIII - fiscalizar as atividades das operadoras de planos privados de assistência à saúde e zelar pelo cumprimento das normas atinentes ao seu funcionamento; XXIV - exercer o controle e a avaliação dos aspectos concernentes à garantia de acesso, manutenção e qualidade dos serviços prestados, direta ou indiretamente, pelas operadoras de planos privados de assistência à saúde; (...) e XXX aplicar as penalidades pelo descumprimento da Lei no 9.656, de 1998, e de sua regulamentação;"

${ }^{440}$ A Agência Nacional de Saúde Suplementar (ANS), com fundamento nessas competências, divulgou em 13/11/2013 o $7^{\circ}$ ciclo de monitoramento da garantia de atendimento dos planos de saúde, resultado do descumprimento de prazos e das negativas indevidas de cobertura assistencial, determinando a suspensão da comercialização de 150 (cento e cinquenta) planos de 41 (quarenta e uma) operadoras de planos de assistência à saúde, por duas razões: descumprimento dos prazos máximos de atendimento para marcação de consultas, exames e cirurgias e negativas indevidas de cobertura. Segundo a ANS, a medida é preventiva e visa melhorar o acesso dos consumidores aos serviços contratados. O Grupo Técnico do Monitoramento da 
Por fim, é preciso consignar que o parágrafo $3^{\circ}$, do artigo 199 , proíbe a participação direta ou indireta de empresas ou capitais estrangeiros na assistência à saúde no país, exceto nos casos previstos em lei. ${ }^{441}$ No entanto, a Lei n. 9.656, de 3 de junho de 1998, em seu artigo $1^{\circ}$, parágrafo $3^{\circ}$, admite que pessoas físicas ou jurídicas residentes ou domiciliadas no exterior constituam ou participem do capital de pessoas jurídicas de direito privado sob regência das leis brasileiras para operar planos provados de assistência à saúde. ${ }^{442}$

O artigo 200 da Constituição Federal ${ }^{443}$ é dedicado à previsão de uma série de atribuições do Sistema Único de Saúde, em seus aspectos essenciais, explicitando bens a serem tutelados e ações a serem desenvolvidas (vigilância sanitária e epidemiológica, proteção da saúde do trabalhador, fiscalização e controle de alimentos e atividades que envolvam substâncias e produtos psicoativos, tóxicos ou radioativos), admitindo que outras possam ser explicitadas em lei. Este dispositivo constitucional também expressa algumas conexões entre o direito à saúde e outros direitos fundamentais, como a educação (inciso III), o saneamento básico (inciso IV), o desenvolvimento científico e tecnológico (inciso V), a alimentação (inciso VI) e o meio ambiente (inciso VIII).

A análise integrada das atribuições do Sistema Único de Saúde (SUS) definidas pela Constituição Federal, de forma expressa, no artigo 200, de cumprimento obrigatório pelo Poder Público, permite verificar de plano quão amplo é o alcance do direito

Garantia de Atendimento é formado por técnicos da ANS, representantes das operadoras de planos de saúde, consumidores, membros do Ministério Público e da Defensoria Pública. Os resultados deste ciclo de monitoramento da garantia de atendimento dos planos de saúde foram publicados no site oficial da Agência Nacional de Saúde Suplementar (ANS). Disponível em: <http://www.ans.gov.br>. Consulta em: 15/11/2013. 441 “Art. 199. A assistência à saúde é livre à iniciativa privada. (...) $§ 3^{\circ}$ - É vedada a participação direta ou indireta de empresas ou capitais estrangeiros na assistência à saúde no País, salvo nos casos previstos em lei.

442 “Art. $1^{\circ}$ Submetem-se às disposições desta Lei as pessoas jurídicas de direito privado que operam planos de assistência à saúde, sem prejuízo do cumprimento da legislação específica que rege a sua atividade, adotando-se, para fins de aplicação das normas aqui estabelecidas, as seguintes definições: (...) $\S 3^{\circ}$ As pessoas físicas ou jurídicas residentes ou domiciliadas no exterior podem constituir ou participar do capital, ou do aumento do capital, de pessoas jurídicas de direito privado constituídas sob as leis brasileiras para operar planos privados de assistência à saúde."

443 “Art. 200. Ao sistema único de saúde compete, além de outras atribuições, nos termos da lei: I - controlar e fiscalizar procedimentos, produtos e substâncias de interesse para a saúde e participar da produção de medicamentos, equipamentos, imunobiológicos, hemoderivados e outros insumos; II - executar as ações de vigilância sanitária e epidemiológica, bem como as de saúde do trabalhador; III - ordenar a formação de recursos humanos na área de saúde; IV - participar da formulação da política e da execução das ações de saneamento básico; V - incrementar em sua área de atuação o desenvolvimento científico e tecnológico; VI fiscalizar e inspecionar alimentos, compreendido o controle de seu teor nutricional, bem como bebidas e águas para consumo humano; VII - participar do controle e fiscalização da produção, transporte, guarda e utilização de substâncias e produtos psicoativos, tóxicos e radioativos; VIII- colaborar na proteção do meio ambiente, nele compreendido o do trabalho." 
fundamental à saúde. Os artigos $5^{\circ 444}$ e $6^{\text {o445 }}$ da Lei n. 8.080/90 caracterizam de forma mais precisa os objetivos do Sistema Único de Saúde e as tarefas abrangidas em seu campo de atuação, respectivamente. Tais temas serão desenvolvidos no próximo capítulo do trabalho.

\subsection{Competências constitucionais em matéria de saúde}

O sistema de repartição de competências ${ }^{446}$ é questão nuclear no Estado Federal para o exercício e o desenvolvimento de atividades normativas pelas unidades federadas e para a manutenção de um relacionamento harmônico entre União e Estados-membros. De acordo com ALMEIDA, além de fator de eficiência de governo, o federalismo consiste em instrumento de limitação do poder. ${ }^{447}$

A Constituição Federal de 1988 inovou o modelo de repartição de competências em relação ao direito anterior, estabelecendo um sistema complexo no qual coexistem competências privativas, repartidas horizontalmente, com competências concorrentes,

\footnotetext{
${ }^{444}$ Nos termos do artigo $5^{\circ}$, da Lei n. 8.80/90: “Art. $5^{\circ}$ São objetivos do Sistema Único de Saúde SUS: I - a identificação e divulgação dos fatores condicionantes e determinantes da saúde; II - a formulação de política de saúde destinada a promover, nos campos econômico e social, a observância do disposto no $§ 1^{\circ}$ do art. $2^{\circ}$ desta lei; III - a assistência às pessoas por intermédio de ações de promoção, proteção e recuperação da saúde, com a realização integrada das ações assistenciais e das atividades preventivas."

${ }^{445} \mathrm{O}$ artigo $6^{\circ}$, incisos I a XI, da Lei n. 8.080/90 assim dispõe: "Art. $6^{\circ}$ Estão incluídas ainda no campo de atuação do Sistema Único de Saúde (SUS): I - a execução de ações: a) de vigilância sanitária; b) de vigilância epidemiológica; c) de saúde do trabalhador; e d) de assistência terapêutica integral, inclusive farmacêutica; II - a participação na formulação da política e na execução de ações de saneamento básico; III - a ordenação da formação de recursos humanos na área de saúde; IV - a vigilância nutricional e a orientação alimentar; V - a colaboração na proteção do meio ambiente, nele compreendido o do trabalho; VI - a formulação da política de medicamentos, equipamentos, imunobiológicos e outros insumos de interesse para a saúde e a participação na sua produção; VII - o controle e a fiscalização de serviços, produtos e substâncias de interesse para a saúde; VIII - a fiscalização e a inspeção de alimentos, água e bebidas para consumo humano; IX - a participação no controle e na fiscalização da produção, transporte, guarda e utilização de substâncias e produtos psicoativos, tóxicos e radioativos; X - o incremento, em sua área de atuação, do desenvolvimento científico e tecnológico; XI - a formulação e execução da política de sangue e seus derivados.”

${ }^{446}$ Sobre competências na Constituição de 1988, conferir: ALMEIDA, Fernanda Dias Menezes de. Competências na Constituição de 1988. 3.ed. São Paulo: Atlas, 2005.

${ }^{447}$ ALMEIDA esclarece que a Federação brasileira teve início com a República e é fruto de processo de descentralização política do Estado unitário que era o Brasil ao tempo do Império. A evolução do sistema federativo no Brasil, marcada pela tendência centralizadora de poder político e financeiro no governo central, em detrimento de Estados e Municípios, colocou ao Constituinte de 1988 a tarefa de reverter este movimento e idealizar um sistema no qual o relacionamento entre as entidades federadas fosse mais equilibrado. A recomposição do equilíbrio perdido permitiria o atendimento das finalidades precípuas do federalismo: a garantia de liberdade e de eficiência. Mais modernamente, conforme ALMEIDA, ao federalismo também caberia assegurar a democracia participativa, na medida em que a multiplicação de círculos de decisões políticas permitiria uma maior proximidade entre o cidadão e o poder. Além disso, o federalismo teria aptidão para que os Estados desenvolvessem novas ideias sociais, econômicas e políticas. ALMEIDA, Fernanda Dias Menezes de. Competências na Constituição de 1988. 3.ed. São Paulo: Atlas, 2005, p.24-30 e 41-46.
} 
repartidas verticalmente, abrindo espaços para a participação das ordens parciais no âmbito de competências privativas da ordem central, mediante delegação, como alternativa para alcançar a descentralização almejada. ${ }^{448}$

O objetivo de maior descentralização de competências transpareceu anteriormente na $8^{\text {a }}$ Conferência Nacional de Saúde ${ }^{449}$, realizada em 1986, que marcou o momento no qual as mudanças ganharam contornos claros, ampliando o espectro de atores envolvidos e explicitando as diretrizes para a reorganização do Sistema Nacional de Saúde. ${ }^{450}$ Dentre as proposições apresentadas nesta conferência estava incluída a definição de responsabilidades das unidades federadas na gestão do sistema de saúde, que deveria estar fundamentada no caráter federativo da República, a fim de romper a centralização que havia esvaziado o poder e as funções próprias dos Estados, Distrito Federal e Municípios. ${ }^{451}$

À luz das proposições apresentadas pela $8^{\text {a }}$ Conferência Nacional de Saúde e do trabalho da Comissão Nacional da Reforma Sanitária, a Constituição Federal de 1988, no campo da competência material em saúde, estabeleceu expressamente, em seu artigo $23^{452}$, que "cuidar da saúde e assistência pública, da proteção e garantia das pessoas portadoras de deficiência" se trata de assunto de competência comum, guiado pelo ideal de cooperação entre todos os entes federativos. ${ }^{453}$

${ }^{448}$ ALMEIDA, Fernanda Dias Menezes de. Competências na Constituição de 1988. 3.ed. São Paulo: Atlas, 2005, p.13-14.

${ }^{449}$ A $8^{\text {a }}$ Conferência Nacional de Saúde, convocada pelo ministro Carlos Santanna, por meio do Decreto $\mathrm{n}$. 91.466, de 23 de julho de 1985, e realizada sob a gestão de Roberto Figueira Santos, teve sua Comissão organizadora presidida por Sérgio Arouca, um dos líderes do Movimento da Reforma Sanitária. Os temas dessa conferência foram: (i) saúde como direito; (ii) reformulação do Sistema Nacional de Saúde; e (iii) financiamento do setor. BRASIL. Conselho Nacional de Secretários de Saúde. As Conferências Nacionais de Saúde: Evolução e perspectivas. Brasília: CONASS, 2009, p.16-17.

${ }^{450}$ BRASIL. Conselho Nacional de Secretários de Saúde. As Conferências Nacionais de Saúde: Evolução e perspectivas. Brasília: CONASS, 2009, p.16.

${ }^{451}$ BRASIL. Conselho Nacional de Secretários de Saúde. As Conferências Nacionais de Saúde: Evolução e perspectivas. Brasília: CONASS, 2009, p.18

452 "Art. 23. É competência comum da União, dos Estados, do Distrito Federal e dos Municípios: (...) II cuidar da saúde e assistência pública, da proteção e garantia das pessoas portadoras de deficiência;"

${ }^{453}$ ALMEIDA afirma que a exploração das potencialidades das competências concorrentes buscada pelo constituinte representa alternativa válida para se atingir uma descentralização maior, reclamada pelo federalismo brasileiro, sem prejuízo da direção uniforme a que devam ser submetidas determinadas matérias. Também esclarece que a integração de ordens parciais na implementação de políticas gerais, mediante o exercício de competências legislativas e de execução comuns, gera a possibilidade de participação das unidades federativas apta a vivificar a diversidade própria do modelo federal de Estado. Assim, embora ainda persista uma acentuada concentração de poderes na União, conclui que houve progresso na Constituição de 1988 em relação à partilha de competências. ALMEIDA, Fernanda Dias Menezes de. Competências na Constituição de 1988. 3.ed. São Paulo: Atlas, 2005, p.161-162. 
Cabe observar que em relação aos Municípios, como integrantes da Federação ${ }^{454}$, a Constituição Federal de 1988 conferiu-lhes capacidade de auto-organização, tornando completa a autonomia municipal. O constituinte englobou num mesmo artigo as competências legislativas e materiais, privativas e concorrentes dos Municípios.

No tocante às competências materiais privativas dos Municípios, a Constituição Federal de 1988 não se limitou a estabelecer a área das competências circunscrita à categoria genérica dos assuntos concernentes ao interesse local do Município, mantida pelo artigo 30, inciso I, da Constituição Federal, tendo acrescentado outras competências materiais privativas expressamente enumeradas. ${ }^{455}$ Contudo, conforme observa ALMEIDA $^{456}$, a competência prevista no inciso VII, relativa à prestação de serviços de atendimento à saúde da população, não é exclusiva do Município, inscrevendo-se na área das competências materiais comuns, conforme expressamente incluído no elenco do artigo 23 da Constituição Federal.

Por sua vez, quanto à possibilidade de legislar em matéria de saúde, a Constituição Federal de 1988 repetiu a norma contida na Constituição de $1967^{457}$ e estabeleceu hipótese de competência legislativa concorrente primária ${ }^{458}$. Nos termos do artigo 24, inciso XII e

454 Os artigos $1^{\circ}$, caput, e 18, caput, da Constituição Federal estabelecem, respectivamente: “Art. $1^{\circ}$ A República Federativa do Brasil, formada pela união indissolúvel dos Estados e Municípios e do Distrito Federal, constitui-se em Estado Democrático de Direito e tem como fundamentos: (...)" “Art. 18. A organização político-administrativa da República Federativa do Brasil compreende a União, os Estados, o Distrito Federal e os Municípios, todos autônomos, nos termos desta Constituição."

455 “Art. 30. Compete aos Municípios: I - legislar sobre assuntos de interesse local; II - suplementar a legislação federal e a estadual no que couber; III - instituir e arrecadar os tributos de sua competência, bem como aplicar suas rendas, sem prejuízo da obrigatoriedade de prestar contas e publicar balancetes nos prazos fixados em lei; IV - criar, organizar e suprimir distritos, observada a legislação estadual; V - organizar e prestar, diretamente ou sob regime de concessão ou permissão, os serviços públicos de interesse local, incluído o de transporte coletivo, que tem caráter essencial; VI - manter, com a cooperação técnica e financeira da União e do Estado, programas de educação infantil e de ensino fundamental; VII - prestar, com a cooperação técnica e financeira da União e do Estado, serviços de atendimento à saúde da população; VIII promover, no que couber, adequado ordenamento territorial, mediante planejamento e controle do uso, do parcelamento e da ocupação do solo urbano; IX - promover a proteção do patrimônio histórico-cultural local, observada a legislação e a ação fiscalizadora federal e estadual. VII - prestar, com a cooperação técnica e financeira da União e do Estado, serviços de atendimento à saúde da população;"

${ }^{456}$ Conforme ALMEIDA, além da matéria prevista no artigo 30, inciso VII, as competências estabelecidas nos incisos VI e no inciso IX desse artigo também não são exclusivas dos Municípios, inserindo-se na área das competências materiais comuns. ALMEIDA, Fernanda Dias Menezes de. Competências na Constituição de 1988. 3.ed. São Paulo: Atlas, 2005, p.112-117.

${ }^{457}$ Conferir: capítulo 1.2. Direito à saúde antes da Constituição Federal de 1988.

458 Conforme classificação apresentada por ALMEIDA, na Constituição Federal de 1988 é possível identificar competências legislativas concorrentes denominadas primárias, por encontrarem abrigo no próprio texto constitucional, e competências legislativas secundárias, não previstas expressamente na Constituição, porém decorrentes da necessidade de que atuem competências materiais comuns. ALMEIDA, Fernanda Dias Menezes de. Competências na Constituição de 1988. 3.ed. São Paulo: Atlas, 2005, p.140. 
parágrafo $1^{\text {o459}}$, da Constituição Federal de 1988, compete à União legislar concorrentemente ${ }^{460}$ sobre "proteção e defesa da saúde", restringindo-se, na espécie, à edição de normas gerais, fixando diretrizes e princípios que serão obrigatórios para a União, os Estados, o Distrito Federal e os Municípios. ${ }^{461} 462$

Aos Estados e ao Distrito Federal ${ }^{463} 464$ caberá desenvolver uma legislação específica sobre a temática de "promoção e defesa da saúde", no exercício da competência

459 “Art. 24. Compete à União, aos Estados e ao Distrito Federal legislar concorrentemente sobre: (...) XII previdência social, proteção e defesa da saúde; (...) $\S 1^{\circ}$ - No âmbito da legislação concorrente, a competência da União limitar-se-á a estabelecer normas gerais."

460 SILVA afirma que a noção de competência legislativa concorrente compreende dois elementos: possibilidade de disposição sobre o mesmo assunto por mais de uma entidade federativa, isto é, de participação de mais de uma entidade na esfera da normatividade; e primazia da União no que tange ao estabelecimento de normas gerais. A competência suplementar apresenta correlação com a competência concorrente, e "significa o poder de formular normas que desdobrem o conteúdo de princípios ou normas gerais ou que supram a ausência ou omissão destas (art. 24, §§ $1^{\circ}$ a $4^{\circ}$ )" SILVA, José Afonso da. Curso de Direito Constitucional Positivo. 16 ed. São Paulo: Malheiros, 1998, p.481.

${ }^{461}$ Como é próprio de quaisquer leis serem gerais, MELLO afirma que quando o texto constitucional reportase a "normas gerais", está, por certo, referindo-se a normas cujo nível de generalidade é peculiar em relação às demais leis. MELLO oferece o seguinte conceito: "[normas gerais são aquelas que] veiculam apenas: a) preceitos que estabelecem os princípios, os fundamentos, as diretrizes, os critérios básicos, conformadores das leis que necessariamente terão de sucedê-las para completar a regência da matéria. Isto é: daquel'outras que produzirão a ulterior disciplina específica e suficiente, ou seja, indispensável, para regular o assunto que foi objeto de normas apenas 'gerais'; (...) b) preceitos que podem ser aplicados uniformemente em todo o País, por se adscreverem a aspectos nacionalmente indiferençados, de tal sorte que repercutem com neutralidade, indiferentemente, em quaisquer de suas regiões ou localidades." MELLO, Celso Antônio Bandeira de. Curso de Direito Administrativo. 20.ed. São Paulo: Malheiros. 2006, p. 499-500.

462 ALMEIDA afirma ser inevitável certa dose de subjetivismo na identificação das normas gerais, visto que é um campo restrito, de demarcação conceitual complexa, decorrendo disto a conhecida dificuldade de se conter a União nos limites que lhe são impostos pela repartição vertical de competências. Daí sobressair, na espécie, o papel do Judiciário de dirimir eventuais conflitos de competência com os demais entes federativos. Contudo, ALMEIDA registra que o maior avanço da Constituição Federal de 1988 foi no campo das competências legislativas concorrentes, em termos de participação das ordens periféricas, cabendo à União a fixação dos contornos gerais, princípios e diretrizes da ação legiferante. Indica que o constituinte se preocupou com o federalismo como fator de eficiência da ação governamental, optando por maior descentralização de competências materiais, detalhadamente discriminadas, mantendo-se a atuação concorrente sob o comando legislativo da União, sem cercear, contudo, a legislação específica que as unidades federadas editarão para atender a suas peculiaridades. Do mesmo modo, o esquema de repartição de competências adotado demonstra preocupação com a "gestão eficiente dos negócios públicos", decorrente da ênfase dada pelo constituinte ao planejamento, previsto como determinante e obrigatório para o setor público. ALMEIDA, Fernanda Dias Menezes de. Competências na Constituição de 1988. 3.ed. São Paulo: Atlas, 2005. p.138-165.

463 O Distrito Federal também é titular da competência suplementar (ou complementar) atribuída aos Estados prevista no artigo 24 , parágrafo $2^{\circ}$ e da competência supletiva prevista no artigo 24 , parágrafo $3^{\circ}$, ambos da Constituição Federal. ALMEIDA, Fernanda Dias Menezes de. Competências na Constituição de 1988. 3.ed. São Paulo: Atlas, 2005, p.152.

${ }^{464}$ Apesar do caput do artigo 24 da Constituição Federal não mencionar expressamente os Municípios, isto não significa que estejam excluídos da partilha constitucional de competências. Com efeito, o artigo 30, II, da Constituição Federal prevê hipótese de competência legislativa concorrente primária, porque prevista diretamente na Constituição. Por força dessa norma, "compete aos Municípios: (...) II - suplementar a legislação federal e a estadual no que couber". Assim, adotando a posição de ALMEIDA, em se tratando de assuntos que digam respeito ao interesse local, o Município poderá suplementar a legislação federal ou a legislação estadual para atuar competências materiais privativas do Município ou para atuar competências 
suplementar ${ }^{465}$. Cada um dos Estados e o Distrito Federal poderão detalhar as normas gerais da União para melhor equacionar problemas sociais graves ${ }^{466}$, conforme suas especificidades nesta seara e que, por isso mesmo, comportam um tratamento diferenciado em relação aos demais Estados. Na ausência de normas gerais editadas pela União, os Estados e o Distrito Federal exercerão a competência legislativa plena, para que cada um atenda às respectivas necessidades ${ }^{467}$, não podendo nenhum deles legislar para os demais. ${ }^{468}$

A superveniência de normas gerais editadas pela titular primeira da competência, suspende a eficácia da legislação estadual, no que lhe for contrária ${ }^{469}$, na forma estabelecida pelo parágrafo $4^{\circ}$ do artigo 24 da Constituição Federal. ${ }^{470}$ Como a norma estabelece a perda da eficácia do diploma estadual conflitante à lei federal superveniente que venha a estabelecer normas gerais, caso a legislação federal seja revogada, a lei estadual recupera sua eficácia e passa a incidir novamente.

No artigo 30, incisos I e II ${ }^{471}$, o constituinte estabeleceu a competência legislativa privativa que o Município exercerá em relação aos assuntos de seu interesse peculiar, e a competência legislativa concorrente, cabendo-lhe suplementar a legislação federal e estadual, no que couber. No exercício da competência legislativa suplementar, os Municípios poderão preencher eventuais lacunas normativas necessárias para atender as

materiais comuns. ALMEIDA, Fernanda Dias Menezes de. Competências na Constituição de 1988, 3.ed. São Paulo: Atlas, 2005, p.156-159.

465 “Art. 24. Compete à União, aos Estados e ao Distrito Federal legislar concorrentemente sobre: (...) § $2^{\circ}$ A competência da União para legislar sobre normas gerais não exclui a competência suplementar dos Estados.”

466 ALMEIDA, Fernanda Dias Menezes de. Competências na Constituição de 1988. 3.ed. São Paulo: Atlas, 2005, p. 144.

467 “Art. 24. Compete à União, aos Estados e ao Distrito Federal legislar concorrentemente sobre: (...) $§ 3^{\circ}$ Inexistindo lei federal sobre normas gerais, os Estados exercerão a competência legislativa plena, para atender a suas peculiaridades."

468 A competência prevista no artigo 24, parágrafo $3^{\circ}$, da Constituição Federal é supletiva, ou seja, na hipótese de ausência de normas gerais da União, Estados e Distrito Federal irão suprir a falta, legislando para atender a suas peculiaridades. ALMEIDA, Fernanda Dias Menezes de. Competências na Constituição de 1988. 3.ed. São Paulo: Atlas, 2005, p.151-155.

469 Como explica ALMEIDA, no momento em que a União decide exercer sua competência primária de editar normas gerais, prevalecerá o direito federal, com a consequência lógica de suspensão da eficácia da legislação estadual que com ele conflitar, tanto legislação que estabelecer normas gerais, como a que fixar normas de complementação. ALMEIDA, Fernanda Dias Menezes de. Competências na Constituição de 1988. 3.ed. São Paulo: Atlas, 2005, p.156.

470 “Art. 24. Compete à União, aos Estados e ao Distrito Federal legislar concorrentemente sobre: (...) § $4^{\circ}$ A superveniência de lei federal sobre normas gerais suspende a eficácia da lei estadual, no que lhe for contrário."

${ }^{471} \mathrm{O}$ artigo 30, caput, e incisos I e II da Constituição Federal, prescreve: “Art. 30. Compete aos Municípios: I - legislar sobre assuntos de interesse local; II - suplementar a legislação federal e a estadual no que couber;” 
peculiaridades locais, respeitando as normas gerais estabelecidas pela União e as normas editadas pelos Estados que integrem. ${ }^{472}$

A competência legislativa concorrente estabelece, segundo AITH, um consórcio legislativo que, ao mesmo tempo, uniformiza a legislação brasileira sobre saúde, por meio da edição de normas gerais pela União, e possibilita a existência de diversas normas jurídicas complementares às da União nos entes federativos (Estados e Municípios), organizando a gestão de seus respectivos sistemas de saúde (estaduais e municipais) a partir dos modelos permitidos pelas normas gerais federais. ${ }^{473}$

\subsection{A multifuncionalidade do direito à saúde}

A Constituição Federal de 1988 reconheceu expressamente a saúde como direito fundamental social ${ }^{474}$, qualificando como interesse público a proteção, a promoção e a defesa da saúde. Além disso, determinou ao Estado o dever de tutelar a saúde por meio de ações e serviços considerados de relevância pública. ${ }^{475}$ Neste item do trabalho buscar-se-á esclarecer quais as consequências jurídicas que decorrem da afirmação deste direito fundamental, delimitando, assim, o conteúdo do direito à saúde. Em outras palavras, procurar-se-á investigar as diferentes funções que, conforme a situação concreta analisada, podem estar vinculadas ao direito à saúde.

472 Conforme observa ALMEIDA, a competência conferida aos Estados para complementarem as normas gerais da União, não exclui a competência do Município de fazê-lo também, modelando-as de forma adequada às particularidades locais, sem contrariar as normas gerais da União e as normas estaduais de complementação. Da mesma forma, se inexistirem normas gerais da União, a possibilidade de suprir a lacuna editando normas gerais para atender às suas peculiaridades se abre tanto para os Estados quanto para os Municípios. Se houver normas gerais expedidas pelo Estado, o Município haverá de respeitá-las, podendo ainda complementá-las. Caso não haja normas estaduais supletivas, o Município é livre para estabelecer as normas que entenda necessárias para o exercício da competência comum. Porém, a superveniência de normas gerais editadas pela União diretamente, ou pelos Estados supletivamente, irá acarretar a suspensão da eficácia das normas municipais colidentes. ALMEIDA, Fernanda Dias Menezes de. Competências na Constituição de 1988. 3.ed. São Paulo: Atlas, 2005, p.158-159.

473 AITH, Fernando. A saúde como direito de todos e dever do Estado: o papel dos Poderes Executivo, Legislativo e Judiciário na efetivação do direito à saúde no Brasil. In: Direito Sanitário: Saúde e Direito, um Diálogo Possível. AITH, Fernando; SATURNINO, Luciana Tarbes Mattana; DINIZ, Maria Gabriela Araújo; MONTEIRO, Tammy Claret (organizadores). Belo Horizonte: ESP-MG, 2012, p. 85.

474 “Art. $6^{\circ}$ São direitos sociais a educação, a saúde, a alimentação, o trabalho, a moradia, o lazer, a segurança, a previdência social, a proteção à maternidade e à infância, a assistência aos desamparados, na forma desta Constituição”. (Redação dada pela Emenda Constitucional no 64, de 2010)

475 O artigo 197 da Constituição Federal prevê: "Art. 197. São de relevância pública as ações e serviços de saúde, cabendo ao Poder Público dispor, nos termos da lei, sobre sua regulamentação, fiscalização e controle, devendo sua execução ser feita diretamente ou através de terceiros e, também, por pessoa física ou jurídica de direito privado". 
A origem remota e precursora do fenômeno da multifuncionalidade dos direitos fundamentais é atribuída ao publicista alemão JELLINEK ${ }^{476}$, que elaborou uma teoria no final do século XIX, portanto, fortemente influenciada pelos elementos do liberalismo, acerca das quatro grandes categorias de posições jurídicas (status) que se estabeleciam entre os indivíduos e o Estado: negativa, positiva e ativa. De acordo com JELLINEK ${ }^{477}$, a posição negativa se refere ao círculo de atividades individuais que está livre das ordens estatais, pois a subordinação do indivíduo ao Estado é juridicamente limitada ${ }^{478}$; a posição positiva está relacionada à possibilidade do indivíduo utilizar as instituições e de exigir a realização de ações concretas do Estado, como reflexo e compensação por sua sujeição às normas impostas pelo Estado ${ }^{479}$. A posição ativa se refere ao indivíduo como titular de competências que lhe asseguram a possibilidade de participação ativa na formação da vontade estatal como, por exemplo, pelo voto na formação da vontade de um órgão permanente do Estado. Por fim, JELLINEK afirma que os indivíduos enquanto membros componentes do povo e objeto da soberania do Estado ocupariam uma posição passiva, pois seriam meramente detentores de deveres. Assim, cita como exemplo, o dever de prestar o serviço militar, o dever de ser jurado em eleições e o dever de aceitar cargos permanentes honoríficos. ${ }^{480}$

Embora a teoria analítica dos status de JELLINEK possa ser objeto de crítica ${ }^{481}$, o reconhecimento da multifuncionalidade dos direitos fundamentais tem grande importância e utilidade. Numa visão contextualizada e adequada à ordem jurídico-constitucional brasileira, esta teoria serviu de base para a elaboração de uma classificação funcional dos direitos fundamentais, apresentada por SARLET, que os separa em dois grandes grupos: (i) direitos fundamentais como direitos de defesa (direitos a não intervenção por parte do

\footnotetext{
${ }^{476}$ Ingo Wolfgang; MARINONI, Guilherme; MITIDIERO, Daniel. Curso de Direito Constitucional. 2. ed. São Paulo: Editora Revista dos Tribunais, 2013, p.311-312.

477 JELLINEK, Georg. Teoría General del Estado. Fondo de Cultura Económica. Trad. y prólogo de Fernando de los Ríos. México: FCE, 2000, p. 388-394.

${ }^{478}$ Para JELLINEK, tal categoria abrange as liberdades (de crença, de manifestação do pensamento, de reunião, de imprensa), o direito à vida, o direito à propriedade e o direito à igualdade formal. JELLINEK, Georg. Teoría General del Estado. Fondo de Cultura Económica. Trad. y prólogo de Fernando de los Ríos. México: FCE, 2000, p. 388-389.

479 Segundo JELLINEK, podem ser consideradas liberdades positivas os direitos à educação, à saúde, à assistência social, ao trabalho, dentre outros para o exercício dos quais seja necessária a atuação estatal. JELLINEK, Georg. Teoría General del Estado. Fondo de Cultura Económica. Trad. y prólogo de Fernando de los Ríos. México: FCE, 2000, p. 388-389.

480 JELLINEK, Georg. Teoría General del Estado. Fondo de Cultura Económica. Trad. y prólogo de Fernando de los Ríos. México: FCE, 2000, p. 392-394.

481 ALEXY, Robert. Teoria dos Direitos Fundamentais. Tradução de Virgílio Afonso da Silva. 2.ed. 2012. São Paulo: Malheiros, p.269-275.
} 
Estado e de outros particulares); e (ii) direitos fundamentais como direitos a prestações de natureza normativa (jurídica) e material (fática). ${ }^{482}$

Não se pode olvidar que a classificação proposta por SARLET rejeita qualquer compreensão dicotômica a respeito dos direitos fundamentais como direitos de defesa (negativos) e direitos a prestações (positivos), pois ambas se complementam e se reforçam mutuamente. O que há é um complexo de posições jurídico-subjetivas fundamentais que, no âmbito das múltiplas funções exercidas pelos direitos fundamentais, podem assumir tanto uma dimensão positiva quanto negativa. ${ }^{483}$

A teoria dos direitos fundamentais deve ser compreendida a partir de uma dogmática unitária e abrangente tanto dos direitos de liberdade (primeira dimensão) quanto dos direitos sociais (segunda dimensão), considerando as peculiaridades de cada um deles. Em consequência disso, a classificação metodológica habitualmente feita para diferenciar os direitos fundamentais, segmentados em dimensões, pode ser utilizada sem perder de vista que se refere tão-somente à função mais aparente e marcante desses direitos.

Assim, a despeito de os direitos sociais serem habitualmente referidos como direitos de conteúdo positivo, marcados por sua ligação ao princípio da igualdade na sua vertente substantiva, não é correta a afirmação de que as posições jurídicas decorrentes da positivação dos direitos sociais se limitam a gerar direitos a prestações (função positiva), o que pode ser evidenciado pela dimensão defensiva (função negativa) que possuem como, por exemplo, o direito de associação sindical e o direito de greve dos servidores públicos $^{484}$, o direito do trabalhador a férias. ${ }^{485}$ Assim, a despeito de os direitos sociais possuírem aspecto predominantemente prestacional (função positiva), também possuem aspecto defensivo (função negativa).

É preciso enfatizar que a concepção acerca das funções dos direitos sociais se modificou dialeticamente ao longo da história e somente pode ser compreendida diante de

482 SARLET, Ingo Wolfgang; MARINONI, Guilherme; MITIDIERO, Daniel. Curso de Direito Constitucional. 2. ed. São Paulo: Editora Revista dos Tribunais, 2013, p.312-313.

483 SARLET, Ingo Wolfgang; MARINONI, Guilherme; MITIDIERO, Daniel. Curso de Direito Constitucional. 2. ed. São Paulo: Editora Revista dos Tribunais, 2013, p.313.

484 “Art. 37. A administração pública direta e indireta de qualquer dos Poderes da União, dos Estados, do Distrito Federal e dos Municípios obedecerá aos princípios de legalidade, impessoalidade, moralidade, publicidade e eficiência e, também, ao seguinte: (...) VI - é garantido ao servidor público civil o direito à livre associação sindical; VII - o direito de greve será exercido nos termos e nos limites definidos em lei específica;"

485 "Art. $7^{\text {o }}$ São direitos dos trabalhadores urbanos e rurais, além de outros que visem à melhoria de sua condição social: (...) XVII - gozo de férias anuais remuneradas com, pelo menos, um terço a mais do que o salário normal;", 
uma situação específica. Portanto, a eficácia social do direito à saúde depende de um conjunto de circunstâncias fáticas, como o contexto econômico, social e tecnológico de uma determinada sociedade, num momento histórico.

De acordo com SARLET ${ }^{486}$, a evolução da teoria dos direitos fundamentais levou à construção da noção atual de que os direitos fundamentais desempenhariam um complexo de funções na ordem jurídico-constitucional, que podem ser consideradas tanto sob a perspectiva jurídico-subjetiva, que se refere aos direitos subjetivos atribuídos aos seus titulares, quanto sob a perspectiva jurídico-objetiva.

$\mathrm{Na}$ perspectiva jurídico-objetiva, os direitos fundamentais incorporam e expressam valores e princípios essenciais da comunidade, assegurados na Constituição e que se projetam sobre todo o ordenamento jurídico (eficácia irradiante), constituindo diretrizes que orientam a atuação dos poderes públicos. Por força disso, devem ter sua eficácia valorada não apenas sob o ponto de vista da pessoa individual e sua posição perante o Estado, mas também sob o ponto de vista da sociedade como um todo, já que consistem em escolhas valorativas e fins definidos pelo constituinte para serem concretizados. ${ }^{487}$ Desta forma, o dever geral de concretização dos direitos fundamentais, dos quais todos os indivíduos são titulares, é atribuído ao Estado em decorrência da perspectiva objetiva desses direitos.

Em relação à perspectiva subjetiva, o direito à saúde assume as seguintes posições jurídicas $^{488}$ : (i) negativas, como direitos de defesa, no sentido de proibição de intervenção

\footnotetext{
${ }^{486}$ Ingo Wolfgang; MARINONI, Guilherme; MITIDIERO, Daniel. Curso de Direito Constitucional. 2. ed. São Paulo: Editora Revista dos Tribunais, 2013, p.311-313.

${ }^{487}$ SARLET afirma que foi após a promulgação da Lei Fundamental Alemã de 1949, que houve o impulso decisivo para o que hoje se considera a dimensão jurídico-objetiva dos direitos fundamentais. Na época, a doutrina e a jurisprudência evocavam a paradigmática decisão proferida em 1958 pelo Tribunal Constitucional Federal (Bundesverfassungsgericht) da Alemanha no caso Lüth, na qual, além de outros aspectos relevantes, ficou consagrado que os direitos fundamentais não se limitam à função precípua de direitos subjetivos de defesa do indivíduo contra atos do poder público, mas, além disso, constituem decisões valorativas de natureza jurídico-objetiva da Constituição, com eficácia em todo o ordenamento jurídico, e que fornecem diretrizes para o Legislativo, o Judiciário e o Executivo. Nesta decisão, o Tribunal Constitucional Federal da Alemanha ressaltou que, na sua dimensão objetiva, os valores incorporados pelas normas de direitos fundamentais têm eficácia irradiante sobre a ordem jurídica em sua integralidade, fornecendo bases e diretrizes para a interpretação e aplicação desses direitos. SARLET, Ingo Wolfgang. Os direitos fundamentais, sua dimensão organizatória e procedimental e o direito à saúde: algumas aproximações. In: Revista de Processo. Editora Revista dos Tribunais, v.175, ano 34, agosto/2009.

${ }^{488}$ Conforme ALEXY, posição jurídica significa que há uma correspondente norma que protege um direito. Por isso, dentre os direitos a ações negativas estatais, o cidadão tem o direito frente ao Estado de que este não elimine determinadas posições jurídicas do titular do direito, ou seja, não derrogue certas normas. ALEXY, Robert. Teoria dos direitos fundamentais. Tradução de Virgílio Afonso da Silva. 2.ed. São Paulo: Malheiros, 2012, p.199-201.
} 
indevida (exigência de abstenção ou omissão de promover agressão à sua esfera jurídica individual); (ii) positivas, no sentido de direitos a prestações fáticas (materiais) e a prestações normativas (jurídicas), abrangendo, neste caso, o dever de emitir normas de proteção, organização e procedimento; ${ }^{489}$ e (iii) ativas, no sentido de participação na formulação e na execução de políticas públicas de saúde.

As funções positivas do direito à saúde compreendem a possibilidade de qualquer pessoa exigir do Estado a realização concreta de ações e prestações normativas e materiais relativas à proteção deste direito fundamental, marca típica dos direitos sociais, embora também apareça em relação aos direitos civis e políticos. Os direitos a prestações em sentido amplo (direitos a ações estatais positivas) geram direitos que, segundo ALEXY, podem ser divididos em três grupos: (i) direitos a proteção, consistentes em direitos fundamentais em face do Estado a que este o proteja contra intervenções de terceiros, ou seja, direitos subjetivos a ações positivas fáticas ou normativas (normas de direito penal, de direito processual, atos administrativos e ações fáticas); (ii) direitos a organização e procedimento, entendidos como direitos a medidas estatais de natureza organizacional e a sistemas de regras e princípios para assegurar um resultado, com suficiente probabilidade e em suficiente medida, conforme os direitos fundamentais; (iii) direitos a prestações em sentido estrito. ${ }^{490}$

Embora os contornos do direito à saúde não estejam precisamente definidos no ordenamento jurídico brasileiro, é certo que as prestações fáticas exigíveis do Estado não podem abranger todo e qualquer objeto material ou serviço que se destine a assegurar bemestar físico, mental e social a cada pessoa. Nesta concepção prestacional, o Estado tem o dever de oferecer ações e serviços voltados à promoção, à proteção e à recuperação da saúde das pessoas, viabilizando, assim, a fruição do direito à saúde.

Contudo, o que está assegurado aos indivíduos, conforme a interpretação lógica e teleológica do artigo 196 da Constituição Federal $^{491}$ são aquelas prestações materiais básicas e vitais à melhoria das condições individuais de saúde, ou seja, um núcleo essencial

489 SARLET, Ingo Wolfgang; MARINONI, Guilherme; MITIDIERO, Daniel. Curso de Direito Constitucional. 2. ed. São Paulo: Editora Revista dos Tribunais, 2013, p.313-314.

${ }^{490}$ ALEXY, Robert. Teoria dos Direitos Fundamentais. Tradução de Virgílio Afonso da Silva. 2.ed. 2012. São Paulo: Malheiros, p. 450-503.

491 "Art. 196. A saúde é direito de todos e dever do Estado, garantido mediante políticas sociais e econômicas que visem à redução do risco de doença e de outros agravos e ao acesso universal e igualitário às ações e serviços para sua promoção, proteção e recuperação." 
definido por meio das políticas públicas elaboradas pelo Poder Legislativo, em respeito aos princípios e normas constitucionais e às demandas sociais. ${ }^{492}$

As prestações normativas (jurídicas) compreendem o direito das pessoas à proteção do direito à saúde frente ao Estado e a outros cidadãos, através da edição de normas de organização e de procedimento (de direito penal, de direito processual, a prática de atos administrativos), vinculados à persecução de determinados objetivos. ${ }^{493}$

Como exemplos da atuação do Estado na esfera prestacional de cunho normativo é possível mencionar, dentre outras: a elaboração de normas de organização e funcionamento do Sistema Único de Saúde (SUS); a elaboração de políticas públicas direcionadas à concretização do direito à saúde; e a regulação da Emenda Constitucional n ${ }^{\circ} 29$ no tocante à garantia de recursos orçamentários para financiar o sistema de saúde. Quanto às prestações estatais de cunho material, é possível mencionar a realização de campanhas de vacinação e o fornecimento de medicamentos à população por intermédio de programas como o "Farmácia Popular" (assistência farmacêutica).

As funções defensivas do direito à saúde asseguram aos indivíduos um espaço de liberdade em todas as suas formas de expressão, possibilitando sua proteção contra agressões ao bem jurídico tutelado por parte do próprio Estado ou de terceiros.

$\mathrm{O}$ direito de defesa na área da saúde se aproxima dos direitos individuais de liberdade e de personalidade, inerentes à autonomia privada. Cabe ao titular do direito à saúde, ou de seu responsável legal, decidir acerca de submeter-se ou não a determinada intervenção cirúrgica ou tratamento de saúde, de acordo com seus valores morais, crenças religiosas e o domínio sobre seu corpo e mente.

A necessidade de consentimento livre e esclarecido do paciente para a realização de qualquer procedimento médico é orientada por princípios da bioética, que têm na autonomia sua regra fundamental. Por isso, a "preservação da autonomia das pessoas na defesa de sua integridade física e moral" foi expressamente consagrada como corolário da

\footnotetext{
${ }^{492}$ MARRARA, Thiago e NUNES, Lydia Neves Bastos Telles. Reflexões sobre o controle das políticas de saúde e de medicamentos In Direito à vida e à saúde: impactos orçamentário e judicial. BLIACHERIENE, Ana Carla; DOS SANTOS, José Sebastião. São Paulo: Atlas, 2010, p.84-85.

${ }^{493}$ ALEXY, Robert. Teoria dos Direitos Fundamentais. Tradução de Virgílio Afonso da Silva. 2.ed. 2012. São Paulo: Malheiros, p. 450-503.
} 
prática da medicina e como princípio das ações e serviços públicos de saúde na Lei n. 8.080/90 (artigo $7^{\circ}$, inciso III). ${ }^{494} 495$

No mesmo sentido, o artigo 101, da Lei n. 8.213/91 ${ }^{496}$, prevê que o segurado em gozo do benefício de auxílio-doença ou aposentadoria por invalidez e o pensionista inválido devem se submeter a tratamento e a processo de reabilitação profissional prescrito e gratuitamente oferecido pela Previdência Social, com exceção de procedimento cirúrgico e transfusão de sangue, que são facultativos. A título de exemplo, uma pessoa que adote a confissão religiosa de testemunha de Jeová pode se recusar legitimamente a receber transfusão de sangue.

No entanto, assume relevo sublinhar que autonomia privada relativa ao direito à saúde não é absoluta e sofre limitação quando necessária à tutela de outros direitos igualmente tutelados pela Constituição Federal, inclusive da própria pessoa. Neste sentido, a Lei n. 10.216/2001 prevê a possibilidade excepcional de internação involuntária ou compulsória de pessoas acometidas de transtorno mental ${ }^{497}$ que não possam ser tratadas

\footnotetext{
${ }^{494}$ Nos termos do artigo $7^{\circ}$, inciso III, da Lei no $8.080 / 90$ : “Art. $7^{\circ}$ As ações e serviços públicos de saúde e os serviços privados contratados ou conveniados que integram o Sistema Único de Saúde (SUS), são desenvolvidos de acordo com as diretrizes previstas no art. 198 da Constituição Federal, obedecendo ainda aos seguintes princípios: (...) III - preservação da autonomia das pessoas na defesa de sua integridade física e moral;"

495 O Código de Ética Médica, aprovado pela Resolução do Conselho Federal de Medicina n. 1931/2009, em vigor desde 13 de abril de 2010, reforça desde seu preâmbulo a importância da autonomia da vontade, estabelecendo que objetiva, dentre outras finalidades, a "busca de melhor relacionamento com o paciente e a garantia de maior autonomia à sua vontade". No capítulo $\mathrm{V}$, trata da relação com pacientes e familiares e prevê, ser vedado ao médico, dentre outras práticas: "Art. 31. Desrespeitar o direito do paciente ou de seu representante legal de decidir livremente sobre a execução de práticas diagnósticas ou terapêuticas, salvo em caso de iminente risco de morte."; e "Art. 42. Desrespeitar o direito do paciente de decidir livremente sobre método contraceptivo, devendo sempre esclarecê-lo sobre indicação, segurança, reversibilidade e risco de cada método." (Resolução do Conselho Federal de Medicina n. 1931/2009, publicada no Diário Oficial da União de 24 de setembro de 2009, Seção I, p. 90. Retificação publicada no Diário Oficial da União de 13 de outubro de 2009, Seção I, p. 173).

496 "Art. 101. O segurado em gozo de auxílio-doença, aposentadoria por invalidez e o pensionista inválido estão obrigados, sob pena de suspensão do benefício, a submeter-se a exame médico a cargo da Previdência Social, processo de reabilitação profissional por ela prescrito e custeado, e tratamento dispensado gratuitamente, exceto o cirúrgico e a transfusão de sangue, que são facultativos".

${ }^{497}$ A Lei n. 10.216/2001 prevê a internação como forma de tratamento excepcional, indicado somente "(...) quando os recursos extra-hospitalares se mostrarem insuficientes" (artigo $4^{\circ}$ ). Estabelece, ainda, a necessidade de laudo médico circunstanciado em qualquer das modalidades de internação psiquiátrica, que pode ser voluntária, involuntária e compulsória, como define o artigo $6^{\circ}$ desta lei: "Art. $6^{\circ} \mathrm{A}$ internação psiquiátrica somente será realizada mediante laudo médico circunstanciado que caracterize os seus motivos. Parágrafo único. São considerados os seguintes tipos de internação psiquiátrica: I - internação voluntária: aquela que se dá com o consentimento do usuário; II - internação involuntária: aquela que se dá sem o consentimento do usuário e a pedido de terceiro; e III - internação compulsória: aquela determinada pela Justiça."
} 
fora dos hospitais ou que este tratamento seja insuficiente. ${ }^{498} 499$ Assim, um exemplo em que a internação hospitalar é recomendada consiste naquele em que a permanência do paciente acometido de transtorno mental fora do hospital possa gerar riscos graves à sua própria vida ou à integridade física ou psíquica de terceiro. ${ }^{500}$

A tensão entre a liberdade individual e as limitações impostas pelo Estado também pode ser motivada por razões de interesse público, como ações de vigilância sanitária e de controle de doenças endêmicas. Todas as medidas promovidas para o atendimento do interesse da coletividade à saúde atingem diretamente a esfera de autonomia da vontade de

498 Sobre saúde mental, REY apresenta o seguinte conceito: "maturidade ou normalidade emocional, comportamental e social; ausência de distúrbio mental ou comportamental, um estado de bem-estar psicológico em que o indivíduo alcança uma integração satisfatória de seus impulsos instintivos aceitáveis tanto para ele próprio como para o meio social; um equilíbrio apropriado de procura de amor, trabalho e lazer. REY, Luís. Dicionário de termos técnicos de medicina e saúde. 2.ed. Rio de Janeiro: Guanabara Koogan, 2008, p. 701.

499 A discussão sobre a "autoridade do Estado" para determinar a internação compulsória de dependente químico em face de sua "liberdade" de escolha sobre cuidar da própria saúde e como fazê-lo voltou à tona no início de 2013, devido ao programa Recomeço, do Governo do Estado de São Paulo, realizado pelas Secretarias de Estado da Saúde, de Desenvolvimento Social e da Justiça e da Defesa da Cidadania, para combater o uso e o tráfico de drogas, principalmente o crack, oferecendo proteção à saúde e acompanhamento multiprofissional ao dependente químico e seus familiares. Em primeiro lugar, é preciso realçar a intersetorialidade do programa, recomendada para ações de promoção da saúde, mormente em se tratando de pessoas em estado de vulnerabilidade social. Cumpre notar que o referido programa foi implementado no Centro de Referência de Álcool, Tabaco e Outras Drogas (CRATOD), criado pelo Decreto $\mathrm{n}^{\circ}$ 46.860, de 25 de junho de 2002, do estado de São Paulo, que dentre outras atribuições: constitui-se em referência para a definição de políticas públicas relacionadas à promoção da saúde, prevenção e tratamento dos transtornos decorrentes do uso indevido de substâncias psicoativas (álcool, tabaco e outras drogas); elabora, promove e coordena programas em consonância com a matéria de sua competência; e atua de forma articulada e integrada com as demais unidades pertencentes ao Sistema Único de Saúde - SUS, bem como com entidades públicas e privadas (Decreto $\mathrm{n}^{\circ} 46.860 / 2002$, artigo $3^{\circ}$, incisos I, IV e VIII, respectivamente). A base normativa do programa é formada por termos de cooperação técnica, celebrados entre o Governo do Estado de São Paulo, Tribunal de Justiça, Ministério Público e Ordem dos Advogados do Brasil, os quais estabelecem a atuação integrada dessas instituições, em regime de plantão, no Centro de Referência de Álcool, Tabaco e Outras Drogas, além das equipes de saúde. Segundo dados do CRATOD, desde 21 de janeiro foram realizados mais de 4.000 atendimentos nos Centros de Atenção Psicossocial e cerca de 900 internações, das quais 830 foram voluntárias (com o consentimento do usuário), 76 involuntárias (a pedido de terceiro, em geral um familiar) e apenas uma foi compulsória (por ordem judicial, embasada em laudo médico circunstanciado). A internação compulsória foi de um rapaz de 25 anos, que apresentava sinais de intoxicação por diversas drogas e foi diagnosticado com retardo mental. Sob o prisma jurídico, a análise específica dessa internação compulsória, a partir das informações fáticas apresentadas pelo CRATOD, revelam a legalidade e a legitimidade da medida, que encontra fundamento no artigo $4^{\circ}$, combinado com o artigo $6^{\circ}$, inciso III, da Lei n. 10.216/2001, que estão transcritos na nota de rodapé anterior. No plano dos fatos, segundo o CRATOD, as circunstâncias clínicas graves do indivíduo, verificadas em avaliação médica, indicavam a necessidade da internação compulsória para o tratamento de sua saúde. Além disso, como desconhecia o paradeiro de sua família e declarou ser viciado em diversas drogas, a internação compulsória parecia mesmo ser imprescindível, razoável e guardar compatibilidade com o fundamento da dignidade da pessoa humana. Informações disponíveis nos sites oficiais do programa, da Secretaria de Estado da Saúde e do Governo do Estado de São Paulo, em: <http://www.programarecomeco.sp.gov.br>; $<$ http://www.saude.sp.gov.br>; e <http://saopaulo.sp.gov.br>. Consulta em: 08/11/2013.

${ }^{500}$ Para aprofundar o estudo do tema, conferir: CONSELHO FEDERAL DE PSICOLOGIA. A regulação dos serviços de saúde mental no Brasil: inserção da Psicologia no Sistema Único de Saúde e na Saúde Suplementar. Brasília: CFP, 2013. 
um conjunto de indivíduos, como se pode verificar, por exemplo, em campanhas de imunização. Nessas situações, o interesse público primário consubstanciado no direito à saúde da coletividade, que se materializa com a diminuição dos riscos de contaminação (ações de profilaxia e controle de endemias e epidemias), prevalece em face da autonomia privada relativa ao direito à saúde..$^{501}$

Por conta dessas posições jurídicas negativas, é assegurado aos titulares do direito à saúde o direito de impugnação de medidas que ofendam suas condições de saúde. Este efeito não impede a interferência do Estado de forma legítima na esfera jurídica das pessoas, impondo deveres, exercendo atividades de fiscalização e, eventualmente, aplicando sanções àqueles que descumprirem os deveres fixados na legislação sanitária. Contudo, a atuação estatal deve respeitar os princípios e normas previstos na Constituição Federal e na legislação sanitária.

Há uma derivação doutrinária desta modalidade de eficácia negativa denominada de "eficácia vedativa do retrocesso", segundo a qual os titulares de direito fundamentais poderiam exigir ao Poder Judiciário que declare a inconstitucionalidade ou a ilegalidade da norma que importe em revogação de enunciados que, regulamentando determinado princípio constitucional, asseguravam a aplicação e fruição de direitos fundamentais, sem que tenha sido acompanhada de uma política substitutiva. ${ }^{502} \mathrm{~A}$ ideia é que a revogação ou a restrição de um direito já incorporado como efeito próprio do princípio constitucional, esvazia seu conteúdo e o viola, tratando-se de uma ação inconstitucional. ${ }^{503} \mathrm{Na}$ área da

${ }^{501}$ MARRARA, Thiago e NUNES, Lydia Neves Bastos Telles. Reflexões sobre o controle das políticas de saúde e de medicamentos. In: Direito à vida e à saúde: impactos orçamentário e judicial. BLIACHERIENE, Ana Carla; DOS SANTOS, José Sebastião. São Paulo: Atlas, p.83, 2010.

502 BARCELLOS, Ana Paula de. A eficácia jurídica dos princípios constitucionais: O princípio da dignidade da pessoa humana. 3.ed. Rio de Janeiro: Renovar, 2011, p.85-93.

503 BARCELLOS afirma que ao regulamentar um determinado direito fundamental, o legislador faz opções valorativas consentâneas ao momento histórico em que vive e para um futuro próximo. Assim, caso se entendesse que a vedação de retrocesso impediria qualquer tipo de restrição da regulamentação vigente, isso redundaria em inalterabilidade das opções para o legislador, salvo para ampliar o alcance do direito ou a proteção e as prerrogativas por ele conferidas, ou seja, a norma constitucional que assegura um direito somada à sua regulamentação concreta formaria uma espécie de bloco de constitucionalidade, com a máxima proteção da cláusula pétrea, inviabilizando sua restrição. Contudo, BARCELLOS pondera que esta interpretação excessivamente abrangente da eficácia de vedação ao retrocesso não é correta, porque invadiria o espaço reservado à deliberação democrática e à manifestação do pluralismo político. Assim, para além da hipótese utilizada como exemplo, consistente na revogação total de uma disciplina existente em matéria de direitos fundamentais, na qual incidiria a eficácia vedativa de retrocesso, BARCELLOS propõe um confronto da nova regulamentação com a garantia mínima que decorre da Constituição e não propriamente pelo legislador ordinário para se identificar sua validade ou invalidade. Se a nova regulamentação garantir a concretização real, de forma minimamente adequada, do bem jurídico tutelado (isto é, a fruição do direito fundamental) por seus titulares, a nova regulamentação será válida e a vedação do retrocesso não será 
saúde, por exemplo, a revogação total das normas que disciplinam a participação social no Sistema Único de Saúde (SUS) seria evidentemente inconstitucional, visto que interferiria nos níveis de proteção da democracia sanitária já concretizados pelo Estado.

As funções positivas e as funções negativas do direito à saúde asseguram posições jurídicas aos seus titulares, que, em caso de ameaça de lesão ou efetiva violação ao direito, podem valer-se do direito de petição para postular sua proteção na via administrativa, e/ou ajuizar medida perante o Poder Judiciário, individualmente ou em grupo ${ }^{504}$, com esteio no princípio da inafastabilidade da apreciação jurisdicional $\left(\mathrm{CF} \text {, art. } 5^{\circ} \text {, inciso XXXV) }\right)^{505}$.

Em relação à faceta positiva do direito, é bastante comum a propositura de ação judicial em que se postula a condenação dos poderes públicos ao fornecimento de prestações materiais em saúde. Além da via jurisdicional, o administrado também pode se valer da via administrativa para a solução do conflito, valendo-se do direito de petição, que será adiante estudado (subitem 4.2). De outro lado, no tocante à faceta defensiva do direito à saúde, é assegurado ao titular do direito violado ou ameaçado de violação, a possibilidade de requerer, administrativa e/ou judicialmente, seja determinado que os poderes públicos ou terceiros se abstenham de adotar medidas que possam causar prejuízos à sua saúde.

Por sua vez, as funções ativas do direito à saúde representam as posições jurídicas fundamentais que asseguram aos indivíduos: (i) a possibilidade de participarem diretamente da Administração Pública, a fim de colaborarem com a elaboração de políticas

aplicável. BARCELLOS, Ana Paula de. A eficácia jurídica dos princípios constitucionais: O princípio da dignidade da pessoa humana. 3. ed. Rio de Janeiro: Renovar, 2011. p.85-93.

${ }^{504} \mathrm{~A}$ tutela do direito à saúde pode ser feita por meio de ação individual ou coletiva, a depender do interesse tutelado e da legitimidade para a sua propositura. A título de exemplo de interesse coletivo (em sentido amplo) na área da saúde, AITH cita a poluição ambiental causada pelo despejo de resíduos sólidos nos rios e a utilização de combustível danoso ao meio-ambiente nos veículos oficiais. AITH, Fernando. A saúde como direito de todos e dever do Estado: o papel dos Poderes Executivo, Legislativo e Judiciário na efetivação do direito à saúde no Brasil. In: Direito Sanitário: Saúde e Direito, um Diálogo Possível. AITH, Fernando; SATURNINO, Luciana Tarbes Mattana; DINIZ, Maria Gabriela Araújo; MONTEIRO, Tammy Claret (organizadores). Belo Horizonte: ESP-MG, p.79, 2012.

${ }^{505} \mathrm{O}$ artigo $5^{\circ}$, inciso XXXV, da Constituição Federal, disciplina o princípio da inafastabilidade do controle judicial, nos seguintes termos: "Art. $5^{\circ}$ Todos são iguais perante a lei, sem distinção de qualquer natureza, garantindo-se aos brasileiros e aos estrangeiros residentes no País a inviolabilidade do direito à vida, à liberdade, à igualdade, à segurança e à propriedade, nos termos seguintes: (...) XXXV - a lei não excluirá da apreciação do Poder Judiciário lesão ou ameaça a direito;" 
sanitárias $^{506}$; e (ii) a utilização dos mecanismos de controle e supervisão das ações e serviços públicos de saúde. ${ }^{507}$

No Estado Democrático de Direito, o povo é titular do poder, podendo exercê-lo diretamente ou por meio de representantes eleitos para mandatos temporários. ${ }^{508} \mathrm{Na}$ área da saúde, a Constituição Federal estabelece expressamente que o Sistema Único de Saúde deve observar a diretriz de "participação da comunidade" (artigo 198, inciso III) ${ }^{509}$, reforçada pela Lei n. 8.080/90 como princípio (artigo $7^{\circ}$ inciso VIII) ${ }^{510}$ e disciplinada pela Lei n. 8.142/90.

Tendo em vista que os deveres de proteção do Estado podem e devem concretizarse por meio de normas dispondo sobre o procedimento administrativo e judicial, bem como pela criação de órgãos incumbidos da tutela e promoção de direitos, verifica-se a conexão existente entre os deveres de proteção e a dimensão organizatória e procedimental dos direitos fundamentais.

A organização e o procedimento podem ser considerados como pressupostos necessários à eficácia dos direitos fundamentais, daí a imprescindibilidade de que sejam instituídos e funcionem de forma adequada para garantir a implementação eficiente desses direitos. ${ }^{511}$

\footnotetext{
${ }^{506}$ MARRARA, Thiago e NUNES, Lydia Neves Bastos Telles. Reflexões sobre o controle das políticas de saúde e de medicamentos. In Direito à vida e à saúde: impactos orçamentário e judicial. BLIACHERIENE, Ana Carla; DOS SANTOS, José Sebastião. São Paulo: Atlas, p. 85, 2010.

${ }^{507}$ AITH, Fernando. A saúde como direito de todos e dever do Estado: o papel dos Poderes Executivo, Legislativo e Judiciário na efetivação do direito à saúde no Brasil. In: Direito Sanitário: Saúde e Direito, um Diálogo Possível. AITH, Fernando; SATURNINO, Luciana Tarbes Mattana; DINIZ, Maria Gabriela Araújo; MONTEIRO, Tammy Claret (organizadores). Belo Horizonte: ESP-MG, p. 81-82, 2012.

$508 \mathrm{O}$ parágrafo único do artigo $1^{\circ}$ da Constituição Federal estabelece o seguinte: "Art. $1^{\circ}$ A República Federativa do Brasil, formada pela união indissolúvel dos Estados e Municípios e do Distrito Federal, constitui-se em Estado Democrático de Direito e tem como fundamentos: (...) Parágrafo único. Todo o poder emana do povo, que o exerce por meio de representantes eleitos ou diretamente, nos termos desta Constituição."

509 "Art. 198. As ações e serviços públicos de saúde integram uma rede regionalizada e hierarquizada e constituem um sistema único, organizado de acordo com as seguintes diretrizes: (...) III - participação da comunidade."

${ }^{510} \mathrm{O}$ artigo $7^{\circ}$, inciso VIII da Lei n. 8.080/90 dispõe: "Art. $7^{\circ}$ As ações e serviços públicos de saúde e os serviços privados contratados ou conveniados que integram o Sistema Único de Saúde (SUS), são desenvolvidos de acordo com as diretrizes previstas no art. 198 da Constituição Federal, obedecendo ainda aos seguintes princípios: (...) VIII - participação da comunidade;"

511 As normas que prevêem direitos fundamentais asseguram aos seus titulares, ao lado da faceta subjetiva (direitos fundamentais como direitos subjetivos, ou seja, como posições jurídicas exigíveis pelo seu titular), uma faceta objetiva, parcialmente autônoma em relação à perspectiva subjetiva, o que implica o reconhecimento de conteúdos normativos e, portanto, de agregar funções distintas aos direitos fundamentais. SARLET, Ingo Wolfgang. Os direitos fundamentais, sua dimensão organizatória e procedimental e o direito à saúde: algumas aproximações. In: Revista de Processo. Revista de Processo. São Paulo: Editora Revista dos Tribunais, v. 175, ano 34, p.13-18, agosto de 2009.
} 
Segundo SARLET, numa concepção abrangente, os direitos à organização e ao procedimento podem ser considerados direitos a prestações, visto que asseguram ao indivíduo a implementação de procedimentos ou organizações em geral ou a possibilidade de participar em procedimentos ou estruturas organizacionais já existentes. ${ }^{512}$ Neste sentido, é possível constatar que o direito fundamental à participação na organização e nos procedimentos viabiliza a realização da democracia participativa.

Há que se salientar a imprescindibilidade de cumprimento do dever estatal de colocar à disposição de todos os seus titulares, prestações estatais de cunho organizacional e procedimental para a fruição do direito fundamental à saúde, sem as quais não se poderia dar-lhe efetividade. Neste sentido, a organização e o procedimento, de um modo geral, podem ser considerados como condição para sua concretização.

Dentre os novos conteúdos que têm sido reconduzidos à perspectiva jurídicoobjetiva encontram-se os deveres de proteção do Estado, no sentido de que a este incumbe zelar, inclusive preventivamente, pela proteção dos direitos fundamentais dos indivíduos não somente contra os poderes públicos, mas também contra agressões provindas de particulares e até mesmo de outros Estados. Os deveres de proteção vinculam os órgãos estatais em relação à necessidade de atuarem de modo suficiente. ${ }^{513}$ Assim, mesmo nos casos em que o Estado disponha de uma ampla margem de liberdade na definição dos meios a serem utilizados na efetivação desta proteção, deverá criar procedimentos adequados e suficientes à tutela dos direitos fundamentais. ${ }^{514}$

De um lado, a dimensão organizacional do direito fundamental à saúde compreende a estrutura organizacional do Sistema Único de Saúde (SUS), fundada na diretriz de participação comunitária (CF, artigo 198, inciso III), bem como a criação de órgãos (em

512 SARLET, Ingo Wolfgang. Os direitos fundamentais, sua dimensão organizatória e procedimental e o direito à saúde: algumas aproximações. Revista de Processo. Revista de Processo. São Paulo: Editora Revista dos Tribunais, v. 175, ano 34, p.13-18, agosto de 2009.

513 SARLET, Ingo Wolfgang. Os direitos fundamentais, sua dimensão organizatória e procedimental e o direito à saúde: algumas aproximações. Revista de Processo. Revista de Processo. São Paulo: Editora Revista dos Tribunais, v. 175, ano 34, p.13-18, agosto de 2009.

${ }^{514} \mathrm{Na}$ lição de ALEXY, a dimensão organizatória e procedimental dos direitos fundamentais compreende os direitos a medidas estatais de natureza organizacional e a sistemas de regras e princípios destinados a alcançar um resultado, com suficiente probabilidade e em suficiente medida, conforme aos direitos fundamentais. No tocante ao objeto dos direitos à organização e ao procedimento, ALEXY afirma que estes direitos podem ser tanto direitos à emissão de determinadas normas procedimentais, quanto direitos a uma determinada interpretação e aplicação concreta das normas sobre procedimento. Contudo, ressalta que em relação aos direitos prestacionais, na condição de direitos a prestações normativas, interessam, sobretudo, aqueles, que tem por destinatário o legislador, pois o direito a procedimentos como direito a proteção jurídica efetiva tem como destinatários os tribunais. ALEXY, Robert. Teoria dos Direitos Fundamentais. Tradução de Virgílio Afonso da Silva. 2.ed. 2012. São Paulo: Malheiros, p. 472-474. 
especial, as Defensorias Públicas e o Ministério Público nos âmbitos federal e estadual) com recursos humanos e financeiros adequados e suficientes para promover medidas com o objetivo de proteger o direito à saúde, conforme os objetivos gerais e específicos consagrados na Constituição Federal.

De outro lado, a dimensão procedimental abrange o direito de participar da gestão e da fiscalização da execução de políticas públicas de saúde, bem como o direito de postular prestações normativas que regulamentem as normas constitucionais, para tornar viável o exercício do direito fundamental à saúde.

Para os fins do presente trabalho, interessa diretamente a dimensão procedimental do direito fundamental à saúde, considerando a necessidade da instituição de mecanismos especificamente na seara administrativa, nos quais seja realizado um devido processo, ordenado e justo, que assegure ao indivíduo a possibilidade de buscar a implementação do direito fundamental à saúde, mediante o recebimento de prestações materiais.

Nesta perspectiva, o processo administrativo alcança particular relevância como instrumento voltado à garantia do direito fundamental à saúde, em sua dimensão positiva, concernente ao direito a prestações materiais (ações e serviços), no âmbito do Sistema Único de Saúde (SUS).

$\mathrm{O}$ direito fundamental à saúde gera, pois, um conjunto de direitos subjetivos dos indivíduos exercidos em face do Estado e de terceiros. ${ }^{515}$ Ao Estado incumbe o dever de proteger, promover e recuperar a saúde das pessoas, por meio de ações variadas e concertadas, por todos os entes federativos. Aos indivíduos cabe o dever de cuidado com a sua própria saúde e também em relação à saúde dos demais. ${ }^{516}$

\footnotetext{
515 Neste sentido, MARRARA E NUNES, em artigo publicado em 2010, afirmam que o ressurgimento do direito à saúde no Brasil há pouco mais de dez anos deve-se a dois fatores, um fator normativo e outro político: o progresso normativo no campo da saúde pública e em seus direitos correlatos, especialmente após a Constituição de 1988; e à atuação dos três Poderes na concretização do direito à saúde. Assim, sustentam que, "o direito à saúde passou a ser a somatória de deveres estatais e, cada vez mais, um conjunto de direitos subjetivos exercidos perante o Estado e também terceiros". MARRARA, Thiago e NUNES, Lydia Neves Bastos Telles. Reflexões sobre o controle das políticas de saúde e de medicamentos. In: Direito à vida e à saúde: impactos orçamentário e judicial. BLIACHERIENE, Ana Carla; DOS SANTOS, José Sebastião. São Paulo: Atlas, p.79, 2010.

${ }^{516}$ A mencionada Lei estadual paulista $\mathrm{n}^{\mathrm{o}} 13.541$, de 7 de maio de 2009 e a Lei federal $\mathrm{n}^{\mathrm{o}} 12.546$, de 14 de dezembro de 2001, que modificou a Lei $\mathrm{n}^{\mathrm{o}}$ 9.294, de 15 de julho de 1996, estabelecem, cada uma com suas peculiaridades, a proibição ao uso de produtos fumígenos em ambientes fechados, constituindo, assim, exemplos do dever de cuidado de cada indivíduo em relação à sua própria saúde e à saúde dos demais. $\mathrm{O}$ interesse público especificamente tutelado é de proteção da saúde tanto dos fumantes ativos, quanto passivos, pois foi cientificamente demonstrado, por meio de estudos clínicos, que para ambos aumentam os riscos de morte em decorrência de enfermidades provocadas pelo tabagismo. Segundo WANNMACHER, no Brasil, cerca de 80 mil pessoas morrem ao ano em razão de complicações causadas pelo fumo e o crescimento do
} 
A análise das variadas funções exercidas pelo direito à saúde no plano jurídicosubjetivo deve ser feita de forma combinada com os deveres que gera ao Estado e também a terceiros. Os deveres de proteção dos direitos fundamentais, no plano jurídico-objetivo, vinculam os órgãos do Estado no sentido de atuarem de modo a garantir-lhes pelo menos um grau de eficácia suficiente, tanto em relação a violações oriundas do próprio Estado, quanto no que diz respeito a ameaças e violações originárias de outros particulares.

No Brasil, os três Poderes do Estado atuam na concretização do direito à saúde. Contudo, a quem cabe a competência de definir normativamente o sentido, o conteúdo e a eficácia do direito à saúde?

O conteúdo do direito fundamental à saúde, previsto em norma constitucional de aplicabilidade imediata e de eficácia $\operatorname{contida}^{517}$, assim como os demais direitos sociais, produz efeitos desde logo, mas a definição precisa de seus contornos depende da regulamentação ulterior por parte do Legislativo e da atuação do Executivo, especialmente no tocante à elaboração e execução de políticas públicas de saúde, que irão delimitar as prestações materiais (ações e serviços) ofertados pelo poder público.

Ao Legislativo cabe a função típica de editar normas gerais que assegurem as condições sociais e os instrumentos necessários para a execução de políticas sociais e econômicas voltadas à redução dos riscos à saúde e ao acesso universal e igualitário às ações e serviços para a promoção, proteção e recuperação da saúde. A Constituição Federal de 1988 estabelece em seu artigo 24 a competência legislativa concorrente para "proteção e

número de fumantes passivos estimula o hábito nos indivíduos jovens que têm familiares fumantes, bem como doenças causadas pela exposição passiva ao fumo usado por outros. Assim, afirma que somente ambientes $100 \%$ livres de fumantes protegem contra o tabagismo passivo. WANNMACHER, Lenita. Tratamento Medicamentoso Antitabagismo. Boletim da Organização Pan-Americana de Saúde, v.4, Brasília, março de 2007, p. 1-6. Embora o Plano Nacional de Saúde 2012-2015 apresente uma marcada redução do tabagismo no Brasil nos últimos anos (em 1989, a pesquisa nacional de saúde e nutrição/PNPS mostrou prevalência de fumantes de $34,8 \%$ e o Vigitel encontrou prevalência de $15,5 \%$ em 2009), o combate ao tabagismo continua inserido em programa de saúde estratégico, voltado à construção da cultura de paz, em campanhas e projetos sistemáticos de comunicação e educação, porque ainda é uma das principais doenças crônicas não transmissíveis no mundo. (BRASIL. Ministério da Saúde. Secretaria-Executiva. Secretaria de Planejamento e Orçamento. Plano Nacional de Saúde- PNS: 2012-2015. Brasília. 2011. Disponível em: http://bvsms.saude.gov.br. Consulta em: 10/10/2013). Sobre morbidade respiratória em crianças fumantes passivas, conferir: CARVALHO, Luísa Maria Torres de; PEREIRA, Eanes Delgado Barros. Morbidade Respiratória em Crianças Fumantes Passivas. In: Jornal Brasileiro de Pneumologia, v. 28, p. 8-14, 2002. Este artigo é parte da Dissertação de mestrado "Prevalência da Morbidade Respiratória em crianças fumantes passivas de zero a cinco anos de idade", de Luísa Maria Torres de Carvalho, aprovada no Departamento de Clínica Médica da Universidade Federal do Ceará em 1999 e vencedora do Prêmio Nacional de Pesquisa em Tabagismo em 2000.

517 MARRARA, Thiago e NUNES, Lydia Neves Bastos Telles. Reflexões sobre o controle das políticas de saúde e de medicamentos. In: Direito à vida e à saúde: impactos orçamentário e judicial. BLIACHERIENE, Ana Carla; DOS SANTOS, José Sebastião. São Paulo: Atlas, p.82, 2010. 
defesa da saúde”. Assim, incumbe à União editar normas gerais de saúde, obrigatórias para todas as unidades federativas. ${ }^{518}$ No exercício desta competência, a União editou, dentre outras: a Lei n. 8.080/90, que regula as ações e serviços de saúde no âmbito do Sistema Único de Saúde (SUS); a Lei n. 8.142/90, que dispõe sobre a participação da comunidade na gestão do Sistema Único de Saúde; a Lei n. 11.445/2007 ${ }^{519}$, que estabelece as diretrizes nacionais para o saneamento básico; a Lei n. 10.216/2001 ${ }^{520}$, conhecida como "Lei da Reforma Psiquiátrica"; a Lei n. 9.782/1999, que cria a Agência Nacional de Vigilância Sanitária (ANVISA); e a Lei n. 9.961/2000, que cria a Agência Nacional de Saúde Suplementar (ANS).

Ao Executivo cabe cumprir as políticas públicas de saúde ${ }^{521}$ elaboradas pelo Legislativo, organizar a rede de serviços públicos de saúde e realizar ações e serviços

518 Sobre competências em matéria de saúde, conferir o subitem 2.1.3. Cumpre recordar apenas que a competência legislativa sobre saúde no Brasil está prevista no artigo 24, inciso XII, da Constituição Federal. Aos Estados-membros foi atribuída a competência suplementar para editar normas específicas às particularidades estaduais (artigo 24, parágrafos $1^{\circ}$ e $2^{\circ}$ ). Aos Municípios também foi atribuída competência legislativa suplementar para atender às necessidades locais, respeitadas as normas gerais estabelecidas pela União e pelos respectivos Estados (artigo 30, inciso II). Além disso, também foi previsto no texto constitucional a competência supletiva dos Estados e dos Municípios (artigo 24, parágrafo $3^{\circ}$ ).

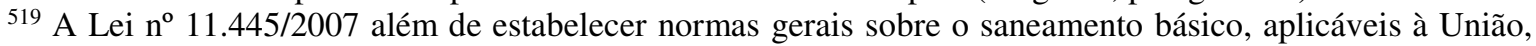
aos Estados, ao Distrito Federal e aos Municípios, fixa normas específicas para a política federal de saneamento básico. A Lei $\mathrm{n}^{\circ} 12.862 / 2013$ alterou a Lei $\mathrm{n}^{\circ}$ 11.445/2007 para estabelecer como princípio fundamental dos serviços de saneamento básico, dentre outros, a adoção de medidas de fomento à moderação do consumo de água (artigo $2^{\circ}$, XIII) e, no tocante à política federal de saneamento básico, previu que a União também observará, como diretriz, o estímulo ao desenvolvimento e aperfeiçoamento de equipamentos e métodos economizadores de água (artigo 48, XII) e previu mais dois objetivos da Política Federal de Saneamento Básico: incentivar a adoção de equipamentos sanitários que contribuam para a redução do consumo de água; e promover educação ambiental voltada para a economia de água pelos usuários. (artigo 49 , incisos XI e XII, respectivamente).

${ }^{520}$ Sobre a Reforma psiquiátrica e a política de saúde mental no Brasil, é interessante conferir o histórico da Reforma: a crítica ao modelo hospitalocêntrico (1978-1991); o início da implantação da rede extra-hospitalar (1992-2000); e a Reforma psiquiátrica depois da Lei Nacional (Lei n. 10.216/2001). Foi no contexto da promulgação da Lei n. 10.216/2001 e da realização da III Conferência Nacional de Saúde Mental, que a política de saúde mental do governo federal, alinhada com as diretrizes da Reforma Psiquiátrica, passa a consolidar-se, ganhando maior sustentação e visibilidade. A III Conferência Nacional de Saúde Mental, cuja etapa nacional foi realizada em dezembro de 2001, em Brasília, consolida a Reforma Psiquiátrica como política de governo, confere aos Centros de Atenção Psicossocial (CAPS) o valor estratégico para a mudança do modelo de assistência, defende a construção de uma política de saúde mental para os usuários de álcool e outras drogas, e estabelece o controle social como a garantia do avanço da Reforma Psiquiátrica no Brasil. Este processo foi caracterizado por ações dos governos federal, estadual, municipal (como o programa "De volta para a Casa") e dos movimentos sociais (dos quais cumpre citar o primeiro Congresso Brasileiro de Centros de Atenção Psicossocial, realizado em 2004, em São Paulo), para efetivar a construção da transição de um modelo de assistência centrado no hospital psiquiátrico, para um modelo de atenção comunitário. Brasil. Ministério da Saúde. Secretaria de Atenção à Saúde. DAPE. Coordenação Geral de Saúde Mental. Reforma psiquiátrica e política de saúde mental no Brasil. Documento apresentado à Conferência Regional de Reforma dos Serviços de Saúde Mental: 15 anos depois de Caracas. OPAS. Brasília, novembro de 2005. Disponível em: <http://bvsms.saude.gov.br>. Consulta em 04/11/2013.

${ }^{521}$ Não obstante isso, cumpre salientar que o Programa "Mais Médicos" foi instituído pela Medida Provisória n. 621, de 09 de julho de 2013, adotada pela Presidente da República sob a alegação de se tratar de matéria 
públicos voltados à concretização do direito à saúde, direta ou indiretamente, por meio do Sistema Único de Saúde (SUS). A execução de ações e serviços públicos de saúde pode ser feita por variados modelos jurídicos de organização e gestão, observadas as normas definidas pela Constituição Federal e as normas gerais editadas pela União em matéria de saúde. ${ }^{522}$

relevante e urgente, com fundamento no artigo 62, caput, da Constituição Federal de 1988. Segundo a Exposição de Motivos desta medida provisória, na 14 Conferência Nacional de Saúde, realizada em 2011, foi aprovada a diretriz de que todas as pessoas e famílias devem ter assegurado o direito a uma equipe de saúde da família. O Brasil possui 359.691 médicos ativos e apresenta, em média, uma proporção de 1,8 médicos para cada 1.000 (mil) habitantes, conforme dados primários obtidos no Conselho Federal de Medicina (CFM) e na estimativa populacional do Instituto Brasileiro de Geografia e Estatística (IBGE). A proporção de médico para cada 1.000 habitantes no Brasil é menor do que em outros países latinoamericanos com perfil socioeconômico semelhante ou países que têm sistemas universais de saúde, como Canadá $(2,0)$, Reino Unido (2,7), Argentina (3,2), Uruguai $(3,7)$, Portugal $(3,9)$, Espanha $(4,0)$ e Cuba $(6,7)$ (Estadísticas Sanitarias Mundiales de 2011 e 2012 - Organização Mundial da Saúde - OMS). Embora não haja parâmetro que estabeleça uma proporção ideal de médico por habitante reconhecido e validado internacionalmente, utiliza-se como referência a proporção de 2,7 médicos por 1.000 habitantes, que é a encontrada no Reino Unido, país que, depois do Brasil, tem o maior sistema de saúde público de caráter universal orientado pela atenção básica. Nesse cenário, para que o Brasil alcance a mesma relação de médicos por habitante seriam necessários mais 168.424 médicos. Mantendo-se a taxa atual de crescimento do número de médicos no país, o cumprimento dessa meta só será viável em 2035. Além disso, a diretriz n. 1 do Plano Nacional de Saúde fixado pelo Ministério da Saúde para o período de 2012 a 2015, orientou a redefinição e o aprimoramento da Política Nacional de Atenção Básica à Saúde, em articulação com estados, Distrito Federal e municípios, como estratégia para enfrentar os principais problemas de acesso da população às ações e serviços de saúde com qualidade e fortalecer as linhas de atuação já consolidadas, como a Estratégia de Saúde da Família (ESF). A implementação das Redes de Atenção à Saúde (RAS) visa ampliar o acesso às ações e serviços de saúde assegurados pelo SUS com equidade, garantindo a integralidade da atenção e a qualificação das práticas de gestão de cuidados para a resolubilidade dos serviços prestados, levando em conta as necessidades e as diversidades regionais (Plano Nacional de Saúde - PNS: 2012-2015. Ministério da Saúde. Secretaria Executiva. Subsecretaria de Planejamento e Orçamento. Brasília: Ministério da Saúde. 2011. p. 70-72). Posteriormente, a Medida Provisória n. 621, de 09 de julho de 2013 foi convertida na Lei n. 12.871, de 22 de outubro de 2013, e regulamentada pelo Decreto 8.040/2013. Tendo em vista a implementação deste projeto, foi editada a Portaria conjunta dos Ministérios da Saúde e da Educação n. 1.369/2013. O artigo $1^{\circ}$ da Lei n. 12.871, de 22 de outubro de 2013, define os objetivos deste Programa: "Art. $1^{\circ}$ É instituído o Programa Mais Médicos, com a finalidade de formar recursos humanos na área médica para o Sistema Único de Saúde (SUS) e com os seguintes objetivos: I - diminuir a carência de médicos nas regiões prioritárias para o SUS, a fim de reduzir as desigualdades regionais na área da saúde; II - fortalecer a prestação de serviços de atenção básica em saúde no País; III - aprimorar a formação médica no País e proporcionar maior experiência no campo de prática médica durante o processo de formação; IV - ampliar a inserção do médico em formação nas unidades de atendimento do SUS, desenvolvendo seu conhecimento sobre a realidade da saúde da população brasileira; V - fortalecer a política de educação permanente com a integração ensino-serviço, por meio da atuação das instituições de educação superior na supervisão acadêmica das atividades desempenhadas pelos médicos; VI - promover a troca de conhecimentos e experiências entre profissionais da saúde brasileiros e médicos formados em instituições estrangeiras; VII aperfeiçoar médicos para atuação nas políticas públicas de saúde do País e na organização e no funcionamento do SUS; e VIII - estimular a realização de pesquisas aplicadas ao SUS."

522 O artigo 197, caput, da Constituição Federal prescreve o seguinte: "Art. 197. São de relevância pública as ações e serviços de saúde, cabendo ao Poder Público dispor, nos termos da lei, sobre sua regulamentação, fiscalização e controle, devendo sua execução ser feita diretamente ou através de terceiros e, também, por pessoa física ou jurídica de direito privado.”. O artigo 199, caput e parágrafo $1^{\circ}$, assim dispõem: "Art. 199. A assistência à saúde é livre à iniciativa privada. § $1^{\circ}$ - As instituições privadas poderão participar de forma complementar do sistema único de saúde, segundo diretrizes deste, mediante contrato de direito público ou convênio, tendo preferência as entidades filantrópicas e as sem fins lucrativos.” A possibilidade de instituição 
Ao Judiciário, por sua vez, cabe analisar e decidir o caso concreto mediante provocação do titular do direito subjetivo à saúde que alegue ameaça ou efetiva violação ao seu direito, por força da unicidade da jurisdição e da inafastabilidade do controle judicial $^{523}$, não sendo permitido proferir o non liquet. O crescente aumento do número de demandas judiciais por prestações materiais de saúde, para além de representar a consolidação de instituições democráticas no Brasil ${ }^{524}$, revela a existência de problemas na efetividade do direito à saúde e no cumprimento, pelo Sistema Único de Saúde (SUS), das finalidades para as quais foi instituído pela Constituição Federal de 1988.

Em que pese a relevância da atuação do Judiciário amiúde em ações individuais ${ }^{525}$ propostas em face do poder público e da iniciativa privada, nas quais são pleiteadas as mais variadas prestações materiais de saúde, configurando, assim, o fenômeno que ficou conhecido como “judicialização das políticas públicas de saúde”, uma análise aprofundada de toda a problemática envolvida neste tema extrapolaria os limites deste trabalho. Com

de diferentes tipos de modelos de gestão de serviços públicos de saúde foi consolidada na Lei 8.080/90, ao estabelecer, em seu artigo $4^{\circ}$, o seguinte: Art. $4^{\circ} \mathrm{O}$ conjunto de ações e serviços de saúde, prestados por órgãos e instituições públicas federais, estaduais e municipais, da Administração direta e indireta e das fundações mantidas pelo Poder Público, constitui o Sistema Único de Saúde (SUS). §1. Estão incluídas no disposto neste artigo as instituições públicas federais, estaduais e municipais de controle de qualidade, pesquisa e produção de insumos, medicamentos, inclusive de sangue e hemoderivados, e de equipamentos para saúde. $\$ 2^{\circ}$. A iniciativa privada poderá participar do Sistema Único de Saúde (SUS), em caráter complementar.". Os artigos $7^{\circ}$ e 24 da Lei 8.080/90 também estabelecem normas sobre a forma de participação da iniciativa privada no Sistema Único de Saúde (SUS).

${ }^{523}$ A garantia fundamental de inafastabilidade do Poder Judiciário está prevista no artigo $5^{\circ}$, inciso XXXV da Constituição Federal, que estabelece: “Art. $5^{\circ}$ Todos são iguais perante a lei, sem distinção de qualquer natureza, garantindo-se aos brasileiros e aos estrangeiros residentes no País a inviolabilidade do direito à vida, à liberdade, à igualdade, à segurança e à propriedade, nos termos seguintes: (...) XXXV- a lei não excluirá da apreciação do Poder Judiciário lesão ou ameaça a direito;" É assegurado a todas as pessoas o direito de ajuizar ação cujo objeto seja o fornecimento de alguma prestação material relativa à saúde, independentemente da formulação prévia de requerimento na esfera administrativa. Caso o titular deste direito tenha formulado sua pretensão em âmbito administrativo e a mesma seja rechaçada, poderá se insurgir contra o ato administrativo por meio recurso na esfera administrativa ou propor ação judicial, já com prova da resistência do poder público ao atendimento da pretensão. Contudo, não é necessário esgotar a via administrativa para propor ação perante o Judiciário.

${ }^{524}$ Não se pode negar que o Ministério Público e da Defensoria Pública consistem em instituições essenciais à justiça que, de fato, asseguram a ampliação do acesso à justiça,

${ }^{525}$ A atuação do Judiciário não se limita a apreciar e julgar conflitos concretos, individuais e coletivos nos quais o objeto do pedido consiste em prestação material na área da saúde, mas também atua em conflitos abstratos, em sede de controle concentrado de constitucionalidade, neste caso, pelo Supremo Tribunal Federal, que pode confirmar a constitucionalidade das políticas públicas adotadas ou declarar a inconstitucionalidade das mesmas e, ainda, decidir sobre eventual descumprimento de preceito fundamental. Nestes casos, a competência do Supremo Tribunal Federal está prevista no artigo 102, inciso I, alínea "a" (ação direta de inconstitucionalidade e ação declaratória de constitucionalidade) e parágrafo $1^{\circ}$ (ação de argüição de descumprimento de preceito fundamental). A ação direta de inconstitucionalidade e a ação declaratória de constitucionalidade são regulamentadas pela Lei n. 9.868, de 10 de novembro de 1999 e a ação de argüição de descumprimento de preceito fundamental está disciplinada pela Lei n. 9.882, de 3 de dezembro de 1999. 
efeito, o que se tem em mira é a análise crítica da atuação do Executivo, em relação à concretização do direito à saúde, sobretudo em sua dimensão positiva (direito a prestações), na via administrativa e de forma voltada à consensualização.

Não obstante isso, no próximo item deste capítulo serão delineados os limites à eficácia do direito fundamental à saúde, que consistem em parâmetros tanto para a atuação administrativa, quanto para a atuação judicial, importando, assim, numa análise panorâmica acerca desta matéria. ${ }^{526}$

Em cumprimento às atribuições fixadas na ordem jurídico-constitucional e infraconstitucional em matéria de saúde pública, a atuação do Executivo para a promoção e defesa da saúde pública pode ser agrupada no âmbito da Administração de Serviços e da Administração Ordenadora ${ }^{527 .}$

A Administração de Serviços se refere à dimensão positiva do direito à saúde (direito a prestações em sentido amplo) e é desenvolvida por meio de ações e serviços de prevenção, cura e promoção da saúde, frequentemente através do fornecimento de prestações materiais de fruição individual ${ }^{528}$ ou coletiva. A Administração Ordenadora diz

${ }^{526}$ Para aprofundar o estudo do tema, conferir: GROSS, Alexandre Felix. Atuação do STF na efetivação do direito à saúde no Brasil: perspectivas da judicialização entre escassez e políticas públicas. In: Revista do Tribunal Regional Federal da Primeira Região. Ano 24, número 3, março/2012. Brasília: TRF $1^{\text {a }}$ Região; DUARTE, Luciana Gaspar Melquíades. Possibilidades e limites do controle judicial sobre as políticas públicas de saúde: um contributo para a dogmática do direito à saúde. Belo Horizonte: Fórum, 2011; ANTUNES, Euzébio Henzel; GONÇALVES, Janaína Barbier. Redução da judicialização e efetivação das políticas públicas sob o enfoque do planejamento e gestão sistêmicos. In: Revista da Procuradoria-Geral do Estado. Procuradoria-Geral do Estado do Rio Grande do Sul. Volume 31, número 67. 2010. Porto Alegre: PGE. p.9-23; POZZA, Carla. Controle Judicial das políticas públicas no Estado constitucional. In: Revista da Procuradoria-Geral do Estado. Procuradoria-Geral do Estado do Rio Grande do Sul, v.31, n. 67. Porto Alegre: PGE, p.41-68, 2010; BORGES, Alice Gonzales. Reflexões sobre a judicialização de políticas públicas. In: Revista Brasileira de Direito Público, ano 7, n. 25, Belo Horizonte: Editora Fórum, p.9-44, abril/junho 2009; e MARQUES, Silvia Badim; e DALLARI, Sueli Gandolfi. Garantia do direito social à assistência farmacêutica no estado de São Paulo. In: Revista Saúde Pública, v.41, n.1. São Paulo. Fevereiro, p.101-107, 2007.

${ }_{527}$ A classificação utilizada foi concebida por SUNDFELD em artigo apresentado ao Centro de Estudos e Pesquisas de Direito Sanitário que organizou, em 2002, com o patrocínio da Fundação Nacional de Saúde, uma oficina de trabalho para discutir a polêmica questão jurídica derivada do conflito entre a proteção das liberdades e das garantias individuais e o controle sanitário, ambos estabelecidos pela Constituição em vigor. SUNDFELD, Carlos Ari. Vigilância epidemiológica e direitos constitucionais. In: Programa Nacional de Controle da Dengue: amparo legal à execução das ações de campo - imóveis fechados, abandonados ou com acesso não permitido pelo morador. Ministério da Saúde, Secretaria de Vigilância em Saúde. 2. ed. Série C. Projetos, Programas e Relatórios. Brasília: Ministério da Saúde, p. 99-120, 2006.

${ }^{528}$ Como exemplo de Administração de Serviços é a Política Nacional de Medicamentos (PNM), instituída pela Portaria GM/MS n. 3.916, de 30 de outubro de 1998 (D.O.U. de 10 de novembro de 1998), após ter sido aprovada pela Comissão Intergestores e pelo Conselho Nacional de Saúde, e anteriormente à criação da Agência Nacional de Vigilância Sanitária (ANVISA- Lei n. 9.782/99). Com fundamento no disposto no artigo 196 da Constituição Federal, que reconhece o dever do Estado de assegurar o direito fundamental à saúde, bem como os artigos $2^{\circ}$ ("Art. $2^{\circ} \mathrm{A}$ saúde é um direito fundamental do ser humano, devendo o Estado prover as condições indispensáveis ao seu pleno exercício") e $6^{\circ}$, inciso VI, da Lei n. 8.080/90 (Art. $6^{\circ}$ Estão 
respeito à dimensão negativa do direito à saúde, abrangendo as medidas que limitam o exercício de direitos individuais ou condicionam a esfera de liberdade dos indivíduos: (i) Obrigando-os a agir; (ii) Obrigando-os a se absterem de agir ${ }^{529}$; e (iii) Obrigando-os a suportar interferências estatais ${ }^{530}$.

Em relação à medida estatal ordenadora que impõe obrigação de agir a determinados indivíduos, um exemplo é a notificação compulsória de doenças, agravos e eventos em saúde pública. Assim, em cumprimento ao disposto na Lei n. 10.778, de 24 de novembro de 2003, a Portaria n. 104, de 25 de janeiro de 2011, do Ministério da Saúde, define, dentre outros, como evento em saúde pública de notificação compulsória, a violência contra a mulher que seja atendida em serviços de saúde públicos e privados, em todo o território nacional. ${ }^{531}$ Os destinatários do cumprimento da obrigação são todos os profissionais de saúde (médicos, enfermeiros, odontólogos, médicos veterinários, biólogos,

incluídas ainda no campo de atuação do Sistema Único de Saúde (SUS): (...)"VI - a formulação da política de medicamentos, equipamentos, imunobiológicos e outros insumos de interesse para a saúde e a participação na sua produção;", a Política Nacional de Medicamentos, como parte essencial da Política Nacional de Saúde, foi aprovada com o objetivo de implementar ações capazes de promover a melhoria das condições da assistência à saúde da população. Conforme a apresentação dessa Portaria, seu propósito consistia em "garantir a necessária segurança, eficácia e qualidade destes produtos, a promoção do uso racional e o acesso da população àqueles considerados essenciais". As principais diretrizes da Política Nacional de Medicamentos (PNM) são: o estabelecimento da relação de medicamentos essenciais; a reorientação da assistência farmacêutica; o estímulo à produção de medicamentos; e a sua regulamentação sanitária. A Portaria n. 3.916/98 é a base de toda a estrutura de fornecimento de medicamentos no Brasil. O Decreto n. 5.090/04, regulamentou a Lei n. 10.858, de 13 de abril de 2004 e instituiu o Programa "Farmácia Popular do Brasil", a partir da necessidade de implementar ações que promovam a universalização do acesso da população aos medicamentos; a disponibilização de medicamentos a baixo custo, para os cidadãos que são assistidos pela rede privada e a diminuição do impacto causado pelos gastos com medicamentos no orçamento familiar, ampliando o acesso aos tratamentos.

${ }^{529}$ O Estado impõe o dever de abstenção à utilização indevida de drogas, estabelecendo na hipótese normativa do artigo 28, da Lei n. 11.343, de 23 de agosto de 2006, a imposição de medidas educativas a quem “(...) adquirir, guardar, tiver em depósito, transportar ou trouxer consigo, para consumo pessoal, drogas sem autorização ou em desacordo com determinação legal ou regulamentar". As medidas consistem em: "I advertência sobre os efeitos das drogas; II - prestação de serviços à comunidade; e III - medida educativa de comparecimento a programa ou curso educativo." Caso o agente que tenha incidido no comportamento proscrito se recuse injustificadamente ao cumprimento das medidas educativas impostas pelo Magistrado, o parágrafo $6^{\circ}$ do mesmo dispositivo dispõe que o juiz poderá submetê-lo, sucessivamente a: "I - admoestação verbal; e II - multa."

530 SUNDFELD, Carlos Ari. Vigilância epidemiológica e direitos constitucionais. In: Programa Nacional de Controle da Dengue: amparo legal à execução das ações de campo - imóveis fechados, abandonados ou com acesso não permitido pelo morador. Ministério da Saúde, Secretaria de Vigilância em Saúde. 2. ed. Série C. Projetos, Programas e Relatórios. Brasília: Ministério da Saúde, p. 99-120, 2006.

531 A Portaria $n^{\circ}$ 104, de 25 de janeiro de 2011, do Ministério da Saúde, estabelece a obrigatoriedade de cumprimento “(...) a todos os profissionais de saúde médicos, enfermeiros, odontólogos, médicos veterinários, biólogos, biomédicos, farmacêuticos e outros no exercício da profissão, bem como os responsáveis por organizações e estabelecimentos públicos e particulares de saúde e de ensino, em conformidade com os arts. $7^{\circ}$ e $8^{\circ}$, da Lei $n^{\circ} 6.259$, de 30 de outubro de 1975". A citada portaria é composta por três anexos que contêm: a Lista de Notificação Compulsória- LNC (anexo I), a Lista de Notificação Compulsória Imediata - LNCI (anexo II) e a Lista de Notificação Compulsória em Unidades SentinelasLNCS (anexo III). 
biomédicos, farmacêuticos, dentre outros no exercício da profissão), bem como os responsáveis por organizações e estabelecimentos públicos e particulares de saúde e de ensino, em conformidade com os artigos $7^{\circ}$ e $8^{\circ}$, da Lei n. 6.259, de 30 de outubro de 1975, que se aplica subsidiariamente, nos termos do artigo $6^{\circ}$, da Lei n. 10.778/2003. ${ }^{532}$

No tocante à intervenção estatal que impõe obrigação de não agir, um exemplo pode ser extraído da Lei estadual n. 13.541, de 7 de maio de 2009, conhecida como "lei antifumo", que proíbe, no território do Estado de São Paulo, o uso de cigarro ou de qualquer outro produto fumígeno, derivado ou não do tabaco, em ambientes de uso coletivo, públicos ou privados, total ou parcialmente fechados. ${ }^{533}$

No concernente à obrigação de suportar interferências estatais, um exemplo é o ingresso não autorizado de agente sanitário em ambiente privado, no exercício da função de vigilância epidemiológica, para descoberta e combate dos focos do Aedes aegypti (mosquito da dengue). Nesses casos, a medida interventiva estatal encontra fundamento nos artigos 11, 12 e 13 da Lei n. 6.259/1975 e no artigo 10 da Lei n. 6.437/1977 e poderia, em tese, violar o direito constitucional à inviolabilidade do domicílio, previsto no artigo $5^{\circ}$, inciso XI, da Constituição Federal. Contudo, o ingresso forçado em domicílio numa determinada região, como medida de caráter geral, no contexto de um programa de vigilância epidemiológica em que se busque a cobertura universalizada contra a dengue,

${ }^{532} \mathrm{O}$ artigo $6^{\circ}$ da Lei n. 10.778 , de 24 de novembro de 2003 prevê o seguinte: "Art. $6^{\circ}$ Aplica-se, no que couber, à notificação compulsória prevista nesta Lei, o disposto na Lei n ${ }^{\circ} 6.259$, de 30 de outubro de 1975." ${ }^{533} \mathrm{O}$ artigo $2^{\circ}$, caput, e parágrafos $1^{\circ}$ e $2^{\circ}$, da Lei estadual $n^{\circ} 13.541$, de 7 de maio de 2009, dispõe: “Artigo $2^{\circ}$ - Fica proibido no território do Estado de São Paulo, em ambientes de uso coletivo, públicos ou privados, o consumo de cigarros, cigarrilhas, charutos ou de qualquer outro produto fumígeno, derivado ou não do tabaco. $\S 1^{\circ}$ - Aplica-se o disposto no "caput" deste artigo aos recintos de uso coletivo, total ou parcialmente fechados em qualquer dos seus lados por parede, divisória, teto ou telhado, ainda que provisórios, onde haja permanência ou circulação de pessoas. $\S 2^{\circ}$ - Para os fins desta lei, a expressão "recintos de uso coletivo" compreende, dentre outros, os ambientes de trabalho, de estudo, de cultura, de culto religioso, de lazer, de esporte ou de entretenimento, áreas comuns de condomínios, casas de espetáculos, teatros, cinemas, bares, lanchonetes, boates, restaurantes, praças de alimentação, hotéis, pousadas, centros comerciais, bancos e similares, supermercados, açougues, padarias, farmácias e drogarias, repartições públicas, instituições de saúde, escolas, museus, bibliotecas, espaços de exposições, veículos públicos ou privados de transporte coletivo, viaturas oficiais de qualquer espécie e táxis." Essa lei também estabelece em seu artigo $8^{\circ}$ uma atribuição específica ao Poder Público estadual consistente na disponibilização de assistência terapêutica e medicamentos voltados a estimular os fumantes a pararem de fumar, nos seguintes termos: “Artigo $8^{\circ}$ Caberá ao Poder Executivo disponibilizar em toda a rede de saúde pública do Estado, assistência terapêutica e medicamentos antitabagismo para os fumantes que queiram parar de fumar." No mesmo sentido, foi editada a Lei federal $n^{\circ}$ 12.546, de 14 de dezembro de 2001, que modificou a Lei $n^{\circ}$ 9.294, de 15 de julho de 1996, para estabelecer, dentre outras normas, o seguinte: “Art. $2^{\circ}$ É proibido o uso de cigarros, cigarrilhas, charutos, cachimbos ou qualquer outro produto fumígeno, derivado ou não do tabaco, em recinto coletivo fechado, privado ou público.” O parágrafo $3^{\circ}$ desse artigo esclarece que se considera recinto coletivo “(...) o local fechado, de acesso público, destinado a permanente utilização simultânea por várias pessoas”. 
pode ser necessário ao atendimento do interesse público específico de evitar a proliferação da dengue e, neste caso, independe de autorização judicial. ${ }^{534} 535$

Portanto, a multifuncionalidade do direito à saúde também compreende o plexo de atribuições que incumbe aos Poderes Executivo, Legislativo e Judiciário desempenhar, conforme as respectivas competências constitucional e legalmente definidas.

\subsection{Eficácia e efetividade no direito à saúde}

Da afirmação da saúde como direito fundamental social à efetiva concretização do núcleo essencial da saúde para todos há um longo caminho a percorrer. ${ }^{536} \mathrm{O}$ desafio que se coloca ao jurista é descobrir as condições, os meios e as situações para a efetividade do direito à saúde, bem como os limites à eficácia deste direito fundamental. ${ }^{537}$

Primeiramente é preciso registrar que eficácia de uma norma constitucional ${ }^{538}$ significa sua aptidão para produzir efeitos jurídicos. ${ }^{539}$ Para José Afonso da Silva, a

${ }^{534}$ Neste sentido é a conclusão apresentada por SUNDFELD, conferir: SUNDFELD, Carlos Ari. Vigilância epidemiológica e direitos constitucionais. In: Programa Nacional de Controle da Dengue: amparo legal à execução das ações de campo - imóveis fechados, abandonados ou com acesso não permitido pelo morador. Ministério da Saúde, Secretaria de Vigilância em Saúde. 2. ed. Série C. Projetos, Programas e Relatórios. Brasília: Ministério da Saúde, p. 99-120, 2006.

${ }^{535}$ Sobre o tema, conferir: BRASIL. Ministério da Saúde. Secretaria de Vigilância em Saúde. Programa Nacional de Controle da Dengue: amparo legal à execução das ações de campo- imóveis fechados, abandonados ou com acesso não permitido pelo morador / Ministério da Saúde, Secretaria de Vigilância em Saúde. 2. ed. Brasília: Ministério da Saúde, 2006.

${ }^{536}$ BOBBIO admitiu existir uma crise de fundamentos de direitos do homem e se propôs a buscar, em cada caso concreto, os vários fundamentos possíveis (e não um fundamento absoluto) para que este ou aquele direito possa ser realizado. BOBBIO rebateu o dogma do racionalismo ético de que os valores últimos não só podem ser demonstrados como teoremas, mas de que basta demonstrá-los para que seja assegurada sua realização, por três razões: os direitos do homem não foram mais respeitados nas épocas em que os eruditos acordaram considerar que haviam encontrado um argumento irrefutável para defendê-los; apesar da crise dos fundamentos, grande parte dos governos proclamou nas últimas décadas uma Declaração Universal dos Direitos do Homem, o que significa que encontraram boas razões para fazê-lo, todavia é preciso criar condições para a realização dos direitos proclamados; o atual problema fundamental em relação aos direitos humanos não é de enuncia-los, mas de sim o de coloca-los em prática, pois os reacionários de todos os países contra os direitos do homem não alegam a sua falta de fundamento, mas sim sua inexequibilidade. BOBBIO, Norberto. A era dos direitos. Tradução de Carlos Nelson Coutinho, nova ed. Rio de Janeiro: Elsevier. 2004, p. 22-24.

${ }_{537}$ BOBBIO afiança que o problema grave de nosso tempo, com relação aos direitos humanos, não é mais o de fundamentá-los, e sim o de saber qual é o modo mais seguro para garanti-los, impedindo que, apesar das solenes declarações, eles sejam continuamente violados. Afirma que não se trata de um problema filosófico, mas de um problema jurídico e, num sentido mais amplo, político. BOBBIO, Norberto. A era dos direitos. Tradução de Carlos Nelson Coutinho, nova ed. Rio de Janeiro: Elsevier. 2004, p. 25.

${ }^{538}$ De acordo com BARROSO, as normas constitucionais quanto ao conteúdo podem ser classificadas em três grandes categorias: as que organizam o poder político (normas constitucionais de organização); as que definem direitos fundamentais (normas definidoras de direitos) e as que indicam valores e fins públicos 
eficácia de uma norma apresenta duas acepções: jurídica e social. A eficácia jurídica (ou aplicabilidade, exigibilidade ou executoriedade) designa a capacidade de uma norma atingir os objetivos previamente estabelecidos como metas, ou seja, a qualidade de produzir, em maior ou em menor grau, efeitos jurídicos, ao regular as situações, relações e comportamentos de que cogita. ${ }^{540}$ A eficácia social (efetividade), por sua vez, é a medida da extensão em que o objetivo é alcançado, relacionado ao produto final. ${ }^{541}$

A partir classificação concebida pela doutrina norte-americana sobre a eficácia das normas constitucionais como auto-aplicáveis (self executing) e não auto-aplicáveis (non self-executing), José Afonso da Silva apresentou sua crítica, observando que nem as normas ditas auto-aplicáveis produzem, desde logo, todos os seus efeitos, pois são sempre passíveis de novos desenvolvimentos, mediante legislação ordinária, nem as ditas não auto-aplicáveis têm eficácia nula, porque produzem efeitos jurídicos, ainda que reduzidos. $^{542}$ Não há, pois norma jurídica destituída de eficácia. ${ }^{543}$ Toda norma constitucional tem juridicidade e valor normativo, irradiando efeitos jurídicos até onde possa. Embora cada norma tenha eficácia e valor jurídico diverso, todas importam em inovação da ordem jurídica preexistente à ordenação instaurada pela nova Constituição a que aderem. ${ }^{544}$

A questão é, justamente, verificar quais são os efeitos parciais possíveis de cada norma constitucional e, no caso em estudo, do artigo $6^{\circ}$, combinado com os artigos 196 a 200 da Constituição da República.

De acordo com a formulação clássica de SILVA, as normas constitucionais comportam uma classificação tricotômica quanto à eficácia e aplicabilidade, assim

(normas constitucionais de princípio ou programáticas). BARROSO, Luís Roberto. Curso de Direito Constitucional contemporâneo: os conceitos fundamentais e a construção do novo modelo. São Paulo: Saraiva, 2009, p. 82-84.

${ }^{539}$ Luís Roberto. Curso de Direito Constitucional contemporâneo: os conceitos fundamentais e a construção do novo modelo. São Paulo: Saraiva, 2009, p. 212.

${ }^{540}$ BARCELLOS assim define eficácia jurídica: “(...) é um atributo associado aos enunciados normativos e consiste naquilo que se pode exigir, judicialmente se necessário, com fundamento em cada um deles." BARCELLOS, Ana Paula de. A eficácia jurídica dos princípios constitucionais: O princípio da dignidade da pessoa humana. 3.ed, Rio de Janeiro: Renovar, 2011, p.75.

${ }^{541}$ SILVA, José Afonso da. Aplicabilidade das normas constitucionais. 3.ed. São Paulo: Malheiros, 1998, p.65-66.

542 SILVA, José Afonso da. Aplicabilidade das normas constitucionais. 3.ed. São Paulo: Malheiros. 1998, p.73-77.

${ }^{543}$ Segundo SILVA: "Cada norma constitucional é sempre executável por si mesma até onde possa, até onde seja suscetível de execução". SILVA, José Afonso da. Aplicabilidade das normas constitucionais. 3.ed. São Paulo: Malheiros, 1998, p.76.

544 SILVA, José Afonso da. Aplicabilidade das normas constitucionais. 3.ed. São Paulo: Malheiros, 1998, p.77-81. 
enunciada: (i) normas constitucionais de eficácia plena e aplicabilidade direta, imediata e integral; (ii) normas constitucionais de eficácia contida e aplicabilidade direita e imediata, mas possivelmente não integral, porque sujeitas a restrições previstas ou dependentes de regulamentação que limite sua eficácia e aplicabilidade; e (iii) normas constitucionais de eficácia limitada, de aplicabilidade indireta, mediata e reduzida, pois apenas positivam princípios ou esquemas sobre a matéria objeto de cogitação do constituinte, sem que tenham recebido normatividade suficiente para sua aplicação, cabendo ao legislador ordinário a tarefa de completar a regulamentação das matérias nelas tratadas para que produzam principais efeitos. As normas constitucionais de eficácia limitada ou reduzida podem ser: (a) declaratórias de princípios institutivos ou organizativos; e (b) declaratórias de princípio programático. ${ }^{545}$

A classificação de José Afonso da Silva recebeu variadas críticas, condensadas e fortalecidas por Virgílio Afonso da Silva. Em síntese, Virgílio Afonso da Silva entende que não é apropriada a identificação de normas de eficácia plena (não restringíveis), ao menos em relação aos direitos fundamentais, porque tais normas consagrariam direitos absolutos. Como é pacífico o entendimento doutrinário e jurisprudencial acerca da inexistência de direitos absolutos, todos estão sujeitos a restrições, sejam decorrentes de disposições expressas ou implícitas no texto constitucional, de restrições impostas pelo legislador ordinário e às vezes até mesmo por ato entre particulares. Como exemplo, cita o direito de acesso ao Judiciário que seria restringido pela Lei de Arbitragem (Lei n. 9.307/96). Na sequência, afirma que toda norma que garante direitos fundamentais pode ser restringida e pode ser regulamentada, não tendo razão de existir, como categoria autônoma, as normas de eficácia contida. Por fim, afirma que todos os direitos dependem da atuação estatal, pois para que possam produzir os efeitos desejáveis são necessárias além de condições jurídicas, condições fáticas, institucionais e financeiras. Por isso, tampouco se justifica a referência a normas de eficácia limitada, porque todas estariam enquadradas nessa categoria.

Virgílio Afonso da Silva sustenta que as condições fáticas não são algo externo ao direito e devem, por isso, ser consideradas também na análise constitucional, que alguns autores (como José Afonso da Silva) entendem ser estritamente jurídica. Como todo direito

545 SILVA, José Afonso da. Aplicabilidade das normas constitucionais. 3.ed. São Paulo: Malheiros, 1998, p.81-87. 
implica em custos aos Estados, às vezes altíssimos, a questão da eficácia e da efetividade das normas constitucionais não se poderia se limitar a questões meramente textuais ou jurídicas, mas abranger também opções político-ideológicas. Para esclarecer sua teoria, Virgílio Afonso da Silva confronta a norma definidora do direito à saúde (Constituição Federal, artigo $6^{\circ}$ ) com a norma que estabelece o direito ao sufrágio (Constituição Federal, artigo 14), afirmando que no plano da possibilidade de produção dos efeitos desejados, a diferença eventualmente existente entre elas não está na dicotomia necessidade/desnecessidade de regulamentação e de regulação estatal, pois ambas dependem da ação estatal para produzirem efeitos. A diferença essencial entre estas normas estaria no plano jurídico-empírico e não no plano jurídico-analítico. Em outras palavras, se já existem condições institucionais, legais e financeiras para que a norma prevista no artigo 14 da Constituição Federal seja capaz de produzir seus efeitos, não se pode dizer que as condições institucionais, legais e, sobretudo, financeiras para a concretização do direito à saúde sejam ideais: faltam hospitais, faltam planos de carreira para os médicos, faltam recursos materiais para comprar medicamentos etc. Diante dessas condições, e somente por isso, na visão de Virgílio Afonso da Silva a norma que garante o direito à saúde é de eficácia limitada, porquanto incapaz de produzir os efeitos desejados. ${ }^{546}$

Em que pese a argumentação de Virgílio Afonso da Silva, adotamos o entendimento esposado por MARRARA e NUNES no sentido de que, segundo a classificação de José Afonso da Silva e com fundamento no disposto no parágrafo $1^{\circ}$, do artigo $5^{\circ}$, da Constituição Federal ${ }^{547}$, o direito à saúde está definido em norma constitucional de aplicabilidade imediata e de eficácia contida, produzindo efeitos desde logo, mas balizadas posteriormente pela atuação legislativa, especialmente no que diz respeito às prestações e aos bens oferecidos pelo Estado, a que o titular desse direito terá

\footnotetext{
546 Virgílio Afonso da Silva. Direitos fundamentais: conteúdo essencial, restrições e eficácia. 2.ed. São Paulo: Malheiros, 2010, p. 232-234.

547 “Art. $5^{\circ}$ Todos são iguais perante a lei, sem distinção de qualquer natureza, garantindo-se aos brasileiros e aos estrangeiros residentes no País a inviolabilidade do direito à vida, à liberdade, à igualdade, à segurança e à propriedade, nos termos seguintes: (...) $\S 1^{\circ}$ - As normas definidoras dos direitos e garantias fundamentais têm aplicação imediata."
} 
acesso. $^{548}$ De conseguinte, a norma é direta e imediatamente aplicável, contudo sua eficácia pode vir a ser restringida pela atuação do legislador ordinário.

O direito à saúde, por sua própria natureza, exige do Estado, dentre outras condutas, determinadas prestações de natureza material que nem sempre se tornam efetivas por razões políticas e jurídicas. BONAVIDES recorda que, inicialmente, o descumprimento dos direitos fundamentais de segunda geração estava arrimado na exiguidade, carência ou limitação essencial de meios e recursos. Em seguida, atravessaram uma crise de observância e execução, pois foram considerados direitos de eficácia contida, previstos em normas de conteúdo programático. ${ }^{549}$ Com o advento da Constituição da República de 1988, os direitos fundamentais de segunda geração caminham para a materialização na realidade social. ${ }^{550}$

Ao pensamento otimista de BONAVIDES, no sentido de uma progressiva evolução quanto à efetividade dos direitos sociais ${ }^{551}$, cumpre acrescentar que a realização desses direitos está imbricada com o grau de desenvolvimento econômico e social de cada País e a decisões de cunho político, num determinado momento histórico, que devem ser consideradas para a determinação de seus contornos. Assim, a efetividade dos direitos sociais deve ser a máxima possível conforme as condições fáticas de determinada sociedade.

\footnotetext{
${ }^{548}$ MARRARA, Thiago e NUNES, Lydia Neves Bastos Telles. Reflexões sobre o controle das políticas de saúde e de medicamentos. In: Direito à vida e à saúde: impactos orçamentário e judicial. BLIACHERIENE, Ana Carla; DOS SANTOS, José Sebastião. São Paulo: Atlas, p. 80, 2010.

${ }^{549}$ Neste sentido, de início era a posição dominante no Superior Tribunal de Justiça, como se infere do exame do acórdão proferido no Recurso Ordinário em Mandado de Segurança n. 6564/Rio Grande do Sul, no qual se decidiu: "Normas constitucionais meramente programáticas - ad exemplum, o direito à saúde - protegem um interesse geral, todavia, não conferem, aos beneficiários desse interesse, o poder de exigir sua satisfação pela via do mandamus - eis que não delimitado o seu objeto, nem fixada a sua extensão, antes que o legislador exerça o munus de completá-las através da legislação integrativa. Essas normas (Arts. 195, 196, 204 e 227 da CF) são de eficácia limitada, ou, em outras palavras, não têm força suficiente para desenvolverse integralmente, "ou não dispõem de eficácia plena", posto que dependem, para ter incidência sobre os interesses tutelados, de legislação complementar. (...) No sistema jurídico pátrio, a nenhum órgão ou autoridade é permitido realizar despesas sem a devida previsão orçamentaria, sob pena de incorrer no desvio de verbas. Recurso a que se nega provimento. (RMS 6564/RS, Rel. Ministro DEMÓCRITO REINALDO, PRIMEIRA TURMA, julgado em 23/05/1996, DJ 17/06/1996, p. 21448).

${ }^{550}$ BONAVIDES explica que a crise de baixa normatividade ou de eficácia duvidosa pela qual passaram os direitos sociais, culturais e econômicos estava ligada ao discurso sobre as limitações orçamentárias e o caráter programático das normas jurídicas que previam os direitos fundamentais de segunda geração. Contudo, entende que a crise de observância e execução desses direitos parece estar perto do fim, visto que recentes Constituições, inclusive a do Brasil, estabeleceram o preceito da aplicabilidade imediata dos direitos fundamentais. BONAVIDES, Paulo. Curso de Direito Constitucional. 22 ed. São Paulo: Malheiros, 2008, p. 564-569.

${ }^{551}$ BONAVIDES, Paulo. Curso de Direito Constitucional. 22 ed. São Paulo: Malheiros, 2008, p. 564-569.
} 
Não se pode deixar de observar que, assim como os demais direitos fundamentais, houve importante avanço com o reconhecimento expresso na Constituição de 1988 dos direitos sociais, ainda que haja avanços, retrocessos e limitações quanto à efetividade destes direitos.

Contudo, a questão da concretização dos direitos sociais no mundo dos fatos, ou seja, do plano do ser (ideal) ao do dever ser (real) não parece se restringir a mera questão de tempo, impondo-se uma contínua luta política. De acordo com BOBBIO, embora haja um sinal de progresso moral da humanidade, a garantia de proteção efetiva aos direitos sociais é mais difícil do que dos direitos de liberdade, pois a medida que as pretensões da sociedade aumentam, a satisfação delas torna-se cada vez mais difícil. ${ }^{552}$

Da evidente caracterização da Constituição de 1988 como uma Constituição social, dirigente e compromissária, é absolutamente lógico afirmar que seu conteúdo está dirigido para a conquista das promessas da modernidade. Contudo, por melhor que seja o texto constitucional, não é suficiente para a realização do Direito. Daí porque STRECK afirma que a eficácia (social) das normas constitucionais depende de um redimensionamento do papel do Judiciário e do jurista ante o seguinte paradoxo: "uma Constituição rica em direitos (individuais, coletivos e sócias) e uma prática jurídico-judiciária que, reiteradamente, (só)nega a aplicação de tais direitos". 553

Da Constituição enquanto mistificação ideológica e da ausência de determinação política em dar-lhe cumprimento, foi desenvolvida a "doutrina brasileira da efetividade", que visa basicamente tornar as normas constitucionais direta e imediatamente aplicáveis, na máxima extensão de sua densidade normativa. ${ }^{554}$

De acordo com BARROSO, a efetividade da Constituição há de se assentar sobre quatro pressupostos: (i) senso de realidade por parte do constituinte, para não normatizar o inalcançável; (ii) boa técnica legislativa, para regulamentar adequadamente as posições em que se investem os indivíduos e os bens jurídicos protegidos; (iii) vontade política do

${ }^{552}$ BOBBIO, Norberto. A era dos direitos; tradução de Carlos Nelson Coutinho; apresentação de Celso Lafer. Nova ed. $13^{\mathrm{a}}$ reimpressão. Rio de Janeiro: Elsevier, 2004, p.58-61.

${ }^{553}$ Para STRECK, portanto, o Direito, como legado da modernidade, deve ser visto hoje como um campo de luta social para a implantação das promessas de igualdade, justiça social, respeito aos direitos fundamentais, dentre outras, não podendo continuar a ser entendido como mera racionalidade instrumental. STRECK, Lenio Luiz. Jurisdição constitucional e hermenêutica: uma nova crítica do direito. Porto Alegre: Livraria do Advogado, 2002, p.28-29.

554 BARROSO, Luís Roberto. Da falta de efetividade à judicialização excessiva: Direito à saúde, fornecimento gratuito de medicamentos e parâmetros para a atuação judicial In Revista da ProcuradoriaGeral do Estado. Procuradoria-Geral do Estado do Rio Grande do Sul, v.31, n.66, p.91, julho/dezembro 2007. 
Poder Público de observar e aplicar as normas constitucionais; e (iv) o consciente exercício de cidadania, através da exigência por meio de articulação política e de medidas judiciais, do cumprimento dos valores e dos direitos subjetivos constitucionais. ${ }^{555} 556$

O legislador ordinário encontra-se juridicamente vinculado ao dever de utilizar a citada "boa técnica legislativa" para regular, de forma adequada, as normas constitucionais definidoras de direitos fundamentais, criando condições para o seu exercício, delimitando seu conteúdo frente a outros direitos, ou realizando medidas que tornem viáveis seu exercício e concretização (dimensão jurídico-objetiva dos direitos fundamentais). ${ }^{557}$

Da mesma forma que o aumento da densidade normativa dos direitos sociais depende da atividade do Legislativo e do Executivo, muitos dos direitos de liberdade também não têm todos os seus contornos previamente estabelecidos na norma constitucional que os definem. Assim, a interposição do legislador também pode aumentar a densidade normativa dos direitos de liberdade, fixando restrições à sua aplicabilidade. A norma constitucional que define "é livre o exercício de qualquer trabalho, ofício ou profissão, atendidas as qualificações profissionais que a lei estabelecer;" 558 ao tempo em que prevê um direito fundamental de liberdade, permite uma restrição indiretamente constitucional, autorizando a fixação de balizas ao direito por lei. Logo, em geral, ambas as categorias de direitos - direitos de liberdade e direitos sociais - demandam atuação legislativa e administrativa que fixe balizas, conferindo maior densidade aos seus conteúdos.

\footnotetext{
${ }^{555}$ BARROSO, Luís Roberto. Curso de Direito Constitucional contemporâneo: os conceitos fundamentais e a construção do novo modelo. São Paulo: Saraiva, 2009, p.220-221.

${ }^{556}$ Sobre o regime jurídico-constitucional dos direitos fundamentais, importa repisar que o parágrafo $2^{\circ}$, do artigo $5^{\circ}$, da Constituição Federal estabelece uma cláusula de abertura material para outros direitos fundamentais não previstos no Título II da Constituição Federal, mas que decorram do regime e dos princípios adotados pela Constituição, ou dos tratados internacionais que a República Federativa do Brasil seja parte: "Art. $5^{\circ}(\ldots) \S 2^{\circ}$ - Os direitos e garantias expressos nesta Constituição não excluem outros decorrentes do regime e dos princípios por ela adotados, ou dos tratados internacionais em que a República Federativa do Brasil seja parte." E, no mesmo sentido, o artigo $7^{\circ}$, caput, da Constituição Federal prevê a possibilidade de progressiva ampliação do catálogo de direitos dos trabalhadores previstos em seus incisos I a XXXIV: "Art. $7^{\circ}$ São direitos dos trabalhadores urbanos e rurais, além de outros que visem à melhoria de sua condição social: (...)".

557 Conforme MIRANDA, não basta declarar os direitos, hoje se reconhece a importância de "(...) instituir meios organizatórios de realização, procedimentos adequados e equitativos". MIRANDA, Jorge. Manual de Direito Constitucional. Parte IV: Direitos Fundamentais. 3.ed. Coimbra: Coimbra Editora, 2000, p.93.

558 “Art. $5^{\circ}$ Todos são iguais perante a lei, sem distinção de qualquer natureza, garantindo-se aos brasileiros e aos estrangeiros residentes no País a inviolabilidade do direito à vida, à liberdade, à igualdade, à segurança e à propriedade, nos termos seguintes: (...) XIII - é livre o exercício de qualquer trabalho, ofício ou profissão, atendidas as qualificações profissionais que a lei estabelecer;"
} 
A diferença entre os direitos de liberdade e os direitos sociais não consiste na necessidade ou desnecessidade da intermediação do legislador ordinário para conformálos. A diferença consiste, basicamente, no fato de que os direitos de liberdade foram os primeiros direitos historicamente reconhecidos e protegidos, já possuindo tradição de consolidação e conformação pelo legislador ordinário, ao passo que os direitos sociais somente num período mais recente passaram a ser reconhecidos como direitos fundamentais, sob a forma de preceitos juridicamente obrigatórios e vinculantes. ${ }^{559}$

Num sistema pluralista, as normas que reconhecem direitos sociais devem ser, por exigência lógica, normas abertas, para que possam receber concretizações conforme as alternativas periodicamente escolhidas pelo eleitorado. ${ }^{560}$ Nesse sentido, os direitos sociais têm uma densidade constitucional ${ }^{561}$, um conteúdo determinado, em maior ou em menor medida, pela atividade conformadora do legislador.

Após a intermediação legislativa, é necessária a atuação do Executivo, responsável pela implementação de políticas públicas dirigidas à promoção, proteção e recuperação da saúde e, assim, dos contornos mais precisos das prestações materiais oferecidas pelo Estado para a concretização do bem-estar físico e mental de todos e de cada um.

Cumpre realçar que a ausência de determinação precisa na ordem jurídicoconstitucional do alcance e do conteúdo normativo do direito à saúde não conduziu a defesa, pela doutrina constitucional brasileira, do entendimento de que estaria restringida ou afastada sua imediata justiciabilidade, ante a garantia constitucional expressamente prevista no artigo $5^{\circ}$, inciso XXXV, da Constituição Federal, segundo a qual "a lei não excluirá da apreciação do judiciário lesão ou ameaça a direito". Afinal, não se discute que o direito à saúde consiste em direito subjetivo, formal e materialmente fundamental, do qual decorrem variadas posições jurídicas que podem ser exigidas inclusive mediante ação judicial. ${ }^{562} 563$

\footnotetext{
${ }^{559}$ De acordo com PIOVESAN, o compromisso de realização dos direitos sociais significa um avanço no exercício das necessidades humanas básicas, assegurando condições materiais para uma vida com dignidade, baseada na solidariedade e na igualdade substancial. PIOVESAN, Flávia. Temas de Direitos Humanos. 6.ed. São Paulo: Saraiva, 2013, p. 146-151.

${ }^{560}$ MIRANDA, Jorge. Manual de Direito Constitucional. Parte IV: Direitos Fundamentais. 3.ed. rev. e atual. Coimbra: Coimbra Editora, 2000, p.113.

561 A expressão é utilizada por Jorge Miranda. MIRANDA, Jorge. Manual de Direito Constitucional. Parte IV: Direitos Fundamentais. 3.ed. rev. e atual. Coimbra: Coimbra Editora, 2000, p.113.

${ }^{562}$ Sobre as ações cabíveis para a tutela do direito à saúde, conferir: DUARTE, Luciana Gaspar Melquíades. Possibilidades e limites do controle judicial sobre as políticas públicas de saúde: um contributo para a dogmática do direito à saúde. Belo Horizonte: Fórum, 2011.
} 


\title{
A doutrina ${ }^{564}$ e a jurisprudência pátrias ${ }^{565} 566$ consagraram o entendimento de que o
}

\author{
direito fundamental à saúde não implica no dever de atendimento pelo Estado de qualquer
}

tipo de demanda de natureza prestacional relativa à saúde.

${ }^{563}$ É interessante o estudo feito por MARQUES E DALLARI sobre as funções do Executivo e do Judiciário na área de políticas de saúde, no qual exploram o problema dos critérios utilizados em decisões judiciais. Nas palavras dessas doutrinadoras: "o sistema jurídico deve garantir a existência de uma política pública de medicamentos pautada pela universalidade e equidade, que vise a assistência segura e eficaz à saúde dos cidadãos. Também, deve garantir a prestação ininterrupta de um serviço público de assistência farmacêutica para todos que dele necessitarem. Esta garantia refere-se às expectativas normativas, função que deve desempenhar o sistema jurídico. Nesse contexto, cabe à administração pública elaborar uma política e organizar um serviço que vise a atender, de forma integral e universal, o direito à assistência farmacêutica dos cidadãos. Para tanto, o sistema político precisa tomar decisões coletivas, com base nas principais necessidades de saúde da população e nos recursos disponíveis, para atender os cidadãos de forma segura e equânime. É de suma importância para a manutenção do equilíbrio social que o direito reconheça as políticas públicas, devidamente formalizadas perante o direito, como elemento integrante dos direitos sociais (...) É mister que o sistema jurídico garanta aos indivíduos o acesso ao serviço público de assistência farmacêutica ofertado pelo Estado e padronizado pela respectiva política pública. Ou, no caso da inexistência do serviço ou da política, que garanta a assistência farmacêutica e determine a prestação do serviço. Para que este direito seja garantido de forma adequada para toda coletividade, é necessário que o sistema jurídico conheça os elementos da política pública de medicamentos." MARQUES, Silvia Badim; e DALLARI, Sueli Gandolfi. Garantia do direito social à assistência farmacêutica no estado de São Paulo. In:Revista Saúde Pública, v.41, n. 1. São Paulo, p.101-107, fevereiro/2007.

${ }^{564}$ Conferir neste sentido: BARROSO, Luís Roberto. Da falta de efetividade à judicialização excessiva: Direito à saúde, fornecimento gratuito de medicamentos e parâmetros para a atuação judicial. In: Revista da Procuradoria-Geral do Estado. Procuradoria-Geral do Estado do Rio Grande do Sul, v.31, n.66, p.89-114, julho/dezembro 2007; MARRARA, Thiago e NUNES, Lydia Neves Bastos Telles. Reflexões sobre o controle das políticas de saúde e de medicamentos. In: Direito à vida e à saúde: impactos orçamentário e judicial. BLIACHERIENE, Ana Carla; DOS SANTOS, José Sebastião (organizadores). São Paulo: Atlas, p.79-96, 2010; SCAFF, Fernando Facury. A efetivação dos direitos sociais no Brasil: garantias constitucionais de financiamento e judicialização. In: A eficácia dos Direitos Sociais. SCAFF, Fernando Facury; ROMBOLI, Roberto; MIGUEL, Revenga (coordenadores). São Paulo: Quartier Latin, p.21-42, 2010. 565 Na Suspensão de Segurança n. 3073, a Ministra Ellen Gracie deferiu o pedido do Estado do Rio Grande do Norte para suspender a execução da liminar, acolhendo os argumentos de que o direito à saúde garante a "efetivação de políticas públicas que alcancem a população como um todo, assegurando-lhe acesso universal e igualitário, e não a situações individualizadas" e que, no caso concreto, o medicamento solicitado pelo impetrante além de ser de alto custo, não constava da lista do Programa de Dispensação de Medicamentos em Caráter Excepcional do Ministério da Saúde, se encontrando em fase de estudos e pesquisas. (STF, SS n. 3073/RN. Julgado em 09/02/2007. Ministra Ellen Gracie Presidente. DJ n. 32, de 14/02/2007); e no julgamento do Agravo Regimental interposto na Suspensão de Tutela Antecipada n. 175, do Ceará, o Plenário do Supremo Tribunal Federal avançou ao fixar parâmetros objetivos para o julgamento de demandas individuais promovidas em face do Estado, cujo pedido seja o fornecimento de medicamentos. No caso concreto foi negado provimento ao agravo, por unanimidade de votos, com fundamento no fato de o medicamento estar registrado na Agência Nacional de Vigilância Sanitária (ANVISA), na possibilidade de ocorrência de dano inverso e da não comprovação de lesão à ordem, à economia, à saúde e à segurança públicas. Nos termos do voto do Ministro relator: os direitos a prestações envolvem valores variáveis, conforme as necessidades de cada cidadão (distributividade); há um conflito entre direitos individuais e bens coletivos (ponderação); o atendimento da pretensão estatal não pode comprometer o funcionamento do Sistema Único de Saúde (SUS), que deve ser comprovado caso a caso (reserva do financeiramente possível); o dever de atendimento das demandas na área da saúde é de todos os entes da federação, com base no artigo 23, inciso II, da Constituição Federal (responsabilidade solidária) e os precedentes firmados pela $2^{\mathrm{a}}$ Turma do Supremo Tribunal Federal (RE 195.192-3/RS, RE-AgR 255.627-1 e RE 280.642); e o Estado deve cumprir as políticas públicas existentes (vinculação do Estado). Além dessas considerações, a grande contribuição do julgado consiste na definição dos seguintes critérios para a solução de casos que envolvam a dimensão positiva do direito à saúde: (i) a existência de política pública de saúde (em caso positivo, há direito subjetivo 
a prestação, em razão da vinculação do Estado às próprias normas que editou para regulamentar o cumprimento de suas tarefas na área da saúde); (ii) caso a prestação de saúde pleiteada não esteja abrangida por uma política pública é necessário desvendar se a ausência de prestação decorre de (ii.1) omissão legislativa ou administrativa, (ii.2) de uma decisão administrativa de não fornecê-la ou (ii.3) de uma vedação legal a sua dispensação. No último caso, há vedação legal à Administração Pública fornecer medicamento que não possua registro na ANVISA (Lei n. 6.360/76, artigos 12, 16 e 18 e Lei n. 9.782/99), sendo dispensado excepcionalmente em programas de saúde pública do Ministério da Saúde. Na hipótese de existir decisão administrativa no sentido do não atendimento da pretensão porque inexistiam evidências científicas suficientes para autorizar sua inclusão, é preciso verificar se o SUS fornece tratamento alternativo, mas inadequado a determinado paciente, ou se o SUS não disponibiliza nenhum tratamento específico para a patologia que apresenta. A princípio, a obrigação do Estado ante o disposto no artigo 196 da Constituição, limita-se ao fornecimento das políticas sociais e econômicas por ele formuladas para a promoção, proteção e recuperação da saúde, pois o Sistema Único de Saúde filiou-se à corrente da "Medicina com base em evidências", tendo sido adotados Protocolos Clínicos e Diretrizes Terapêuticas, que representam um consenso científico sobre o tratamento eficaz e eficiente atual. Também por conta do custo da pretensão do demandante deve ser preferida a alternativa oferecida pelo SUS e somente se for comprovada a ineficácia ou a impropriedade da política de saúde existente é que será assegurada a opção diversa escolhida pelo paciente (o que pode ser feito pela Administração ou pelo Judiciário). Em caso de inexistência de tratamento oferecido pela rede pública é preciso verificar se a pretensão se refere a tratamento puramente experimental (sem comprovação científica de sua eficácia) ou a novo tratamento ainda não testado pelo Sistema de Saúde brasileiro. No primeiro caso, o tratamento consiste em pesquisas clínicas e a participação do indivíduo nesta fase é regida pelas normas que regulam a pesquisa médica, não sendo possível condenar o Estado a fornecêlo. Na hipótese de se tratar de um medicamento novo, a demora na elaboração de Protocolo Clínico não pode importar em violação ao princípio da integralidade do sistema, nem justificar a diferença entre as opções de tratamento acessíveis aos usuários da rede pública e aquelas disponíveis aos usuários da rede privada. Nesses casos, a omissão administrativa no tratamento de determinada patologia poderá ser objeto de impugnação judicial (por ações individuais ou coletivas), sendo necessária a instrução processual, com ampla produção de provas, para se verificar a adequação da pretensão à ordem jurídica. (STF, AR STA 175/CE. Plenário. Relator e Presidente Ministro Gilmar Mendes, julgado em 17/03/2010. DJ n. 76, de 30/04/2010).

566 Tendo em consideração a complexidade das demandas judiciais envolvendo o direito à saúde, o Conselho Nacional de Justiça editou a Recomendação n. 31, de 30 de março de 2010, pela qual recomenda aos Tribunais, dentre outras, a adoção de medidas para melhor subsidiar os magistrados e demais operadores do direito, para assegurar maior eficiência na solução das demandas judiciais envolvendo a assistência à saúde, especialmente no tocante ao conhecimento aprofundado do Direito Sanitário e das políticas públicas. Por meio deste ato, o Conselho Nacional de Justiça recomenda aos Tribunais de Justiça dos Estados e aos Tribunais Regionais Federais que, dentre outras medidas: I. Recomendar aos Tribunais de Justiça dos Estados e aos Tribunais Regionais Federais que: a) até dezembro de 2010 celebrem convênios que objetivem disponibilizar apoio técnico composto por médicos e farmacêuticos para auxiliar os magistrados na formação de um juízo de valor quanto à apreciação das questões clínicas apresentadas pelas partes das ações relativas à saúde, observadas as peculiaridades regionais; b) orientem, através das suas corregedorias, aos magistrados vinculados, que: b.1) procurem instruir as ações, tanto quanto possível, com relatórios médicos, com descrição da doença, inclusive CID, contendo prescrição de medicamentos, com denominação genérica ou princípio ativo, produtos, órteses, próteses e insumos em geral, com posologia exata; b.2) evitem autorizar o fornecimento de medicamentos ainda não registrados pela ANVISA, ou em fase experimental, ressalvadas as exceções expressamente previstas em lei; b.3) ouçam, quando possível, preferencialmente por meio eletrônico, os gestores, antes da apreciação de medidas de urgência; b.4) verifiquem, junto à Comissão Nacional de Ética em Pesquisas (CONEP), se os requerentes fazem parte de programas de pesquisa experimental dos laboratórios, caso em que estes devem assumir a continuidade do tratamento; b.5) determinem, no momento da concessão de medida abrangida por política pública existente, a inscrição do beneficiário nos respectivos programas; c) incluam a legislação relativa ao direito sanitário como matéria individualizada no programa de direito administrativo dos respectivos concursos para ingresso na carreira da magistratura, de acordo com a relação mínima de disciplinas estabelecida pela Resolução 75/2009 do Conselho Nacional de Justiça; d) promovam, para fins de conhecimento prático de funcionamento, visitas dos magistrados aos Conselhos Municipais e Estaduais de Saúde, bem como às unidades de saúde pública ou conveniadas ao SUS, dispensários de medicamentos e a hospitais habilitados em Oncologia como Unidade de Assistência de Alta Complexidade em Oncologia - UNACON ou Centro de Assistência de Alta Complexidade em Oncologia - CACON; II. Recomendar à Escola Nacional de Formação e Aperfeiçoamento 
O Supremo Tribunal Federal, em decisão paradigmática proferida no Agravo Regimental interposto na Suspensão de Tutela Antecipada n. 175, contribuiu para o avanço da discussão sobre a "judicialização da saúde", fixando critérios objetivos para o julgamento de demandas individuais sobre direito a prestações em saúde, quais sejam: o exame da situação fática do indivíduo, o cumprimento dos deveres estatais concernentes ao direito a prestações e a motivação do Estado para o não atendimento específico do bem ou serviço objeto da pretensão deduzida em juízo.

Nesta decisão, o Supremo Tribunal Federal minudenciou os desdobramentos desses critérios nas seguintes hipóteses: (i) a existência de política pública de saúde que, em caso positivo, evidencia a existência de um direito subjetivo público à prestação, em razão da vinculação do Estado às próprias normas que editou para regulamentar o cumprimento de suas tarefas na área da saúde ${ }^{567}$; (ii) caso a prestação de saúde pleiteada não esteja abrangida por uma política pública é necessário verificar se a ausência de prestação decorre de (ii.1) omissão legislativa ou administrativa, (ii.2) de uma decisão administrativa de não fornecê-la, caso em que deve ser verificada a existência de tratamento alternativo fornecido pelo sistema público de saúde e se o mesmo é adequado para tratar o paciente com eficiência, ou (ii.3) de uma vedação legal a sua dispensação. Nesta última situação se enquadram os medicamentos e tratamentos de saúde em fase experimental e aqueles que não tenham sido registrados pela Agência Nacional de Vigilância Sanitária (ANVISA), sobretudo devido à ausência de comprovação científica acerca da segurança e dos benefícios que o fármaco apresenta, pois o Sistema Único de Saúde (SUS) adota a "Medicina com base em evidências", utilizando Protocolos Clínicos e Diretrizes

de Magistrados - ENFAM, à Escola Nacional de Formação e Aperfeiçoamento de Magistrados do Trabalho ENAMAT e às Escolas de Magistratura Federais e Estaduais que: a) incorporem o direito sanitário nos programas dos cursos de formação, vitaliciamento e aperfeiçoamento de magistrados; b) promovam a realização de seminários para estudo e mobilização na área da saúde, congregando magistrados, membros do ministério público e gestores, no sentido de propiciar maior entrosamento sobre a matéria." (Publicado no

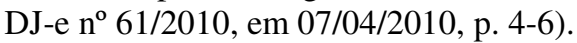

567 Neste sentido: "Doente portadora do vírus HIV, carente de recursos indispensáveis à aquisição dos medicamentos de que necessita para seu tratamento. Obrigação imposta pelo acórdão ao Estado. Alegada ofensa aos artigos $5^{\circ}$, I e 196 da CF. Decisão que teve por fundamento central dispositivo de lei (art. $1^{\circ}$ da Lei 9.908/1993) por meio da qual o próprio Estado do Rio Grande do Sul, regulamentando a norma do art. 196 da CF, vinculou-se a um programa de distribuição de medicamentos a pessoas carentes, não havendo, por isso, que se falar em ofensa aos dispositivos constitucionais apontados." (RE 242.859, relator Ministro Ilmar Galvão, julgamento em 29-6-1999, Primeira Turma, DJ de 17-9-1999). 
Terapêuticas (PCDT), que representam um consenso científico atual sobre o tratamento eficaz e eficiente de cada doença ou agravo à saúde. ${ }^{568}$

A despeito da complexidade existente em matéria de controle judicial de políticas públicas, é extreme de dúvidas que a atuação do Supremo Tribunal Federal de estabelecer critérios objetivos para a apreciação e o julgamento de demandas relativas ao direito a prestações materiais de saúde significou um progresso nas discussões sobre a concretização do direito à saúde.

Em sede de conclusão, a configuração das balizas do direito à saúde deve ser feita a partir da integração de preceitos constitucionais e legais que o regulamentam, determinando, no mundo dos fatos, o alcance de seu conteúdo. O direito à saúde deve ser implementado através de "políticas sociais e econômicas", que alcancem toda a coletividade, por meio de um conjunto de normas emitidas pelo Legislativo e pelo Executivo, ao qual o Estado fica juridicamente vinculado.

\subsubsection{Teoria do mínimo existencial}

O direito à saúde, em sua dimensão positiva, gera um direito a prestações materiais cujo atendimento exige elevados recursos financeiros do Estado. Ante a escassez de recursos e a infinidade de necessidades sociais, o direito à saúde pode sofre restrições, respeitado, porém, seu núcleo essencial, denominado também de "mínimo existencial". O que seria o núcleo essencial do direito à saúde que seria intangível à ação do Estado? Qual o standard mínimo de concreção do direito à saúde é possível exigir do Estado?

Há uma parcela do conteúdo do direito à saúde que materializa posições jurídicas protegidas em face das intervenções do Poder Público e de particulares (eficácia horizontal). Muito embora a Constituição Federal de 1988 não tenha reconhecido expressamente uma garantia do mínimo existencial dos direitos fundamentais, a salvaguarda desse núcleo essencial vem sendo reconhecida judicialmente. ${ }^{569}$

\footnotetext{
${ }^{568}$ STF, AR STA 175/CE. Plenário. Relator e Presidente Ministro Gilmar Mendes, julgado em 17/03/2010. DJ n. 76, de 30/04/2010.

569 “(...) A controvérsia pertinente à "reserva do possível” e a intangibilidade do mínimo existencial: a questão das "escolhas trágicas". A destinação de recursos públicos, sempre tão dramaticamente escassos, faz instaurar situações de conflito, quer com a execução de políticas públicas definidas no texto constitucional, quer, também, com a própria implementação de direitos sociais assegurados pela Constituição da República, daí resultando contextos de antagonismo que impõem, ao Estado, o encargo de superá-los mediante opções por determinados valores, em detrimento de outros igualmente relevantes, compelindo, o Poder Público, em face dessa relação dilemática, causada pela insuficiência de disponibilidade financeira e orçamentária, a
} 
O tema da vinculação dos direitos fundamentais com o que foi designado de uma garantia de um mínimo existencial não é novo e, segundo SARLET e FIGUEIREDO, teve significativa influência da experiência germânica. ${ }^{570}$ Afirmam que, para a doutrina e jurisprudência alemã prevalente, o conteúdo do mínimo existencial compreende as condições materiais para uma vida condigna, protegida contra necessidades de caráter básico (mínimo fisiológico), somadas à inserção do indivíduo na vida social (mínimo sociocultural). Nesta linha argumentativa, o mínimo existencial abrangeria a garantia de condições básicas de vida saudável, no contexto do Estado Social, fundado no direito à vida, na dignidade da pessoa humana e no princípio da igualdade material. ${ }^{571}$

No Brasil, é relevante a contribuição doutrinária de Ricardo Lobo Torres, que se dedica ao estudo da matéria pelo menos desde 1989, quando foi publicado seu artigo intitulado "O Mínimo Existencial e os Direitos Fundamentais." ${ }^{572}$ Neste artigo, TORRES esclarece que o direito fundamental às condições mínimas de existência digna se insere dentre os direitos de liberdade, pois sem ele desaparecem as condições para o exercício da

proceder a verdadeiras “escolhas trágicas”, em decisão governamental cujo parâmetro, fundado na dignidade da pessoa humana, deverá ter em perspectiva a intangibilidade do mínimo existencial, em ordem a conferir real efetividade às normas programáticas positivadas na própria Lei Fundamental. Magistério da doutrina. - A cláusula da reserva do possível - que não pode ser invocada, pelo Poder Público, com o propósito de fraudar, de frustrar e de inviabilizar a implementação de políticas públicas definidas na própria Constituição encontra insuperável limitação na garantia constitucional do mínimo existencial, que representa, no contexto de nosso ordenamento positivo, emanação direta do postulado da essencial dignidade da pessoa humana. Doutrina. Precedentes. - A noção de "mínimo existencial", que resulta, por implicitude, de determinados preceitos constitucionais $\left(\mathrm{CF}\right.$, art. $1^{\circ}$, III, e art. $3^{\circ}$, III), compreende um complexo de prerrogativas cuja concretização revela-se capaz de garantir condições adequadas de existência digna, em ordem a assegurar, à pessoa, acesso efetivo ao direito geral de liberdade e, também, a prestações positivas originárias do Estado, viabilizadoras da plena fruição de direitos sociais básicos, tais como o direito à educação, o direito à proteção integral da criança e do adolescente, o direito à saúde, o direito à assistência social, o direito à moradia, o direito à alimentação e o direito à segurança. Declaração Universal dos Direitos da Pessoa Humana, de 1948 (Artigo XXV)." (Agravo Regimental no Recurso Extraordinário com Agravo RE 639337 AgR, relator Ministro CELSO DE MELLO, Segunda Turma, julgado em 23/08/2011, DJe-177 DIVULG 14-09-2011 PUBLIC 15-09-2011 EMENT VOL-02587-01 PP-00125).

${ }^{570}$ Segundo SARLET e FIGUEIREDO, desde o Segundo pós-Guerra, no início da década de 1950, já havia doutrinadores que defendiam a possibilidade do reconhecimento de um direito subjetivo a recursos mínimos para uma existência digna. Afirmam que o primeiro jurista renomado a defender a possibilidade de o indivíduo postular recursos materiais ao Estado, com fundamento na dignidade da pessoa humana, prevista no artigo $1^{\circ}$, inciso I, da Lei Fundamental da Alemanha, foi Otto Bachof. SARLET, Ingo Wolfgang; FIGUEIREDO, Mariana Filchner. Reserva do possível, mínimo existencial e direito à saúde: algumas aproximações. In: Revista de Doutrina da $4^{a}$ Região. Porto Alegre, n. 24, p.8, julho de 2008.

${ }^{571}$ SARLET, Ingo Wolfgang; FIGUEIREDO, Mariana Filchner. Reserva do possível, mínimo existencial e direito à saúde: algumas aproximações. In: Revista de Doutrina da $4^{\text {a }}$ Região. Porto Alegre, n. 24, p.9-10, julho de 2008.

572 TORRES, Ricardo Lobo. O Mínimo Existencial e os Direitos Fundamentais. In: Revista de Direito Administrativo, n. 177, p. 20-49, julho/setembro 1989. 
liberdade. ${ }^{573}$ Embora seja difícil estremar o mínimo existencial dos direitos econômicos e sociais, entende que o mínimo existencial visa garantir as condições da liberdade, da segurança jurídica e da personalidade, encontrando-se inserido nos direitos de liberdade (abrangendo proteção negativa e proteção positiva ${ }^{574}$ ), ao passo que os direitos econômicos e sociais estão relacionados à justiça social. ${ }^{575}$

Para TORRES, portanto, não se confundem o status positivus socialis e o status positivus libertatis. A distinção é relevante, porque as prestações positivas para apoio aos direitos sociais (status positivus socialis) não seriam obrigatórias e dependeriam da situação econômica conjuntural do país e da riqueza nacional (reserva do possível e autorização orçamentária), sendo tanto mais abrangente, quanto mais rico e menos suscetível a crises seja o Estado. De outro lado, as posições jurídicas relativas ao status positivus libertatis, geram a obrigatoriedade da entrega de prestações positivas para a defesa dos direitos fundamentais, constituindo direito subjetivo do cidadão. ${ }^{576}$

Sob o ponto de vista de SARLET e FIGUEIREDO, o mínimo existencial compreende os direitos sociais, pois abarca o conjunto de prestações materiais indispensáveis para assegurar a cada pessoa uma vida condigna, saudável. Seria o núcleo essencial dos direitos fundamentais, blindado contra qualquer intervenção estatal ou da

\footnotetext{
573 TORRES faz uma relação do direito ao mínimo existencial e à vedação ao retrocesso ao afirmar o seguinte: "A dignidade humana e as condições materiais da existência não podem retroceder aquém de um mínimo, do qual nem os prisioneiros, os doentes mentais e os indigentes podem ser privados". Para ilustrar, cita Anatole France, dizendo que liberdade de viver em baixo da ponte não é liberdade. TORRES, Ricardo Lobo. O Mínimo Existencial e os Direitos Fundamentais In Revista de Direito Administrativo, n. 177, p. 20, julho/setembro 1989.

${ }^{574}$ A proteção negativa do mínimo existencial se refere, por exemplo, às imunidades tributárias e a proteção positiva abrange as prestações estatais obrigatórias e necessárias ao mínimo existencial, como a entrega de bens públicos independentemente de contraprestação financeira, como a celebração do casamento civil e a assistência judiciária aos necessitados. TORRES, Ricardo Lobo. O Mínimo Existencial e os Direitos Fundamentais In Revista de Direito Administrativo, n. 177, p. 20-49, julho/setembro 1989.

575 TORRES, Ricardo Lobo. O Mínimo Existencial e os Direitos Fundamentais In Revista de Direito Administrativo, n. 177, p.20-49, julho/setembro 1989.

${ }^{576}$ Em suas conclusões, TORRES destaca que o direito às condições mínimas de existência humana digna por ser inato nem sempre está expresso no texto constitucional, mas independentemente disso, está protegido negativamente contra a intervenção estatal e garantido positivamente mediante prestações materiais. Afirma que este direito se concretiza pelo processo democrático e que cada um dos Poderes tem seu papel: ao Legislativo cabe regulamentar as imunidades fiscais; ao Executivo compete a entrega das prestações positivas, que constituem direito subjetivo do cidadão, independentemente de contraprestação financeira; e ao Judiciário cabe assegurar as imunidades e determinar a entrega das prestações positivas necessárias à liberdade, ainda que não previstas na lei. TORRES, Ricardo Lobo. O Mínimo Existencial e os Direitos Fundamentais In Revista de Direito Administrativo, n. 177, p. 20-49, julho/setembro 1989.
} 
sociedade. Não haveria a possibilidade de se estabelecer a priori e taxativamente um elenco fechado das posições jurídico-subjetivas correspondentes ao mínimo existencial. ${ }^{577}$

No plano internacional, conforme exposto no capítulo 1, além da concepção ampla de saúde propugnada pela Organização Mundial de Saúde (OMS), segundo a qual se aproximam as noções de saúde e qualidade de vida, a Recomendação Geral n. 14, de 2000, do Comitê sobre os Direitos Econômicos, Sociais e Culturais (CDESC) das Nações Unidas estabelece em seus itens 43 e 44, parâmetros para definir o conteúdo mínimo essencial quanto ao direito de toda pessoa desfrutar do mais alto nível possível de saúde física e mental, previsto no artigo 12 do Pacto Internacional sobre Direitos Econômicos, Sociais e Culturais $^{578}$, quais sejam, as obrigações básicas e prioritárias atribuídas aos Estados Partes. ${ }^{579}$

577 SARLET, Ingo Wolfgang; FIGUEIREDO, Mariana Filchner. Reserva do possível, mínimo existencial e direito à saúde: algumas aproximações In Revista de Doutrina da $4^{\text {a }}$ Região. Porto Alegre, n. 24, p.9-10, julho de 2008.

${ }^{578}$ O Pacto Internacional de Direitos Econômicos, Sociais e Culturais (PIDESC), de 1966, dispõe o seguinte em seu artigo 12: "Artigo 12. 1. Os Estados Partes no presente Pacto reconhecem o direito de todas as pessoas de gozar do melhor estado de saúde física e mental possível de atingir. 2. As medidas que os Estados Partes no presente Pacto tomarem com vista a assegurar o pleno exercício deste direito deverão compreender as medidas necessárias para assegurar: a) A diminuição da mortinatalidade e da mortalidade infantil, bem como o são desenvolvimento da criança; b) $\mathrm{O}$ melhoramento de todos os aspectos de higiene do meio ambiente e da higiene industrial; c) A profilaxia, tratamento e controlo das doenças epidêmicas, endêmicas, profissionais e outras; d) A criação de condições próprias a assegurar a todas as pessoas serviços médicos e ajuda médica em caso de doença."

${ }^{579} \mathrm{Na}$ Observação geral n. 3, o Comitê confirma que os Estados Partes têm a obrigação fundamental de assegurar como mínimo a satisfação de níveis essenciais de cada um dos direitos enunciados no Pacto, incluída a atenção primária básica de saúde. Considerada conjuntamente com instrumentos mais recientes, como o Programa de Ação da Conferência Internacional sobre População e Desenvolvimento, a Declaração de Alma-Ata oferece uma orientação inequívoca quanto às obrigações básicas nos termos do artigo 12. Por conseguinte, o Comité considera como obrigações fundamentais pelo menos as seguintes: (i) garantir o direito de acesso a bens, instalações e serviços de saúde sem discriminação alguma, em especial em relação aos grupos vulneráveis ou marginalizados; (ii) assegurar o acesso a uma alimentação essencial mínima, nutritivamente adequada e segura e assegurar que ninguém padeça de fome; (iii) garantir o acesso à habitação, condições sanitárias adequadas e água limpa e potável; (iv) fornecer medicamentos essenciais, segundo as orientações periódicas da Organização Mundial de Saúde; (v) zelar pela distribuição equitativa de bens, instalações e serviços de saúde; e (vi) adotar e aplicar, a partir de estudos epidemiológicos, uma estratégia e plano de ação nacional de saúde pública para fazer frente às preocupações em matéria de saúde de toda a população. A estratégia e o plano de ação deverão ser elaborados e periodicamente revisados, num processo participativo e transparente, que estabeleça o direito a indicadores de saúde, mediante a instituição de sistemas de informação, e bases de referência da saúde que permitam monitorar eficazmente os progressos realizados (item 43 da Recomendação Geral n. 14, de 2000). Há também obrigações específicas, definidas como prioritárias: a) zelar pela atenção à saúde materna e infantil; b) proporcionar imunização contra as principais enfermidades infecciosas; c) adotar medidas para prevenir, tratar e combater as enfermidades epidêmicas e endêmicas; d) estimular políticas educacionais que tenham como objeto o acesso à informação sobre os principais problemas em saúde da comunidade; e) proporcionar capacitação adequada ao pessoal do setor da saúde, incluída a educação em matéria de saúde e direitos humanos (item 44 da Recomendação Geral n. 14, de 2000). 
Neste sentido, seria possível afirmar que a satisfação dos níveis essenciais mínimos do direito à saúde depende, pois, da garantia de acesso a serviços de saúde de forma igualitária; de uma alimentação básica, de acesso à moradia, de condições sanitárias adequadas, de água potável, do fornecimento de medicamentos essenciais, do zelo pela distribuição equitativa de serviços de saúde e da adoção de políticas públicas de saúde a partir de estudos epidemiológicos, dentre outras medidas. ${ }^{580}$

No plano interno, os contornos essenciais do direito à saúde foram desenhados no próprio texto constitucional. A Constituição Federal de 1988 não se limitou a reconhecer o direito à saúde como direito fundamental dentre os demais direitos sociais consagrados em seu artigo $6^{\circ}$, dedicando uma seção própria no capítulo da seguridade social ao tema da saúde. ${ }^{581}$ Nos artigos 196 a 200 da Constituição Federal foram especificadas algumas das obrigações dos poderes públicos em relação à saúde da população, definidas as diretrizes das ações e dos serviços de saúde, as linhas gerais que regulam a gestão administrativa dos serviços de saúde e um conjunto exemplificativo de competências do Sistema Único de Saúde (SUS).

O artigo 196 da Constituição Federal estabelece que a saúde é direito de todos e dever do Estado, que deve garanti-lo mediante políticas sociais e econômicas que objetivem "a redução do risco de doença e de outros agravos" e "ao acesso universal e igualitário às ações e serviços para sua promoção, proteção e recuperação”. Com efeito, no Direito Constitucional brasileiro está expresso o dever do Estado de realizar ações e serviços voltados à promoção, proteção e recuperação da saúde, que tenham por fim a redução dos riscos de doença e enfermidades (medidas preventivas) e estejam disponíveis a todas as pessoas (universalidade), sem discriminação (tratamento igualitário). Assim, o núcleo essencial mínimo do direito à saúde impõe aos poderes públicos a elaboração e implementação de políticas sociais e econômicas que visem, primordialmente, a prevenção da ocorrência de doenças e de outros agravos, além de assegurar a universalidade de acesso

\footnotetext{
${ }^{580}$ Segundo OLIVEIRA, embora seja possível discutirmos sobre a noção de dignidade humana, é intuitivamente perceptível que os elementos constituintes das obrigações essenciais podem ser considerados como o conteúdo tangível da dignidade humana, na medida em que sua substância intangível sustenta-se em valores de outra ordem, como honra, autonomia, liberdade e privacidade. OLIVEIRA, Aline Albuquerque Sant'Anna de. Direito à Saúde: conteúdo, essencialidade e monitoramento. In: Revista CEJ (Brasília). Ano XIV. Volume 48, p.99, Janeiro/março 2010. .

581 Seção II (Da Saúde), do Capítulo II (Da Seguridade Social), do Título VIII (Da ordem Social) da Constituição Federal de 1988.
} 
e a ausência de discriminação em todas as ações e serviços para a promoção, a proteção e a recuperação da saúde.

O artigo 197 reconhece a relevância pública das ações e dos serviços de saúde ${ }^{582}$ e em seguida, o artigo 198 prevê que "as ações e serviços públicos de saúde integram uma rede regionalizada e hierarquizada e constituem um sistema único, organizado de acordo com as seguintes diretrizes: descentralização, com direção única em cada esfera de governo; atendimento integral, com prioridade para as atividades preventivas, sem prejuízo dos serviços assistenciais; a participação da comunidade."

Os artigos 197 e 198 da Constituição Federal conferem maior precisão ao conteúdo jurídico mínimo do direito à saúde, definindo que as ações e serviços públicos de saúde, em razão de sua essencialidade, têm relevância pública e formam um sistema único, orientado pela descentralização, atendimento integral e participação ampla da comunidade. No tocante à diretriz de atendimento integral, as condutas positivas do Estado devem compreender: (i) prestações preventivas, ou seja, medidas fáticas e normativas que objetivem evitar a ocorrência e a proliferação de doenças, agravos e eventos em saúde (abrangem os deveres de proteção da saúde); (ii) prestações curativas, isto é, medidas fáticas consistentes no oferecimento de medicamentos ou tratamentos que viabilizem a cura da população (se referem aos deveres de recuperação da saúde); (iii) prestações promocionais, que incluem medidas fáticas e normativas voltadas a incrementar a qualidade de vida das pessoas (consistem nos deveres de promoção da saúde).

O dever de observância do mínimo existencial relativo ao direito à saúde tem como princípio nuclear a dignidade da pessoa humana ${ }^{583}$ e seu estreito vínculo com direito à vida. Todas as pessoas têm direito de que sejam respeitadas e promovidas as condições necessárias à manutenção da própria existência com alguma qualidade ${ }^{584} \mathrm{e}$ têm o direito de receber igual tratamento, sem distinção de qualquer natureza.

Na perspectiva do que se pode compreender como um mínimo existencial devem ser incluídos os serviços de saneamento básico pelo poder público, considerada a

582 “Art. 197 São de relevância pública as ações e serviços de saúde, cabendo ao Poder Público dispor, nos termos da lei, sobre sua regulamentação, fiscalização e controle, devendo sua execução ser feita diretamente ou através de terceiros e, também, por pessoa física ou jurídica de direito privado".

583 PIOVESAN, Flávia. Temas de Direitos Humanos. 6.ed. São Paulo: Saraiva, 2013, p.157.

${ }^{584}$ Para FIGUEIREDO o critério de interpretação do direito fundamental à saúde deve ser extensivo, no sentido de assegurar a melhor e mais ampla eficácia às normas de direitos fundamentais e ao texto constitucional como um todo. FIGUEIREDO, Mariana Filchtiner. Algumas notas sobre a eficácia e efetividade do direito fundamental à saúde no contexto constitucional brasileiro in Boletim do Instituto de Saúde. Direito à Saúde, v.12, n.3, p.224, Dezembro de 2010. . 
essencialidade desses serviços à vida e à saúde pública. A Lei n. 11.445 , de 5 de janeiro de 2007 estabelece as diretrizes nacionais para o saneamento básico e a política federal de saneamento básico. Nos termos do artigo $3^{\circ}$ dessa lei, o saneamento básico abrange: o abastecimento de água potável; o esgotamento sanitário; a limpeza urbana e manejo de resíduos sólidos; e a drenagem e manejo das águas pluviais urbanas. 585586

A política nacional de saneamento básico tem como objetivos assegurar o acesso de toda população (universalização) a este conjunto de serviços (integralidade) ${ }^{587}$, que podem ser prestados diretamente pelo poder público, mediante contrato de programa ou concessão de serviço público.

Contudo, as metas previstas no artigo $2^{\circ}$, da Lei 11.445/2007 estão longe de ser alcançadas: os serviços de coleta de esgoto são prestados a menos de $50 \%$ (cinquenta por cento) da população brasileira e do esgoto gerado menos de $40 \%$ recebe algum tipo de

585 A Lei n. 11.445, de 5 de janeiro de 2007 estabelece as diretrizes nacionais para o saneamento básico e a política federal de saneamento básico e foi regulamentada pelo Decreto n. 7.217, de 21 de junho de 2010. Nos termos do artigo $3^{\circ}$ da Lei n. 11.445/2007: "Art. $3^{\circ}$ Para os efeitos desta Lei, considera-se: I saneamento básico: conjunto de serviços, infra-estruturas e instalações operacionais de: a) abastecimento de água potável: constituído pelas atividades, infra-estruturas e instalações necessárias ao abastecimento público de água potável, desde a captação até as ligações prediais e respectivos instrumentos de medição; b) esgotamento sanitário: constituído pelas atividades, infra-estruturas e instalações operacionais de coleta, transporte, tratamento e disposição final adequados dos esgotos sanitários, desde as ligações prediais até o seu lançamento final no meio ambiente; c) limpeza urbana e manejo de resíduos sólidos: conjunto de atividades, infra-estruturas e instalações operacionais de coleta, transporte, transbordo, tratamento e destino final do lixo doméstico e do lixo originário da varrição e limpeza de logradouros e vias públicas; d) drenagem e manejo das águas pluviais urbanas: conjunto de atividades, infra-estruturas e instalações operacionais de drenagem urbana de águas pluviais, de transporte, detenção ou retenção para o amortecimento de vazões de cheias, tratamento e disposição final das águas pluviais drenadas nas áreas urbanas;"

586 Sobre o tema, conferir: DI PIETRO, Maria Sylvia Zanella. Cobrança de tarifa independentemente da conclusão do mecanismo de tratamento do esgoto: exame dos aspectos de constitucionalidade e legalidade. In: Revista de Direito Administrativo \& Constitucional. Belo Horizonte, ano 13, n. 53, p. 233-263, julho/setembro 2013; CAMMAROSANO, Márcio. A Divisão Constitucional de Competências e a Cooperação Federativa na Prestação de Serviços Municipais de Saneamento Básico. In: Estudos sobre o marco regulatório de saneamento básico no Brasil. OLIVEIRA, José Roberto Pimenta Oliveira. DAL POZZO, Augusto Neves (organizadores). Belo Horizonte: Editora Fórum, p. 143-153, 2011; OLIVEIRA, Gustavo H. Justino de; HOHMANN, Ana Carolina C. A lei federal de saneamento básico e os serviços públicos de limpeza urbana. In: Fórum Administrativo, Belo Horizonte, ano 7, n. 73, edição digital, março 2007; e PICININ, Juliana de Almeida. Saneamento básico, implantação gradual e modicidade da tarifa. In: Fórum Administrativo, Belo Horizonte, ano 11, n. 125, p.9-19, julho 2011.

${ }^{587} \mathrm{O}$ artigo $2^{\circ}$, incisos I e II, da Lei n. 11.445, de 5 de janeiro de 2007 assim estabelece: “Art. $2^{\circ}$ Os serviços públicos de saneamento básico serão prestados com base nos seguintes princípios fundamentais: I universalização do acesso; II - integralidade, compreendida como o conjunto de todas as atividades e componentes de cada um dos diversos serviços de saneamento básico, propiciando à população o acesso na conformidade de suas necessidades e maximizando a eficácia das ações e resultados;" 
tratamento $^{588}$, o que gera graves reflexos em relação à concretização de outros direitos fundamentais por conta do fenômeno da "pobreza multidimensional". 589590

Portanto, do exame das normas constitucionais referidas é possível afirmar que além das obrigações internacionais assumidas pelo Estado brasileiro, o próprio texto constitucional desenvolveu o conteúdo e o alcance do direito à saúde, fixando obrigações básicas que devem ser implementadas para assegurar o núcleo essencial do direito à saúde e, progressivamente, melhorar as condições sanitárias da população brasileira, para que possa desfrutar do melhor estado de saúde física e mental possível de atingir, alcançando a meta estabelecida no artigo $12,1^{\circ}$ do Pacto Internacional de Direitos Econômicos, Sociais e Culturais (PIDESC). ${ }^{591}$

As atividades do Legislativo (edição de leis) e do Executivo (poder normativo) ${ }^{592}$ ${ }^{593}$ assumem especial relevância na medida em que devem desenvolver ou preencher o

${ }^{588}$ O documento "Diagnóstico de Serviços de Água e Esgoto", da Secretaria Nacional de Saneamento Ambiental do Ministério das Cidades, apresenta a consolidação de dados relativos aos serviços de saneamento básico no Brasil, em 2011, dos quais se destacam os seguintes: $82,4 \%$ da população tem acesso a água potável; $48,1 \%$ da população recebe atendimento em coleta de esgotos; do esgoto gerado, apenas 37,5\% recebe algum tipo de tratamento. Secretaria Nacional de Saneamento Ambiental. Sistema Nacional de Informações sobre Saneamento: Diagnóstico dos Serviços de Água e Esgotos - 2011. Brasília: MCIDADES. SNSA, 2013.

589 Considerando que a pobreza é um fenômeno multidimensional, o Programa das Nações Unidas para o Desenvolvimento (PNUD) passou a utilizar, desde 2010, o Índice de Pobreza Multidimensional, que incorpora diversos critérios para a compreensão da pobreza para além da questão econômica na realidade do território estudado. O Relatório do Desenvolvimento Humano 2013 - A Ascensão do Sul: Progresso Humano num Mundo Diversificado, publicado pelo Programa das Nações Unidas para o Desenvolvimento (PNUD), está disponível para consulta no site oficial: <http://www.pnud.org.br/>.

${ }^{590}$ DI PIETRO afirma que a implantação dos serviços de saneamento básico só pode ocorrer de forma paulatina, devido à exigência de prévias e custosas atividades de infraestrutura e instalações de elevada tecnologia. Mesmo que o abastecimento de água e o esgotamento sanitário com todas as atividades que nele se inserem não estejam implantados e em funcionamento, é possível a cobrança da tarifa, definida pelo critério do custo, pois a própria Lei ${ }^{\circ} 11.445 / 2007$ coloca como uma das previsões obrigatórias nos contratos de concessão de serviço de saneamento básico a fixação de metas progressivas e graduais de expansão dos serviços, de qualidade, de eficiência, além da definição das prioridades de ação compatíveis com as metas estabelecidas (art. 11, $\S^{\circ}$, II da Lei no 11.445/2007). DI PIETRO, Maria Sylvia Zanella. Cobrança de tarifa independentemente da conclusão do mecanismo de tratamento do esgoto: exame dos aspectos de constitucionalidade e legalidade. In: Revista de Direito Administrativo \& Constitucional. Belo Horizonte, ano 13, n. 53, p. 233-263, julho/setembro 2013.

${ }^{591}$ Tal objetivo consta do artigo 12 do Pacto Internacional de Direitos Econômicos, Sociais e Culturais (PIDESC), de 1966: "Artigo 12. 1. Os Estados Partes no presente Pacto reconhecem o direito de todas as pessoas de gozar do melhor estado de saúde física e mental possível de atingir. 2. As medidas que os Estados Partes no presente Pacto tomarem com vista a assegurar o pleno exercício deste direito deverão compreender as medidas necessárias para assegurar: a) A diminuição da mortinatalidade e da mortalidade infantil, bem como o são desenvolvimento da criança; b) O melhoramento de todos os aspectos de higiene do meio ambiente e da higiene industrial; c) A profilaxia, tratamento e controlo das doenças epidêmicas, endêmicas, profissionais e outras; d) A criação de condições próprias a assegurar a todas as pessoas serviços médicos e ajuda médica em caso de doença."

${ }^{592}$ De acordo com MENEZES DE ALMEIDA, “o regulamento, fruto do exercício do poder regulamentar (do qual decorre a regulamentação), é ato normativo geral e abstrato, possuindo caráter materialmente legislativo, 
conteúdo jurídico-constitucional do direito à saúde. ${ }^{594}$ A elaboração de políticas públicas confere maior densidade normativa do direito à saúde, minudenciando as prestações materiais que os poderes públicos ficam vinculados a fornecer aos cidadãos para a proteção, a promoção e a recuperação da saúde. ${ }^{595}$

Por fim, cumpre observar que há enorme gama de atos normativos infralegais em matéria de saúde (vigilância sanitária, epidemiológica, assistência farmacêutica etc.) adotadas pelas três esferas de gestão, que revelam a existência de planejamento e ações

apesar de tratar-se de ato da competência privativa própria do chefe do Poder Executivo. (...) No Brasil, entretanto, parece adequado sustentar a ocorrência de duas hipóteses: regulamentos de execução e regulamentos independentes. O regulamento de execução, previsto no inciso IV do artigo 84 da Constituição Federal, é ato normativo infralegal, vinculado à lei e nela fundamentando sua validade. O regulamento, diferentemente da lei, não cria Direito novo, não cria direitos e obrigações aos indivíduos, não pode "inovar no Direito já existente". (...) Já o regulamento independente, compatível com o Direito brasileiro, é o regulamento que também prescinde de lei (distinguindo-se do de execução), sendo derivado diretamente da Constituição, porém não se situando no mesmo plano normativo da lei como fonte de direitos e obrigações (distinguindo-se do autônomo). Cabe nos casos em que seja lícito ao Poder Executivo atuar diretamente a partir das normas constitucionais (auto-executáveis) disciplinadoras de determinada matéria de fundo, ou ainda normas constitucionais que apenas prevejam competência dos entes da Administração, respeitando-se, de todo modo, o princípio da legalidade (ou seja, apenas a lei cria obrigações aos indivíduos). MENEZES DE ALMEIDA, Fernando Dias. Considerações sobre a "Regulação" no Direito Positivo Brasileiro. In: Revista de Direito Público da Economia (RDPE). Belo Horizonte, ano 3, n. 12, edição digital, outubro/dezembro 2005.

593 Segundo MELLO, a Constituição prevê os regulamentos executivos, eis que o cumprimento de determinadas leis pressupõe a interferência de órgãos administrativos para a aplicação do quanto nelas se dispõe, sem, contudo, predeterminar de forma exaustiva, o detalhamento da atuação administrativa pressuposta. Como existe liberdade administrativa (discricionariedade), o sistema requer ou admite regulamento, visando criar condições para a fiel execução das leis. Há dois casos em que a edição de regulamento e cabível: (i) sempre que necessário um regramento procedimental para regência da conduta que órgãos e agentes administrativos deverão observar e fazer observar em cumprimento à lei, na efetivação das sobreditas relações. Neste caso, se inexistissem tais disposições relativas ao modus procedendi, a multiplicidade de maneiras pelas quais poderiam ser realizadas, ante a ausência de pormenores legais quanto a isto, permitiria que se adotassem soluções díspares, incompatíveis com o tratamento igualitário a que os administrados fazem jus e a boa ordem administrativa; e (ii) quando a dicção legal, em sua generalidade e abstração, comporta, por ocasião da passagem deste plano para o plano concreto e específico da multiplicidade de atos individuais a serem praticados para a aplicação da lei, intelecções mais ou menos amplas e compreensivas. Diante disso, perante situações idênticas, órgãos e agentes poderiam adotar medidas diversas, a partir da mesma regra legal. Por isso, a Administração limita a discricionariedade que decorreria da dicção não específica da lei. MELLO, Celso Antônio Bandeira de. Curso de Direito Administrativo. 27. ed. São Paulo: Malheiros, 2010, p.33-344.

594 De acordo com MIRANDA, a regulamentação ou preenchimento ou desenvolvimento legislativo (ou convencional) do conteúdo do direito não se confunde com a restrição ou diminuição ou compressão desse conteúdo. Uma coisa é regulamentar, devido à necessidade de certeza jurídica, de delimitação de direitos ou de clarificação da norma, podendo inclusive ampliar direitos. Outra coisa é restringir visando a determinados objetivos constitucionais. MIRANDA, Jorge. Manual de Direito Constitucional. Parte IV: Direitos Fundamentais. 3.ed. Coimbra: Coimbra Editora, 2000, p.330.

595 Neste sentido, o Supremo Tribunal Federal já decidiu: "O direito a saúde é prerrogativa constitucional indisponível, garantido mediante a implementação de políticas públicas, impondo ao Estado a obrigação de criar condições objetivas que possibilitem o efetivo acesso a tal serviço." (AI 734.487-AgR, Relatora Ministra Ellen Gracie, julgamento em 3-8-2010, Segunda Turma, DJE de 20-8-2010.) Conferir também: RE 436.996-AgR, relator Ministro Celso de Mello, julgamento em 22-11-2005, Segunda Turma, DJ de 3-22006; RE 271.286-AgR, relator Ministro Celso de Mello, julgamento em 12-9-2000, Segunda Turma, DJ de 24-11-2000. 
implementadas no âmbito do Sistema Único de Saúde. Como exemplos dessas medidas, apenas no âmbito federal, é pertinente citar os atos elaborados pelo Chefe do Executivo, no exercício da competência regulamentar, prevista no artigo 84, inciso IV da Constituição Federal $^{596}$, pelo Ministério da Saúde, baseado na competência prevista no artigo 87, parágrafo único incisos I e II, da Constituição Federal 597598 , pela Agência Nacional de Vigilância Sanitária (ANVISA) ${ }^{599}$, criada pela Lei n. 9782, de 26 de janeiro de 1999 e pelos demais órgãos públicos cujas áreas de atuação se relacionem direta ou indiretamente com a área da saúde. ${ }^{600} 601$

${ }^{596}$ O artigo 84, inciso IV da Constituição Federal prevê: "Art. 84. Compete privativamente ao Presidente da República: (...) IV - sancionar, promulgar e fazer publicar as leis, bem como expedir decretos e regulamentos para sua fiel execução;" Como exemplo do exercício da competência regulamentar, foi editado pela Presidente da Republica o Decreto n. 7508, de 28 de junho de 2011, que regulamenta a Lei n. 8.080, de 19 de setembro de 1990, para dispor sobre a organização do Sistema Único de Saúde - SUS, o planejamento da saúde, a assistência à saúde e a articulação interfederativa.

${ }^{597}$ Nos termos do artigo 87, parágrafo único, incisos I e II: “Art. 87. Os Ministros de Estado serão escolhidos dentre brasileiros maiores de vinte e um anos e no exercício dos direitos políticos. Parágrafo único. Compete ao Ministro de Estado, além de outras atribuições estabelecidas nesta Constituição e na lei: I - exercer a orientação, coordenação e supervisão dos órgãos e entidades da administração federal na área de sua competência e referendar os atos e decretos assinados pelo Presidente da República; II - expedir instruções para a execução das leis, decretos e regulamentos;"

598 O Ministro de Estado da Saúde, no exercício da competência prevista no artigo 87, parágrafo único, incisos I e II, da Constituição Federal editou, dentre outras: as Portarias GM/MS n.1.555/GMMS, e n. 1.554/GM/MS, ambas de 30 de julho de 2013, que estabelecem, respectivamente, normas de financiamento e de execução do Componente Básico e do Componente Especializado da Assistência Farmacêutica no âmbito do Sistema Único de Saúde; a Portaria n. 533/GM/MS, de 28 de março de 2012, que estabelece o elenco de medicamentos e insumos da Relação Nacional de Medicamentos Essenciais (RENAME) no Sistema Único de Saúde; e a Portaria n. 886/GM/MS, de 20 de abril de 2010, que institui a Farmácia Viva no âmbito do Sistema Único de Saúde.

${ }^{599}$ Nos termos do artigo $6^{\circ}$, da Lei n. 9.782, de 26 de janeiro de 1999, a Agência Nacional de Vigilância Sanitária (ANVISA) tem por finalidade institucional a promoção da “(...) proteção da saúde da população, por intermédio do controle sanitário da produção e da comercialização de produtos e serviços submetidos à vigilância sanitária, inclusive dos ambientes, dos processos, dos insumos e das tecnologias a eles relacionados, bem como o controle de portos, aeroportos e de fronteiras." A competência da Agência Nacional de Vigilância Sanitária (ANVISA) compreende a regulação sanitária e a regulação econômica do mercado, bem como a coordenação do Sistema Nacional de Vigilância Sanitária (SNVS), nos termos do artigo $7^{\circ}$, inciso I, de forma integrada com outros órgãos públicos relacionados direta ou indiretamente ao setor saúde. Um exemplo de ato infralegal editado pela ANVISA no exercício de sua competência de regulação sanitária consiste na Resolução n. 39, de 14 de agosto de 2013, da Diretoria Colegiada da Agência Nacional de Vigilância Sanitária, que dispõe sobre os procedimentos administrativos para concessão da Certificação de Boas Práticas de Fabricação e da Certificação de Boas Práticas de Distribuição e/ou Armazenagem de medicamentos, produtos para saúde e insumos farmacêuticos.

${ }^{600}$ Neste sentido, cabe conjuntamente a Agência Nacional de Vigilância Sanitária (ANVISA) e ao Instituto Nacional da Propriedade Industrial (INPI) a análise de pedidos de patentes relacionados a produtos e processos farmacêuticos. A atribuição da ANVISA se justifica porque cabe a esta autarquia analisar o pedido de patente sob o prisma do interesse da saúde publica e encontra fundamento legal no artigo 229-C da Lei n. 9.279, de 14 de maio de 1996, inclú́do pela Lei n. 10.196, de 2001, nos seguintes termos: "Art. 229-C. A concessão de patentes para produtos e processos farmacêuticos dependerá da prévia anuência da Agência Nacional de Vigilância Sanitária - ANVISA". Nos termos da Resolução da Diretoria Colegiada (RDC) n. 21/2013 da Agência Nacional de Vigilância Sanitária (ANVISA), publicada no Diário Oficial da União de 15 de abril de 2013, a ANVISA irá analisar os pedidos de patente após o encaminhamento pelo INPI, e 
O núcleo essencial abrange mais do que as prestações de serviços básicos de saúde ${ }^{602}$, engloba também as prestações necessárias à manutenção de uma vida digna, com certa qualidade. Em regra, o direito à saúde é assegurado pelo direito subjetivo derivado às prestações contempladas pelas políticas de saúde delimitadas pelo Executivo e pelo Legislativo, em respeito às normas e aos princípios expressamente previstos na Constituição Federal, dentre os quais se encontram o princípio da separação dos Poderes (artigo $2^{\circ}$ ), os princípios que definem os objetivos maiores do Estado (artigo $3^{\circ}$ ), os princípios que regem a Administração Pública (artigo 37) e os princípios da ordem social relativos à saúde (artigos 196 a 200) e na Lei Orgânica da Saúde.

Entretanto, excepcionalmente é possível que ocorram situações concretas nas quais as políticas públicas de saúde não assegurem o "mínimo existencial" ou núcleo essencial do direito à saúde. Nesses casos, seja por conta do tratamento de saúde oferecido pelo Sistema Único de Saúde (SUS) ser ineficaz para determinado indivíduo (por circunstâncias

considerará que o pedido é contrário à saúde pública em duas situações (Artigo $4^{\circ}$, paragrafo $1^{\circ}$, incisos I e II), confira: "Art. $4^{\circ}$ Após recebimento dos pedidos de patente encaminhados pelo INPI, a Anvisa analisará tais pedidos à luz da saúde pública, mediante decisão consubstanciada em parecer técnico emitido pela unidade organizacional competente no âmbito da Agência. $\S 1^{\circ}$ : Considera-se que o pedido de patente será contrário à saúde pública quando: I- O produto ou o processo farmacêutico contido no pedido de patente apresentar risco à saúde; ou II - O pedido de patente de produto ou de processo farmacêutico for de interesse para as políticas de medicamentos ou de assistência farmacêutica no âmbito do SUS e não atender aos requisitos de patenteabilidade e demais critérios estabelecidos pela Lei $n^{\circ}$. 9.279, de 1996 . $\$ 2^{\circ} \mathrm{O}$ risco à saúde será caracterizado quando o produto farmacêutico compreender, ou o processo farmacêutico resultar em, substância cujo uso tenha sido proibido no país. $\S 3^{\circ} \mathrm{O}$ pedido de patente de produto ou processo farmacêutico será considerado de interesse para as políticas de medicamentos ou de assistência farmacêutica no âmbito do SUS quando compreender, ou resultar em, substância constante das Portarias do Ministério da Saúde que dispõem sobre listas de produtos estratégicos, no âmbito do SUS, e suas atualizações, bem como compreender, ou resultar em, substância pertencente à destinação terapêutica listada nas Portarias supracitadas. $\S 4^{\circ}$ Os parâmetros para análise de risco à saúde e interesse das políticas de medicamentos ou de assistência farmacêutica no âmbito do SUS serão detalhados em ato próprio. $\S 5^{\circ} \mathrm{O}$ requerente deverá apresentar à ANVISA, sempre que solicitado, por meio de exigência, todos os documentos necessários para esclarecer dúvidas surgidas durante o exame. $\S 6^{\circ}$ Até o final da análise de que trata esta Resolução, será facultada a apresentação, pelos interessados, de documentos e informações que a subsidiem."

${ }^{601}$ Diante desse contexto, o Ministro Gilmar Mendes, no julgamento do Agravo Regimental na Suspensão de Tutela Antecipada n. 175, observou que a ausência de efetividade do direito à saúde no Brasil e a consequente intervenção judicial dificilmente são causadas por ausência de legislação regulamentadora, pois na maioria dos casos não ocorre “(...) uma omissão absoluta em matéria de políticas públicas voltadas à proteção do direito à saúde, mas tendo em vista uma necessária determinação judicial para o cumprimento de políticas já estabelecidas." STF, AR STA 175/CE. Plenário. Relator e Presidente Ministro Gilmar Mendes, julgado em 17/03/2010. DJ n. 76, de 30/04/2010.

602 De acordo com DUARTE, é equivocado o entendimento de que o núcleo essencial do direito à saúde abrange apenas prestação de serviços de saúde básica (saúde bucal, saúde da família, doenças nãotransmissíveis, hipertensão, diabetes, monitoramento da situação nutricional e a estruturação de uma rede de atendimento assistencial básico nos Municípios). "Embora sejam serviços que possuem notória essencialidade não bastam para preservar a vida na totalidade de situações." DUARTE, Luciana Gaspar Melquíades. Possibilidades e limites do controle judicial sobre as políticas públicas de saúde: um contributo para a dogmática do direito à saúde. Belo Horizonte: Fórum, 2011, p. 160-171. 
pessoais), seja pela inexistência de política pública para o tratamento de doença ou enfermidade específica (como anomalias congênitas, problemas metabólicos, deficiência intelectual e doenças raras não genéticas $)^{603}$, para além do direito às políticas públicas de saúde disponibilizadas no âmbito do SUS (direito subjetivo derivado), também pode ser assegurado o direito subjetivo originário a prestações estatais (medicamentos, insumos, tratamentos, cirurgias, leito hospitalar etc.) desde que comprovada a necessidade do indivíduo, uma vez que, nesses casos, as prestações se referem a um patamar mínimo imprescindível para que possa viver dignamente.

Não há consenso doutrinário e jurisprudencial em relação ao direito a medicamentos e tratamentos de saúde não contemplados em políticas públicas. Para alguns, o direito subjetivo abrangeria apenas as prestações já reguladas em lei em sentido amplo (direitos subjetivos derivados). Para outros, também compreenderia as prestações não disciplinadas em lei (direitos subjetivos originários). Porém, é possível verificar uma tendência jurisprudencial no sentido do reconhecimento de posições subjetivas, inclusive originárias, decorrentes do direito à saúde na condição de direito a prestações materiais nas hipóteses em que possam ser consideradas essenciais à garantia de condições mínimas à vida com dignidade e certa qualidade. ${ }^{604}$

603 O Ministério da Saúde adotou o conceito de doença rara recomendado pela Organização Mundial de Saúde (OMS), a saber, a doença que afeta até 65 pessoas em cada 100.000 indivíduos, ou seja, 1,3 pessoas para cada 2.000 indivíduos. O número de doenças raras é estimado entre 6.000 a 8.000. As doenças raras geralmente são crônicas, progressivas, degenerativas e incapacitantes, afetando severamente a qualidade de vida das pessoas e de suas famílias. A União, por intermédio do Ministério da Saúde, pretende estruturar uma Política Nacional de Atenção às Pessoas com Doenças Raras no Sistema Único de Saúde (SUS), que compatibiliza o cuidado integral (promoção, prevenção, tratamento e reabilitação) em todos os níveis de atenção, com equipe multiprofissional e atuação interdisciplinar, possibilitando equacionar os principais problemas de saúde relacionados a doenças raras no âmbito do SUS. Em 11 de abril de 2013 foi publicada a consulta pública n. 7: "Normas para Habilitação de Serviços de Atenção Especializada e Centros de Referência em Doenças Raras no Sistema Único de Saúde" e "Diretrizes para Atenção Integral às Pessoas com Doenças Raras no âmbito do Sistema Único de Saúde - SUS", para colher contribuições de setores especializados e da sociedade em geral sobre essa política pública. Os textos estão disponíveis para consulta nos endereços eletrônicos: <http://www.conass.org.br>; <http://www.saude.gov.br/consultapublica>; e $<$ www.saude.gov.br/sas $>$. Consulta em: 18/11/2013.

604 Neste sentido: Supremo Tribunal Federal, RE-AgR no 2771.286/RS. DJ de 24/11/2000; e Superior Tribunal de Justiça: “(...) A substituição do medicamento anteriormente utilizado não representa mero capricho da impetrante, mas se apresenta como condição de sobrevivência diante da ineficácia da terapêutica tradicional. Assim sendo, uma simples restrição contida em norma de inferior hierarquia (Portaria/MS n. ${ }^{\circ}$ 863/02) não pode fazer tábula rasa do direito constitucional à saúde e à vida, especialmente, diante da prova concreta trazida aos autos pela impetrante e à mingua de qualquer comprovação por parte do recorrido que venha a ilidir os fundamentos lançados no único laudo médico anexado aos autos. As normas burocráticas não podem ser erguidas como óbice à obtenção de tratamento adequado e digno por parte do cidadão carente, em especial, quando comprovado que a medicação anteriormente aplicada não surte o efeito desejado, apresentando o paciente agravamento em seu quadro clínico. RMS 17.903/MG, Rel. Ministro CASTRO MEIRA, SEGUNDA TURMA, julgado em 10/08/2004, DJ 20/09/2004, p. 215. 


\subsubsection{Restrições ao direito à saúde}

Com a definição do plexo de posições jurídicas relacionadas ao direito à saúde ficou assentado que a sua dimensão positiva, no sentido de direitos subjetivos a prestações fáticas (materiais), está vinculada ao dever do Estado Social de Direito de garantir sua efetividade. Neste segmento interessa analisar a possibilidade de a Administração opor restrições à concretização do direito à saúde, conforme a ordem jurídica.

As normas de direitos fundamentais, inclusive de direitos sociais, podem ser veiculadas em normas com a estrutura de regras e normas com a estrutura de princípios, bem como com um caráter duplo, de regras e princípios. Se as disposições relativas a direitos fundamentais forem construídas sob a forma de princípios, segundo a teoria dos princípios de ALEXY, fica permitida a sua concretização em diversos níveis, pois está sujeita a sopesamentos. ${ }^{605}$

A partir da exigência externa ao direito em si, de conciliar direitos fundamentais de diversos indivíduos, bem como direitos fundamentais individuais e coletivos, o direito prima facie garantido pela norma que assegura o direito fundamental à saúde, nos termos da teoria dos princípios, pode ser restringido, retirando-lhe determinadas posições com fundamento na ordem jurídico-constitucional. ${ }^{606}$ As restrições, que constituem algo

${ }^{605}$ É importante assinalar que regras e princípios são espécies de normas, porque prevêem o "dever ser" e podem ser formulados por meio das expressões deônticas básicas de dever, permissão ou proibição. Embora a distinção utilizada com maior frequência seja baseada no critério da generalidade, segundo o qual princípios são normas com grau relativamente alto de generalidade, ao passo que as regras são normas com grau relativamente baixo de abstração, para ALEXY, a tese correta é a de que normas podem ser distinguidas entre regras e princípios com base num critério qualitativo. ALEXY afirma que as regras são "normas que contêm determinações no âmbito daquilo que é fática e juridicamente possível", devendo ser aplicadas se forem consideradas válidas ou extirpadas do ordenamento jurídico caso sejam consideradas inválidas, ou seja, as regras são normas que sempre ou são satisfeitas ou não o são (na expressão de Dworkin, as regras, se válidas, devem ser aplicadas na forma do tudo-ou-nada). Por sua vez, os princípios são "normas que ordenam que algo seja realizado na maior medida possível dentro das possibilidades jurídicas e fáticas existentes. Princípios são, por conseguinte, mandamentos de otimização, que são caracterizados por poderem ser satisfeitos em graus variados e pelo fato de que a medida devida de sua satisfação não depende somente das possibilidades fáticas, mas também das possibilidades jurídicas. O âmbito das possibilidades jurídicas é determinado pelos princípios e regras colidentes." Na hipótese de colisão entre princípios haverá precedência de um sobre o outro, sem que o princípio cedente deva ser declarado inválido. ALEXY, Robert. Teoria dos Direitos Fundamentais. Tradução de Virgílio Afonso da Silva. 2.ed. São Paulo: Malheiros, 2012, p.90-144.

${ }^{606}$ Adotamos a posição no sentido de que os direitos sociais existem em si e podem vir a ter seus conteúdos normativos restringidos devido a fatores externos às normas que os definem, o que guarda compatibilidade com a teoria externa das restrições. Segundo esta teoria, os direitos fundamentais prima facie podem ser restringidos no contexto da ordem jurídico-constitucional, conforme a harmonização e a proporcionalidade, visando a máxima eficácia dos direitos fundamentais. Por outro lado, para os adeptos da teoria interna, os direitos fundamentais são concebidos como posições definitivas, que nunca podem ser restringidas. Segundo esta teoria, apenas os bens constitucionalmente podem ser restringidos, sendo o conteúdo da norma fixado de antemão, por meio de um procedimento interno que considera somente o objeto do direito, 
exterior ao direito, lhe reduzem o âmbito de eficácia, diminuindo seus conteúdos normativos. ${ }^{607}$

A restrição de posições que a priori estariam compreendidas no direito fundamental $^{608}$ pode decorrer de norma prevista de forma expressa ou implícita na Constituição Federal. De forma expressa, a restrição pode vir estabelecida no próprio texto constitucional (restrição diretamente constitucional), ou pode estar autorizada a edição de legislação infraconstitucional que a estabeleça (restrição indiretamente constitucional). Em caso de norma implícita, a restrição estará fundada em princípios constitucionais (sopesamento). ${ }^{609}$

A teoria da reserva do possível, formulada a partir de decisões do Tribunal Constitucional alemão ${ }^{610}$, especialmente a partir dos anos 1970, significava que o direito a

independentemente de elementos de influência externa. ALEXY, Robert. Teoria dos Direitos Fundamentais. Tradução de Virgílio Afonso da Silva. 2.ed. São Paulo: Malheiros, 2012, p.50-144 e 276-280.

607 De acordo com MIRANDA, as restrições de direitos fundamentais em sentido estrito se referem às atuações normativas do Estado, através do legislador ou da atividade regulamentadora da Administração Pública, que delimitam a dimensão objetiva do direito, comprimindo ou amputando determinadas faculdades que anteriormente estariam contempladas pela norma aos seus titulares. MIRANDA, Jorge. Manual de Direito Constitucional. Parte IV: Direitos Fundamentais. 3.ed. Coimbra: Coimbra Editora. 2000, p.328-337.

${ }^{608}$ As restrições à aplicabilidade dos direitos fundamentais devem guardar compatibilidade formal e material com a Constituição. Sob a perspectiva formal, em razão da supremacia das normas constitucionais, que estão situadas no ápice da hierarquia normativa imanente ao ordenamento jurídico. Sob a perspectiva material, devido à ordem axiológica prevista no texto constitucional, baseada no valor da dignidade da pessoa humana e na proteção de direitos fundamentais que lhe são inerentes. São limites à restrição dos direitos fundamentais: o princípio da proporcionalidade, atuando no sentido do controle de legitimidade constitucional de medidas restritivas do âmbito de proteção de direitos fundamentais, bem como para o controle da omissão ou atuação insuficiente do Estado no cumprimento de seus deveres de proteção; e a garantia do núcleo essencial dos direitos fundamentais, no sentido de que há conteúdos invioláveis dos direitos fundamentais que se reconduzem a posições imunes às ações dos poderes públicos e que também podem, na visão de alguns, ser oponíveis a particulares.

SARLET, Ingo Wolfgang; MARINONI, Guilherme; MITIDIERO, Daniel. Curso de Direito Constitucional. 2. ed. São Paulo: Editora Revista dos Tribunais, 2013, p.347-359.

${ }^{609}$ MIRANDA, Jorge. Manual de Direito Constitucional. Parte IV: Direitos Fundamentais. 3.ed. Coimbra: Coimbra Editora. 2000, p.328-337.

${ }^{610}$ Em relação ao reconhecimento do direito subjetivo a prestações com fundamento na Constituição da Alemanha, é importante mencionar a contribuição dada pelo Tribunal Constitucional Federal, especialmente em duas decisões. SCAFF narra um caso relatado pelo Tribunal Constitucional alemão, duas Universidades daquele país estabeleceram restrições ao acesso direito de alunos ao curso de medicina e odontologia nos anos de 1969 e 1970. A Universidade de Hamburgo determinou que as vagas disponíveis para os candidatos alemães deveriam ser distribuídas na proporção de $60 \%$ segundo o curriculum do candidato, e $40 \%$ segundo o ano de nascimento, sendo possível haver a reserva de vagas para situações excepcionais, contudo não limitou o número total de vagas. A Universidade da Bavária, por sua vez, que é o ponto central do tema, estabeleceu limitação de vagas para algumas áreas do conhecimento, se isso fosse estritamente necessário à manutenção do funcionamento regular do curso, considerando a capacidade das instalações dos "campi" daquela Universidade. Foi em relação a estas normas que o Tribunal Constitucional alemão se pronunciou contrariamente, em sede de controle concentrado. O Tribunal decidiu ser inadequada a limitação de vagas feita pela Universidade da Bavária, devido ao seu efeito extremamente incisivo, pois permite que um número maior ou menor dos candidatos tenha que adiar o início do curso desejado por um tempo mais ou menos longo. Os candidatos socialmente mais carentes não têm as possibilidades de aguardar longos períodos ou 
prestações positivas em face do Estado deve corresponder àquilo que o indivíduo pode esperar, de maneira racional, da sociedade. Desta forma, em sua origem, a teoria da reserva do possível não se refere diretamente à existência de recursos materiais suficientes para a efetividade do direito social, mas à razoabilidade da pretensão ajuizada visando sua concretização.

Todavia, da forma como foi transposta para o direito brasileiro passou a ser compreendida unicamente como uma teoria da reserva do financeiramente possível, na medida em que se interpretou como restrição absoluta à concretização de direitos sociais (em sua dimensão positiva) a suficiência de recursos públicos e a previsão orçamentária da despesa. ${ }^{611}$

A par disso, SARLET e FIGUEIREDO afirmam que a teoria da reserva do possível em sentido amplo abrange três facetas diversas, porém entrelaçadas: (i) a ausência ou insuficiência de recursos financeiros propriamente ditos indispensáveis ao atendimento dos direitos sociais em sua dimensão positiva (limites fáticos); (ii) a impossibilidade jurídica para dispor dos recursos, conforme a lei orçamentária, o princípio da separação

tentar a realização de um curso no exterior. (BVerfGE 33, 303, de 18/7/1972). SCAFF, Fernando Facury. A efetivação dos direitos sociais no Brasil: garantias constitucionais de financiamento e judicialização. In: A eficácia dos Direitos Sociais. SCAFF, Fernando Facury; ROMBOLI, Roberto; MIGUEL, Revenga (coordenador). São Paulo: Quartier Latin, p.25-26, 2010. Sobre a mesma decisão do Tribunal Constitucional alemão (BVerfGE 33, 303, de 18/7/1972), ALEXY afirma que se trata da primeira sobre numerus clausus. Nesta decisão, foram diferenciados dois direitos: o direito à participação nas instituições de ensino existentes e o direito à criação de novas vagas universitárias. Em relação ao direito denominado de "participação", o tribunal apresenta como fundamento o enunciado da igualdade, o princípio do Estado Social e a constatação de que o Estado tem o monopólio fático da formação para as profissões acadêmicas, que é pressuposto necessário para a realização de direitos fundamentais. Tais fundamentos, relacionados ao direito à livre escolha do estabelecimento de ensino e da profissão, bem como ao enunciado da igualdade, no sentido de proibição do arbítrio, são compatíveis com a garantia de um direito à educação para a formação acadêmica. $\mathrm{O}$ aspecto relevante dessa decisão é a utilização do direito de liberdade em sua motivação, não apenas como direito de defesa, mas como pressuposto fático para o seu exercício (BVerfGE 33, 303, de 18/07/1972). Sobre o direito à criação de novas vagas universitárias, ALEXY comenta outra decisão do Tribunal Constitucional alemão (BVerfGE 43, 291, de 8/2/1977), na qual diferenciou, de forma mais clara do que na decisão anteriormente referida, um direito abstrato do cidadão que preenche os pressupostos subjetivos de admissão no curso universitário de sua escolha, submetido "à reserva do possível, no sentido daquilo que o indivíduo pode razoavelmente exigir da sociedade" e uma pretensão individual que pode ser ajuizada à ampliação da capacidade das instituições universitárias. De conseguinte, segundo a teoria dos princípios apresentada por ALEXY, o tribunal considerou o direito abstrato de criação de novas vagas universitárias como um direito prima facie, que se torna definitivo se outras razões colidentes ("se e sob quais pressupostos") não exigirem o contrário. Já o direito à uma pretensão concreta à ampliação da capacidade universitária, tem um caráter de direito definitivo. ALEXY, Robert. Teoria dos Direitos Fundamentais. Tradução de Virgílio Afonso da Silva. 2.ed. São Paulo: Malheiros, 2012, p.433-440.

${ }^{611}$ Neste sentido: MÂNICA, Fernando Borges. Teoria da Reserva do Possivel: Direitos Fundamentais a Prestações e a Intervenção do Poder Judiciário na Implementação de Políticas Públicas. In: Revista Brasileira de Direito Público, Belo Horizonte, ano 5, n. 18, p.181-182, julho/setembro 2007. 
dos poderes e o princípio do pacto federativo (limites jurídicos); e (iii) a razoabilidade (ponderação). ${ }^{612}$

Em primeiro lugar, a reserva do possível no sentido da existência de limites fáticos ao atendimento pelo Estado da pretensão deduzida para o fornecimento de prestações materiais, denominada de teoria da reserva do financeiramente possível, está relacionada à escassez de recursos públicos, às exigências de harmonização econômica geral e à necessidade de previsão orçamentária da respectiva despesa.

Embora a proteção e efetivação dos direitos de liberdade também envolva uma alocação significativa de recursos humanos e materiais, os custos assumem ainda maior relevância em se cuidando de direitos a prestações materiais. ${ }^{613}$ Deve ser considerado que durante as crises econômicas aumentam as pretensões relativas às prestações materiais, de acordo com o número de pessoas que deles necessitam, e é exatamente nesses momentos que há poucos recursos financeiros para viabilizar a distribuição de bens. ${ }^{614}$

Diante disso, a dimensão econômica dos direitos sociais consiste numa das principais objeções apresentadas pelos poderes públicos para que sejam concretizados.

612 SARLET, Ingo Wolfgang; FIGUEIREDO, Mariana Filchner. Reserva do possível, mínimo existencial e direito à saúde: algumas aproximações. In: Revista de Doutrina da $4^{\text {a }}$ Região. Porto Alegre, p.16-17, n. 24, julho de 2008.

${ }^{613}$ Mesmo em relação ao acesso às prestações materiais já disponíveis é possível vislumbrar a repercussão econômica dos direitos sociais, eis que resultaram da alocação e aplicação de recursos humanos e/ou recursos financeiros oriundos das receitas tributárias. SARLET, Ingo Wolfgang; FIGUEIREDO, Mariana Filchner. Reserva do possível, mínimo existencial e direito à saúde: algumas aproximações. In: Revista de Doutrina da $4^{\mathrm{a}}$ Região. Porto Alegre, n. 24, p. 9-10 e 16, julho de 2008.

${ }^{614}$ ALEXY considera os argumentos contrários e favoráveis aos direitos fundamentais sociais e apresenta um modelo que não determina os direitos fundamentais sociais definitivos que o indivíduo tem, mas afirma que o indivíduo pode ter alguns direitos e o que é relevante para a definição de sua existência e seu conteúdo. Para ALEXY, os direitos fundamentais previstos na Constituição alemã são posições tão importantes que a decisão sobre garanti-las ou não garanti-las não poderia ser atribuída ao legislador, devendo ser uma decisão de sopesamento e princípios. Pela ideia-guia de ALEXY, uma posição relativa ao direito a prestações deve ser definitivamente garantida se (1) o princípio da liberdade fática a exigir de forma premente e se (2) o princípio da separação dos poderes e o princípio democrático (que inclui a competência orçamentária do parlamento), bem como (3) os princípios materiais colidentes forem afetados em uma medida relativamente pequena pela garantia constitucional da posição prestacional e pelas decisões do tribunal constitucional que a levaram em consideração. Tais condições são necessariamente satisfeitas no caso dos direitos a um mínimo existencial como, por exemplo, a uma moradia simples, à educação fundamental e média, à educação profissionalizante e a um patamar mínimo de assistência médica. Ainda de acordo com ALEXY, mesmo os direitos fundamentais sociais mínimos têm enormes efeitos financeiros, em especial quando são muitos os que dele necessitam. Contudo, tal fato isoladamente não justifica uma conclusão contrária à sua existência. Na visão de ALEXY, parece fundada a objeção de que a existência de direitos fundamentais sociais definitivos (ainda que mínimos) tornaria impossível a necessária flexibilidade em época de recessão econômica e poderia transformar uma crise econômica em uma crise constitucional. ALEXY, Robert. Teoria dos Direitos Fundamentais. Tradução de Virgílio Afonso da Silva. 2.ed. São Paulo: Malheiros, 2012, p. 513519. 
Atualmente, especialmente em razão do entendimento consagrado pelo Supremo Tribunal Federal, a teoria da reserva do financeiramente possível vem sendo afastada como objeção à concretização dos direitos sociais pelo Estado. O Judiciário tem imposto ao poder público o ônus da prova, em cada caso concreto, da ausência ou insuficiência de recursos financeiros. ${ }^{615}$ Além disso, firmou entendimento de que esta teoria não é oponível no que tange ao mínimo existencial. ${ }^{616}$

Em conclusão, a teoria da reserva do financeiramente possível é objeção que pode afastar a obrigação de atendimento pelo Estado da pretensão deduzida para o fornecimento de prestações materiais relativas ao direito à saúde apenas em caso de comprovação de ausência de recursos orçamentários, objetivamente aferível, e desde que o pedido não esteja incluído no mínimo existencial. Sem o atendimento cumulativo dessas duas condicionantes, a teoria da reserva do financeiramente possível tem sido rechaçada como argumento que visa injustamente limitar direitos sociais impregnados de fundamentalidade.

Em segundo lugar, a reserva do possível como limite jurídico para dispor dos recursos está estritamente relacionada à lei orçamentária, ao princípio da separação dos poderes e ao pacto federativo.

O surgimento do Estado Social e a transformação da sua forma de atuação na ordem econômica e social provocaram mudanças relativas à noção clássica e à importância do orçamento público. Conforme MÂNICA, de mero documento contábil que continha a

615 O Superior Tribunal de Justiça entendeu ser descabido o argumento da reserva do possível num caso em que se buscava a implementação do modelo de assistência à saúde do índio e a instalação material dos serviços de saúde à população indígena do Rio Grande do Sul. Na ementa do julgado, o Ministro relator Luz Fux fez consignar: "Cumpre advertir, desse modo, que a cláusula da 'reserva do possível' - ressalvada a ocorrência de justo motivo objetivamente aferível - não pode ser invocada, pelo Estado, com a finalidade de exonerar-se do cumprimento de suas obrigações constitucionais, notadamente quando, dessa conduta governamental negativa, puder resultar nulificação ou, até mesmo, aniquilação de direitos constitucionais impregnados de um sentido de essencial fundamentalidade. (...)". (STJ. REsp 811.608/RS, Relator Ministro LUIZ FUX, PRIMEIRA TURMA, julgado em 15/05/2007, DJ 04/06/2007, p. 314)

${ }^{616}$ Nas palavras do Ministro Humberto Martins, constantes da ementa do acórdão: "O indivíduo não pode exigir do estado prestações supérfluas, pois isto escaparia do limite do razoável, não sendo exigível que a sociedade arque com esse ônus. Eis a correta compreensão do princípio da reserva do possível, tal como foi formulado pela jurisprudência germânica. Por outro lado, qualquer pleito que vise a fomentar uma existência minimamente decente não pode ser encarado como sem motivos, pois garantir a dignidade humana é um dos objetivos principais do Estado Democrático de Direito. Por este motivo, o princípio da reserva do possível não pode ser oposto ao princípio do mínimo existencial. Assegurar um mínimo de dignidade humana por meio de serviços públicos essenciais, dentre os quais a educação e a saúde, é escopo da República Federativa do Brasil que não pode ser condicionado à conveniência política do administrador público. A omissão injustificada da administração em efetivar as políticas públicas constitucionalmente definidas e essenciais para a promoção da dignidade humana não deve ser assistida passivamente pelo Poder Judiciário. Recurso especial parcialmente conhecido e improvido.” (STJ. REsp 1041197/MS, Rel. Ministro Humberto Martins, Segunda Turma, julgado em 25/08/2009, DJe 16/09/2009). 
previsão das receitas e a autorização das despesas, o orçamento tornou-se instrumento de governo, importante para o desenvolvimento econômico, social e político do país, voltado a auxiliar o Estado em todas as etapas do processo administrativo: programação, execução e controle. ${ }^{617}$

A execução dos orçamentos públicos passou a ser condicionada à adoção, pelo Estado, de políticas públicas para a concretização dos objetivos, metas e programas previstos na Constituição Federal. Daí a afirmação de MÂNICA no sentido de que a noção moderna de orçamento está diretamente ligada às políticas públicas, pois o Estado social intervém positivamente na ordem econômica e social, por meio de políticas públicas e do orçamento. ${ }^{618}$

No Brasil, cabe ao Poder Legislativo estabelecer as prioridades a serem implementadas em curto e médio prazo, através do sistema orçamentário, visando alcançar as metas (objetivos de longo prazo) previstos na Constituição. Conforme SCAFF, a possibilidade de escolha pelo Legislativo das prioridades para os gastos públicos é denominada de discricionariedade do legislador. ${ }^{619}$

Ao Executivo é atribuída a tarefa de implementar os objetivos de curto e médio prazo $^{620}$, com a definição das políticas públicas, a previsão e a execução orçamentária, conforme os princípios e regras aplicáveis à Administração Pública. As escolhas a serem tomadas pelo administrador público dependem da avaliação da conveniência e da oportunidade (discricionariedade administrativa) da alocação de recursos escassos ante a ampla gama de necessidades públicas e possibilidades políticas. ${ }^{621}$

A elaboração de políticas públicas, a escolha das prioridades orçamentárias e quantificação de recursos financeiros que serão destinados a cada área são estabelecidas no

617 MÂNICA, Fernando Borges. Teoria da Reserva do Possível: Direitos Fundamentais a Prestações e a Intervenção do Poder Judiciário na Implementação de Políticas Públicas. Revista Brasileira de Direito Público, Belo Horizonte, ano 5, n. 18, p.170, julho/setembro 2007.

${ }^{618}$ MÂNICA, Fernando Borges. Teoria da Reserva do Possível: Direitos Fundamentais a Prestações e a Intervenção do Poder Judiciário na Implementação de Políticas Públicas. Revista Brasileira de Direito Público, Belo Horizonte, ano 5, n. 18, p.170, julho/setembro 2007.

619 SCAFF, Fernando Facury. A efetivação dos direitos sociais no Brasil: garantias constitucionais de financiamento e judicialização In: A eficácia dos Direitos Sociais. SCAFF, Fernando Facury; ROMBOLI, Roberto; MIGUEL, Revenga (coordenador). São Paulo: Quartier Latin, p.27, 2010

${ }^{620}$ SCAFF, Fernando Facury. A efetivação dos direitos sociais no Brasil: garantias constitucionais de financiamento e judicialização. In: A eficácia dos Direitos Sociais. SCAFF, Fernando Facury; ROMBOLI, Roberto; MIGUEL, Revenga (coordenador). São Paulo: Quartier Latin. p.27, 2010.

${ }^{621}$ MÂNICA, Fernando Borges. Teoria da Reserva do Possível: Direitos Fundamentais a Prestações e a Intervenção do Poder Judiciário na Implementação de Políticas Públicas. In: Revista Brasileira de Direito Público, Belo Horizonte, ano 5, n. 18, p. 172-173, julho/setembro 2007 
orçamento, conforme o grau de importância que a efetivação dos direitos afirmados represente para uma determinada sociedade, num determinado momento histórico. ${ }^{622}$

A Administração Pública está completamente subordinada à lei, cabendo-lhe fazer exatamente o que a lei determina, por força do princípio da legalidade. ${ }^{623} \mathrm{~A}$ atividade financeira do Estado está disciplinada nos artigos 165 e 169 da Constituição Federal. O artigo 165, incisos I, II e III ${ }^{624}$, estabelece três leis que se sucedem e se complementam: a Lei do Plano Plurianual (PPA), a Lei de Diretrizes Orçamentárias (LDO) e a Lei Orçamentária Anual (LOA), que engloba os orçamentos fiscal, de investimento e da seguridade social. ${ }^{625} \mathrm{O}$ princípio da legalidade da despesa pública traduz a obrigação ao administrador público de observar as autorizações e limites constantes nas leis orçamentárias, sendo vedada a realização de qualquer despesa sem previsão orçamentária $^{626}$, sob pena de crime de responsabilidade. ${ }^{627}$

A função precípua do Poder Judiciário é a de solucionar lides, com definitividade e não a de substituir o Poder Legislativo na definição das despesas em que os recursos públicos devem ser aplicados. Neste sentido, a reserva do possível consistiria num óbice à determinação judicial de fornecimento de prestações materiais (ou de pagamento de valores) sem amparo orçamentário e sem lei que o determine.

Na mesma linha, a capacidade de revisão judicial das políticas públicas e decisão quanto à alocação de recursos públicos também encontraria vedação no princípio da

622 Nas palavras de SCAFF: "de nada adianta falarmos de direitos se não olharmos quanto de recursos financeiros o Estado estabeleceu para a realização daqueles direitos. A singela proclamação de direitos custosos serve de muito pouco, caso não sejam atribuídos os recursos necessários para sua implementação." SCAFF, Fernando Facury. A efetivação dos direitos sociais no Brasil: garantias constitucionais de financiamento e judicialização. In: A eficácia dos Direitos Sociais. SCAFF, Fernando Facury; ROMBOLI, Roberto; MIGUEL, Revenga (coordenador). São Paulo: Quartier Latin, p.26, 2010.

${ }^{623} \mathrm{O}$ artigo 37, caput, do Constituição Federal assim dispõe: “Art. 37. A administração pública direta e indireta de qualquer dos Poderes da União, dos Estados, do Distrito Federal e dos Municípios obedecerá aos princípios de legalidade, impessoalidade, moralidade, publicidade e eficiência e, também, ao seguinte: (...)"

624 “Art. 165. Leis de iniciativa do Poder Executivo estabelecerão: I - o plano plurianual; II - as diretrizes orçamentárias; III - os orçamentos anuais."

${ }^{625}$ Nesse sistema, todos os planos e programas governamentais devem ser compatíveis com o plano plurianual e a lei de diretrizes orçamentárias deve estar em harmonia com o plano plurianual, conforme prescrevem os artigos 165 , parágrafo $4^{\circ}$ e 166 , parágrafo $4^{\circ}$, da Constituição Federal, que dispõem, respectivamente: "§ $4^{\circ}$ - Os planos e programas nacionais, regionais e setoriais previstos nesta Constituição serão elaborados em consonância com o plano plurianual e apreciados pelo Congresso Nacional."; e "§ $4^{\circ}$ As emendas ao projeto de lei de diretrizes orçamentárias não poderão ser aprovadas quando incompatíveis com o plano plurianual.".

${ }^{626}$ Nos termos do artigo 167, inciso II, da Constituição Federal: “Art. 167. São vedados: (...) II - a realização de despesas ou a assunção de obrigações diretas que excedam os créditos orçamentários ou adicionais;"

${ }^{627} \mathrm{O}$ artigo 85, inciso VI, da Constituição Federal prevê: “Art. 85. São crimes de responsabilidade os atos do Presidente da República que atentem contra a Constituição Federal e, especialmente, contra: (...) VI - a lei orçamentária;" 
separação dos Poderes. De acordo com este argumento, o controle amplo de políticas públicas pelo Judiciário significaria indevida usurpação de competências do Legislativo e do Executivo, incidindo em violação à harmonia entre os Poderes, prevista no artigo $2^{\circ}$ da Constituição Federal. ${ }^{628} 629$

O entendimento jurisprudencial é firme em rejeitar tal argumento, com base na inafastabilidade da jurisdição (artigo $5^{\circ}, \mathrm{XXXV}$ ), que impede o Judiciário de responder com o non liquet e na proteção da inviolabilidade do direito à vida e à saúde em face do interesse financeiro do Estado. ${ }^{630}$

No concernente ao princípio federativo, previsto nos artigos $1^{\circ}$ e 18 da Constituição Federal, a reserva do possível vincula-se às noções de descentralização de atribuições de cada uma das unidades federadas, regionalização e hierarquização das ações e dos serviços de saúde (art. 198). A Constituição Federal estabelece normas sobre repartição de competências legislativas e materiais e a Lei n. 8.080/90 regulamenta a distribuição de competências materiais na área da saúde.

O Judiciário já consolidou o entendimento de que a responsabilidade para a promoção, proteção e recuperação da saúde é solidária dos entes federativos, tendo em vista a norma constitucional que estabelece a competência material comum para cuidar da saúde. ${ }^{631}$

628 “Art. $2^{\circ}$ São Poderes da União, independentes e harmônicos entre si, o Legislativo, o Executivo e o Judiciário".

${ }^{629}$ De acordo com SCAFF, "torna-se imprescindível, portanto, fazer cessar esta "captura" de recursos públicos destinados à implementação de políticas públicas, por aqueles que, utilizando-se do Poder Judiciário, tomam para si nacos do orçamento público social em proveito próprio, e não da sociedade." SCAFF, Fernando Facury. A efetivação dos direitos sociais no Brasil: garantias constitucionais de financiamento e judicialização. In: A eficácia dos Direitos Sociais. SCAFF, Fernando Facury; ROMBOLI, Roberto; MIGUEL, Revenga (coord.). São Paulo: Quartier Latin, p.27, 2010.

${ }^{630}$ Há inúmeros julgados neste sentido. Um dos mais mencionados é o Agravo Regimental em Petição $\mathrm{n}$. 1246-1, do Estado de Santa Catarina, em que foi relator o Ministro Celso de Mello. Embora o Plenário do Supremo Tribunal Federal não tenha admitido o pedido de suspensão no agravo regimental interposto contra a decisão que o indeferida, por entender ser processualmente inadequado (julgado em 10 de abril de 1997. Ministro Sepúlveda Pertence Presidente e relator. DJ 17/04/98. Ementário 1906-01), a decisão monocrática permanece sendo utilizada como precedente da Corte.

${ }_{631}$ Neste sentido: "Consolidou-se a jurisprudência desta Corte no sentido de que, embora o art. 196 da Constituição de 1988 traga norma de caráter programático, o Município não pode furtar-se do dever de propiciar os meios necessários ao gozo do direito à saúde por todos os cidadãos. Se uma pessoa necessita, para garantir o seu direito à saúde, de tratamento médico adequado, é dever solidário da União, do Estado e do Município providenciá-lo." (AI 550.530-AgR, relator Ministro Joaquim Barbosa, julgamento em 26-62012, Segunda Turma, DJE de 16-8-2012.); e "O recebimento de medicamentos pelo Estado é direito fundamental, podendo o requerente pleiteá-los de qualquer um dos entes federativos, desde que demonstrada sua necessidade e a impossibilidade de custeá-los com recursos próprios. Isso por que, uma vez satisfeitos tais requisitos, o ente federativo deve se pautar no espírito de solidariedade para conferir efetividade ao direito garantido pela Constituição, e não criar entraves jurídicos para postergar a devida prestação 
Em terceiro lugar, a reserva do possível quanto à razoabilidade significa que a prestação material deduzida em face do Estado deverá ser analisada no caso concreto, mediante ponderação de bens e alternativas em pauta, com base no princípio da proporcionalidade. ${ }^{632}$ Para ALEXY, é a lei do sopesamento, segundo a qual a medida permitida de não-satisfação ou de afetação de um princípio depende do grau de importância da satisfação do outro, ou seja, o peso de cada um não é determinado em si mesmo ou de forma absoluta, somente sendo possível falar em pesos relativos. ${ }^{633}$

A observância da técnica da ponderação (sopesamento) possibilita a apresentação de uma resposta suficiente para as questões relativas à eficácia do direito fundamental à saúde, pois satisfaz as exigências de consideração das relações fáticas e da dogmática dos direitos fundamentais específicos, bem como permite a aferição da importância de realização de princípios colidentes, conforme elementos valorativos. ${ }^{634}$

Como anteriormente mencionado, os julgados que deram origem à teoria da reserva do possível do Tribunal Constitucional alemão acerca dos numerus clausus reconheceram que o direito a prestações materiais deve estar vinculado àquilo que o indivíduo pode esperar, de maneira racional, da sociedade. A determinação exata da racionalidade de que se trata somente pode ser verificada a partir de um suporte fático, dos dados reais de cada caso concreto, com a ponderação dos valores envolvidos.

O princípio da proporcionalidade pode ser desdobrado em três elementos: (i) adequação ou conformidade, no sentido da idoneidade da medida para a tutela do direito fundamental de forma eficaz; (ii) necessidade ou exigibilidade da pretensão, que envolve a investigação sobre a importância da medida para a realização do direito fundamental e a existência de meios alternativos para promover igualmente o fim almejado; e (iii) a proporcionalidade em sentido estrito (razoabilidade), que exige uma ponderação que

jurisdicional." (RE 607.381-AgR, relator Ministro Luiz Fux, julgamento em 31-5-2011, Primeira Turma, DJE de 17-6-2011.) No mesmo sentido: AI 553.712-AgR, relator Ministro Ricardo Lewandowski, julgamento em 19-5-2009, Primeira Turma, DJE de 5-6-2009; AI 604.949-AgR, relator Ministro Eros Grau, julgamento em 24-10-2006, Segunda Turma, DJ de 24-11-2006

${ }^{632}$ MÂNICA, Fernando Borges. Teoria da Reserva do Possível: Direitos Fundamentais a Prestações e a Intervenção do Poder Judiciário na Implementação de Políticas Públicas. In: Revista Brasileira de Direito Público, Belo Horizonte, ano 5, n. 18, p. 184, julho/setembro 2007.

633 ALEXY, Robert. Teoria dos Direitos Fundamentais. Tradução de Virgílio Afonso da Silva. 2.ed.. São Paulo: Malheiros, 2012, p. 163-176.

634 ALEXY, Robert. Teoria dos Direitos Fundamentais. Tradução de Virgílio Afonso da Silva. 2.ed. São Paulo: Malheiros, 2012, p. 175-176. 
considere de forma ampla a manutenção de um equilíbrio entre os meios utilizados e os fins colimados. ${ }^{635}$

De conseguinte, no processo de ponderação deve ser considerada a natureza da providência almejada, particularmente no que se refere à sua necessidade, adequação e proporcionalidade em sentido estrito para a proteção do direito fundamental à saúde. Além disso, outros elementos devem ser sopesados, como a adequação da pretensão, os custos do tratamento ou medicamento almejado ${ }^{636}$, a apresentação de prescrição subscrita por médico do Sistema Único de Saúde (SUS) ${ }^{637}$ e a eventual submissão do demandante ao programa específico oferecido pelo Sistema Único de Saúde (SUS).

635 SARLET, Ingo Wolfgang; MARINONI, Guilherme; MITIDIERO, Daniel. Curso de Direito Constitucional. 2. ed. São Paulo: Editora Revista dos Tribunais, 2013, p.348-355.

${ }^{636}$ Neste sentido, na Ação de Descumprimento de Preceito Fundamental n. 45, do Distrito Federal, o Ministro Celso de Mello reconheceu a necessidade da presença do binômio razoabilidade da pretensão e disponibilidade financeira estatal para atende-la. Na decisão, o Ministro relator consignou que o encargo governamental de tornar efetiva a aplicação dos direitos econômicos, sociais e culturais depende da configuração em situação cumulativa da razoabilidade da pretensão e da disponibilidade financeira do Estado, eis que, ausentes qualquer desses elementos, restará descaracterizada a possibilidade estatal de realização prática de tais direitos. Supremo Tribunal Federal. ADPF-MC no 45/DF. Relator Min. Celso de Mello. DJ 4/5/2004.

${ }^{637}$ Dentre os julgados do Supremo Tribunal Federal neste sentido, conferir: "Para obtenção de medicamento pelo SUS, não basta ao paciente comprovar ser portador de doença que o justifique, exigindo-se prescrição formulada por médico do Sistema" (STA 334-AgR, Rel. Min. Presidente Cezar Peluso, julgamento em 24-62010, Plenário, DJE de 13-8-2010). 


\section{CAPÍTUlo 3 - O SISTEMA ÚNICO DE SAÚde E AS POLÍTICAS PÚBLICAS DE SAÚDE}

O Sistema Único de Saúde (SUS) apresenta grande significação histórica decorrente da forte mobilização popular em torno do Movimento de Reforma Sanitária, que culminou com a encampação do alvissareiro modelo universalista e de atenção integral, colocando fim ao modelo privatista e meramente curativo até então existente no Brasil.

Este capítulo é organizado em duas partes. A primeira tem como objetivo específico analisar a estrutura normativa do Sistema Único de Saúde (SUS) de forma aprofundada, os objetivos para os quais foi instituído, seus princípios reitores e as normas sobre o financiamento deste sistema, à luz da Lei Complementar n. 141/2012, que regulamentou a Emenda Constitucional n. 29/2000. O estudo parte do modelo jurídicoconstitucional para, em seguida, abordar os principais aspectos da legislação estruturante e das normas operacionais que regem o funcionamento do Sistema Único de Saúde (SUS).

A segunda parte deste capítulo volta sua atenção à questão da atividade planejadora do Estado frente aos novos e complexos desafios trazidos pela Constituição Federal de 1988 com o reconhecimento do direito fundamental à saúde e o correlato dever do Estado de dar-lhe efetividade, por meio de políticas econômicas e sociais. O foco deste item será discutir os principais aspectos relativos ao planejamento estatal e as políticas públicas de saúde.

\subsection{O Sistema Único de Saúde}

\subsubsection{Organização e funcionamento (Lei n. 8.080/90 e Lei n. 8.142/90)}

A Constituição Federal de 1988 agregou o modelo Social ao Estado de Direito, o que importa, como reflexo, uma mudança paradigmática em relação às atribuições pertinentes à Administração Pública, especialmente no campo dos direitos fundamentais sociais. 
Todo o agir da Administração Pública está previamente demarcado por uma pluralidade de princípios e valores definidos pela Constituição Federal. ${ }^{638}$ Os objetivos que o Estado Social de Direito se propõe a perseguir condicionam as funções da Administração Pública e estas, por sua vez, determinam os modos de atuação e de organização dirigidos a alcançá-los. ${ }^{639}$

No concernente ao direito fundamental à saúde, ao Estado incumbe não apenas o dever de abstenção, de maneira a assegurar a autonomia privada na esfera de proteção do direito individual em relação aos cuidados com a saúde (dimensão negativa), mas também o dever de proporcionar o acesso, a todas as pessoas, às prestações normativas e materiais (dimensão positiva) que garantam, no mínimo, o atendimento ao núcleo essencial do direito à saúde, bem como de viabilizar mecanismos para o exercício do direito de participação da comunidade no Sistema Único de Saúde (dimensão ativa).

A dimensão positiva do direito fundamental à saúde é concretizada mediante prestações estatais de natureza fática (material) e normativa (jurídica). ${ }^{640}$ Neste capítulo será analisada com maior detalhamento a dimensão positiva dos direitos fundamentais sociais, sob o prisma do Estado brasileiro, no que tocam às prestações normativas, sobretudo em relação ao Sistema Único de Saúde (SUS).

As posições jurídicas normativas do direito à saúde asseguram aos titulares desse direito: (i) a edição de normas que o tutelam4"1; (ii) a elaboração de "políticas sociais e

${ }^{638}$ BACELLAR FILHO, Romeu Felipe. Reflexos da constitucionalização do direito administrativo. Revista Interesse Público, ano 15, n. 81, p. 15-30, setembro/outubro 2013.

${ }^{639}$ Sobre as múltiplas funções do direito à saúde, conferir o item 2.4 deste trabalho.

${ }^{640}$ A Constituição Federal reconheceu a saúde como direito fundamental, inserindo-o num amplo catálogo de direitos sociais previstos em seu artigo $6^{\circ}$, atribuindo-lhes o regime jurídico dos direitos fundamentais. Assim, o direito à saúde, em suas dimensões negativa, positiva e ativa, tem aplicabilidade imediata. Ainda que possa haver intermediação legislativa fixando balizas quanto ao conteúdo do direito a prestações materiais (dimensão positiva), suas posições jurídicas podem ser judicialmente exigidas desde logo.

${ }^{641}$ Dentre prestações normativas para a tutela do direito à saúde cabe mencionar dois exemplos, com fundamento no disposto no artigo $7^{\circ}$, incisos IV e XXII, da Constituição Federal: o dever do Estado de editar uma lei que fixe o valor do salário mínimo em patamar suficiente ao atendimento das necessidades vitais básicas do trabalhador e de sua família, relacionado à noção de núcleo essencial ou mínimo existencial; e o dever do Estado de editar normas de proteção da saúde, higiene e segurança do trabalhador, bem como o dever dos empregadores de respeitá-las para prevenir reduzir os riscos inerentes ao trabalho (efeito perante terceiros ou efeito horizontal dos direitos fundamentais). Os referidos dispositivos prescrevem o seguinte: "Art. $7^{\circ}$ São direitos dos trabalhadores urbanos e rurais, além de outros que visem à melhoria de sua condição social: (...) IV - salário mínimo, fixado em lei, nacionalmente unificado, capaz de atender a suas necessidades vitais básicas e às de sua família com moradia, alimentação, educação, saúde, lazer, vestuário, higiene, transporte e previdência social, com reajustes periódicos que lhe preservem o poder aquisitivo, sendo vedada sua vinculação para qualquer fim; (...) XXII - redução dos riscos inerentes ao trabalho, por meio de normas de saúde, higiene e segurança;" 
econômicas" ${ }^{\text {642; }}$ e (iii) a organização do Sistema Único de Saúde, que assume na ordem jurídico-constitucional brasileira a condição de garantia institucional fundamental ${ }^{643}$, protegida igualmente aos demais direitos fundamentais, inclusive quanto ao poder constituinte derivado reformador, eis que inserida entre os limites materiais de emenda à Constituição. ${ }^{644} 645$

A instituição do Sistema Único de Saúde (SUS) originariamente pela própria Constituição Federal de 1988, como mecanismo para a implementação do direito à saúde representou uma importante conquista da sociedade civil organizada, ${ }^{646}$ porquanto acarretou uma transformação em relação ao sistema adotado em nosso passado histórico recente: (i) o modelo privatista ${ }^{647}$ foi abandonado para adotar um modelo universalista ${ }^{648}$, baseado na igualdade substancial e na solidariedade; e (ii) a atuação do Estado na área da

${ }^{642}$ O artigo 196 da Constituição Federal assim dispõe: “Art. 196. A saúde é direito de todos e dever do Estado, garantido mediante políticas sociais e econômicas que visem à redução do risco de doença e de outros agravos e ao acesso universal e igualitário às ações e serviços para sua promoção, proteção e recuperação."

${ }^{643}$ Neste sentido: BONAVIDES, Paulo. Curso de Direito Constitucional. 22. ed. São Paulo: Malheiros, 2008, 2008. p. 565-569; e SARLET, Ingo Wolfgang; FIGUEIREDO, Mariana Filchtiner. Algumas considerações sobre o direito fundamental à proteção e promoção da saúde aos 20 anos da Constituição Federal de 1988. In: Revista de Direito do Consumidor n. 67, p. 125-172, 2008.

${ }^{644}$ Neste sentido: BONAVIDES, Paulo. Curso de Direito Constitucional. 22.ed. São Paulo: Malheiros, 2008. p. 548-550.

${ }^{645}$ Conforme prevê a Constituição Federal em seu artigo 60, parágrafo $4^{\circ}$, inciso IV: “Art. 60. A Constituição poderá ser emendada mediante proposta: (...) $\S 4^{\circ}$ - Não será objeto de deliberação a proposta de emenda tendente a abolir: (...) IV - os direitos e garantias individuais."

${ }^{646}$ Como observado no capítulo 1, a mobilização social que culminou com a $8^{\text {a }}$ Conferência Nacional de Saúde, realizada em 1986, foi relevante tanto pela articulação de diferentes segmentos sociais quanto pelas recomendações apresentadas à Comissão Nacional da Reforma Sanitária (CNRS) para a reorganização do sistema, que serviram de base à elaboração da Seção da Saúde da Constituição Federal de 1988. A Comissão Nacional da Reforma Sanitária (CNRS) visava elaborar propostas tanto para a redação dos dispositivos constitucionais, quanto para a legislação posterior que os regulamentaria.

${ }^{647} \mathrm{O}$ sistema público de saúde vigente anteriormente à Constituição beneficiava apenas os trabalhadores urbanos que pagavam contribuição aos Institutos de Aposentadoria e Pensão (IAPs) e, nesta condição, portavam uma carteirinha do Instituto Nacional de Assistência Médica da Previdência Social (INAMPS) para que pudessem ser atendidos em hospitais públicos. Aqueles que estavam excluídos desse sistema contributivo contavam apenas com a atenção ambulatorial provida por unidades de medicina simplificada e a atenção hospitalar prestada por entidades filantrópicas aos indigentes. A instituição do Sistema Único de Saúde produziu resultados imediatos, superando a separação que havia entre os incluídos economicamente e os excluídos. BRASIL. Conselho Nacional de Secretários de Saúde. Legislação Estruturante do SUS. Conselho Nacional de Secretários de Saúde. Brasília: CONASS, 2011, p.17.

${ }^{648}$ A universalidade do direito à saúde é inerente ao gênero humano e encontra fundamento jurídico nos princípios da isonomia e da impessoalidade, previstos no caput do artigo $5^{\circ}$ e no caput do artigo 37 , ambos da Constituição Federal, bem como em norma especifica albergada na seção da saúde, que dispõe: "Art. 196. A saúde é direito de todos e dever do Estado, garantido mediante políticas sociais e econômicas que visem à redução do risco de doença e de outros agravos e ao acesso universal e igualitário às ações e serviços para sua promoção, proteção e recuperação.” 
saúde pública que se limitava ao aspecto curativo ${ }^{649}$, passou a englobar a atenção integral à saúde (prevenção, a proteção e a promoção). ${ }^{650}$

Uma das preocupações do Movimento de Reforma Sanitária, segundo DALLARI e NUNES, era a de que a previsão constitucional do direito à saúde não fosse limitada a uma previsão genérica, relativa ao dever do Estado de realizá-lo, sem detalhamento do teor dessas atribuições e do modo necessário a tanto. ${ }^{651}$ Em razão disso, além de prever a saúde como um direito social no rol do artigo $6^{\mathrm{o652}}$, o constituinte acrescentou várias disposições voltadas a dar-lhe efetividade, dentre as quais: a competência material comum dos entes federados para "cuidar da saúde" (artigo 23, inciso II) ${ }^{653}$; a criação de um "sistema único"

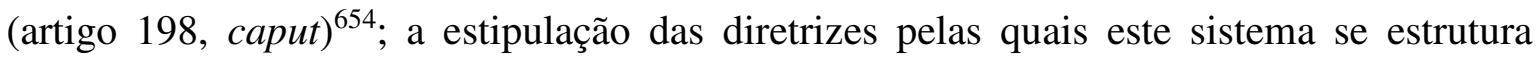
(artigo 198, incisos I, II e III) ${ }^{655}$ e das finalidades que deve atender (artigo 196) ${ }^{656}$; a qualificação das ações e serviços de saúde como de relevância pública (artigo 197) ${ }^{657}$; e

649 Nos início da República as políticas sanitárias eram, basicamente, curativas e impostas de forma autoritária. As medidas de saúde tinham por objetivo o combate às epidemias para evitar que se alastrassem sobre a população e, desta forma, prejudicassem a imagem do País no cenário internacional e a produção de café, em razão da contaminação dos trabalhadores. O autoritarismo das medidas sanitárias gerava movimentos de revolta da população. O caso mais emblemático é a "Revolta da Vacina", ocorrida em 1904, que demonstra o inconformismo da população brasileira ao modo autoritário e como a vacinação foi imposta pelo Estado, sem informar a população sobre o que consistia e quais eram seus benefícios, para evitar que a epidemia de varíola assolasse a cidade do Rio de Janeiro. Sobre a atuação do poder público em relação à saúde pública anteriormente ao advento da Constituição Federal de 1988, conferir Capítulo 1, item 1.3 deste trabalho.

${ }^{650} \mathrm{O}$ artigo 198, inciso II, da Constituição Federal define a abrangência das ações e serviços de saúde da seguinte forma: “Art. 198. As ações e serviços públicos de saúde integram uma rede regionalizada e hierarquizada e constituem um sistema único, organizado de acordo com as seguintes diretrizes: (...) I atendimento integral, com prioridade para as atividades preventivas, sem prejuízo dos serviços assistenciais". 651 DALLARI, Sueli Gandolfi e NUNES JÚNIOR, Vidal Serrano. Direito Sanitário. São Paulo: Editora Verbatim, 2010, p.26-27.

652 “Art. $6^{\circ}$ São direitos sociais a educação, a saúde, a alimentação, o trabalho, a moradia, o lazer, a segurança, a previdência social, a proteção à maternidade e à infância, a assistência aos desamparados, na forma desta Constituição."

${ }^{653}$ Nos termos do artigo 23, inciso II, da Constituição Federal: “Art. 23. É competência comum da União, dos Estados, do Distrito Federal e dos Municípios: (...) II - cuidar da saúde e assistência pública, da proteção e garantia das pessoas portadoras de deficiência; (os destaques não constam do texto original)

${ }^{654}$ A Constituição Federal de 1988, em seu artigo 198, caput, prevê que as ações e serviços públicos de saúde integram uma rede regionalizada e hierarquizada e constituem um sistema único.

655 Nos termos do artigo 198 da Constituição Federal: “Art. 198. As ações e serviços públicos de saúde integram uma rede regionalizada e hierarquizada e constituem um sistema único, organizado de acordo com as seguintes diretrizes: I - descentralização, com direção única em cada esfera de governo; II - atendimento integral, com prioridade para as atividades preventivas, sem prejuízo dos serviços assistenciais; III participação da comunidade."

656 O artigo 196 prescreve o seguinte: “Art. 196. A saúde é direito de todos e dever do Estado, garantido mediante políticas sociais e econômicas que visem à redução do risco de doença e de outros agravos e ao acesso universal e igualitário às ações e serviços para sua promoção, proteção e recuperação."

657 O artigo 197 dispõe que: "Art. 197. São de relevância pública as ações e serviços de saúde, cabendo ao Poder Público dispor, nos termos da lei, sobre sua regulamentação, fiscalização e controle, devendo sua 
uma ampla relação das áreas de atuação do Sistema Único de Saúde, ressalvando, expressamente, a possibilidade da fixação de outras, por lei (artigo 200). ${ }^{658}$

Apesar da estruturação jurídico-constitucional do Sistema Único de Saúde no texto constitucional, sua regulamentação somente foi feita por meio da Lei n. 8.080, de 19 de setembro de 1990 e da Lei n. 8.142, de 28 de dezembro de 1990. Nessas leis nacionais, elaboradas pela União com base em sua competência para editar normas gerais sobre "proteção e defesa da saúde" ${ }^{659}$, foram explicitados os objetivos, as atribuições e os princípios que devem orientar a organização e a gestão do Sistema Único de Saúde (SUS), bem como a distribuição de tarefas entre as três esferas de governo para garantir a proteção e a promoção da saúde.

Os contornos da tarefa do legislador de estruturar o Sistema Único de Saúde foram fixados pela própria Constituição Federal que definiu, em seu artigo 198, caput, a ideia de sistema, ao dispor que "as ações e serviços públicos de saúde integram uma rede regionalizada e hierarquizada e constituem um sistema único (...)". E mais, determinou a observância das diretrizes definidas nos incisos I a III do artigo 198, que podem ser assim dispostas: (i) descentralização, com direção única em cada esfera de governo; (ii) atendimento integral; (iii) prioridade para as atividades preventivas, sem prejuízo dos serviços assistenciais; e (iv) participação da comunidade.

Conquanto a Federação brasileira seja formada por União, Estados, Distrito Federal e Municípios, todos autônomos ${ }^{660}$, a unicidade do sistema importa em que as ações e serviços de saúde sejam desenvolvidos em conformidade com as mesmas diretrizes e políticas públicas de saúde, de forma coordenada e harmônica. Aliás, num País de extensão

execução ser feita diretamente ou através de terceiros e, também, por pessoa física ou jurídica de direito privado."

${ }^{658}$ Nos termos do artigo 200 da Constituição Federal: "Art. 200. Ao sistema único de saúde compete, além de outras atribuições, nos termos da lei: I - controlar e fiscalizar procedimentos, produtos e substâncias de interesse para a saúde e participar da produção de medicamentos, equipamentos, imunobiológicos, hemoderivados e outros insumos; II - executar as ações de vigilância sanitária e epidemiológica, bem como as de saúde do trabalhador; III - ordenar a formação de recursos humanos na área de saúde; IV - participar da formulação da política e da execução das ações de saneamento básico; V - incrementar em sua área de atuação o desenvolvimento científico e tecnológico; VI - fiscalizar e inspecionar alimentos, compreendido o controle de seu teor nutricional, bem como bebidas e águas para consumo humano; VII - participar do controle e fiscalização da produção, transporte, guarda e utilização de substâncias e produtos psicoativos, tóxicos e radioativos; VIII - colaborar na proteção do meio ambiente, nele compreendido o do trabalho." ${ }^{659} \mathrm{O}$ artigo 24, inciso XII e parágrafo $1^{\circ}$ dispõem: "Art. 24. Compete à União, aos Estados e ao Distrito Federal legislar concorrentemente sobre: (...) XII - previdência social, proteção e defesa da saúde; (...) $\S 1^{\circ}$ No âmbito da legislação concorrente, a competência da União limitar-se-á a estabelecer normas gerais."

${ }^{660}$ Nos termos do artigo 18, caput, da Constituição Federal, "a organização político-administrativa da República Federativa do Brasil compreende a União, os Estados, o Distrito Federal e os Municípios, todos autônomos, nos termos desta Constituição". 
continental, com 26 Estados, o Distrito Federal e 5.570 Municípios $^{661}$, a articulação entre os entes federativos e a plasticidade das políticas públicas sanitárias às particularidades regionais e locais é indispensável à efetividade do direito à saúde e a melhoria do estado de saúde dos brasileiros e estrangeiros que aqui residem.

A Lei n. 8.080, de 19 de setembro de 1990 tem como objetivo regular, “(...) em todo o território nacional, as ações e serviços de saúde, executados isolada ou conjuntamente, em caráter permanente ou eventual, por pessoas naturais ou jurídicas de direito Público ou privado"662. Estabelece que o Sistema Único de Saúde abrange "o conjunto de ações e serviços de saúde, prestados por órgãos e instituições públicas federais, estaduais e municipais, da Administração direta e indireta e das fundações mantidas pelo Poder Público (...)" e também compreende “as instituições públicas federais, estaduais e municipais de controle de qualidade, pesquisa e produção de insumos, medicamentos, inclusive de sangue e hemoderivados, e de equipamentos para saúde". Tal qual dispõe o artigo 199, parágrafo $1^{\text {o }}$ da Constituição Federal, prevê a possibilidade de atuação complementar da atuação da iniciativa privada no Sistema Único de Saúde (SUS). ${ }^{663}$

À luz desses dispositivos, o Sistema Único de Saúde (SUS) pode ser definido como a política pública de saúde instituída e estruturada originariamente pela Constituição Federal, abrangente de todas as ações e serviços de saúde prestados de forma isolada ou em parceria pelos entes federados e instituições públicas, bem como por entidades privadas, de forma coordenada e articulada, com as garantias de universalidade e acesso igualitário, visando a promoção, a proteção e a recuperação da saúde.

O dever de realizar ações e prestar os serviços públicos de saúde pode ser exercido diretamente pelo poder público, ou em parceria com entidades privadas, com prioridade às

${ }^{661}$ Brasil. Ministério do Planejamento, Orçamento e Gestão. Instituto Brasileiro de Geografia e Estatística (IBGE). Diretoria de Pesquisas. Coordenação de População e Indicadores Sociais. Estimativas da população residente nos Municípios Brasileiros com data de referência em $1^{\text {o }}$ de julho de 2013. Agosto de 2013. Disponível em: www.ibge.gov.br. Consulta em: 28/11/2013.

662 Assim dispõe o artigo $1^{\circ}$, da Lei n. 8.080/90: Art. $1^{\circ}$ Esta lei regula, em todo o território nacional, as ações e serviços de saúde, executados isolada ou conjuntamente, em caráter permanente ou eventual, por pessoas naturais ou jurídicas de direito Público ou privado.

${ }^{663}$ Nos termos do artigo $4^{\circ}$ da Lei n. 8.080/90: "Art. $4^{\circ} \mathrm{O}$ conjunto de ações e serviços de saúde, prestados por órgãos e instituições públicas federais, estaduais e municipais, da Administração direta e indireta e das fundações mantidas pelo Poder Público, constitui o Sistema Único de Saúde (SUS). $§ 1^{\circ}$ Estão incluídas no disposto neste artigo as instituições públicas federais, estaduais e municipais de controle de qualidade, pesquisa e produção de insumos, medicamentos, inclusive de sangue e hemoderivados, e de equipamentos para saúde. $\S 2^{\circ}$ A iniciativa privada poderá participar do Sistema Único de Saúde (SUS), em caráter complementar." 
filantrópicas e sem fins lucrativos. ${ }^{664}$ A possibilidade da participação de entidades privadas com finalidade lucrativa no Sistema Único de Saúde (SUS) é permitida, de forma complementar, pelo artigo 199, parágrafo $1^{\text {o }}$ da Constituição Federal. ${ }^{665} 666$ Na hipótese de participarem do Sistema Único de Saúde (SUS), deverão observar suas diretrizes e normas, sendo vedado ao poder público destinar-lhes subvenções e auxílios (artigo 199, parágrafo $2^{\circ}$ e artigo 38 da Lei n. 8.080/90). ${ }^{667} 668$

De acordo com o artigo $3^{\circ}$ da Lei n. $8 \cdot 080 / 90^{669}$, foi expressamente reconhecida a interface existente entre o estado de saúde da população e a educação, o saneamento básico, o meio ambiente, a alimentação, a moradia, a renda, o transporte, a prática de atividade física, o lazer, o acesso aos bens e serviços essenciais, dentre outros. A abertura do rol se justifica, porque também são claras as conexões entre a saúde e, por exemplo, a qualidade do ar, o acesso à água potável, a eficácia dos agrotóxicos, as pesquisas científicas ${ }^{670}$ e o desenvolvimento de novas tecnologias em saúde ${ }^{671}$.

664 “Art. 197. São de relevância pública as ações e serviços de saúde, cabendo ao Poder Público dispor, nos termos da lei, sobre sua regulamentação, fiscalização e controle, devendo sua execução ser feita diretamente ou através de terceiros e, também, por pessoa física ou jurídica de direito privado."

665 “Art. 199. A assistência à saúde é livre à iniciativa privada. $\S 1^{\circ}$ - As instituições privadas poderão participar de forma complementar do sistema único de saúde, segundo diretrizes deste, mediante contrato de direito público ou convênio, tendo preferência as entidades filantrópicas e as sem fins lucrativos."

${ }^{666}$ Segundo OLIVEIRA e MÂNICA, a permissão para que entes privados atuem junto ao Poder Público na realização de ações e na prestação de serviços públicos de saúde, tem como premissa o reconhecimento por parte do Poder Constituinte de que, considerado o leque de atribuições da Municipalidade, é plausível a hipótese da atuação da iniciativa privada no setor de saúde para atender a todas as demandas da população. OLIVEIRA, Gustavo Justino de; Mânica, Fernando Borges. Parcerias na saúde: reflexões sobre a Emenda Constitucional n. 51/2006 e a Lei Federal n. 11.350/2006. Belo Horizonte: Editora Fórum, 2009, p.22.

667 “Art. 199. A assistência à saúde é livre à iniciativa privada. $§ 2^{\circ}$ - É vedada a destinação de recursos públicos para auxílios ou subvenções às instituições privadas com fins lucrativos."

668 “Art. 38. Não será permitida a destinação de subvenções e auxílios a instituições prestadoras de serviços de saúde com finalidade lucrativa."

669 “Art. $3^{\circ}$ Os níveis de saúde expressam a organização social e econômica do País, tendo a saúde como determinantes e condicionantes, entre outros, a alimentação, a moradia, o saneamento básico, o meio ambiente, o trabalho, a renda, a educação, a atividade física, o transporte, o lazer e o acesso aos bens e serviços essenciais. Parágrafo único. Dizem respeito também à saúde as ações que, por força do disposto no artigo anterior, se destinam a garantir às pessoas e à coletividade condições de bem-estar físico, mental e social."

${ }^{670}$ A Lei n. 11.105, de 24 de março de 2005, conhecida como "Lei de Biosegurança", estabelece normas de segurança e mecanismos de fiscalização sobre a construção, o cultivo, a produção, a manipulação, o transporte, a transferência, para disciplinar a importação, a exportação, o armazenamento, a pesquisa, a comercialização, o consumo, a liberação no meio ambiente e o descarte de organismos geneticamente modificados - OGM e seus derivados, nas áreas de biotecnologia e biossegurança, tendo como diretrizes o estímulo ao avanço científico, a proteção à vida e à saúde humana, animal e vegetal, e a observância do princípio da precaução para a proteção do meio ambiente, nos termos do que prevê seu artigo $1^{\circ}$, caput. O parágrafo $1^{\circ}$, do artigo $1^{\circ}$ desta lei, define atividade de pesquisa como “(...) a realizada em laboratório, regime de contenção ou campo, como parte do processo de obtenção de OGM e seus derivados ou de avaliação da biossegurança de OGM e seus derivados, o que engloba, no âmbito experimental, a construção, o cultivo, a 
De conseguinte, as tarefas ligadas à proteção, à promoção e à recuperação da saúde envolvem atividades de órgãos públicos integrantes de diversas áreas, o que impõe a adoção de políticas públicas intersetoriais, para além das políticas desenvolvidas no âmbito do Ministério da Saúde e das Secretarias Estaduais e Municipais de Saúde.

O artigo $6^{\circ}$ da Lei n. 8.080/90 672 , com o propósito de auxiliar na execução das atribuições do Sistema Único de Saúde (SUS), definiu o que se compreende por vigilância sanitária ${ }^{673}$, vigilância epidemiológica ${ }^{674}$ e saúde do trabalhador. ${ }^{675}$ Ademais, reiterou o

manipulação, o transporte, a transferência, a importação, a exportação, o armazenamento, a liberação no meio ambiente e o descarte de OGM e seus derivados."

${ }^{671}$ De acordo com MARRARA, as tecnologias de saúde “(...) designam técnicas e métodos de manipulação do corpo humano no intuito de manter a saúde e promovê-la. Na medida em que a sociedade atual busca meios para ampliar a autonomia sobre o corpo e seus processos naturais de evolução, essas tecnologias, assim como os benefícios e problemas delas decorrentes, ganham extrema relevância no mundo atual." MARRARA, Thiago. Direito administrativo e novas tecnologias. In: Revista de Direito Administrativo, v. 256, p. 225-251, 2011.

${ }^{672} \mathrm{O}$ artigo $6^{\circ}$, incisos I a XI, da Lei n. 8.080/90 assim dispõe: “Art. $6^{\circ}$ Estão incluídas ainda no campo de atuação do Sistema Único de Saúde (SUS): I - a execução de ações: a) de vigilância sanitária; b) de vigilância epidemiológica; c) de saúde do trabalhador; e d) de assistência terapêutica integral, inclusive farmacêutica; II - a participação na formulação da política e na execução de ações de saneamento básico; III - a ordenação da formação de recursos humanos na área de saúde; IV - a vigilância nutricional e a orientação alimentar; V - a colaboração na proteção do meio ambiente, nele compreendido o do trabalho; VI - a formulação da política de medicamentos, equipamentos, imunobiológicos e outros insumos de interesse para a saúde e a participação na sua produção; VII - o controle e a fiscalização de serviços, produtos e substâncias de interesse para a saúde; VIII - a fiscalização e a inspeção de alimentos, água e bebidas para consumo humano; IX - a participação no controle e na fiscalização da produção, transporte, guarda e utilização de substâncias e produtos psicoativos, tóxicos e radioativos; $\mathrm{X}$ - o incremento, em sua área de atuação, do desenvolvimento científico e tecnológico; XI - a formulação e execução da política de sangue e seus derivados.”

673 "Art. $6^{\circ}(\ldots) \S 1^{\circ}$ Entende-se por vigilância sanitária um conjunto de ações capaz de eliminar, diminuir ou prevenir riscos à saúde e de intervir nos problemas sanitários decorrentes do meio ambiente, da produção e circulação de bens e da prestação de serviços de interesse da saúde, abrangendo: I - o controle de bens de consumo que, direta ou indiretamente, se relacionem com a saúde, compreendidas todas as etapas e processos, da produção ao consumo; e II - o controle da prestação de serviços que se relacionam direta ou indiretamente com a saúde."

674 “Art. $6^{\circ}(\ldots) \S 2^{\circ}$ Entende-se por vigilância epidemiológica um conjunto de ações que proporcionam o conhecimento, a detecção ou prevenção de qualquer mudança nos fatores determinantes e condicionantes de saúde individual ou coletiva, com a finalidade de recomendar e adotar as medidas de prevenção e controle das doenças ou agravos."

675 "Art. $6^{\circ}(\ldots) \S 3^{\circ}$ Entende-se por saúde do trabalhador, para fins desta lei, um conjunto de atividades que se destina, através das ações de vigilância epidemiológica e vigilância sanitária, à promoção e proteção da saúde dos trabalhadores, assim como visa à recuperação e reabilitação da saúde dos trabalhadores submetidos aos riscos e agravos advindos das condições de trabalho, abrangendo: I - assistência ao trabalhador vítima de acidentes de trabalho ou portador de doença profissional e do trabalho; II - participação, no âmbito de competência do Sistema Único de Saúde (SUS), em estudos, pesquisas, avaliação e controle dos riscos e agravos potenciais à saúde existentes no processo de trabalho; III - participação, no âmbito de competência do Sistema Único de Saúde (SUS), da normatização, fiscalização e controle das condições de produção, extração, armazenamento, transporte, distribuição e manuseio de substâncias, de produtos, de máquinas e de equipamentos que apresentam riscos à saúde do trabalhador; IV - avaliação do impacto que as tecnologias provocam à saúde; $\mathrm{V}$ - informação ao trabalhador e à sua respectiva entidade sindical e às empresas sobre os riscos de acidentes de trabalho, doença profissional e do trabalho, bem como os resultados de fiscalizações, avaliações ambientais e exames de saúde, de admissão, periódicos e de demissão, respeitados os preceitos da ética profissional; VI - participação na normatização, fiscalização e controle dos serviços de saúde do 
elenco de matérias previsto no artigo 200 da Constituição Federal, acrescentando a formulação e execução da política de sangue e seus derivados. ${ }^{676}$

A Lei n. 8.080/90 estabelece, ainda, os princípios e diretrizes do Sistema Único de Saúde (artigo $7^{\circ}$ ), as normas sobre organização, direção e gestão (artigos $8^{\circ}$ a 14 ), a competência e atribuições de cada uma das entidades federadas (artigos 15 a 19), o subsistema de atenção à saúde indígena (artigo 19-A a 19-H), o subsistema de atendimento e internação domiciliar (artigo 19-I), o subsistema de acompanhamento durante o trabalho de parto, parto e pós-parto imediato (artigo 19-J), as normas sobre a assistência terapêutica e a incorporação de tecnologia em saúde (incluída pela Lei n. 12.401/2011 - artigos 19-M a 19-U), as normas sobre os serviços privados de assistência à saúde (artigos 20 a 30) e, por fim, a disciplina do financiamento da saúde (artigo 31 a 38).

As disposições previstas no Projeto de Lei Orgânica da Saúde relativas à participação social no Sistema Único de Saúde e às transferências intergovernamentais de recursos financeiros inicialmente foram objeto de veto pelo então Presidente da República Fernando Collor de Mello. ${ }^{677}$ Entretanto, houve uma intensa reação da sociedade civil organizada e do movimento sanitarista, que pressionaram o Poder Legislativo para a aprovação dos dispositivos que tinham sido vetados. Posteriormente, como resultado dessa importante mobilização social, a Lei n. 8.142, de 28 de dezembro de 1990, foi aprovada

trabalhador nas instituições e empresas públicas e privadas; VII - revisão periódica da listagem oficial de doenças originadas no processo de trabalho, tendo na sua elaboração a colaboração das entidades sindicais; e VIII - a garantia ao sindicato dos trabalhadores de requerer ao órgão competente a interdição de máquina, de setor de serviço ou de todo ambiente de trabalho, quando houver exposição a risco iminente para a vida ou saúde dos trabalhadores."

${ }^{676}$ O parágrafo $4^{\circ}$ do artigo 199 da Constituição Federal dispõe que: “Art. 199. (...) § 4 - A lei disporá sobre as condições e os requisitos que facilitem a remoção de órgãos, tecidos e substâncias humanas para fins de transplante, pesquisa e tratamento, bem como a coleta, processamento e transfusão de sangue e seus derivados, sendo vedado todo tipo de comercialização.” A lei n. 10.205, de 21 de março de 2001 regulamenta este dispositivo, estabelecendo a política nacional de sangue, componentes e hemoderivados, cujas finalidades consistem em: “(...) garantir a auto-suficiência do País nesse setor e harmonizar as ações do poder público em todos os níveis de governo (...)" (artigo 8º). Para a execução da lei, sobreveio o Decreto n. 3.990, de 30 de outubro de 2001.

${ }^{677}$ Conforme a mensagem n. 680, em relação à participação comunitária, o veto foi fundamentado na norma que prevê a iniciativa privativa do Presidente da República de lei que disponha sobre a criação, estruturação e definição de atribuição de órgãos da Administração Pública (CF, art. 61, § 1º II, "e"), e no fato de que já compunha a estrutura do Ministério da Saúde o Conselho Nacional de Saúde, ao qual teriam sido atribuídas competências idênticas aquelas do Conselho e da Conferência de Saúde. O texto integral da mensagem n. 680 está disponível no site do Planalto: http://www.planalto.gov.br. Consulta em: 21/11/2013. 
para estabelecer as normas sobre a participação da comunidade na gestão do Sistema Único de Saúde ${ }^{678}$ e sobre as transferências intergovernamentais de recursos financeiros.

O artigo $1^{\circ}$ da Lei n. 8.142, de 28 de dezembro de 1990, prevê que o Sistema Único de Saúde (SUS) contará com a participação comunitária, por meio de instâncias colegiadas. Assim, cada esfera de governo, deve organizar e manter Conselho de Saúde em caráter permanente e deliberativo e, ainda, deve realizar Conferências de Saúde, a cada quatro anos, com a representação dos diversos segmentos sociais, com o fim de avaliar a situação de saúde e propor as diretrizes para a formulação das políticas de saúde nos níveis correspondentes. 679

Portanto, a organização normativa básica do Sistema Único de Saúde (SUS) está prevista nos artigos 196 a 200 da Constituição Federal e nas Leis n. 8.080, de 19 de setembro de 1990, e 8.142, de 28 de dezembro de 1990. A implantação do Sistema Único de Saúde (SUS), porém, ocorre num processo de construção e permanente reforma com base em normas de operacionalização, que mesmo após vinte e cinco anos da promulgação da Constituição Federal de 1988, continuam sendo aprimoradas para a garantia do oferecimento de serviços públicos de saúde adequados.

O início desse processo ocorreu pelas Normas Operacionais Básicas do Sistema Único de Saúde (SUS), instituídas por portarias, do Instituto Nacional de Assistência Médica da Previdência Social (INAMPS) ${ }^{680}$ e depois do Ministério da Saúde, que

\footnotetext{
${ }^{678}$ Nos termos do que dispõe o artigo 198, inciso III da Constituição Federal, o Sistema Único de Saúde tem como diretriz a "participação da comunidade", que é repetida, como um princípio, pela Lei n. 8.080/90 (artigo $7^{\circ}$, inciso VIII).

${ }^{679}$ A Lei n.8.142/90 estabelece em seu artigo $1^{\circ}$ : “Art. $1^{\circ}$ O Sistema Único de Saúde (SUS), de que trata a Lei n ${ }^{\circ} 8.080$, de 19 de setembro de 1990, contará, em cada esfera de governo, sem prejuízo das funções do Poder Legislativo, com as seguintes instâncias colegiadas: I - a Conferência de Saúde; e II - o Conselho de Saúde. $\S 1^{\circ}$ A Conferência de Saúde reunir-se-á a cada quatro anos com a representação dos vários segmentos sociais, para avaliar a situação de saúde e propor as diretrizes para a formulação da política de saúde nos níveis correspondentes, convocada pelo Poder Executivo ou, extraordinariamente, por esta ou pelo Conselho de Saúde. $\S 2^{\circ}$ O Conselho de Saúde, em caráter permanente e deliberativo, órgão colegiado composto por representantes do governo, prestadores de serviço, profissionais de saúde e usuários, atua na formulação de estratégias e no controle da execução da política de saúde na instância correspondente, inclusive nos aspectos econômicos e financeiros, cujas decisões serão homologadas pelo chefe do poder legalmente constituído em cada esfera do governo.§ $3^{\circ}$ O Conselho Nacional de Secretários de Saúde (Conass) e o Conselho Nacional de Secretários Municipais de Saúde (Conasems) terão representação no Conselho Nacional de Saúde.§ $4^{\circ}$ A representação dos usuários nos Conselhos de Saúde e Conferências será paritária em relação ao conjunto dos demais segmentos.§ $5^{\circ}$ As Conferências de Saúde e os Conselhos de Saúde terão sua organização e normas de funcionamento definidas em regimento próprio, aprovadas pelo respectivo conselho."

${ }^{680}$ O Instituto Nacional de Assistência Médica da Previdência Social (INAMPS) foi vinculado ao Ministério da Saúde por força do Decreto n. 99.060, de 7 de março de 1990, porém continuou com sua estrutura sobreposta à Secretaria de Assistência à Saúde do Ministério da Saúde durante três anos.
} 
estabeleceram as relações entre a União, os Estados e os Municípios no federalismo de cooperação na área da saúde. Tais normas definiram as competências de cada esfera de governo na implantação do Sistema Único de Saúde (SUS), as condições de gestão necessárias para que Estados e Municípios pudessem assumir as novas atribuições, bem como os critérios para repasses de recursos do Fundo Nacional de Saúde aos Fundos Estaduais e Municipais de Saúde. ${ }^{681}$

A primeira Norma Operacional Básica do SUS - NOB-SUS 1/91, foi editada pela Presidência do Instituto Nacional de Assistência Médica da Previdência Social (INAMPS $)^{682}$, que era o gestor de fato do sistema. Esta norma se limitava a determinar que o sistema de pagamento fosse operacionalizado com a Unidade de Cobertura Ambulatorial (UCA), valor unitário, que, multiplicado pela população, definia o teto financeiro anual a ser transferido. ${ }^{683}$

Em seguida, o Instituto Nacional de Assistência Médica da Previdência Social (INAMPS) editou a Norma Operacional Básica NOB-SUS $1 / 92^{684}$, como resultado de consenso entre o Ministério da Saúde, o Conselho Nacional de Secretários de Saúde (CONASS) e Conselho Nacional de Secretários Municipais de Saúde (Conasems) para estimular a implantação, o desenvolvimento e o funcionamento do sistema, e fornecer instrumentos operacionais à efetivação dos preceitos constitucionais sobre saúde. ${ }^{685} \mathrm{~A}$ NOB-SUS 1/92 vinculava a liberação de recursos da União aos Municípios, Estados e Distrito Federal ao cumprimento do disposto no artigo $4^{\circ}$, da Lei n. 8.142/90, que determina à instituição de: Fundo de Saúde; Conselho de Saúde, plano de saúde; relatórios de gestão; contrapartida de recursos no respectivo orçamento; e comissão de elaboração do plano de carreira, cargos e salários (PCCS), que deveria ser implantado em dois anos. ${ }^{686}$

${ }^{681}$ BRASIL. Conselho Nacional de Secretários de Saúde. Legislação Estruturante do SUS. Brasília: CONASS, 2011, p.18.

${ }^{682}$ Resolução n. 258, de 7 de janeiro de 1991, reeditada com alterações pela Resolução n. 273, de 17 de janeiro de 1991.

${ }_{683}$ A NOB 1/91 tinha forte conotação centralista e considerava os Estados e Municípios como gerentes de serviços que se alinhavam aos demais prestadores privados para negociar com o INAMPS questões de interesse comum. BRASIL. Conselho Nacional de Secretários de Saúde. Legislação Estruturante do SUS. Brasília: CONASS, 2011, p.18-19 e 65-76.

${ }^{684}$ Portaria da Secretaria Nacional de Assistência à Saúde do Ministério da Saúde, n. 234, de 7 de fevereiro de 1992.

${ }^{685}$ BRASIL. Conselho Nacional de Secretários de Saúde. Legislação Estruturante do SUS. Brasília: CONASS, 2011, p.19 e 78-95.

686 "Art. $4^{\circ}$ Para receberem os recursos, de que trata o art. $3^{\circ}$ desta lei, os Municípios, os Estados e o Distrito Federal deverão contar com: I - Fundo de Saúde; II - Conselho de Saúde, com composição paritária de acordo com o Decreto n ${ }^{\circ}$ 99.438, de 7 de agosto de 1990; III - plano de saúde; IV - relatórios de gestão que 
A extinção do Instituto Nacional de Assistência Médica da Previdência Social (INAMPS) pela Lei n. 8.689, de 27 de julho de 1993, permitiu que o Ministério da Saúde passasse a ser a única autoridade sanitária em nível federal, as Secretarias de Estado da Saúde (SES), em nível estadual, e as Secretarias Municipais de Saúde (SMS), em âmbito municipal, alcançando, assim, a meta de direção única em cada esfera de governo, prevista como diretriz do Sistema Único de Saúde (SUS) pela Constituição Federal ${ }^{687}$

A Norma Operacional Básica do SUS - NOB-SUS 1/93, editada por portaria ${ }^{688}$ do Ministério da Saúde, formalizou princípios aprovados na $9^{\text {a }}$ Conferência Nacional de Saúde, criando os mecanismos de gestão participativos e descentralizados. As principais características da Norma Operacional Básica NOB/1993 são: institucionaliza a Comissão Intergestores Tripartite (CIT), formada por gestores da União, Estados e Municípios e a Comissão Intergestores Bipartite (CIB), formada por gestores dos Estados e Municípios, criando um modelo compartilhado de tomada das decisões pelas diferentes unidades federativas; impulsiona o processo de municipalização da gestão com habilitação nas condições de gestão criadas (incipiente, parcial e semiplena); cria a transferência regular e automática fundo a fundo ${ }^{689}$ do teto global da assistência para municípios em gestão semiplena; habilita municípios como gestores, criando a terceira instância do Sistema Único de Saúde (SUS); e apresenta frágil definição do papel dos estados, que também passam a assumir seu papel de gestor do sistema estadual de saúde. ${ }^{690}$

A regulamentação das relações intergovernamentais evoluiu com a edição da Norma Operacional Básica do SUS - NOB-SUS 1/96, por portaria do Ministério da

permitam o controle de que trata o $\S 4^{\circ}$ do art. 33 da Lei $\mathrm{n}^{\circ} 8.080$, de 19 de setembro de 1990; V contrapartida de recursos para a saúde no respectivo orçamento; VI - Comissão de elaboração do Plano de Carreira, Cargos e Salários (PCCS), previsto o prazo de dois anos para sua implantação.”

${ }^{687} \mathrm{O}$ artigo 198, inciso I, assim dispõe: “Art. 198. As ações e serviços públicos de saúde integram uma rede regionalizada e hierarquizada e constituem um sistema único, organizado de acordo com as seguintes diretrizes: I - descentralização, com direção única em cada esfera de governo;"

${ }^{688}$ Portaria GM/MS n. 545, de 20 de maio de 1993.

689 O Decreto n. 1.232, de 30 de agosto de 1994, instituiu o repasse fundo a fundo, que é um dos mais importantes instrumentos de gestão e operacionalização do Sistema Único de Saúde (SUS), pois estabelece as condições e a forma de repasse regular e automático de recursos do Fundo Nacional de Saúde para os fundos de saúde estaduais, municipais e do Distrito Federal. Esse modelo de transferência intergovernamental de recursos financeiros confere a agilidade necessária ao sistema e caracteriza-se por uma solução particular do setor de saúde em relação aos demais sistemas públicos, como educação e segurança. BRASIL. Conselho Nacional de Secretários de Saúde. Legislação Estruturante do SUS. Brasília: CONASS, 2011, p.20.

690 BRASIL. Conselho Nacional de Secretários de Saúde. Legislação Estruturante do SUS. Brasília: CONASS, 2011, p.19-20. 
Saúde ${ }^{691}$ e aprovada pelo Conselho Nacional de Saúde, que consolida a política de municipalização e o pleno exercício do poder municipal na função de gestão da saúde. Foi criada a rubrica PAB (Piso de Atenção Básica) especialmente para a atenção de base e o sistema de pagamento por produção de serviço, condicionando uma parte variável desse teto $(\mathrm{PAB})$ à adoção de programas federais, limitando, neste aspecto, a autonomia das unidades federativas para o recebimento de recursos federais. ${ }^{692}$

As esferas de atenção à saúde foram sistematizadas em três grandes campos: (i) $d a$ assistência, relativo às atividades dirigidas ao indivíduo ou à coletividade, em âmbito hospitalar, ambulatorial e em outros espaços, especialmente domiciliar; (ii) das intervenções ambientais, incluindo as relações e as condições sanitárias nos ambientes de vida e de trabalho, o controle de vetores hospedeiros e o saneamento ambiental; e (iii) das políticas externas ao setor saúde, que interferem nos determinantes sociais do processo saúde-doença das coletividades e, por esta razão, devem ser consideradas as questões relativas às políticas macroeconômicas, ao emprego, ao lazer, à habitação, à educação etc. $^{693}$

Em 2001 foi editada a Norma Operacional de Assistência à Saúde NOAS-SUS 1/01, publicada como portaria do Ministério da Saúde ${ }^{694}$, a partir do reconhecimento de que a ampliação das responsabilidades dos municípios na garantia de acesso aos serviços de atenção básica, a regionalização e a organização funcional do sistema são elementos

${ }^{691}$ A NOB-SUS 1/96 foi aprovada pela Portaria GM/MS n. 2.203, de 3 de novembro de 1996 do Ministério da Saúde, posteriormente alterada pela Portaria GM/MS 1.882, de 18 de dezembro de 1997, que modificou o conceito de Piso Assistencial Básico, do Piso Básico de Vigilância Sanitária e do incentivo aos Programas de Saúde da Família e Agentes Comunitários de Saúde. Outros atos que alteraram a NOB-SUS 1/96 foram: Portaria GM/MS 1.399, de 15 de dezembro de 1999; Portaria GM/MS 1.172, de 15 de junho de 2004; as NOAS 2001 e 2002.

692 A Norma Operacional Básica do SUS - NOB-SUS 1/96 apresenta como caraterísticas principais: a redefinição das responsabilidades, prerrogativas e requisitos das condições de gestão; a instituição da gestão plena do sistema municipal e da gestão plena da atenção básica; o estabelecimento de vínculo entre o cidadão e o SUS; a caracterização de responsabilidade sanitária de cada gestor; o fortalecimento da gestão do SUS; a reorganização do modelo assistencial, descentralizando aos municípios a responsabilidade pela gestão e execução direta da atenção básica de saúde; o aumento da participação percentual da transferência regular e automática (fundo a fundo) dos recursos federais a estados e municípios; a regulamentação das relações entre os sistemas municipais e destes com as instâncias estadual e federal; a definição de que os poderes públicos estadual e federal são sempre corresponsáveis com o município na respectiva competência e o substituem na sua ausência; a instituição da Programação Pactuada e Integrada (PPI) como principal instrumento formalizador das relações entre gestores; a incorporação de ações de vigilância sanitária, epidemiologia e controle de doenças, sendo as últimas coordenadas pela Fundação Nacional de Saúde. BRASIL. Conselho Nacional de Secretários de Saúde. Legislação Estruturante do SUS. Brasília: CONASS, 2011, p.21-22.

693 BRASIL. Conselho Nacional de Secretários de Saúde. Legislação Estruturante do SUS. Brasília: CONASS, 2011, p.130-131.

${ }^{694}$ Portaria GM/MS n. 95, de 26 de janeiro de 2001. 
indispensáveis para o avanço do processo de consolidação e aprimoramento do Sistema Único de Saúde (SUS). A NOAS-SUS 1/01 instituiu o Plano Diretor de Regionalização e de Investimentos, permitindo aos gestores estaduais a criação de regiões de saúde, como estratégia de hierarquização dos serviços de saúde e maior equidade e introduziu a ideia de redes de assistência. ${ }^{695}$

Em 2002 foi aprovada e instituída a Norma Operacional de Assistência à Saúde NOAS-SUS 1/02, pela Portaria n. 373, de 27 de fevereiro de 2002, do Ministério da Saúde ${ }^{696}$ e aprovada pelo Conselho Nacional de Saúde, com o objetivo de promover maior equidade na alocação de recursos e no acesso da população às ações e serviços de saúde em todos os níveis de atenção, por meio de três grupos de estratégias articuladas: regionalização e organização da assistência; fortalecimento da capacidade de gestão do Sistema Único de Saúde (SUS); e revisão de critérios de habilitação de municípios e estados. Por força do disposto no artigo $2^{\circ}$ da Portaria n. 373/2002, foram cessados os efeitos da Norma Operacional de Assistência à Saúde NOAS-SUS 1/01. 697698

Por fim, em 2006 foi aprovado, por portaria do Ministério da Saúde, o Pacto pela Saúde- Consolidação do SUS ${ }^{699}$, que contém três outros pactos: o Pacto pela Vida ${ }^{700}$, o Pacto em Defesa do Sistema Único de Saúde (SUS) $)^{701}$ e o Pacto de Gestão. ${ }^{702}$ O Pacto pela

695 BRASIL. Conselho Nacional de Secretários de Saúde. Legislação Estruturante do SUS. Brasília: CONASS, 2011, p.24 e 170-201.

696 A NOAS-SUS 1/02 foi resultado dos encaminhamentos fixados em reunião da Comissão Intergestores Tripartite (CIT), de 22 de novembro de 2001.

697 BRASIL. Conselho Nacional de Secretários de Saúde. Legislação Estruturante do SUS. Brasília: CONASS, 2011.p.24-25 e 227-259.

${ }^{698}$ A Portaria GM/MS n. 373, de 27 de fevereiro de 2002 (NOAS-SUS 1/02), foi alterada pelas Portarias GM/MS n. 1.734, de 19 de agosto de 2004; n. 384, de 4 de abril de 2003, n. 385, de 4 de abril de 2003, n. 321, de 8 de fevereiro de 2003 e pelas Portarias GM/MS n. 399, de 22 de fevereiro de 2006 e n. 699, de 30 de março de 2006, que tratam do Pacto pela Saúde.

${ }^{699}$ Portaria GM/MS n. 399, de 22 de fevereiro de 2006, com as alterações incluídas pela Portaria GM/MS n. 204, de 29/01/07.

700 A instituição do Pacto pela Vida representa duas mudanças para o aprimoramento do Sistema Único de Saúde (SUS): substitui pactos fortuitos por acordos anuais obrigatórios; e direciona as mudanças para alcançar resultados na área da saúde. A definição das prioridades para o desenvolvimento de ações pelos gestores é feita periodicamente, a partir de indicadores e metas, que também são analisados para o monitoramento dos resultados atingidos. BRASIL. Conselho Nacional de Secretários de Saúde. Legislação Estruturante do SUS. Brasília: CONASS, 2011. p.27-28.

${ }^{701}$ O Pacto em Defesa do Sistema Único de Saúde (SUS) deve ser implementado com um movimento de repolitização da saúde. As três esferas de gestão devem desenvolver ações concretas e articuladas no sentido de reforçar a importância do Sistema Único de Saúde (SUS) como política de Estado e de defender os princípios do SUS inscritos na Constituição Federal junto à sociedade brasileira. Este pacto tem como prioridade a regulamentação da Emenda Constitucional n. 29, que dispõe sobre o financiamento do SUS e a aprovação do orçamento consolidado do SUS. BRASIL. Conselho Nacional de Secretários de Saúde. Legislação Estruturante do SUS. Brasília: CONASS, 2011, p.26-27. 
Saúde não consiste em norma de operacionalização, mas num acordo interfederativo articulado entre o Ministério da Saúde, o Conselho Nacional de Secretários de Saúde (CONASS) e Conselho Nacional de Secretários Municipais de Saúde (CONASEMS) que promove reformas nos processos e instrumentos de gestão entre as esferas estaduais e municipais, anualmente revisados, nessas três dimensões.

Os atos normativos esparsos e infralegais editados pelo Ministério da Saúde, Secretarias de Estado da Saúde, Secretarias dos Municípios da Saúde e pelas agências reguladoras (Agência Nacional de Vigilância Sanitária - ANVISA ${ }^{703}$ e Agência Nacional de Saúde Suplementar- $\mathrm{ANS}^{704}$ ) por meio de Portarias válidas e vigentes, compõem o Direito Sanitário brasileiro e consistem em fonte específica deste ramo do Direito.

A despeito da natureza infralegal destes instrumentos normativos, as Portarias pactuadas entre os entes federativos, com aprovação do Conselho Nacional de Saúde assumem relevo tanto pela legitimidade democrática, quanto pelo conteúdo para a concretização dos objetivos do Sistema Único de Saúde (SUS). Tais portarias devem ser interpretadas conforme os princípios e diretrizes do sistema e à luz dos documentos legislativos que lhes serviram de fundamento de validade. ${ }^{705}$

Ademais disso, a legislação criada exclusiva ou principalmente para a proteção do direito à saúde, seja para a organização das ações estatais relativas à prestação de serviços

702 O Pacto de Gestão estabeleceu as responsabilidades de cada ente federativo de forma clara, a fim de fortalecer a gestão compartilhada e solidária do Sistema Único de Saúde (SUS). Este pacto propõe uma forte descentralização e a desburocratização dos processos normativos, estruturação das regiões sanitárias e fortalecimento das Comissões Intergestores Bipartite. BRASIL. Conselho Nacional de Secretários de Saúde. Legislação Estruturante do SUS. Brasília: CONASS, 2011, p.28-29.

703 A Agência Nacional de Vigilância Sanitária (ANVISA) é uma autarquia federal, sob regime especial, vinculada ao Ministério da Saúde, criada pela Lei n. 9.782/1999 (artigo 3º), que criou o Sistema Nacional de Vigilância Sanitária. De acordo com o artigo $1^{\circ}$ dessa lei, o Sistema Nacional de Vigilância Sanitária compreende o conjunto de ações definido pelo parágrafo $1^{\circ}$ do artigo $6^{\circ}$ e pelos artigos 15 a 18 da Lei $\mathrm{n}$. 8.080, de 19 de setembro de 1990, executado por instituições da Administração Pública direta e indireta da União, dos Estados, do Distrito Federal e dos Municípios, que exerçam atividades de regulação, normatização, controle e fiscalização na área de vigilância sanitária. A ANVISA tem por “(...) finalidade institucional promover a proteção da saúde da população, por intermédio do controle sanitário da produção e da comercialização de produtos e serviços submetidos à vigilância sanitária, inclusive dos ambientes, dos processos, dos insumos e das tecnologias a eles relacionados, bem como o controle de portos, aeroportos e de fronteiras." (artigo $\left.6^{\circ}\right)$.

704 A Agência Nacional de Saúde Suplementar (ANS) é uma autarquia federal, sob o regime especial, vinculada ao Ministério da Saúde, criada para auxiliar o Estado no cumprimento de seu dever de garantir a saúde a todas as pessoas, "como órgão de regulação, normatização, controle e fiscalização das atividades que garantam a assistência suplementar à saúde" (artigo $1^{\circ}$, da Lei n. 9.961/2000). Sua finalidade institucional consiste em “(...) promover a defesa do interesse público na assistência suplementar à saúde, regulando as operadoras setoriais, inclusive quanto às suas relações com prestadores e consumidores, contribuindo para o desenvolvimento das ações de saúde no País." (artigo 3º da Lei n. 9.961/2000).

${ }^{705}$ AITH, Fernando. Curso de Direito Sanitário: a proteção do Direito à Saúde no Brasil. São Paulo: Quartier Latin. 2007, p. 292 e 356. 
de saúde, seja para estabelecer infrações sanitárias e suas sanções, constituem fontes específicas de Direito Sanitário. ${ }^{706}$ São exemplos desse tipo de norma: as Leis federais n. 8.080/90 e n. 8.142/90, já mencionadas; a Lei n. 9.782/1999, que cria a Agência Nacional de Vigilância Sanitária (ANVISA); a Lei n. 9.961/2000, que cria a Agência Nacional de Saúde Suplementar (ANS); a Lei n. 11.105/2005, conhecida como "Lei de Biosegurança"; a Lei n. 6.437/77 707 , que define as infrações à legislação sanitária federal; a Lei n. 5.991/73, que dispõe sobre o controle sanitário do comércio de drogas, medicamentos, insumos farmacêuticos e correlatos; e a Lei n. 6.360/76, que estabelece normas de vigilância sanitária a que ficam sujeitos os medicamentos, as drogas, os insumos farmacêuticos e correlatos, definidos na Lei n. 5.991/73, bem como os produtos de higiene, os cosméticos, perfumes, saneantes domissanitários, produtos destinados à correção estética, dentre outros que define.

Há também instrumentos normativos que, apesar de não terem sido elaborados exclusiva ou especialmente para a proteção do direito à saúde, possuem dispositivos que lhe asseguram proteção, constituindo, assim, fontes não específicas do Direito Sanitário,

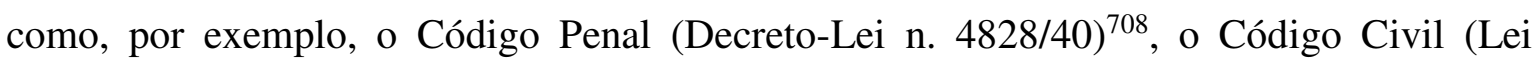
10.406/2002) ${ }^{709}$, o Código de Defesa do Consumidor (Lei 8.078/90) ${ }^{710}$ e a Lei Orgânica da Assistência Social (Lei n. 8.742, de 7 de dezembro de 1993). ${ }^{711}$

\footnotetext{
${ }^{706}$ AITH, Fernando. Curso de Direito Sanitário: a proteção do Direito à Saúde no Brasil. São Paulo: Quartier Latin. 2007, p. 265.

707 A Lei n. 6.437, de 20 de agosto de 1977 teve sua redação alterada pela Lei n. 9.695, de 20 de agosto de 1998.

${ }^{708} \mathrm{O}$ Código Penal estabelece normas que protegem o direito à saúde ao definir como crime, dentre outras, as seguintes condutas: "ofender a integridade corporal ou a saúde de outrem", (artigo 129, lesão corporal); “expor alguém, por meio de relações sexuais ou qualquer ato libidinoso, a contágio de moléstia venérea, de que sabe ou deve saber que está contaminado" (artigo 130, perigo de contágio venéreo); "praticar, com o fim de transmitir a outrem moléstia grave de que está contaminado, ato capaz de produzir o contágio" (artigo 131, perigo de contágio de moléstia grave); "expor a vida ou a saúde de outrem a perigo direto e iminente" (artigo 132, perigo para a vida ou saúde de outrem); "abandonar pessoa que está sob seu cuidado, guarda, vigilância ou autoridade, e, por qualquer motivo, incapaz de defender-se dos riscos resultantes do abandono" (artigo 133, abandono de incapaz); expor ou abandonar recém-nascido, para ocultar desonra própria" (artigo 134, exposição ou abandono de recém-nascido); "deixar de prestar assistência, quando possível fazê-lo sem risco pessoal, à criança abandonada ou extraviada, ou à pessoa inválida ou ferida, ao desamparo ou em grave e iminente perigo; ou não pedir, nesses casos, o socorro da autoridade pública" (artigo 135, omissão de socorro); "exigir cheque-caução, nota promissória ou qualquer garantia, bem como o preenchimento prévio de formulários administrativos, como condição para o atendimento médico-hospitalar emergencial" (artigo 135-A, condicionamento de atendimento médico-hospitalar emergencial) e "expor a perigo a vida ou a saúde de pessoa sob sua autoridade, guarda ou vigilância, para fim de educação, ensino, tratamento ou custódia, quer privando-a de alimentação ou cuidados indispensáveis, quer sujeitando-a a trabalho excessivo ou inadequado, quer abusando de meios de correção ou disciplina" (artigo 136, maus tratos).

709 O Código Civil consiste em fonte não específica do Direito Sanitário porque dentre suas normas, contempla matéria relativa à proteção do direito à saúde. Como exemplo disso, seu artigo $2^{\circ}$ prescreve que "a
} 


\subsubsection{Objetivos e Princípios}

Nos termos do que dispõe o artigo 196 da Constituição Federal, são dois os grandes objetivos do Sistema Único de Saúde, a saber: (i) a redução do risco de doenças e de outros agravos; e (ii) o acesso universal e igualitário às ações e serviços para sua promoção, proteção e recuperação. ${ }^{712}$

A Lei n. 8.080/90 em consonância com a diretriz de atendimento integral e a priorização das ações preventivas, sem prejuízo das assistenciais ${ }^{713}$, define, em seu artigo $5^{\circ}$, os objetivos do Sistema Único de Saúde, quais sejam: (i) identificar e divulgar os fatores condicionantes e determinantes da saúde; (ii) formular políticas de saúde destinadas a promover a redução de riscos de doenças e de outros agravos, e o estabelecimento de

personalidade civil da pessoa começa do nascimento com vida; mas a lei põe a salvo, desde a concepção, os direitos do nascituro." Segundo AITH, este dispositivo está ligado às discussões sobre pesquisas em embriões e aborto, dentre outros. AITH, Fernando. Curso de Direito Sanitário: a proteção do Direito à Saúde no Brasil. São Paulo: Quartier Latin. 2007, p. 293.

${ }^{710}$ O Código de Defesa do Consumidor estabelece normas de proteção e defesa do consumidor, de ordem pública e interesse social, nos termos de seu artigo $1^{\circ}$, que interessam à efetividade do direito à saúde. Dentre tais normas, são exemplos as normas relativas aos direitos básicos do consumidor, à qualidade dos serviços prestados e à responsabilidade pelo fato do serviço, dentre outras, aplicáveis aos contratos celebrados entre consumidores e operadoras dos planos de saúde, pessoas físicas ou jurídicas de direito privado autorizadas a prestar serviços de saúde, por força do artigo 197 da Constituição Federal.

${ }^{711}$ A Lei Orgânica da Assistência Social, com a redação dada pela Lei n. 12.435, de 2011, estabelece que "a assistência social, direito do cidadão e dever do Estado, é Política de Seguridade Social não contributiva, que provê os mínimos sociais, realizada através de um conjunto integrado de ações de iniciativa pública e da sociedade, para garantir o atendimento às necessidades básicas." (artigo $1^{\circ}$ ). A Lei Orgânica da Assistência Social está vinculada à concretização do direito à saúde, pois estabelece que a assistência social se realiza de forma integrada às políticas setoriais para o enfrentamento da pobreza e a garantia do mínimo social (núcleo essencial ou mínimo existencial dos direitos fundamentais), e define como objetivos da assistência social: (i) a redução de danos e a prevenção da incidência de riscos; (ii) a vigilância socioassistencial; e (iii) a defesa de direitos socioassistenciais. Nos termos do artigo $2^{\circ}$ : "A assistência social tem por objetivos: I - a proteção social, que visa à garantia da vida, à redução de danos e à prevenção da incidência de riscos, especialmente: a) a proteção à família, à maternidade, à infância, à adolescência e à velhice; b) o amparo às crianças e aos adolescentes carentes; c) a promoção da integração ao mercado de trabalho; d) a habilitação e reabilitação das pessoas com deficiência e a promoção de sua integração à vida comunitária; e e) a garantia de 1 (um) saláriomínimo de benefício mensal à pessoa com deficiência e ao idoso que comprovem não possuir meios de prover a própria manutenção ou de tê-la provida por sua família; II - a vigilância socioassistencial, que visa a analisar territorialmente a capacidade protetiva das famílias e nela a ocorrência de vulnerabilidades, de ameaças, de vitimizações e danos; III - a defesa de direitos, que visa a garantir o pleno acesso aos direitos no conjunto das provisões socioassistenciais. Parágrafo único. Para o enfrentamento da pobreza, a assistência social realiza-se de forma integrada às políticas setoriais, garantindo mínimos sociais e provimento de condições para atender contingências sociais e promovendo a universalização dos direitos sociais." (artigo $\left.2^{\circ}\right)$.

712 “Art. 196. A saúde é direito de todos e dever do Estado, garantido mediante políticas sociais e econômicas que visem à redução do risco de doença e de outros agravos e ao acesso universal e igualitário às ações e serviços para sua promoção, proteção e recuperação".

713 A preferência das medidas preventivas está expressamente contida no caput do artigo 196, da Constituição Federal, ao afirmar que o direito à saúde é “(...) garantido mediante políticas sociais e econômicas que visem à redução do risco de doença e de outros agravos" e em seu artigo 198, inciso II, que prevê, dentre as diretrizes do Sistema Único de Saúde, "Art. 198. (...) II- atendimento integral, com prioridade para as atividades preventivas, sem prejuízo dos serviços assistenciais;” (os grifos não constam do texto original). 
condições que assegurem acesso universal e igualitário às ações e aos serviços para a sua promoção, proteção e recuperação; e (iii) a assistência às pessoas com a realização integrada das ações assistenciais e atividades preventivas. ${ }^{714}$

É importante destacar que a Lei 8.080/90, ao estabelecer o dever do Estado de garantir a saúde, realça que as pessoas, a família, as empresas e a sociedade também são responsáveis pela própria saúde e de seus familiares, dos colegas de trabalho e da coletividade de pessoas com que convivem. ${ }^{715} \mathrm{O}$ dever de adotar medidas voltadas à proteção e à promoção da saúde cabe a todos, pois para alcançar os objetivos citados e melhorar o estado de saúde da população não é suficiente a atuação do Estado relativa à formulação e à gestão de políticas públicas sanitárias. É também indispensável que a sociedade adote uma série de comportamentos, relacionados à proteção da saúde individual e coletiva. A alimentação equilibrada, a higiene adequada e a prática regular de exercícios físicos pelas pessoas também previnem doenças e agravos à saúde. Já em relação às empresas, o respeito à legislação trabalhista e às normas regulamentadoras editadas pelo Ministério do Trabalho ${ }^{716}$ acerca da proteção da saúde, higiene e segurança dos trabalhadores ${ }^{717}$ asseguram a redução dos riscos inerentes ao trabalho.

Os princípios reitores do Sistema Único de Saúde (SUS) estão previstos em sede constitucional, na seção dedicada à saúde, especialmente nos artigos 196 e 198 da

\footnotetext{
${ }^{714}$ Nos termos do artigo $5^{\circ}$, da Lei n. 8.80/90: “Art. $5^{\circ}$ São objetivos do Sistema Único de Saúde SUS: I - a identificação e divulgação dos fatores condicionantes e determinantes da saúde; II - a formulação de política de saúde destinada a promover, nos campos econômico e social, a observância do disposto no $\S 1^{\circ}$ do art. $2^{\circ}$ desta lei; III - a assistência às pessoas por intermédio de ações de promoção, proteção e recuperação da saúde, com a realização integrada das ações assistenciais e das atividades preventivas."

$715 \mathrm{O}$ artigo $2^{\circ}$, da Lei 8.080/90 assim dispõe: "Art. $2^{\circ}$ A saúde é um direito fundamental do ser humano, devendo o Estado prover as condições indispensáveis ao seu pleno exercício. $\S 1^{\circ} \mathrm{O}$ dever do Estado de garantir a saúde consiste na formulação e execução de políticas econômicas e sociais que visem à redução de riscos de doenças e de outros agravos e no estabelecimento de condições que assegurem acesso universal e igualitário às ações e aos serviços para a sua promoção, proteção e recuperação. $2^{\circ} \mathrm{O}$ dever do Estado não exclui o das pessoas, da família, das empresas e da sociedade."

${ }^{716}$ A Norma Regulamentadora n. 1, item 1.1, assim dispõe: "As Normas Regulamentadoras - NR, relativas à segurança e medicina do trabalho, são de observância obrigatória pelas empresas privadas e públicas e pelos órgãos públicos da administração direta e indireta, bem como pelos órgãos dos Poderes Legislativo e Judiciário, que possuam empregados regidos pela Consolidação das Leis do Trabalho - CLT." Portaria GM n. 3.214, de 8 de junho de 1978, publicada no Diário Oficial da União de 06 de julho de 1978.

717 A Constituição Federal prevê dentre os direitos sociais dos trabalhadores a proteção contra os riscos inerentes ao trabalho, atribuindo aos empresários o dever de observâncias das normas de saúde, higiene e segurança, nos seguintes termos: "Art. $7^{\circ}$ São direitos dos trabalhadores urbanos e rurais, além de outros que visem à melhoria de sua condição social: (...) XXII - redução dos riscos inerentes ao trabalho, por meio de normas de saúde, higiene e segurança."
} 
Constituição Federal, bem como na Lei n. 8.080, de 19 de setembro de 1990, mormente em seu artigo $7^{\circ} .^{718}$

O princípio da descentralização do Sistema Único de Saúde (SUS), previsto no artigo 198, inciso I, da Constituição Federal ${ }^{719}$ e no artigo $7^{\circ}$, IX, da Lei n. 8.080/90 720 , significa a atribuição a todos os entes federados de competência para desenvolver as funções de planejamento, administração e execução das políticas sanitárias regionalmente, devendo ser garantido o equilíbrio na distribuição de recursos para financiá-las. ${ }^{721}$

A Constituição Federal consagra a descentralização política ao estabelecer a competência material comum dos entes federados para "cuidar da saúde" (artigo 23, inciso II) ${ }^{722}$, determinando que a direção do Sistema Único de Saúde (SUS) seja feita em cada esfera governamental. A adoção do federalismo de cooperação importa na distribuição de competências e no fortalecimento dos poderes locais e regionais, para que o planejamento das políticas sanitárias seja feito conjuntamente entre União, Estados, Distrito Federal e Municípios.

${ }^{718} \mathrm{O}$ artigo $7^{\circ}$, da Lei n. 8.080/90 assim estabelece os princípios reitores do Sistema Único de Saúde (SUS): "Art. $7^{\circ}$ As ações e serviços públicos de saúde e os serviços privados contratados ou conveniados que integram o Sistema Único de Saúde (SUS), são desenvolvidos de acordo com as diretrizes previstas no art. 198 da Constituição Federal, obedecendo ainda aos seguintes princípios: I - universalidade de acesso aos serviços de saúde em todos os níveis de assistência; II - integralidade de assistência, entendida como conjunto articulado e contínuo das ações e serviços preventivos e curativos, individuais e coletivos, exigidos para cada caso em todos os níveis de complexidade do sistema; III - preservação da autonomia das pessoas na defesa de sua integridade física e moral; IV - igualdade da assistência à saúde, sem preconceitos ou privilégios de qualquer espécie; V - direito à informação, às pessoas assistidas, sobre sua saúde; VI divulgação de informações quanto ao potencial dos serviços de saúde e a sua utilização pelo usuário; VII utilização da epidemiologia para o estabelecimento de prioridades, a alocação de recursos e a orientação programática; VIII - participação da comunidade; IX - descentralização político-administrativa, com direção única em cada esfera de governo: a) ênfase na descentralização dos serviços para os municípios; b) regionalização e hierarquização da rede de serviços de saúde; $\mathrm{X}$ - integração em nível executivo das ações de saúde, meio ambiente e saneamento básico; XI - conjugação dos recursos financeiros, tecnológicos, materiais e humanos da União, dos Estados, do Distrito Federal e dos Municípios na prestação de serviços de assistência à saúde da população; XII - capacidade de resolução dos serviços em todos os níveis de assistência; e XIII - organização dos serviços públicos de modo a evitar duplicidade de meios para fins idênticos".

${ }^{719}$ Nos termos do artigo 198, inciso I, da Constituição Federal: "Art. 198. As ações e serviços públicos de saúde integram uma rede regionalizada e hierarquizada e constituem um sistema único, organizado de acordo com as seguintes diretrizes: I - descentralização, com direção única em cada esfera de governo; (...).”

720“"Art. $7^{\circ}$ As ações e serviços públicos de saúde e os serviços privados contratados ou conveniados que integram o Sistema Único de Saúde (SUS), são desenvolvidos de acordo com as diretrizes previstas no art. 198 da Constituição Federal, obedecendo ainda aos seguintes princípios: (...) IX - descentralização políticoadministrativa, com direção única em cada esfera de governo:"

${ }^{721} \mathrm{O}$ artigo 15 da Lei n. 8.080/90 define as atribuições comuns da União, Estados, Distrito Federal e Municípios em seu âmbito administrativo.

722 Nos termos do artigo 23, inciso II, da Constituição Federal: “Art. 23. É competência comum da União, dos Estados, do Distrito Federal e dos Municípios: (...) II - cuidar da saúde e assistência pública, da proteção e garantia das pessoas portadoras de deficiência; (os destaques não constam do texto original) 
A descentralização não é focada apenas no reconhecimento de competências autônomas das unidades federadas para tomar decisões na condução de políticas públicas, mas, também, e principalmente, na conscientização dos cidadãos para uma maior participação na Administração local, desenvolvendo, assim, um sentimento de que fazem parte do sistema, tendo em vista a maior proximidade com o gestor público. ${ }^{723}$

A descentralização pode ser analisada por dois aspectos: um político e outro técnico-gerencial. Sob o aspecto político, a descentralização consiste na superação da política centralizadora segundo a qual a União exercia o papel de executora das políticas públicas e tomava as decisões a que os Estados e Municípios deveriam se submeter. Por outro lado, sob o aspecto técnico-gerencial, a descentralização é medida que se impõe ante a enorme dimensão territorial brasileira e às peculiaridades endêmicas de cada região. ${ }^{724}$

No âmbito do Sistema Único de Saúde (SUS), a descentralização permitiu que os municípios fossem alçados à condição de responsáveis imediatos pelo atendimento das demandas de saúde da sua população, como gestores, superando o papel de meros executores das decisões tomadas pelo poder central.

Apesar da descentralização, a direção única das ações e dos serviços de saúde em cada esfera de governo visa a operacionalização do sistema e a organização do sistema, coibindo que numa mesma esfera de governo haja o compartilhamento da direção de serviços de saúde com outros órgãos do governo, bem como que haja dirigentes de saúde, de variadas esferas de governo, executando serviços de forma desarticulada. ${ }^{725}$ A gestão administrativa do Sistema Único de Saúde é organizada e articulada de forma que haja apenas um comando, um planejamento em cada uma das esferas (municipal, estadual e federal), que pode ser compartilhado nos outros níveis.

\footnotetext{
${ }^{723}$ Segundo SANTOS, "a descentralização das ações e serviços de saúde, nos ideais da Reforma Sanitária, visava tornar o cidadão consciente de seu papel de dono indireto do poder exercido pelo Estado, além de buscar maior participação, diálogo e harmonia entre as necessidades de saúde da população e as políticas e programas públicos. SANTOS, Lenir. SUS: regionalizando a descentralização- região de saúde como imposição constitucional ou como ato de vontade dos entes federativos? In: Boletim de Direito Administrativo (BDA), p. 1396-1397, dezembro 2012.

${ }^{724}$ MIRANDA, Ciro Carvalho. Fornecimento Gratuito de Medicamento pelo Poder Público e Protocolos Clínicos: poder regulamentar do Ministério da Saúde e adequação do exercício do direito fundamental. Dissertação (Mestrado). Curso de Pós Graduação em Direito Constitucional. Instituto Brasiliense de Direito Público - IDP. Brasília, 2010. p.14-16.

725 SANTOS, Lenir. SUS: regionalizando a descentralização- região de saúde como imposição constitucional ou como ato de vontade dos entes federativos? Boletim de Direito Administrativo (BDA), p. 1406, dezembro 2012.
} 
A Lei n. 8.080/90 prevê, em seu artigo $9^{\circ}$, que a direção única será exercida pelos seguintes órgãos: no âmbito federal, pelo Ministério da Saúde; no âmbito dos Estados e do Distrito Federal, pela Secretaria de Saúde ou órgão equivalente; no Âmbito dos Municípios, pela Secretaria de Saúde ou órgão equivalente. ${ }^{726}$ A Lei n. 8.080, de 19 de setembro de 1990, estabelece que a direção única deverá ser observada inclusive na hipótese em que os Municípios instituam consórcios administrativos intermunicipais (artigo 10, parágrafo $1^{\circ}$ ). Ainda em relação aos Municípios, a Lei n. 8.080/90 admite a organização administrativa em forma de distritos que possibilitem a articulação de recursos, técnicas e práticas voltadas à cobertura integral das ações de saúde (artigo 10, parágrafo $\left.2^{\circ}\right) .^{727}$

Em linhas gerais, a Lei n. 8.080, de 19 de setembro de 1990, estabeleceu, no Capítulo IV (“da competência e das atribuições”), em seus artigos 15 a 19, a atribuição de cada esfera de governo em relação à realização de ações e à prestação de serviços de saúde, de forma regionalizada e hierarquizada em níveis de complexidade.

De acordo com o artigo 16 da Lei n. 8.080/90, incumbe à União as atividades de planejamento $^{728}$, coordenação, normatização e financiamento do sistema. Suas atribuições

726 “Art. 9 A direção do Sistema Único de Saúde (SUS) é única, de acordo com o inciso I do art. 198 da Constituição Federal, sendo exercida em cada esfera de governo pelos seguintes órgãos: I - no âmbito da União, pelo Ministério da Saúde; II - no âmbito dos Estados e do Distrito Federal, pela respectiva Secretaria de Saúde ou órgão equivalente; e III - no âmbito dos Municípios, pela respectiva Secretaria de Saúde ou órgão equivalente."

727“Art. 10. Os municípios poderão constituir consórcios para desenvolver em conjunto as ações e os serviços de saúde que lhes correspondam. $\S 1^{\circ}$ Aplica-se aos consórcios administrativos intermunicipais o princípio da direção única, e os respectivos atos constitutivos disporão sobre sua observância. § $2^{\circ}$ No nível municipal, o Sistema Único de Saúde (SUS), poderá organizar-se em distritos de forma a integrar e articular recursos, técnicas e práticas voltadas para a cobertura total das ações de saúde."

728 A Cartilha da saúde de 2012 prevê como principais objetivos estratégicos do Ministério da Saúde os seguintes: 1. Garantir acesso da população a serviços de qualidade, com equidade e em tempo adequado ao atendimento das necessidades de saúde, aprimorando a política de atenção básica e a atenção especializada; 2. Reduzir os riscos e agravos à saúde da população, por meio das ações de promoção e vigilância em saúde; 3. Promover atenção integral à saúde da mulher e da criança e implementar a Rede Cegonha, com especial atenção às áreas e populações de maior vulnerabilidade; 4. Aprimorar a Rede de Urgência e Emergência, com expansão e adequação de Unidades de Pronto-Atendimento (UPAs), Serviço de Atendimento Móvel de Urgência (SAMU), prontos-socorros e centrais de regulação, articulando-a com outras redes de atenção; 5. Fortalecer a Rede de Saúde Mental, com ênfase no enfrentamento da dependência de crack e outras drogas; 6. Garantir a atenção integral à saúde da pessoa idosa e dos portadores de doenças crônicas, estimulando o envelhecimento ativo e saudável e fortalecendo as ações de promoção e prevenção; 7. Implementar o Subsistema de Atenção à Saúde Indígena, articulado com o SUS, baseado no cuidado integral, observando as práticas de saúde e as medicinas tradicionais, com controle social, garantindo o respeito às especificidades culturais; 8. Contribuir para a adequada formação, alocação, qualificação, valorização e democratização das relações do trabalho dos profissionais e trabalhadores de saúde; 9. Implementar novo modelo de gestão e instrumentos de relação federativa, com centralidade na garantia do acesso, gestão participativa com foco em resultados, participação social e financiamento estável; 10. Qualificar instrumentos de execução direta, gerando ganhos de produtividade e eficiência para o SUS; 11. Garantir assistência farmacêutica no âmbito do 
compreendem, dentre outras: a formulação, a avaliação e o apoio às políticas de alimentação e nutrição (inciso I); a definição e coordenação dos sistemas de rede integrada de assistência de alta complexidade, de rede laboratorial da saúde pública, o sistema de vigilância epidemiológica e sanitária (inciso III); identificar os serviços estaduais e municipais de referência nacional para o estabelecimento de padrões técnicos de assistência à saúde (inciso XI); e a elaboração de normas para regular as relações entre o Sistema Único de Saúde (SUS) e os serviços privados contratados de assistência à saúde (inciso XIV).

A direção nacional do Sistema Único de Saúde (SUS) tem responsabilidades que devem ser exercidas em cooperação técnica com os demais níveis de gestão (estadual e municipal), dentre as quais cabe mencionar: a elaboração do planejamento estratégico nacional no âmbito do SUS (inciso XVIII); a formulação e implementação das políticas de controle de agressões ao meio ambiente, de saneamento básico e relativa às condições de trabalho (artigo 16, inciso II, "a", "b" e "c"); e a definição de normas e mecanismos de controle, com órgão afins, de agravo sobre o meio ambiente ou dele decorrentes, que tenham repercussão na saúde humana (artigo 16, inciso IV, combinado com os artigos 17 , inciso $\mathrm{V}$ e 18 , inciso VI).

Apenas em circunstâncias excepcionais a direção nacional do Sistema Único de Saúde (SUS) executará diretamente ações de saúde. Nos termos do parágrafo único do artigo 16, da Lei n. 8.080/90, a União poderá executar ações de vigilância epidemiológica e sanitária em situações especiais, como na hipótese de agravos de saúde que extrapolem a capacidade de controle da direção estadual do Sistema Único de Saúde (SUS) ou que representem risco de disseminação nacional.

Nos termos do artigo 17, da Lei n. 8.080/90, às direções estaduais compete promover a descentralização para os Municípios das ações e serviços de saúde (inciso I).

SUS; 12. Fortalecer o complexo industrial e de ciência, tecnologia e inovação em saúde como vetor estruturante da agenda nacional de desenvolvimento econômico, social e sustentável, reduzindo a vulnerabilidade do acesso à saúde e da assistência farmacêutica no âmbito do SUS; 13. Aprimorar a regulação e a fiscalização da saúde suplementar, articulando a relação público-privada, gerando maior racionalidade e qualidade no setor saúde; 14 . Promover internacionalmente os interesses brasileiros no campo da saúde, bem como compartilhar as experiências e saberes do SUS com outros países, em conformidade com as diretrizes da política externa brasileira; 15. Implementar ações de saneamento básico e saúde ambiental, de forma sustentável, para promoção da saúde e redução das desigualdades sociais; e 16. Contribuir para erradicar a extrema pobreza no país. Cartilha para apresentação de propostas no Ministério da Saúde/ Ministério da Saúde. Secretaria-Executiva; Fundo Nacional de Saúde. Brasília: Ministério da Saúde, 2012. 
Para tanto, é necessário acompanhar, controlar e avaliar as redes hierarquizadas do Sistema Único de Saúde (inciso II), bem como prestar apoio técnico e financeiro aos Municípios e, de forma supletiva, executar as ações e serviços de saúde (inciso III). As direções estaduais também têm atribuição para, dentre outras: identificar os estabelecimentos hospitalares de referência e gerir os sistemas públicos de alta complexidade, de referência estadual e regional (inciso IX); coordenar a rede estadual de laboratórios de saúde pública e hemocentros, e gerir as unidades que permaneçam em sua organização administrativa (inciso $\mathrm{X}$ ); e colaborar com a União na execução da vigilância sanitária de portos, aeroportos e fronteiras (inciso XIII).

As atribuições da direção municipal do Sistema Único de Saúde (SUS) estão fixadas no artigo 18, da Lei n. 8.080/90 e abrangem, dentre outras: o planejamento, a organização, o controle e a avaliação das ações e serviços de saúde, bem como a gestão e execução dos serviços públicos de saúde (inciso I); a participação no planejamento, programação e organização da rede regionalizada e hierarquizada do Sistema Único de Saúde (SUS) em articulação com sua direção estadual (inciso II); e a execução dos serviços de a) de vigilância epidemiológica; b) vigilância sanitária; c) de alimentação e nutrição; d) de saneamento básico; e e) de saúde do trabalhador (inciso IV).

A atuação municipal é realizada de forma coordenada e integrada com as atividades da direção nacional e estadual do Sistema Único de Saúde (SUS). Conforme prevê o artigo 36, caput, da Lei n. 8.080, de 19 de setembro de 1990, o processo de planejamento do sistema será ascendente e integrado, iniciando-se no nível local até o nível federal, com a participação dos respectivos Conselhos de Saúde, de modo a compatibilizar as necessidades da política de saúde com a disponibilidade de recursos financeiros, no âmbito dos planos em saúde, que serão resultado do planejamento integrado dos entes federativos e devem conter as metas de saúde (artigo 36, parágrafo $1^{\circ}$, da Lei n. 8.080/90 ${ }^{729}$ e artigo 15, do Decreto n. $7.508 / 2011^{730}$ ).

729 “Art. 36. O processo de planejamento e orçamento do Sistema Único de Saúde (SUS) será ascendente, do nível local até o federal, ouvidos seus órgãos deliberativos, compatibilizando-se as necessidades da política de saúde com a disponibilidade de recursos em planos de saúde dos Municípios, dos Estados, do Distrito Federal e da União. $\S 1^{\circ}$ Os planos de saúde serão a base das atividades e programações de cada nível de direção do Sistema Único de Saúde (SUS), e seu financiamento será previsto na respectiva proposta orçamentária."

730“Art. 15. O processo de planejamento da saúde será ascendente e integrado, do nível local até o federal, ouvidos os respectivos Conselhos de Saúde, compatibilizando-se as necessidades das políticas de saúde com a disponibilidade de recursos financeiros. $\S 1^{\circ} \mathrm{O}$ planejamento da saúde é obrigatório para os entes públicos e será indutor de políticas para a iniciativa privada. $\S 2^{\circ} \mathrm{A}$ compatibilização de que trata o caput será efetuada 
O modelo compartilhado de planejamento e de tomada das decisões pelas diferentes unidades federativas foi concebido pela Norma Operacional Básica do SUS - NOB-SUS 1/93, editada pela Portaria GM/MS n.545, de 20 de maio de 1993, que formalizou os princípios aprovados na $9^{a}$ Conferência Nacional de Saúde ${ }^{731}$, institucionalizando a Comissão Intergestores Tripartite (CIT), formada por gestores da União, Estados e Municípios e a Comissão Intergestores Bipartite (CIB), formada por gestores dos Estados e Municípios, além de impulsionar a municipalização. A Norma Operacional Básica do SUS - NOB-SUS 1/96 também previu a Comissão Intergestores Tripartite (CIT) e a Comissão Intergestores Bipartite (CIB) como fóruns de articulação descentralizada e participativa entre gestores, viabilizando a harmonização de toda a rede de ações e serviços prestados à população.

Tais mecanismos de gestão foram introduzidos na Lei n. 8.080/90, em seu artigo 14-A, por força da Lei n. 12.466/2011, que reconheceu as Comissões Intergestores Tripartite (CIT) e Bipartite (CIB), como foros de negociação e pactuação entre os gestores quanto aos aspectos operacionais do Sistema Único de Saúde (SUS). ${ }^{732}$

As pactuações estabelecidas pela Comissão Intergestores Tripartite (CIT) viabilizam a integração dos planos de saúde dos entes federativos na Rede de Atenção à Saúde, que conduz à celebração do "Contrato Organizativo da Ação Pública da Saúde" (artigo 34, Decreto n. 7.508/2011). ${ }^{733}$ Este contrato pode ser definido como o acordo de

no âmbito dos planos de saúde, os quais serão resultado do planejamento integrado dos entes federativos, e deverão conter metas de saúde. $\S 3^{\circ} \mathrm{O}$ Conselho Nacional de Saúde estabelecerá as diretrizes a serem observadas na elaboração dos planos de saúde, de acordo com as características epidemiológicas e da organização de serviços nos entes federativos e nas Regiões de Saúde."

731 O tema da $9^{a}$ Conferência Nacional de Saúde, ocorrida em 1992, buscou adotar medidas voltadas à atribuição aos municípios de maiores responsabilidades na gestão dos serviços de saúde, tendo como tema "A municipalização é o caminho".

732 “Art. 14-A. As Comissões Intergestores Bipartite e Tripartite são reconhecidas como foros de negociação e pactuação entre gestores, quanto aos aspectos operacionais do Sistema Único de Saúde (SUS). Parágrafo único. A atuação das Comissões Intergestores Bipartite e Tripartite terá por objetivo: I - decidir sobre os aspectos operacionais, financeiros e administrativos da gestão compartilhada do SUS, em conformidade com a definição da política consubstanciada em planos de saúde, aprovados pelos conselhos de saúde; II - definir diretrizes, de âmbito nacional, regional e intermunicipal, a respeito da organização das redes de ações e serviços de saúde, principalmente no tocante à sua governança institucional e à integração das ações e serviços dos entes federados; III - fixar diretrizes sobre as regiões de saúde, distrito sanitário, integração de territórios, referência e contrarreferência e demais aspectos vinculados à integração das ações e serviços de saúde entre os entes federados."

733 “Art. 34. O objeto do Contrato Organizativo de Ação Pública da Saúde é a organização e a integração das ações e dos serviços de saúde, sob a responsabilidade dos entes federativos em uma Região de Saúde, com a finalidade de garantir a integralidade da assistência aos usuários. Parágrafo único. O Contrato Organizativo de Ação Pública da Saúde resultará da integração dos planos de saúde dos entes federativos na Rede de Atenção à Saúde, tendo como fundamento as pactuações estabelecidas pela CIT." 
colaboração pactuado entre os entes federativos com a finalidade de organizar e integrar as ações e serviços de saúde na rede regionalizada e hierarquizada, nos termos dos artigos $2^{\circ}$, inciso II $^{734}$ e $33^{735}$, do Decreto n. 7.508/2011, que regulamenta a Lei n. 8.080, de 19 de setembro de $1990 .{ }^{736}$ O objeto do "Contrato Organizativo da Ação Pública da Saúde" é a organização e a integração das ações e dos serviços de saúde sob a responsabilidade dos entes federativos numa determinada Região de Saúde, com a finalidade de garantir a integralidade da assistência à população. Portanto, serão determinadas neste "contrato organizativo" as responsabilidades individuais e solidárias dos entes federativos com relação às ações e serviços de saúde, os indicadores e metas de saúde, bem como os critérios de avaliação de desempenho, os recursos financeiros disponibilizados, a forma de controle e físcalização da sua execução, dentre outros elementos necessários à implementação integrada das ações e serviços de saúde. ${ }^{737}$

Há um vínculo entre a descentralização e o princípio da subsidiariedade, embasado na teoria segundo a qual tudo o que o Município pode fazer de forma autônoma (com seus próprios recursos humanos e materiais) não deve ser realizado pelo Estado, assim como tudo o que puder ser feito pelo Estado não deve ser transferido à responsabilidade da União, devido à racionalidade, à economicidade e à maior eficiência do sistema. $\mathrm{O}$ princípio da subsidiariedade deve orientar as relações interfederativas para que haja harmonia na organização das redes de atenção à saúde. Segundo SANTOS, esta harmonia

\footnotetext{
734 “Art. $2^{\circ}$ Para efeito deste Decreto, considera-se: (...) II - Contrato Organizativo da Ação Pública da Saúde acordo de colaboração firmado entre entes federativos com a finalidade de organizar e integrar as ações e serviços de saúde na rede regionalizada e hierarquizada, com definição de responsabilidades, indicadores e metas de saúde, critérios de avaliação de desempenho, recursos financeiros que serão disponibilizados, forma de controle e fiscalização de sua execução e demais elementos necessários à implementação integrada das ações e serviços de saúde;"

735 "Art. 33. O acordo de colaboração entre os entes federativos para a organização da rede interfederativa de atenção à saúde será firmado por meio de Contrato Organizativo da Ação Pública da Saúde."

736 O Decreto n. 7.508/2011 regulamenta a Lei $\mathrm{n}^{\circ}$ 8.080, de 19 de setembro de 1990, para dispor sobre a organização do Sistema Único de Saúde - SUS, o planejamento da saúde, a assistência à saúde e a articulação interfederativa.

737 O artigo 35, do Decreto n. 7.508/2011 estabelece o seguinte: “Art. 35. O Contrato Organizativo de Ação Pública da Saúde definirá as responsabilidades individuais e solidárias dos entes federativos com relação às ações e serviços de saúde, os indicadores e as metas de saúde, os critérios de avaliação de desempenho, os recursos financeiros que serão disponibilizados, a forma de controle e fiscalização da sua execução e demais elementos necessários à implementação integrada das ações e serviços de saúde. $§ 1^{\circ} \mathrm{O}$ Ministério da Saúde definirá indicadores nacionais de garantia de acesso às ações e aos serviços de saúde no âmbito do SUS, a partir de diretrizes estabelecidas pelo Plano Nacional de Saúde. $\S 2^{\circ} \mathrm{O}$ desempenho aferido a partir dos indicadores nacionais de garantia de acesso servirá como parâmetro para avaliação do desempenho da prestação das ações e dos serviços definidos no Contrato Organizativo de Ação Pública de Saúde em todas as Regiões de Saúde, considerando-se as especificidades municipais, regionais e estaduais."
} 
somente é possível se for adotada uma política de contratualização com força vinculante entre os entes federativos que defina suas responsabilidades sanitárias. ${ }^{738}$

De acordo com AITH, é necessário o aperfeiçoamento constante da descentralização política para que cada ente federativo exerça sua autonomia de forma integrada e coordenada com as demais unidades federativas através do processo de regionalização. ${ }^{739}$

O princípio da descentralização está ligado ao princípio da regionalização das ações e serviços de saúde, que consiste numa forma avançada de organização dos espaços territoriais por regiões (ou microrregiões), através de consensos obtidos em instâncias administrativas $^{740}$, criados para favorecer o diálogo, com fundamento na autonomia e na cooperação entre os entes federativos. ${ }^{741}$

A regionalização das ações e serviços de saúde não é um ato de vontade dos entes federativos, mas sim uma imposição constitucional ${ }^{742}$ em decorrência da determinação constitucional de que as ações e serviços públicos de saúde integrem uma rede regionalizada. A competência para promover esta divisão territorial cabe aos Estados, em articulação com os Municípios, que serão aglutinados em regiões de saúde (ou microrregiões). ${ }^{743}$ Também podem ser instituídas regiões de saúde interestaduais, compostas por Municípios limítrofes, por ato conjunto dos respectivos Estados e em áreas de fronteira, conforme as normas de regência internacionais. ${ }^{744}$ Como os Municípios são

738 SANTOS, Lenir. SUS: regionalizando a descentralização- região de saúde como imposição constitucional ou como ato de vontade dos entes federativos? Boletim de Direito Administrativo (BDA), p.1399, dezembro 2012.

${ }^{739}$ AITH, Fernando. Curso de Direito Sanitário: a proteção do Direito à Saúde no Brasil. São Paulo: Quartier Latin. 2007, p. 355.

${ }^{740}$ A atividade voltada ao diálogo, harmonização e ao consenso é realizada no âmbito administrativo por meio das comissões criadas para favorecer esse diálogo, a Comissão Intergestores Tripartite (CIT), formada por gestores da União, Estados e Municípios e a Comissão Intergestores Bipartite (CIB), composta por gestores dos Estados e Municípios.

${ }^{741}$ AITH, Fernando. Curso de Direito Sanitário: a proteção do Direito à Saúde no Brasil. São Paulo: Quartier Latin. 2007, p. 354-355.

742 SANTOS, Lenir. SUS: regionalizando a descentralização- região de saúde como imposição constitucional ou como ato de vontade dos entes federativos? Boletim de Direito Administrativo (BDA), p. 1400-1406, dezembro 2012.

743 A Constituição Federal dispõe em seu artigo 25, parágrafo $3^{\circ}$ : “Art. 25. Os Estados organizam-se e regem-se pelas Constituições e leis que adotarem, observados os princípios desta Constituição. (...) $\S 3^{\circ}$ - Os Estados poderão, mediante lei complementar, instituir regiões metropolitanas, aglomerações urbanas e microrregiões, constituídas por agrupamentos de municípios limítrofes, para integrar a organização, o planejamento e a execução de funções públicas de interesse comum."

${ }^{744} \mathrm{O}$ artigo $4^{\circ}$, parágrafos $1^{\circ}$ e $2^{\circ}$, do Decreto n. 7.508/2011 estabelecem o seguinte: “Art. $4^{\circ}$ As Regiões de Saúde serão instituídas pelo Estado, em articulação com os Municípios, respeitadas as diretrizes gerais pactuadas na Comissão Intergestores Tripartite - CIT a que se refere o inciso I do art. $30 . \S 1^{\circ}$ Poderão ser 
unidades assimétricas quanto ao seu desenvolvimento, é imperioso que a organização do Sistema Único de Saúde (SUS) e a distribuição de competências dos entes federativos na área da saúde observem as características demográficas, culturais, sociais e econômicas de cada ente da Federação.

A rede de atenção à saúde deve estar organizada em regiões de saúde 745 , formadas por agrupamentos de Municípios limítrofes para o planejamento e a execução dos serviços públicos de saúde sejam feitos de forma integrada, num sistema que permita ganhar escala, visando economicidade e a efetividade do cuidado à saúde em todas as suas dimensões. Os entes federativos devem definir os seguintes elementos em relação às regiões de saúde: limites geográficos; população usuária das ações e serviços; rol de ações e serviços que serão ofertados; e as respectivas responsabilidades, os critérios de acessibilidade e escala para conformação dos serviços. ${ }^{746}$

Os Municípios integrados passam a constituir uma região de saúde para a organização, o planejamento e a execução compartilhada das ações e serviços de saúde. ${ }^{747}$ A região de saúde deve conter, pelo menos: ações e serviços de atenção primária; urgência e emergência; atenção psicossocial; atenção ambulatorial especializada e hospitalar; e vigilância em saúde (artigo 5º Decreto n. 7.508/2011).

Pelo princípio da regionalização as ações e serviços de saúde são adaptadas ao perfil epidemiológico local, permitindo a adoção de políticas sanitárias a partir das características socioeconômicas de determinada região ou microrregião. A região de saúde garante conformação territorial à integração das ações e serviços de saúde dos entes federativos em rede.

instituídas Regiões de Saúde interestaduais, compostas por Municípios limítrofes, por ato conjunto dos respectivos Estados em articulação com os Municípios. $§ 2^{\circ}$ A instituição de Regiões de Saúde situadas em áreas de fronteira com outros países deverá respeitar as normas que regem as relações internacionais."

${ }^{745} \mathrm{O}$ artigo $2^{\circ}$, inciso I do Decreto n. 7.508/2011 estabelece o conceito de região de saúde: "Art. $2^{\circ}$ Para efeito deste Decreto, considera-se: I - Região de Saúde - espaço geográfico contínuo constituído por agrupamentos de Municípios limítrofes, delimitado a partir de identidades culturais, econômicas e sociais e de redes de comunicação e infraestrutura de transportes compartilhados, com a finalidade de integrar a organização, o planejamento e a execução de ações e serviços de saúde;"

746 “Art. $7^{\circ}$ As Redes de Atenção à Saúde estarão compreendidas no âmbito de uma Região de Saúde, ou de várias delas, em consonância com diretrizes pactuadas nas Comissões Intergestores. Parágrafo único. Os entes federativos definirão os seguintes elementos em relação às Regiões de Saúde: I - seus limites geográficos; II - população usuária das ações e serviços; III - rol de ações e serviços que serão ofertados; e IV - respectivas responsabilidades, critérios de acessibilidade e escala para conformação dos serviços".

747 Nas palavras de SANTOS, “(...) saiu-se da individualidade federativa, do interesse local, para a solidariedade interfederativa e o interesse regional, fazendo saltar deveres constitucionais de financiamento interfederativo da saúde”. SANTOS, Lenir. SUS: regionalizando a descentralização- região de saúde como imposição constitucional ou como ato de vontade dos entes federativos? Boletim de Direito Administrativo (BDA), p.1400, Dezembro 2012. 
A regionalização do Sistema Único de Saúde (SUS) promove maior eficiência e racionalidade às ações e serviços públicos de saúde, pois permite que sejam organizados de modo a evitar a duplicidade de meios para a realização de fins idênticos e, ainda, determina que todos os níveis de assistência à saúde tenham capacidade para solucionar os problemas que eventualmente ocorram no funcionamento do sistema (Lei n. 8.080/90, artigo $7^{\circ}$, incisos XIII e XII, respectivamente) $)^{748}$.

Em nível municipal, o Sistema Único de Saúde (SUS) pode ser organizado em distritos, integrando e articulando recursos, técnicas e práticas voltadas para a cobertura total das ações de saúde.

Nos termos do artigo 10, parágrafo $2^{\circ}$, da Lei n. 8.080/90 749 , os Municípios poderão constituir consórcios para o desenvolvimento conjunto de ações e serviços que lhes correspondam. Por esta razão, AITH afirma que a regionalização pode assumir caraterísticas próprias de descentralização administrativa $^{750}$ (artigo 10, da Lei n. 8.080/90). ${ }^{751}$ Os consórcios intermunicipais de saúde, regidos pela Lei n. 11.795/2008 ${ }^{752}$ podem contribuir com o fornecimento de estrutura para determinados serviços de saúde que os entes da região optem por executar em comum acordo, com o fim de ganhar escala e simplificar processos administrativos.

\footnotetext{
${ }^{748}$ Os incisos XII e XIII do artigo $7^{\circ}$, da Lei n. 8.080/90 assim dispõe: “Art. $7^{\circ}$ As ações e serviços públicos de saúde e os serviços privados contratados ou conveniados que integram o Sistema Único de Saúde (SUS), são desenvolvidos de acordo com as diretrizes previstas no art. 198 da Constituição Federal, obedecendo ainda aos seguintes princípios: (...) XII - capacidade de resolução dos serviços em todos os níveis de assistência; XIII - organização dos serviços públicos de modo a evitar duplicidade de meios para fins idênticos".

749،“Art. 10. Os municípios poderão constituir consórcios para desenvolver em conjunto as ações e os serviços de saúde que lhes correspondam (...) $§ 2^{\circ}$ No nível municipal, o Sistema Único de Saúde (SUS), poderá organizar-se em distritos de forma a integrar e articular recursos, técnicas e práticas voltadas para a cobertura total das ações de saúde.

750 A descentralização administrativa ocorre nas hipóteses em que a atividade administrativa não é desempenhada pelo Estado, mas sim por pessoa ou pessoas distintas. Pela descentralização, em vez de desenvolver por si mesmo as atividades que constitucionalmente estão ao seu encargo, o Estado transfere seu exercício para particulares, ou cria pessoas auxiliares suas, com personalidade jurídica de Direito Público ou de Direito Privado para desempenhar os cometimentos dessarte descentralizados. MELLO, Celso Antônio Bandeira de. Curso de Direito Administrativo. 27.ed. São Paulo: Malheiros. 2010, p.139 e 149-151.

${ }^{751}$ AITH, Fernando. Curso de Direito Sanitário: a proteção do Direito à Saúde no Brasil. São Paulo: Quartier Latin. 2007, p. 354-355.

${ }^{752}$ De acordo com o artigo $1^{\circ}$, da Lei n. 11.795/2008, “o Sistema de Consórcios, instrumento de progresso social que se destina a propiciar o acesso ao consumo de bens e serviços, constituído por administradoras de consórcio e grupos de consórcio, será regulado por esta Lei."
} 
A Constituição Federal dispõe em seu artigo 198, caput $^{753}$, que a saúde pública se organiza em rede integrada, regionalizada e hierarquizada já definiu que o modelo adotado de assistência à saúde é piramidal, devendo a assistência à saúde ser organizada por níveis crescentes de atenção: da atenção primária (base da pirâmide), passando pela atenção média (intermediária), à atenção terciária ou de maior complexidade (topo da pirâmide).

O princípio da hierarquização está ligado à descentralização e à estrutura piramidal do Sistema Único de Saúde (SUS), indicando que a execução da assistência à saúde é feita em níveis crescentes de complexidade, para a melhor racionalização do sistema. Assim, o acesso de todos às ações e serviços de saúde se inicia pelas "portas de entrada" do Sistema Único de Saúde (SUS) e se completa na rede regionalizada e hierarquizada, conforme a complexidade do serviço (artigo $8^{\circ}$, do Decreto n. 7.508/2011).

A política de atenção à saúde no âmbito do Sistema Único de Saúde (SUS) foi distribuída, conforme o grau de sua complexidade, em: básica; média; e alta. ${ }^{754} \mathrm{~A}$ programação da assistência à saúde é centrada nas ações básicas de saúde. Por conseguinte, ao usuário deve ser assegurada a prestação de serviços de atenção básica à saúde e a continuidade do cuidado em saúde ${ }^{755}$, inclusive de média e alta complexidade, conforme

\footnotetext{
753 “Art. 198. As ações e serviços públicos de saúde integram uma rede regionalizada e hierarquizada e constituem um sistema único (...)"

754 Nos termos da Norma Operacional de Assistência à Saúde NOAS-SUS 1/02, instituída pela Portaria n. 373, de 27 de fevereiro de 2002, a atenção básica compreende: o controle da tuberculose, a eliminação da hanseníase, o controle da hipertensão arterial, o controle da diabetes mellitus, a saúde da criança, a saúde da mulher e a saúde bucal. A atenção de média complexidade, por sua vez, abrange um conjunto de ações e serviços ambulatoriais e hospitalares que visam atender os principais problemas de saúde da população, cuja prática clínica demande a disponibilidade de profissionais especializados e a utilização de recursos tecnológicos de apoio diagnóstico e terapêutico, que não justifique a sua oferta em todos os municípios do país. Por fim, a atenção de alta complexidade, de responsabilidade do Ministério da Saúde, se traduz nas seguintes atribuições: definição de normas nacionais; controle do cadastro nacional de prestadores de serviços; vistoria de serviços, quando lhe couber, de acordo com as normas de cadastramento estabelecidas pelo próprio Ministério da Saúde; definição de incorporação dos procedimentos a serem ofertados pela população pelo SUS; definição do elenco de procedimentos de alta complexidade; estabelecimento de estratégias que possibilitem o acesso mais equânime diminuindo as diferenças regionais na alocação dos serviços; definição de mecanismos de garantia de acesso para as referências interestaduais, através da Central Nacional de Regulação para Procedimento de Alta Complexidade; formulação de mecanismos voltados à melhoria da qualidade dos serviços prestados; e financiamento das ações. BRASIL. Conselho Nacional de Secretários de Saúde. Legislação Estruturante do SUS. Brasília: CONASS, 2011, p.227-259.

755 Nos termos dos artigos 12 e 20, do Decreto n. 7.508/2011: “Art. 12. Ao usuário será assegurada a continuidade do cuidado em saúde, em todas as suas modalidades, nos serviços, hospitais e em outras unidades integrantes da rede de atenção da respectiva região." "Art. 20. A integralidade da assistência à saúde se inicia e se completa na Rede de Atenção à Saúde, mediante referenciamento do usuário na rede regional e interestadual, conforme pactuado nas Comissões Intergestores".
} 
seja necessário, na respectiva região de saúde (artigo 13, IV, do Decreto n. 7.508/2011), em respeito à integralidade de cobertura. ${ }^{756}$

As ações e serviços de saúde são organizados e oferecidos de forma escalonada, a partir daqueles definidos como de menor complexidade em direção aos níveis mais altos de complexidade, de acordo com o caso concreto e ressalvadas as situações de urgência e emergência, também previstas como portas de entrada do Sistema Único de Saúde. De acordo com o disposto no artigo $9^{\circ}$, do Decreto n. 7.508/2011 $1^{757}$, as "portas de entrada" às ações e aos serviços de saúde nas Redes de Atenção à Saúde os serviços compreendem: (i) de atenção primária ${ }^{758}$; (ii) de atenção de urgência e emergência; (iii) de atenção psicossocial; e (iv) especiais de acesso aberto.

De acordo com esta lógica de funcionamento, dentre as "portas de entrada" do Sistema Único de Saúde (SUS), as unidades de atenção primária à saúde devem ser aptas à realização de atendimentos de menor complexidade (realizam ações e prestam serviços de menor custo), bem como ao "referenciamento" (encaminhamento) do usuário na hipótese em que os serviços de atenção hospitalar e ambulatoriais especializados (secundárias e terciárias) se mostrem necessários, dentre outros de maior complexidade e densidade tecnológica. ${ }^{759}$ Após a realização do atendimento ou tratamento de maior complexidade, esta unidade promove a "contra referência" do usuário para que os cuidados

\footnotetext{
756 Nos termos do artigo 13, do Decreto n. 7.508/2011: "Art. 13. Para assegurar ao usuário o acesso universal, igualitário e ordenado às ações e serviços de saúde do SUS, caberá aos entes federativos, além de outras atribuições que venham a ser pactuadas pelas Comissões Intergestores: I - garantir a transparência, a integralidade e a equidade no acesso às ações e aos serviços de saúde; II - orientar e ordenar os fluxos das ações e dos serviços de saúde; III - monitorar o acesso às ações e aos serviços de saúde; e IV - ofertar regionalmente as ações e os serviços de saúde."

${ }^{757}$ Conforme prevê o artigo $9^{\circ}$ do Decreto n. 7.508/2011: "Art. $9^{\circ}$ São Portas de Entrada às ações e aos serviços de saúde nas Redes de Atenção à Saúde os serviços: I - de atenção primária; II - de atenção de urgência e emergência; III - de atenção psicossocial; e IV - especiais de acesso aberto. Parágrafo único. Mediante justificativa técnica e de acordo com o pactuado nas Comissões Intergestores, os entes federativos poderão criar novas Portas de Entrada às ações e serviços de saúde, considerando as características da Região de Saúde."

${ }^{758} \mathrm{O}$ Decreto n. 7.508/2011, em seu artigo 11, estabelece: "Art. 11. O acesso universal e igualitário às ações e aos serviços de saúde será ordenado pela atenção primária e deve ser fundado na avaliação da gravidade do risco individual e coletivo e no critério cronológico, observadas as especificidades previstas para pessoas com proteção especial, conforme legislação vigente. Parágrafo único. A população indígena contará com regramentos diferenciados de acesso, compatíveis com suas especificidades e com a necessidade de assistência integral à sua saúde, de acordo com disposições do Ministério da Saúde."

${ }^{759} \mathrm{O}$ artigo 10, do Decreto n. 7.508/2011 prescreve o seguinte: "Art. 10. Os serviços de atenção hospitalar e os ambulatoriais especializados, entre outros de maior complexidade e densidade tecnológica, serão referenciados pelas Portas de Entrada de que trata o art. 9०."
} 
complementares voltados à sua recuperação sejam dispensados pela unidade primária de menor complexidade da rede, de onde partiu o encaminhamento. ${ }^{760}$

A integralidade de atendimento está prevista como diretriz do Sistema Único de Saúde, que nos termos da Constituição Federal deve oferecer "atendimento integral, com prioridade para as atividades preventivas, sem prejuízo das assistenciais" (artigo 198, inciso II ${ }^{761}$. O artigo 196, da Constituição Federal ${ }^{762}$, atribui ao Estado o dever de realizar políticas sociais e econômicas voltadas à redução do risco de doenças e outros agravos, bem como de prestar ações e serviços para a promoção, proteção e recuperação da saúde de todas as pessoas. A Lei n. 8.080, de 19 de setembro de 1990, prescreve em seu artigo $7^{\circ}$, inciso II, dentre os princípios do Sistema Único de Saúde, "a integralidade de assistência, entendida como conjunto articulado e contínuo das ações e serviços preventivos e curativos, individuais e coletivos, exigidos para cada caso em todos os níveis de complexidade do sistema."763

A integralidade de ações e serviços de saúde exprime a noção de que a cobertura oferecida pelo Sistema Único de Saúde deve ser a mais ampla possível, com o oferecimento prioritário de atividades preventivas, mas também de atividades curativas e de promoção da saúde. ${ }^{764}$ A Rede de Atenção à Saúde deve abranger a assistência integral, mediante o referenciamento do usuário na rede regional e interestadual, conforme o pacto estabelecido nas Comissões Intergestores (artigo 20, do Decreto n. 7.508/2011).

760 DALLARI, Sueli Gandolfi e NUNES JÚNIOR, Vidal Serrano. Direito Sanitário. São Paulo: Editora Verbatim, 2010, p.83-84.

761 “Art. 198. As ações e serviços públicos de saúde integram uma rede regionalizada e hierarquizada e constituem um sistema único, organizado de acordo com as seguintes diretrizes: (...) II - atendimento integral, com prioridade para as atividades preventivas, sem prejuízo dos serviços assistenciais;"

762 “Art. 196. A saúde é direito de todos e dever do Estado, garantido mediante políticas sociais e econômicas que visem à redução do risco de doença e de outros agravos e ao acesso universal e igualitário às ações e serviços para sua promoção, proteção e recuperação".

${ }^{763} \mathrm{O}$ artigo $7^{\circ}$, inciso II, da Lei n. 8.080/90 assim estabelece: “Art. $7^{\circ}$ As ações e serviços públicos de saúde e os serviços privados contratados ou conveniados que integram o Sistema Único de Saúde (SUS), são desenvolvidos de acordo com as diretrizes previstas no art. 198 da Constituição Federal, obedecendo ainda aos seguintes princípios: (...) II - integralidade de assistência, entendida como conjunto articulado e contínuo das ações e serviços preventivos e curativos, individuais e coletivos, exigidos para cada caso em todos os níveis de complexidade do sistema;"

${ }^{764}$ Segundo AITH, do ordenamento jurídico-constitucional decorre o dever estatal de organizar uma rede de serviços públicos médico-hospitalares eficazes que ofereça uma ampla gama de serviços, de complexidade diversificada, tais como as políticas de vigilância em saúde, a construção e manutenção de postos de atendimento à saúde e hospitais, a adoção de programas de vacinação, a contratação de médicos, enfermeiros e outros profissionais de saúde necessários para a prestação dos serviços públicos de saúde etc. AITH, Fernando. A saúde como direito de todos e dever do Estado: o papel dos Poderes Executivo, Legislativo e Judiciário na efetivação do direito à saúde no Brasil. In: Direito Sanitário: Saúde e Direito, um Diálogo Possível. AITH, Fernando; SATURNINO, Luciana Tarbes Mattana; DINIZ, Maria Gabriela Araújo; MONTEIRO, Tammy Claret (organizadores). Belo Horizonte: ESP-MG, p. 79, 2012. 
O princípio da integralidade de atendimento também abrange o dever de fornecer medicamentos, visto que é indispensável para o tratamento de diversas doenças e agravos, especialmente em se tratando de doenças crônicas. A assistência farmacêutica integral foi expressamente prevista na Lei n. 8.080, de 19 de setembro de 1990 no âmbito de atuação do Sistema Único de Saúde (alínea "d" do inciso I, do artigo $6^{\circ}$ da Lei Federal $n^{\circ}$ $8.080 / 90){ }^{765}$

A Lei n. 12.401, de 28 de abril de 2011, atribuiu nova redação à Lei n. 8.080, de 19 de setembro de 1990, que passa a prever um novo capítulo acerca "da assistência terapêutica e da incorporação de tecnologia em saúde" no âmbito do Sistema Único de Saúde, em linha de compasso com a organização, o planejamento e o orçamento da saúde (artigos 19-M a 19-U).

O Sistema Único de Saúde adotou o modelo de gestão por processos, conhecido por protocolos de atendimento médico, que objetiva padronizar as ações e serviços públicos de saúde, inclusive na área de assistência farmacêutica, como estratégia para atingir o melhor resultado no menor lapso temporal possível e com redução de custos. ${ }^{766}$

Assim, foi definido que a "assistência terapêutica integral" consiste na dispensação de medicamentos conforme as diretrizes terapêuticas definidas em protocolos clínicos para a doença ou agravo à saúde a ser tratado, bem como na oferta de procedimentos terapêuticos constantes de tabelas elaboradas pelo gestor federal no âmbito do Sistema Único de Saúde (artigo 19-M, da Lei n. 12.401/2011). ${ }^{767}$

A finalidade dos protocolos clínicos e diretrizes terapêuticas consiste na padronização no atendimento ao usuário, com fundamento em estudos clínicos cientificamente comprovados e em revisões sistemáticas de toda literatura médica. O inciso II, do artigo 19-N, da Lei n. 12.401/2011, define Protocolo Clínico e Diretriz Terapêutica como o "documento que estabelece critérios para o diagnóstico da doença ou

\footnotetext{
${ }^{765} \mathrm{O}$ artigo $6^{\circ}$, inciso I, alínea "d" assim estabelece: "Art. $6^{\circ}$ Estão incluídas ainda no campo de atuação do Sistema Único de Saúde (SUS): I - a execução de ações: (...) d) de assistência terapêutica integral, inclusive farmacêutica;"

${ }^{766}$ SERRANO, Mônica de Almeida Magalhães. O Sistema Único de Saúde e suas diretrizes constitucionais. 2.ed. São Paulo: Editora Verbatim, 2012. p.125.

${ }_{767}$ "Art. 19-M. A assistência terapêutica integral a que se refere a alínea $d$ do inciso I do art. $6^{\circ}$ consiste em: I - dispensação de medicamentos e produtos de interesse para a saúde, cuja prescrição esteja em conformidade com as diretrizes terapêuticas definidas em protocolo clínico para a doença ou o agravo à saúde a ser tratado ou, na falta do protocolo, em conformidade com o disposto no art. 19-P; II - oferta de procedimentos terapêuticos, em regime domiciliar, ambulatorial e hospitalar, constantes de tabelas elaboradas pelo gestor federal do Sistema Único de Saúde - SUS, realizados no território nacional por serviço próprio, conveniado ou contratado."
} 
do agravo à saúde; o tratamento preconizado, com os medicamentos e demais produtos apropriados, quando couber; as posologias recomendadas; os mecanismos de controle clínico; e o acompanhamento e a verificação dos resultados terapêuticos", fixando critérios que deverão ser seguidos pelos gestores do Sistema Único de Saúde (SUS).

Os procedimentos terapêuticos disponibilizados pelo Sistema Único de Saúde, dirigidos ao atendimento da integralidade da assistência à saúde, constam da Relação Nacional de Ações e Serviços de Saúde - RENASES, que serão estabelecidas pelo Ministério da Saúde em âmbito Nacional, observadas as diretrizes pactuadas pela Comissão Intergestores Tripartite (CIT), atualizadas e publicadas a cada dois anos (artigos 21 e 22 do Decreto $\mathrm{n}$. 7.508/2011). Os Estados, Distrito Federal e Municípios poderão adotar relações específicas e complementares de ações e serviços de saúde, em conformidade com a RENASES. ${ }^{768}$

Os medicamentos indicados para atendimento de doenças e agravos a serem disponibilizados pelo Sistema Único de Saúde (SUS) estão inseridos na Relação Nacional de Medicamentos Essenciais- RENAME, com o devido Formulário Terapêutico NacionalFTN, que serve de base à prescrição, prescrição e uso dos medicamentos que especifica (artigo 25, do Decreto n. 7.508/2011). ${ }^{769}$

Cabe ao Ministério da Saúde dispor sobre a RENAME e os Protocolos Clínicos e Diretrizes Terapêuticas, em âmbito nacional, conforme as diretrizes pactuadas pela Comissão Intergestores Tripartite (CIT), devendo ser bienal a consolidação e a publicação das atualizações da RENAME, do respectivo FTN e dos Protocolos Clínicos e Diretrizes Terapêuticas. ${ }^{770}$

\footnotetext{
${ }^{768}$ As responsabilidades dos entes pelo financiamento das ações e serviços serão fixadas nas Comissões Intergestores Tripartite e Bipartite, nos termos dos artigos 23 e 24, do Decreto n. 7.508/2011, que prevêem: "Art. 23. A União, os Estados, o Distrito Federal e os Municípios pactuarão nas respectivas Comissões Intergestores as suas responsabilidades em relação ao rol de ações e serviços constantes da RENASES.”; e "Art. 24. Os Estados, o Distrito Federal e os Municípios poderão adotar relações específicas e complementares de ações e serviços de saúde, em consonância com a RENASES, respeitadas as responsabilidades dos entes pelo seu financiamento, de acordo com o pactuado nas Comissões Intergestores."

${ }^{769}$ Assim prevê o artigo 25, do Decreto n. 7.508/2011: "Art. 25. A Relação Nacional de Medicamentos Essenciais - RENAME compreende a seleção e a padronização de medicamentos indicados para atendimento de doenças ou de agravos no âmbito do SUS. Parágrafo único. A RENAME será acompanhada do Formulário Terapêutico Nacional - FTN que subsidiará a prescrição, a dispensação e o uso dos seus medicamentos."

770 É o que dispõe o artigo 26 do Decreto n. 7.508/2011: "Art. 26. O Ministério da Saúde é o órgão competente para dispor sobre a RENAME e os Protocolos Clínicos e Diretrizes Terapêuticas em âmbito nacional, observadas as diretrizes pactuadas pela CIT. Parágrafo único. A cada dois anos, o Ministério da Saúde consolidará e publicará as atualizações da RENAME, do respectivo FTN e dos Protocolos Clínicos e Diretrizes Terapêuticas".
} 
O Decreto n. 7.508/2011 estabelece em seu artigo 28 , parágrafo $1^{\circ}$, a possibilidade de que os entes federativos ampliem o acesso do usuário à assistência farmacêutica, desde que estejam presentes razões de saúde pública.

Os Estados, Distrito Federal e Municípios poderão adotar relações específicas e complementares de medicamentos, em consonância com a RENAME. Tanto a RENAME quanto as listagens específicas e complementares de medicamentos disponibilizados pelo Sistema Único de Saúde (SUS) somente poderão abarcar produtos com registro na Agência Nacional de Vigilância Sanitária - ANVISA (artigo 29, Decreto n. 7.508/2011), uma vez que o medicamento é importante insumo no processo de atenção à saúde, mas pode constituir-se em fator de risco quando utilizado de maneira inadequada. Deste modo, o registro do medicamento pela ANVISA também configura uma garantia à saúde. ${ }^{771} 772$

Neste sentido, o artigo 19-T incluído na Lei 8.080/90 pela Lei n. 12.401/2011, proíbe em todas as esferas de gestão do Sistema Único de Saúde a dispensação, pagamento ou ressarcimento de medicamento e produto, nacional ou importado, sem registro ou de uso não autorizado de uso não autorizado pela Agência Nacional de Vigilância Sanitária (ANVISA), bem como aqueles que estejam em fase experimental. ${ }^{773}$

Outrossim, foram concentradas no âmbito federal, por meio do Ministério da Saúde, assessorado pela Comissão Nacional de Incorporação de Tecnologias no Sistema Único de

\footnotetext{
${ }^{771}$ A Lei n. 9.782/1999 prevê em seu artigo $7^{\circ}$, inciso IX, a competência da ANVISA para "conceder registro de produtos, segundo as normas de sua atuação". A Lei n. 6.360/76 que estabelece normas a que ficam sujeitos os medicamentos, as drogas, os insumos farmacêuticos e correlatos determina em seu artigo 12 , caput, o seguinte: "nenhum dos produtos de que trata esta Lei, inclusive os importados, poderá ser industrializado, exposto à venda ou entregue ao consumo antes de registrado no Ministério da Saúde. No artigo 16 estabelece os requisitos específicos para a obtenção do registro e, por fim, o artigo 18 estabelece normas para o registro de medicamentos, drogas e insumos farmacêuticos de procedência estrangeira, nos seguintes termos: "Art. 18 - O registro de drogas, medicamentos e insumos farmacêuticos de procedência estrangeira dependerá, além das condições, das exigências e dos procedimentos previstos nesta Lei e seu regulamento, da comprovação de que já é registrado no país de origem. § 1º Na impossibilidade do cumprimento do disposto no caput deste artigo, deverá ser apresentada comprovação do registro em vigor, emitida pela autoridade sanitária do país em que seja comercializado ou autoridade sanitária internacional e aprovado em ato próprio da Agência Nacional de Vigilância Sanitária do Ministério da Saúde. § 2- No ato do registro de medicamento de procedência estrangeira, a empresa fabricante deverá apresentar comprovação do cumprimento das Boas Práticas de Fabricação, reconhecidas no âmbito nacional."

772 Neste sentido, o Supremo Tribunal Federal decidiu ser requisito indispensável à concessão de qualquer medicamento por ordem judicial sua aprovação pela Agência Nacional de Vigilância Sanitária (ANVISA), nos termos da Lei $n^{\circ}$ 9.782/1999 e da Lei n. 6.360/76. (Agravo Regimental interposto na Suspensão de Tutela Antecipada n.175/CE, plenário, relator e Presidente Ministro Gilmar Mendes, julgado em 17/03/2010. DJ n. 76, de 30/04/2010).

773 “Art. 19-T. São vedados, em todas as esferas de gestão do SUS: I - o pagamento, o ressarcimento ou o reembolso de medicamento, produto e procedimento clínico ou cirúrgico experimental, ou de uso não autorizado pela Agência Nacional de Vigilância Sanitária - ANVISA; II - a dispensação, o pagamento, o ressarcimento ou o reembolso de medicamento e produto, nacional ou importado, sem registro na Anvisa."
} 
Saúde ${ }^{774}$ as atribuições para o processo de incorporação, exclusão ou alteração pelo Sistema Único de Saúde de medicamentos, produtos e procedimentos e a alteração dos protocolos clínicos e diretrizes terapêuticas, a serem exercidas conforme o procedimento administrativo que estabelece no artigo 19-R. ${ }^{775}$

No mesmo diapasão, o Decreto n. 7.508, de 28 de junho de 2011, que regulamenta a Lei n. 8.080, de 19 de setembro de 1990, estabelece normas sobre a organização do Sistema Único de Saúde, o planejamento ascendente e integrado da saúde, do nível local até o federal, e a articulação interfederativa, voltada à racionalidade do sistema (artigos 30 a 32). Em seu artigo $2^{\circ}$, inciso VIII, reitera a definição de Protocolo Clínico e Diretriz Terapêutica contida no 19-N, inciso II, da Lei n. 8.080/90.

Não apenas os medicamentos, mas as ações e serviços prestados no âmbito do Sistema Único de Saúde também devem estar em conformidade ao atual estágio do desenvolvimento tecnológico em saúde e ter sua qualidade, segurança e eficácia reconhecidas pela Agência Nacional de Vigilância Sanitária (ANVISA), para o tratamento terapêutico específico da doença ou agravo que acomete a pessoa.

A padronização consolidada com os protocolos clínicos e diretrizes terapêuticas tem por fim melhorar a qualidade do atendimento ao usuário e da gestão do Sistema Único de Saúde (SUS), através da atuação integrada e coordenada das três esferas governamentais, com o avanço gradual das ações e serviços e a diminuição de gastos.

\footnotetext{
774 “Art. 19-Q. A incorporação, a exclusão ou a alteração pelo SUS de novos medicamentos, produtos e procedimentos, bem como a constituição ou a alteração de protocolo clínico ou de diretriz terapêutica, são atribuições do Ministério da Saúde, assessorado pela Comissão Nacional de Incorporação de Tecnologias no SUS. § $1^{\circ}$ A Comissão Nacional de Incorporação de Tecnologias no SUS, cuja composição e regimento são definidos em regulamento, contará com a participação de 1 (um) representante indicado pelo Conselho Nacional de Saúde e de 1 (um) representante, especialista na área, indicado pelo Conselho Federal de Medicina. § $2^{\circ} \mathrm{O}$ relatório da Comissão Nacional de Incorporação de Tecnologias no SUS levará em consideração, necessariamente: I - as evidências científicas sobre a eficácia, a acurácia, a efetividade e a segurança do medicamento, produto ou procedimento objeto do processo, acatadas pelo órgão competente para o registro ou a autorização de uso; II - a avaliação econômica comparativa dos benefícios e dos custos em relação às tecnologias já incorporadas, inclusive no que se refere aos atendimentos domiciliar, ambulatorial ou hospitalar, quando cabível."

775 "Art. 19-R. A incorporação, a exclusão e a alteração a que se refere o art. 19-Q serão efetuadas mediante a instauração de processo administrativo, a ser concluído em prazo não superior a 180 (cento e oitenta) dias, contado da data em que foi protocolado o pedido, admitida a sua prorrogação por 90 (noventa) dias corridos, quando as circunstâncias exigirem. $\S 1^{\circ} \mathrm{O}$ processo de que trata o caput deste artigo observará, no que couber, o disposto na Lei $\mathrm{n}^{\circ}$ 9.784, de 29 de janeiro de 1999, e as seguintes determinações especiais:

I - apresentação pelo interessado dos documentos e, se cabível, das amostras de produtos, na forma do regulamento, com informações necessárias para o atendimento do disposto no $\S 2^{\circ}$ do art. 19-Q; II - (vetado); III - realização de consulta pública que inclua a divulgação do parecer emitido pela Comissão Nacional de Incorporação de Tecnologias no SUS; IV - realização de audiência pública, antes da tomada de decisão, se a relevância da matéria justificar o evento.
} 
O êxito do modelo de gestão padronizado depende da elaboração eficiente de protocolos clínicos, diretrizes terapêuticas e listagens de medicamentos fornecidos no âmbito do Sistema Único de Saúde, bem como da permanente revisão e atualização, com a participação da comunidade.

A integralidade do atendimento também significa que as ações e os serviços de saúde devem ser planejados, com a participação da comunidade, para que se desenvolvam de forma permanente e harmoniosa pelos gestores nacional, estadual e municipal, em todos os níveis de complexidade, abrangendo políticas públicas de prevenção, cura e promoção da saúde. ${ }^{776}$

A organização e o funcionamento das ações e serviços de saúde devidamente integrados em redes de atenção à saúde, serão pactuados pelas Comissões Intergestores ${ }^{777}$, que decidirão sobre: (i) aspectos operacionais, financeiros e administrativos da gestão compartilhada do Sistema Único de Saúde (SUS), conforme a definição da política de saúde dos entes federativos, contida nos seus planos de saúde, aprovados pelos respectivos conselhos de saúde; (ii) diretrizes gerais sobre Regiões de Saúde, integração de limites geográficos, referência e contrarreferência e outros aspectos vinculados à integração das ações e serviços de saúde entre os entes federativos; (iii) diretrizes de âmbito nacional, estadual, regional e interestadual, a respeito da organização das redes de atenção à saúde; (iv) as responsabilidades individuais e as solidárias dos entes federativos na Rede de Atenção à Saúde, de acordo com o seu porte demográfico e o desenvolvimento econômico-financeiro; e (v) referências das regiões intraestaduais e interestaduais de atenção à saúde para o atendimento da integralidade da assistência (artigo 32, do Decreto n. 7.508/2011).

\footnotetext{
${ }^{776}$ Nos termos do artigo 15, do Decreto n. 7.508/2011: “Art. 15. O processo de planejamento da saúde será ascendente e integrado, do nível local até o federal, ouvidos os respectivos Conselhos de Saúde, compatibilizando-se as necessidades das políticas de saúde com a disponibilidade de recursos financeiros. $\S 1^{\circ} \mathrm{O}$ planejamento da saúde é obrigatório para os entes públicos e será indutor de políticas para a iniciativa privada. $\S 2^{\circ} \mathrm{A}$ compatibilização de que trata o caput será efetuada no âmbito dos planos de saúde, os quais serão resultado do planejamento integrado dos entes federativos, e deverão conter metas de saúde."

777 O artigo 30, do Decreto n. 7.508/2011 assim dispõe: “Art. 30. As Comissões Intergestores pactuarão a organização e o funcionamento das ações e serviços de saúde integrados em redes de atenção à saúde, sendo: I - a CIT, no âmbito da União, vinculada ao Ministério da Saúde para efeitos administrativos e operacionais; II - a CIB, no âmbito do Estado, vinculada à Secretaria Estadual de Saúde para efeitos administrativos e operacionais; e III - a Comissão Intergestores Regional - CIR, no âmbito regional, vinculada à Secretaria Estadual de Saúde para efeitos administrativos e operacionais, devendo observar as diretrizes da CIB".
} 
O planejamento e a gestão compartilhada do sistema de saúde permitem assegurar a integralidade do atendimento, a continuidade das políticas públicas e o aumento progressivo do investimento na área da saúde, com maior racionalidade e eficiência.

A universalidade é um princípio que rege os serviços públicos sociais como a educação $^{778}$ e a saúde. Na área da saúde, a Constituição Federal ${ }^{779}$ e na Lei n. 8.080, de 19 de setembro de $1990^{780}$ estabelecem expressamente que é assegurado a todas as pessoas residentes no Brasil, inclusive estrangeiros o direito de acesso às ações e serviços prestados no âmbito do Sistema Único de Saúde (SUS), independentemente de qualquer contribuição ao sistema de seguridade social.

Para SARLET, o princípio do acesso universal às ações e serviços públicos de saúde não se confunde com a gratuidade das ações e serviços prestados pelo sistema público de saúde, pois o que a Constituição Federal garante é que todos tenham, em princípio, as mesmas condições de acessar o sistema público de saúde. ${ }^{781}$ Em sentido contrário, AITH afirma que as ações e serviços públicos de saúde devem ser prestados de forma isonômica e gratuitamente, para que o acesso seja efetivamente universal. ${ }^{782}$

Nos sistemas públicos de saúde é comum a existência de modelos universais em que há co-participação dos usuários quando da utilização dos serviços ou aquisição de medicamentos. $^{783}$ Os fundamentos do sistema de pagamento compartilhado são: o co-

\footnotetext{
778 A Constituição Federal estabelece em seu artigo 205 o seguinte: “Art. 205. A educação, direito de todos e dever do Estado e da família, será promovida e incentivada com a colaboração da sociedade, visando ao pleno desenvolvimento da pessoa, seu preparo para o exercício da cidadania e sua qualificação para o trabalho."

779 Nos termos do artigo 196 da Constituição Federal: “Art. 196. A saúde é direito de todos e dever do Estado, garantido mediante políticas sociais e econômicas que visem à redução do risco de doença e de outros agravos e ao acesso universal e igualitário às ações e serviços para sua promoção, proteção e recuperação."

780 “Art. $7^{\circ}$ As ações e serviços públicos de saúde e os serviços privados contratados ou conveniados que integram o Sistema Único de Saúde (SUS), são desenvolvidos de acordo com as diretrizes previstas no art. 198 da Constituição Federal, obedecendo ainda aos seguintes princípios: I - universalidade de acesso aos serviços de saúde em todos os níveis de assistência;"

${ }^{781}$ Nas palavras de SARLET: "ao contrário do que pretende expressiva doutrina, não há como deduzir do princípio da universalidade do acesso um princípio da gratuidade do acesso, visto que acesso igualitário e universal (como expressamente enuncia o art. 196 da CF) não se confunde - pelo menos não necessariamente - com um acesso totalmente gratuito". SARLET, Ingo Wolfgang; MARINONI, Guilherme; MITIDIERO, Daniel. Curso de Direito Constitucional. 2. ed. São Paulo: Editora Revista dos Tribunais, 2013.p.592.

${ }^{782}$ AITH, Fernando. Curso de Direito Sanitário: a proteção do Direito à Saúde no Brasil. São Paulo: Quartier Latin. 2007, p.354.

${ }^{783}$ Há sistemas que estabelecem o pagamento compartilhado (também conhecido como co-pagamento ou cofinanciamento). É um mecanismo mediante o qual o sistema de saúde público paga uma parte do preço e o usuário a outra. É baseado no reconhecimento da conveniência de que o sistema de saúde financie o fornecimento de medicamentos, contudo prevê que o usuário participe no pagamento por duas razões: para que contribua com o financiamento do sistema (co-pagamento) e para que o pagamento sirva como
} 
pagamento do sistema pelo usuário; e a racionalização do uso dos serviços e ações disponíveis, na medida em que a participação financeira do usuário desestimularia a utilização desnecessária dos serviços de saúde.

A adoção do sistema compartilhado no Brasil prejudicaria a assistência à saúde das pessoas mais pobres e dos doentes crônicos que não poderiam pagar uma parte do valor das ações e serviços de saúde.

O legislador infraconstitucional optou corretamente por conjugar a universalidade com a gratuidade de acesso às ações e serviços prestados pelo Sistema Único de Saúde (SUS) ao estabelecer, no artigo 43 da Lei n. 8.080/90 784 a conjugação da universalidade e da gratuidade de acesso às ações e serviços prestados pelo SUS, ampliando o acesso de todos os residentes no país às políticas de saúde disponibilizadas pelo sistema público. Assim, está vedada por lei a cobrança por ações e serviços fornecidos pelo Sistema Único de Saúde, independentemente da condição socioeconômica apresentada pelo usuário.

O princípio da igualdade assegura o acesso às ações e serviços oferecidos pelo Sistema Único de Saúde (SUS) de forma equitativa, sem discriminações de qualquer natureza.

A igualdade é um direito fundamental assegurado no artigo $5^{\circ}$, caput, da Constituição Federal. ${ }^{785} \mathrm{Na}$ área da saúde, o princípio da igualdade (ou a não discriminação) está expressamente previsto no artigo 196 da Constituição Federal ${ }^{786}$ e no inciso IV do artigo $7^{\circ}$, da Lei n. 8.080/90, que prevê como princípio do Sistema Único de Saúde o princípio da "igualdade da assistência à saúde, sem preconceitos ou privilégios de qualquer espécie;"

moderador do consumo, desestimulando o consumo desnecessário (evitar o que em economia de saúde é conhecido como risco moral). Sua desvantagem consiste em que a parte que cada pessoa deve desembolsar não é proporcional a sua renda, mas à sua condição de doença e ao preço dos medicamentos. Em outras palavras, é um mecanismo que discrimina os mais pobres e os doentes crônicos. Por esse motivo, a maioria dos seguros de saúde estabelece níveis diferentes de co-financiamento, segundo a gravidade e custo da doença. A cobertura desses medicamentos de alto custo faz com que seu peso sobre os orçamentos públicos resulte em valores muito superiores se comparado a outros medicamentos ambulatoriais, como os utilizados no Atendimento Primário da Saúde. ORGANIZAÇÃO PAN-AMERICANA DA SAÚDE. O acesso aos medicamentos de alto custo nas Américas: contexto, desafios e perspectivas. Brasília: Organização PanAmericana da Saúde; Ministério da Saúde; Ministério das Relações Exteriores, 2009. p. 34.

784 “Art. 43. A gratuidade das ações e serviços de saúde fica preservada nos serviços públicos contratados, ressalvando-se as cláusulas dos contratos ou convênios estabelecidos com as entidades privadas."

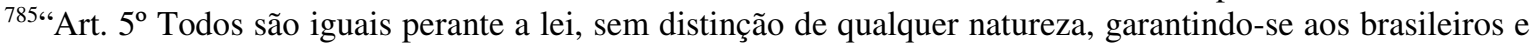
aos estrangeiros residentes no País a inviolabilidade do direito à vida, à liberdade, à igualdade, à segurança e à propriedade, nos termos seguintes: (...)"

786 “Art. 196. A saúde é direito de todos e dever do Estado, garantido mediante políticas sociais e econômicas que visem à redução do risco de doença e de outros agravos e ao acesso universal e igualitário às ações e serviços para sua promoção, proteção e recuperação." 
Na perspectiva do Direito Administrativo, o valor da igualdade encontra tradução no princípio da impessoalidade, de observância obrigatória pela Administração Pública direta e indireta (artigo 37, caput, da Constituição Federal ${ }^{787}$ ), que está vinculado ao sentido de legalidade material, como fundamento do Estado de Direito. ${ }^{788}$ De acordo com o princípio da impessoalidade, no exercício de função administrativa, o tratamento pelos agentes públicos aos casos individuais e concretos deve estar fundamentado numa disposição normativa de caráter geral e abstrato. ${ }^{789}$

O acesso igualitário dos indivíduos às ações e serviços de saúde significa que não haverá discriminação em razão de raça, religião, cor, cultura, razões econômicas ou por opção sexual. Isso não significa que o estabelecimento de tratamento diferenciado a determinada categoria de pessoas seja ofensivo à Constituição Federal e ao princípio da isonomia no acesso às ações e serviços de saúde.

Uma norma que atribui tratamento jurídico diferente pode ser constitucional se: (i) abrange um grupo de pessoas; (ii) adota como critério discriminador elemento fático; (iii) estabelece um elemento discriminador que guarda correlação lógica entre os fatores diferenciais existentes e a disparidade de regimes jurídicos estabelecidos pela norma jurídica em função deles; e (iv) o vínculo de correlação lógica seja pertinente em função de interesses constitucionalmente protegidos, ou seja, resulte em tratamento jurídico diferenciado com fundamento em razão valiosa para o interesse público, conforme definido no Texto Constitucional. ${ }^{790}$

O Decreto n. 7.508/2011, que regulamenta a Lei n. 8.080, de 19 de setembro de 1990, prevê, em seu artigo 28, que o acesso universal e igualitário às ações e serviços de saúde pressupõe, de forma cumulativa: (i) estar o usuário assistido por ações e serviços de saúde do SUS; (ii) ter o medicamento sido prescrito por profissional de saúde, no exercício

787 “Art. 37. A administração pública direta e indireta de qualquer dos Poderes da União, dos Estados, do Distrito Federal e dos Municípios obedecerá aos princípios de legalidade, impessoalidade, moralidade, publicidade e eficiência e, também, ao seguinte: (...)"

788 MENEZES DE ALMEIDA, Fernando Dias. Princípio da impessoalidade. In: Princípios de Direito Administrativo: legalidade, segurança jurídica, impessoalidade, publicidade, motivação, eficiência, moralidade, razoabilidade, interesse público. MARRARA, Thiago (organizador). São Paulo: Atlas, p. 109$118,2012$.

789 MENEZES DE ALMEIDA, Fernando Dias. Princípio da impessoalidade. In: Princípios de Direito Administrativo: legalidade, segurança jurídica, impessoalidade, publicidade, motivação, eficiência, moralidade, razoabilidade, interesse público. MARRARA, Thiago (organizador). São Paulo: Atlas, p.113, 2012.

790 MELLO, Celso Antônio Bandeira de. Conteúdo Jurídico do princípio da Igualdade. 3 ed. atual. 13 tiragem. São Paulo: Malheiros. 2005, p. 38-48. 
regular de suas funções no SUS; (iii) estar a prescrição em conformidade com a RENAME e os Protocolos Clínicos e Diretrizes Terapêuticas ou com a relação específica complementar estadual, distrital ou municipal de medicamentos; e (iv) ter a dispensação ocorrido em unidades indicadas pela direção do SUS.

Este dispositivo também sedimenta em seu parágrafo $2^{\circ}$ a possibilidade de serem estabelecidas regras para o atendimento diferenciado em relação a medicamentos de caráter especializado, determinando o tratamento diverso às pessoas que deles necessitem, como forma de assegurar a equidade.

A Constituição Federal de 1988 assegura proteção especial às crianças e aos adolescentes, aos deficientes físicos, assim como aos idosos, considerando a vulnerabilidade que possuem, a fim de promover a igualdade substancial das pessoas.

O artigo 227, caput, da Constituição Federal prescreve o dever do Estado, da sociedade e da família assegurarem às crianças e aos adolescentes, com absoluta prioridade, o direito à saúde, dentre outros, bem como a obrigação de protegê-los de toda forma de negligência, discriminação, exploração, violência, crueldade e opressão, que colocariam a saúde em risco.

O parágrafo primeiro deste dispositivo determina ao Estado a promoção de programas de assistência integral à saúde da criança, do adolescente e do jovem, admitindo a participação de entidades não-governamentais, mediante políticas específicas e respeitando os seguintes preceitos: (i) aplicação de percentual dos recursos públicos destinados à saúde na assistência materno-infantil; e (ii) criação de programas de prevenção e atendimento especializado para as pessoas que apresentem deficiência física, sensorial ou mental, bem como de integração social do adolescente e do jovem portador de deficiência, mediante a facilitação do acesso aos bens e serviços coletivos, com a eliminação de obstáculos arquitetônicos e de todas as formas de discriminação.

No mesmo sentido, o Estatuto da Criança e do Adolescente (Lei n. 8.069, de 13 de julho de 1990, em seu artigo $4^{\circ}$ reitera o dever da família, da sociedade e do Estado assegurar, com absoluta prioridade, a efetivação do direito à saúde, que compreende: a primazia para receber proteção e socorro em quaisquer circunstâncias; a precedência de atendimento nos serviços públicos ou de relevância pública; a preferência na formulação e 
na execução das políticas sociais públicas; e a destinação privilegiada de recursos públicos nas áreas relacionadas com a proteção à infância e à juventude. ${ }^{791}$

A Lei n. 8.069/90 prevê que proteção da saúde da criança e do adolescente se realizará mediante a efetivação de políticas sociais que permitam o nascimento e o desenvolvimento de forma sadia e harmoniosa, em condições dignas de existência (artigo $7^{\circ}$ ) e assegura à gestante, através do Sistema Único de Saúde, o atendimento pré e perinatal, protegendo a vida e a saúde da mulher e do nascituro. Prevê, ainda, o atendimento psicológico à gestante e, após o nascimento, à mãe, para minimizar os efeitos do estado puerperal $\left(\operatorname{artigo} 8^{\circ}\right)$.

Além disso, a Lei n. 8.069/90 estabelece deveres voltados à proteção da criança e do adolescente: (i) o poder publico, as instituições e os empregados devem garantir condições adequadas para o aleitamento materno, inclusive em estabelecimentos prisionais (artigo $9^{\circ}$ ); os estabelecimentos de atendimento à saúde devem proporcionar condições para que um dos pais ou responsável permaneça com a criança ou adolescente em caso de internação (artigo 12); (iii) o Sistema Único de Saúde deve promover campanhas de educação sanitárias aos pais, educadores e alunos, bem como programas de assistência médica e odontológica para a prevenção das enfermidades que ordinariamente afetam a população infantil (artigo 14, caput); (iv) os pais ou responsáveis devem vacinar as crianças nos casos recomendados pelas autoridades sanitárias (artigo 14 e parágrafo único).

No concernente às pessoas idosas, a Constituição Federal prevê em seu artigo 230 o dever da família, da sociedade e do Estado de ampará-los, assegurando sua participação na comunidade, defendendo sua dignidade e bem-estar e garantindo-lhes o direito à vida. $\mathrm{O}$ parágrafo $1^{\mathrm{o}}$ deste dispositivo estabelece que os programas de amparo aos idosos serão preferencialmente executados em seus lares.

A Lei n. 10.741, de $1^{\circ}$ de outubro de 2003 (Estatuto do Idoso) define como idosas as pessoas com idade igual ou superior a 60 (sessenta) anos (artigo $1^{\circ}$ ), assegurando-lhes além dos direitos fundamentais inerentes à pessoa humana, todas as oportunidades e facilidades,

\footnotetext{
791 A Lei n. 8.069/90 estabelece o atendimento integral das crianças e adolescentes por meio do Sistema Único de Saúde (artigo 11), nos seguintes termos: “Art. 11. É assegurado atendimento integral à saúde da criança e do adolescente, por intermédio do Sistema Único de Saúde, garantido o acesso universal e igualitário às ações e serviços para promoção, proteção e recuperação da saúde. $\S 1^{\circ} \mathrm{A}$ criança e o adolescente portadores de deficiência receberão atendimento especializado. $\S 2^{\circ}$ Incumbe ao poder público fornecer gratuitamente àqueles que necessitarem os medicamentos, próteses e outros recursos relativos ao tratamento, habilitação ou reabilitação."
} 
para preservação de sua saúde física e mental e seu aperfeiçoamento moral, intelectual, espiritual e social, em condições de liberdade e dignidade (artigo $2^{\circ}$ ).

A família, a sociedade e o Estado devem garantir ao idoso, com absoluta prioridade, dentre outros, a proteção do direito à saúde ${ }^{792}$ e determina ao Estado a obrigação de garantir à pessoa idosa a proteção à vida e à saúde, mediante efetivação de políticas sociais públicas, que permitam um envelhecimento saudável e com dignidade (artigo $9^{\circ}$ ).

O capítulo VIII do Título VIII da Constituição Federal (Da Ordem Social) trata “dos Índios" e, no artigo 231, reconhece sua organização social, costumes, crenças e tradições indígenas, bem como o direito originário sobre a terra que tradicionalmente ocupam. $\mathrm{O}$ parágrafo $5^{\circ}$ deste dispositivo veda a remoção dos grupos de suas terras, exceto em dois casos e enquanto durar a situação de risco, a saber: (i) "ad referendum" do Congresso Nacional, na hipótese de catástrofe ou epidemia que ponha em risco sua população; ou (ii) no interesse da soberania do País, após deliberação do Congresso Nacional. ${ }^{793}$

A própria Lei n. 8.080/90, fundada na proteção que a Constituição Federal assegura aos índios, institui um subsistema de atenção à saúde indígena em seus artigos 19-A a 19$\mathrm{H}^{794}$, como componente do Sistema Único de Saúde - SUS, criado e definido pela Lei n. 8.080/90 e pela Lei n.8.142/90, com o qual funcionará em perfeita integração. ${ }^{795}$ Este subsistema será financiado com recursos próprios da União e os Estados, Municípios,

\footnotetext{
${ }^{792}$ Nos termos do artigo $3^{\circ}$, da Lei n. 10.741/2003, a garantia de prioridade abrange: o atendimento preferencial imediato e individualizado junto aos órgãos públicos e privados prestadores de serviços à população; a preferência na formulação e na execução de políticas sociais públicas específicas; a destinação privilegiada de recursos públicos nas áreas relacionadas com a proteção ao idoso; a viabilização de formas alternativas de participação, ocupação e convívio do idoso com as demais gerações; a priorização do atendimento do idoso por sua própria família, em detrimento do atendimento asilar, exceto dos que não a possuam ou careçam de condições de manutenção da própria sobrevivência; a capacitação e reciclagem dos recursos humanos nas áreas de geriatria e gerontologia e na prestação de serviços aos idosos; o estabelecimento de mecanismos que favoreçam a divulgação de informações de caráter educativo sobre os aspectos biopsicossociais de envelhecimento; e a garantia de acesso à rede de serviços de saúde e de assistência social locais.

793 “Art. 231. São reconhecidos aos índios sua organização social, costumes, línguas, crenças e tradições, e os direitos originários sobre as terras que tradicionalmente ocupam, competindo à União demarcá-las, proteger e fazer respeitar todos os seus bens. (...) $\S 5^{\circ}$ - É vedada a remoção dos grupos indígenas de suas terras, salvo, "ad referendum" do Congresso Nacional, em caso de catástrofe ou epidemia que ponha em risco sua população, ou no interesse da soberania do País, após deliberação do Congresso Nacional, garantido, em qualquer hipótese, o retorno imediato logo que cesse o risco."

${ }^{794}$ Incluído pela Lei n. 9.836/1999.

795 “Art. 19-B. É instituído um Subsistema de Atenção à Saúde Indígena, componente do Sistema Único de Saúde - SUS, criado e definido por esta Lei, e pela Lei ${ }^{\circ}$ 8.142, de 28 de dezembro de 1990, com o qual funcionará em perfeita integração."
} 
outras instituições governamentais e não-governamentais poderão atuar complementarmente no custeio e execução das ações. ${ }^{796}$

As ações e serviços de saúde dirigidos ao atendimento das populações indígenas deverão levar em consideração a realidade local e as especificidades da cultura dos povos indígenas e o modelo a ser adotado para a atenção à saúde indígena, pautado por uma abordagem diferenciada e global, contemplando os aspectos de assistência à saúde, saneamento básico, nutrição, habitação, meio ambiente, demarcação de terras, educação sanitária e integração institucional (artigo 19-F, Lei 8.080/90).

Por fim, o subsistema de Atenção à Saúde Indígena será, como o SUS, descentralizado, hierarquizado e regionalizado. Contudo, terá como base os Distritos Sanitários Especiais Indígenas, servindo o Sistema Único de Saúde (SUS) de retaguarda e referência, o que exige adaptações na estrutura e organização do SUS nas regiões onde residem as populações indígenas, para propiciar essa integração e o atendimento necessário em todos os níveis, sem discriminações (artigo 19-G, caput e parágrafos $1^{\circ}$ e $2^{\circ}$ ).

O regime do subsistema de atenção à saúde indígena é diferenciado em relação ao Sistema Único de Saúde. Contudo, as normas são válidas, porquanto há pertinência lógica entre os elementos discriminadores adotados (cultura dos povos indígenas e regionalização baseada em distritos sanitários especiais indígenas) e a disparidade de regimes outorgados em função deles, à luz dos interesses prestigiados pela Constituição Federal em relação à proteção da cultura indígena e ao reconhecimento do direito originário sobre a terra que ocupam.

Por derradeiro, o princípio da participação popular encontra fundamento no caráter democrático do Estado brasileiro, previsto no Preâmbulo ${ }^{797}$ e no artigo $1^{\text {o }}$, caput, e parágrafo único da Constituição Federal $^{798}$, que estabelecem ser o povo o titular de todo o

\footnotetext{
796 “Art. 19-C. Caberá à União, com seus recursos próprios, financiar o Subsistema de Atenção à Saúde Indígena. (...) Art. 19-E. Os Estados, Municípios, outras instituições governamentais e não-governamentais poderão atuar complementarmente no custeio e execução das ações."

797 "Nós, representantes do povo brasileiro, reunidos em Assembleia Nacional Constituinte para instituir um Estado Democrático, destinado a assegurar o exercício dos direitos sociais e individuais, a liberdade, a segurança, o bem-estar, o desenvolvimento, a igualdade e a justiça como valores supremos de uma sociedade fraterna, pluralista e sem preconceitos, fundada na harmonia social e comprometida, na ordem interna e internacional, com a solução pacífica das controvérsias, promulgamos, sob a proteção de Deus, a seguinte CONSTITUIÇÃO DA REPÚBLICA FEDERATIVA DO BRASIL."

798 “Art. $1^{\text {o }}$ A República Federativa do Brasil, formada pela união indissolúvel dos Estados e Municípios e do Distrito Federal, constitui-se em Estado Democrático de Direito e tem como fundamentos: (...) II - a cidadania; (...) Parágrafo único. Todo o poder emana do povo, que o exerce por meio de representantes eleitos ou diretamente, nos termos desta Constituição."
} 
poder e a possibilidade de exercê-lo direta ou indiretamente. A participação popular guarda relação com a dimensão ativa dos direitos fundamentais (status ativo) e consiste na possibilidade de o indivíduo tomar parte na vida política do Estado em relação às decisões que irão vinculá-lo. Assim, a participação política do indivíduo também está ligada à cidadania, prevista como fundamento da República (artigo $1^{\circ}$, inciso II, da Constituição Federal).

$\mathrm{Na}$ área da saúde, especificamente, a participação popular está prevista no artigo 198, III da Constituição Federal, como diretriz do Sistema Único de Saúde (SUS) ${ }^{799}$, nos artigos $7^{0800}, 12^{801}$ e 19-R, parágrafo $1^{\circ}$, incisos I, III e IV, todos da Lei n. 8.080/90 ${ }^{802}$. Ademais, a Lei n. 8.142/90, que dispõe sobre a participação da comunidade na gestão do Sistema Único de Saúde (SUS), determina a criação, em cada uma das esferas de governo, de duas instâncias colegiadas: a conferência de saúde e o conselho de saúde (artigo $1^{\circ}$. I e II). A composição em ambos os órgãos colegiados deve ser paritária entre representantes do governo, prestadores de serviço, profissionais de saúde e usuários (artigo $1^{\circ}$, parágrafo $\left.4^{\mathrm{o}}\right){ }^{803}$

\footnotetext{
799 “Art. 198. As ações e serviços públicos de saúde integram uma rede regionalizada e hierarquizada e constituem um sistema único, organizado de acordo com as seguintes diretrizes: (...) III - participação da comunidade."

800 "Art. $7^{\circ}$ As ações e serviços públicos de saúde e os serviços privados contratados ou conveniados que integram o Sistema Único de Saúde (SUS), são desenvolvidos de acordo com as diretrizes previstas no art. 198 da Constituição Federal, obedecendo ainda aos seguintes princípios: (...) VIII - participação da comunidade;"

801 "Art. 12. Serão criadas comissões intersetoriais de âmbito nacional, subordinadas ao Conselho Nacional de Saúde, integradas pelos Ministérios e órgãos competentes e por entidades representativas da sociedade civil. Parágrafo único. As comissões intersetoriais terão a finalidade de articular políticas e programas de interesse para a saúde, cuja execução envolva áreas não compreendidas no âmbito do Sistema Único de Saúde (SUS)."

802 "Art. 19-R. A incorporação, a exclusão e a alteração a que se refere o art. 19-Q serão efetuadas mediante a instauração de processo administrativo, a ser concluído em prazo não superior a 180 (cento e oitenta) dias, contado da data em que foi protocolado o pedido, admitida a sua prorrogação por 90 (noventa) dias corridos, quando as circunstâncias exigirem.

$\S 1^{\circ} \mathrm{O}$ processo de que trata o caput deste artigo observará, no que couber, o disposto na Lei $\mathrm{n}^{\circ} 9.784$, de 29 de janeiro de 1999, e as seguintes determinações especiais:

I - apresentação pelo interessado dos documentos e, se cabível, das amostras de produtos, na forma do regulamento, com informações necessárias para o atendimento do disposto no $\S 2^{\circ}$ do art. 19-Q; II - (vetado); III - realização de consulta pública que inclua a divulgação do parecer emitido pela Comissão Nacional de Incorporação de Tecnologias no SUS; IV - realização de audiência pública, antes da tomada de decisão, se a relevância da matéria justificar o evento."

803 "Art. $1^{\circ}$ O Sistema Único de Saúde (SUS), de que trata a Lei n ${ }^{\circ} 8.080$, de 19 de setembro de 1990, contará, em cada esfera de governo, sem prejuízo das funções do Poder Legislativo, com as seguintes instâncias colegiadas: I - a Conferência de Saúde; e II - o Conselho de Saúde. (...) § $4^{\circ}$ A representação dos usuários nos Conselhos de Saúde e Conferências será paritária em relação ao conjunto dos demais segmentos."
} 
A Lei n. 8.142/90 inovou ao determinar a criação de Conselhos de Saúde em cada instância de governo, pois até então existia apenas o Conselho Nacional de Saúde, vinculado ao Ministério da Saúde, isto é, apenas na esfera federal.

O conselho de saúde consiste em órgão colegiado, permanente e deliberativo que atua na formulação de estratégias e no controle da execução da política de saúde na respectiva instância, inclusive em relação aos aspectos econômicos e financeiros. As decisões do conselho de saúde serão homologadas pelo chefe do poder legalmente constituído em cada esfera do governo (artigo $1^{\circ}$, parágrafo $2^{\circ}$, da Lei n. 8.142/90).

A conferência de saúde, por sua vez, irá se reunir a cada quatro anos, com a representação dos vários segmentos da sociedade, a fim de avaliar a situação de saúde e propor as diretrizes para a formulação da política de saúde nos níveis correspondentes. A conferência de saúde é convocada pelo Poder Executivo ou, de forma extraordinária, por esta ou pelo Conselho de Saúde (artigo $1^{\circ}$, parágrafo $1^{\circ}$, da Lei n. 8.142/90).

A densificação da dimensão ativa dos direitos fundamentais, no contexto dos direitos a prestações em sentido amplo, se traduz como direitos de participação direta na organização e no procedimento, como reflexo da democracia, in casu, da democracia sanitária.

A participação da comunidade nos conselhos de saúde e nas conferências de saúde não se dá de forma direta, mas por meio de representantes, que poderão interagir no processo de definição das políticas públicas de saúde, colaborando para a tomada de decisão sobre as políticas sociais e econômicas voltadas à proteção da saúde, sem prejuízo do controle social sobre as políticas públicas dotadas pelo poder público.

Ainda que haja limitações de ordem concreta ao exercício da participação social ${ }^{804}$, o Ministério da Saúde tem adotado medidas institucionais como o Programa de Inclusão Digital (PID) e a ampliação de ações de educação permanente de conselheiros para o fortalecimento da cultura democrática e da gestão participativa do Sistema Único de Saúde. Desde 2007, com o repasse de recursos fundo a fundo para a Secretaria de Estado

\footnotetext{
804 Os problemas na efetivação das conferências de saúde e dos conselhos de saúde como espaços democráticos ocorrem devido à baixa capilaridade das resoluções e deliberações, pela pouca diversificação de participantes e pela estrutura e funcionamento deficitários. Assim, por exemplo, dos 3046 municípios participantes de pesquisa realizada pelo Ministério da Saúde em 2007, 2.212 não possuíam sede, 1.046 não dispõem de telefone e 1.462 não têm acesso à internet, o que gera preocupações dos gestores do Sistema Único de Saúde (SUS) quanto ao efetivo funcionamento desses espaços. BRASIL. Ministério da Saúde. Secretaria-Executiva. Subsecretaria de Planejamento e Orçamento. Plano Nacional de Saúde - PNS: 20122015. Brasília: Ministério da Saúde, 2011, p.62.
} 
da Saúde e as Secretarias Municipais de Saúde, essas ações tornaram-se contínuas e institucionais. Em 21 estados, foram capacitados 15.895 conselheiros no período compreendido entre 2008 a $2011 .^{805}$

A Lei de Processo Administrativo federal (Lei n. 9.784/99) também prevê dois instrumentos clássicos que viabilizam a participação do administrado na Administração Pública: a consulta pública e a audiência pública, que se aplicam a qualquer entidade administrativa. Além disso, prevê a possibilidade do estabelecimento de outros meios de participação de administrados, diretamente ou por meio de organizações e associações legalmente reconhecidas. ${ }^{806}$

A razão da abertura de consulta pública consiste na existência de matéria que envolva assunto de relevante interesse coletivo. É um procedimento mais longo, marcado por manifestações basicamente escritas, previamente à decisão do pedido. É necessário que seja dado conhecimento do assunto à população, com a fixação de um prazo razoável para a consulta dos autos, bem como para a apresentação de manifestações por escrito. Desta manifestação decorre um direito à consideração das manifestações feitas. É um direito fundamental implícito em matéria de participação popular, que se justifica na medida em que a desconsideração das manifestações implicaria na nulificação do direito. ${ }^{807}$ Neste sentido, o artigo 34 da Lei n. 9.784/99 prescreve que "os resultados da consulta e audiência pública e de outros meios de participação de administrados deverão ser apresentados com a indicação do procedimento adotado".

A audiência pública, por sua vez, consiste no mecanismo que permite a realização de debates sobre a matéria discutida no processo, em se tratando de casos nos quais esteja sendo discutida questão relevante, a juízo da autoridade. ${ }^{808} 809$

${ }^{805}$ BRASIL. Ministério da Saúde. Secretaria-Executiva. Subsecretaria de Planejamento e Orçamento. Plano Nacional de Saúde - PNS: 2012-2015. Brasília: Ministério da Saúde, 2011, p.62-63.

${ }^{806}$ A Lei n. 9.784/99 dispõe em seu artigo 33: “Art. 33. Os órgãos e entidades administrativas, em matéria relevante, poderão estabelecer outros meios de participação de administrados, diretamente ou por meio de organizações e associações legalmente reconhecidas."

807 “Art. 31. Quando a matéria do processo envolver assunto de interesse geral, o órgão competente poderá, mediante despacho motivado, abrir período de consulta pública para manifestação de terceiros, antes da decisão do pedido, se não houver prejuízo para a parte interessada. $\S 1^{\circ} \mathrm{A}$ abertura da consulta pública será objeto de divulgação pelos meios oficiais, a fim de que pessoas físicas ou jurídicas possam examinar os autos, fixando-se prazo para oferecimento de alegações escritas. $\S 2^{\circ} \mathrm{O}$ comparecimento à consulta pública não confere, por si, a condição de interessado do processo, mas confere o direito de obter da Administração resposta fundamentada, que poderá ser comum a todas as alegações substancialmente iguais."

${ }^{808}$ A Lei n. 9.784/99 assim prescreve: "Art. 32. Antes da tomada de decisão, a juízo da autoridade, diante da relevância da questão, poderá ser realizada audiência pública para debates sobre a matéria do processo.” 
Desta forma, a participação popular na Administração Pública é assegurada por instrumentos de democracia semidireta, que é um dos valores mais importantes do Estado $^{810}$ e demonstram a valorização do indivíduo pela ordem jurídica para se manifestar junto aos órgãos do Estado. ${ }^{811}$

No âmbito do Sistema Único de Saúde (SUS) ganha maior relevo a participação social, visto que os mecanismos instituídos permitem estabelecer um diálogo permanente nos níveis municipal, estadual e federal com os gestores do sistema, as áreas técnicas e os prestadores de serviços sobre todas as questões de interesse da população relativas às ações e aos serviços de saúde (abrangência, qualidade, extensão etc.) e o controle do repasse de recursos financeiros às entidades federadas.

A crescente participação da sociedade civil organizada no planejamento, execução e fiscalização das ações e serviços prestados pelo Sistema Único de Saúde (SUS), pode trazer reflexos positivos à melhoria da qualidade e da eficiência da prestação dos serviços públicos de saúde. A simplificação e a celeridade dos meios de comunicação, a disseminação de ideias nas redes sociais e, principalmente, os movimentos sociais organizados, sempre poderão levantar a bandeira pela efetividade do direito fundamental à saúde, fundados na Constituição Federal de 1988, por um Sistema Único de Saúde eficiente.

\subsubsection{Fontes de financiamento}

O Sistema Único de Saúde (SUS) configura um sistema público de prestação de ações e serviços em âmbito nacional, instituído para a proteção, recuperação e promoção da saúde. O atendimento desses objetivos depende do estabelecimento de relações intergovernamentais e de um financiamento permanente, e em montante adequado e

${ }^{809}$ É com fundamento no artigo 32 da Lei n.9.784/99 que está sendo realizada audiência pública no Supremo Tribunal Federal sobre o Programa "Mais Médicos", instituído pela Medida Provisória n. 621/2013, sob a Presidência do Ministro Marco Aurélio, relator das Ações Diretas de Inconstitucionalidade (ADIs) 5035 e 5037, que contestam a constitucionalidade de dispositivos da Medida Provisória (MP) 621/2013. Informações disponíveis no site oficial do Supremo Tribunal Federal: < http://www.stf.jus.br/>.

${ }^{810}$ BONAVIDES considera a democracia como direito fundamental de quarta geração, imprescindível para que seja legítima e possível a globalização política. O cidadão legitimado deve exercer a cidadania e fiscalizar o cumprimento dos direitos constitucionais enunciados, em moldes compatíveis com a natureza e o exercício da democracia direta. BONAVIDES, Paulo. Curso de Direito Constitucional. 22.ed. São Paulo: Malheiros, 2008, p.570-572.

811 SCHIRATO, Vitor Rhein. O processo administrativo como instrumento do Estado Democrático de Direito e da Democracia. In: Atuais rumos do processo administrativo. MEDAUAR, Odete; SCHIRATO, Vitor Rhein. São Paulo: Editora Revista dos Tribunais, p.36, 2010. 
suficiente, sobretudo por se tratar de um modelo universal, fundado na integralidade do atendimento. São aproximadamente 141 milhões de brasileiros que dependem exclusivamente das ações e serviços da rede pública de saúde e mais de 48 milhões de pessoas que, mesmo com acesso aos planos de assistência médico-hospitalar, podem utilizar as ações e serviços oferecidos pelo Sistema Único de Saúde (SUS). ${ }^{812} 813$

A insuficiência de recursos investidos na área da saúde já acarretou na história recente do Brasil a instabilidade no financiamento das políticas públicas de saúde e a adoção de medidas emergenciais, tais como empréstimos junto ao Fundo do Amparo ao Trabalhador (FAT), obtidos no início dos anos 1990, e a criação da Contribuição Provisória sobre Movimentação Financeira (CPMF), que vigorou de 1997 a 2007.814

A Constituição Federal de 1988 para além de reconhecer o direito fundamental à saúde e estabelecer a estrutura do modelo jurídico-constitucional do Sistema Único de Saúde, definiu a forma de financiamento das políticas públicas sanitárias.

A saúde integra a seguridade social, conforme dispõe o artigo 194, caput, da Constituição Federal ${ }^{815}$. A seguridade social, nos termos do artigo 195 será financiada por toda a sociedade, de forma direta e indireta, nos termos da lei, mediante recursos provenientes dos orçamentos dos entes federativos e das seguintes contribuições sociais: I do empregador, da empresa e da entidade a ela equiparada na forma da lei; II - do trabalhador e dos demais segurados da previdência social; III - sobre a receita de concursos de prognósticos; IV - do importador de bens ou serviços do exterior, ou de quem a lei a ele equiparar. Além disso, lei complementar poderá instituir outras fontes destinadas a garantir

\footnotetext{
${ }^{812}$ Segundo pesquisa realizada pelo Instituto Brasileiro de Geografia e Estatística (IBGE) publicada no dia 31/08/2012 no Diário Oficial da União, a população residente no Brasil foi estimada em 193.946.886 (cento e noventa e três milhões novecentos e quarenta e seis mil oitocentos e oitenta e seis), tendo como referência $1^{\circ}$ de julho de 2012. Disponível no site do IBGE:< http://www.ibge.gov.br>. Consulta em 23/03/2013.

${ }^{813}$ Segundo a Confederação Nacional da Indústria (CNI) e o Instituto Brasileiro de Opinião Pública e Estatística (IBOPE), $27 \%$ da população brasileira têm planos de saúde. Pesquisa CNI - IBOPE: retratos da sociedade brasileira: saúde pública. Brasília: CNI, 2012, p.14 e 17.

${ }^{814}$ Regulamentação da Emenda Constitucional n. 29, de 2000 (piso constitucional de aplicação em saúde): análise das principais inovações trazidas pela Lei Complementar n. 141, de 13 de janeiro de 2012, que regulamentou a Emenda Constitucional n. 29, de 2000. Nota Técnica n. 014/2012, elaborada pelo Núcleo de Saúde da Consultoria de Orçamento e Fiscalização Financeira da Câmara dos Deputados (CONOF/CD). 2012. p.5. Disponível na biblioteca digital da Câmara dos Deputados: <http://bd.camara.leg.br>. Consulta em 26 de novembro de 2013.

815 "Art. 194. A seguridade social compreende um conjunto integrado de ações de iniciativa dos Poderes Públicos e da sociedade, destinadas a assegurar os direitos relativos à saúde, à previdência e à assistência social."
} 
a manutenção ou expansão da seguridade social (artigo 195, parágrafo $4^{\circ}$ ). ${ }^{816} \mathrm{O}$ parágrafo $10^{\circ}$ estabelece que serão definidos em lei os critérios de transferência de recursos para o sistema único de saúde e ações de assistência social da União para os Estados, o Distrito Federal e os Municípios, e dos Estados para os Municípios, observada a respectiva contrapartida de recursos..$^{817}$

Os parágrafos $1^{\circ}, 2^{\circ}$ e $3^{\circ}$ do artigo 198 da Constituição Federal ${ }^{818}$ são dedicados às normas sobre o financiamento do Sistema Único de Saúde (SUS). De acordo com o parágrafo $1^{\circ}$ deste artigo, além de recursos do orçamento da seguridade social de todos os entes políticos, o Sistema Único de Saúde (SUS) também será financiado por outras fontes. Os parágrafos $2^{\circ}$ e $3^{\circ}$ são fruto do poder constituinte derivado reformador, pois foram incluídos ao texto original por meio da Emenda Constitucional n. 29, de 13 de setembro de

816 O artigo 154, inciso I, da Constituição Federal assim dispõe: “Art. 154. A União poderá instituir: I mediante lei complementar, impostos não previstos no artigo anterior, desde que sejam não-cumulativos e não tenham fato gerador ou base de cálculo próprios dos discriminados nesta Constituição;"

${ }^{817}$ Art. 195. A seguridade social será financiada por toda a sociedade, de forma direta e indireta, nos termos da lei, mediante recursos provenientes dos orçamentos da União, dos Estados, do Distrito Federal e dos Municípios, e das seguintes contribuições sociais: I - do empregador, da empresa e da entidade a ela equiparada na forma da lei, incidentes sobre: a) a folha de salários e demais rendimentos do trabalho pagos ou creditados, a qualquer título, à pessoa física que lhe preste serviço, mesmo sem vínculo empregatício; b) a receita ou o faturamento; c) o lucro; II - do trabalhador e dos demais segurados da previdência social, não incidindo contribuição sobre aposentadoria e pensão concedidas pelo regime geral de previdência social de que trata o art. 201; III - sobre a receita de concursos de prognósticos. IV - do importador de bens ou serviços do exterior, ou de quem a lei a ele equiparar. $\S 1^{\circ}$ - As receitas dos Estados, do Distrito Federal e dos Municípios destinadas à seguridade social constarão dos respectivos orçamentos, não integrando o orçamento da União. $\S 2^{\circ}$ - A proposta de orçamento da seguridade social será elaborada de forma integrada pelos órgãos responsáveis pela saúde, previdência social e assistência social, tendo em vista as metas e prioridades estabelecidas na lei de diretrizes orçamentárias, assegurada a cada área a gestão de seus recursos. (...) § $4^{\circ}-\mathrm{A}$ lei poderá instituir outras fontes destinadas a garantir a manutenção ou expansão da seguridade social, obedecido o disposto no art. 154, I. (...) § 10. A lei definirá os critérios de transferência de recursos para o sistema único de saúde e ações de assistência social da União para os Estados, o Distrito Federal e os Municípios, e dos Estados para os Municípios, observada a respectiva contrapartida de recursos.

818 “Art. 198. As ações e serviços públicos de saúde integram uma rede regionalizada e hierarquizada e constituem um sistema único, organizado de acordo com as seguintes diretrizes: (...) $\S 1^{\circ}$. O sistema único de saúde será financiado, nos termos do art. 195, com recursos do orçamento da seguridade social, da União, dos Estados, do Distrito Federal e dos Municípios, além de outras fontes. § $2^{\circ}$ A União, os Estados, o Distrito Federal e os Municípios aplicarão, anualmente, em ações e serviços públicos de saúde recursos mínimos derivados da aplicação de percentuais calculados sobre: I - no caso da União, na forma definida nos termos da lei complementar prevista no $\S 3^{\circ}$; II - no caso dos Estados e do Distrito Federal, o produto da arrecadação dos impostos a que se refere o art. 155 e dos recursos de que tratam os arts. 157 e 159, inciso I, alínea a, e inciso II, deduzidas as parcelas que forem transferidas aos respectivos Municípios; III - no caso dos Municípios e do Distrito Federal, o produto da arrecadação dos impostos a que se refere o art. 156 e dos recursos de que tratam os arts. 158 e 159 , inciso $\mathrm{I}$, alínea b e $\S 3^{\circ}$. $\S 3^{\circ}$ Lei complementar, que será reavaliada pelo menos a cada cinco anos, estabelecerá: I - os percentuais de que trata o $\S 2^{\circ}$; II - os critérios de rateio dos recursos da União vinculados à saúde destinados aos Estados, ao Distrito Federal e aos Municípios, e dos Estados destinados a seus respectivos Municípios, objetivando a progressiva redução das disparidades regionais; III - as normas de fiscalização, avaliação e controle das despesas com saúde nas esferas federal, estadual, distrital e municipal; IV - as normas de cálculo do montante a ser aplicado pela União.” 
$2000^{819}$, com o objetivo de assegurar, de forma duradoura, a aplicação de um piso mínimo de recursos para o financiamento da saúde.

Como observa AITH, a vinculação orçamentária de recursos na área da educação, já utilizada na época em que a Emenda Constitucional n. 29/2000 foi aprovada, serviu de inspiração para o estabelecimento de um orçamento mínimo dos entes federados à área da saúde. ${ }^{820} \mathrm{O}$ artigo 212, caput, da Constituição Federal estabelece que a União aplicará, anualmente, pelo menos 18\% e os Estados, o Distrito Federal e os Municípios pelo menos $25 \%$ da receita resultante de impostos, compreendida a proveniente de transferências, na manutenção e desenvolvimento do ensino.

Por força da Emenda Constitucional n. 29/2000, o parágrafo $2^{\circ}$ do artigo 198 da Constituição Federal prescreve que cada uma das entidades federativas deve aplicar anualmente recursos mínimos em ações e serviços públicos de saúde, na forma da lei complementar prevista no parágrafo $3^{\circ}$ do mesmo dispositivo para a União e no caso dos Estados, Distrito Federal e Municípios, considerada também, a arrecadação dos tributos que especifica. O parágrafo $3^{\circ}$, por sua vez, previu a edição de lei complementar para estabelecer: (i) a revisão dos percentuais de que trata o $\S 2^{\circ}$; (ii) os critérios de rateio dos recursos da União vinculados à saúde destinados aos Estados, ao Distrito Federal e aos Municípios, e dos Estados destinados a seus respectivos Municípios, objetivando a progressiva redução das disparidades regionais; (iii) as normas de fiscalização, avaliação e controle das despesas com saúde nas esferas federal, estadual, distrital e municipal; e (iv) as normas de cálculo do montante a ser aplicado pela União. No entanto, até a aprovação da referida lei complementar (Lei Complementar n. 141, de 13 de janeiro de 2012), foram mantidas as regras transitórias vigentes a partir do exercício financeiro de $2005 .^{821}$

${ }^{819}$ A Emenda Constitucional n. 29, de 13 de setembro de 2000, altera a redação dos artigos 34, 35, 156, 160, 167 e 198 da Constituição Federal e acrescenta o artigo 77 ao Ato das Disposições Constitucionais Transitórias para assegurar os recursos mínimos para o financiamento das ações e serviços públicos de saúde. ${ }^{820}$ AITH, Fernando. Curso de Direito Sanitário: a proteção do Direito à Saúde no Brasil. São Paulo: Quartier Latin, 2007, p.369.

821 O artigo $7^{\circ}$ da EC n. 29/2000 assim determinou: "Art. $7^{\circ}$ O Ato das Disposições Constitucionais Transitórias passa a vigorar acrescido do seguinte art. 77: "Art. 77. Até o exercício financeiro de 2004, os recursos mínimos aplicados nas ações e serviços públicos de saúde serão equivalentes: I - no caso da União: a) no ano 2000, o montante empenhado em ações e serviços públicos de saúde no exercício financeiro de 1999 acrescido de, no mínimo, cinco por cento; $b$ ) do ano 2001 ao ano 2004, o valor apurado no ano anterior, corrigido pela variação nominal do Produto Interno Bruto - PIB; II - no caso dos Estados e do Distrito Federal, doze por cento do produto da arrecadação dos impostos a que se refere o art. 155 e dos recursos de que tratam os arts. 157 e 159, inciso I, alínea $a$, e inciso II, deduzidas as parcelas que forem transferidas aos respectivos Municípios; e III - no caso dos Municípios e do Distrito Federal, quinze por cento do produto da arrecadação dos impostos a que se refere o art. 156 e dos recursos de que tratam os arts. 158 e 159, inciso I, 
Anteriormente à edição da Lei Complementar n. 141/2012, havia muitas divergências sobre a definição do conteúdo das ações e dos serviços de saúde, para fins de computar no piso constitucional da saúde. Para disciplinar e harmonizar a aplicação das normas constitucionais inseridas pela Emenda Constitucional n. 29/2000 em todo o território nacional, o Conselho Nacional de Saúde editou a Resolução n. 322, de 2003. Não obstante isso, alguns Estados, incluíam no orçamento da saúde despesas que não eram consideradas como gastos de saúde pela Resolução n. 322, de 2003, do Conselho Nacional de Saúde como, por exemplo, o pagamento de planos médicos privados para servidores públicos, saneamento, alimentação e assistência social. ${ }^{822}$

Tal Resolução foi objeto de ação direta de inconstitucionalidade (ADI n. 2.999 RJ). Contudo, o Pleno do Supremo Tribunal Federal, em 13.8.2208, não conheceu da ação referida, sob o argumento de que a resolução havia sido expedida com fundamento em regras de competência previstas em um complexo normativo infraconstitucional (Leis $\mathrm{n}^{\circ}$ 8.080, de 1990 e $\mathrm{n}^{\circ}$ 8.142, de 1990). De toda sorte, o país ainda carecia da lei complementar prevista no artigo 198, parágrafo $3^{\circ}$ da Constituição Federal para regulamentar e uniformizar a matéria, pois não houve consenso entre os entes federados quanto às orientações contidas na mencionada Resolução.

Após longo período de luta política, foi aprovada a Lei Complementar n. 141, de 13 de janeiro de 2012, para regulamentar o disposto no parágrafo $3^{\circ}$, do artigo 198, da Constituição Federal. O artigo $1^{\circ}$ desta Lei Complementar afirma instituir ${ }^{823}$ : os valores

alínea $b$ e $\S 3^{\circ} . \S 1^{\circ}$ Os Estados, o Distrito Federal e os Municípios que apliquem percentuais inferiores aos fixados nos incisos II e III deverão elevá-los gradualmente, até o exercício financeiro de 2004, reduzida a diferença à razão de, pelo menos, um quinto por ano, sendo que, a partir de 2000, a aplicação será de pelo menos sete por cento. $\S 2^{\circ}$ Dos recursos da União apurados nos termos deste artigo, quinze por cento, no mínimo, serão aplicados nos Municípios, segundo o critério populacional, em ações e serviços básicos de saúde, na forma da lei. $\S 3^{\circ}$ Os recursos dos Estados, do Distrito Federal e dos Municípios destinados às ações e serviços públicos de saúde e os transferidos pela União para a mesma finalidade serão aplicados por meio de Fundo de Saúde que será acompanhado e fiscalizado por Conselho de Saúde, sem prejuízo do disposto no art. 74 da Constituição Federal. $\S 4^{\circ} \mathrm{Na}$ ausência da lei complementar a que se refere o art. 198, § $3^{\circ}$, a partir do exercício financeiro de 2005, aplicar-se-á à União, aos Estados, ao Distrito Federal e aos Municípios o disposto neste artigo."

${ }^{822}$ Regulamentação da Emenda Constitucional n. 29, de 2000 (piso constitucional de aplicação em saúde): análise das principais inovações trazidas pela Lei Complementar n. 141, de 13 de janeiro de 2012, que regulamentou a Emenda Constitucional n. 29, de 2000. Nota Técnica n. 014/2012, elaborada pelo Núcleo de Saúde da Consultoria de Orçamento e Fiscalização Financeira da Câmara dos Deputados (CONOF/CD). 2012. p.7. Disponível na biblioteca digital da Câmara dos Deputados: http://bd.camara.leg.br. Consulta em 26 de novembro de 2013.

${ }^{823}$ Art. $1^{\circ}$ Esta Lei Complementar institui, nos termos do $\S 3^{\circ}$ do art. 198 da Constituição Federal: I - o valor mínimo e normas de cálculo do montante mínimo a ser aplicado, anualmente, pela União em ações e serviços públicos de saúde; II - percentuais mínimos do produto da arrecadação de impostos a serem aplicados anualmente pelos Estados, pelo Distrito Federal e pelos Municípios em ações e serviços públicos de 
mínimos a serem aplicados anualmente pela União, Estados ${ }^{824}$, Distrito Federal ${ }^{825}$ e Municípios ${ }^{826}$ em ações e serviços públicos de saúde; os critérios de rateio dos recursos de transferências para a saúde e as normas de fiscalização, avaliação e controle das despesas com saúde em cada uma das esferas de governo e revoga dispositivos das Leis $n^{\circ} 8.080$, de 19 de setembro de 1990 e 8.689, de 27 de julho de 1993, dentre outras providências.

$\mathrm{O}$ artigo $5^{\circ}$, caput, da Lei Complementar n. 141, de 13 de janeiro de 2012 prevê a obrigação da União de aplicar, anualmente, em ações e serviços públicos de saúde, o montante correspondente ao valor empenhado no exercício financeiro anterior, acrescido de, pelo menos, o percentual correspondente à variação nominal do Produto Interno Bruto (PIB) ocorrida no ano anterior ao da lei orçamentária ${ }^{827}$, e caso haja variação negativa do Produto Interno Bruto (PIB), o parágrafo $2^{\circ}$ determina que seja aplicado o mesmo valor do exercício financeiro precedente. ${ }^{828}$

Há controvérsias acerca da constitucionalidade do artigo $5^{\circ}$, caput, da Lei Complementar n. 141/2012 829 , visto que ao estabelecer montante pré-definido (valor

saúde; III - critérios de rateio dos recursos da União vinculados à saúde destinados aos Estados, ao Distrito Federal e aos Municípios, e dos Estados destinados aos seus respectivos Municípios, visando à progressiva redução das disparidades regionais; IV - normas de fiscalização, avaliação e controle das despesas com saúde nas esferas federal, estadual, distrital e municipal."

${ }^{824}$ Art. $6^{\circ}$ Os Estados e o Distrito Federal aplicarão, anualmente, em ações e serviços públicos de saúde, no mínimo, $12 \%$ (doze por cento) da arrecadação dos impostos a que se refere o art. 155 e dos recursos de que tratam o art. 157, a alínea "a" do inciso I e o inciso II do caput do art. 159, todos da Constituição Federal, deduzidas as parcelas que forem transferidas aos respectivos Municípios.

${ }^{825}$ Art. $8^{\circ} \mathrm{O}$ Distrito Federal aplicará, anualmente, em ações e serviços públicos de saúde, no mínimo, $12 \%$ (doze por cento) do produto da arrecadação direta dos impostos que não possam ser segregados em base estadual e em base municipal.

${ }^{826}$ Art. $7^{\circ}$ Os Municípios e o Distrito Federal aplicarão anualmente em ações e serviços públicos de saúde, no mínimo, $15 \%$ (quinze por cento) da arrecadação dos impostos a que se refere o art. 156 e dos recursos de que tratam o art. 158 e a alínea "b" do inciso I do caput e o $\$ 3^{\circ}$ do art. 159, todos da Constituição Federal.

${ }^{827}$ Por força do artigo 77, inciso I, "b" e parágrafo $4^{\circ}$, do Ato das Disposições Constitucionais Transitórias e devido à mora legislativa para regulamentar o artigo 198, parágrafo $3^{\circ}$ da Constituição Federal, desde 2001 o critério utilizado para definir o montante do orçamento da União destinado à área da saúde é a variação nominal do PIB anterior (ano da elaboração da proposta orçamentária). Como é levada em consideração a variação nominal do PIB, computa-se no referido cálculo também o percentual da inflação no período, aferido através do índice IPCA, elaborado pelo IBGE. RESENDE, Rodrigo Eugênio Matos. A regulamentação da Emenda Constitucional 29: esperança ou decepção para o financiamento da saúde pública? Revista de Direito. Procuradoria Geral do Estado de Goiás. Goiás: CEJUR. Volume 26, 2011, p.65.

828“Art. 5 A União aplicará, anualmente, em ações e serviços públicos de saúde, o montante correspondente ao valor empenhado no exercício financeiro anterior, apurado nos termos desta Lei Complementar, acrescido de, no mínimo, o percentual correspondente à variação nominal do Produto Interno Bruto (PIB) ocorrida no ano anterior ao da lei orçamentária anual. (...) $\S 2^{\circ}$ Em caso de variação negativa do PIB, o valor de que trata o caput não poderá ser reduzido, em termos nominais, de um exercício financeiro para o outro."

829“Art. 5 A União aplicará, anualmente, em ações e serviços públicos de saúde, o montante correspondente ao valor empenhado no exercício financeiro anterior, apurado nos termos desta Lei Complementar, acrescido de, no mínimo, o percentual correspondente à variação nominal do Produto Interno Bruto (PIB) ocorrida no 
empenhado no exercício financeiro anterior) como valor mínimo a ser aplicado em saúde, o legislador estaria contrariando o disposto nos parágrafos $2^{\circ}$ e $3^{\circ}$, do artigo 198, da Constituição Federal, que determina caber à Lei Complementar o estabelecimento dos percentuais a serem aplicados anualmente em ações e serviços de saúde pela União, pelos Estados, pelo Distrito Federal e pelos Municípios. ${ }^{830} 831$

$\mathrm{O}$ argumento utilizado para arguir a inconstitucionalidade desta norma da lei complementar está centrado na possibilidade de que a União aplique um valor inferior ao que poderia ter sido definido com a aplicação de um percentual que fosse vinculado à arrecadação tributária. O inconformismo se justifica porque o objetivo pretendido com a regulamentação da Emenda Constitucional n. 29/2000, aguardada durante doze anos, era exatamente alterar o quadro de subfinanciamento da saúde pública brasileira, com o aumento de investimentos do orçamento da União e não apenas dos Estados, Distrito Federal e Municípios. ${ }^{832}$ Desde a aprovação da Emenda Constitucional n. 29/2000, a União vem reduzindo sua participação relativa no financiamento da saúde pública: em 2000, a participação relativa da União no gasto total público em saúde era de 58,6\%; em 2005 encolheu para 47,7\%, chegando a 43,4\% em 2008 e atingindo 47,7\% em 2011. De outro

ano anterior ao da lei orçamentária anual. (...) $\S 2^{\circ}$ Em caso de variação negativa do PIB, o valor de que trata o caput não poderá ser reduzido, em termos nominais, de um exercício financeiro para o outro."

830 “Art. 198. As ações e serviços públicos de saúde integram uma rede regionalizada e hierarquizada e constituem um sistema único, organizado de acordo com as seguintes diretrizes: (...) $\S 2^{\circ}$ A União, os Estados, o Distrito Federal e os Municípios aplicarão, anualmente, em ações e serviços públicos de saúde recursos mínimos derivados da aplicação de percentuais calculados sobre: I - no caso da União, na forma definida nos termos da lei complementar prevista no $\S 3^{\circ}$; (...) $\S 3^{\circ}$ Lei complementar, que será reavaliada pelo menos a cada cinco anos, estabelecerá: I - os percentuais de que trata o $\S 2^{\circ}$; II - os critérios de rateio dos recursos da União vinculados à saúde destinados aos Estados, ao Distrito Federal e aos Municípios, e dos Estados destinados a seus respectivos Municípios, objetivando a progressiva redução das disparidades regionais; III - as normas de fiscalização, avaliação e controle das despesas com saúde nas esferas federal, estadual, distrital e municipal; IV - as normas de cálculo do montante a ser aplicado pela União.”

${ }^{831}$ Neste sentido: PIVETTA, Saulo Lindofer. Direito Fundamental à Saúde: regime jurídico-constitucional, políticas públicas e controle judicial. Dissertação (Mestrado). Universidade Federal do Paraná. Curitiba, 2013. p. 153

${ }^{832}$ Como observa RESENDE, o instrumento de desoneração orçamentária denominado Desvinculação de Receitas da União (DRU) foi prorrogado até 2015 através da EC 68/2011, é prejudicial à saúde na medida em que reduz as disponibilidades financeiras da União, aumentando o peso percentual das demais rubricas orçamentárias sobre as receitas não atingidas pela DRU. Ademais, o veto da Presidente da República ao parágrafo $1^{\circ}$ do artigo $5^{\circ}$ da Lei Complementar n. 141/2012, também expressa a vontade de manutenção do subfinanciamento da saúde, pois o dispositivo vetado dispunha que, na hipótese de revisão do valor nominal do PIB que implicasse em alteração do montante até então calculado, créditos adicionais deveriam promover os ajustes correspondentes, nos termos do $\S 8^{\circ}$ do art. 165 da $\mathrm{CF} / 88$. As razões do veto apontam que o PIB apurado num ano passa por revisões periódicas nos anos seguintes e que esta necessidade de constante alteração dos valores a serem destinados à saúde pela União poderia gerar instabilidade na gestão fiscal e orçamentária. RESENDE, Rodrigo Eugênio Matos. A regulamentação da Emenda Constitucional 29: esperança ou decepção para o financiamento da saúde pública? In: Revista de Direito Procuradoria Geral do Estado de Goiás. Goiás: CEJUR, v. 26, p. 66-67, 2011. 
lado, a participação dos demais entes federados aumentou: a participação dos Municípios representava $21,2 \%$ do gasto público total em saúde em 2000, passando para 26,5\% em 2011; e os Estados, a participação que em 2000 era de 20,2\%, em 2011 alcançou 25,7\%. ${ }^{833}$

Em relação aos Estados, Distrito Federal e Municípios, a Lei Complementar n. 141/2012 manteve as disposições contidas no artigo 77, incisos II e III do Ato das Disposições Constitucionais Transitórias e estabeleceu percentuais mínimos vinculados de fontes próprias de recursos a serem aplicados, anualmente, nas ações e serviços públicos de saúde: aos Estados, 12\% (doze por cento) do montante das receitas (impostos ${ }^{834} \mathrm{e}$ transferências constitucionais ${ }^{835}$, com a dedução das verbas transferidas aos Municípios); aos Municípios, $15 \%$ (quinze por cento) do valor das receitas (impostos ${ }^{836}$ e transferências constitucionais $^{837}$ ), ao Distrito Federal, $12 \%$ (doze por cento) e $15 \%$ (quinze por cento),

${ }^{833}$ Financiamento da saúde: Brasil e outros países com cobertura universal. A participação estatal no financiamento de saúde e a situação do Sistema Único de Saúde-SUS. Nota Técnica n. 012, de 2013CONOF/CD. Elaborada pelo Núcleo de Saúde da Consultoria de Orçamento e Fiscalização Financeira da Câmara dos Deputados. Disponível no site oficial da Câmara dos Deputados: www.2.camara.leg.br. Consulta em 27/11/2013.

${ }^{834} \mathrm{O}$ artigo 155 da Constituição Federal assim dispõe: “Art. 155. Compete aos Estados e ao Distrito Federal instituir impostos sobre: I - transmissão causa mortis e doação, de quaisquer bens ou direitos; II - operações relativas à circulação de mercadorias e sobre prestações de serviços de transporte interestadual e intermunicipal e de comunicação, ainda que as operações e as prestações se iniciem no exterior; III propriedade de veículos automotores."

${ }^{835}$ Nos termos do artigo 157 da Constituição Federal: “Art. 157. Pertencem aos Estados e ao Distrito Federal: I - o produto da arrecadação do imposto da União sobre renda e proventos de qualquer natureza, incidente na fonte, sobre rendimentos pagos, a qualquer título, por eles, suas autarquias e pelas fundações que instituírem e mantiverem; II - vinte por cento do produto da arrecadação do imposto que a União instituir no exercício da competência que lhe é atribuída pelo art. 154, I." Por sua vez, o artigo 159 estabelece o seguinte: "Art. 159. A União entregará: I - do produto da arrecadação dos impostos sobre renda e proventos de qualquer natureza e sobre produtos industrializados quarenta e oito por cento na seguinte forma: a) vinte e um inteiros e cinco décimos por cento ao Fundo de Participação dos Estados e do Distrito Federal; (...) II - do produto da arrecadação do imposto sobre produtos industrializados, dez por cento aos Estados e ao Distrito Federal, proporcionalmente ao valor das respectivas exportações de produtos industrializados."

${ }^{836}$ De acordo com o artigo 156 da Constituição Federal: "Art. 156. Compete aos Municípios instituir impostos sobre: I - propriedade predial e territorial urbana; II - transmissão "inter vivos", a qualquer título, por ato oneroso, de bens imóveis, por natureza ou acessão física, e de direitos reais sobre imóveis, exceto os de garantia, bem como cessão de direitos a sua aquisição; III - serviços de qualquer natureza, não compreendidos no art. 155, II, definidos em lei complementar."

837 O artigo 158 da Constituição Federal prescreve o seguinte: "Art. 158. Pertencem aos Municípios: I - o produto da arrecadação do imposto da União sobre renda e proventos de qualquer natureza, incidente na fonte, sobre rendimentos pagos, a qualquer título, por eles, suas autarquias e pelas fundações que instituírem e mantiverem; II - cinquenta por cento do produto da arrecadação do imposto da União sobre a propriedade territorial rural, relativamente aos imóveis neles situados, cabendo a totalidade na hipótese da opção a que se refere o art. $153, \S 4^{\circ}$, III; III - cinquenta por cento do produto da arrecadação do imposto do Estado sobre a propriedade de veículos automotores licenciados em seus territórios; IV - vinte e cinco por cento do produto da arrecadação do imposto do Estado sobre operações relativas à circulação de mercadorias e sobre prestações de serviços de transporte interestadual e intermunicipal e de comunicação." O artigo 159 do texto constitucional, por sua vez, determina: "Art. 159. A União entregará: I - do produto da arrecadação dos impostos sobre renda e proventos de qualquer natureza e sobre produtos industrializados quarenta e oito por cento na seguinte forma: (...) b) vinte e dois inteiros e cinco décimos por cento ao Fundo de Participação dos 
respectivamente, conforme se trate de arrecadação de impostos de competência estadual ou de impostos de competência municipal, e do fundamento da repartição de receitas tributárias. No caso do Distrito Federal, caso o produto da arrecadação direta dos impostos que não possa ser segregado em base estadual e em base municipal, o percentual mínimo deverá ser de $12 \%$ (doze por cento).

Portanto, na realidade, a Lei Complementar n. 141/2012 estabelece um valor mínimo de recursos orçamentários a serem investidos pela União e percentuais mínimos a serem investidos pelos Estados, Distrito Federal e Municípios.

A Lei Complementar n. 141/2012 não estabelece um teto, mas apenas um piso mínimo a ser aplicado em ações e serviços de saúde. Tanto que, para os Estados, Municípios e Distrito Federal, além das regras que asseguram recursos orçamentários mínimos, o artigo $11^{838}$ prescreve que pode ser definido percentual maior em suas respectivas Constituições ou Leis Orgânicas, que neste caso deverá ser observado para que se aplique a percentagem maior de seus respectivos orçamentos na saúde, em detrimento do percentual estabelecido na Lei Complementar n. 141/2012.

A inobservância dos percentuais mínimos da despesa obrigatória em saúde pelos Estados e o Distrito Federal os sujeita à medida excepcional de intervenção da União, conforme dispõe o artigo 34, VII, alínea “e”, da Constituição Federal ${ }^{839}$.

Os Municípios também podem sofrer a medida interventiva dos respectivos Estados caso não tenha sido aplicado o mínimo exigido da receita municipal na manutenção e desenvolvimento das ações e serviços públicos de saúde, com esteio no disposto no artigo 35, inciso III, da Constituição Federal. ${ }^{840}$ Além disso, a não-aplicação em ações e serviços públicos de saúde, anualmente, dos recursos mínimos estabelecidos na Lei Complementar

Municípios; (...) $\S 3^{\circ}$ - Os Estados entregarão aos respectivos Municípios vinte e cinco por cento dos recursos que receberem nos termos do inciso II, observados os critérios estabelecidos no art. 158, parágrafo único, I e II."

${ }^{838}$ Nos termos do artigo 11 da Lei Complementar n. 141, de 13 de janeiro de 2012: "Art. 11. Os Estados, o Distrito Federal e os Municípios deverão observar o disposto nas respectivas Constituições ou Leis Orgânicas sempre que os percentuais nelas estabelecidos forem superiores aos fixados nesta Lei Complementar para aplicação em ações e serviços públicos de saúde."

839 “Art. 34. A União não intervirá nos Estados nem no Distrito Federal, exceto para: (...)VII - assegurar a observância dos seguintes princípios constitucionais: (...) e) aplicação do mínimo exigido da receita resultante de impostos estaduais, compreendida a proveniente de transferências, na manutenção e desenvolvimento do ensino e nas ações e serviços públicos de saúde."

840 “Art. 35. O Estado não intervirá em seus Municípios, nem a União nos Municípios localizados em Território Federal, exceto quando: (...) III - não tiver sido aplicado o mínimo exigido da receita municipal na manutenção e desenvolvimento do ensino e nas ações e serviços públicos de saúde;" 
n. 141/2000, autoriza a União e os Estados a restringirem a entrega de recursos relativos à repartição de receitas tributárias. ${ }^{841}$

A escassez de recursos financeiros e a infinidade de demandas para o atendimento de prestações materiais na área da saúde justificam a previsão, em normas constitucionais, de fontes de financiamento que garantam recursos orçamentários mínimos para a saúde.

O artigo 167, inciso IV, da Constituição Federal, com a redação dada pela Emenda Constitucional n. 29/2000 autoriza, de forma excepcional, a vinculação de recursos às ações e serviços públicos de saúde. ${ }^{842}$ Porém, a regulamentação desta emenda constitucional promovida pela Lei Complementar n. 141, de 13 de janeiro de 2012 frustrou as expectativas que se criaram em torno da ampliação de investimentos no setor, com a maior participação de recursos da União, Estados e Municípios. ${ }^{843} 844845$

Os recursos públicos atualmente destinados pelo Brasil às ações e serviços de saúde mostram-se inferiores comparativamente aos demais países que adotam sistemas semelhantes de atendimento universal. De acordo com os índices de desenvolvimento mundial do Banco Mundial relativos a 2013, as despesas públicas em saúde do Estado brasileiro, como proporção do Produto Interno Bruto (PIB), alcançam apenas 4,07\%, enquanto outros países atingem percentuais maiores, como por exemplo: Canadá $(7,87 \%)$,

\footnotetext{
${ }^{841}$ Nos termos do artigo 160, parágrafo único, inciso II, da Constituição Federal: "Art. 160. É vedada a retenção ou qualquer restrição à entrega e ao emprego dos recursos atribuídos, nesta seção, aos Estados, ao Distrito Federal e aos Municípios, neles compreendidos adicionais e acréscimos relativos a impostos. Parágrafo único. A vedação prevista neste artigo não impede a União e os Estados de condicionarem a entrega de recursos: (...) II - ao cumprimento do disposto no art. 198, § $2^{\circ}$, incisos II e III."

842 "Art. 167. São vedados: (...) IV- a vinculação de receita de impostos a órgão, fundo ou despesa, ressalvadas a repartição do produto da arrecadação dos impostos a que se referem os arts. 158 e 159 , a destinação de recursos para as ações e serviços públicos de saúde e para manutenção e desenvolvimento do ensino, como determinado, respectivamente, pelos arts. $198, \S 2^{\circ}$, e 212 , e a prestação de garantias às operações de crédito por antecipação de receita, previstas no art. $165, \S 8^{\circ}$, bem como o disposto no $\S 4^{\circ}$ deste artigo;"

${ }^{843}$ O Projeto de Lei que tramitou no Senado sob o n. 121/2007, formulado pelo Senador Tião Viana (PT$\mathrm{AC}$ ), previa a vinculação de $10 \%$ da receita corrente bruta da União para a área da saúde.

${ }^{844}$ No mesmo sentido, a reivindicação formulada na $12^{\circ}$ Conferência Nacional de Saúde consistia em que fossem assegurados volumes crescentes de recursos para o financiamento da execução de políticas públicas necessárias à efetivação do direito à saúde. A $12^{\mathrm{a}}$ Conferência Nacional de Saúde foi realizada em Brasília, de 7 a 11 de dezembro de 2003, e teve como tema central: "Saúde direito de todos e dever do Estado, o SUS que temos e o SUS que queremos." Um dos eixos temáticos foi "o financiamento da saúde". O relatório final está disponível no portal da saúde na Internet: <www.portal.saude.gov.br>. Consulta em: 26/11/2013.

${ }^{845} \mathrm{Na} 13^{\mathrm{a}}$ Conferência Nacional de Saúde foi deliberado que deveria ser ampliado o financiamento federal e articuladas outras fontes para investimentos em infra-estruturas urbana e rural, meio ambiente e saneamento básico como condição para a saúde e qualidade de vida e, ainda, garantir recursos financeiros do PAC às políticas de saúde. BRASIL. Ministério da Saúde. Conselho Nacional de Saúde. Relatório Final da $13^{\mathrm{a}}$ Conferência Nacional de Saúde: Saúde e Qualidade de vida: políticas de estado e desenvolvimento. Brasília: Editora do Ministério da Saúde, 2008. p.33 e 35.
} 
França $(8,92 \%)$, Austrália (6,19\%), Espanha (6,95\%) e Argentina (4,92\%). ${ }^{846}$ Segundo o Relatório Mundial da Saúde divulgado pela Organização Mundial de Saúde (OMS), os países que adotam sistemas universais de atendimento devem investir, no mínimo, entre $5 \%$ e $6 \%$ do PIB para o atendimento eficiente das demandas por ações e serviços públicos de saúde. ${ }^{847}$

Se os níveis de financiamento são muito baixos, o País não pode garantir o acesso universal e se os meios não são utilizados de forma eficiente e com equidade, mesmo um financiamento maior pode não representar o aumento da cobertura e qualidade de ações ou serviços ou na melhora dos resultados em saúde. ${ }^{848}$

É evidente que nenhum país é capaz de prover toda a população com todos os novos medicamentos, as modernas tecnologias e intervenções cirúrgicas existentes para melhorar a saúde ou prolongar a vida. Também é estreme de dúvidas que no caso do Brasil há dificuldades para enfrentar as limitações orçamentárias motivadas pelo envelhecimento populacional e pelo aumento da expectativa de vida, dentre outros.

Porém, o modelo jurídico-constitucional do Sistema Único de Saúde, regido pelos princípios da universalidade e da integralidade de cobertura demostra a necessidade de ampliar os gastos públicos na área da saúde. E mais, considerando a atual participação dos Estados e Municípios, resta bem clara a necessidade de expansão de recursos federais em ações e serviços públicos de saúde. ${ }^{849}$

846 Fonte: Indicadores de Desenvolvimento Mundial do Banco Mundial (World Development Indicators). Disponível em: <http://data.worldbank.org/>. Consulta em 26/11/2013.

847 Organização Mundial de Saúde (OMS). Relatório Mundial da Saúde. Financiamento dos sistemas de saúde: o caminho para a cobertura universal. Disponível em: <http://www.who.int/>. Consulta em: 27/11/2013.

${ }^{848}$ De acordo com a publicação da Organização Mundial de Saúde "Estadísticas sanitarias Mundiales: una instantánea de la salud mundial", os sistemas de financiamento da saúde apresentam grande importância no auxílio a países para alcançarem e manterem a cobertura universal. Segundo o documento, o nível global de financiamento atribuído à saúde fixa os limites aos serviços a que a população tem acesso. A cobertura universal exige financiamento suficiente e aplicação eficiente e equânime dos recursos. Os países ricos enfrentam com maior facilidade as questões relativas à limitação orçamentária decorrente do envelhecimento da população e da diminuição de recursos humanos na área da saúde. Mas, todos os países buscam angariar fundos capazes de arcar com os serviços de saúde que as populações necessitam. A riqueza relativa de um país não é o único fator que afeta o financiamento da saúde, pois alguns países de baixo rendimento dedicam à saúde proporções mais elevadas da despesa governamental total que países de rendimentos elevados. Título original do relatório: World Health Statistics 2012. Disponível em inglês, francês e espanhol no site: http://www.who.int/gho/publications/world_health_statistics/2012/en/. Consulta em: 27/11/2013.

849 Neste sentido é a conclusão apresentada na Nota Técnica n. 012, de 2013-CONOF/CD: "a reforma sanitária brasileira que levou ao reconhecimento do direito à saúde na Constituição de 1988 e à criação do Sistema Único de Saúde (SUS), de caráter público e universal, pressupunha profundas mudanças no papel desenvolvido pelo Estado nas três esferas de governo. Era evidente a intenção de ampliar a participação de Estados e Municípios nas despesas do setor, mas não a de congelar ou de reduzir a participação da União. (...) 
Embora a Constituição Federal tenha reconhecido a essencialidade da promoção, proteção e recuperação da saúde para o bem-estar dos indivíduos, as opções políticas tomadas pelo legislador infraconstitucional em relação às estratégias de financiamento da saúde não guardam pertinência com as decisões do constituinte quanto aos valores que devem ser investidos para assegurar a efetividade deste direito fundamental.

$\mathrm{O}$ atendimento do compromisso constitucional de oferecer um sistema de acesso universal e integralidade de cobertura exige o investimento de recursos em montante adequado para o funcionamento eficiente do Sistema Único de Saúde.

Apesar de a Constituição de 1988 (artigo 196) e a Lei n. 8.080, de 19 de setembro de 1990 (artigo $3^{\circ}$ ) atribuírem um alcance significativamente amplo para o conceito de saúde, nele incluindo fatores condicionantes afetos à alimentação, habitação, educação, renda, meio ambiente, trabalho, transporte, emprego, lazer, liberdade, dentre outros, não esclareceram qual é o núcleo essencial ou básico de ações e serviços públicos de saúde a ser mantido e ampliado com os recursos do piso constitucional. ${ }^{850}$

Não obstante isso, neste aspecto a Lei Complementar n. 141, de 13 de janeiro de 2012 apresentou avanços, visto que estabeleceu as diretrizes e regras para identificar quais as despesas que devem e que não devem ser consideradas como "ações e serviços públicos de saúde" para fins de apuração do mínimo constitucional.

Em linhas gerais, a Lei Complementar $n^{\circ}$ 141/2012 manteve o entendimento previsto na Resolução n. 322, de 2003, do Conselho Nacional de Saúde (CNS). Contudo, sua aplicação implica em mudanças significativas nos procedimentos adotados pelos entes federados, pois como lei complementar, é aplicável em todo o território nacional, contribuindo para reduzir a subjetividade que durante anos permeou a definição de "ações

Dentro da configuração constitucional do sistema - com garantia de universalidade e integralidade -, e considerando a atual participação dos entes subnacionais, é patente a necessidade de expansão dos recursos federais, ao menos para resgatar os patamares de despesa à época da $\mathrm{EC} \mathrm{n}^{\circ} 29$, de 2000. Como paliativo para atenuar o problema do subfinanciamento do setor, sem a necessidade imediata de alteração da LC $n^{\circ}$ 141/2012, poder-se-ia cogitar da inserção de dispositivo na lei de diretrizes orçamentárias para fixação de diretriz de execução com a ampliação dos gastos em ações e serviços públicos de saúde." Financiamento da saúde: Brasil e outros países com cobertura universal. A participação estatal no financiamento de saúde e a situação do Sistema Único de Saúde-SUS. Nota Técnica n. 012, de 2013-CONOF/CD. Elaborada pelo Núcleo de Saúde da Consultoria de Orçamento e Fiscalização Financeira da Câmara dos Deputados. Disponível no site oficial da Câmara dos Deputados: <www.2.camara.leg.br>. Consulta em 27/11/2013

${ }^{850}$ Regulamentação da Emenda Constitucional n. 29, de 2000 (piso constitucional de aplicação em saúde): análise das principais inovações trazidas pela Lei Complementar n. 141, de 13 de janeiro de 2012, que regulamentou a Emenda Constitucional n. 29, de 2000. Nota Técnica n. 014/2012, elaborada pelo Núcleo de Saúde da Consultoria de Orçamento e Fiscalização Financeira da Câmara dos Deputados (CONOF/CD). 2012. p.7-8. Disponível na biblioteca digital da Câmara dos Deputados: http://bd.camara.leg.br. Consulta em 26 de novembro de 2013. 
e serviços de saúde" para o cômputo no piso constitucional da saúde e o atendimento do objetivo do constituinte com a edição da EC n. 29/2000. ${ }^{851}$ A partir destas definições é possível quantificar e assegurar o financiamento das despesas essenciais para a manutenção do sistema, conforme desejado pelo constituinte ao aprovar a Emenda Constitucional n. 29/2000.

É possível agrupar os requisitos previstos na Lei Complementar n. 141/2010 em: (i) gerais de atendimento cumulativo (artigo $2^{\circ}$ ); (ii) específicos afetos ao objeto do gasto: computáveis no piso (artigo $3^{\circ}$ ) e não-computáveis no piso (artigo $4^{\circ}$ ); (iii) específicos afetos às fontes de recursos: computáveis no piso (artigos $5^{\circ}, 6^{\circ}, 7^{\circ}$ e $8^{\circ}$ ) e não-computáveis no piso (artigos $4^{\circ}$, inciso $\mathrm{X}$, e $24, \S 4^{\circ}$ ); e (iv) específicos afetos ao estágio da despesa para fins de atendimento do piso (artigo 24, incisos I e II). ${ }^{852}$

Os parâmetros para que determinadas despesas integrem o piso mínimo estão fixados no artigo $2^{\circ}$, incisos I, II e III e parágrafo único da Lei Complementar n. 141/2012, segundo o qual serão considerados gastos de saúde aqueles voltados à promoção, proteção e recuperação da saúde que atendam de forma simultânea aos princípios previstos no artigo $7^{\text {o }}$ da Lei n. 8.080, de 19 de setembro de 1990, e às seguintes diretrizes gerais e cumulativas: (i) sejam destinadas às ações e serviços públicos de saúde de acesso universal, igualitário e gratuito; (ii) estejam em conformidade com objetivos e metas explicitados nos Planos de Saúde de cada ente da Federação; (iii) sejam de responsabilidade específica do setor da saúde, não se aplicando a despesas relacionadas a outras políticas públicas que atuam sobre determinantes sociais e econômicas, ainda que

\footnotetext{
${ }^{851}$ De acordo com a quinta diretriz da Resolução n. 322/2003 do CNS, "Para efeito da aplicação da Emenda Constitucional $n^{\circ} 29$, consideram-se despesas com ações e serviços públicos de saúde aquelas com pessoal ativo e outras despesas de custeio e de capital, financiadas pelas três esferas de governo, conforme o disposto nos artigos 196 e 198, $\S 2^{\circ}$, da Constituição Federal e na Lei $n^{\circ}$ 8080/90, relacionadas a programas finalísticos e de apoio, inclusive administrativos, que atendam, simultaneamente, aos seguintes critérios: I sejam destinadas às ações e serviços de acesso universal, igualitário e gratuito; II - estejam em conformidade com objetivos e metas explicitados nos Planos de Saúde de cada ente federativo; III - sejam de responsabilidade específica do setor de saúde, não se confundindo com despesas relacionadas a outras políticas públicas que atuam sobre determinantes sociais e econômicos, ainda que com reflexos sobre as condições de saúde. § Único - Além de atender aos critérios estabelecidos no caput, as despesas com ações e serviços de saúde, realizadas pelos Estados, Distrito Federal e Municípios deverão ser financiadas com recursos alocados por meio dos respectivos Fundos de Saúde, nos termos do Art. 77, § $3^{\circ}$ do ADCT."

${ }^{852}$ Regulamentação da Emenda Constitucional n. 29, de 2000 (piso constitucional de aplicação em saúde): análise das principais inovações trazidas pela Lei Complementar n. 141, de 13 de janeiro de 2012, que regulamentou a Emenda Constitucional n. 29, de 2000. Nota Técnica n. 014/2012, elaborada pelo Núcleo de Saúde da Consultoria de Orçamento e Fiscalização Financeira da Câmara dos Deputados (CONOF/CD). 2012. p. 9. Disponível na biblioteca digital da Câmara dos Deputados: <http://bd.camara.leg.br>. Consulta em 26 de novembro de 2013.
} 
incidentes sobre as condições de saúde da população; e (iv) se realizadas pela União, Estados, Distrito Federal e Municípios devem ser financiadas com recursos movimentados por meio dos respectivos fundos de saúde.

No concernente ao objeto do gasto, são computáveis no piso como despesas com ações e serviços públicos de saúde, dentre outras as referentes a vigilância em saúde, incluindo a epidemiológica e a sanitária, à atenção integral e universal à saúde em todos os níveis de complexidade, incluindo assistência terapêutica e recuperação de deficiências nutricionais e a capacitação do pessoal de saúde do Sistema Único de Saúde (artigo $3^{\circ}$, incisos I, II e III). De outro lado, não são computáveis no piso, dentre outras, as despesas relativas ao pagamento de aposentadorias e pensões, inclusive dos servidores da saúde, ao saneamento básico, à limpeza urbana e remoção de resíduos, a preservação e correção do meio ambiente e as ações de assistência social (artigo $4^{\circ}$, incisos I, V, VI, VII e VIII).

No tocante às fontes de recursos, devem ser computados no piso constitucional os recursos mínimos previstos nos artigos $5^{\text {o853 }}, 6^{\text {o854 }}, 7^{\text {o855 }}$ e $8^{\text {o856 }}$, da Lei Complementar n. 141/2012. ${ }^{857}$ E não devem ser computadas no piso da Saúde as despesas financiadas com recursos de operações de crédito, nos termos do artigo 24 , parágrafo $4^{\text {o }} .^{858}$

\footnotetext{
853““Art. 5 A União aplicará, anualmente, em ações e serviços públicos de saúde, o montante correspondente ao valor empenhado no exercício financeiro anterior, apurado nos termos desta Lei Complementar, acrescido de, no mínimo, o percentual correspondente à variação nominal do Produto Interno Bruto (PIB) ocorrida no ano anterior ao da lei orçamentária anual.(...) $\S 2^{\circ}$ Em caso de variação negativa do PIB, o valor de que trata o caput não poderá ser reduzido, em termos nominais, de um exercício financeiro para o outro. “

854“'Art. $6^{\circ}$ Os Estados e o Distrito Federal aplicarão, anualmente, em ações e serviços públicos de saúde, no mínimo, $12 \%$ (doze por cento) da arrecadação dos impostos a que se refere o art. 155 e dos recursos de que tratam o art. 157, a alínea "a" do inciso I e o inciso II do caput do art. 159, todos da Constituição Federal, deduzidas as parcelas que forem transferidas aos respectivos Municípios."

855 “Art. $7^{\circ}$ Os Municípios e o Distrito Federal aplicarão anualmente em ações e serviços públicos de saúde, no mínimo, $15 \%$ (quinze por cento) da arrecadação dos impostos a que se refere o art. 156 e dos recursos de que tratam o art. 158 e a alínea "b" do inciso I do caput e o $\S^{\circ} 3^{\circ}$ do art. 159, todos da Constituição Federal." 856 “Art. $8^{\circ} \mathrm{O}$ Distrito Federal aplicará, anualmente, em ações e serviços públicos de saúde, no mínimo, 12\% (doze por cento) do produto da arrecadação direta dos impostos que não possam ser segregados em base estadual e em base municipal."

${ }^{857}$ O artigo 14 da Lei Complementar n. 141/2012 prescreve que: “o Fundo de Saúde, instituído por lei e mantido em funcionamento pela administração direta da União, dos Estados, do Distrito Federal e dos Municípios, constituir-se-á em unidade orçamentária e gestora dos recursos destinados a ações e serviços públicos de saúde, ressalvados os recursos repassados diretamente às unidades vinculadas ao Ministério da Saúde e que não integram a União”. Assim, em regra devem ser considerados no piso os recursos repassados pela União às entidades vinculadas ao Ministério da Saúde, como a Fundação Nacional de Saúde (artigo 14 da Lei $n^{\circ}$ 8.029, de 1990, e Decreto ${ }^{\circ}$ 100, de 1991), a Fundação Instituto Oswaldo Cruz - FIOCRUZ (artigo $3^{\circ}$ do Decreto-Lei $n^{\circ}$ 904, de 1969) e a parte dos recursos das agências (Agência Nacional de Vigilância Sanitária - ANVISA, autarquia especial criada pela Lei no 9.782, de 1999; e Agência Nacional de Saúde Suplementar - ANS, também autarquia sob o regime especial, criada pela Lei $\mathrm{n}^{\circ} 9.961$ de 2000) e dos hospitais vinculados ao Ministério da Saúde e constituídos sob a forma de sociedades de economia mista (Hospital Nossa Senhora da Conceição, Hospital Fêmina e Hospital Cristo Redentor). Regulamentação da Emenda Constitucional n. 29, de 2000 (piso constitucional de aplicação em saúde): análise das principais
} 
Por fim, quanto ao estágio da despesa, somente estão incluídas do cômputo do mínimo constitucional "as despesas liquidadas e pagas no exercício" e "as despesas empenhadas e não liquidadas, inscritas em Restos a Pagar até o limite das disponibilidades de caixa ao final do exercício, consolidadas no Fundo de Saúde” (artigo 24, incisos I e II).

De conseguinte, embora seja estimado um valor menor do orçamento federal a ser aplicado em ações e serviços de saúde em 2012 (R \$ 74.939.059.254,00) em comparação ao valor que seria aplicado sem a regulamentação promovida pela Lei Complementar $n$. 141/2012 (R \$ 78.842.945.247,00), não se pode afirmar que haverá redução das despesas em saúde, na medida em que houve a qualificação das "ações e serviços de saúde" que devem ser consideradas para fins do piso constitucional, vinculando todos os entes da federação à execução de um núcleo indispensável de saúde (piso constitucional). ${ }^{859}$ Ao contrário, é possível que haja um aporte maior de recursos públicos na área da saúde porquanto, como visto, a Lei Complementar incorporou as diretrizes expressas pelo Conselho Nacional de Saúde (CNS) na Resolução n. 322, de 8 de maio de 2003, excluindo do mínimo constitucional as despesas que não atendam aos princípios de universalidade, integralidade e gratuidade, que não guardem conformidade com objetivos e metas explicitados nos Planos de Saúde de cada ente federativo e que não sejam de responsabilidade específica do setor de saúde. ${ }^{860}$

\footnotetext{
inovações trazidas pela Lei Complementar n. 141, de 13 de janeiro de 2012, que regulamentou a Emenda Constitucional n. 29, de 2000. Nota Técnica n. 014/2012, elaborada pelo Núcleo de Saúde da Consultoria de Orçamento e Fiscalização Financeira da Câmara dos Deputados (CONOF/CD). 2012. p.25-26. Disponível na biblioteca digital do site da Câmara dos Deputados: <http://bd.camara.leg.br>. Consulta em 26 de novembro de 2013.

858 “Art. 24. Para efeito de cálculo dos recursos mínimos a que se refere esta Lei Complementar, serão consideradas: (...) $\S 4^{\circ}$ Não serão consideradas para fins de apuração dos mínimos constitucionais definidos nesta Lei Complementar as ações e serviços públicos de saúde referidos no art. $3^{\circ}$ : I - na União, nos Estados, no Distrito Federal e nos Municípios, referentes a despesas custeadas com receitas provenientes de operações de crédito contratadas para essa finalidade ou quaisquer outros recursos não considerados na base de cálculo da receita, nos casos previstos nos arts. $6^{\circ}$ e $7^{\circ}$;"

${ }^{859}$ Regulamentação da Emenda Constitucional n. 29, de 2000 (piso constitucional de aplicação em saúde): análise das principais inovações trazidas pela Lei Complementar n. 141, de 13 de janeiro de 2012, que regulamentou a Emenda Constitucional n. 29, de 2000. Nota Técnica n. 014/2012, elaborada pelo Núcleo de Saúde da Consultoria de Orçamento e Fiscalização Financeira da Câmara dos Deputados (CONOF/CD). 2012. p.36. Disponível no site da biblioteca digital da Câmara dos Deputados: <http://bd.camara.leg.br>. Consulta em 26 de novembro de 2013.

${ }^{860}$ De acordo com o disposto na quinta diretriz da Resolução n. 322, de 8 de maio de 2003, do Conselho Nacional de Saúde (CNS), a qual está disponível no site do próprio Conselho Nacional de Saúde: $<$ http://conselho.saude.gov.br>. Consulta em: 27/11/2013.
} 


\subsection{Políticas públicas de saúde}

A Constituição Federal de 1988 consagrou a saúde como um “direito de todos”, colocando em destaque os aspectos afetos à universalidade e à equidade de acesso às ações e serviços públicos de saúde a quem deles necessite. Além disso, prescreveu que é dever do Estado dar efetividade a este direito, "mediante políticas sociais e econômicas" e definiu, democraticamente, os objetivos específicos que devem ser atendidos: a redução do risco de doença e de outros agravos; e o acesso universal e igualitário às ações e serviços para a promoção, proteção e recuperação da saúde. ${ }^{861}$

No mesmo sentido, a Lei n. 8.080, de 19 de setembro de 1990, determinou a obrigatoriedade da atividade estatal consistente na formulação e execução de políticas econômicas e sociais que tenham por fim a redução de riscos de doenças e outros agravos e o estabelecimento de condições que garantam acesso universal e igualitário às ações e aos serviços para a sua promoção, proteção e recuperação (Lei n. 8.080/90, artigo $2^{\circ}$, parágrafo $1^{\circ}$ ). Previu, ainda, a elaboração (e a consequente implementação) de políticas de saúde como um dos objetivos para os quais o Sistema Único de Saúde foi instituído (Lei n. $8.080 / 90$, artigo $5^{\circ}$, inciso II). ${ }^{862}$

O cumprimento pelo Estado Social do compromisso de satisfazer as metas juridicamente vinculantes insculpidas na Constituição Federal, pressupõe a coordenação e o planejamento das ações, medidas e planos estratégicos e adequados que irão conformar as políticas sociais e econômicas.

O artigo 174, caput, da Constituição Federal prevê que o "planejamento" é "determinante para o setor público"863 A expressão "planejamento" contida no neste dispositivo, é ambígua, podendo exprimir tanto o processo estatal em sentido amplo, quanto o plano concreto resultante da atividade de planejamento. Naquela acepção

\footnotetext{
861 “Art. 196. A saúde é direito de todos e dever do Estado, garantido mediante políticas sociais e econômicas que visem à redução do risco de doença e de outros agravos e ao acesso universal e igualitário às ações e serviços para sua promoção, proteção e recuperação."

${ }^{862}$ Nos termos do artigo 5º da Lei n. 8.80/90: “Art. 5 São objetivos do Sistema Único de Saúde SUS: I - a identificação e divulgação dos fatores condicionantes e determinantes da saúde; II - a formulação de política de saúde destinada a promover, nos campos econômico e social, a observância do disposto no $\S 1^{\circ}$ do art. $2^{\circ}$ desta lei; III - a assistência às pessoas por intermédio de ações de promoção, proteção e recuperação da saúde, com a realização integrada das ações assistenciais e das atividades preventivas."

863 “Art. 174. Como agente normativo e regulador da atividade econômica, o Estado exercerá, na forma da lei, as funções de fiscalização, incentivo e planejamento, sendo este determinante para o setor público e indicativo para o setor privado."
} 
(planejamento como processo), a norma impõe ao Estado o dever de planejar, na medida em que apenas uma gestão pública organizada e eficiente é compatível com o Estado de Direito Democrático e Republicano.

No outro sentido (planejamento como plano), a expressão está relacionada a um dos resultados possíveis da atividade planejadora, ou seja, ao plano ou programa estatal e à vinculação dos órgãos públicos aos elementos e decisões nele contidas. Também é possível que do plano decorram obrigações para particulares, fundadas no poder de polícia, devendo ser respeitados, neste caso, o princípio da legalidade e as normas constitucionais definidoras de competências. ${ }^{864}$

É também imperativa a disciplina, por lei, das diretrizes e bases do desenvolvimento nacional equilibrado, que introduza uma política de compatibilização entre os planos nacionais e regionais de desenvolvimento (artigo 174, parágrafo primeiro $)^{865}$, o que é salutar numa Federação tripartite para minimizar ou superar a fragmentação ou desarticulação da ação governamental e permitir a evolução no sentido do desenvolvimento. ${ }^{866}$

A atuação do Estado num percurso que pode levar ao desenvolvimento, com a modificação das estruturas que reproduzem desigualdade social depende: primeiro, da atividade planejadora estatal; segundo, da execução da política pública ${ }^{867}$; e, terceiro, do controle relativo aos resultados alcançados em relação aos escopos perseguidos. ${ }^{868}$

Neste contexto, o Estado detém um papel relevante e ativo para o desenvolvimento econômico e social do País, pois ao contrário das estruturas estatais que se limitam a produzir atos concretos, repetindo rotinas, o planejamento expressa o Estado em

\footnotetext{
${ }^{864}$ MARRARA, Thiago. A atividade de planejamento na Administração Pública: o papel e o conteúdo das normas previstas no anteprojeto da Nova Lei de Organização Administrativa. In: Revista Brasileira de Direito Público, v. 34, p. 23-24, 2011.

865 “Art. 174. (...) $\S 1^{\circ}$ - A lei estabelecerá as diretrizes e bases do planejamento do desenvolvimento nacional equilibrado, o qual incorporará e compatibilizará os planos nacionais e regionais de desenvolvimento."

866 BUCCI afirma que o caráter sistêmico das políticas públicas possibilita a alcançar a coesão tanto em âmbito intragovernamental, como extragovernamental. BUCCI, Maria Paula Dallari. Fundamentos para uma teoria jurídica das políticas públicas. São Paulo: Saraiva, 2013, p.253.

${ }^{867}$ A execução do programa depende de um feixe de manifestação, decisões e medidas concretas, fundadas em vários centros de decisão administrativa e política. BUCCI, Maria Paula Dallari. Fundamentos para uma teoria jurídica das políticas públicas. São Paulo: Saraiva, 2013, p.263.

${ }^{868}$ BUCCI propõe um "regime de efeitos" às políticas públicas para que o arranjo institucional preveja não apenas os meios suficientes à escala e aos fins do programa, mas também as responsabilidades dos agentes públicos com autoridade sobre a política pública. BUCCI, Maria Paula Dallari. Fundamentos para uma teoria jurídica das políticas públicas. São Paulo: Saraiva, 2013, p. 42.
} 
movimento, com a gestão dos recursos financeiros colocados à disposição pela sociedade, para animar os valores previstos na Constituição Federal. ${ }^{869}$

Porém, atividade de planejamento não se limita ao tratamento de questões econômicas. O planejamento é um processo preparatório e indispensável à atuação do Estado em todos os setores de atuação, seja para restringir os direitos dos cidadãos com base em um interesse público maior ("administração restritiva”) ou para oferecer-lhes comodidades (“administração prestativa"). 870

Ademais, há uma estreita relação entre os princípios estruturantes do Estado e o planejamento, que envolve, ao mesmo tempo, um aspecto negativo e outro positivo. Conforme MARRARA, de um lado, os princípios estruturantes do Estado Republicano, Democrático e Social de Direito funcionam como restrição ao exercício da atividade discricionária de planejamento, que está inteiramente submetida aos seus postulados (relação negativa), vale dizer, o Estado se submete à lei e ao Direito.

De outro lado, a finalidade do planejamento consiste precipuamente na concretização dos princípios e valores constitucionais (relação positiva) ${ }^{871}$, uma vez que o Estado Social não é indiferente aos problemas de desigualdade da sociedade contemporânea.

Em sentido estrito e jurídico-administrativo, MARRARA define o planejamento como um processo abrangente da sequência de atos estatais e privados, voltados à elaboração e execução de estratégias (ou políticas públicas) necessárias à concretização de finalidades públicas definidas na Constituição Federal ou em leis que regulam as atividades maiores do Estado. O processo de planejamento poderá ter como resultado a elaboração de um plano, a alteração de um plano existente ou uma "omissão estatal planejada" ${ }^{872}$

O plano, como um dos resultados possíveis do processo de planejamento, em geral materializado como ato administrativo, contém um conjunto de elementos orientadores da

869 BUCCI, Maria Paula Dallari. Fundamentos para uma teoria jurídica das políticas públicas. São Paulo: Saraiva, 2013, p. 39 e 90.

${ }^{870}$ MARRARA, Thiago. A atividade de planejamento na Administração Pública: o papel e o conteúdo das normas previstas no anteprojeto da Nova Lei de Organização Administrativa. In: Revista Brasileira de Direito Público, v. 34, p.1-2, 2011.

${ }^{871}$ MARRARA, Thiago. A atividade de planejamento na Administração Pública: o papel e o conteúdo das normas previstas no anteprojeto da Nova Lei de Organização Administrativa. In: Revista Brasileira de Direito Público, v. 34, p. 9, 2011.

872 MARRARA, Thiago. A atividade de planejamento na Administração Pública: o papel e o conteúdo das normas previstas no anteprojeto da Nova Lei de Organização Administrativa. In: Revista Brasileira de Direito Público, v. 34, p. 1-7, 2011. 
conduta do Estado e de particulares (normas de conduta ou determinações), além de elementos matemáticos e gráficos (tal como mapas e fluxos etc.) com grau de vinculação variável. O processo administrativo de planejamento também pode conduzir à conclusão de que deve ser alterado um plano já existente. Por fim, o resultado do processo de planejamento pode ser a decisão no sentido de uma "omissão estatal planejada", ou seja, “não agir". 873

O planejamento apresenta as seguintes características: (i) complexidade, resultante da multiplicidade de elementos que o constituem, de seu procedimento, dos variados interesses envolvidos e dos diversos sujeitos que dele participam; (ii) orientação finalística, na medida em que tem por fim a concretização de objetivos específicos; (iii) seletividade, pois é a definição do objeto de forma clara, específica e exequível que permitirá atingir resultados mais concretos e pontuais; (iv) conexidade, que significa compatibilidade e racionalidade das medidas determinadas ao longo do processo para atingir uma mesma finalidade; (v) flexibilidade, a qual se alcança pela possibilidade de alteração e correção contínua dos rumos do planejamento e dos produtos desse processo, de forma a respeitar uma proteção mínima da segurança jurídica dos afetados pelo plano e manter um grau adequado de discricionariedade decisória da autoridade pública; e (vi) criatividade, que representa, para o planejador, a capacidade de inventar soluções conforme a lei e o direito, viáveis e hábeis à superação de problemas concretos que lhe são subjacentes, bem como para a consecução das metas planejadas. ${ }^{874}$

A atividade planejadora do Estado está ligada ao princípio da eficiência ${ }^{875}$, na medida em que oferece as ferramentas para avaliar o modo de atuação racional, oportuno e adequado das funções estatais dirigidas à realização dos valores consagrados na

\footnotetext{
${ }^{873}$ MARRARA, Thiago. A atividade de planejamento na Administração Pública: o papel e o conteúdo das normas previstas no anteprojeto da Nova Lei de Organização Administrativa. In: Revista Brasileira de Direito Público, v. 34, p. 7, 2011.

${ }^{874}$ MARRARA, Thiago. A atividade de planejamento na Administração Pública: o papel e o conteúdo das normas previstas no anteprojeto da Nova Lei de Organização Administrativa. In: Revista Brasileira de Direito Público, v. 34, p. 3-5, 2011.

${ }^{875}$ De acordo com FREITAS, o princípio da eficiência está abrangido pelo direito fundamental à boa Administração Pública, que tem caráter vinculante, e é direta e imediatamente aplicável. Para FREITAS, o direito fundamental à boa administração pode ser compreendido como: "o direito à administração pública eficiente e eficaz, proporcional cumpridora de seus deveres, com transparência, motivação, imparcialidade e respeito à moralidade, à participação social e à plena responsabilidade por suas condutas omissivas $\mathrm{e}$ comissivas." FREITAS, Juarez. Discricionariedade administrativa e o direito fundamental à boa administração pública. São Paulo: Malheiros, 2007. p. 96.
} 
Constituição Federal, sobretudo os direitos fundamentais. ${ }^{876}$ A eficiência é, pois, aqui entendida em sentido abrangente da utilização de métodos e processos adequados, da justa medida de utilização dos recursos disponíveis (economicidade) e dos resultados obtidos em relação aos interesses públicos a serem satisfeitos (eficácia).

Como explicita MARRARA, o planejamento possui vinculação ao Estado Democrático, pela simples razão de que se mostra inaceitável do ponto de vista da teoria da legitimação democrática um Estado desorganizado e ineficiente na consecução das finalidades de interesse público que o ordenamento jurídico lhe imputa: o poder público somente está autorizado a agir se o fizer conforme as finalidades subjacentes à sua criação e manutenção. ${ }^{877} \mathrm{O}$ Estado deve agir em conformidade ao interesse público juridicamente expresso na Constituição Federal e nas leis, conforme os referenciais de legalidade e de legitimidade.

O Estado republicano tem o dever de viabilizar à sociedade o acesso à informação, com ampla divulgação e transparência de suas atividades administrativas e de governo (princípio da publicidade, previsto no artigo 37, caput, da Constituição Federal). Neste aspecto, as tecnologias da informação e comunicação consistem em instrumentos que permitem organizar processos governamentais e criar novas formas de expressão dos administrados, num cenário inclusivo e dialógico.

No Estado democrático devem emergir canais de comunicação entre a Administração Pública e a sociedade, que assegurem condições de legitimação social, fortalecendo a democracia. A democracia participativa foi enaltecida com a consagração da diretriz de participação da comunidade no Sistema Único de Saúde (SUS), prevista no artigo 198, inciso III, da Constituição Federal, e a institucionalização dos conselhos e das conferências de saúde (artigo $1^{\circ}$ da Lei n.8.142/90).

\footnotetext{
${ }^{876}$ Nas palavras de MARRARA: "Na medida em que o planejamento busca resolver, racionalmente, o uso e distribuição de recursos finitos e escassos (recursos financeiros estatais, espaço territorial, recursos humanos etc.), ele é capaz de contribuir para a ampliação da justiça na execução das funções administrativas, sobretudo as prestativas (e.g. serviço público e fomento), e também na regulação dos agentes privados (buscando mitigar os efeitos socialmente nocivos de sua atividade)." MARRARA, Thiago. A atividade de planejamento na Administração Pública: o papel e o conteúdo das normas previstas no anteprojeto da Nova Lei de Organização Administrativa. In: Revista Brasileira de Direito Público, v. 34, p. 12, 2011.

${ }^{877}$ Para MARRARA, o Estado que prescinde do planejamento tenderá a se tornar arbitrário pela negação dos objetivos democraticamente escolhidos e inscritos na Constituição e ineficiente devido à incapacidade de concretizar os interesses públicos sob sua tutela, de modo racional, eficaz e econômico. MARRARA, Thiago. A atividade de planejamento na Administração Pública: o papel e o conteúdo das normas previstas no anteprojeto da Nova Lei de Organização Administrativa. In: Revista Brasileira de Direito Público, v. 34, p. $1-3,2011$.
} 
De conseguinte, a Administração Pública deve instituir mecanismos de democracia participativa no bojo do processo administrativo de planejamento de políticas públicas de saúde, que viabilizem a expressão das demandas e das necessidades reais da coletividade. Assim, além dos órgãos estatais, a sociedade civil organizada também participa como sujeito do processo administrativo de planejamento, execução da política e controle dos resultados.

Cumpre ressaltar a importância de criar meios para evitar o risco de "participação falsificada", em que autoridades públicas tentam manipular os participantes, ou de "privatização" do planejamento, na qual interesses privados de grupos que não representam a coletividade (nem defendem interesses públicos) logram apoderar-se das decisões administrativas ou predominar na participação. ${ }^{878} 879$

O planejamento estatal deve ser um instrumento para a realização das finalidades do Estado Social tanto no presente, quanto no futuro. ${ }^{880}$ Devem ser examinadas as atividades a serem realizadas num horizonte temporal breve, na medida necessária para não se perder a credibilidade do processo, sem perder de vista a projeção de prazo longo o bastante para que o Estado possa concretizar as finalidades que o ordenamento jurídico lhe impõe. $^{881}$

Cumpre realçar que o atendimento dos interesses da sociedade atual não deve implicar no exaurimento ou no uso exagerado dos recursos financeiros e ambientais disponíveis, desprotegendo os interesses das futuras gerações. Em razão disso, na difícil tarefa de elaboração do planejamento, devem ser levadas em consideração a economicidade de recursos e as vigorosas restrições à discricionariedade administrativa decorrentes dos princípios estruturantes Estado Social. ${ }^{882}$

Esta perspectiva temporal do planejamento se mostra absolutamente compatível com a função dirigente (ou impositiva) da Constituição, eis que as normas constitucionais

878 ODETE, Medauar. O Direito Administrativo em evolução. São Paulo: Editora Revista dos Tribunais, 1992, p.218-221.

${ }^{879}$ O tema da participação na Administração Pública será objeto do próximo capítulo do presente trabalho.

${ }^{880}$ MARRARA, Thiago. A atividade de planejamento na Administração Pública: o papel e o conteúdo das normas previstas no anteprojeto da Nova Lei de Organização Administrativa. In: Revista Brasileira de Direito Público, v. 34, p. 9-12, 2011.

${ }^{881}$ BUCCI, Maria Paula Dallari. Fundamentos para uma teoria jurídica das políticas públicas. São Paulo: Saraiva, 2013. p.33.

${ }^{882}$ MARRARA, Thiago. A atividade de planejamento na Administração Pública: o papel e o conteúdo das normas previstas no anteprojeto da Nova Lei de Organização Administrativa. In: Revista Brasileira de Direito Público, v. 34, p. 9-12, 2011. 
já estabeleceram metas, fins e tarefas que vinculam os poderes constituídos. Assim, é por meio do planejamento que será viável decidir a melhor fórmula e momento para implementá-los.

Portanto, os planos (ou políticas públicas) devem observar os objetivos gerais $\left(\operatorname{artigo~} 3^{\circ}\right.$ ) e específicos (artigos 196 e 198) impostos aos órgãos estatais e à sociedade civil pela Constituição Federal. Ademais, como sucessão de atos e medidas encadeadas e dirigidas ao atendimento desses objetivos, os planos afiguram-se imprescindíveis à eficiência e à racionalidade da atividade estatal, bem como à efetividade dos direitos fundamentais (no caso do direito à saúde, previsto no artigo $6^{\circ}$ da Constituição Federal).

Afinal, conforme CANOTILHO, o Estado de direito é um Estado de direitos fundamentais, que foram constitucionalizados por representarem uma dimensão essencial para a vida da comunidade. ${ }^{883}$ A constitucionalização desses direitos reafirma a sua positividade, no sentido de que se desdobram posições juridicamente garantidas. Estas posições jurídicas, sob a perspectiva positiva, se referem ao direito a prestações materiais (fáticas) e normativas (jurídicas). A elaboração de políticas sociais e econômicas para a concretização do direito à saúde está inserida nas prestações normativas.

Na lição de BUCCI, a política pública pode ser definida como um programa de ação governamental, abrangente de um conjunto de medidas articuladas (coordenadas), cuja finalidade é impulsionar a máquina do governo, no sentido de concretizar um direito. A política pública tem um componente de ação estratégica, pois incorpora elementos sobre a ação necessária e possível naquele momento determinado, naquele conjunto institucional e projeta-os para o futuro mais próximo. ${ }^{884}$ A política pública resulta de um processo ou conjunto de processos juridicamente regulados, visando coordenar os meios à disposição do Estado e as atividades privadas, para a realização de objetivos socialmente relevantes e politicamente determinados. $^{885}$

COMPARATO define a política pública como uma atividade formada por um conjunto organizado de normas e atos tendentes à realização de um objetivo determinado. A política unifica os atos, decisões ou normas que a compõem pela sua finalidade, porém não se confundem os regimes jurídicos. Os atos e normas que compõem a política são de

${ }^{883}$ CANOTILHO, José Joaquim Gomes. Estado de Direito. Lisboa: Gradiva Publicações, 1999.p.19. ${ }^{884}$ BUCCI, Maria Paula Dallari. O conceito de política pública em direito. In: Políticas públicas: reflexões sobre o conceito jurídico. BUCCI, Maria Paula Dallari (organizadora). São Paulo: Saraiva, 2006, p.14 e 19. ${ }^{885}$ BUCCI, Maria Paula Dallari. Fundamentos para uma teoria jurídica das políticas públicas. São Paulo: Saraiva, 2013. p.38 
natureza heterogênea e submetem-se a um regime jurídico que lhes é próprio. Consequentemente, o juízo de validade de uma política é diverso do juízo de validade das normas e dos atos que a compõem. ${ }^{886}$

Um problema que surge nas democracias pouco maduras é a descontinuidade administrativa, que coloca em risco a execução de programas de ação quando ocorrem mudanças de comando político, associadas ou não ao processo eleitoral. O enfrentamento desta questão, para além dos aspectos políticos, pode ser feito a partir da estruturação jurídica da ação governamental de responsabilidade (ou "regime de efeitos") dos agentes públicos envolvidos na elaboração e execução da política pública. ${ }^{887}$

A obrigação do Estado relativa ao planejamento na área da saúde se refere ao processo de definição de tarefas a serem desempenhadas a partir das metas fixadas na Constituição Federal e nas Leis n. 8.080/90 e 8.142/90. Em outras palavras, é através da atividade planejadora que são tomadas as decisões acerca da forma de organização, estruturação e os modos de atuação da Administração Pública para a consecução do interesse público de proteção, recuperação e promoção da saúde, e a prestação de serviços públicos contínuos, com qualidade e de forma equânime para todos.

A Lei n. 8.080/90, em seu capítulo III, intitulado "do planejamento e do orçamento" prevê o processo de planejamento do Sistema Único de Saúde e determina, em seu artigo 36, caput, que ele seja ascendente, isto é, do nível local até o federal, visando compatibilizar as necessidades da política de saúde com a disponibilidade de recursos, nos planos de saúde dos Municípios, dos Estados, do Distrito Federal e da União. ${ }^{888}$

A Lei n. 8.142/90 estabelece em seu artigo $3^{\circ}$ que as transferências financeiras intergovernamentais serão feitas de forma automática e regular para a garantia de políticas públicas de saúde, a serem implementadas pelos Municípios, Estados e Distrito Federal. ${ }^{889}$

886 COMPARATO, Fábio Konder. Ensaio sobre o juízo de constitucionalidade de políticas públicas. In: Revista de informação legislativa, v. 35, n. 138, p.45, abr./jun. de 1998.

${ }_{87}$ BUCCI, Maria Paula Dallari. Fundamentos para uma teoria jurídica das políticas públicas. São Paulo: Saraiva, 2013. p.253.

888 “Art. 36. O processo de planejamento e orçamento do Sistema Único de Saúde (SUS) será ascendente, do nível local até o federal, ouvidos seus órgãos deliberativos, compatibilizando-se as necessidades da política de saúde com a disponibilidade de recursos em planos de saúde dos Municípios, dos Estados, do Distrito Federal e da União."

889 “Art. $3^{\circ}$ Os recursos referidos no inciso IV do art. $2^{\circ}$ desta lei serão repassados de forma regular e automática para os Municípios, Estados e Distrito Federal, de acordo com os critérios previstos no art. 35 da Lei $\mathrm{n}^{\circ} 8.080$, de 19 de setembro de 1990". 
Deste modo, o planejamento envolve a coordenação e a harmonização das políticas públicas, de forma integrada e uniformizada. A atividade planejadora na área da saúde se coaduna com as ideias de cooperação e colaboração imanentes ao Sistema Único de Saúde, e se mostra indispensável ao seu funcionamento eficaz. ${ }^{890}$

As atividades e programas ${ }^{891}$ de cada nível de direção do Sistema Único de Saúde (SUS) devem ser fundadas nos planos de saúde, e seu financiamento será previsto na respectiva proposta orçamentária (artigo 36, parágrafo $1^{\circ}$ ). Excepcionadas as situações de emergência ou calamidade pública, a Lei n. 8.080/90 proíbe a transferência de recursos para o financiamento de ações não previstas nos planos de saúde (artigo 36, parágrafo $\left.2^{\circ}\right){ }^{892}$

Os planos de saúde devem ser elaborados a partir de diretrizes assentadas pelo Conselho Nacional de Saúde em consequência das caraterísticas epidemiológicas e da organização dos serviços de cada região (Lei n. 8.080/90, artigo 37). ${ }^{893}$

O estabelecimento de planos que definam ações e os serviços a serem implantados na área da saúde, a modificação de planos existentes e a decisão eloquente de não executar determinado plano, por meio de um processo que possibilite a participação da comunidade e a previsibilidade da ação estatal, ao tempo em que traz segurança jurídica ${ }^{894}$, possibilita

\footnotetext{
${ }^{890}$ Sobre o traço cooperativo do Sistema Único de Saúde (SUS), DALLARI e NUNES apresentam, como exemplo, a hipótese de um Município não realizar as funções essenciais que lhe são atribuídas pelo sistema, o gestor estadual do Sistema Único de Saúde (SUS) tem o dever de assumir a gestão dos serviços municipais até que ocorra a regularização das atividades. DALLARI, Sueli Gandolfi e NUNES JÚNIOR, Vidal Serrano. Direito Sanitário. São Paulo: Editora Verbatim, 2010, p.80.

${ }^{891}$ Um exemplo de programa que estabelece atividades preventivas para a promoção da saúde é o "Programa Academia da Saúde", instituído no âmbito do Sistema Único de Saúde (SUS) pela Portaria n. 719 de 7 de abril de 2011, do Ministério da Saúde, que tem por principal objetivo “(...) contribuir para a promoção da saúde da população a partir da implantação de polos com infraestrutura, equipamentos e quadro de pessoal qualificado para a orientação de práticas corporais e atividade física e de lazer e modos de vida saudáveis" (artigo $2^{\circ}$ ).

892 “Art. 36. O processo de planejamento e orçamento do Sistema Único de Saúde (SUS) será ascendente, do nível local até o federal, ouvidos seus órgãos deliberativos, compatibilizando-se as necessidades da política de saúde com a disponibilidade de recursos em planos de saúde dos Municípios, dos Estados, do Distrito Federal e da União. $\S 1^{\circ}$ Os planos de saúde serão a base das atividades e programações de cada nível de direção do Sistema Único de Saúde (SUS), e seu financiamento será previsto na respectiva proposta orçamentária. $\S 2^{\circ}$ É vedada a transferência de recursos para o financiamento de ações não-previstas nos planos de saúde, exceto em situações emergenciais ou de calamidade pública, na área de saúde.”

893 "Art. 37. O Conselho Nacional de Saúde estabelecerá as diretrizes a serem observadas na elaboração dos planos de saúde, em função das características epidemiológicas e da organização dos serviços em cada jurisdição administrativa."

${ }^{894}$ Para MELLO, o princípio da segurança jurídica evita alterações surpreendentes que instabilizem a situação dos administrados e permite a minoração dos efeitos traumáticos resultantes de novas disposições jurídicas que alcançariam situações em curso. MELLO, Celso Antônio Bandeira de. Curso de Direito Administrativo. 27. ed. São Paulo: Malheiros. 2010, p.87.
} 
um melhor gerenciamento das medidas a serem adotadas e dos resultados efetivamente obtidos, evitando o mau uso dos recursos públicos. ${ }^{895}$

Atualmente está em vigor o Plano Nacional de Saúde (PNS) para orientar a gestão do Sistema Único de Saúde (SUS) relativa ao período de 2012 a $2015 .{ }^{896}$ O Plano Nacional de Saúde (PNS) foi elaborado pelo Ministério da Saúde, tendo sido discutido e aprovado pelo Conselho Nacional de Saúde (CNS). O plano constitui lei em sentido material, mas não em sentido formal, pois não foi elaborado de acordo com o procedimento legislativo típico. O plano está estruturado em 14 diretrizes que compreendem ações estratégicas e compromissos para o setor e foi utilizado como parâmetro para a confecção do plano plurianual no tocante ao setor de saúde.

O Pacto de Gestão ${ }^{897}$ criou condições propícias ao desenvolvimento de um federalismo cooperativo no Sistema Único de Saúde (SUS), visto que estabeleceu de forma inequívoca as responsabilidades de cada ente federativo, e definiu as diretrizes para fortalecer a gestão compartilhada e solidária do Sistema Único de Saúde (SUS), com ênfase na descentralização, na desburocratização dos processos normativos, na estruturação das regiões sanitárias e no fortalecimento das Comissões Intergestores Bipartite. $^{898}$

Entre as diretrizes para a gestão do Sistema Único de Saúde (SUS) trazidos pelo Pacto de Gestão, figuram o planejamento e a programação pactuada e integrada. No tocante ao planejamento, este Pacto estabeleceu o dever de desenvolver um processo de forma articulada, integrada e solidária entre as três esferas de gestão, baseado nas

\footnotetext{
${ }^{895}$ SARLET e FIGUEIREDO analisando a questão da escassez de recursos para o atendimento de demandas em termos de políticas sociais afirmam: "com efeito, quanto mais diminuta a disponibilidade de recursos, mais se impõe uma deliberação responsável a respeito de sua destinação, o que nos remete diretamente à necessidade de buscarmos o aprimoramento dos mecanismos de gestão democrática do orçamento público, assim como do próprio processo de administração das políticas públicas em geral, seja no plano de atuação do legislador, seja na esfera administrativa (...)". SARLET, Ingo Wolfgang; FIGUEIREDO, Mariana Filchtiner. Reserva do possível, mínimo existencial e direito à saúde: algumas aproximações. In: SARLET, Ingo Wolfgang; TIMM, Luciano Benetti (Organizadores). Direitos Fundamentais, orçamento e "reserva do possível". Porto Alegre: Livraria do Advogado, p. 31, 2008.

${ }^{896}$ O Plano Nacional de Saúde (PNS) atual, relativo ao período de 2012 a 2015, apresenta a seguinte organização: faz um panorama das condições de saúde, conforme aspectos demográfico, de morbidade e mortalidade; trata dos determinantes e condicionantes de saúde; aborda a questão do acesso a ações e serviços de saúde; discute a gestão em saúde; e traça objetivo, diretrizes e metas. BRASIL. Ministério da Saúde. Secretaria-Executiva. Subsecretaria de Planejamento e Orçamento. Plano Nacional de Saúde - PNS: 2012-2015. Brasília: Ministério da Saúde, 2011.

897 O Pacto de Gestão foi implantado como parte do Pacto pela Saúde, por meio da Portaria GM/MS n. 399, de 22 de fevereiro de 2006.

898 BRASIL. Conselho Nacional de Secretários de Saúde. Legislação Estruturante do SUS. Brasília: CONASS, 2011, p.28-29 e 326-327.
} 
responsabilidades de cada uma delas, com a definição de objetivos e da forma de monitoramento e avaliação dos resultados atingidos, contribuindo para sua transparência. Este processo de planejamento pressupõe que cada esfera de gestão realize sua atividade de planejamento, articulando-se de modo a “(...) fortalecer e consolidar os objetivos e diretrizes do Sistema Único de Saúde (SUS), contemplando as peculiaridades, necessidades e realidades de saúde locorregionais." $" 899$

De outro lado, a programação pactuada e integrada da atenção em saúde (PPI) foi conceituada pelo Pacto de Gestão como um processo que tem por fim definir a programação das ações de saúde em cada território e orientar a alocação dos recursos financeiros para saúde a partir de critérios e parâmetros pactuados entre os gestores. ${ }^{900}$

O Sistema Único de Saúde (SUS) dispõe de outro instrumento que viabiliza o planejamento de suas ações em relação à área da assistência farmacêutica ${ }^{901}$, qual seja, o Protocolo Clínico e Diretriz Terapêutica (PCDT). ${ }^{902}$

O Protocolo Clínico e Diretriz Terapêutica está relacionado à Medicina Baseada em Evidências e pode ser compreendido como o conjunto de recomendações, desenvolvidas por meio de revisão sistemática da literatura científica existente, para apoiar a decisão do profissional e do paciente sobre o cuidado médico mais apropriado, em relação às condutas preventivas, diagnósticas ou terapêuticas relativas a determinada doença, agravo em saúde ou situação clínica. O protocolo organiza o conhecimento disponível e oferece um padrão

899 BRASIL. Conselho Nacional de Secretários de Saúde. Legislação Estruturante do SUS. Brasília: CONASS, 2011, p.344-345.

900 BRASIL. Conselho Nacional de Secretários de Saúde. Legislação Estruturante do SUS. Brasília: CONASS, 2011, p.346.

901 A Lei n. 8.080/90, com a redação atribuída pela Lei n. 12.401/2011, prevê em que consiste a assistência terapêutica integral, que está incluída no campo de atuação no Sistema Único de Saúde: “Art. 19-M. A assistência terapêutica integral a que se refere a alínea $d$ do inciso I do art. $6^{\circ}$ consiste em: I - dispensação de medicamentos e produtos de interesse para a saúde, cuja prescrição esteja em conformidade com as diretrizes terapêuticas definidas em protocolo clínico para a doença ou o agravo à saúde a ser tratado ou, na falta do protocolo, em conformidade com o disposto no art. 19-P; II - oferta de procedimentos terapêuticos, em regime domiciliar, ambulatorial e hospitalar, constantes de tabelas elaboradas pelo gestor federal do Sistema Único de Saúde - SUS, realizados no território nacional por serviço próprio, conveniado ou contratado."

902 O artigo 19-N da Lei n. 8.080/90 assim dispõe: “Art. 19-N. Para os efeitos do disposto no art. 19-M, são adotadas as seguintes definições: (...) II - protocolo clínico e diretriz terapêutica: documento que estabelece critérios para o diagnóstico da doença ou do agravo à saúde; o tratamento preconizado, com os medicamentos e demais produtos apropriados, quando couber; as posologias recomendadas; os mecanismos de controle clínico; e o acompanhamento e a verificação dos resultados terapêuticos, a serem seguidos pelos gestores do SUS." 
de manejo clínico mais seguro e consistente do ponto de vista científico para determinado problema de saúde. ${ }^{903}$

Além da importância na assistência farmacêutica propriamente dita, os Protocolos Clínicos e Diretrizes Terapêuticas (PCDT) apresentam um papel fundamental nos processos de planejamento acerca de quais medicamentos devem integrar o rol dos programas de assistência farmacêutica. Nesta área, uma política pública relevante está consubstanciada na Política Nacional de Medicamentos ${ }^{904}$, que tem por fim assegurar a necessária segurança, eficácia e qualidade destes produtos, a promoção do uso racional e o acesso da população àqueles considerados essenciais. ${ }^{905}$

Por derradeiro, a Política Sanitária brasileira também é conformada pela Política Nacional de Assistência Farmacêutica ${ }^{906}$, que integra a Política Nacional de Saúde, e deve ser compreendida como política pública norteadora para a formulação de políticas setoriais, entre as quais se destacam as políticas de medicamentos, de ciência e tecnologia, de desenvolvimento industrial e de formação de recursos humanos, dentre outras, garantindo a intersetorialidade ${ }^{907}$ inerente ao sistema de saúde do País (SUS). ${ }^{908}$

\footnotetext{
${ }^{903} \mathrm{Na}$ prática clínica há quatro situações básicas que sempre se repetem: diagnóstico, tratamento, prognóstico e prevenção. Cada uma dessas situações abrange cinco componentes: acesso à informação; avaliação crítica da literatura; principais desenhos de pesquisa clínica; métodos estatísticos e planejamento de pesquisas clínicas. Para essas situações específicas é necessário saber acessar a informação, avaliar a literatura, entender as limitações (vantagens e desvantagens) de cada desenho de estudo, os métodos estatísticos envolvidos com a situação clínica e como planejar pesquisas para que seus resultados sejam válidos. No momento em que todas as informações relativas às quatro situações básicas são sintetizadas, incorporando a experiência clínica acumulada, elas podem ser transformadas em recomendações, denominadas Protocolos Clínicos e Diretrizes Terapêuticas. BRASIL. Conselho Nacional de Secretários de Saúde. Assistência Farmacêutica no SUS. Coleção para entender a gestão do SUS, v.7. Brasília: CONASS, 2011, p. 114-116.

${ }^{904}$ Portaria GM/MS n. 3.916, de 30 de outubro de 1998.

905 De acordo com o prefácio da Política Nacional de Medicamentos (Portaria GM/MS n. 3.916, de 30 de outubro de 1998, "Políticas configuram decisões de caráter geral que apontam os rumos e as linhas estratégicas de atuação de uma determinada gestão. Assim, devem ser explicitadas de forma a: tornar públicas e expressas as intenções do Governo; permitir o acesso da população em geral e dos formadores de opinião em particular à discussão das propostas de Governo; orientar o planejamento governamental no detalhamento de programas, projetos e atividades; funcionar como orientadoras da ação do Governo, reduzindo os efeitos da descontinuidade administrativa e potencializando os recursos disponíveis.

No âmbito do Ministério da Saúde, a formulação de políticas desenvolve-se mediante a adoção de metodologia apropriada baseada num processo que favoreça a construção de propostas de forma participativa, e não em um modelo único e acabado (...) Paralelamente, deve-se ressaltar que a operacionalização das políticas formuladas exige o desenvolvimento de processo voltado à elaboração ou reorientação de planos, projetos e atividades, que permitirão consequência prática às políticas."

906 A Política Nacional de Assistência Farmacêutica foi instituída pela Resolução do Conselho Nacional de Saúde n. 338, de 6 de maio de 2004 e homologada pelo Ministro de Estado da Saúde.

$907 \mathrm{O}$ art. $3^{\circ}$ da Lei $\mathrm{n}^{\text {o }}$ 8.080, de 1990, estabeleceu que a saúde tem como "fatores determinantes e condicionantes, entre outros, a alimentação, a moradia, o saneamento básico, o meio ambiente, o trabalho, a renda, a educação, o transporte, o lazer e o acesso aos bens e serviços essenciais". A norma reconhece ainda a influência sobre a saúde de ações que se destinam a garantir às pessoas e à coletividade condições de bem-estar físico, mental e social. Implica dizer que saúde, em termos legais, envolve ações e serviços a cargo
} 


\section{CAPÍTULO 4 - PARTICIPAÇÃO POPULAR NA ADMINISTRAÇÃO PÚBLICA}

O objetivo deste capítulo consiste em analisar o processo institucionalizado de participação popular na Administração Pública e, em especial, a relação entre a "participação administrativa" e o "Sistema Único de Saúde": se e, em caso positivo, em qual medida a Administração atua conforme o vetor democrático do Estado, permitindo que o cidadão participe das atividades de planejamento, gestão e fiscalização das políticas públicas de saúde, superando, assim, as dificuldades culturais históricas.

O capítulo foi subdividido em quatro itens. O primeiro introduz o tema da participação, com uma incursão pela seara do direito político, e trata da participação popular na Administração Pública à luz do caráter Democrático do Estado de Direito e da constitucionalização do Direito Administrativo. O segundo item apresenta mecanismos institucionalizados de participação administrativa, classificando-os em três grandes categorias: pró-consensuais procedimentais, pró-consensuais contratuais e próconsensuais orgânicos. No terceiro item, são abordados os pressupostos da participação administrativa no contexto democrático: educação; acesso à informação (publicidade e motivação); e processo administrativo conforme os princípios do Estado Democrático de Direito. Por fim, o quarto item faz o recorte temático proposto como linha de pesquisa, para examinar a participação administrativa no âmbito do Sistema Único de Saúde (SUS), bem como os problemas e avanços deste sistema.

\subsection{Democracia e participação}

A democracia constitui um dos valores mais importantes de um povo, pois é o regime que permite às sociedades livres se governarem, mediante a intervenção no processo decisório acerca dos fins que o Estado deve perseguir e dos meios que deve

de diversos órgãos públicos, e não apenas aquilo que é prestado no âmbito do Ministério da Saúde e das secretarias de saúde, e só pode ser garantida por meio de uma política governamental intersetorial.

908 A definição utilizada de Política Nacional de Assistência Farmacêutica consta do artigo $1^{\circ}$, incisos I e II, da Resolução n. 338, de 6 de maio de 2004, do Conselho Nacional de Saúde. 
empregar para alcançá-los. O autogoverno do povo é o principal fundamento do Estado Democrático, revelado pela própria etimologia do termo democracia. ${ }^{909}$

Como ponto de partida para a reflexão que se pretende realizar, importa notar que, na linguagem comum, a palavra democracia é utilizada indistintamente para designar um objetivo, bem como uma realidade, que consiste apenas na consecução parcial desse objetivo. ${ }^{910}$ Como afirmou o Presidente dos Estados Unidos da América Abraham Lincoln, empregando o termo no sentido de um ideal a ser alcançado, a democracia é "o governo do povo, pelo povo e para o povo". 911

Muito embora a democracia venha sendo discutida há pelo menos vinte e cinco séculos, o exercício do poder pelo povo não teve ao longo da história uma configuração única. A noção de democracia surgida na Grécia antiga reconhecia o direito dos cidadãos participarem de forma efetiva e plena da vida política dos Estados, mas apenas poderiam se manifestar aqueles que recebiam o título de cidadão: uma minoria de adultos, sobretudo homens com elevado poder político ou financeiro. ${ }^{912}$

\footnotetext{
${ }^{909} \mathrm{Na}$ visão de ROUSSEAU, a rigor, nunca existiu verdadeira democracia nem nunca existirá, eis que contraria a ordem natural o grande número de pessoas a governar e o pequeno que governa. Não é possível ao povo estar incessantemente reunido para cuidar dos negócios públicos; e é fácil compreender que não seria possível estabelecer comissões para isso sem alterar a forma de administração. Para ROUSSEAU, uma democracia supõe, primeiramente, um Estado pequeno em que seja fácil congregar o povo, e onde cada cidadão possa facilmente conhecer todos os outros; em segundo lugar, uma simplicidade de costumes, que antecipe a diversidade de negócios e as discussões espinhosas; e em terceiro lugar, igualdade de classes e de riquezas, para que esta subsista no tempo em relação aos direitos e à autoridade; e enfim, pouco ou nenhum luxo, pois, ou o luxo é feito de riquezas, ou as torna necessárias, corrompendo ao mesmo tempo ricos e pobres, uns pela posse e outros pela cobiça, afastando do Estado todos os cidadãos. ROUSSEAU, Jean Jacques. Contrato Social. Versão original: 1762. Tradução de Rolando Roque da Silva. Edição eletrônica: Ridendo Castigat Moraes, 2002, p.94-95.

${ }^{910}$ DAHL, Robert A. Sobre a democracia. Tradução de Beatriz Sidou. Brasília: Editora Universidade de Brasília, 2001, p. 97-100.

${ }^{911}$ No discurso realizado em 19 de novembro de 1863, no Cemitério Nacional dos Soldados, após a batalha de Gettysburg, Abraham Lincoln exaltou novamente aos Estados Unidos da América a importância dos valores democráticos que inspiraram a revolução: "Four score and seven years ago, the United States had been conceived in Liberty and dedicated to the proposition that all men are created equal. In honouring the sacrifice at Gettysburg, Americans should resolve that the nation shall have a new birth of freedom and that the principle of government of the people, by the people, for the people, shall not perish from the earth". ROPER, Jon. The complete illustrated guide to the presidents of America. Londres: Lorenz books, 2009. p.92-93. Em tradução livre: "oitenta e sete anos atrás, os Estados Unidos tinham sido concebidos em liberdade, dedicados à ideia de que todos os homens são criados iguais. Em honra ao sacrifício em Gettysburg, os americanos devem deliberar que a liberdade nascerá novamente no país e que o princípio do governo do povo, pelo povo, para o povo, não deve desaparecer da Terra."

912 DALLARI explica que por influência das ideias de Aristóteles contidas no livro III de "A Política", o título de legítimo cidadão só deveria ser atribuído com propriedade àqueles que tivessem parte na autoridade deliberativa e na autoridade judiciária. Assim, pregava-se que na cidade-modelo jamais deveria admitir-se o artesão no número de seus cidadãos, porquanto a virtude política, que é a sabedoria para mandar e obedecer, pertence exclusivamente àqueles que não têm necessidade de trabalhar para viver, não sendo possível exercer
} 
A preferência pelo regime democrático se afirmou em todo o hemisfério ocidental a partir do século XVIII, estendendo-se posteriormente ao hemisfério oriental, não apenas por conta da construção grega de democracia, mas por circunstâncias históricas, num momento em que a consagração dos valores democráticos era o caminho para enfraquecer os regimes absolutistas e de ascensão política da classe burguesa. ${ }^{913}$ Foi somente no século XX que passou a se entender que a democracia exige a extensão dos direitos de participação ampla na vida política a toda população adulta com residência permanente em um País. ${ }^{914}$

De acordo com DALLARI, a maior preocupação na organização do Estado, na formação e atuação do governo, sempre foi a participação popular, por se presumir que o povo, expressando livremente sua vontade soberana, teria o saber necessário para a proteção dos valores de liberdade e igualdade. ${ }^{915}$ No entanto, devido à vastidão dos territórios, ao número de habitantes, aos interesses das classes dominantes e à complexidade de problemas que demandavam solução, a democracia entendida como a participação de todos os cidadãos para a formação das decisões do Estado tornou-se empiricamente inviável.

Em consequência disso, a noção de democracia passou a equivaler à possibilidade atribuída ao povo de escolher diretamente aqueles que exerceriam o poder, por delegação (democracia representativa ou democracia indireta). Essa formulação teórica teve grande aceitação à época e ainda tem até os dias atuais, contudo é alvo de fortes críticas, pois não há como assegurar que o representante proceda, em todos os assuntos relativos ao exercício do poder, conforme a vontade dos representados. ${ }^{916}$ De um lado, é possível verificar que este modelo tem lacunas, porque permite o descompasso entre a vontade dos representados

a virtude quando se leva a vida de artesão ou de mercenário. DALLARI, Dalmo de Abreu. Elementos de Teoria Geral do Estado. 2.ed. São Paulo: Saraiva, 1998, p.54.

${ }^{913}$ DALLARI, Dalmo de Abreu. Elementos de Teoria Geral do Estado. 2.ed. São Paulo: Saraiva, 1998, p.54.

914 DAHL, Robert A. Sobre a democracia. Tradução de Beatriz Sidou. Brasília: Editora Universidade de Brasília, 2001, especialmente p.17-35 e 100-104.

${ }^{915}$ Para DALLARI, a consolidação da noção de que o Estado Democrático é aquele em que o próprio povo governa está fundada em três pressupostos: (i) a supremacia da vontade popular; (ii) a preservação da liberdade; e (iii) a igualdade de direitos. As transformações do Estado, ocorridas durante o século XIX e a primeira metade do século $\mathrm{XX}$, foram determinadas para a realização desses valores, os quais se puseram também como limites a qualquer objetivo político. DALLARI, Dalmo de Abreu. Elementos de Teoria Geral do Estado. 2.ed. São Paulo: Saraiva, 1998, p.56.

$916 \mathrm{~A}$ democracia representativa não corresponde à vontade dos representantes ou das classes dominantes. Os representantes devem manter-se fiéis à vontade dos representados. Ora, mesmo sem cuidar dos casos de desvirtuamento da vontade dos representados, é possível que os representados sequer tenham uma opinião formada sobre algum assunto, e os representantes, instados, devam se manifestar, de forma que sua manifestação não irá necessariamente corresponder à vontade dos representados. 
e do representante. De outro, é um modelo que tem a virtude de atribuir aos representantes o direito (e o dever) de escolher quem os represente, preferencialmente pelo sistema eleitoral, mesmo nos países muito populosos ou de grande extensão territorial. ${ }^{917}$

O exercício do governo por representação, que é a essência da democracia representativa, articula povo e poder, de forma que ao povo cabe a escolha daqueles que o representariam, ao passo que aos escolhidos cabe deliberar em nome da coletividade, permitindo que a sociedade civil, que distribuiu o poder, possa controlar o seu exercício. ${ }^{918}$ ${ }^{919}$ Se a atuação do poder público não obedece à vontade popular primária, devidamente consagrada em normas jurídicas que garantam a fidelidade política dessa atuação dos representantes, não há legitimidade democrática.

O modelo de democracia representativa se multiplicou no chamado Estado Liberal, inspirado pela ideia de forjar e manter uma relação de confiança entre representantes e representados que legitimaria esta fórmula indireta de exercício do poder. ${ }^{920}$

Alcançada a fase do Estado Social de Direito, a técnica do exercício do governo por representação foi se revelando insatisfatória. Mais do que limitar o âmbito de atuação dos representantes eleitos, os indivíduos (representados) passaram a manifestar o anseio natural de participar das decisões coletivas sobre assuntos que possam repercutir sobre seus interesses políticos e, mais particularmente, administrativos.

\footnotetext{
917 Para DALLARI, apesar de suas imperfeições, o sistema eleitoral é o meio que mais se aproxima da expressão direta da vontade popular, além de ser mais justo que os próprios governados escolham livremente seus representantes para governá-los. O sufrágio consiste num direito confiado aos cidadãos para escolher quem os represente, cujo exercício é necessário para completar a formação da vontade do Estado. Por isto, o sufrágio também corresponde a uma função social, o que justifica sua imposição como um dever. DALLARI, Dalmo de Abreu. Elementos de Teoria Geral do Estado. 2.ed. São Paulo: Saraiva, 1998, p.67.

918 A importância do controle social já era destacada por ROUSSEAU, segundo o qual o governo democrático tende, continuamente, a mudar de forma, pois está sujeito às agitações populares intestinas e às guerras civis, exigindo mais vigilância e coragem para manter sua forma. Logo, o cidadão deve estar sempre armado de força, e afirmar em cada dia de sua vida: "malo periculosam libertatem quam quietum servitium", que, em tradução livre, significa "eu prefiro a liberdade perigosa à escravidão calma". ROUSSEAU, Jean Jacques. Contrato Social. Versão original: 1762. Tradução de Rolando Roque da Silva. Edição eletrônica: Ridendo Castigat Moraes, 2002, p.95.

${ }^{919}$ De acordo com BOBBIO, nas sociedades modernas, a democracia representativa é o estado no qual a luta contra o abuso do poder é travada simultaneamente contra o poder que parte do alto em nome do poder que vem de baixo (controle indireto), e contra o poder concentrado em nome do poder distribuído (controle recíproco). BOBBIO, Norberto. O futuro da Democracia: uma defesa das regras do jogo; tradução de Mário Aurélio Nogueira. Rio de Janeiro: Paz e Terra. 6 ed. 1986, p. 41-45.

920 VALLE, Vanice Regina Lírio do. Controle social: promovendo a aproximação entre Administração Pública e cidadania. In: Brasil. Tribunal de Contas da União. Prêmio Serzedello Corrêa 2001. Monografias vencedoras: Perspectivas para o Controle Social e a Transparência da Administração Pública. Brasília: TCU, Instituto Serzedello Corrêa, p.80, 2002.
} 
Sem pretender aprofundar a análise das modificações históricas ocorridas no século $\mathrm{XX}$, é preciso realçar o significativo avanço do ponto de vista político e jurídico das relações entre a sociedade e o Estado, com a passagem do Estado Social para o Estado Democrático de Direito.

Neste contexto, DAHL explica que as exigências minimamente necessárias para que um país seja democraticamente governado são as seguintes: funcionários eleitos pelos cidadãos para o exercício das funções legislativa e executiva; eleições livres ${ }^{921}$, justas e frequentes; liberdade de expressão; fontes de informação diversificadas e independentes; autonomia para formar associações ${ }^{922}$; e cidadania inclusiva. ${ }^{923} 924$ A soma dessas seis práticas consolidadas constituem mais do que um novo tipo de sistema político, configuram uma nova espécie de governo popular democrático em grande escala, chamada de poliarquia, isto é, "governo de muitos". 925

A atual concepção de democracia se refere à forma de governo adotada por um Estado, seja republicano ou monárquico, em que se reconhece no povo a origem do poder. MOREIRA NETO afirma que "povo" deve ser entendido como a parcela de membros da sociedade apta a manifestar a vontade política primária, e, em razão disso, é estabelecida a igualdade de todos perante a lei, o que inclui a escolha de representantes. Aos representantes caberá exercer o poder estatal com fidelidade à vontade popular, a ser manifestada em sufrágios e em outras formas de expressão política formal, consoante os processos instituídos pela ordem jurídica, ou de expressão informal, conforme resultado das instituições da sociedade civil. ${ }^{926}$

${ }^{921}$ O termo "livre" foi empregado por DAHL no sentido de que a coerção seja relativamente incomum. DAHL, Robert A. Sobre a democracia. Tradução de Beatriz Sidou. Brasília: Editora Universidade de Brasília, 2001, p. 99.

922 Os cidadãos têm o direito de formar associações ou organizações com relativa independência, como também partidos políticos e grupos de interesses voltados à conquista de seus direitos, inclusive daqueles necessários para o funcionamento eficaz das instituições políticas democráticas. DAHL, Robert A. Sobre a democracia. Tradução de Beatriz Sidou. Brasília: Editora Universidade de Brasília, 2001, p. 100.

923 Todos os adultos com residência permanente no país e sujeitos à sua ordem jurídica podem exercer os direitos relativos às instituições políticas e práticas anteriormente referidas, necessárias para o funcionamento ótimo da democracia em grande escala. DAHL, Robert A. Sobre a democracia. Tradução de Beatriz Sidou. Brasília: Editora Universidade de Brasília, 2001, p. 100.

${ }^{224}$ DAHL, Robert A. Sobre a democracia. Tradução de Beatriz Sidou. Brasília: Editora Universidade de Brasília, 2001, p. 97-100.

${ }^{225}$ DAHL, Robert A. Sobre a democracia. Tradução de Beatriz Sidou. Brasília: Editora Universidade de Brasília, 2001, p. 104-105.

${ }^{926}$ MOREIRA NETO, Diogo de Figueiredo. Curso de Direito Administrativo: parte introdutória, parte geral e parte especial. 15. ed. Rio de Janeiro: Editora Forense, 2011, p.84-85. 
O princípio democrático vem explícito na configuração do Estado brasileiro ${ }^{927}$, no artigo $1^{\circ}$, caput, da Constituição Federal de 1988 ao dispor que a República Federativa do Brasil se constitui em Estado Democrático de Direito e no parágrafo único do mesmo dispositivo que declara a origem do poder político no povo e afirma que seu exercício pode ocorrer tanto pela representação, quanto pela participação. ${ }^{928}$ Em seguida, o texto constitucional inscreve a cidadania ${ }^{929}$ no rol de fundamentos do Estado brasileiro ${ }^{930}$, estabelece formas de participação semidireta aplicáveis no âmbito da Administração Pública (artigo 14, incisos I, II e III) ${ }^{931}$ e, ainda, protege o voto direto, secreto, universal e periódico como cláusula pétrea (artigo 60 , parágrafo $4^{\circ}$, inciso II). ${ }^{932}$

A adoção dos princípios próprios do Estado Democrático de Direito pela Constituição Federal de 1988 conduz a duas relevantes consequências: à sujeição do Estado à lei e ao Direito; e à participação popular na Administração Pública. Já não é suficiente a sujeição do Estado ao princípio da legalidade em sentido amplo, ou seja, da lei em conformidade com princípios e valores albergados de forma implícita ou explícita no texto constitucional. Há outros princípios igualmente relevantes que são próprios do Estado

927 O Preâmbulo da Constituição Federal assim dispõe: "Nós, representantes do povo brasileiro, reunidos em Assembleia Nacional Constituinte para instituir um Estado Democrático, destinado a assegurar o exercício dos direitos sociais e individuais, a liberdade, a segurança, o bem-estar, o desenvolvimento, a igualdade e a justiça como valores supremos de uma sociedade fraterna, pluralista e sem preconceitos, fundada na harmonia social e comprometida, na ordem interna e internacional, com a solução pacífica das controvérsias, promulgamos, sob a proteção de Deus, a seguinte CONSTITUIÇÃ̃ DA REPÚBLICA FEDERATIVA DO BRASIL."

928 "Art. $1^{\circ}$ A República Federativa do Brasil, formada pela união indissolúvel dos Estados e Municípios e do Distrito Federal, constitui-se em Estado Democrático de Direito e tem como fundamentos: (...) Parágrafo único. Todo o poder emana do povo, que o exerce por meio de representantes eleitos ou diretamente, nos termos desta Constituição."

${ }^{929}$ A previsão da cidadania como um dos pilares do Estado brasileiro ampliou seu conteúdo juspolítico, erigindo o princípio da participação, abrangente de todas as formas de intervenção na vida política do Estado brasileiro, a um instrumento indispensável à concretude da legitimidade do exercício do poder. A cidadania pode ser definida como a prerrogativa atribuída à pessoa física para exercer direitos políticos. É também requisito para o gozo de certas prerrogativas e garantias constitucionais. Assim, por exemplo, somente o cidadão tem legitimidade para propor a ação popular (artigo $5^{\circ}$, inciso LXXIII, da Constituição Federal) e participar do processo de iniciativa das leis complementares e ordinárias (artigo 61, caput, da Constituição Federal).

${ }_{930} \mathrm{O}$ artigo $1^{\circ}$, II, da Constituição Federal dispõe: “Art. $1^{\circ}$ A República Federativa do Brasil, formada pela união indissolúvel dos Estados e Municípios e do Distrito Federal, constitui-se em Estado Democrático de Direito e tem como fundamentos: I- a soberania; II- a cidadania; (...)"

931 "Art. 14. A soberania popular será exercida pelo sufrágio universal e pelo voto direto e secreto, com valor igual para todos, e, nos termos da lei, mediante: I - plebiscito; II - referendo; III - iniciativa popular."

932 "Art. 60. A Constituição poderá ser emendada mediante proposta: (...) $\S 4^{\circ}$ - Não será objeto de deliberação a proposta de emenda tendente a abolir: (...) II - o voto direto, secreto, universal e periódico;" 
Democrático de Direito, como a participação do indivíduo na Administração Pública ${ }^{933} 934$, no processo político, econômico, social e cultural. ${ }^{935}$

Há uma gradativa procura do povo por novas formas de intervenção nas decisões do Estado em razão da crise de representatividade e do alto nível de insatisfação e descrença do povo em seus representantes. ${ }^{936}$ Cada vez mais a legitimação dos poderes do Estado Democrático de Direito depende de sua capacidade de expressar os interesses e satisfazer as demandas dos representados, o que, segundo GABARDO, o faz adquirir uma inafastável característica pragmática ou até mesmo utilitarista. ${ }^{937}$

Os órgãos representativos perderam a legitimidade e apenas podem sobreviver como tributários da instância do poder soberano, que se concentra na autoridade popular. A democracia participativa transfere o centro de gravidade do poder das formas representativas oligarquizadas, corrompidas e degradadas, para formas políticas de maior intervenção, presença e participação direta do elemento popular, conferindo, assim, maior

${ }^{933} \mathrm{Na}$ visão de BONAVIDES, o parágrafo único do artigo $1^{\circ}$ da Constituição Federal consiste na síntese e na essência do princípio da democracia participativa, estabelecido como conteúdo de natureza hegemônica. BONAVIDES, Paulo. Teoria Constitucional da Democracia Participativa: por um Direito Constitucional de luta e resistência: por uma nova hermenêutica: por uma repolitização da legitimidade. 3.ed. São Paulo: Malheiros, 2008, p.2-3.

934 Para GROTTI, o ordenamento jurídico estabelece um princípio de participação dos cidadãos na Administração Pública, reclamado pelo Estado Democrático. GROTTI, Dinorá Adelaide Musetti. $A$ participação popular e a consensualidade na Administração Pública. In: Revista de Direito Constitucional e Internacional. Volume 10, n.39, p.132-144, abril/junho 2002.

935 Segundo DI PIETRO, a ideia de submissão do Estado ao princípio da legalidade em sentido amplo, levando em consideração os princípios e valores agasalhados pela Constituição, foi adotada por várias Constituições, como a espanhola e a portuguesa, e teve inspiração na Lei Fundamental da República Federal da Alemanha, de 8 de maio de 1949, cujo artigo 20 parágrafo 3. ${ }^{\circ}$, estabelece que "o poder legislativo está vinculado à ordem constitucional; os poderes executivo e judicial obedecem à lei e ao direito." Apesar de não haver norma expressa na Constituição Federal de 1988 que determine a sujeição do Estado à lei em sentido amplo, não há dúvida de que ela consagra esta ideia, pela referência reiterada a valores e princípios. DI PIETRO, Maria Sylvia Zanella. 500 anos de direito administrativo brasileiro. In: Revista da Procuradoria Geral do Estado da Bahia, Brasília: ENAP. Volume 26, n.2, p. 29-54, 2000.

936 Segundo BONAVIDES, é enorme o descompasso entre o significado da democracia e como o poder é exercido nos países em desenvolvimento. No Brasil a soberania popular de há muito vem sendo desfigurada e ferida pela covardia dos quadros representativos nas duas Casas do Congresso Nacional, os quais, em aliança espúria com o Executivo, consentem que este desobedeça a Constituição e as leis. Desta forma o Estado mantém o povo enclausurado numa gaiola obscura e estreita, despido das armas imprescindíveis para lutar, resistir e se libertar da recolonização promovida pelas classes políticas dominantes. BONAVIDES, Paulo. Teoria Constitucional da Democracia Participativa: por um Direito Constitucional de luta e resistência: por uma nova hermenêutica; por uma repolitização da legitimidade. 3.ed. São Paulo: Malheiros, 2008, p.8-34.

937 Para GABARDO, a democracia torna-se um valor demagógico, uma fonte de legitimação de cunho ideológico, irreal, impossível de ser alcançada no Estado racional. GABARDO, Emerson. A eficiência no desenvolvimento do Estado brasileiro: uma questão política e administrativa. In: Princípios de direito administrativo: legalidade, segurança jurídica, impessoalidade, publicidade, motivação, eficiência, moralidade, razoabilidade, interesse público. MARRARA, Thiago (organizador.). São Paulo: Atlas, p. 329, 2012. 
grau de legitimidade às decisões fundamentais do governo. ${ }^{938} \mathrm{O}$ princípio da soberania popular é a carta de emancipação da cidadania rumo às conquistas democráticas da presente e das futuras gerações.

Somado a este fator, o desenvolvimento de mecanismos de comunicação vem contribui para novas transformações da sociedade, mais instigada ao pluralismo e ao compartilhamento de informações de forma rápida. MOREIRA NETO afiança que o incremento de formas de comunicação permite a expansão da consciência social de que a participação popular administrativa é um fato decisivo para o desenvolvimento de um saudável sentido de cidadania e de responsabilidade pela coisa comum. ${ }^{939}$

A reivindicação por mudanças quanto ao exercício do poder leva à passagem dos modelos de democracias representativas para modelos politicamente mais complexos, que permitem aos cidadãos escolher quem os governará e também como querem ser governados, como ocorre nas democracias participativas. ${ }^{940} \mathrm{~A}$ era da comunicação impulsiona este novo modelo, pois os novos mecanismos eletrônicos simplificam e agilizam o processo de reunião de pessoas, multiplicando os formadores de opinião e fortalecendo as reivindicações populares na tomada de decisões coletivas, não mais pela proximidade física como à época da democracia grega, mas pela rápida transmissão de informações pela Internet.

Ademais disso, a cidadania não se circunscreve à possibilidade de manifestar-se, periodicamente, por meio de eleições para os membros do Legislativo e os chefes do Poder Executivo (democracia representativa). A noção de cidadania está entrelaçada com a participação popular na Administração Pública, visto que, apesar da afirmação do sufrágio universal como direito, na prática há um grande distanciamento entre as demandas da sociedade e a atuação governamental, gerando um déficit de legitimidade estatal.

Além da democracia representativa ${ }^{941}$, a Constituição Federal prevê instrumentos de democracia semidireta ${ }^{942}$, como $\operatorname{corretivos}^{943}$ necessários à representação política

\footnotetext{
938 BONAVIDES, Paulo. Teoria Constitucional da Democracia Participativa: por um Direito Constitucional de luta e resistência: por uma nova hermenêutica; por uma repolitização da legitimidade. 3.ed. São Paulo: Malheiros, 2008, p.2-24.

${ }^{939}$ MOREIRA NETO, Diogo de Figueiredo. Curso de Direito Administrativo: parte introdutória, parte geral e parte especial. 15. ed. Rio de Janeiro: Editora Forense, 2011, p.86.

${ }^{940}$ MOREIRA NETO, Diogo de Figueiredo. Curso de Direito Administrativo: parte introdutória, parte geral e parte especial. 15. ed. Rio de Janeiro: Editora Forense, 2011, p.86.

941 Os mecanismos democráticos indiretos compreendem o direito de eleger os integrantes do Poder Legislativo (artigos 45 e 46 da Constituição Federal) e os Chefes do Poder Executivo (artigos 28, caput, 29, inciso II e 77, caput, todos da Constituição Federal) e o direito de se candidatar a cargos públicos.
} 
tradicional, pelos quais o povo participa na elaboração do Direito, a saber: o plebiscito, o referendo ${ }^{944}$ e a iniciativa popular. ${ }^{945}$

Os traços distintivos entre o plebiscito e o referendo são dois, um relativo à natureza da questão que motiva a consulta popular e outro referente ao momento de convocação. Quanto à natureza da questão em causa, o referendo abarca unicamente normas legais ou constitucionais, já o plebiscito concerne a qualquer tipo de questão de interesse público, não necessariamente de ordem normativa, referindo-se, inclusive, a políticas governamentais. No que tange ao momento da convocação: o referendo é convocado sempre após a edição de atos normativos, seja para confirmar ou rejeitar normas legais ou constitucionais vigentes, enquanto o plebiscito implica sempre numa manifestação popular sobre medidas futuras, referentes ou não à edição de normas jurídicas. ${ }^{946}$

A concepção de democracia participativa surgiu em contraposição ao modelo hegemônico de democracia representativa, a partir de movimentos sociais que defendiam

942 Os mecanismos democráticos semidiretos se dirigem à edição de atos legislativos e abrangem o plebiscito, o referendo e a iniciativa popular, previstos, respectivamente, no artigo 14, incisos I, II e III da Constituição Federal e regulamentados pela Lei n. 9.709, de 18 de novembro de 1998.

943 O sentido da expressão "corretivos" é de consertar, endireitar, corrigir vícios clássicos da atuação parlamentar, dos quais se destacam: omissão ou desatenção sobre questões de interesse público, defesa de interesses corporativos dos próprios representantes ou de grupos privados, não exercício do controle sobre o Executivo e irresponsabilidade política. BENEVIDES, Maria Victoria de Mesquita. A cidadania ativa: referendo, plebiscito e iniciativa popular. São Paulo: Ática, 1991, p.69 e 77.

944 O plebiscito e o referendo são "consultas formuladas ao povo para que delibere sobre matéria de acentuada relevância, de natureza constitucional, legislativa ou administrativa", por meio de voto obrigatório, direto e secreto, com valor igual para todos (artigo $1^{\circ}$, incisos I e II e artigo $2^{\circ}$, parágrafos $1^{\circ}$ e $2^{\circ}$, da Lei $n$. 9.709/98). Segundo DALLARI, o referendum consiste na consulta à opinião pública para a introdução de uma emenda constitucional ou lei ordinária, nos casos que envolvem um interesse público relevante. $\mathrm{O}$ plebiscito consiste numa consulta prévia à opinião popular. Dependendo do resultado do plebiscito é que, se necessário, serão adotadas providências legislativas. DALLARI, Dalmo de Abreu. Elementos de Teoria Geral do Estado. 2.ed. São Paulo: Saraiva, 1998, p.57.

${ }^{945}$ A iniciativa popular de leis ordinárias e complementares "pode ser exercida pela apresentação à Câmara dos Deputados de projeto de lei subscrito por, no mínimo, um por cento do eleitorado nacional, distribuído pelo menos por cinco Estados, com não menos de três décimos por cento dos eleitores de cada um deles" (artigo 61, parágrafo $2^{\circ}$, da Constituição Federal). A iniciativa popular foi disciplinada pela Lei n. 9.709/98, que a prevê no artigo $1^{\circ}$, inciso III, como uma das formas de exercício da soberania popular. O artigo 13, caput, desta lei, repete a norma constitucional: "Art. 13. A iniciativa popular consiste na apresentação de projeto de lei à Câmara dos Deputados, subscrito por, no mínimo, um por cento do eleitorado nacional, distribuído pelo menos por cinco Estados, com não menos de três décimos por cento dos eleitores de cada um deles." Determina no parágrafo primeiro que o projeto de lei de iniciativa popular deverá circunscrever-se a um único assunto e, em seu parágrafo segundo, proíbe a rejeição do projeto de lei de iniciativa popular por vício de forma, atribuindo à Câmara dos Deputados, que é a Casa em que será apresentado o projeto de lei, por seu órgão competente, o dever de providenciar a correção de eventuais impropriedades de técnica legislativa ou de redação. Em seguida, a Câmara dos Deputados deverá dar seguimento à iniciativa popular, consoante as normas do Regimento Interno (artigo 14).

${ }^{946}$ BENEVIDES, Maria Victoria de Mesquita. A cidadania ativa: referendo, plebiscito e iniciativa popular. São Paulo: Ática, 1991, p. 40. 
uma participação maior dos indivíduos nas decisões e no controle social do Estado. Não obstante isso, BENEVIDES assevera que a oposição tradicional entre democracia representativa e democracia direta é um falso dilema, pois não existem, satisfatoriamente, soluções excludentes "puras", reconhecendo a necessária complementariedade entre representação e formas de participação social direta. ${ }^{947}$

Conquanto a representação consista em fator de ordem e estabilidade, uma sociedade bem constituída é mais do que ordem e estabilidade: demanda também justiça e equidade. Nesta linha, BENEVIDES conclui que os mecanismos de participação popular revigoram as instituições representativas herméticas e empedernidas, fazem sentir o sopro das aspirações populares, paralelamente, ou mesmo contra, a vontade dos representantes. ${ }^{948}$

Assim, levar a sério a aspiração democrática do Estado implica em: estabelecer formas de complementaridade entre a democracia representativa e a democracia participativa; reivindicar a ampliação e o fortalecimento da democracia participativa; e pressionar as instituições de democracia representativa, a fim de as torná-las mais inclusivas.

A participação popular é, sobretudo, uma questão política, vinculada ao grau de desenvolvimento e efetivação da democracia num determinado País e à valorização do indivíduo na ordem jurídica.

$\mathrm{Na}$ atividade administrativa outros mecanismos de democracia participativa têm sido buscados para aproximar o cidadão e a Administração, com a finalidade de propiciar maior congruência entre a vontade geral e as decisões tomadas pela Administração na gestão de bens que pertencem a todos, conforme o princípio republicano. ${ }^{949}$

\footnotetext{
${ }^{947}$ BENEVIDES, Maria Victoria de Mesquita. A cidadania ativa: referendo, plebiscito e iniciativa popular. São Paulo: Ática, 1991, p. 48.

${ }^{948}$ BENEVIDES, Maria Victoria de Mesquita. A cidadania ativa: referendo, plebiscito e iniciativa popular. São Paulo: Ática, 1991, p. 66.

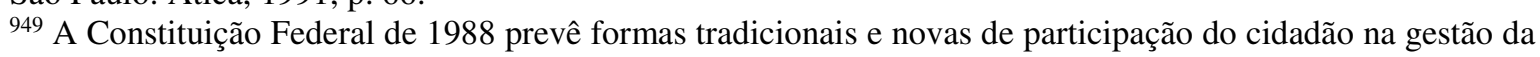
coisa pública. Dentre as clássicas se insere a ação popular, porém apenas estão autorizados a ajuizá-la os detentores de direitos políticos, os cidadãos no sentido técnico-jurídico do termo. Cumpre observar que a ação popular já estava prevista na Constituição do Império do Brasil, de 25 de março de 1824, que em seu artigo 157 dispunha: "por suborno, peita, peculato, e concussão haverá contra elles acção popular, que poderá ser intentada dentro de anno, e dia pelo proprio queixoso, ou por qualquer do Povo, guardada a ordem do Processo estabelecida na Lei." Posteriormente foi disciplinada pela Lei n. 4.717, de 29 de junho de 1965, a qual foi recepcionada pela Constituição Federal de 1988, cujo artigo $5^{\circ}$, inciso LXXIII prescreve que "qualquer cidadão é parte legítima para propor ação popular que vise a anular ato lesivo ao patrimônio público ou de entidade de que o Estado participe, à moralidade administrativa, ao meio ambiente e ao patrimônio histórico e cultural, ficando o autor, salvo comprovada má-fé, isento de custas judiciais e do ônus da sucumbência;"
} 
A presença dos cidadãos e das organizações sociais no interior da Administração Pública constitui uma tendência de longa data ${ }^{950}$ e uma exigência da sociedade moderna, complexa e plural. Esta tendência, consentânea à democratização do País, foi conquistada com a promulgação da Constituição Federal de 1988, após vinte e quatro anos de regime autoritário, instaurado pelo golpe militar de $1964 .{ }^{951}$

Da afirmação do Estado Democrático de Direito decorrem mudanças paradigmáticas nas relações entre a Administração Pública e os administrados. Os administrados não podem mais ser vistos como súditos ou sujeitos passivos, mas como cidadãos, destinatários da atuação dos órgãos e entidades administrativas e potenciais coautores do processo de definição do interesse público a ser perseguido, ombreados com a Administração Pública.

BACELLAR FILHO afirma que foi superado o quadro tradicional de um "Direito Administrativo autoritário", marcado pela pouca atenção dispensada aos direitos e garantias dos cidadãos e pelo exercício das funções administrativas acobertado pelo manto da incontestabilidade do interesse público. A Constituição de 1988 instaurou uma nova era para a Administração Pública do Estado Social, ao estabelecer os princípios constitucionais da atividade administrativa em seu artigo 37, caput. A concepção atual do "Direito Administrativo constitucionalizado" é de uma Administração de prestação, de cooperação, centrada no cidadão. ${ }^{952} 953$

\footnotetext{
${ }^{950}$ Neste sentido: CLÈVE, Clèmerson Merlin. O cidadão, a administração pública e a nova Constituição. In: Revista de Informação Legislativa. Brasília, ano 27, n. 106, p. 82-83, abril/junho 1990 e MEDAUAR, Odete. O direito administrativo em evolução. São Paulo: Editora Revista dos Tribunais, 1992, p.214.

${ }^{951}$ Durante este período, a sociedade brasileira conviveu com um regime autoritário fundado, juridicamente, a partir de duas ordens paralelas: a ordem legal tradicional, integrada pela legislação liberal anterior a 1964; e a ordem legal da segurança nacional, formada por uma legislação que restringia os direitos e garantias individuais. Na época, a teoria jurídica no Brasil era vocacionada, com base em um discurso liberalindividualista, à legitimação dos interesses do Estado autoritário, dirigido à implementação de um capitalismo desenvolvimentista, num sistema ilegítimo, construído com base numa Constituição semântica. SCHIER, Paulo Ricardo. Ensaio sobre a constitucionalização do Direito Administrativo no contexto brasileiro: complexidade do processo. In: Direito Público sem fronteiras. SILVA, Vasco Pereira da; SARLET, Ingo Wolfgang (coord.). Lisboa: Instituto de Ciências Jurídico-Políticas. 2011. p.218.

${ }_{952}$ BACELLAR FILHO, Romeu Felipe. Reflexos da constitucionalização do direito administrativo: pessoa, processo, procedimento e contrato administrativo. Revista Argentina del Régimen de la Administración Pública, v. XXXV, p. 171-186, 2013.

${ }^{953}$ A dignidade da pessoa humana foi erigida a fundamento do Estado Democrático de Direito (artigo $1^{\circ}$, inciso III, da Constituição Federal): o indivíduo pela única condição de pertencer ao gênero humano é titular de direitos fundamentais em todas as suas dimensões. Enfim, o humanismo e o princípio da igualdade substancial triunfaram.
} 
O modo de ser do Estado contemporâneo ${ }^{954}$, mais permeável a valores democráticos, provocou uma alteração do eixo: do monolitismo do centro de poder para o pluralismo caracterizado, basicamente, pela multiplicidade de atores sociais, pelas relações entre indivíduo e sociedade e pela heterogeneidade de interesses em pauta. Portanto, a tendência posta ao exercício do poder estatal está vinculada à atuação por cooperação entre Estado e sociedade, materializada pela participação, com ênfase na consensualidade. MEDAUAR assevera que ocorre uma ruptura da imagem dual radical entre Administração e administrado e o empenho em atuar diretamente na atividade administrativa, formando o indissolúvel binômio pluralismo-participação. ${ }^{955}$

Na lição de BOBBIO, uma sociedade pluralista e democrática é fundada na distribuição e controle do poder, e na possibilidade de dissentir. Bem por isso, a democratização social pode ser alcançada com o aumento dos espaços públicos abertos à sociedade para o dissenso, viabilizando que as principais deliberações políticas sejam feitas nesses locais e não por organizações de cunho hierárquico ou burocrático. ${ }^{956}$

Em acepção ampla, a participação abrange os mecanismos democráticos clássicos relativos ao universo político. Em acepção restrita, a participação está limitada ao universo da atividade administrativa. A "participação administrativa" é subdividida em duas categorias: uma mais abrangente, que inclui empresas privadas que executam serviços públicos delegados (concessionárias), servidores públicos e particulares em colaboração com a Administração Pública no exercício de suas atividades (com base em contrato,

\footnotetext{
${ }^{954}$ Segundo CHEVALLIER, o Estado Moderno, constituído com base num princípio fundamental de unidade orgânica, garantida por mecanismos formais e informais de integração, por vínculos de hierarquia e tutela, mesmo com a ampliação de suas tarefas, decorrentes da atuação do Estado na ordem social, não alterou seu quadro unitário. Contudo, a partir dos anos 1980 teve início um movimento de desintegração e segmentação do Estado, que se evidencia pelos seguintes aspectos: diversificação crescente das estruturas administrativas; desenvolvimento de autonomia; afrouxamento dos laços que asseguram a integração do conjunto e a manutenção da coesão e do todo. Daí a substituição do aparelho de gestão clássico do Estado Moderno, de tipo "arborecente", que comporta unidades, raízes, um centro comum, fundado na hierarquia (piramidal), por outro congruente com a pós-modernidade, em que as entidades são religadas umas às outras por relações horizontais de interdependência, em rede. CHEVALLIER afirma que o Estado Pós-Moderno é policêntrico, pois se desenvolve a partir de relações horizontais de interdependência, simbolizado pela figura pós-moderna da rede, que tende a substituir àquela da pirâmide. A nova concepção das funções estatais e a inviabilidade de solução a partir do quadro da "administração de gestão" clássica levam à concepção da "administração de missão", na qual o Estado assume novos papéis, fundado na cooperação de um conjunto de parceiros para a realização dos objetivos fixados, intervindo de forma pontual e limitada no tempo, conforme a lógica da parceria e da subsidiariedade. CHEVALLIER, Jacques. O Estado Pós-Moderno. Volume 1. Coleção Fórum Brasil-França de Direito Público. Tradução de Marçal Justen Filho. Belo Horizonte: Fórum. 2009.p.98-102. 955 ODETE, Medauar. O direito administrativo em evolução. São Paulo: Editora Revista dos Tribunais, 1992, p.214-215.

${ }_{956}$ BOBBIO, Norberto. O futuro da Democracia: uma defesa das regras do jogo; tradução de Mário Aurélio Nogueira. Rio de janeiro: Paz e Terra. 6 ed. 1986, p. 51-64.
} 
convênio, requisição de serviços ou delegação a titulares de certas profissões); e outra, menos abrangente, que somente inclui particulares que atuam na gestão e no controle da Administração Pública, que é a participação administrativa propriamente dita.

É neste sentido mais estrito de participação dos cidadãos na Administração Pública que interessa ter em foco para os fins deste trabalho. ${ }^{957}$ Nesta seara, devem ser consideradas tanto as formas de participação direta, quanto indireta. ${ }^{958}$ A participação direta é aquela operada pelo próprio cidadão individualmente considerado e o Estado, enquanto que a participação indireta se realiza por meio de mandatários eleitos ou entidades intermediárias, como representantes de grupos e associações. ${ }^{959}$

A participação na Administração Pública é característica essencial do Estado Democrático de Direito, porque aproxima o particular da Administração, diminuindo ou eliminando as barreiras entre o Estado e a sociedade. ${ }^{960}$

A extensão do progresso de democratização é revelada com a instituição de canais por meio dos quais se assegura ao cidadão o direito de participar do processo de tomada das decisões sobre a definição dos interesses públicos a serem protegidos e o modo de atuar da Administração Pública, seja diretamente ou por meio de representantes eleitos ou escolhidos. O Estado plural interioriza em suas estruturas a diversidade constitutiva da sociedade, implicando numa aproximação e recíproca colaboração entre a Administração e a sociedade.

\footnotetext{
${ }^{957}$ No mesmo sentido como a matéria foi tratada por MEDAUAR, estão excluídos da concepção de participação ora analisada: o exercício privado de funções públicas (concessão de serviço público); a atuação do indivíduo na defesa direta de direitos próprios perante a Administração (como em casos de multa ou interdição do exercício de atividades, indeferimento de licenças); e a colaboração técnica ou pericial. ODETE, Medauar. O direito administrativo em evolução. São Paulo: Editora Revista dos Tribunais, 1992, p.217. Assim, o direito de petição, e de certidão em repartições públicas, e o devido processo legal na esfera administrativa, assegurados como direitos fundamentais pela Constituição Federal de 1988 (artigo 5º, XXXIV e LV, da Constituição Federal), não estão abrangidos no conceito estrito de participação popular na Administração Pública.

${ }^{958}$ DI PIETRO também apresenta classificação dicotômica, asseverando que a participação administrativa pode ser direta ou indireta. A participação direta consiste naquela em que não há intermediário entre o administrado e a Administração Pública, enquanto que na participação indireta há um eleito ou intermediário entre o administrado e a Administração Pública. DI PIETRO, Maria Sylvia Zanella. Participação popular na administração pública. In: Revista de Direito Administrativo, p. 33-34, 1993.

${ }^{959}$ CLĖVE denomina a participação indireta de "participação mediatizada". CLÈVE, Clèmerson Merlin. $O$ cidadão, a administração pública e a nova Constituição. In: Revista de Informação Legislativa. Brasília, ano 27, n. 106, p. 97, abril/junho 1990.

${ }^{960}$ DI PIETRO, Maria Sylvia Zanella. Participação popular na administração pública. In: Revista de Direito Administrativo, p. 32, 1993.
} 
A conjugação de esforços do Estado e da sociedade na compreensão dos problemas, na ponderação de interesses em discussão e na formatação das soluções valoriza a consensualidade, que não pode prescindir da participação social. ${ }^{961}$

A ampliação do campo de atividade de consenso-negociação entre poder público e cidadãos, gera consequências nas concepções clássicas do Direito Administrativo: (i) a Administração Pública não mais detém exclusividade no estabelecimento do interesse público que tutela, que passa a ser definido e identificado de forma compartilhada com a sociedade; (ii) a imposição unilateral e autoritária de decisões perde espaço com a valorização da participação dos administrados quanto à formação da conduta administrativa; (iii) há uma redução da imposição unilateral e autoritária de decisões e ascensão das práticas contratuais baseadas no consenso, negociação e conciliação de interesses; (iv) a Administração passa a ter atividade de mediação voltada a dirimir e compor conflitos de interesses entre várias partes ou entre estas e a Administração; e (v) a Administração passa a agir centrada no ato como atividade aberta à colaboração dos indivíduos. ${ }^{962}$

Por fim, importa observar que a participação popular na Administração Pública se aproxima do controle social (de legalidade e de legitimidade) da Administração, mas com ele não se confunde. Ambos os fenômenos convergem para que o Estado atue na prossecução do interesse público, democraticamente formulado e definido pela ordem jurídica. Porém, a participação social tem uma acepção mais ampla do que o controle social, podendo ser afirmada como gênero do qual o controle é espécie. ${ }^{963}$

Os meios de participação na Administração propiciam controles internos e preventivos exercidos por indivíduos ou grupos na formação das decisões administrativas $^{964}$, impedindo que seja praticado ato ilegal ou contrário ao interesse público. O controle social, por sua vez, é promovido por entidade não integrante da

961 VALLE, Vanice Regina Lírio do. Controle social: promovendo a aproximação entre Administração Pública e cidadania. In: Brasil. Tribunal de Contas da União. Prêmio Serzedello Corrêa 2001. Monografias vencedoras: Perspectivas para o Controle Social e a Transparência da Administração Pública. Brasília: TCU, Instituto Serzedello Corrêa, 2002, p.81-82.

962 MEDAUAR, Odete. O direito administrativo em evolução. São Paulo: Editora Revista dos Tribunais, 1992, p.202 e 216.

963 Neste sentido: VALLE, Vanice Regina Lírio do. Controle social: promovendo a aproximação entre Administração Pública e cidadania. In: BRASIL. Tribunal de Contas da União. Prêmio Serzedello Corrêa 2001. Monografias vencedoras: Perspectivas para o Controle Social e a Transparência da Administração Pública. Brasília: TCU, Instituto Serzedello Corrêa, 2002, p.86.

964 MEDAUAR, Odete. O direito administrativo em evolução. São Paulo: Editora Revista dos Tribunais, 1992, p.216. 
estrutura em que está inserido o órgão controlado, e é realizado após a prática dos atos, para corrigi-los ou desfazê-los.

A relação estreita entre a participação popular e o controle social baseia-se no exercício da cidadania (status ativo dos direitos fundamentais) e a prática de um gera, como consequência, o aumento qualitativo do outro, de forma diretamente proporcional: de um lado, os administrados, que colaboram no processo administrativo para a elaboração de uma decisão, estarão melhor qualificados para impugnar a opção feita pela Administração Pública; de outro lado, a atuação do cidadão no controle da Administração pode gerar um maior interesse em participar do processo em que foi construída a decisão administrativa objeto de discussão.

A Administração Pública no contexto do Estado de Direito contemporâneo deve criar novos canais de comunicação com a população e otimizar os instrumentos existentes, de modo a integrá-la, permanentemente, aos processos de tomada de decisões.

Como se passará a analisar no próximo tópico, a participação popular na Administração compreende instrumentos que apresentam como características marcantes e não estanques: a criação de espaços de debate e negociação entre o poder público e os particulares; a busca de consensos; e a intervenção dos particulares no processo de tomada de decisões e no controle da Administração Pública.

\subsection{Instrumentos de participação popular na Administração Pública}

A atividade da Administração Pública voltada à consensualização compreende mecanismos que permitem maior coincidência entre as necessidades sociais e o conteúdo das decisões administrativas, inclusive para alcançar maior adesão dos cidadãos.

A participação dos administrados na Administração Pública se faz por mecanismos que têm em mira a obtenção do consenso e podem ser classificados em três grandes categorias: (i) Instrumentos pró-consensuais procedimentais; (ii) Instrumentos próconsensuais contratuais; e (iii) Instrumentos pró-consensuais orgânicos.

Os instrumentos pró-consensuais procedimentais permitem a atuação do indivíduo junto à Administração Pública durante o processo que culminará com a tomada da decisão administrativa, sem se incorporar ao órgão administrativo. 
$\mathrm{Na}$ categoria de instrumentos pró-consensuais procedimentais enquadram-se o direito de ser ouvido, a enquete, a audiência pública e a consulta pública, dentre outros.

O direito de ser ouvido é um mecanismo de participação direta na Administração Pública, que está relacionado ao direito de defesa, aos princípios do contraditório e do devido processo legal. Deve ser assegurado não apenas em sede de processo administrativo disciplinar, mas em todas as hipóteses em que haja limitação ao exercício de direitos individuais.

Conforme DI PIETRO, o direito de ser ouvido está previsto na Constituição de 1988 em diversos dispositivos, dentre os quais os que asseguram: o direito de petição, que abrange os direitos de requerer e de recorrer à Administração Pública até o ápice da hierarquia administrativa, independente do pagamento de taxas (artigo $5^{\circ}$, inciso XXXIV, “a") $)^{965}$; os direitos ao contraditório e à ampla defesa (artigo $5^{\circ}$, inciso LV) ${ }^{966}$; e o direito ao devido processo legal (artigo $5^{\circ}$, inciso LIV) ${ }^{967} .{ }^{968}$

A enquete, por sua vez, consiste na consulta à opinião pública previamente à elaboração de normas de caráter geral e abstrato, por meio da qual é facultada a apresentação de sugestões pelos interessados, que podem ser úteis à decisão sobre assuntos de interesse público. ${ }^{969}$

Também são exemplos de instrumentos pró-consensuais procedimentais a audiência pública e a consulta pública, que apresentam as seguintes características comuns: fortalecem os laços entre a Administração Pública e a sociedade; oferecem aos indivíduos a possibilidade de se manifestarem; visam esclarecer fatos e fornecer subsídios oportunos e adequados ao poder público; permitem legitimar a atuação da Administração Pública. Esses dois instrumentos participativos foram expressamente previstos na Lei n. 9.784, de 29 de janeiro de 1999, que regula o processo administrativo no âmbito da Administração Pública Federal e serão doravante analisados.

\footnotetext{
965 “Art. $5^{\circ}$ Todos são iguais perante a lei, sem distinção de qualquer natureza, garantindo-se aos brasileiros e aos estrangeiros residentes no País a inviolabilidade do direito à vida, à liberdade, à igualdade, à segurança e à propriedade, nos termos seguintes: (...) XXXIV - são a todos assegurados, independentemente do pagamento de taxas: a) o direito de petição aos Poderes Públicos em defesa de direitos ou contra ilegalidade ou abuso de poder;"

966 "Art. $5^{\circ}(\ldots)$ LV - aos litigantes, em processo judicial ou administrativo, e aos acusados em geral são assegurados o contraditório e ampla defesa, com os meios e recursos a ela inerentes;"

967 "Art. $5^{\circ}$ (...) LIV - ninguém será privado da liberdade ou de seus bens sem o devido processo legal;"

${ }^{968}$ DI PIETRO, Maria Sylvia Zanella. Participação popular na administração pública. In: Revista de Direito Administrativo, p. 33-34, 1993.

${ }^{969}$ DI PIETRO, Maria Sylvia Zanella. Participação popular na administração pública. In: Revista de Direito Administrativo, p. 33-34, 1993.
} 
O artigo 31, caput, da Lei n. 9.784, de 29 de janeiro de $1999^{970}$, prevê a consulta pública nos casos em que o processo envolva assunto de interesse geral. A análise acerca da definição do objeto ser ou não ser de interesse geral deve ser feita pelo órgão competente $^{971}$ em cada caso concreto, considerando suas circunstâncias e os efeitos que o ato administrativo pode vir a gerar. ${ }^{972}$

Caso esteja configurado o objeto de interesse geral e o órgão competente decida abrir a consulta pública ${ }^{973}$, deverá fazê-lo mediante despacho motivado ${ }^{974}$, ou seja, por meio de um ato que contenha a indicação precisa dos pressupostos fáticos e jurídicos que embasam a realização da consulta pública, inclusive com relação aos custos. ${ }^{975} \mathrm{O}$ dever de motivação decorre do disposto no artigo 50, inciso I, da Lei n. 9.784/99976, pois a consulta pública pode tornar o processo demorado, afetando direitos dos próprios interessados ${ }^{977}$

970 “Art. 31. Quando a matéria do processo envolver assunto de interesse geral, o órgão competente poderá, mediante despacho motivado, abrir período de consulta pública para manifestação de terceiros, antes da decisão do pedido, se não houver prejuízo para a parte interessada."

${ }^{971} \mathrm{O}$ órgão competente para a determinação de abertura de uma consulta pública é tanto aquele que conduz a instrução do processo administrativo, como o órgão competente para o seu julgamento e, ainda, o órgão recursal. Nos casos em que o órgão de instrução não se confunde com o órgão de julgamento, NOHARA e MARRARA advertem que compete a ambos solicitar a abertura da consulta pública, "uma vez configurado o assunto de interesse geral e ponderadas as vantagens e desvantagens da abertura da consulta para o bom andamento do processo administrativo". ${ }^{971}$ NOHARA, Irene Patrícia; MARRARA, Thiago. Processo Administrativo: Lei n. 9.784/99 comentada. São Paulo: Atlas, 2009, p.231.

972 Conforme exemplificam NOHARA e MARRARA, os atos normativos e os atos relativos ao planejamento e à concessão de licenças de construção de grandes infraestruturas (aeroportos, rodovias, hidrovias, ferrovias etc.) expressam atos de "interesse geral". NOHARA, Irene Patrícia; MARRARA, Thiago. Processo Administrativo: Lei n. 9.784/99 comentada. São Paulo: Atlas, 2009, p.230-231.

$973 \mathrm{O}$ ato é praticado no exercício de competência discricionária. Os requisitos de que o processo envolva assunto de "interesse geral" e não cause prejuízo aos interessados no processo é necessário, mas insuficiente para determinar sua realização, pois também devem ser ponderadas as vantagens e desvantagens que a realização da consulta pública pode gerar ao processo e, ainda, o momento mais apropriado, conforme um juízo baseado em conveniência e oportunidade. Neste sentido: NOHARA, Irene Patrícia; MARRARA, Thiago. Processo Administrativo: Lei n. 9.784/99 comentada. São Paulo: Atlas, 2009, p.233.

${ }^{974}$ De acordo com FERRAZ e DALLARI, tanto a decisão pela realização de consulta pública, quanto a de não-realização, deverão ser objeto de despacho motivado, se houver interesse geral em discussão: quando se decida pela realização, por força do princípio da celeridade e da menor onerosidade; e quando a deliberação for pela não-realização, em atenção ao principio da participação popular. FERRAZ, Sérgio; DALLARI, Adilson Abreu. Processo Administrativo. 2.ed. São Paulo: Malheiros, 2007, p.181.

975 NOHARA e MARRARA salientam a importância de serem considerados os recursos físicos e humanos necessários para a realização da consulta pública para que não haja o desperdício de dinheiro público e do emprego desnecessário da força de trabalho, comprometimento do desempenho das funções de um determinado órgão administrativo. Por essas razões, a autoridade administrativa deve motivar o ato, de forma clara e congruente, afirmando a presença dos requisitos legais e a imprescindibilidade da consulta para a tomada de uma decisão administrativa legal e legítima. NOHARA, Irene Patrícia; MARRARA, Thiago. Processo Administrativo: Lei n. 9.784/99 comentada. São Paulo: Atlas, 2009, p.232.

976 "Art. 50. Os atos administrativos deverão ser motivados, com indicação dos fatos e dos fundamentos jurídicos, quando: I - neguem, limitem ou afetem direitos ou interesses;"

977 Os interessados são as pessoas físicas ou jurídicas que provocam a abertura do processo administrativo para a proteção de direitos e interesses individuais, coletivos ou difusos. Em sentido estrito, os interessados são partes do processo administrativo, como prevê o artigo $9^{\circ}$, da Lei n. 9.784/99 e não se confundem com os 
como o direito fundamental a uma solução célere, racional e efetiva do processo administrativo (Constituição Federal, artigo 5º LXXVIII) ${ }^{978}$.

A divulgação do despacho de abertura da consulta deve ser feita de forma ampla, efetiva e isonômica, conforme orienta o princípio da publicidade, previsto no artigo 37, caput, da Constituição Federal e o artigo 31, parágrafo $1^{\circ}$, da Lei n. 9.784/99. ${ }^{979}$ Além de sua publicação no Diário Oficial e na página eletrônica do órgão responsável pelo processo e pela consulta pública, pode ser feito convite à entidade representativa de direitos coletivos que possa sofrer os efeitos da decisão a ser tomada no processo, desde que seja atribuído tratamento isonômico a todas que se encontrem nessa situação. ${ }^{980}$

A partir da data de abertura da consulta pública, as pessoas físicas e jurídicas ficam autorizadas a examinar os autos, com exceção dos documentos confidenciais eventualmente contidos no processo administrativo. ${ }^{981} \mathrm{O}$ acesso aos autos do processo administrativo constitui um requisito para o exercício do direito de participação na consulta pública, na medida em que permite ao participante da consulta o conhecimento aprofundado da matéria do processo, para que possa apresentar comentários, críticas e sugestões apropriadas ao objeto específico da consulta pública. Esta manifestação deve ser apresentada no prazo fixado pela autoridade e na forma escrita. ${ }^{982}$

participantes na consulta ou audiência pública. NOHARA, Irene Patrícia; MARRARA, Thiago. Processo Administrativo: Lei n. 9.784/99 comentada. São Paulo: Atlas, 2009, p.233.

978 “Art. 5 Todos são iguais perante a lei, sem distinção de qualquer natureza, garantindo-se aos brasileiros e aos estrangeiros residentes no País a inviolabilidade do direito à vida, à liberdade, à igualdade, à segurança e à propriedade, nos termos seguintes: (...) LXXVIII a todos, no âmbito judicial e administrativo, são assegurados a razoável duração do processo e os meios que garantam a celeridade de sua tramitação."

979 “Art. 31. (...) $§ 1^{\circ} \mathrm{A}$ abertura da consulta pública será objeto de divulgação pelos meios oficiais, a fim de que pessoas físicas ou jurídicas possam examinar os autos, fixando-se prazo para oferecimento de alegações escritas."

${ }^{980}$ NOHARA, Irene Patrícia; MARRARA, Thiago. Processo Administrativo: Lei n. 9.784/99 comentada. São Paulo: Atlas, 2009, p.234-235.

981 O sigilo pode ser determinado por norma constitucional ou legal. A Constituição Federal assegura os direitos fundamentais à inviolabilidade da intimidade, da vida privada, da honra e da imagem das pessoas, bem como de dados, em seu artigo $5^{\circ}$, incisos X e XII, sendo este último regulamentado pela Lei n. 9.296, de 24 de julho de 1996. Nos termos do artigo $5^{\circ}$ da Constituição Federal: “Art. $5^{\circ}$ (...) X - são invioláveis a intimidade, a vida privada, a honra e a imagem das pessoas, assegurado o direito a indenização pelo dano material ou moral decorrente de sua violação; (...) XII - é inviolável o sigilo da correspondência e das comunicações telegráficas, de dados e das comunicações telefônicas, salvo, no último caso, por ordem judicial, nas hipóteses e na forma que a lei estabelecer para fins de investigação criminal ou instrução processual penal;"

982 Conforme NOHARA e MARRARA, o exame dos autos e a contribuição para a consulta são atos independentes, sendo possível a apresentação de contribuição sem a prévia consulta dos autos, como também que os autos sejam consultados e não seja apresentada contribuição do participante na consulta pública. NOHARA, Irene Patrícia; MARRARA, Thiago. Processo Administrativo: Lei n. 9.784/99 comentada. São Paulo: Atlas, 2009, p.235-236. 
Em consequência disso, a Administração deve receber e considerar as manifestações dos participantes da consulta no processo de tomada da decisão administrativa. Contudo, por força do princípio da eficiência na Administração Pública (artigo 37, caput, da Constituição Federal ${ }^{983}$ e artigo $2^{\circ}$, caput, da Lei n. 9.784/99 ${ }^{984}$ ), a Administração está autorizada a apresentar uma resposta fundamentada comum a todos os argumentos que forem substancialmente idênticas (artigo 31, parágrafo $2^{\circ}$ )..$^{985}$

Afora a consulta pública, a Lei n. 9.784/99, em seu artigo $32^{986}$, prevê a audiência pública como instrumento prévio à tomada de decisão administrativa, visando debater matéria relevante a juízo da autoridade.

Não é apenas o Poder Executivo que pode realizar audiência pública para promover um debate, de forma aberta e transparente, sobre matérias de cunho relevante, previamente a tomada de decisões. O Poder Legislativo ${ }^{987}$ e o Poder Judiciário ${ }^{988}$ também podem.

A audiência pública deve ser precedida de publicação sobre sua realização, com informações precisas acerca do assunto a ser discutido, local e horário, participantes

983 “Art. 37. A administração pública direta e indireta de qualquer dos Poderes da União, dos Estados, do Distrito Federal e dos Municípios obedecerá aos princípios de legalidade, impessoalidade, moralidade, publicidade e eficiência e, também, ao seguinte: (...)"

984 "Art. 20 A Administração Pública obedecerá, dentre outros, aos princípios da legalidade, finalidade, motivação, razoabilidade, proporcionalidade, moralidade, ampla defesa, contraditório, segurança jurídica, interesse público e eficiência."

985“'Art. 31 (...) $\S 2^{\circ} \mathrm{O}$ comparecimento à consulta pública não confere, por si, a condição de interessado do processo, mas confere o direito de obter da Administração resposta fundamentada, que poderá ser comum a todas as alegações substancialmente iguais."

986 “Art. 32. Antes da tomada de decisão, a juízo da autoridade, diante da relevância da questão, poderá ser realizada audiência pública para debates sobre a matéria do processo."

987 A Constituição Federal prescreve em seu artigo 58, parágrafo $2^{\circ}$, inciso II, a possibilidade de realização de audiências públicas pelas Comissões permanentes e temporárias do Congresso Nacional e de suas Casas, com setores da sociedade civil, nos seguintes termos: “Art. 58. O Congresso Nacional e suas Casas terão comissões permanentes e temporárias, constituídas na forma e com as atribuições previstas no respectivo regimento ou no ato de que resultar sua criação. (...) $\S 2^{\circ}$ - às comissões, em razão da matéria de sua competência, cabe: (...) II - realizar audiências públicas com entidades da sociedade civil;",

${ }^{988}$ Sem a pretensão de aprofundar a análise do papel do Judiciário na efetivação do direito à saúde, é preciso recordar que o Supremo Tribunal Federal, por meio do Ministro Presidente Gilmar Mendes, já convocou audiência pública para ouvir o depoimento de pessoas com experiência e autoridade em matéria de Sistema Único de Saúde, objetivando esclarecer questões técnicas, científicas, administrativas, políticas, econômicas e jurídicas relativas às ações de prestação em saúde. A audiência foi convocada anteriormente à apreciação e ao julgamento dos diversos pedidos de Suspensão de Segurança, Suspensão de Liminar e Suspensão de Tutela Antecipada, que objetivavam suspender medidas cautelares que determinavam o fornecimento das mais variadas prestações de saúde pelo Sistema Único de Saúde (SUS). Tendo em vista a obtenção de subsídios que contribuíssem com a qualidade das decisões, os Ministros ouviram cinquenta especialistas, entre magistrados, professores, advogados, defensores públicos, promotores e procuradores de justiça, gestores e usuários do Sistema Único de Saúde (SUS), médicos e técnicos de saúde, nos dias 27, 28 e 29 de abril, e 4, 6 e 7 de maio de 2009, sobre diversas questões que envolviam a garantia efetiva do Direito à Saúde no Brasil, intimamente relacionadas com as políticas públicas de saúde e a estrutura do Sistema Único de Saúde (SUS). O material completo desta audiência pública está disponível na página do Supremo Tribunal Federal na Internet: <http://www.stf.jus.br>. Consulta em: 19/12/2013. 
convidados, rito a ser observado, dentre outros aspectos importantes para viabilizar a participação do maior número possível de interessados. ${ }^{989}$

Para que a audiência pública tenha um desenvolvimento viável e produtivo, é preciso estabelecer regras básicas, devendo ser levada a efeito por intermédio de intensa participação oral. Contudo, o resumo dos argumentos apresentados deve ser consignado em ata, para que seja registrado de forma permanente tudo o que foi dito e decidido. ${ }^{990}$

Os principais aspectos envolvidos numa audiência pública são dois: (i) informativo, tanto por parte dos cidadãos, que tomam conhecimento sobre questão relevante de interesse público, como por parte da Administração, que a realiza para ouvir as alegações e reivindicações trazidas pela coletividade; e (ii) de busca pelo consenso, para que a decisão a ser tomada posteriormente pela Administração tenha maior legitimidade ${ }^{991}$ e aceitação (efetividade).

Diversamente da consulta pública, a audiência pública é caracterizada pela oralidade e, em regra, apresenta breve duração, sendo concentrada em algumas horas. Ademais, somente a audiência pública permite a interação dinâmica entre a sociedade e o Estado, bem como entre os próprios membros da sociedade. ${ }^{992}$ Conforme salientam FERRAZ e DALLARI, apenas se poderá falar de audiência pública quando, em sua realização, não apenas se garanta a efetiva participação do indivíduo, mas especialmente quando nela sejam utilizados mecanismos "provocativos", a fim de que permitam aos participantes se expressarem sem timidez ou temor em face da Administração Pública. ${ }^{993}$

A afirmação dos cânones e valores do Estado Democrático de Direito gera posições jurídicas aos participantes do processo administrativo em que é realizada a audiência pública, bem como à autoridade competente. Conforme NOHARA e MARRARA, os direitos dos participantes em audiência pública são quatro: (i) direito ao exame dos autos; (ii) direito à manifestação oral, que pode ser afastada nas circunstâncias em que o

\footnotetext{
${ }^{989}$ A audiência pública não se confunde com eventuais audiências internas realizadas durante a instrução do processo para esclarecer questões formais ou materiais com os próprios interessados, pois consiste em espécie de "audiência externa", aberta à participação de todos, de forma irrestrita. NOHARA, Irene Patrícia; MARRARA, Thiago. Processo Administrativo: Lei n. 9.784/99 comentada. São Paulo: Atlas, 2009, p.238239.

${ }^{990}$ FERRAZ, Sérgio; DALLARI, Adilson Abreu. Processo Administrativo. 2.ed. São Paulo: Malheiros, 2007, p.183.

${ }^{991}$ NOHARA, Irene Patrícia. Direito Administrativo. 3.ed. São Paulo: Atlas, 2013, p.272.

${ }^{992}$ NOHARA, Irene Patrícia; MARRARA, Thiago. Processo Administrativo: Lei n. 9.784/99 comentada. São Paulo: Atlas, 2009, p.238-239.

${ }^{993}$ FERRAZ, Sérgio; DALLARI, Adilson Abreu. Processo Administrativo. 2.ed. São Paulo: Malheiros, 2007, p.182.
} 
particular não possa se expressar oralmente; (iii) direito à consideração da manifestação; e (iv) direito à resposta fundamentada quanto à sua manifestação, que tem caráter meramente opinativo. Por sua vez, a autoridade que realiza a audiência pública tem os seguintes deveres: (i) divulgar amplamente a abertura da audiência e franquear acesso aos autos do processo administrativo; (ii) considerar as manifestações orais apresentadas no debate, de modo isonômico e eficiente; (iii) responder eventuais questionamentos sobre o objeto da audiência pública com base em elementos objetivos contidos nos autos do processo administrativo; e (iv) registrar os debates ocorridos durante a audiência. ${ }^{994}$

Além desses dois instrumentos participativos, a Lei n. 9.784/99 confere uma faculdade para que órgãos e entidades da Administração Pública utilizem, de forma residual, outros meios de participação popular, direta ou indireta, independentemente de previsão legal, nos casos de processos que incluam matéria relevante e conforme um juízo de razoabilidade (artigo 33). ${ }^{995}$ Assim, nas hipóteses em que não houver mecanismos de participação popular instituídos por lei, a autoridade administrativa responsável pela instrução do processo administrativo dispõe de discricionariedade para permitir que os administrados participem de forma direta, ou de forma indireta, por meio de entidades representativas de interesses coletivos em sentido amplo (organizações, associações, partidos políticos etc.), desde que esteja configurada questão relevante e a participação popular se mostre adequada, necessária e proporcional, num juízo de razoabilidade. Conforme NOHARA e MARRARA observam, caso a autoridade decida utilizar um mecanismo de participação não previsto em lei, poderá restringir a participação, desde que estabeleça tratamento isonômico. Assim, por exemplo, pode ser autorizada a participação de associações e autoridades representativas desses direitos em vez da participação direta de seus titulares nos processos que versem sobre interesses ou direitos coletivos ${ }^{996}$, ou pode ser estabelecida uma limitação temporal para que os administrados exponham suas contribuições ou sugestões em encontro ou conferência.

\footnotetext{
994 NOHARA, Irene Patrícia; MARRARA, Thiago. Processo Administrativo: Lei n. 9.784/99 comentada. São Paulo: Atlas, 2009, p.243-244.

995 “Art. 33. Os órgãos e entidades administrativas, em matéria relevante, poderão estabelecer outros meios de participação de administrados, diretamente ou por meio de organizações e associações legalmente reconhecidas."

996 NOHARA e MARRARA citam como exemplos desses instrumentos participativos os encontros, enquetes através da Internet, consultas eletrônicas, conferências. NOHARA, Irene Patrícia; MARRARA, Thiago. Processo Administrativo: Lei n. 9.784/99 comentada. São Paulo: Atlas, 2009, p.245-248.
} 
Os mecanismos de participação popular têm por finalidade democratizar o processo administrativo e permitir a colheita de subsídios para o aprimoramento da decisão administrativa $^{997}$, não devendo se transformar em instrumentos meramente formais para legitimar qualquer decisão da Administração Pública. De conseguinte, embora as alegações e manifestações apresentadas pelos participantes nesses canais participativos não tenham força vinculante, elas não podem ser desprezadas. Assim, embora a Administração possa rejeitá-las, deve motivar a decisão de forma cabal. ${ }^{998}$

Nos termos do artigo 34, da Lei n. 9.784/99, a autoridade administrativa deve apresentar formalmente e por escrito os resultados da consulta pública, da audiência pública ou de outros meios de participação de administrados que tenham por fim permitir a participação dos administrados em geral no processo administrativo, com a descrição do procedimento adotado. É uma decorrência do princípio da publicidade, de observância obrigatória pela Administração Pública ${ }^{999}$, que permite o controle popular da atividade administrativa. 10001001

A Lei estadual n. 10.177, de 30 de dezembro de 1998, que regula o processo administrativo no âmbito da Administração Pública do Estado de São Paulo, também disciplina a consulta pública, a audiência pública, a possibilidade dos órgãos e entidades públicas estabelecerem outros meios de participação dos administrados e a divulgação dos resultados alcançados por cada um desses instrumentos participativos, conforme dispõem seus artigos 28 a 31, inseridos na seção relativa à instrução do processo. ${ }^{1002}$

${ }^{997}$ NOHARA, Irene Patrícia; MARRARA, Thiago. Processo Administrativo: Lei n. 9.784/99 comentada. São Paulo: Atlas, 2009. p.247.

${ }^{998}$ Neste sentido: FERRAZ, Sérgio; DALLARI, Adilson Abreu. Processo Administrativo. 2.ed. São Paulo: Malheiros, 2007.p.182.

${ }_{999}$ Artigo 37, caput, da Constituição Federal e artigo $2^{\circ}$, inciso V, da Lei n. 9.784/99.

1000 "Art. 34. Os resultados da consulta e audiência pública e de outros meios de participação de administrados deverão ser apresentados com a indicação do procedimento adotado."

${ }^{1001}$ NOHARA e MARRARA asseveram que o dever de apresentação de resultados não se confunde com o dever de descrição do procedimento adotado na audiência, na consulta pública ou em outro meio de participação popular na Administração, mas significa a demonstração de como a realização do mecanismo consensual se mostrou útil para o processo administrativo no qual foi realizado. É, portanto, expressão direta de princípios constitucionais: moralidade, publicidade e eficiência, combinado com o princípio democrático. NOHARA, Irene Patrícia; MARRARA, Thiago. Processo Administrativo: Lei n. 9.784/99 comentada. São Paulo: Atlas, 2009. p.248-249.

1002 "Artigo 28 - Quando a matéria do processo envolver assunto de interesse geral, o órgão competente poderá, mediante despacho motivado, autorizar consulta pública para manifestação de terceiros, antes da decisão do pedido, se não houver prejuízo para a parte interessada. § $10^{\circ}$ - A abertura da consulta pública será objeto de divulgação pelos meios oficiais, a fim de que os autos possam ser examinados pelos interessados, fixando-se prazo para oferecimento de alegações escritas. § 2..$^{\circ}$ O comparecimento à consulta pública não confere, por si, a condição de interessado no processo, mas constitui o direito de obter da Administração resposta fundamentada. Artigo 29 - Antes da tomada de decisão, a juízo da autoridade, diante da relevância 
A Agência Nacional de Saúde Suplementar (ANS) ${ }^{1003}$ instituiu em seu quadro normativo mecanismos de participação popular direta e indireta. Seu Regimento Interno ${ }^{1004}$ estabelece que o processo de consulta pública e a audiência pública serão objeto de Resolução Normativa específica ${ }^{1005}$, a qual foi estabelecida pela Resolução Normativa n. 242, de 7 de dezembro de 2010. Esta resolução normativa dispõe sobre a participação da sociedade civil e dos agentes regulados no processo de edição de normas e de tomada de decisão no âmbito da Agência Nacional de Saúde Suplementar (ANS), mediante a realização de consultas públicas, audiências públicas, e câmaras técnicas.

O capítulo II, da Resolução Normativa n. 242/2010 (artigos $4^{\circ}$ a $8^{\circ}$ ), disciplina o processo das consultas públicas, que poderão ser realizadas, por deliberação da Diretoria Colegiada da Agência Nacional de Saúde Suplementar (ANS), para analisar propostas de atos normativos. Neste contexto, a consulta pública é instrumento por meio do qual a sociedade civil pode colaborar com a apresentação de sugestões sobre normas que serão editadas, participando diretamente do processo de tomada de decisão. Por meio deste mecanismo, a Administração Pública se aproxima dos cidadãos, atendendo aos anseios democráticos da sociedade pluralista no exercício da função normativa. ${ }^{1006}$

da questão, poderá ser realizada audiência pública para debates sobre a matéria do processo. Artigo 30 - Os órgãos e entidades administrativas, em matéria relevante, poderão estabelecer outros meios de participação dos administrados, diretamente ou por meio de organizações e associações legalmente reconhecidas. Artigo 31 - Os resultados da consulta e audiência pública e de outros meios de participação dos administrados deverão ser acompanhados da indicação do procedimento adotado."

${ }^{1003}$ A Agência Nacional de Saúde Suplementar (ANS) foi criada pela Lei n. 9.961, de 28 de janeiro de 2000, no processo de reforma da estrutura organizacional do Estado, conduzido pelo Ministro Bresser Pereira, no governo do então Presidente Fernando Henrique Cardoso. As empresas que operavam planos e seguros privados de assistência à saúde permaneceram por muito tempo sem fiscalização até a edição da Lei $\mathrm{n}$. 9.656/98. A ANS foi instituída a partir da necessidade de estabelecer uma regulamentação estatal da atuação da iniciativa privada na área da assistência suplementar à saúde. A ANS tem natureza jurídica autárquica, sob regime especial, vinculada ao Ministério da Saúde e é o órgão competente para a regulação, normatização, fiscalização e controle das atividades da iniciativa privada na área de assistência suplementar à saúde, com a finalidade institucional de promover a defesa do interesse público e contribuir para o desenvolvimento das ações de saúde no país (artigos $1^{\circ}, 3^{\circ}$ e $4^{\circ}$, da Lei n. 9.656/98).

${ }^{1004}$ Resolução Normativa n. 197, de 16 de julho de 2009.

${ }^{1005}$ Nos termos do artigo 97, da Resolução Normativa n. 197/2009: "Art. 97. O processo de consulta pública e a audiência pública serão objeto de Resolução Normativa específica".

${ }^{1006}$ A consulta pública deve ser formalizada por meio de publicação no Diário Oficial da União e divulgação no sítio da ANS na Internet, com informações sobre: (i) o período de recebimento de sugestões e contribuições; (ii) a forma do encaminhamento das sugestões e contribuições; e (iii) a indicação do link no sítio da ANS na Internet, onde se encontra a minuta objeto da consulta pública e os demais documentos importantes para a sua apreciação. O período de consulta pública será iniciado após sete dias da publicação e terá duração de, pelo menos, trinta dias, podendo ser prorrogado. Durante a realização da consulta deverão ser mantidos no sítio da ANS na Internet, a exposição de motivos do ato normativo que se pretende editar, a proposta do ato normativo e o formulário de sugestões e contribuições. A participação da sociedade civil e dos agentes regulados nas consultas públicas será feita preferencialmente por meio eletrônico, mediante o preenchimento do formulário de sugestões e contribuições, podendo também ser feitos por via postal. Após o 
Por sua vez, o capítulo III (artigos $9^{\circ}$ a 16), da Resolução Normativa n. 242/2010, trata das audiências públicas, estabelecendo duas hipóteses de cabimento: em caso de elaboração de anteprojeto de lei a ser proposto pela agência, hipótese em que é obrigatória a realização da audiência; e nos processos decisórios concernentes a matérias relevantes para o setor, hipótese em que é facultativa a realização de audiência pública para ouvir e colher subsídios da sociedade civil e dos agentes regulados por deliberação da Diretoria Colegiada da Agência Nacional de Saúde Suplementar (ANS). ${ }^{1007}$

A despeito da regulamentação das consultas e audiências públicas no âmbito da Agência Nacional de Saúde Suplementar (ANS) abrangerem as tecnologias da comunicação, de forma complementar, favorecendo, assim, a publicidade e o acesso à informação, tanto o Relatório da Consulta Pública, quanto o Relatório da Audiência Pública não atendem adequadamente o princípio da motivação do ato administrativo, na medida em que apenas serão consolidadas e motivadas as sugestões e contribuições dos participantes que forem consideradas "principais" pela Diretoria Colegiada da ANS. Para que esses instrumentos promovam substancialmente a participação popular na Administração Pública é necessário que todas as sugestões e contribuições sejam consideradas e consolidadas, bem como devidamente fundamentadas as decisões em caso de acatamento ou de rejeição das manifestações pela autoridade. A decisão administrativa deverá ser motivada em qualquer caso, sob pena de nulidade, devido ao propósito de esclarecer aos cidadãos as razões de decidir da Administração, legitimando sua atuação.

decurso do prazo para o encaminhamento de sugestões e contribuições, a ANS divulgará em seu sítio na Internet um Relatório da Consulta Pública (RCP), que deve conter, no mínimo: (i) o número de sugestões e contribuições recebidas no total; (ii) dados estatísticos sobre as sugestões e contribuições; (iii) a consolidação das principais sugestões e contribuições; (iv) a manifestação motivada sobre o acatamento ou a rejeição das principais sugestões e contribuições; e (v) a identificação das sugestões e contribuições incorporadas à proposta do ato normativo.

${ }^{1007}$ Da mesma forma que a consulta pública, a convocação da audiência pública será formalizada por meio de publicação no Diário Oficial da União e eletronicamente no sítio da ANS na Internet, que conterá: a data e local da realização da audiência pública; a matéria objeto da audiência pública; o endereço eletrônico para requerimento dos interessados em participar da audiência pública; e a indicação do link no sítio da ANS na Internet em que será divulgada a audiência pública. $\mathrm{O}$ interessado deve apresentar no momento da inscrição os pontos a defender e indicar, quando for o caso, sua representatividade. Todos os documentos relativos à audiência pública poderão ser encaminhados para este endereço eletrônico. Após o término de todas as etapas da audiência pública será divulgada no sítio da ANS na Internet um Relatório da Audiência Pública (RAP), que deverá conter, no mínimo: (i) a ata da audiência pública e seus respectivos anexos; (ii) a consolidação das principais sugestões e contribuições dos participantes; (iii) dados estatísticos relativos à participação na audiência pública; (iv) a manifestação motivada sobre o acatamento ou a rejeição das principais sugestões e contribuições; e (v) a identificação das sugestões e contribuições incorporadas ao processo decisório da ANS. 
Por fim, o capítulo IV (artigos 17 a 19) da Resolução Normativa n. 242/2010 refere-se às câmaras técnicas, que poderão ser realizadas em processo decisório, que verse sobre matéria relevante para o setor, por deliberação da Diretoria Colegiada da Agência Nacional de Saúde Suplementar (ANS), para ouvir e colher subsídios de determinados órgãos, entidades, pessoas naturais ou jurídicas, previamente convidados. A formalização da câmara técnica será feita mediante a expedição de ofício aos convidados, que deve conter, no mínimo: a data e o local da realização da câmara técnica; e a matéria objeto de deliberação. Ao funcionamento das câmaras técnicas serão aplicados subsidiariamente os procedimentos previstos para consulta e audiências públicas.

As câmaras técnicas consistem em mecanismos participativos aplicáveis em processos decisórios que tratem sobre matéria relevante para o setor, assim como as audiências públicas. A finalidade das câmaras técnicas consiste em ouvir e receber informações e documentos de determinados órgãos, entidades, pessoas naturais ou jurídicas, diferenciando-se das audiências públicas, nas quais os subsídios são colhidos junto à sociedade civil e aos agentes regulados.

O problema que se coloca à validade e efetividade deste instrumento ocorre em relação à observância do princípio da impessoalidade, pois a Agência Nacional de Saúde Suplementar (ANS) irá formular convite àqueles que a Diretoria Colegiada pretende que sejam ouvidos ou possam vir a apresentar subsídios. Porém, a ANS tem a obrigação de convidar todos aqueles que se encontrem na mesma situação, de forma isonômica, sem discriminar nenhum por motivos pessoais, subjetivos. Conforme MEDAUAR, o princípio da impessoalidade busca que predomine o sentido de função, a noção de que os poderes atribuídos são instrumentais à satisfação do interesse de toda a coletividade. ${ }^{1008}$ No caso da Agência Nacional de Saúde Suplementar (ANS), o verdadeiro fím da atividade administrativa deve ser a promoção da defesa do interesse público na assistência suplementar à saúde, contribuindo para o desenvolvimento das ações de saúde no País (artigo $3^{\circ}$, da Lei n. 9.961/2000).

A Agência Nacional de Vigilância Sanitária (ANVISA) ${ }^{1009}$ instituiu em seu regulamento a audiência e a consulta pública, como instrumentos de democracia

${ }^{1008}$ MEDAUAR, Odete. Direito administrativo moderno. 17. ed. São Paulo: Ed. Revista dos Tribunais, 2013, p.142.

${ }^{1009}$ A Agência Nacional de Vigilância Sanitária - ANVISA foi criada pela Lei n. 9.782, de 26 de janeiro de 1999, como autarquia sob regime especial, vinculada ao Ministério da Saúde, com a finalidade institucional 
participativa, estreitando a relação entre Administração e cidadãos (artigos 32 a 35, do anexo I, do Decreto n. 3.029, de 16 de abril de 1999).

A audiência pública pode ser designada em duas situações, conforme as características e a relevância do tema: em processo decisório de registros de novos produtos, bens e serviços, bem como seus procedimentos, a critério da Diretoria Colegiada; e nos casos de elaboração de anteprojeto de lei a ser proposto pela Agência, hipótese em que é obrigatória. Dentre os objetivos da audiência pública, merecem destaque os seguintes: (i) recolher subsídios, conhecimentos e informações para o processo decisório da Agência Nacional de Vigilância Sanitária (ANVISA); (ii) propiciar aos agentes econômicos, consumidores e usuários a possibilidade de esclarecer ou reforçar opiniões e sugestões; (iii) identificar, de forma mais ampla possível, todos os aspectos relevantes à matéria objeto da Audiência Pública; e (iv) conferir transparência e legitimidade às regulamentações da ANVISA.

As consultas públicas no âmbito da Agência Nacional de Vigilância Sanitária (ANVISA) são cabíveis previamente à edição de atos normativos e devem ser formalizadas por publicação no Diário Oficial da União, exigindo-se exame acurado das críticas e sugestões apresentadas, as quais deverão permanecer à disposição do público, conforme prevê o regimento interno. ${ }^{1010}$

A participação administrativa foi reforçada pela Emenda Constitucional n. 19, de 4 de junho de 1998, que inseriu o parágrafo $3^{\circ}$ no artigo 37 da Constituição Federal ${ }^{1011}$, para estabelecer que serão disciplinadas por lei as formas de participação do usuário na Administração Pública direta e indireta, regulando, especialmente: (i) as reclamações

de promover a proteção da saúde da população, por meio do controle sanitário da produção e comercialização de produtos e serviços submetidos à vigilância sanitária, inclusive dos ambientes, processos, insumos e tecnologias a eles relacionados, bem como o controle de portos, aeroportos e de fronteiras $\left(\operatorname{artigos} 3^{\circ}\right.$ e $6^{\circ}$, da Lei n. 9.782/99).

1010 Nos termos do artigo 35, do anexo I, do Decreto n. 3.029, de 16 de abril de 1999: "Art. 35. As minutas de atos normativos poderão ser submetidas à consulta pública, formalizada por publicação no Diário Oficial da União, devendo as críticas e sugestões merecer exame e permanecer à disposição do público, nos termos do regimento interno."

$1011 \mathrm{O}$ parágrafo $3^{\circ}$, do artigo 37, da Constituição Federal, incluído pela Emenda Constitucional n. 19, de 1988, prevê o seguinte: “Art. 37. A administração pública direta e indireta de qualquer dos Poderes da União, dos Estados, do Distrito Federal e dos Municípios obedecerá aos princípios de legalidade, impessoalidade, moralidade, publicidade e eficiência e, também, ao seguinte: (...) $\S 3^{\circ}$ A lei disciplinará as formas de participação do usuário na administração pública direta e indireta, regulando especialmente: I - as reclamações relativas à prestação dos serviços públicos em geral, asseguradas a manutenção de serviços de atendimento ao usuário e a avaliação periódica, externa e interna, da qualidade dos serviços; II - o acesso dos usuários a registros administrativos e a informações sobre atos de governo, observado o disposto no art. $5^{\circ}, \mathrm{X}$ e XXXIII; III - a disciplina da representação contra o exercício negligente ou abusivo de cargo, emprego ou função na administração pública." 
relativas à prestação dos serviços públicos, devendo ser instituído um serviço de atendimento ao usuário que seja periodicamente avaliado; (ii) o acesso dos usuários a registros administrativos e a informações sobre atos de governo, observado o disposto no artigo $5^{\circ}$, XXXIII $^{1012}$, na Lei n. 12.527, de 18 de novembro de 2011 e no Decreto n. 7.724, de 16 de maio de 2012; e (iii) a representação contra o exercício negligente ou abusivo de cargo, emprego ou função na Administração Pública, decorrentes da responsabilidade administrativa dos servidores públicos, prevista no artigo 37, parágrafo $6^{\circ}$ da Constituição Federal. ${ }^{1013}$ As reclamações relativas à prestação dos serviços públicos e a representação contra o exercício negligente ou abusivo de cargo, emprego ou função na Administração Pública, conforme a classificação proposta, podem ser consideradas pró-consensuais procedimentais. Por outro lado, o acesso à informação constitui pressuposto para o exercício da participação administrativa, conforme será visto a seguir neste capítulo. ${ }^{1014}$

A regulamentação por lei dos três aspectos particularmente expressos no artigo 37, parágrafo $3^{\circ}$, do texto constitucional, relativos à participação dos usuários na Administração Pública é obrigatória, estando permitida a disciplina por lei ordinária de outros meios de participação administrativa.

A competência legislativa incumbe a cada uma das entidades da Federação, em atenção ao princípio da autonomia político-administrativa consagrado no artigo 18, caput, da Constituição Federal. ${ }^{1015}$ Muito embora o artigo 27 da Emenda Constitucional n. 19, de 4 de junho de 1998, determine ao Congresso Nacional a elaboração da lei de defesa do usuário de serviços públicos no prazo de cento e vinte dias, contados da promulgação desta Emenda, a referida lei ainda não foi aprovada. ${ }^{1016} 1017$

1012 “Art. 5 $5^{\circ}$ Todos são iguais perante a lei, sem distinção de qualquer natureza, garantindo-se aos brasileiros e aos estrangeiros residentes no País a inviolabilidade do direito à vida, à liberdade, à igualdade, à segurança e à propriedade, nos termos seguintes: (...) XXXIII - todos têm direito a receber dos órgãos públicos informações de seu interesse particular, ou de interesse coletivo ou geral, que serão prestadas no prazo da lei, sob pena de responsabilidade, ressalvadas aquelas cujo sigilo seja imprescindível à segurança da sociedade e do Estado;"

1013 “Art. 37. (...) $\S 6^{\circ}$ - As pessoas jurídicas de direito público e as de direito privado prestadoras de serviços públicos responderão pelos danos que seus agentes, nessa qualidade, causarem a terceiros, assegurado o direito de regresso contra o responsável nos casos de dolo ou culpa."

${ }^{1014}$ Conferir o subitem 4.3.2.

1015 “Art. 18. A organização político-administrativa da República Federativa do Brasil compreende a União, os Estados, o Distrito Federal e os Municípios, todos autônomos, nos termos desta Constituição."

1016 O artigo 27 da Emenda Constitucional n. 19, de 4 de junho de 1998 assim dispõe: “Art. 27. O Congresso Nacional, dentro de cento e vinte dias da promulgação desta Emenda, elaborará lei de defesa do usuário de serviços públicos."

${ }^{1017}$ Em 20 de junho de 2013, o Conselho Federal da Ordem dos Advogados do Brasil (OAB) ajuizou ação direta de inconstitucionalidade por omissão (ADO 24/DF) perante o Supremo Tribunal Federal (STF) para 
No mesmo sentido, o artigo 175, parágrafo único, inciso I, prevê o dever do Poder Público estabelecer, por lei, os direitos dos usuários dos serviços públicos prestados por empresas concessionárias ou permissionárias, dentre outros aspectos. ${ }^{1018}$

A Lei n. 8.987, de 13 de fevereiro de 1995, que prevê o regime jurídico a que se sujeitam estas empresas, prevê a físcalização dos serviços pelo poder concedente "com a cooperação dos usuários", periodicamente, nos termos fixados em norma regulamentar (artigo $3^{\circ}$ e 30 , parágrafo único) ${ }^{1019}$. De um lado, sem prejuízo dos direitos previstos no Código de Defesa do Consumidor, assegura aos usuários o direito à informação (artigo $7^{\circ}$, inciso II) e, de outro, atribui aos usuários as obrigações de comunicar ao poder público e à

que seja declarada a mora do Congresso Nacional quanto à discussão e votação da lei de defesa do usuário de serviços públicos, prevista no artigo 27 da Emenda Constitucional 19, de 4 de junho de 1998, a fim de que seja fixado um prazo para que a matéria seja deliberada. O Conselho Federal da Ordem dos Advogados do Brasil (OAB) pediu como medida de urgência que seja determinado imediatamente: “(a.1) (...) aos Presidentes da Câmara dos Deputados e do Senado Federal, bem assim à Presidência da República, que adotem providências para que a análise do Projeto de Lei $n^{\circ}$ 6.953/2002 (Substitutivo do PL n 674/1999) e sua conversão em lei ocorram, no prazo máximo, de 120 (cento e vinte) dias, a contar da intimação da $\mathrm{r}$. decisão que deferir a medida cautelar; (a.2) determinar a aplicação subsidiária e provisória da Lei $\mathrm{n}^{\circ}$ 8.078/90 Código de Proteção e Defesa do Consumidor enquanto não editada Lei de Defesa dos Usuários de Serviços Público, de modo a resguardar minimamente o cidadão contribuinte em suas relações com o Poder Público." O Relator, Ministro Dias Toffoli, reconheceu a inatividade legislativa durante alargado lapso temporal (quinze anos) referente à regulamentação de norma constitucional, na espécie, do artigo 27 da Emenda Constitucional $n^{\circ}$ 19, de 4 de junho de 1998 (EC n. 19/98) e destacou a importância da ação em razão da temática de fundo: a prestação de serviços públicos no País e os instrumentos de defesa dos seus usuários. Tendo em vista o prazo definido no próprio artigo 27da EC n.19/98, o Ministro relator deferiu em parte a medida cautelar, ad referendum do Plenário, para reconhecer o estado de mora do Congresso Nacional, fixando o prazo de 120 (cento e vinte) dias para a edição da lei em questão. Na decisão, o Ministro salientou que “(...) o prazo aqui indicado não tem por objetivo resultar em interferência desta Corte na esfera de atribuições dos demais Poderes da República. Antes, há de expressar como que um apelo ao Legislador para que supra a omissão inconstitucional concernente à matéria tão relevante para a cidadania brasileira - a defesa dos usuários de serviços públicos no País. Cumpre observar que, nos termos do artigo 103 , parágrafo $2^{\circ}$ da Constituição Federal, caso o Supremo Tribunal Federal reconheça a procedência do pedido formulado na ação direta de inconstitucionalidade por omissão, o Poder Legislativo será comunicado para que adote as providências cabíveis, editando a lei conforme deliberado pelo constituinte derivado, confira: “Art. 103 (...) § $2^{\circ}$ - Declarada a inconstitucionalidade por omissão de medida para tornar efetiva norma constitucional, será dada ciência ao Poder competente para a adoção das providências necessárias e, em se tratando de órgão administrativo, para fazê-lo em trinta dias." A petição inicial da ADO 24/DF e a decisão cautelar proferida pelo Ministro relator Dias Toffoli constam do site do Supremo Tribunal Federal. Disponível em: <http://www.stf.jus.br>. Consulta em: 04/12/2013.

1018 “Art. 175. Incumbe ao Poder Público, na forma da lei, diretamente ou sob regime de concessão ou permissão, sempre através de licitação, a prestação de serviços públicos. Parágrafo único. A lei disporá sobre: I - o regime das empresas concessionárias e permissionárias de serviços públicos, o caráter especial de seu contrato e de sua prorrogação, bem como as condições de caducidade, físcalização e rescisão da concessão ou permissão; II - os direitos dos usuários; III - política tarifária; IV - a obrigação de manter serviço adequado." 1019 “Art. $3^{\circ}$ As concessões e permissões sujeitar-se-ão à fiscalização pelo poder concedente responsável pela delegação, com a cooperação dos usuários." “Art. 30. No exercício da fiscalização, o poder concedente terá acesso aos dados relativos à administração, contabilidade, recursos técnicos, econômicos e financeiros da concessionária. Parágrafo único. A fiscalização do serviço será feita por intermédio de órgão técnico do poder concedente ou por entidade com ele conveniada, e, periodicamente, conforme previsto em norma regulamentar, por comissão composta de representantes do poder concedente, da concessionária e dos usuários." 
concessionária as irregularidades quanto aos serviços prestados, assim como o dever de comunicar às autoridades competentes os atos ilícitos praticados pela concessionária na prestação do serviço (artigo $7^{\circ}$, incisos IV e V). ${ }^{1020}$ Por fim, prevê o dever do poder concedente de incentivar a formação de associações de usuários para a defesa de interesses relativos ao serviço, fortalecendo a participação dos usuários na Administração Pública (artigo 29, XII). ${ }^{1021}$

No mesmo sentido, a Lei n. 9.074, de 7 de julho de 1995, que disciplina a outorga de concessões e permissões de serviços públicos, prevê a edição de um regulamento de cada modalidade de serviço público que estabeleça a forma de participação dos usuários na fiscalização e disponibilize ao público, de forma periódica, do relatório dos serviços prestados (artigo 33). ${ }^{1022}$

A governança baseia-se numa abordagem pluralista e interativa da ação coletiva. Este novo estilo de agir e de decidir da Administração apresenta aspectos procedimental e instrumental. $\mathrm{O}$ aspecto procedimental consiste na abertura da ação pública aos cidadãos, aos grupos e à comunidade. Por sua vez, o aspecto instrumental se refere ao objetivo de alcançar a melhor eficácia da ação pública, com o estabelecimento de relações de cooperação dos múltiplos atores sociais e a procura de adesão. ${ }^{1023}$

Ainda conforme CHEVALLIER, à emergência de um Estado pós-moderno corresponde o surgimento de um Direito pós-moderno, como reflexo da institucionalização do poder, que passa pela mediação do Direito, num movimento de juridicização da governança. ${ }^{1024}$ A ligação indissociável da governança ao Direito se justifica na medida em que, para que se desenvolva é necessário: (i) o estabelecimento de um quadro claro de interação, com a definição das "regras do jogo", tais como, o número de participantes,

1020 “Art. $7^{\circ}$. Sem prejuízo do disposto na Lei n ${ }^{\circ}$ 8.078, de 11 de setembro de 1990, são direitos e obrigações dos usuários: (...) II - receber do poder concedente e da concessionária informações para a defesa de interesses individuais ou coletivos; (...) IV - levar ao conhecimento do poder público e da concessionária as irregularidades de que tenham conhecimento, referentes ao serviço prestado; V - comunicar às autoridades competentes os atos ilícitos praticados pela concessionária na prestação do serviço".

1021 “Art. 29. Incumbe ao poder concedente: (...) XII - estimular a formação de associações de usuários para defesa de interesses relativos ao serviço."

1022“Art. 33. Em cada modalidade de serviço público, o respectivo regulamento determinará que o poder concedente, observado o disposto nos arts. $3^{\circ}$ e 30 da Lei $n^{\circ} 8.987$, de 1995, estabeleça forma de participação dos usuários na físcalização e torne disponível ao público, periodicamente, relatório sobre os serviços prestados."

${ }^{1023}$ CHEVALLIER, Jacques. A governança e o Direito. In: Revista de Direito Público da Economia- RDPE, Belo Horizonte, ano 3, n. 12, p. 129-146, outubro/dezembro 2005.

1024 CHEVALLIER, Jacques. O Estado Pós-Moderno. Volume 1. Coleção Fórum Brasil-França de Direito Público. Tradução de Marçal Justen Filho. Belo Horizonte: Fórum. 2009.p.115. 
como serão conduzidas as negociações e quais as bases de um acordo possível; e (ii) a juridicidade dos compromissos na linguagem e na forma do Direito, para que o produto das negociações tenha força obrigatória. ${ }^{1025}$

Por sua vez, os instrumentos pró-consensuais contratuais são aqueles celebrados entre o poder público e o administrado (pessoa física ou jurídica), grupos de pessoas, entidades representativas de interesses ou instituições, visando promover um acordo sobre o objeto discutido, podendo contemplar deveres para uma ou ambas as partes.

Enquadram-se como instrumentos pró-consensuais contratuais os mecanismos criados pela Administração Pública voltados a alcançar uma solução consensual de conflitos de interesses na esfera administrativa.

Os compromissos de ajustamento de conduta à lei, ou figuras similares, são exemplos de instrumentos pró-consensuais contratuais, que os órgãos da Administração Pública direta e indireta, o Ministério Público e a Defensoria Pública podem celebrar para estabelecer as condições, os meios e o prazo para cumprimento do Direito, mediante conduta omissiva ou comissiva, consoante fixado no termo de ajustamento de conduta (TAC).

A Lei n. 7.347 de 24 de julho de 1985, que disciplina a ação civil pública, prevê em seu artigo $5^{\circ}$, parágrafo $6^{\circ}$, a possibilidade de que os órgãos públicos legitimados à sua propositura celebrem compromissos de ajustar sua conduta às exigências legais, mediante cominações, cujo ajuste terá eficácia de título executivo extrajudicial. ${ }^{1026}$

A ação civil pública e, consequentemente, o termo de ajustamento de conduta, pode ter como objeto a proteção de interesses coletivos em sentido amplo, abrangendo interesses individuais homogêneos, interesses coletivos em sentido estrito e interesses

1025 CHEVALLIER, Jacques. A governança e o Direito. In: Revista de Direito Público da Economia- RDPE, Belo Horizonte, ano 3, n. 12, p. 129-146, outubro/dezembro 2005.

${ }^{1026} \mathrm{O}$ artigo $5^{\circ}$, parágrafo $6^{\circ}$, inserido pelo artigo 113 , da Lei n. 8.078, de 11 de setembro de 1990 assim dispõe: "Art. $5^{\circ}$ Têm legitimidade para propor a ação principal e a ação cautelar: I - o Ministério Público; II a Defensoria Pública; III - a União, os Estados, o Distrito Federal e os Municípios; IV - a autarquia, empresa pública, fundação ou sociedade de economia mista; V - a associação que, concomitantemente: a) esteja constituída há pelo menos 1 (um) ano nos termos da lei civil; b) inclua, entre suas finalidades institucionais, a proteção ao meio ambiente, ao consumidor, à ordem econômica, à livre concorrência ou ao patrimônio artístico, estético, histórico, turístico e paisagístico. (...) $§ 6^{\circ}$ Os órgãos públicos legitimados poderão tomar dos interessados compromisso de ajustamento de sua conduta às exigências legais, mediante cominações, que terá eficácia de título executivo extrajudicial." 
difusos, definidos pelo artigo 81, parágrafo único, incisos I, II e III, da Lei n. 8.078/90 (Código de Defesa do Consumidor). ${ }^{1027} 1028$

Nos casos que envolvam interesse da União, suas autarquias e fundações, o termo de ajustamento de conduta, para prevenir ou terminar litígios, firmado pela AdvocaciaGeral da União, deverá conter: a descrição das obrigações assumidas; o prazo e o modo para o cumprimento das obrigações; a forma de fiscalização da sua observância; os fundamentos de fato e de direito; e a previsão de multa ou de sanção administrativa, no caso de seu descumprimento (artigo $4^{\circ}$-A, da Lei n. 9.469, de 10 de julho de 1997). ${ }^{1029}$

Por sua vez, os instrumentos de participação pró-consensuais orgânicos são aqueles que viabilizam a atuação do particular em órgãos colegiados da Administração com atividade contínua ou formados ad hoc para a discussão de matérias específicas. ${ }^{1030}$ Os instrumentos de participação pró-consensuais orgânicos têm um viés de controle interno e preventivo da legalidade e legitimidade da atuação administrativa e podem ser utilizados por indivíduos ou grupos. São exemplos desta categoria: a participação popular em órgãos de consulta ou em órgãos de decisão, a utilização do "ombudsman" 1031 e a instituição de ouvidorias.

1027 “Art. 81. A defesa dos interesses e direitos dos consumidores e das vítimas poderá ser exercida em juízo individualmente, ou a título coletivo. Parágrafo único. A defesa coletiva será exercida quando se tratar de: I interesses ou direitos difusos, assim entendidos, para efeitos deste código, os transindividuais, de natureza indivisível, de que sejam titulares pessoas indeterminadas e ligadas por circunstâncias de fato; II - interesses ou direitos coletivos, assim entendidos, para efeitos deste código, os transindividuais, de natureza indivisível de que seja titular grupo, categoria ou classe de pessoas ligadas entre si ou com a parte contrária por uma relação jurídica base; III - interesses ou direitos individuais homogêneos, assim entendidos os decorrentes de origem comum."

${ }^{1028}$ De forma exemplificativa, o artigo $1^{\circ}$, da Lei n. 7.347/85 prevê o cabimento da ação civil pública de responsabilidade por danos morais e patrimoniais causados: (i) ao meio-ambiente; (ii) ao consumidor; (iii) a bens e direitos de valor artístico, estético, histórico, turístico e paisagístico; (iv) por infração da ordem econômica; (v) à ordem urbanística; e (vi) a qualquer outro interesse difuso ou coletivo.

1029 “Art. $4^{\circ}$-A. O termo de ajustamento de conduta, para prevenir ou terminar litígios, nas hipóteses que envolvam interesse público da União, suas autarquias e fundações, firmado pela Advocacia-Geral da União, deverá conter: I - a descrição das obrigações assumidas; II - o prazo e o modo para o cumprimento das obrigações; III - a forma de fiscalização da sua observância; IV - os fundamentos de fato e de direito; e V - a previsão de multa ou de sanção administrativa, no caso de seu descumprimento. Parágrafo único. A Advocacia-Geral da União poderá solicitar aos órgãos e entidades públicas federais manifestação sobre a viabilidade técnica, operacional e financeira das obrigações a serem assumidas em termo de ajustamento de conduta, cabendo ao Advogado-Geral da União a decisão final quanto à sua celebração."

1030 MEDAUAR, Odete. O direito administrativo em evolução. São Paulo: Editora Revista dos Tribunais, 1992 , p. 219.

1031 Segundo a classificação proposta por DI PIETRO, a participação popular em órgãos de consulta e de decisão da Administração Pública e a participação por meio do "ombudsman" é indireta, tendo em vista a existência de um intermediário entre o administrado e a Administração Pública. DI PIETRO, Maria Sylvia Zanella. Participação popular na administração pública. In: Revista de Direito Administrativo, p. 34-38, 1993. 
A consulta é um procedimento que teve origem nos regimes autoritários, nos quais o monarca se cercava de conselheiros que o ajudavam na tomada de decisões. Com a instalação do regime democrático, o procedimento foi mantido mediante a criação, junto à Administração Pública, de órgãos consultivos com funcionamento permanente ou provisório, sempre com a participação da sociedade. ${ }^{1032}$ A Constituição Federal prevê um órgão dessa natureza, que é o Conselho da República, definido como órgão superior de consulta do Presidente da República, formado por seis cidadãos, dentre outros integrantes (artigo 89). ${ }^{1033}$

Dentre os instrumentos de participação pró-consensual em órgãos de decisão, a Constituição Federal estabelece a participação dos trabalhadores e empregados nos órgãos em que seja discutida ou deliberada matéria relativa aos seus interesses profissionais ou previdenciários (artigo 10) ${ }^{1034}$

Em seu artigo 194, caput, a Constituição Federal prevê a atuação integrada e conjunta da sociedade e do poder público nas ações concernentes à seguridade social, conforme o caráter democrático e descentralizado da administração, mediante gestão quadripartite nos órgãos colegiados, com a participação dos trabalhadores, empregadores, aposentados e de Governo (parágrafo único, inciso VII). ${ }^{1035}$

O problema é que as normas instituidoras dos órgãos de decisão são programáticas, dependendo de medidas posteriores para que se tornem efetivas. Alguns órgãos consultivos

\footnotetext{
1032 Conforme DI PIETRO, o maior problema dos órgãos de consulta consiste em sua real representatividade, vez que para assegurar este cunho, é imprescindível que a eleição de seus integrantes seja feita pela própria sociedade e, preferencialmente, entre pessoas desvinculadas do Poder Público. De qualquer forma, os órgãos de consulta podem desempenhar um papel importantíssimo, especialmente quando suas conclusões são vinculantes para a Administração e mesmo quando isso não ocorre, a existência formal dos conselhos contribui para aproximar os particulares da Administração. DI PIETRO, Maria Sylvia Zanella. Participação popular na administração pública. In: Revista de Direito Administrativo, p. 34-35, 1993.

1033 “Art. 89. O Conselho da República é órgão superior de consulta do Presidente da República, e dele participam: I - o Vice-Presidente da República; II - o Presidente da Câmara dos Deputados; III - o Presidente do Senado Federal; IV - os líderes da maioria e da minoria na Câmara dos Deputados; V - os líderes da maioria e da minoria no Senado Federal; VI - o Ministro da Justiça; VII - seis cidadãos brasileiros natos, com mais de trinta e cinco anos de idade, sendo dois nomeados pelo Presidente da República, dois eleitos pelo Senado Federal e dois eleitos pela Câmara dos Deputados, todos com mandato de três anos, vedada a recondução."

1034 “Art. 10. É assegurada a participação dos trabalhadores e empregadores nos colegiados dos órgãos públicos em que seus interesses profissionais ou previdenciários sejam objeto de discussão e deliberação."

1035“Art. 194. A seguridade social compreende um conjunto integrado de ações de iniciativa dos Poderes Públicos e da sociedade, destinadas a assegurar os direitos relativos à saúde, à previdência e à assistência social. Parágrafo único. Compete ao Poder Público, nos termos da lei, organizar a seguridade social, com base nos seguintes objetivos: (...) VII - caráter democrático e descentralizado da administração, mediante gestão quadripartite, com participação dos trabalhadores, dos empregadores, dos aposentados e do Governo nos órgãos colegiados."
} 
também se enquadram nesta categoria, como o Conselho Federal de Educação, os colegiados das Universidades e o Conselho Tutelar previsto no Estatuto da Criança e do Adolescente. ${ }^{1036}$

A legislação ordinária prevê outros instrumentos pró-consensuais de participação orgânica. Na área da saúde especificamente há os Conselhos de Saúde e as Conferências de Saúde, instâncias colegiadas de instituição obrigatória em cada uma das esferas de governo (artigo $1^{\circ}$, incisos I e II, e parágrafos $1^{\circ}, 2^{\circ}, 4^{\circ}$ e $5^{\circ}$, da Lei n. 8.142 , de 28 de dezembro de 1990) ${ }^{1037}$, que serão analisados no subitem 4.3.4.

Por sua vez, a figura do "ombudsman" (representante, intermediário) surgiu em países escandinavos e foi adotada em outros países, nos quais recebeu denominação diversa, como mediador, ouvidor geral, defensor do povo e "prokuratura". O “ombudsman" é um órgão de proteção dos cidadãos ligado ao Parlamento e que detém um conjunto de prerrogativas de controle da Administração Pública. Embora seja designado pelo Parlamento, ele atua com independência e é despido de formalismos. A importância do "ombudsman" é grande na proteção das liberdades públicas do cidadão, contribuindo para criar clima de confiança na Administração, prevenindo a prática de atos abusivos e arbitrariedades das autoridades administrativas. Tendo em vista a grande publicidade conferida às atividades do "ombudsman", somada à força da opinião pública e ao prestígio que lhe empresta o Parlamento, consiste num dos meios mais eficazes para o controle da legalidade e da moralidade administrativa. ${ }^{1038}$

${ }^{1036}$ DI PIETRO, Maria Sylvia Zanella. Participação popular na administração pública. In: Revista de Direito Administrativo, p. 35, 1993.

1037 "Art. $1^{\circ}$ O Sistema Único de Saúde (SUS), de que trata a Lei n. 8.080, de 19 de setembro de 1990, contará, em cada esfera de governo, sem prejuízo das funções do Poder Legislativo, com as seguintes instâncias colegiadas: I - a Conferência de Saúde; e II - o Conselho de Saúde. § $1^{\circ}$ A Conferência de Saúde reunir-se-á a cada quatro anos com a representação dos vários segmentos sociais, para avaliar a situação de saúde e propor as diretrizes para a formulação da política de saúde nos níveis correspondentes, convocada pelo Poder Executivo ou, extraordinariamente, por esta ou pelo Conselho de Saúde. § $2^{\circ}$ O Conselho de Saúde, em caráter permanente e deliberativo, órgão colegiado composto por representantes do governo, prestadores de serviço, profissionais de saúde e usuários, atua na formulação de estratégias e no controle da execução da política de saúde na instância correspondente, inclusive nos aspectos econômicos e financeiros, cujas decisões serão homologadas pelo chefe do poder legalmente constituído em cada esfera do governo. (...) $\S 4^{\circ}$ A representação dos usuários nos Conselhos de Saúde e Conferências será paritária em relação ao conjunto dos demais segmentos. $\S 5^{\circ}$ As Conferências de Saúde e os Conselhos de Saúde terão sua organização e normas de funcionamento definidas em regimento próprio, aprovadas pelo respectivo conselho."

${ }^{1038}$ DI PIETRO, Maria Sylvia Zanella. Participação popular na administração pública. In: Revista de Direito Administrativo, p. 36, 1993. 
No Brasil não há uma figura semelhante ao "ombudsman"1039, embora tenham sido instituídas ouvidorias na Administração Pública em diversas unidades federativas ${ }^{1040} 1041$, nos Poderes Legislativo ${ }^{1042}$ e Judiciário, bem como no Ministério Público ${ }^{1043}$, com

${ }^{1039}$ Em nível constitucional, o projeto Afonso Arinos havia previsto o Defensor do Povo, atribuindo-lhe as funções de apurar irregularidades e omissões das autoridades administrativas, contudo no segundo substitutivo foi retirada essa figura. Para DI PIETRO é indispensável que seja instituído um "ombudsman" semelhante ao modelo escandinavo, ante a ineficácia da atuação de órgãos esparsos, tais como os Tribunais de Contas, o Ministério Público e o Congresso Nacional. DI PIETRO, Maria Sylvia Zanella. Participação popular na administração pública. In: Revista de Direito Administrativo, p. 36-39, 1993.

1040 À época em que fora publicado este artigo, como ressaltou DI PIETRO, eram tímidas e isoladas as experiências de criação de figuras semelhantes ao "ombudsman". A iniciativa precursora foi do Município de Curitiba, que criou a Ouvidoria municipal, por meio do Decreto n. 215, de 21 de março de 1986, visando atuar na defesa de direitos contra atos e omissões ilegais ou injustas cometidas pela Administração Pública. DI PIETRO, Maria Sylvia Zanella. Participação popular na administração pública. In: Revista de Direito Administrativo, p. 36, 1993.

${ }^{1041}$ Em âmbito federal, a Ouvidoria-Geral da República foi criada pela Lei n. 8.490/1992, na estrutura regimental do Ministério da Justiça (artigo 19, inciso I, alínea “j”). O Decreto n. 4.177/2002 transferiu as competências de Ouvidoria-Geral do Ministério da Justiça para a Corregedoria-Geral da União, com exceção daquelas relativas à de Ouvidoria-Geral de direitos humanos, que permaneceram no Ministério da Justiça (artigo $3^{\circ}$ e parágrafo único). O Decreto n. 4.490/2002 criou a Ouvidoria-Geral da República na estrutura regimental básica da Corregedoria-Geral da União (artigo 2º, inciso III, alínea “a”). A Lei n. 10.683/03 transforma a Corregedoria-Geral da União em Controladoria-Geral da União, mantendo dentre as sua competências as atividades de Ouvidoria-Geral, exceto as atividades de ouvidoria dos indígenas, consumidor e polícia federal, a cargo do Ministério da Justiça, e dos direitos humanos, a cargo da Secretaria Especial de Direitos Humanos da Presidência da República (artigos 17 e 18). A Lei n. 10.689/2004 alterou a denominação de Ouvidoria-Geral da República para Ouvidoria-Geral da União, cujas atribuições foram previstas no Decreto n. 4.785/2003. Este decreto foi revogado pelo Decreto n. 5.683/2006, que, por sua vez, foi revogado pelo Decreto n. 8.109/2013, que prevê a estrutura regimental da Controladoria-Geral da União, órgão central do Sistema de Controle Interno do Poder Executivo federal e integrante da estrutura da Presidência da República, dirigida pelo Ministro de Estado Chefe da Controladoria-Geral da União, que tem como competência assistir direta e imediatamente o Presidente da República no desempenho de suas atribuições quanto aos assuntos e providências, no âmbito do Poder Executivo federal, especialmente relativos a atividades de ouvidoria (artigo $1^{\circ}$, inciso VI). A Ouvidoria-Geral da União consiste em órgão específico singular inserido na estrutura organizacional da Controladoria-Geral da União (artigo $3^{\circ}$, inciso II, alínea "b"), cujas competências abrangem, dentre outras: (i) realizar a coordenação técnica das atividades de ouvidoria no Poder Executivo federal, e sugerir a expedição de atos normativos e de orientações; (ii) receber denúncias direcionadas à Controladoria-Geral da União e dar o encaminhamento, conforme a matéria, à unidade, ao órgão ou à entidade competente; (iii) receber e analisar as manifestações referentes a serviços públicos prestados pelos órgãos e entidades do Poder Executivo federal, propor e monitorar a adoção de medidas para a correção e a prevenção de falhas e omissões na prestação desses serviços; (iv) receber e responder os pedidos de acesso à informação de que trata a Lei n. 12.527/2011; (v) promover capacitação e treinamento relacionados às atividades de ouvidoria no âmbito do Poder Executivo federal; (vi) promover a conciliação e a mediação na resolução de conflitos evidenciados no desempenho das atividades de ouvidoria entre cidadãos e órgãos, entidades ou agentes do Poder Executivo federal; (vii) produzir estatísticas indicativas do nível de satisfação dos usuários dos serviços públicos prestados no âmbito do Poder Executivo federal; (viii) promover formas de participação popular no acompanhamento e fiscalização da prestação dos serviços públicos (artigo 14, incisos I, II, III, IV, VII, VIII, IX e X).

${ }^{1042}$ Em 2001 foi criada a Ouvidoria Parlamentar da Câmara dos Deputados, por meio da Resolução n. 19, de 14 de março de 2001, modificando a redação do Regimento Interno da Câmara (Resolução n. 17, de 1989). Disponível no site da Câmara dos Deputados: <http://www.camara.leg.br>. Consulta em: 12/12/2013.

1043 A Emenda Constitucional n. 45, de 30 de dezembro de 2004, determinou a criação de ouvidorias no Poder Judiciário e no Ministério Público no âmbito da União, Estados, Distrito Federal e Territórios. A Constituição Federal, com a redação dada pela Emenda Constitucional n. 45/2004, passou a prescrever o seguinte: “Art. 103-B. O Conselho Nacional de Justiça compõe-se de quinze membros com mais de trinta e 
atribuições para receber denúncias, apurá-las e promover medidas voltadas à correção de falhas e ao aprimoramento do serviço público.

A ouvidoria é um canal de participação popular administrativa, que tem como finalidade auxiliar o cidadão em suas relações com a Administração Pública. Cabe à ouvidoria atuar no processo de interlocução entre o cidadão e a Administração Pública, de forma que as manifestações decorrentes do exercício da cidadania provoquem contínua melhoria dos serviços públicos prestados. Como agente promotor de mudanças, a ouvidoria favorece uma gestão mais flexível, voltada para a satisfação das necessidades do cidadão, garantindo o aprimoramento na prestação de serviços públicos e a garantia de direitos. A indicação pelos cidadãos de problemas no funcionamento dos órgãos públicos induz a mudanças estruturais e a melhorias conjunturais. Para que seja possível atender aos desafios atuais, as ouvidorias vêm promovendo uma integração sistêmica, estabelecendo relações colaborativas não hierarquizadas, de forma presencial ou virtual, continuada e em rede, visando compartilhar conhecimentos e gerar inovações, com o fim de garantir a participação da sociedade de forma permanente e institucionalizada na Administração Pública. ${ }^{1044}$

A Constituição de 1988 instituiu competências e criou instrumentos com efeitos potencialmente semelhantes àqueles provocados pela atuação do "ombudsman", a saber: (i) incumbiu ao Ministério Público a defesa do regime democrático, atribuindo-lhe como função precípua o zelo pelo efetivo respeito dos Poderes Públicos, dos serviços de relevância pública e dos direitos assegurados na Constituição, atribuindo-lhe o dever de promover as medidas necessárias a sua garantia (artigo 127, caput, e 129 , inciso II) ${ }^{1045}$; (ii)

cinco e menos de sessenta e seis anos de idade, com mandato de dois anos, admitida uma recondução, sendo: (...) $\S 7^{\circ}$ A União, inclusive no Distrito Federal e nos Territórios, criará ouvidorias de justiça, competentes para receber reclamações e denúncias de qualquer interessado contra membros ou órgãos do Poder Judiciário, ou contra seus serviços auxiliares, representando diretamente ao Conselho Nacional de Justiça"; "Artigo 130A. O Conselho Nacional do Ministério Público compõe-se de quatorze membros nomeados pelo Presidente da República, depois de aprovada a escolha pela maioria absoluta do Senado Federal, para um mandato de dois anos, admitida uma recondução, sendo: (...) $§ 5^{\circ}$ Leis da União e dos Estados criarão ouvidorias do Ministério Público, competentes para receber reclamações e denúncias de qualquer interessado contra membros ou órgãos do Ministério Público, inclusive contra seus serviços auxiliares, representando diretamente ao Conselho Nacional do Ministério Público."

1044 BRASIL. Controladoria-Geral da União. Ouvidoria-Geral da União. Orientações para implantação de uma unidade de ouvidoria: rumo ao sistema participativo. 5.ed. Coleção OGU. Brasília: Controladoria-Geral da União. 2012. p.8-9.

1045 “Art. 127. O Ministério Público é instituição permanente, essencial à função jurisdicional do Estado, incumbindo-lhe a defesa da ordem jurídica, do regime democrático e dos interesses sociais e individuais indisponíveis“; e "Art. 129. São funções institucionais do Ministério Público: (...) II - zelar pelo efetivo 
assegurou ao cidadão, aos partidos políticos, às associações ou sindicato o direito de denunciar irregularidades ou ilegalidades perante o Tribunal de Contas da União (artigo 74, parágrafo $\left.2^{\circ}\right)^{1046}$; e (iii) atribuiu às Comissões do Congresso Nacional e suas Casas competência para receber petições, reclamações, representações ou queixas de qualquer pessoa contra atos ou omissões das autoridades ou entidades públicas (artigo 58, parágrafo $2^{\mathrm{o}}$, inciso IV). ${ }^{1047}$

Apesar do progresso que a institucionalização destes instrumentos representa, DI PIETRO menciona dois grandes problemas relacionados à efetividade dos mesmos: a dispersão de responsabilidades, decorrentes da existência de vários órgãos com funções semelhantes; e o desconhecimento por parte da população acerca da existência e das atribuições desses órgãos. DI PIETRO sugere a criação de um órgão único que seja por todos recebido e respeitado e que concentre poderes para receber denúncias de irregularidades a fim de apurá-las. ${ }^{1048} \mathrm{Em}$ âmbito federal, este papel foi atribuído à Ouvidoria-Geral da União, como visto acima, cujo extenso conjunto de atribuições está previsto no artigo 14, do Decreto n. 8.109, de 17 de setembro de 2013. É, pois, imprescindível a ampla divulgação da existência e das funções deste órgão para que possa realizar as finalidades precípuas para as quais foi instituído.

As ouvidorias das agências reguladoras também constituem instrumentos próconsensuais de participação orgânica. A Agência Nacional de Saúde Suplementar (ANS) inseriu a Ouvidoria em sua estrutura básica (artigo $4^{\circ}$, inciso IV, do Anexo I, do Decreto n.

respeito dos Poderes Públicos e dos serviços de relevância pública aos direitos assegurados nesta Constituição, promovendo as medidas necessárias a sua garantia;"

1046 “Art. 74. Os Poderes Legislativo, Executivo e Judiciário manterão, de forma integrada, sistema de controle interno com a finalidade de: (...) $§ 2^{\circ}$ - Qualquer cidadão, partido político, associação ou sindicato é parte legítima para, na forma da lei, denunciar irregularidades ou ilegalidades perante o Tribunal de Contas da União."

1047 “Art. 58. O Congresso Nacional e suas Casas terão comissões permanentes e temporárias, constituídas na forma e com as atribuições previstas no respectivo regimento ou no ato de que resultar sua criação. (...) $\S 2^{\circ}-$ às comissões, em razão da matéria de sua competência, cabe: (...) IV - receber petições, reclamações, representações ou queixas de qualquer pessoa contra atos ou omissões das autoridades ou entidades públicas;",

1048 Além disso, DI PIETRO afirma que a provocação do Poder Judiciário é, ainda, a forma mais eficaz de controle da Administração Pública, por intermédio da Justiça. DI PIETRO, Maria Sylvia Zanella. Participação popular na administração pública. In: Revista de Direito Administrativo, p. 37-38, 1993. Os remédios jurisdicionais para provocar o controle jurisdicional de ato da Administração Pública são: o habeas data, o habeas corpus, o mandado de segurança individual, o mandado de segurança coletivo, o mandado de injunção e a ação popular. Além disso, com base no artigo $5^{\circ}$, inciso XXXV, da Constituição, que prevê a inafastabilidade do Poder Judiciário ante qualquer lesão ou ameaça a direito, o administrado pode utilizar os diversos tipos de ação previstos na legislação ordinária para impugnar os atos da Administração. DI PIETRO, Maria Sylvia Zanella. Direito Administrativo. 23. ed. São Paulo: Atlas, 2010, p. 765. 
3.327, de 5 de janeiro de 2000), regulamentando-a no âmbito da ANS, ao estabelecer como funções que lhe são próprias: (i) formular e encaminhar as denúncias e queixas aos órgãos competentes, em especial à Diretoria Colegiada, à Procuradoria e à Corregedoria da ANS, e ao Ministério Público; e (ii) dar ciência das infringências de normas de assistência suplementar à saúde ao Diretor-Presidente da ANS (artigos 18 a 21).

Por seu turno, a Agência Nacional de Vigilância Sanitária (ANVISA), criada pela Lei n. 9.782/99 (artigo 3º), prevê em seu regulamento (anexo I, do Decreto n. 3.029, de 16 de abril de 1999) que a Ouvidoria faz parte de sua estrutura básica (artigo $5^{\circ}$, inciso IV), disciplinando numa seção específica suas regras, atribuições, bem como as funções do Ouvidor. De maneira semelhante à Ouvidoria da ANS, cabe à Ouvidoria da ANVISA: (i) formular e encaminhar as denúncias e queixas aos órgãos competentes, em especial à Diretoria Colegiada, à Procuradoria e à Corregedoria da Agência e ao Ministério Público; e (ii) dar ciência das infringências de normas de vigilância sanitária ao Diretor-Presidente da Agência (artigos 25 a 28).

Para que as Ouvidorias desempenhem as funções em conformidade com as finalidades para as quais foram instituídas, é necessário que o Ouvidor ${ }^{1049}$ atue de forma independente, desvinculado dos demais órgãos que compõem a estrutura organizacional das Agências e esteja munido de meios adequados para o exercício de suas atividades. É também expressamente proibido que o Ouvidor tenha interesse em qualquer empresa ou pessoa sujeita à área de atuação da Agência Nacional de Saúde Suplementar (ANS) ou da Agência Nacional de Vigilância Sanitária (ANVISA). Cabe ao Ouvidor receber reclamações e denúncias de violações de direitos individuais ou coletivos praticados por agentes ou servidores públicos de qualquer natureza, vinculados direta ou indiretamente às atividades dessas Agências e promover as ações necessárias à apuração de sua veracidade.

1049 Os Regulamentos da ANVISA e da ANS estabelecem que a independência do Ouvidor para o exercício de suas funções é assegurada por meio de mandato de dois anos, admitida uma recondução. Cada uma das Agências terá um Ouvidor, indicado pelo Ministro de Estado da Saúde e nomeado pelo Presidente da República. Ao Ouvidor cabem as seguintes funções: ouvir as reclamações de qualquer cidadão, relativas a infringências de normas de vigilância sanitária e de normas da assistência suplementar à saúde, conforme o caso; receber denúncias de quaisquer violações de direitos individuais ou coletivos, neles incluídos todos os contrários à saúde pública, bem como qualquer ato de improbidade administrativa praticados por agentes ou servidores públicos de qualquer natureza, vinculados direta ou indiretamente ao Sistema Nacional de Vigilância Sanitária ou às atividades da ANS; e produzir, semestralmente, ou quando oportuno, apreciações críticas sobre a atuação da respectiva Agência, encaminhando-as à Diretoria Colegiada, ao Conselho Consultivo e ao Ministério da Saúde (artigos 25 e 27 do anexo I, do Decreto n. 3029/99- Regulamento da ANVISA e artigos 18 e 20 do anexo I, do Decreto n. 3.327/2000- Regulamento da ANS). 
Se for o caso, o Ouvidor deverá tomar as providências necessárias ao saneamento das irregularidades e ilegalidades verificadas.

Além disso, no concernente à atividade planejadora do Estado, o artigo 29, inciso XII, da Constituição Federal, estabelece normas básicas de organização dos Municípios e prevê expressamente a cooperação das associações representativas no planejamento municipal, orientando a Administração Pública dos Municípios a adotarem instrumentos de participação popular, por intermédio de associações representativas. ${ }^{1050}$ Conforme a classificação apresentada, este é um meio de participação popular indireta, por meio de entidades representativas de direitos e interesses, capilarizado nos entes municipais da Federação.

A Constituição Federal também regula, em dispositivos esparsos, a participação da comunidade para a formulação e o controle das políticas públicas, assegurando instrumentos pró-consensuais procedimentais e orgânicos, nas seguintes áreas: atenção integral à criança e do adolescente (artigo 227, caput e parágrafo $1^{\circ}$ ) ${ }^{1051}$; assistência social $\left(\right.$ artigo 204, inciso II) ${ }^{1052}$; educação (artigos 205 e 206, inciso VI) ${ }^{1053}$; agrícola (artigo 187, caput e parágrafo $\left.1^{\circ}\right)^{1054}$; meio-ambiente (artigo 225 , caput $)^{1055}$; bem como proteção do

1050 “Art. 29. O Município reger-se-á por lei orgânica, votada em dois turnos, com o interstício mínimo de dez dias, e aprovada por dois terços dos membros da Câmara Municipal, que a promulgará, atendidos os princípios estabelecidos nesta Constituição, na Constituição do respectivo Estado e os seguintes preceitos: (...) XII - cooperação das associações representativas no planejamento municipal;",

1051 “Art. 227. É dever da família, da sociedade e do Estado assegurar à criança, ao adolescente e ao jovem, com absoluta prioridade, o direito à vida, à saúde, à alimentação, à educação, ao lazer, à profissionalização, à cultura, à dignidade, ao respeito, à liberdade e à convivência familiar e comunitária, além de colocá-los a salvo de toda forma de negligência, discriminação, exploração, violência, crueldade e opressão. (...) $\S 1^{\circ} \mathrm{O}$ Estado promoverá programas de assistência integral à saúde da criança, do adolescente e do jovem, admitida a participação de entidades não governamentais, mediante políticas específicas e obedecendo aos seguintes preceitos: (...)"

1052“Art. 204. As ações governamentais na área da assistência social serão realizadas com recursos do orçamento da seguridade social, previstos no art. 195, além de outras fontes, e organizadas com base nas seguintes diretrizes: (...) II - participação da população, por meio de organizações representativas, na formulação das políticas e no controle das ações em todos os níveis."

1053 “Art. 205. A educação, direito de todos e dever do Estado e da família, será promovida e incentivada com a colaboração da sociedade, visando ao pleno desenvolvimento da pessoa, seu preparo para o exercício da cidadania e sua qualificação para o trabalho." "Art. 206. O ensino será ministrado com base nos seguintes princípios: (...) VI - gestão democrática do ensino público, na forma da lei;”'

1054 “Art. 187. A política agrícola será planejada e executada na forma da lei, com a participação efetiva do setor de produção, envolvendo produtores e trabalhadores rurais, bem como dos setores de comercialização, de armazenamento e de transportes, levando em conta, especialmente: (...) $\S 1^{\circ}$ - Incluem-se no planejamento agrícola as atividades agro-industriais, agropecuárias, pesqueiras e florestais."

1055 “Art. 225. Todos têm direito ao meio ambiente ecologicamente equilibrado, bem de uso comum do povo e essencial à sadia qualidade de vida, impondo-se ao Poder Público e à coletividade o dever de defendê-lo e preservá- lo para as presentes e futuras gerações." 
patrimônio cultural brasileiro (artigo 216, caput e parágrafo $1^{\circ}$ ). ${ }^{1056}$ No concernente ao aproveitamento de recursos naturais em terras indígenas, a Constituição Federal determina que sejam ouvidas as comunidades afetadas, às quais cabe participação nos resultados da lavra de riquezas minerais (artigo 231, parágrafo $\left.3^{\circ}\right) .{ }^{1057}$

Embora não haja uma regulamentação sistemática dos institutos participativos, a Constituição Federal e a legislação infraconstitucional superveniente criaram variados instrumentos pró-consensuais que viabilizam a participação popular na Administração Pública, proporcionando a aproximação entre Administração e cidadãos e a legitimação do exercício do poder. Muitos desses instrumentos já foram institucionalizados, em atendimento às exigências constitucionais e legais esparsas, permitindo, assim, que a sociedade tenha conhecimento e segurança jurídica quanto à sua existência, estrutura e forma de funcionamento. A estabilidade deste sistema torna viável a interconexão de diferentes atores sociais envolvidos com a elaboração e a execução de políticas públicas.

É inegável que a partir da Constituição de 1988 houve avanços em relação à estruturação de um aparato normativo que viabiliza a participação popular na Administração Pública, mediante a valorização do cidadão, com a passagem deste, de mero expectador, a ator do processo de construção das decisões políticas e normativas. Estruturação esta que privilegia o controle da atuação administrativa.

De outro lado, não é menos correto afirmar que ainda há grandes problemas a serem superados no sentido da construção de uma democracia participativa como, dentre outros: (i) a ausência de informações claras e acessíveis sobre a existência dos instrumentos de participação na Administração e sobre os direitos e deveres dos cidadãos; (ii) o desconhecimento sobre os órgãos instituídos para o controle social da Administração e suas funções; (iii) a falta de cultura cívica e o desinteresse da população por questões aparentemente distantes e desvinculadas de seus problemas concretos; (iv) a descrença dos

1056 “Art. 216. Constituem patrimônio cultural brasileiro os bens de natureza material e imaterial, tomados individualmente ou em conjunto, portadores de referência à identidade, à ação, à memória dos diferentes grupos formadores da sociedade brasileira, nos quais se incluem: (...) $\S 1^{\circ}-$ O Poder Público, com a colaboração da comunidade, promoverá e protegerá o patrimônio cultural brasileiro, por meio de inventários, registros, vigilância, tombamento e desapropriação, e de outras formas de acautelamento e preservação."

1057 “Art. 231. São reconhecidos aos índios sua organização social, costumes, línguas, crenças e tradições, e os direitos originários sobre as terras que tradicionalmente ocupam, competindo à União demarcá-las, proteger e fazer respeitar todos os seus bens. (...) $\S 3^{\circ}-\mathrm{O}$ aproveitamento dos recursos hídricos, incluídos os potenciais energéticos, a pesquisa e a lavra das riquezas minerais em terras indígenas só podem ser efetivados com autorização do Congresso Nacional, ouvidas as comunidades afetadas, ficando-lhes assegurada participação nos resultados da lavra, na forma da lei." 
cidadãos no sistema de democracia participativa; (v) a falta de recursos humanos e materiais para que os instrumentos participativos funcionem de forma adequada e eficiente; (vi) a falta de recursos financeiros dos cidadãos para participar; (vii) o desconhecimento de questões técnicas para discutir ou contribuir com sugestões sobre a matéria discutida; (viii) a tradição autoritária do Estado brasileiro e a cultura política dominante; (ix) a ausência de informação sobre os requisitos exigidos para a participação na Administração Pública. ${ }^{1058}$

Por derradeiro, além das formas institucionalizadas de participação na Administração Pública, não se pode deixar de mencionar a participação de fato, definida por CLÈVE como aquela não regulada ou não admitida pelo direito, mas que exerce influência sobre a atividade administrativa. A participação de fato pode ser pública e legítima ou oculta e ilegítima. ${ }^{1059}$

Dentre as formas de participação públicas e legítimas encontram-se os movimentos populares que reivindicam novos direitos ou clamam por efetividade de direitos já reconhecidos. Exemplo desta forma de participação se encontra nos movimentos de rua que têm acontecido frequentemente no atual quadro de crise do Estado brasileiro, deflagrados, em junho de 2013, a partir da publicação, em diversas unidades da Federação, de que seriam majorados os valores das tarifas dos meios de transporte coletivos; fato este somado à insatisfação geral decorrente da baixa qualidade dos serviços públicos, notadamente nas áreas da saúde e da educação. Tais movimentos sociais, que já contavam com a adesão de grande parte da população, foram ainda exacerbados com a divulgação dos recursos públicos investidos em estádios para a Copa do Mundo de 2014 a ser

1058 MODESTO reúne as situações patológicas em relação à participação popular especialmente na Administração Pública em três classes: (i) apatia política (falta de estímulo para ação cidadã); (ii) abulia política (não querer participar da ação cidadã, é dizer, recusar a participação); e (iii) acracia política (não poder participar da ação cidadã). A apatia política relaciona-se diretamente à ausência de informação acerca dos direitos e deveres dos cidadãos, à falta de vias de comunicação direta realmente ágeis ao cidadão em face do aparato do Estado, à falta de resposta a solicitações, à falta de tradição participativa e à excessiva demora na resposta de solicitações ou críticas. Por sua vez, a abulia política está ligada ao ceticismo quanto à manifestação do cidadão efetivamente ser levada em consideração pela Administração Pública, bem como pela falta de reconhecimento e estima coletiva para atividades de participação cidadã. Já a acracia política diz diretamente respeito ao baixo grau de escolarização dos indivíduos, ao formalismo administrativo e à ausência da prática de conversão de solicitações orais em solicitações formalizadas, à falta de esclarecimento dos direitos e deveres das partes nos processos administrativos, à complexidade e prolixidade excessiva das normas administrativas, além dos graves problemas de ordem política e econômica própria de países subdesenvolvidos. MODESTO, Paulo. Participação popular na administração pública: mecanismos de operacionalização. In: Revista Diálogo Jurídico. Salvador: Centro de Atualização Jurídica (CAJ), v.1, n. 7, edição digital, outubro, 2001. Disponível em: <http://www.direitopublico.com.br>. Consulta em 17/12/2013.

${ }^{1059}$ CLÈVE, Clèmerson Merlin. O cidadão, a administração pública e a nova Constituição. In: Revista de Informação Legislativa. Brasília, ano 27, n. 106, p. 95, abril/junho 1990. 
realizada no Brasil, revelando o descompasso entre a vontade dos governantes e dos governados. O que merece ser discutido em futuros estudos é se e como essas novas formas de participação incentivadas através de "redes sociais", sem que haja liderança nem bandeira que lhes dê norte, favorecem a construção de uma cultura cívica em prol da satisfação dos interesses públicos de uma sociedade complexa e massificada, inserida num Estado Democrático.

Por outra parte, a participação oculta ou ilegítima devem ser repudiadas, por afrontarem os princípios da legalidade, da impessoalidade, da moralidade e da publicidade, sabidamente de observância obrigatória pela Administração Pública (artigo 37, caput, da Constituição Federal), como são exemplos o tráfico de influências, as negociatas e o clientelismo. ${ }^{1060}$

\subsection{Pressupostos da participação popular na Administração Pública}

O modelo de Administração Pública configurado a partir da Constituição Federal de 1988 trouxe inovações à sua estrutura e às relações com os administrados, redimensionando a tensão entre autoridade e liberdade. Este modelo preconiza não apenas uma atividade administrativa congruente com o princípio da legalidade em sentido amplo, mas também que esta seja mais próxima e permeável à participação popular.

A possibilidade de efetiva participação dos cidadãos na Administração depende, basicamente, além do aparato jurídico, de três pressupostos, a saber: (i) educação; (ii) acesso à informação (publicidade e motivação); e (iii) processo administrativo conforme os princípios do Estado Democrático de Direito.

\subsubsection{Educação}

O primeiro pressuposto para que o cidadão se valha dos instrumentos participativos é a educação. Não há dúvidas de que quanto mais educado e consciente de seus direitos, mais livre e menos manietado será o indivíduo, porquanto a educação, como

${ }^{1060}$ CLÈVE afirma que práticas como o tráfico de influências, as negociatas e o clientelismo, tão corriqueiras na experiência brasileira, devem ser descartadas por constituírem formas de exclusão da cidadania do processo de decisão. CLÈVE, Clèmerson Merlin. O cidadão, a administração pública e a nova Constituição. In: Revista de Informação Legislativa. Brasília, ano 27, n. 106, p. 93, abril/junho 1990. 
forma de conscientização da realidade que cerca a condição humana, conduz à libertação em face da dominação ideológica e da violência invisível capaz de subjugar as escolhas contra quem é dirigida, sem que o cidadão disso se dê conta. ${ }^{1061}$

A educação é um instrumento hábil para o crescimento intelectual e moral, que possibilita a elevação cultural das pessoas e a redução das desigualdades sociais e econômicas, equalizando oportunidades nos planos profissional, acadêmico, cultural, político, dentre outros.

A Constituição de 1988 reconhece a educação como direito fundamental (artigo $\left.6^{\circ}\right)^{1062}$ e dever do Estado e da família, com tríplice finalidade: o pleno desenvolvimento da pessoa; o preparo do indivíduo para o exercício da cidadania; e a qualificação individual para o trabalho (artigo 205). ${ }^{1063}$

O vínculo estreito entre a educação e a formação do indivíduo para o exercício da cidadania conduzem à conclusão de que não apenas a participação da sociedade na gestão da saúde, mas a vida humana, em toda sua dimensão político-social, restará empobrecida se não houver a devida valorização da educação. A própria subsistência da democracia pode ser ameaçada se o direito à educação não for efetivado em toda sua extensão, de forma a aproximar o povo soberano de seus governantes. Por isso, ANDRADE afirma que o amadurecimento democrático de um Estado verifica-se na relação direta do acesso à educação proporcionado aos membros da comunidade. ${ }^{1064}$

O grande problema da representação política no Brasil é que são os próprios representantes do povo que têm interesse direto em manter a despolitização de seus representados, ou melhor, o "eleitorado" pacífico e cândido, que se contenta com vãs promessas eleitorais.

A educação deve contribuir para a autoformação da pessoa e o aprendizado pelo cidadão acerca de seus direitos e deveres e o conhecimento sobre a ordem jurídica, permitindo o enraizamento de sua identidade nacional e a constituição da cidadania.

1061 ANDRADE, Cássio Cavalcante. Direito educacional: interpretação do direito constitucional à educação. Belo Horizonte: Fórum, 2010. p.54.

1062 "Art. $6^{\circ}$ São direitos sociais a educação, a saúde, a alimentação, o trabalho, a moradia, o lazer, a segurança, a previdência social, a proteção à maternidade e à infância, a assistência aos desamparados, na forma desta Constituição."

1063 “Art. 205. A educação, direito de todos e dever do Estado e da família, será promovida e incentivada com a colaboração da sociedade, visando ao pleno desenvolvimento da pessoa, seu preparo para o exercício da cidadania e sua qualificação para o trabalho."

1064 ANDRADE, Cássio Cavalcante. Direito educacional: interpretação do direito constitucional à educação. Belo Horizonte: Fórum, 2010, p.20. 
A missão da educação relativa à cidadania deve compreender: a transmissão do conhecimento necessário acerca dos direitos fundamentais e dos mecanismos para efetiválos; o encorajamento dos indivíduos ao exercício da cidadania; o resgate da dimensão política do direito; e o apoderamento da ideia da função transformadora do Direto, como espaço de luta e emancipação, bem como de sua linguagem como materialização de uma relação de forças. ${ }^{1065}$

A tomada de consciência do papel ativo que o cidadão pode desempenhar nos campos da elaboração, execução e controle de políticas públicas de saúde somente pode emergir a partir da educação.

A participação popular no âmbito do Sistema Único de Saúde (SUS) está condicionada à educação para formar, conservar e transmitir conhecimentos capazes de conscientizar o cidadão da sua importância como ser social, cultural e político essencial para a transformação da realidade social.

O conteúdo programático do ensino fundamental deve abranger em seu "conteúdo mínimo" o conhecimento acerca dos direitos fundamentais em todas as suas dimensões (positiva, negativa e ativa) e os meios previstos na ordem jurídica brasileira para exigir seu cumprimento, "de maneira a assegurar formação básica comum e respeito aos valores nacionais", dentre os quais se destaca o valor democrático. ${ }^{1066}$ No ensino médio, deve ser reforçado o conhecimento de que o Estado brasileiro é Democrático, assim como devem ser apontados quais são os direitos e deveres que decorrem para os cidadãos e para o Estado em virtude do Estado de Direito (artigo 208, incisos I e II da Constituição Federal). ${ }^{1067} 1068$

${ }^{1065}$ CLÈVE, Clèmerson Merlin. O direito e os direitos: elementos para uma crítica do direito contemporâneo. 3.ed. Belo Horizonte: Fórum, 2011, p. 148-151.

${ }^{1066} \mathrm{O}$ artigo 210 , caput e parágrafo $2^{\circ}$ da Constituição Federal assim dispõem: “Art. 210. Serão fixados conteúdos mínimos para o ensino fundamental, de maneira a assegurar formação básica comum e respeito aos valores culturais e artísticos, nacionais e regionais. (...) $\S 2^{\circ}-\mathrm{O}$ ensino fundamental regular será ministrado em língua portuguesa, assegurada às comunidades indígenas também a utilização de suas línguas maternas e processos próprios de aprendizagem."

1067 "Art. 208. O dever do Estado com a educação será efetivado mediante a garantia de: I - educação básica obrigatória e gratuita dos 4 (quatro) aos 17 (dezessete) anos de idade, (...); II - progressiva universalização do ensino médio gratuito;"

${ }^{1068}$ Conforme BOBBIO, a participação eleitoral tem grande valor educativo, pois é através da discussão política que o cidadão pode compreender a conexão existente entre a coisa pública e seus interesses pessoais, estabelecendo relações com outros cidadãos, tornando-se membro consciente de uma comunidade Deve haver um compromisso entre as partes através do livre debate para a formação de uma maioria, para que se defina a proposta que melhor reflita a realidade da democracia direta. BOBBIO, Norberto. O futuro da Democracia: uma defesa das regras do jogo; tradução de Mário Aurélio Nogueira. Rio de janeiro: Paz e Terra. 6 ed. 1986, p. 12 e 31-32. 
Embora estas pessoas possam futuramente vir a frequentar a escola ${ }^{1069}$, o dever do Estado de assegurar a educação para o exercício da cidadania não pode se circunscrever ao ensino em ambiente escolar (artigos $1^{\circ}$ e $2^{\circ}$, da Lei n. 9.394 de 20 de dezembro de 1996) ${ }^{1070}$ até porque, de acordo com o Instituto Brasileiro de Geografia e Estatística (IBGE), há um contingente de treze milhões e duzentas mil (13.200.000) pessoas no Brasil que não sabem ler nem escrever ( $8,7 \%$ da população), considerando apenas as pessoas com quinze anos ou mais. ${ }^{1071}$ A alfabetização desse elevado número de pessoas, que estão à margem da sociedade, é um dever ético e jurídico do Estado, e um dever fraterno e solidário da sociedade civil para emancipá-las e conceder-lhes as ferramentas necessárias à conquista da autonomia, a partir do pleno desenvolvimento de suas capacidades física, mental, moral e espiritual. ${ }^{1072}$

É possível vislumbrar duas dificuldades relacionadas à educação que poderão causar embaraços à participação administrativa no Sistema Único de Saúde (SUS): a ausência de consciência dos administradores; e a complexidade das questões técnicas.

A primeira dificuldade se refere à desconfiança de administradores em relação à participação popular na Administração, vista como intromissão indevida, pois ainda não enxergam os cidadãos como partícipes do processo democrático, mas como meros sujeitos

1069 “Art. 208. O dever do Estado com a educação será efetivado mediante a garantia de: I - educação básica obrigatória e gratuita dos 4 (quatro) aos 17 (dezessete) anos de idade, assegurada inclusive sua oferta gratuita para todos os que a ela não tiveram acesso na idade própria;"

1070 "Art. $1^{\circ}$ A educação abrange os processos formativos que se desenvolvem na vida familiar, na convivência humana, no trabalho, nas instituições de ensino e pesquisa, nos movimentos sociais e organizações da sociedade civil e nas manifestações culturais. $\S 1^{\circ}$ Esta Lei disciplina a educação escolar, que se desenvolve, predominantemente, por meio do ensino, em instituições próprias. $\S 2^{\circ} \mathrm{A}$ educação escolar deverá vincular-se ao mundo do trabalho e à prática social."; e "Art. $2^{\circ}$ A educação, dever da família e do Estado, inspirada nos princípios de liberdade e nos ideais de solidariedade humana, tem por finalidade o pleno desenvolvimento do educando, seu preparo para o exercício da cidadania e sua qualificação para o trabalho."

1071 Segundo a Pesquisa Nacional de Amostra de Domicílios 2012 (PNAD), divulgada em 30 de setembro de 2013 pelo Instituto Brasileiro de Geografia e Estatística (IBGE), a taxa de analfabetismo no Brasil passou de 8,6\% (12,9 milhões de pessoas) em 2011 para 8,7\% (13,2 milhões de pessoas) em 2012. No Nordeste o contingente de analfabetos brasileiros também aumentou de 6,8 milhões para 7,1 milhões dos brasileiros analfabetos. A pesquisa considera como analfabetos apenas os cidadãos com 15 anos ou mais que não saibam ler e escrever. O relatório está disponível no site do IBGE na Internet: <http://www.ibge.gov.br/>. Consulta em: 09/12/2013.

1072 O Preâmbulo da Constituição Federal prevê: "Nós, representantes do povo brasileiro, reunidos em Assembleia Nacional Constituinte para instituir um Estado Democrático, destinado a assegurar o exercício dos direitos sociais e individuais, a liberdade, a segurança, o bem-estar, o desenvolvimento, a igualdade e a justiça como valores supremos de uma sociedade fraterna (...)". Por sua vez, o artigo $3^{\circ}$, inciso I estabelece: "Art. $3^{\circ}$ Constituem objetivos fundamentais da República Federativa do Brasil: I - construir uma sociedade livre, justa e solidária". 
passivos. É necessário alterar a "psicologia coletiva dos administradores"1073 para conscientizá-los acerca do papel que os administrados devem desempenhar no universo administrativo e de suas responsabilidades concernentes à garantia de realização substancial da participação administrativa institucionalizada, em respeito às normas constitucionais e legais que assim exigem.

Diante desse quadro, cabe à Administração realizar treinamentos e cursos de capacitação de administradores voltada especialmente para: (i) esclarecer como pode ser exercido o direito à participação dos cidadãos em processos que lhes interessem, sob o prisma individual ou coletivo, para a tomada de decisões mais adequadas à satisfação do interesse público; (ii) realizar treinamento sobre o procedimento de cada um dos instrumentos participativos; (iii) enaltecer as finalidades da participação administrativa para os cidadãos e para a Administração na tomada da decisão administrativa mais oportuna e efetiva; e (iv) adverti-los sobre as responsabilidades decorrentes do descumprimento de seus deveres ou da violação de direitos dos cidadãos, seja por conduta omissiva ou comissiva, em relação à participação na Administração Pública.

A outra dificuldade que se põe é a participação administrativa na elaboração e na implementação de políticas públicas ou na incorporação de novas tecnologias que envolvam questões técnicas e complexas. As pessoas precisam estar preparadas para discutir essas questões de forma a propiciar debates profícuos no sentido do esclarecimento de quais são os interesses envolvidos e que devem ser tutelados em cada situação concreta.

Como nem todos os usuários poderão se fazer ouvir frente ao Sistema Único de Saúde (SUS), se os cidadãos que participarem de conselhos ou conferências de saúde, de audiências ou consultas públicas não estiverem preparados, a participação popular na Administração Pública será frustrada quanto ao seu principal objetivo de garantir um papel ativo à comunidade, para que intervenha e colabore de forma positiva nas discussões para a tomada de decisões sobre as políticas públicas sanitárias.

É imprescindível que o Estado assegure a efetividade do direito à educação voltada à formação de cidadãos. Além de garantir o ensino fundamental e médio de boa qualidade, o poder público deve promover programas específicos de ensino que esclareçam os

1073 CLÈVE, Clèmerson Merlin. O cidadão, a administração pública e a nova Constituição. In: Revista de Informação Legislativa. Brasília, ano 27, n. 106, p. 94, abril/junho 1990. 
indivíduos sobre os meios e requisitos de participação administrativa, bem como sobre as posições jurídicas decorrentes do direito à saúde.

Além disso, diante de um caso concreto sobre matéria complexa, a Administração deve oferecer informações completas, claras e em linguagem de fácil compreensão, para ampliar o rol de pessoas qualificadas que possam se interessar e contribuir para a discussão do objeto colocado no processo administrativo. ${ }^{1074}$

\subsubsection{Acesso à informação}

Como visto alhures, no processo dinâmico de universalização dos direitos fundamentais e de institucionalização do Estado Social, a democracia participativa, a informação e o pluralismo, considerados por BONAVIDES como direitos fundamentais de quarta dimensão, são necessários à concretização dos direitos de primeira, segunda e terceira dimensões e à globalização política, na qual o homem é o centro de convergência de todos os interesses do sistema. A democracia participativa, a informação e o pluralismo estão interligados: a democracia direta e semi-direta são materialmente possíveis graças aos avanços da tecnologia da comunicação e são legitimamente sustentáveis devido à informação correta e às aberturas pluralistas do sistema. ${ }^{1075}$

1074 Um exemplo de questão técnica complexa recentemente discutida em audiência pública realizada no Supremo Tribunal Federal versou sobre a utilização do amianto. A Lei n. 12.684, de 26 de julho de 2007, do Estado de São Paulo, proibiu o uso, no âmbito territorial do referido ente federado, de produtos materiais ou artefatos que contenham quaisquer tipos de amianto ou asbesto ou outros minerais que, acidentalmente, tenham fibras de amianto na sua composição. A Confederação Nacional de Trabalhadores na Indústria (CNTI) ajuizou a Ação Direta de Inconstitucionalidade (ADI) n. 3.937 questionando a integralidade da Lei $\mathrm{n}^{\circ}$ 12.684/2007. Ante o requerimento formulado pelo Instituto Brasileiro de Crisotila, o Ministro Marco Aurélio, relator da ADI n. 3.937, designou audiência pública para debater a temática objeto dessa ação, a qual foi realizada nos dias 24 e 31 de agosto de 2012, para analisar, do ponto de vista científico, a possibilidade de uso seguro do amianto da espécie crisotila e os riscos à saúde pública que o referido material pode trazer, bem como verificar se as fibras alternativas ao amianto crisotila são viáveis à substituição do mencionado material, considerados, igualmente, os eventuais prejuízos à higidez física e mental da coletividade. Além da possibilidade de encaminhamento de memoriais por meio eletrônico, foi permitido aos interessados se habilitarem para expor seus conhecimentos sobre o tema. Na abertura da referida audiência, o Ministro Marco Aurélio destacou a importância da audiência pública como meio de discussão democrática que ocorre, geralmente, nos processos objetivos, em razão da eficácia irradiante, além dos muros subjetivos processuais. Afirmou que os Juízes precisam de fatos e de dados para um julgamento seguro e realçou que os profissionais especializados iriam colaborar para a entrega da prestação jurisdicional neste caso, que envolve a saúde pública e o desenvolvimento nacional, sob o ângulo da Constituição Federal que a todos, indistintamente, submete. Ao final, agradeceu em nome do Supremo Tribunal Federal todos aqueles que acorreram a esta convocação cívica para a elucidação da matéria. As informações relativas a esta audiência pública, a programação e as transcrições constam do site do Supremo Tribunal Federal na Internet: <http://www.stf.jus.br>. Consulta em: 09/12/2013.

1075 BONAVIDES, Paulo. Curso de Direito Constitucional, São Paulo: Malheiros. 22. ed., 2008, p.570-572 e BONAVIDES, Paulo. Teoria Constitucional da Democracia Participativa: por um Direito Constitucional de 
Neste subitem interessa tratar do acesso à informação como condicionante da participação administrativa. Este requisito pode ser desdobrado em dois: publicidade (ou transparência ou visibilidade) e motivação, princípios de observância obrigatória pela Administração Pública direita e indireta. A informação deve ser publicada para se tornar conhecida, e deve ser motivada, viabilizando que, a par de seus fundamentos fáticos e jurídicos, seja possível impugná-la e buscar sua reforma ou anulação, por meio da interposição de recurso administrativo ou da propositura de ação perante o Judiciário, com base no artigo $5^{\circ}$, inciso $\mathrm{XXXV}$, da Constituição Federal, que garante o direito à apreciação judicial de qualquer ameaça ou lesão de direito.

O princípio da publicidade consagra o dever da Administração Pública de manter plena transparência, ou visibilidade, da atividade que desenvolve, conferindo aos administrados a possibilidade de conhecer como estão sendo conduzidas as atividades administrativas em relação aos interesses públicos definidos pela ordem jurídica. Tal princípio está expressamente previsto no artigo 37, caput, da Constituição Federal. ${ }^{1076}$

É possível identificar três grandes eixos de significado no princípio da publicidade: (i) como mandamento de otimização para a ação transparente dos agentes públicos e da própria Administração, de forma a estabelecer como regra da ação administrativa a sua divulgação ao público, estimulando o controle social e o acesso a informações sobre a condução dos negócios públicos; (ii) como condição de validade e eficácia dos atos administrativos, exigência formal vinculada à ordem de transparência que condiciona seja a atividade da Administração realizada às luzes claras como regra e o sigilo seja permitido apenas em situações excepcionais; e (iii) como possibilidade de acesso de qualquer interessado a dados e informações relativas à ação da Administração Pública, o que se coaduna com a tendência de incremento de participação do cidadão nos assuntos públicos, especialmente nos processos de deliberação e tomada de decisão. ${ }^{1077}$

Com efeito, a transparência do poder é a base do direito à informação, indissociável da democracia, eis que torna viável a participação consciente dos cidadãos na

luta e resistência: por uma nova hermenêutica; por uma repolitização da legitimidade. 3.ed. São Paulo: Malheiros, 2008, p.7-10.

1076 O caput do artigo 37 estabelece alguns dos princípios a que a Administração Pública está sujeita: "Art. 37. A administração pública direta e indireta de qualquer dos Poderes da União, dos Estados, do Distrito Federal e dos Municípios obedecerá aos princípios de legalidade, impessoalidade, moralidade, publicidade e eficiência e, também, ao seguinte: (...)"

1077 MIRAGEM, Bruno. A nova Administração Pública e o Direito Administrativo. São Paulo: Editora Revista dos Tribunais, 2011, p. 309-310. 
vida política do Estado. ${ }^{1078}$ Conforme MIRAGEM, a publicidade tem basicamente duas finalidades: assegurar o conhecimento aos destinatários do ato e a todos aqueles que por ele possam ser afetados, da existência do mesmo; e permitir o controle da ação administrativa, mediante a externalização do ato e, particularmente, de sua motivação, a qual deve constar no procedimento que lhe dá origem. ${ }^{1079}$

Um instrumento essencial para a garantia de acesso à informação é o direito fundamental à obtenção de certidões em repartições públicas para a defesa de direitos e o esclarecimento de situações de interesse pessoal, assegurado pela Constituição Federal de 1988, no artigo 50, inciso XXXIV, alínea "b". ${ }^{1080}$ A certidão requerida à Administração direita e indireta, para a defesa de direitos ou esclarecimento de situações de interesse pessoal, deverá ser expedida no prazo máximo de quinze dias, conforme o artigo $1^{\circ}$, da Lei n. 9.051 , de 18 de maio de 1995 .

A Constituição Federal de 1988 também reconhece o direito fundamental de todos a receberem as informações que constem em órgãos públicos que sejam de seu interesse particular ou coletivo, nos termos do artigo $5^{\circ}$, inciso XXXIII. ${ }^{1081}$ Ainda no artigo $5^{\circ}$, no inciso LXXII, consagra a garantia do habeas data para garantir judicialmente o conhecimento de informações relativas ao impetrante que constem de registros de bancos de dados de entidades governamentais ou de âmbito público, bem como para a retificação de dados que neles estejam armazenados. ${ }^{1082}$ Em outras situações, o indivíduo poderá impetrar mandado de segurança ou ajuizar ação de procedimento ordinário para assegurar o direito à informação.

1078 Para CLÈVE, sem informação correta e um aparato institucional transparente, a participação pode se transformar em mera cooptação legitimadora. CLÈVE, Clèmerson Merlin. $O$ cidadão, a administração pública e a nova Constituição. In: Revista de Informação Legislativa. Brasília, ano 27, n. 106, p. 93, abril/junho 1990.

1079 MIRAGEM, Bruno. A nova Administração Pública e o Direito Administrativo. São Paulo: Editora Revista dos Tribunais, 2011, p. 311.

1080 “Art. $5^{\circ}$ (...) XXXIV - são a todos assegurados, independentemente do pagamento de taxas: (...) b) a obtenção de certidões em repartições públicas, para defesa de direitos e esclarecimento de situações de interesse pessoal;",

1081 O inciso XXXIII do artigo 5 , da Constituição Federal, estabelece: “Art. 50 Todos são iguais perante a lei, sem distinção de qualquer natureza, garantindo-se aos brasileiros e aos estrangeiros residentes no País a inviolabilidade do direito à vida, à liberdade, à igualdade, à segurança e à propriedade, nos termos seguintes: XXXIII - todos têm direito a receber dos órgãos públicos informações de seu interesse particular, ou de interesse coletivo ou geral, que serão prestadas no prazo da lei, sob pena de responsabilidade, ressalvadas aquelas cujo sigilo seja imprescindível à segurança da sociedade e do Estado".

1082 “Art. $5^{\circ}$ (...) LXXII - conceder-se-á "habeas-data": a) para assegurar o conhecimento de informações relativas à pessoa do impetrante, constantes de registros ou bancos de dados de entidades governamentais ou de caráter público; b) para a retificação de dados, quando não se prefira fazê-lo por processo sigiloso, judicial ou administrativo;" 
Ademais, a Constituição Federal de 1988, com a redação atribuída pela Emenda Constitucional n. 19, de 4 de junho de 1998, estabeleceu caber à lei ordinária disciplinar as formas de participação do usuário na Administração Pública direta e indireta, regulando, especialmente, o acesso dos usuários a registros administrativos e a informações sobre atos de governo, observado o disposto no artigo $5^{\circ}$, incisos $\mathrm{X}^{1083}$ e XXXIII (artigo 37, parágrafo $3^{\circ}$, inciso II $)^{1084}$, e determina à Administração a gestão da documentação governamental, franqueando a consulta àqueles a quem dela necessite (artigo 216, parágrafo $2^{\circ}$ ). ${ }^{1085} \mathrm{~A}$ regulamentação do direito fundamental de acesso à informação somente foi feita pela Lei n. 12.527, de 18 de novembro de 2011 (Lei de Acesso à Informação) e pelo Decreto $n$. 7.724 , de 16 de maio de 2012, que disciplina os procedimentos a serem observados para a garantia de exercício desse direito. ${ }^{1086}$

Os procedimentos previstos na Lei de Acesso à Informação modificam a "tradição do secreto" que predominava no Estado, em contrariedade ao seu caráter democrático, sendo de observância obrigatória pelos órgãos públicos integrantes da Administração direta e indireta, do Legislativo, Judiciário e Ministério Público, bem como pelas entidades de direito privado, sem fins lucrativos, que recebam recursos públicos para desempenhar atividades de interesse público. ${ }^{1087}$

1083“"Art. $5^{\circ}$ (...) X - são invioláveis a intimidade, a vida privada, a honra e a imagem das pessoas, assegurado o direito a indenização pelo dano material ou moral decorrente de sua violação;"

1084 O parágrafo $3^{\circ}$, do artigo 37, da Constituição Federal, incluído pela Emenda Constitucional n. 19, de 1988, prevê o seguinte: "Art. 37. A administração pública direta e indireta de qualquer dos Poderes da União, dos Estados, do Distrito Federal e dos Municípios obedecerá aos princípios de legalidade, impessoalidade, moralidade, publicidade e eficiência e, também, ao seguinte: (...) $\S 3^{\circ}$ A lei disciplinará as formas de participação do usuário na administração pública direta e indireta, regulando especialmente: I - as reclamações relativas à prestação dos serviços públicos em geral, asseguradas a manutenção de serviços de atendimento ao usuário e a avaliação periódica, externa e interna, da qualidade dos serviços; II - o acesso dos usuários a registros administrativos e a informações sobre atos de governo, observado o disposto no art. $5^{\circ}, \mathrm{X}$ e XXXIII; III - a disciplina da representação contra o exercício negligente ou abusivo de cargo, emprego ou função na administração pública."

1085““Art. 216. Constituem patrimônio cultural brasileiro os bens de natureza material e imaterial, tomados individualmente ou em conjunto, portadores de referência à identidade, à ação, à memória dos diferentes grupos formadores da sociedade brasileira, nos quais se incluem: (...) § $2^{\circ}$ - Cabem à administração pública, na forma da lei, a gestão da documentação governamental e as providências para franquear sua consulta a quantos dela necessitem."

${ }^{1086}$ Além disso, foi criada pela Lei n. 12.258, de 18 de novembro de 2011, a Comissão Nacional da Verdade no âmbito da Casa Civil da Presidência da República que, nos termos de seu artigo $1^{\circ}$, tem o objetivo de examinar e esclarecer as graves violações de direitos humanos praticadas no período de 18 de setembro de 1946 até 5 de outubro de 1988, fixado no art. $8^{\circ}$ do Ato das Disposições Constitucionais Transitórias, a fim de efetivar o direito à memória e à verdade histórica e promover a reconciliação nacional.

${ }^{1087}$ Nos termos dos artigos $1^{\circ}$ e $2^{\circ}$, da Lei n. 12.527/2011: “Art. $1^{\circ}$ Esta Lei dispõe sobre os procedimentos a serem observados pela União, Estados, Distrito Federal e Municípios, com o fim de garantir o acesso a informações previsto no inciso XXXIII do art. $5^{\circ}$, no inciso II do $\S 3^{\circ}$ do art. 37 e no $\S 2^{\circ}$ do art. 216 da Constituição Federal. Parágrafo único. Subordinam-se ao regime desta Lei: I - os órgãos públicos integrantes 
$\mathrm{O}$ artigo $3^{\circ}$ da Lei n. 12.527, de 18 de novembro de 2011, reforça o dever de cumprimento dos princípios que regem a Administração Pública e acrescenta as seguintes diretrizes: (i) a observância da publicidade, como regra, e o sigilo somente em casos excepcionais; (ii) a divulgação de informações de interesse público, mesmo sem solicitação neste sentido; (iii) a utilização de meios de comunicação propiciados pela tecnologia da informação; (iv) o incentivo ao desenvolvimento da cultura de transparência na Administração Pública; e (v) o desenvolvimento do controle social da Administração Pública.

O dever do Estado de viabilizar o acesso à informação, através de “(...) procedimentos objetivos e ágeis, de forma transparente, clara e em linguagem de fácil compreensão" ${ }^{" 1088}$, consubstancia um pressuposto para a garantia desse direito fundamental dos cidadãos, para o controle permanente sobre suas atividades e para a participação popular na Administração Pública.

Para os fins deste trabalho, ganha relevo o disposto no artigo 21, caput, da Lei n. 12.527, de 18 de novembro de 2011, segundo o qual "não poderá ser negado acesso à informação necessária à tutela judicial ou administrativa de direitos fundamentais. "1089

A previsão expressa de vedação à restrição do direito à informação protege o cidadão, garantindo-lhe o acesso a dados ou a unidade de registro de informações necessárias para a tutela de um direito fundamental tanto em âmbito administrativo como judicial. É o caso, por exemplo, do relatório da Comissão Nacional de Incorporação de Tecnologias no Sistema Único de Saúde ${ }^{1090}$, que deverá ser apresentado no processo

da administração direta dos Poderes Executivo, Legislativo, incluindo as Cortes de Contas, e Judiciário e do Ministério Público; II - as autarquias, as fundações públicas, as empresas públicas, as sociedades de economia mista e demais entidades controladas direta ou indiretamente pela União, Estados, Distrito Federal e Municípios."

Art. $2^{\circ}$ Aplicam-se as disposições desta Lei, no que couber, às entidades privadas sem fins lucrativos que recebam, para realização de ações de interesse público, recursos públicos diretamente do orçamento ou mediante subvenções sociais, contrato de gestão, termo de parceria, convênios, acordo, ajustes ou outros instrumentos congêneres. Parágrafo único. A publicidade a que estão submetidas as entidades citadas no caput refere-se à parcela dos recursos públicos recebidos e à sua destinação, sem prejuízo das prestações de contas a que estejam legalmente obrigadas."

$1088 \mathrm{O}$ artigo $5^{\circ}$ da Lei n. 12.527/2011 assim estabelece: “Art. 5 ${ }^{\circ}$ É dever do Estado garantir o direito de acesso à informação, que será franqueada, mediante procedimentos objetivos e ágeis, de forma transparente, clara e em linguagem de fácil compreensão."

$1089 \mathrm{O}$ artigo 21, da Lei n. 12.527/2011 assim dispõe: “Art. 21. Não poderá ser negado acesso à informação necessária à tutela judicial ou administrativa de direitos fundamentais. Parágrafo único. As informações ou documentos que versem sobre condutas que impliquem violação dos direitos humanos praticada por agentes públicos ou a mando de autoridades públicas não poderão ser objeto de restrição de acesso."

1090 “Art. 19-Q. A incorporação, a exclusão ou a alteração pelo SUS de novos medicamentos, produtos e procedimentos, bem como a constituição ou a alteração de protocolo clínico ou de diretriz terapêutica, são 
administrativo de consulta pública, para que os participantes tenham acesso a tal documento previamente à apresentação de suas manifestações escritas, como assegura o artigo 19-R, parágrafo $1^{\circ}$, III, da Lei n. 8.080/90, com a redação atribuída pela Lei n. 12.401/2011. ${ }^{1091}$ A consulta pública está disciplinada no artigo 31 da Lei de Processo Administrativo federal, que se aplica subsidiariamente ao processo de incorporação, exclusão ou alteração pelo Sistema Único de Saúde, de novos medicamentos, produtos e procedimentos, bem como de constituição ou alteração de protocolo clínico ou de diretriz terapêutica, por força do disposto no artigo 19-R, parágrafo $1^{\circ}$, da Lei n. 8.080/90.

É interessante notar a imprescindibilidade das novas tecnologias para garantir a efetiva participação dos administrados na Administração Pública, especialmente porque promovem a ampliação do acesso, a redução dos custos e a celeridade na difusão da informação, sobretudo em um País com a extensão territorial do Brasil. MARRARA observa que alguns mecanismos de participação administrativa, como a consulta e a audiência pública, seriam praticamente inviáveis sem as novas tecnologias de comunicação e informação, exatamente porque é por meio delas que se garante o aumento da acessibilidade aos processos administrativos, rompendo com o monopólio do acesso presencial com os custos que lhe são próprios, tornando mais simples, barato e rápido o controle popular sobre os atos de gestão da coisa pública, o que repercute favoravelmente sobre o princípio republicano. ${ }^{1092}$

Os ganhos gerados pelo emprego de novas tecnologias se afiguram significativos quando se trata de publicização e democratização. A ampliação dos meios de informação e a melhoria da sua qualidade conduzem ao maior acesso da população aos serviços públicos e a ganhos significativos quanto aos graus de cidadania, mediante a concretização, em

atribuições do Ministério da Saúde, assessorado pela Comissão Nacional de Incorporação de Tecnologias no SUS. (...) $\S 2^{\circ} \mathrm{O}$ relatório da Comissão Nacional de Incorporação de Tecnologias no SUS levará em consideração, necessariamente: I - as evidências científicas sobre a eficácia, a acurácia, a efetividade e a segurança do medicamento, produto ou procedimento objeto do processo, acatadas pelo órgão competente para o registro ou a autorização de uso; II - a avaliação econômica comparativa dos benefícios e dos custos em relação às tecnologias já incorporadas, inclusive no que se refere aos atendimentos domiciliar, ambulatorial ou hospitalar, quando cabível."

1091 “Art. 19-R. A incorporação, a exclusão e a alteração a que se refere o art. 19-Q serão efetuadas mediante a instauração de processo administrativo, a ser concluído em prazo não superior a 180 (cento e oitenta) dias, contado da data em que foi protocolado o pedido, admitida a sua prorrogação por 90 (noventa) dias corridos, quando as circunstâncias exigirem. $\S 1^{\circ} \mathrm{O}$ processo de que trata o caput deste artigo observará, no que couber, o disposto na Lei $\mathrm{n}^{\circ}$ 9.784, de 29 de janeiro de 1999, e as seguintes determinações especiais: II realização de consulta pública que inclua a divulgação do parecer emitido pela Comissão Nacional de Incorporação de Tecnologias no SUS;"

1092 MARRARA, Thiago. Direito administrativo e novas tecnologias. In: Revista de Direito Administrativo, v. 256, p. 225-251, 2011. 
favor dos indivíduos, de direitos fundamentais antes irrealizáveis por conta de ausência de informação. O maior acesso aos serviços públicos gera um ciclo virtuoso que estimula a ampliação do controle popular das ações desenvolvidos pelo poder público. ${ }^{1093}$ Aliás, é natural que os indivíduos bem informados sobre seus direitos se conscientizem da noção de interesse público e busquem a contínua melhoria da qualidade dos serviços públicos.

A ampliação da transparência eletrônica é absolutamente pertinente à área da saúde, porque contribui para a efetivação deste direito fundamental, antes obstado por ausência de informação sobre a existência da ação ou do serviço ou das condições necessárias para acessá-lo (inscrição em programa, apresentação de relatório médico etc.). Conquanto o uso de novas tecnologias facilite o acesso à informação, a publicidade e a democratização da Administração Pública, essas novas técnicas não são capazes, por si sós, de garantir esses valores em níveis adequados. É indispensável que a informação eletrônica seja organizada, sem prejuízo da utilização ampla dos mecanismos tradicionais de publicização da informação.

A substituição dos meios tradicionais de divulgação de informações oficiais pelos meios eletrônicos, por ora, não atenderia a finalidade a que se destina, qual seja, o maior alcance da publicidade da atividade administrativa, a transparência e a democratização. Ao contrário, a insuficiente inclusão digital poderia reconduzir a Administração Pública brasileira à nefasta situação de segredo sobre suas atividades, protegida pelo manto da informação eletrônica.

Com efeito, além do baixo grau de inclusão digital da população brasileira, grande parte das pessoas não tem computador em suas residências, não sabe manejar os programas de um computador, não consegue encontrar as informações pesquisadas (o que é corriqueiro em razão da desorganização e da obscuridade dos sites do poder público) ou, se as encontra, não consegue compreendê-las (analfabetismo funcional). É necessário que o Estado assegure meios de ensino das novas tecnologias da comunicação, especialmente para a população mais carente, e ofereça a possibilidade de utilização gratuita de computadores em espaços públicos. Logo, as novas tecnologias devem ser mais uma ferramenta de inclusão dos indivíduos na gestão pública, não sendo possível, por ora,

1093 MARRARA, Thiago. Direito administrativo e novas tecnologias. In: Revista de Direito Administrativo, v. 256, p. 225-251, 2011. 
substituir os meios tradicionais de publicidade da atividade administrativa pela informação eletrônica, sob pena de obstaculizar ou diminuir a necessária transparência. ${ }^{1094}$

Por sua vez, a obrigatoriedade de motivação dos atos administrativos decorre implicitamente da afirmação do Estado Democrático de Direito, previsto no artigo $1^{\circ}$, parágrafo único, da Constituição Federal, segundo o qual todo o poder emana do povo, e do inciso II deste dispositivo, que indica a cidadania como fundamento da República, pois os cidadãos têm o direito de saber as razões da prática do ato. ${ }^{1095}$ A motivação é instrumental ao controle da Administração Pública, pois permite o reconhecimento da congruência da atuação administrativa com os princípios da legalidade, da finalidade, da razoabilidade, da eficiência, dentre outros fixados pela ordem jurídica.

Os fundamentos explícitos do princípio da motivação estão previstos na Constituição Federal, que no Capítulo relativo ao Poder Judiciário, determina aos tribunais o dever de motivação das decisões administrativas (artigo 93, X) ${ }^{1096}$, bem como na Lei n. 9.784/99, que estabelece em seu artigo $2^{\circ}$, caput, a motivação como princípio da Administração Pública ${ }^{1097}$ e no artigo 50 disciplina as hipóteses em que os atos administrativos deverão ser motivados, com a indicação de seus fundamentos de fato e de direito. ${ }^{1098}$ Embora a enumeração da relação dos atos que devem ser motivados seja

1094 Como conclui MARRARA, para que ocorra a efetiva democratização da Administração Pública brasileira, é preciso que as novas tecnologias de informações sejam somadas aos mecanismos tradicionais de publicização, para promover uma efetiva ampliação do acesso dos cidadãos a dados e informações de natureza e relevância públicas. MARRARA, Thiago. Direito administrativo e novas tecnologias. In: Revista de Direito Administrativo, v. 256, p. 225-251, 2011.

1095 MELLO, Celso Antônio Bandeira de. Curso de Direito Administrativo. 27. ed. São Paulo: Malheiros. 2010, p.112-113.

1096 O Título IV da Constituição Federal, relativo à Organização dos Poderes, trata em seu capítulo III do Poder Judiciário, no qual estabelece, dentre outros princípios e regras, o seguinte: “Art. 93. Lei complementar, de iniciativa do Supremo Tribunal Federal, disporá sobre o Estatuto da Magistratura, observados os seguintes princípios: (...) X- as decisões administrativas dos tribunais serão motivadas e em sessão pública, sendo as disciplinares tomadas pelo voto da maioria absoluta de seus membros;"

1097 “Art. 20 A Administração Pública obedecerá, dentre outros, aos princípios da legalidade, finalidade, motivação, razoabilidade, proporcionalidade, moralidade, ampla defesa, contraditório, segurança jurídica, interesse público e eficiência."

1098 “Art. 50. Os atos administrativos deverão ser motivados, com indicação dos fatos e dos fundamentos jurídicos, quando: I - neguem, limitem ou afetem direitos ou interesses; II - imponham ou agravem deveres, encargos ou sanções; III - decidam processos administrativos de concurso ou seleção pública; IV - dispensem ou declarem a inexigibilidade de processo licitatório; V - decidam recursos administrativos; VI - decorram de reexame de ofício; VII - deixem de aplicar jurisprudência firmada sobre a questão ou discrepem de pareceres, laudos, propostas e relatórios oficiais; VIII - importem anulação, revogação, suspensão ou convalidação de ato administrativo. $\S 1^{\circ}$ A motivação deve ser explícita, clara e congruente, podendo consistir em declaração de concordância com fundamentos de anteriores pareceres, informações, decisões ou propostas, que, neste caso, serão parte integrante do ato. $\S 2^{\circ} \mathrm{Na}$ solução de vários assuntos da mesma natureza, pode ser utilizado meio mecânico que reproduza os fundamentos das decisões, desde que não prejudique direito ou garantia dos 
abrangente, conforme alertam FERRAZ e DALLARI, diante dos riscos decorrentes da ausência de motivação, seria melhor afirmar, de vez, a motivação prévia como regra geral, sempre exigível, estabelecendo de forma exemplificativa as exceções, como despachos de mero expediente, simples encaminhamentos, juntadas e outros atos de menor relevância. ${ }^{1099}$

O princípio da motivação descende do princípio democrático e impõe à Administração Pública o dever de expor as razões fáticas e jurídicas pelas quais tomou a providência adotada. São estas razões que irão permitir avaliar a conformidade, ou a desconformidade do ato aos princípios a que deve obediência, sobretudo nos casos em que dispõe de certa discricionariedade administrativa para praticar o ato. ${ }^{1100}$ A motivação deve ser prévia ou concomitante à expedição do ato. Logo, a ausência de motivação faz o ato inválido sempre que sua enunciação prévia ou contemporânea à prática do ato seja requisito para se averiguar as razões do ato. ${ }^{1101}$

Dentre as finalidades da motivação, cumpre destacar as seguintes: a ampliação da segurança do cidadão perante a Administração Pública; a possibilidade de controle da Administração Pública; a permissão de maior participação dos cidadãos no encaminhamento de seus requerimentos, mediante o conhecimento e o juízo crítico sobre os critérios adotados pela Administração na escolha entre uma ou outra das opções contempladas pela lei; a melhoria das relações entre a Administração e os administrados; a garantia de direitos dos administrados; e o convencimento do interessado e da coletividade sobre a legalidade, a conveniência e a oportunidade da decisão.

interessados. $\S 3^{\circ}$ A motivação das decisões de órgãos colegiados e comissões ou de decisões orais constará da respectiva ata ou de termo escrito."

1099 FERRAZ, Sérgio; DALLARI, Adilson Abreu. Processo Administrativo. 2.ed. São Paulo: Malheiros, 2007 , p.78.

1100 MELLO, Celso Antônio Bandeira de. Curso de Direito Administrativo. 27. ed. São Paulo: Malheiros, 2010, p.79-80.

${ }^{1101}$ MELLO explica que nas hipóteses de atos praticados no exercício de competência vinculada em que há aplicação quase automática da lei, em razão de inexistir esfera para a interferência de juízos subjetivos do administrador, a simples referência do fato e da regra de Direito aplicável pode ser suficiente, ante a motivação estar implícita no ato e explícita na lei. Naqueles outros em que há campo de discricionariedade administrativa ou que a prática do ato vinculado depende de ponderação dos fatos e das regras jurídicas aplicáveis é imprescindível motivação detalhada de suas razões. Nesta hipótese, se os atos administrativos forem praticados sem a devida e tempestiva motivação, serão ilegítimos e invalidáveis pelo Poder Judiciário (e pela própria Administração), pois a fundamentação tardia, apresentada depois da impugnação do ato em juízo, não confere segurança e certeza de que os motivos aduzidos efetivamente existiam ou foram aqueles que deram esteio à providência impugnada. MELLO, Celso Antônio Bandeira de. Curso de Direito Administrativo. 27. ed. São Paulo: Malheiros, 2010, p.112-113. 
A motivação ganha relevo como meio de aferir a legitimidade do exercício das funções administrativas, associando-se ao princípio da publicidade, na medida em que a transparência da decisão assegura a participação consciente dos cidadãos na vida democrática, tornando possível o controle social da Administração.

Portanto, a efetiva participação dos cidadãos e dos diversos grupos sociais no processo de manifestação do Poder Público também depende do acesso radical à informação, de forma transparente e com decisão final suficientemente motivada.

\subsubsection{Processo administrativo conforme os princípios do Estado Democrático de Direito}

Além de educação e acesso à informação, a participação popular na Administração Pública não se perfaz sem um processo administrativo ${ }^{1102}$ aberto e transparente, conforme o vetor democrático do Estado. ${ }^{1103}$

No Estado Democrático de Direito o exercício das diversas funções (legislativa, executiva e jurisdicional) exige a observância de processo regulado. $\mathrm{Na}$ função administrativa, o processo permite o equilíbrio entre autoridade e liberdade, como contrapartida assegurada aos particulares pelo fato de serem atingidos por atos unilaterais, condicionando a produção do ato a um processo do qual ele possa participar. ${ }^{104}$

A participação popular no processo administrativo representa verdadeira contraface ao autoritarismo arraigado no Estado brasileiro. ${ }^{1105}$ Mas o caminho de democratização não depende de um processo administrativo que preveja um equilíbrio de faculdades apenas formal entre seus participantes. É imperioso que no próprio núcleo material do processo administrativo se reflitam os propósitos éticos, princípios e valores constitucionais, como

\footnotetext{
1102 Sobre processo administrativo é de rigor citar duas obras específicas que se aprofundam no exame do tema: FERRAZ, Sérgio; DALLARI, Adilson Abreu. Processo Administrativo. 2.ed. São Paulo: Malheiros, 2007; e NOHARA, Irene Patrícia; MARRARA, Thiago. Processo Administrativo: Lei n. 9.784/99 comentada. São Paulo: Atlas, 2009.

1103 Segundo NOHARA, processo administrativo é atividade estatal realizada por intermédio do encadeamento de atos que se direcionam a assegurar, seja no exercício de função administrativa, por todos os Poderes, ou, no caso da Administração Pública, também em função atípica de julgar, a proteção dos direitos dos administrados, que se dá pelo respeito a garantias constitucionais relacionadas com o devido processo legal, o contraditório e a ampla defesa, e o melhor cumprimento dos fins da Administração. NOHARA, Irene Patrícia. Direito Administrativo. 3. ed. São Paulo: Atlas, 2013, p.248-249.

1104 SUNDFELD, Carlos Ari. Fundamentos de Direito Público. 4 ed. 10 tiragem. São Paulo: Malheiros, 2009, p. 89-94.

1105 FERRAZ, Sérgio; DALLARI, Adilson Abreu. Processo Administrativo. 2.ed. São Paulo: Malheiros, 2007, p 22.
} 
um bastião potencial de defesa dos direitos e interesses dos cidadãos. ${ }^{1106}$ Por isso, no processo administrativo devem ser asseguradas ao administrado as mesmas garantias que lhe são deferidas no processo jurisdicional, especialmente, o direito ao contraditório, à prova, ao recurso e à publicidade. ${ }^{1107}$

A Administração está vinculada à lei e ao Direito, como consequência elementar da força normativa da Constituição, na qual estão consagrados os direitos fundamentais. Assim, a atuação administrativa está sujeita à observância de parâmetros legais e de parâmetros axiológicos (princípios e valores constitucionais) ${ }^{108}$, numa perspectiva sistemática do ordenamento jurídico, que transcende o legalismo formal.

A procedimentalização da atividade administrativa é um instrumento essencial para, de um lado, prevenir a arbitrariedade ${ }^{1109} \mathrm{e}$, de outro, apresentar aos cidadãos, não apenas os atos administrativos praticados, mas os meios pelos quais os interesses são sopesados, compostos ou relativizados, constituindo um elemento essencial de legitimação de uma Administração democrática e eficaz. Logo, processo administrativo e democracia estão permanentemente imbricados. ${ }^{1110}$

Mais do que um caminho para a produção dos atos administrativos, atualmente o processo administrativo é um instrumento que apresenta diversas finalidades, das quais destacamos seis, que serão abordadas a seguir: (i) conter o exercício do poder; (ii) facilitar o controle da Administração; (iii) assegurar garantias aos administrados; (iv) viabilizar a participação popular; (v) melhorar o conteúdo das decisões; e (vi) realizar justiça na Administração.

\footnotetext{
${ }^{1106}$ No âmbito da função administrativa, o processo caracteriza-se pela atuação dos interessados, seja ante a própria Administração, seja ante outro sujeito (administrado em geral, licitante, contribuinte, entre outros), em contraditório, confrontando seus direitos em face da Administração Pública. MEDAUAR, Odete. Direito administrativo moderno. 17. ed. São Paulo: Editora Revista dos Tribunais, 2013, p.183.

${ }^{1107}$ De acordo com FERRAZ e DALLARI, o processo administrativo pode ser conceituado como uma série de atos, lógica e juridicamente concatenados, dispostos com o objetivo de ensejar a formação da vontade da Administração. FERRAZ, Sérgio; DALLARI, Adilson Abreu. Processo Administrativo. 2.ed. São Paulo: Malheiros, 2007, p 22.

${ }^{1108}$ SCHMIDT-ASSMANN, Eberhard. La teoría general del derecho administrativo como sistema: objeto y fundamentos de la construcción sistemática. Madrid,Barcelona: INAP-Marcial Pons, 2003, p. 54-58.

${ }^{1109}$ FERRAZ, Sérgio; DALLARI, Adilson Abreu. Processo Administrativo. 2.ed. São Paulo: Malheiros, 2007, p 24.

${ }^{1110}$ Noutro cenário, NOHARA e MARRARA afirmam que uma Administração escastelada em suas certezas, que atua apenas de forma imperativa e unilateral, considerando a coletividade como objeto de suas condutas, tornará impossível que o administrado se conscientize de seu importante papel ativo na transformação político-social. NOHARA, Irene Patrícia; MARRARA, Thiago. Processo Administrativo: Lei n. 9.784/99 comentada. São Paulo: Atlas, 2009, p.6.
} 
O fenômeno da constitucionalização do Direito trouxe reflexos importantes no que diz respeito à incorporação de direitos e garantias fundamentais de matriz processual na Constituição Federal de 1988, como são exemplos, dentre outros, a garantia de acesso à justiça $^{1111}$, algumas ações de origem constitucional ${ }^{1112}$, o direito fundamental à razoável duração do processo ${ }^{1113}$, o devido processo legal ${ }^{1114}$, o contraditório e a ampla defesa ${ }^{1115}$. Estes três últimos direitos fundamentais aplicam-se tanto em processo judicial, quanto em processo administrativo.

O processo administrativo surge como instrumento de contenção e objetivação do poder pessoal das autoridades, pois disciplina e sistematiza a atuação da Administração Pública, protegendo os direitos dos administrados contra a arbitrariedade no exercício da atividade administrativa.

O conhecimento dos meios e dos métodos de atuação administrativa, decorrente de esquema processual uniforme, e a colaboração de sujeitos no processo administrativo facilitam o controle por parte da sociedade do correto desempenho da função administrativa. ${ }^{1116}$ Além disso, a abertura do iter de formação da vontade estatal à participação dos administrados permite a realização de um controle preventivo de legalidade e legitimidade dos atos administrativos.

O processo administrativo é, também, um instrumento de garantia dos administrados de observância dos princípios constitucionais do contraditório e da ampla defesa e dos direitos que o ato pode vir a atingir. Assim, o processo administrativo tem por

\footnotetext{
${ }^{1111}$ Nos termos do artigo $5^{\circ}$, inciso XXXV, da Constituição Federal: "Art. $5^{\circ}$ Todos são iguais perante a lei, sem distinção de qualquer natureza, garantindo-se aos brasileiros e aos estrangeiros residentes no País a inviolabilidade do direito à vida, à liberdade, à igualdade, à segurança e à propriedade, nos termos seguintes: (...) XXXV- a lei não excluirá da apreciação do Poder Judiciário lesão ou ameaça a direito".

${ }^{1112}$ Dentre as ações previstas na Constituição Federal que podem servir como instrumento processual para a tutela de direitos fundamentais vale citar o mandado de segurança individual e coletivo (CF, art. $5^{\circ}$, LXIX e LXX), o mandado de injunção (CF, art. $5^{\circ}$, LXXI), o habeas data (CF, art. $5^{\circ}$, LXXII), a arguição de descumprimento de preceito fundamental $\left(\mathrm{CF}\right.$, art. $\left.102, \S 1^{\circ}\right)$, a ação direta de inconstitucionalidade $(\mathrm{CF}$, art. 102, I, "a") e a ação civil pública (CF, art. 129, III).

${ }^{1113}$ O inciso LXXVIII, do artigo $5^{\circ}$, da Constituição Federal dispõe o seguinte: “Art. $5^{\circ}$ (...) LXXVIII - a todos, no âmbito judicial e administrativo, são assegurados a razoável duração do processo e os meios que garantam a celeridade de sua tramitação."

${ }_{114} \mathrm{O}$ inciso LIV, do art. $5^{\circ}$, da Constituição Federal prescreve o seguinte: "Art. $5^{\circ}$ (...) LIV - ninguém será privado da liberdade ou de seus bens sem o devido processo legal;"

1115 O inciso LV, do art. $5^{\circ}$ da Constituição Federal assim dispõe: "Art. $5^{\circ}$ (...) LV - aos litigantes, em processo judicial ou administrativo, e aos acusados em geral são assegurados o contraditório e ampla defesa, com os meios e recursos a ela inerentes".

${ }^{1116}$ MEDAUAR, Odete. Direito administrativo moderno. 17. ed. São Paulo: Ed. Revista dos Tribunais, 2013, p.185.
} 
finalidade proteger o administrado em face de outros administrados e, sobretudo, da própria Administração. ${ }^{1117}$

O processo administrativo visa, ainda, assegurar a participação popular na construção dos atos administrativos, rompendo com a exclusividade da direção do Estado, que passa a atuar de forma mais condizente com o ideal de democracia participativa, atendendo às exigências pluralistas da sociedade. Com a aproximação entre a Administração e os cidadãos se ampliam os subsídios para a formação da vontade estatal, contribuindo para a otimização das decisões administrativas.

Ademais, outra finalidade do processo administrativo que merece realce é a justiça na Administração, visto que a realização da lei e do Direito não é atributo exclusivo do Judiciário. Enquanto pela função legislativa o Estado edita o direito positivo posterior à Constituição, estabelecendo normas gerais, abstratas e obrigatórias, destinadas a reger a vida coletiva (formação do direito), tanto a função administrativa quanto a função jurisdicional se prendem à fase de realização do direito (execução do direito). ${ }^{118}$

Com efeito, cabe à Administração realizar o direito pela individualização dos preceitos gerais e abstratos, dirigida a concretizar a vontade neles expressa. Esta postura implica em mudanças nas condutas administrativas inertes ou negligentes no atendimento de direitos dos cidadãos. ${ }^{1119}$ Conforme sejam os interesses dos cidadãos tutelados pela ordem jurídica, devem ser reconhecidos pela Administração Pública.

Além disso, o processo administrativo aumenta a possibilidade de se obter uma decisão justa, pois a participação e a cooperação de vários atores sociais anteriormente à tomada de decisão que irá afetá-los propicia a ponderação de interesses envolvidos numa determinada situação.

A cooperação, de modo geral, pode ser definida como prestar ajuda, colaborar, trabalhar em conjunto, apoiar, somar esforços ou dar suporte operacional. No campo do Direito Administrativo e da Administração Pública, interessa diretamente para este trabalho a cooperação na relação entre Poder Público e cidadão. Assim como o cidadão tem o dever de cooperar com a Administração Pública no exercício de suas funções,

${ }^{1117}$ FERRAZ, Sérgio; DALLARI, Adilson Abreu. Processo Administrativo. 2.ed. São Paulo: Malheiros, 2007, p 25-26.

${ }^{1118}$ FAGUNDES, Miguel Seabra. O controle dos atos administrativos pelo Poder Judiciário. 8.ed. atualizada por Gustavo Binenbojm. Rio de Janeiro: Forense, 2010, p.6-14.

${ }^{1119}$ MEDAUAR, Odete. Direito administrativo moderno. 17. ed. São Paulo: Ed. Revista dos Tribunais, 2013, p. 184. 
incumbe à Administração Pública, de ofício, o dever de auxiliar os cidadãos no exercício de seus direitos e no cumprimento de seus deveres. Em relação ao exercício dos direitos, o dever de cooperação importa para a autoridade pública o dever de suprir as dificuldades do indivíduo para o exercício de sua cidadania, oferecendo-lhe todas as informações necessárias acerca dos requisitos e procedimentos, bem como as condições materiais para o devido gozo de direitos. ${ }^{1120}$ Nos termos do que estabelece a Lei de Processo Administrativo federal em seu artigo $3^{\circ}$, inciso I, o administrado tem o direito, perante a Administração Pública, de ser tratado com respeito pelas autoridades e servidores, que deverão facilitar o exercício de seus direitos e o cumprimento de suas obrigações". ${ }^{1121}$

O Estado Democrático impõe uma Administração Pública comprometida com a realização dos interesses públicos legitimamente consagrados na Constituição Federal, o que compreende a cooperação administrativa nas relações entre Administração Pública e cidadão. Somente a atuação administrativa integralmente compatível com os princípios e os valores constitucionais permite que se fale de uma "boa administração". ${ }^{1122}$

A efetiva participação dos indivíduos e grupos sociais no processo administrativo também torna o processo apto à solução dialógica de potenciais conflitos de interesses entre os cidadãos e o Estado, propiciando, por vezes, maior eficiência e justiça na solução dos casos concretos e, sobretudo, maior aceitabilidade.

O processo administrativo serve para disciplinar tanto a emanação de atos de Administração imperativa, quanto a celebração de atos de Administração consensual,

1120 MARRARA afirma que a cooperação consiste em um dos vetores de concretização do princípio da moralidade administrativa, somado à probidade e à razoabilidade. Considera que a cooperação se divide basicamente em três modalidades: a cooperação interna ou intra-administrativa, a cooperação interadministrativa e a cooperação na relação entre Poder Público e cidadão. A cooperação intra-administrativa ou interna consiste naquela que opera no âmbito dos órgãos e entidades públicas. A cooperação interadministrativa, por sua vez, é aquela que envolve duas ou mais instituições públicas de uma ou mais esferas da Federação. A cooperação administrativa na relação entre Administração Pública e cidadão significa que, assim como o cidadão tem o dever de cooperar com a Administração Pública no exercício de suas funções, às autoridades, aos órgãos públicos e às entidades públicas compete a tarefa de auxiliar os cidadãos no exercício de seus direitos e no cumprimento de seus deveres. MARRARA, Thiago. O conteúdo do princípio da moralidade: probidade, razoabilidade e cooperação. In: Princípios de Direito Administrativo: legalidade, segurança jurídica, impessoalidade, publicidade, motivação, eficiência, moralidade, razoabilidade, interesse público. MARRARA, Thiago (organizador). São Paulo: Atlas, p.174-176, 2012.

1121 Nos termos da Lei n. 9.784/99: "Art. $3^{\circ} \mathrm{O}$ administrado tem os seguintes direitos perante a Administração, sem prejuízo de outros que lhe sejam assegurados: I - ser tratado com respeito pelas autoridades e servidores, que deverão facilitar o exercício de seus direitos e o cumprimento de suas obrigações".

1122 MARRARA, Thiago. O conteúdo do princípio da moralidade: probidade, razoabilidade e cooperação. In: Princípios de Direito Administrativo: legalidade, segurança jurídica, impessoalidade, publicidade, motivação, eficiência, moralidade, razoabilidade, interesse público. MARRARA, Thiago (organizador). São Paulo: Atlas, p.177-178, 2012. 
constituindo-se no mecanismo idôneo a conferir transparência, segurança e tratamento isonômico aos administrados.

Cumpre destacar que a exigência de atuação administrativa processualizada vincula-se à cláusula do devido processo legal, previsto no inciso LIV do artigo $5^{\circ}$ da Constituição Federal, ${ }^{1123}$ segundo a qual a realização do processo administrativo, com as garantias do contraditório e da ampla defesa, é obrigatória nos casos de controvérsia e ante a existência de acusados, sem afastar outras aplicações decorrentes deste preceito.

O devido processo legal significa o conjunto de garantias constitucionais que, de um lado, asseguram às partes o exercício de suas faculdades e poderes processuais e, de outro, são indispensáveis ao correto exercício da atuação administrativa processualizada. ${ }^{1124}$

Do devido processo legal decorrem, primordialmente, as garantias do contraditório e da ampla defesa, aplicadas no processo administrativo, conforme o disposto no inciso LV, do artigo $5^{\circ}$, da Constituição Federal: "aos litigantes, em processo judicial ou administrativo, e aos acusados em geral são assegurados o contraditório e ampla defesa, com os meios e recursos a ela inerentes". ${ }^{1125}$ Em relação à Administração, o preceito garante aos litigantes ${ }^{1126}$ em processo administrativo, e aos acusados no âmbito administrativo, em razão da prática de infração administrativa, o contraditório e a ampla

1123 “Art. $5^{\circ}$ Todos são iguais perante a lei, sem distinção de qualquer natureza, garantindo-se aos brasileiros e aos estrangeiros residentes no País a inviolabilidade do direito à vida, à liberdade, à igualdade, à segurança e à propriedade, nos termos seguintes: (...) LIV - ninguém será privado da liberdade ou de seus bens sem o devido processo legal;",

${ }^{1124}$ A Constituição Federal também usa o termo "processo" para outras atuações em âmbito administrativo: no processo de licitação, previsto no artigo 37, inciso XXI, ao estabelecer que “(...) as obras, serviços, compras e alienações serão contratados mediante processo de licitação pública que assegure igualdade de condições a todos os concorrentes (...)"; e no processo disciplinar de servidores públicos que gozem de estabilidade, que somente perderão o cargo "mediante processo administrativo em que lhe seja assegurada ampla defesa“", previsto no inciso II, do parágrafo $1^{\circ}$, do artigo 41 .

1125 Conforme MEDAUAR, o inciso LV do artigo $5^{\circ}$, da Constituição Federal consiste em garantia fundamental, porquanto se destina à tutela de direitos, representa meio para que os direitos dos indivíduos na atuação administrativa sejam preservados, reconhecidos ou cumpridos. Sob o prisma do cidadão, trata-se de direito instrumental. É garantia constitucional individual e coletiva (defesa de interesses difusos, coletivos em sentido estrito e individuais homogêneos). MEDAUAR, Odete. Direito administrativo moderno. 17. ed. São Paulo: Editora Revista dos Tribunais, 2013, p.185-186.

${ }^{1126}$ A análise do inciso LV do artigo $5^{\circ}$ da Constituição também suscita a questão do significado do termo litigantes na perspectiva do processo administrativo. O termo "litigantes" deve ser entendido em sentido amplo: sempre que houver um conflito de interesses, uma controvérsia, sejam situações em que dois ou mais administrados apresentem-se em posição de controvérsia entre si, perante a Administração, que a decidirá, ou casos de controvérsia entre administrados e a Administração. CINTRA, Antônio Carlos de; GRINOVER, Ada Pellegrini; DINAMARCO, Cândido Rangel. Teoria Geral do Processo. 22.ed. São Paulo: Malheiros. 2006. p.148-150. 
defesa, com os meios e recursos a ela inerentes. ${ }^{1127} \mathrm{O}$ contraditório implica na possibilidade de informação e reação, acrescido do direito à ampla defesa, que compreende o direito de participar intensamente do processo: pedir, requerer, impugnar, responder, provar e recorrer. ${ }^{1128}$

Desse modo, a Administração Pública tem o dever jurídico de assegurar no processo administrativo o respeito ao devido processo legal, com todos os seus desdobramentos, sobretudo o contraditório e a ampla defesa. Além disso, conforme MELLO, a Administração Pública deve obediência aos princípios constitucionais expressos e implícitos contidos na Constituição Federal, que informam a interpretação das normas referentes ao processo administrativo. ${ }^{1129}$

$\mathrm{O}$ artigo 37, caput, da Constituição Federal reportou expressamente à Administração Pública direta e indireta apenas cinco princípios: da legalidade, da impessoalidade, da moralidade, da publicidade e da eficiência. Apesar de não mencionados neste dispositivo, a Administração deve obediência a outros princípios, por decorrerem logicamente dos princípios textualmente mencionados ou por serem implicações inerentes ao próprio Estado de Direito e, portanto, do sistema constitucional como um todo.

Assim, a Administração também está sujeita a respeitar o princípio da finalidade, da razoabilidade, da proporcionalidade, da motivação, da moralidade administrativa, da segurança jurídica, da boa administração, do controle judicial dos atos administrativos e da responsabilidade do Estado por atos administrativos. O princípio da supremacia do interesse público sobre o interesse privado é também essencial a qualquer Estado, pois consiste em verdadeiro princípio geral de direito, que apresenta reflexos na esfera administrativa. ${ }^{1130}$

As normas de processo administrativo, que disciplinam o exercício dos poderes administrativos e atribuem direitos e faculdades aos administrados, encerram, inegavelmente, uma limitação do poder pessoal da autoridade. Daí a importância da atuação administrativa processualizada. Como afirma MEDAUAR, a reunião ordenada,

${ }^{1127}$ MEDAUAR, Odete. Direito administrativo moderno. 17. ed. São Paulo: Ed. Revista dos Tribunais, 2013. p. 185.

1128 CINTRA, Antônio Carlos de; GRINOVER, Ada Pellegrini; DINAMARCO, Cândido Rangel. Teoria Geral do Processo. 22.ed. São Paulo: Malheiros. 2006. p.32 e 61-63.

${ }_{129}$ MELLO, Celso Antônio Bandeira de. Curso de Direito Administrativo. 27. ed. São Paulo: Malheiros. 2010 , p.96.

1130 MELLO, Celso Antônio Bandeira de. Curso de Direito Administrativo. 27. ed. São Paulo: Malheiros. 2010, p.95-126. 
num só texto de lei, de preceitos referentes ao processo administrativo é necessária para o tratamento unitário da matéria, a garantia de segurança jurídica e o respeito aos direitos dos administrados. ${ }^{1131}$

No Brasil, somente em 1999 foi editada a primeira lei geral federal de processo administrativo, visando, em especial, a proteção dos direitos dos administrados e o melhor cumprimento dos fins da Administração (artigo $1^{\circ}$, caput). A Lei federal n. 9.784/99 regula o processo administrativo no âmbito da Administração Pública Federal direta e indireta. A lei também se aplica aos órgãos dos Poderes Legislativo e Judiciário da União quando no desempenho de função administrativa (artigo $1^{\circ}$, parágrafo $\left.1^{\circ}\right) .^{1132}$

A Lei federal n. 9.784, de 29 de janeiro de 1999, estabelece os princípios do processo administrativo em seu artigo $2^{\circ}$, e também em preceitos topograficamente disseminados em seu texto. $\mathrm{O}$ artigo $2^{\circ}$ da Lei n. 9.784/99 ${ }^{1133}$ prevê expressamente os princípios da legalidade (parágrafo único, I), da eficiência (parágrafo único, IX e XII), da moralidade (parágrafo único, IV), da publicidade (parágrafo único, V), do contraditório e da ampla defesa (parágrafo único, X), da oficialidade (parágrafo único, XII), da verdade material, e do formalismo moderado (artigo $2^{\circ}$, parágrafo único, IX). ${ }^{1134}$

${ }^{1131}$ MEDAUAR, Odete. Direito administrativo moderno. 17. ed. São Paulo: Editora Revista dos Tribunais, 2013, p. 194-195.

1132 "Art. $1^{\circ}$ Esta Lei estabelece normas básicas sobre o processo administrativo no âmbito da Administração Federal direta e indireta, visando, em especial, à proteção dos direitos dos administrados e ao melhor cumprimento dos fins da Administração. $\S 1^{\circ}$ Os preceitos desta Lei também se aplicam aos órgãos dos Poderes Legislativo e Judiciário da União, quando no desempenho de função administrativa."

1133 “Art. $2^{\circ}$ A Administração Pública obedecerá, dentre outros, aos princípios da legalidade, finalidade, motivação, razoabilidade, proporcionalidade, moralidade, ampla defesa, contraditório, segurança jurídica, interesse público e eficiência. Parágrafo único. Nos processos administrativos serão observados, entre outros, os critérios de: I - atuação conforme a lei e o Direito; II - atendimento a fins de interesse geral, vedada a renúncia total ou parcial de poderes ou competências, salvo autorização em lei; III - objetividade no atendimento do interesse público, vedada a promoção pessoal de agentes ou autoridades; IV - atuação segundo padrões éticos de probidade, decoro e boa-fé; V - divulgação oficial dos atos administrativos, ressalvadas as hipóteses de sigilo previstas na Constituição; VI - adequação entre meios e fins, vedada a imposição de obrigações, restrições e sanções em medida superior àquelas estritamente necessárias ao atendimento do interesse público; VII - indicação dos pressupostos de fato e de direito que determinarem a decisão; VIII - observância das formalidades essenciais à garantia dos direitos dos administrados; IX adoção de formas simples, suficientes para propiciar adequado grau de certeza, segurança e respeito aos direitos dos administrados; X - garantia dos direitos à comunicação, à apresentação de alegações finais, à produção de provas e à interposição de recursos, nos processos de que possam resultar sanções e nas situações de litígio; XI - proibição de cobrança de despesas processuais, ressalvadas as previstas em lei; XII impulsão, de ofício, do processo administrativo, sem prejuízo da atuação dos interessados; XIII interpretação da norma administrativa da forma que melhor garanta o atendimento do fim público a que se dirige, vedada aplicação retroativa de nova interpretação."

${ }^{1134}$ MEDAUAR, Odete. Direito administrativo moderno. 17. ed. São Paulo: Ed. Revista dos Tribunais, 2013, p. 191-192. 
Conforme anteriormente mencionado, a Administração Pública deve obediência a inúmeros outros princípios não consagrados expressamente no artigo 37, caput, ou em outros artigos da Constituição Federal, por serem valores incontestáveis do ordenamento jurídico brasileiro. Neste sentido, o artigo $2^{\circ}$ da Lei n. 9.784/99 prevê, expressamente, alguns princípios que, conquanto não estejam nominalmente referidos na Constituição Federal, encontram-se logicamente abrigados no sistema constitucional, como consequências irrefutáveis dos aludidos princípios, ou como implicações do próprio Estado de Direito. É o que ocorre com os princípios da finalidade (parágrafo único, II), da razoabilidade (parágrafo único, IX), da proporcionalidade (parágrafo único, VI), da segurança jurídica (parágrafo único, IX), e do interesse público (parágrafo único, XIII), Outros princípios expressamente consignados na lei federal fora do catálogo do artigo $2^{\circ}$ são: o da impessoalidade (artigo 18) ${ }^{1135}$ e o da motivação (artigo 50) ${ }^{1136}$. O princípio da impessoalidade consta expressamente no artigo 37, caput, da Constituição Federal, ao passo que o princípio da motivação pode ser considerado como um princípio constitucional implícito.

No Estado de São Paulo foi editada a Lei n. 10.177, de 30 de dezembro de 1998, regulando os processos administrativos no âmbito da Administração Pública estadual que não tenham recebido disciplina legal específica (artigo $1^{\circ}$ ). Tendo em consideração a importância nuclear do tema relativo aos princípios do processo administrativo, esta lei dedicou os artigos $4^{\circ}$ a $6^{\circ}$ (Título II) ${ }^{1137}$ para o tratamento da matéria e também previu outros princípios ao longo do diploma como, por exemplo: o devido processo legal, o contraditório, a ampla defesa, a publicidade, a motivação, a igualdade entre os

1135 “Art. 18. É impedido de atuar em processo administrativo o servidor ou autoridade que: I - tenha interesse direto ou indireto na matéria; II - tenha participado ou venha a participar como perito, testemunha ou representante, ou se tais situações ocorrem quanto ao cônjuge, companheiro ou parente e afins até o terceiro grau; III - esteja litigando judicial ou administrativamente com o interessado ou respectivo cônjuge ou companheiro."

1136 "Art. 50. Os atos administrativos deverão ser motivados, com indicação dos fatos e dos fundamentos jurídicos, quando: I - neguem, limitem ou afetem direitos ou interesses; II - imponham ou agravem deveres, encargos ou sanções; III - decidam processos administrativos de concurso ou seleção pública; IV - dispensem ou declarem a inexigibilidade de processo licitatório; V - decidam recursos administrativos; VI - decorram de reexame de ofício; VII - deixem de aplicar jurisprudência firmada sobre a questão ou discrepem de pareceres, laudos, propostas e relatórios oficiais; VIII - importem anulação, revogação, suspensão ou convalidação de ato administrativo."

1137 "Artigo $4^{\circ}$ - A Administração Pública atuará em obediência aos princípios da legalidade, impessoalidade, moralidade, publicidade, razoabilidade, finalidade, interesse público e motivação dos atos administrativos." "Artigo $5^{\circ}$ - A norma administrativa deve ser interpretada e aplicada da forma que melhor garanta a realização do fim público a que se dirige." Artigo $6^{\circ}$ - Somente a lei poderá: I - criar condicionamentos aos direitos dos particulares ou impor - lhes deveres de qualquer espécie; e II- prever infrações ou prescrever sanções." 
administrados (artigo 22) $)^{1138}$, a eficiência e a oficialidade (artigo 25) ${ }^{1139}$, a segurança jurídica e a participação popular (artigo 29$)^{1140}$ e a proporcionalidade $(\operatorname{artigo} 90)^{1141}$.

Portanto, além da educação e do acesso à informação como condicionantes da participação popular na Administração Pública, é necessário que o processo administrativo seja congruente com os princípios e valores do Estado Democrático de Direito, com o comando normativo nacional ${ }^{1142}$ da Lei n. 9.784/99, e com as regras previstas na lei de processo administrativo do respectivo ente federativo. ${ }^{1143}$

\subsection{Participação popular no Sistema Único de Saúde (SUS)}

A Constituição Federal de 1988 contempla um projeto normativo para a construção de uma sociedade justa, formada por cidadãos livres e solidários (artigo $3^{\circ}$, inciso I). ${ }^{1144}$ Embora atualmente a sociedade seja mais plural, aberta e inclusiva, ainda é profundamente desigual e caracterizada pela baixa intensidade democrática da participação popular na vida política. ${ }^{1145}$

1138 "Artigo 22- Nos procedimentos administrativos observar-se-ão, entre outros requisitos de validade, a igualdade entre os administrados e o devido processo legal, especialmente quanto à exigência de publicidade, do contraditório, da ampla defesa e, quando for o caso, do despacho ou decisão motivados. § $1^{\circ}$ - Para atendimento dos princípios previstos neste artigo, serão assegurados às partes o direito de emitir manifestação, de oferecer provas e acompanhar sua produção, de obter vista e de recorrer. § $2^{\circ}$ - Somente poderão ser recusadas, mediante decisão fundamentada, as provas propostas pelos interessados quando sejam ilícitas, impertinentes, desnecessárias ou protelatórias."

1139 "Artigo 25- Os procedimentos serão impulsionados e instruídos de ofício, atendendo - se à celeridade, economia, simplicidade e utilidade dos trâmites."

1140 "Artigo 29 - Antes da tomada de decisão, a juízo da autoridade, diante da relevância da questão, poderá ser realizada audiência pública para debates sobre a matéria do processo."

1141 "Artigo 90- O descumprimento injustificado, pela Administração, dos prazos previstos nesta lei gera responsabilidade disciplinar, imputável aos agentes públicos encarregados do assunto, não implicando, necessariamente, em nulidade do procedimento."

${ }^{1142}$ FERRAZ, Sérgio; DALLARI, Adilson Abreu. Processo Administrativo. 2.ed. São Paulo: Malheiros, 2007, p.29-30.

${ }^{1143} \mathrm{O}$ artigo 24, inciso XI, da Constituição Federal estabelece a competência legislativa concorrente da União, Estados e Distrito Federal para editar normas sobre "procedimentos em matéria processual", de forma que a competência legislativa em matéria de processo administrativo cabe concorrentemente à União, aos Estados e ao Distrito Federal. Nos termos do parágrafo $1^{\circ}$ deste dispositivo, a competência da União limitarse-á a estabelecer normas gerais, sem excluir a competência suplementar dos Estados (artigo 24, parágrafo $2^{\circ}$ ), os quais exercerão a competência legislativa plena, para atender a suas peculiaridades em caso de inexistência de lei federal sobre normas gerais (artigo 24, parágrafo $3^{\circ}$ ). Caso sobrevenha lei federal sobre normas gerais, a eficácia da lei estadual, no que lhe for contrária, será suspensa (artigo 24, parágrafo $4^{\circ}$ ).

1144 "Art. $3^{\circ}$ Constituem objetivos fundamentais da República Federativa do Brasil: I - construir uma sociedade livre, justa e solidária;"

${ }^{1145}$ Em artigo sobre os 20 (vinte) anos da Constituição Federal de 1988, CLÈVE trata do que ainda está para ser feito: "A tarefa a cumprir nos próximos anos envolve superação progressiva da distância entre a idealidade e a concretude, a promessa e a realização, a norma e a experiência vital. Daí a necessidade de 
A par dos instrumentos de participação popular na Administração Pública vistos no item 4.2, também aplicáveis na área da saúde, neste item serão explicitados os mecanismos institucionalizados na ordem jurídica brasileira para operacionalizar a participação popular na Administração, especificamente na área da saúde. Também serão abordadas as vantagens, dificuldades e insuficiências concretas de efetividade dos instrumentos participativos existentes.

A República Federativa do Brasil foi constituída como Estado Democrático de Direito, no qual todo o poder pertence ao povo. E para exercitá-lo pode agir em nome próprio ou eleger representantes, mas o poder deve ser sempre exercido em seu proveito (artigo $1^{\circ}$, caput, e parágrafo único). A afirmação da cidadania e da dignidade humana como fundamentos do Estado valorizam os cidadãos e a importância da intervenção popular nos processos decisórios estatais. ${ }^{1146} \mathrm{O}$ exercício do poder estatal deve, pois, harmonizar a democracia representativa e participativa.

Na Administração Pública, a participação popular consiste na interferência no processo de realização da função administrativa do Estado, implementada em favor de interesses da coletividade, por cidadão ou representante de grupo social, neste último caso se e enquanto legitimado a agir em nome coletivo. ${ }^{1147}$

A participação administrativa na área da saúde pode ser vista sob duas perspectivas: dos cidadãos, ligada à consagração de direitos fundamentais em sua dimensão ativa (status activus), que não mais se restringe ao direito ao voto, mas abrange também a prerrogativa de participar ativamente nos processos de tomada das decisões políticas e normativas do Estado; e da Administração Pública, concernente ao dever de instituir espaços públicos nos quais possa haver debate acerca da elaboração, execução e controle das políticas públicas de saúde.

políticas públicas, da ação legislativa do Congresso, da atuação do Executivo como amigo da Constituição e das demandas de grande parcela da população que, com a bandeira da Constituição, e não vociferando contra ela, pretende superar sua triste condição, ainda contaminada pela precariedade, pela dependência e pela insuficiência. (...) Se nem tudo são flores, plantamos todos os dias as mudas que desenham e redesenham nosso jardim da democracia." CLÈVE, Clèmerson Merlin. A Constituição completa 20 anos. In: Revista Internacional de Direito e Cidadania, v. 2, p. 45-47, 2009.

1146 “Art. $1^{\circ}$ A República Federativa do Brasil, formada pela união indissolúvel dos Estados e Municípios e do Distrito Federal, constitui-se em Estado Democrático de Direito e tem como fundamentos: (...) II - a cidadania; III - a dignidade da pessoa humana; (...) Parágrafo único. Todo o poder emana do povo, que o exerce por meio de representantes eleitos ou diretamente, nos termos desta Constituição."

${ }^{1147}$ MODESTO, Paulo. Participação popular na Administração Pública: mecanismos de operacionalização. In: Revista Diálogo Jurídico. Salvador: Centro de Atualização Jurídica (CAJ), v.1, n. 7, edição digital, outubro, 2001. Disponível em: <http://www.direitopublico.com.br>. Consulta em 17/12/2013. 
A saúde é um direito com facetas individual e coletiva, que se afirmam por meio de políticas públicas sociais e econômicas, em relação às quais os titulares desse direito podem (e devem) se manifestar, compartilhando as responsabilidades relativas às decisões coletivas relevantes ou de interesse público. Esse processo participativo politiza criticamente todos os planos de ação e exige uma mudança na estrutura das relações entre os cidadãos e a Administração.

A institucionalização jurídica da democracia participativa na área da saúde significa que os espaços públicos devem ser organizados de forma a permitir os influxos comunicativos entre o Estado e a sociedade, num debate permanente acerca da temática relativa à concretização do direito à saúde, necessário à formação racional da vontade coletiva, que torna legítimas as decisões estatais.

A participação na Administração Pública é, ao mesmo tempo, direito e dever do cidadão de colaborar com a Administração na tomada de decisões sobre saúde, configurando, portanto, um "direito-dever". Neste aspecto, merece referência a Declaração de Alma-Ata, de 1978, que afirma o direito e o dever de todos os povos de participarem da elaboração e da execução de políticas públicas de saúde. ${ }^{1148}$

A participação da comunidade foi expressamente prevista como diretriz do Sistema Único de Saúde (SUS), no artigo 198, inciso III, da Constituição Federal. ${ }^{1149}$ Cada um dos poderes constituídos do Estado, no âmbito de suas atribuições, deve zelar para que haja real participação popular na efetivação do direito à saúde: o Poder Legislador, no processo de definição das regras gerais de organização do Sistema Único de Saúde (SUS) e na elaboração de políticas públicas de saúde; o Poder Executivo, na gestão das políticas públicas sanitárias; e o Poder Judiciário, quando provocado, na apreciação e no procedimento de decisão, num caso concreto, sobre o respeito ao direito de participação popular assegurado pela Constituição e pela legislação vigente.

O mandamento constitucional de participação da comunidade no Sistema Único de Saúde é abrangente, tendo se convencionado chamar de "democracia sanitária" o conjunto

1148 Nos termos em que prescreve a Declaração de Alma-Ata: "é direito e dever dos povos participar individual e coletivamente no planejamento e na execução de seus cuidados de saúde" (inciso IV). Esta Declaração também prescreve que os cuidados primários de saúde requerem e promovem a máxima autoconfiança e participação comunitária e individual no planejamento, organização, operação e controle, fazendo o uso mais pleno possível de recursos disponíveis, locais, nacionais e outros, e para esse fim desenvolvem, através da educação apropriada, a capacidade de participação das comunidades (inciso VII, 5). 1149 “Art. 198. As ações e serviços públicos de saúde integram uma rede regionalizada e hierarquizada e constituem um sistema único, organizado de acordo com as seguintes diretrizes: (...) III - participação da comunidade." 
de mecanismos de participação cidadã nas ações estatais voltadas à efetivação do direito à saúde. De acordo com AITH, a participação da comunidade constitui um instrumento que permite uma gestão mais eficiente dos serviços públicos de saúde, o que é fundamental para que estes serviços possam ser aperfeiçoados e para que haja integração da sociedade nos processos de elaboração, planejamento, regulamentação normativa e execução das políticas públicas de saúde. ${ }^{1150}$

Cabe ao Poder Legislativo elaborar políticas públicas de saúde voltadas à promoção, à proteção e à recuperação da saúde, editando leis conforme os princípios e as normas definidas no texto constitucional para a concretização do direito à saúde. Ao Poder Executivo compete a execução das políticas públicas de saúde.

Em casos excepcionais, justificados pela relevância e urgência, o Chefe do Poder Executivo está autorizado a adotar medidas provisórias, com força de lei, devendo submetê-las ao Congresso Nacional de imediato (artigo 62, caput, da Constituição Federal). ${ }^{1151} 1152$ Como a saúde não consta do rol de matérias sobre o qual está expressamente vedada a edição de medidas provisórias (artigo 62, parágrafo $1^{\circ}$, incisos I a IV, da Constituição Federal), é juridicamente viável que, presentes os pressupostos normativos, a política pública de saúde seja não apenas executada, mas também elaborada pelo Poder Executivo, o que restringe a participação popular.

O artigo 200 da Constituição Federal ${ }^{1153}$ estabelece algumas atribuições do Sistema Único de Saúde (SUS), e remete à legislação ordinária o estabelecimento de outras. O

1150 AITH, Fernando. A saúde como direito de todos e dever do Estado: o papel dos Poderes Executivo, Legislativo e Judiciário na efetivação do direito à saúde no Brasil. In: DIREITO SANITÁRIO: Saúde e Direito, um Diálogo Possível. AITH, Fernando; SATURNINO, Luciana Tarbes Mattana; DINIZ, Maria Gabriela Araújo; MONTEIRO, Tammy Claret (organizadores). Belo Horizonte: ESP-MG, 2012, p.82.

1151 “Art. 62. Em caso de relevância e urgência, o Presidente da República poderá adotar medidas provisórias, com força de lei, devendo submetê-las de imediato ao Congresso Nacional."

${ }^{1152}$ A deliberação do plenário de cada uma das Casas do Congresso Nacional sobre o mérito da medida provisória dependerá de um juízo prévio sobre o atendimento de seus pressupostos constitucionais e terá início na Câmara dos Deputados (artigo 62, parágrafos $5^{\circ}$ e $8^{\circ}$, da Constituição Federal). Antes de serem apreciadas pelo plenário de cada uma das Casas do Congresso Nacional, caberá à comissão mista de Deputados e Senadores examinar as medidas provisórias e sobre elas emitir parecer (artigo 62, parágrafo $9^{\circ}$, da Constituição Federal). As medidas provisórias perderão a eficácia desde a edição (ex tunc), se não forem convertidas em lei no prazo de 60 (sessenta) dias, prorrogável uma vez, por igual período, devendo o Congresso Nacional disciplinar, por decreto legislativo, as relações jurídicas delas decorrentes e, se não o fizer no prazo de sessenta dias, após a rejeição ou perda da eficácia, ditas relações jurídicas constituídas e decorrentes de atos praticados durante sua vigência conservar-se-ão por ela regidas. Caso o Congresso Nacional não tenha encerrado a votação da matéria no prazo de 60 (sessenta) dias, ocorre a prorrogação automática deste prazo e, assim, somente se transcorridos 120 (cento e vinte) dias sem a conversão da medida provisória em lei, haverá perda de eficácia da medida provisória (artigo 62, parágrafos $3^{\circ}, 7^{\circ}$ e 11 , da Constituição Federal).

1153 “Art. 200. Ao sistema único de saúde compete, além de outras atribuições, nos termos da lei: (...)” 
artigo 198, incisos I, II e III, da Constituição, por sua vez, prevê que as ações e serviços públicos de saúde integram uma rede regionalizada e hierarquizada, formando um sistema único, a ser organizado, por lei ordinária, conforme as diretrizes de descentralização, atendimento integral e participação da comunidade. ${ }^{1154}$

No plano infraconstitucional, a Lei n. 8.080, de 19 de setembro de 1990, com fundamento na norma constitucional contida no artigo 198, inciso III, afirma a participação da comunidade como princípio do Sistema Único de Saúde (artigo $7^{\circ}$, inciso VIII). ${ }^{1155}$ Além disso, determina a criação de comissões intersetoriais subordinadas ao Conselho Nacional de Saúde e formadas por Ministérios, órgãos e entidades representativas da sociedade civil, com a finalidade de articular políticas e programas de interesse para a saúde, mas cuja execução não esteja compreendida no âmbito do SUS (artigo 12). ${ }^{1156} 1157$

A Lei n. 8.080, de 19 de setembro de 1990, com a redação incluída pela Lei n. 12.401, de 28 de abril de 2011, instituiu outros instrumentos participativos na Administração, que se referem ao processo de incorporação de tecnologia em saúde no Sistema Único de Saúde.

É atribuição do Ministério da Saúde, assessorado pela Comissão Nacional de Incorporação de Tecnologias no SUS, incorporar, excluir ou alterar novos medicamentos, produtos e procedimentos ${ }^{1158}$, o que deve ser feito mediante processo administrativo, a ser concluído em até cento e oitenta dias, contados da data do protocolo do pedido, admitindo-

\footnotetext{
1154 “Art. 198. As ações e serviços públicos de saúde integram uma rede regionalizada e hierarquizada e constituem um sistema único, organizado de acordo com as seguintes diretrizes: I - descentralização, com direção única em cada esfera de governo; II - atendimento integral, com prioridade para as atividades preventivas, sem prejuízo dos serviços assistenciais; III - participação da comunidade."

1155 “Art. $7^{\circ}$ As ações e serviços públicos de saúde e os serviços privados contratados ou conveniados que integram o Sistema Único de Saúde (SUS), são desenvolvidos de acordo com as diretrizes previstas no art. 198 da Constituição Federal, obedecendo ainda aos seguintes princípios: (...) VIII - participação da comunidade;"

1156 “Art. 12. Serão criadas comissões intersetoriais de âmbito nacional, subordinadas ao Conselho Nacional de Saúde, integradas pelos Ministérios e órgãos competentes e por entidades representativas da sociedade civil. Parágrafo único. As comissões intersetoriais terão a finalidade de articular políticas e programas de interesse para a saúde, cuja execução envolva áreas não compreendidas no âmbito do Sistema Único de Saúde (SUS)."

${ }^{1157} \mathrm{O}$ artigo 11 e parágrafos da Lei n. 8.080/90, que disciplinavam a participação da comunidade no Sistema Único de Saúde, foram objeto de veto pelo Presidente da República Fernando Collor de Mello.

1158 “Art. 19-Q. A incorporação, a exclusão ou a alteração pelo SUS de novos medicamentos, produtos e procedimentos, bem como a constituição ou a alteração de protocolo clínico ou de diretriz terapêutica, são atribuições do Ministério da Saúde, assessorado pela Comissão Nacional de Incorporação de Tecnologias no SUS. $\S 1^{\circ}$ A Comissão Nacional de Incorporação de Tecnologias no SUS, cuja composição e regimento são definidos em regulamento, contará com a participação de 1 (um) representante indicado pelo Conselho Nacional de Saúde e de 1 (um) representante, especialista na área, indicado pelo Conselho Federal de Medicina."
} 
se a prorrogação deste prazo por noventa dias corridos, nos casos em que as circunstâncias exigirem. O processo administrativo observará, subsidiariamente, o disposto na Lei de Processo Administrativo federal (Lei n. 9.784/99) e as seguintes determinações especiais: (i) a apresentação pelo interessado de documentos e, se cabível, das amostras de produtos, na forma do regulamento, com informações necessárias para a avaliação econômica comparativa dos benefícios e dos custos em relação às tecnologias já incorporadas; (ii) a realização de consulta pública, precedida da divulgação do parecer emitido pela Comissão Nacional de Incorporação de Tecnologias no Sistema Único de Saúde (SUS); e (iii) a realização de audiência pública, previamente à tomada de decisão, em caso de matéria relevante (artigo 19-R, parágrafo $1^{\text {o }}$, incisos I, III e IV). ${ }^{1159}$

As três novas formas de participação administrativa consistem em instrumentos pró-consensuais procedimentais. No primeiro caso, a participação popular na Administração Pública é direta, ao passo que no segundo e no terceiro é indireta, pois será feita por intermédio de um representante do administrado ou de um grupo de administrados.

A apresentação pelo interessado ${ }^{1160}$, pessoa física ou jurídica, de documentos e, se for o caso, de produtos que permitam analisar, de forma comparativa, os benefícios e os custos de tecnologias já incorporadas ao Sistema Único de Saúde (SUS) em relação a novos medicamentos, produtos e procedimentos, é relevante do ponto de vista da efetividade que possuem e dos recursos públicos a serem dispendidos. A decisão irá gerar reflexos sobre o conteúdo das ações e serviços públicos de saúde no âmbito do Sistema

1159 “Art. 19-R. A incorporação, a exclusão e a alteração a que se refere o art. 19-Q serão efetuadas mediante a instauração de processo administrativo, a ser concluído em prazo não superior a 180 (cento e oitenta) dias, contado da data em que foi protocolado o pedido, admitida a sua prorrogação por 90 (noventa) dias corridos, quando as circunstâncias exigirem. $\S 1^{\circ} \mathrm{O}$ processo de que trata o caput deste artigo observará, no que couber, o disposto na Lei $\mathrm{n}^{\circ}$ 9.784, de 29 de janeiro de 1999, e as seguintes determinações especiais: I apresentação pelo interessado dos documentos e, se cabível, das amostras de produtos, na forma do regulamento, com informações necessárias para o atendimento do disposto no $§ 2^{\circ}$ do art. 19-Q; II - (vetado); III - realização de consulta pública que inclua a divulgação do parecer emitido pela Comissão Nacional de Incorporação de Tecnologias no SUS; IV - realização de audiência pública, antes da tomada de decisão, se a relevância da matéria justificar o evento."

${ }^{1160}$ A possibilidade de participação a que se refere o artigo 19-R, parágrafo $1^{\circ}$, inciso I, não se restringe àquelas pessoas físicas ou jurídicas detentoras de direitos ou interesses objetos do processo, como prevê o artigo 10, da Lei n. 9.784/99, por três razões fundamentais: primeiro, a finalidade da norma é que a participação popular traga novos elementos de convicção para a Comissão Nacional de Incorporação de Tecnologias no Sistema Único de Saúde (SUS), o que ficaria prejudicado se fosse limitado àqueles que detêm interesse objeto do processo; segundo, porque a decisão a ser tomada pela Administração é de interesse público e a titularidade do direito à saúde é de todos; terceiro, porque a aplicação da Lei n. 9.784/99 ao processo administrativo e a incorporação de novas tecnologias em saúde é subsidiária, naquilo que for compatível, sendo descabida no presente caso. 
Único de Saúde (SUS), o que está imbricado ao acesso igualitário às ações e serviços públicos de saúde oferecidos, de forma democrática. Neste caso, a participação permite que a Administração recolha subsídios, especialmente de caráter técnico, que permitam a tomada de uma decisão mais adequada.

Não basta que a indústria farmacêutica desenvolva medicamentos, produtos e procedimentos, em geral com custo mais elevado, para que sejam incorporados no âmbito do Sistema Único de Saúde. É necessário que sejam comprovadas a segurança, a eficácia e a efetividade, conforme critérios técnicos cientificamente reconhecidos, e que apresentem custo menor do que as tecnologias já incorporadas ou que, apesar de terem custo maior, tragam mais benefícios aos usuários, sendo necessário realizar um estudo de avaliação econômica (análise de custo-utilidade) pela Comissão Nacional de Incorporação de Tecnologias no Sistema Único de Saúde (SUS). ${ }^{1161}$

O segundo mecanismo de participação administrativa é a consulta pública, que à evidência, consiste em etapa prévia à decisão, que deverá, inclusive, considerar as manifestações e os argumentos nela expendidos. A lei prevê uma condicionante à realização da consulta pública: a divulgação prévia do parecer emitido pela Comissão Nacional de Incorporação de Tecnologias no Sistema Único de Saúde (SUS), que, como opinião técnica sobre a matéria, fixa balizas às manifestações dos interessados. A norma não estabelece os casos em que a realização da consulta pública tem caráter de obrigatoriedade, devendo ser aplicado, de forma subsidiária, o disposto na Lei n. 9.784/99, especialmente o artigo 31, que faculta a realização de consulta pública quando a matéria objeto do processo for de interesse geral. Tanto a decisão pela realização da consulta pública quanto pela sua não-realização, quando houver interesse geral em discussão, deverão ser motivadas.

O terceiro mecanismo de participação é a audiência pública, cabível anteriormente à tomada de decisão em caso de matéria relevante. No mesmo sentido da consulta pública,

1161 “Art. 19-Q. A incorporação, a exclusão ou a alteração pelo SUS de novos medicamentos, produtos e procedimentos, bem como a constituição ou a alteração de protocolo clínico ou de diretriz terapêutica, são atribuições do Ministério da Saúde, assessorado pela Comissão Nacional de Incorporação de Tecnologias no SUS. (...) § $2^{\circ} \mathrm{O}$ relatório da Comissão Nacional de Incorporação de Tecnologias no SUS levará em consideração, necessariamente: I - as evidências científicas sobre a eficácia, a acurácia, a efetividade e a segurança do medicamento, produto ou procedimento objeto do processo, acatadas pelo órgão competente para o registro ou a autorização de uso; II - a avaliação econômica comparativa dos benefícios e dos custos em relação às tecnologias já incorporadas, inclusive no que se refere aos atendimentos domiciliar, ambulatorial ou hospitalar, quando cabível." 
a audiência pública tem o propósito de obter maior publicidade e participação. ${ }^{1162}$ Ao procedimento da audiência pública aplica-se, subsidiariamente, o disposto na Lei $\mathrm{n}$. 9.784/99, especialmente no artigo 32.

Tendo em vista a regulamentação da participação popular na gestão do Sistema Único de Saúde (SUS), no exercício da competência legislativa concorrente prevista no artigo 24, inciso XII, e parágrafo $1^{\mathrm{o} 1163}$, da Constituição Federal, a União editou a Lei $\mathrm{n}$. 8.142, de 28 de dezembro de 1990. Em consequência disso, as normas gerais (princípios e diretrizes) contidas nesta lei nacional são de observância obrigatória não apenas pela União, mas também pelos Estados, Distrito Federal e Municípios. As legislações estaduais que venham a regulamentar o sistema de saúde no âmbito de suas respectivas entidades federativas, não podem restringir o direito à participação da comunidade. ${ }^{1164}$

Ao dever objetivo do Estado (União, Estados, Distrito Federal e Municípios) de criar sistemas de regras, com o fim de respeitar a participação popular no Sistema Único de Saúde (SUS), corresponde um direito subjetivo dos indivíduos aos instrumentos participativos previstos na Lei n. 8.142, de 28 de dezembro de 1990. É o direito à organização e ao procedimento, definido por ALEXY como direito à criação de normas, de forma que o resultado seja, com suficiente probabilidade e em suficiente medida, congruente à realização do direito ${ }^{1165}$, no caso, o direito à participação administrativa. ${ }^{1166}$

A Lei n. 8.142, de 28 de dezembro de 1990 assegura a participação da comunidade na gestão do Sistema Único de Saúde, por intermédio de duas instâncias colegiadas em

1162 FERRAZ, Sérgio; DALLARI, Adilson Abreu. Processo Administrativo. 2.ed. São Paulo: Malheiros, 2007, p. 181.

1163 “Art. 24. Compete à União, aos Estados e ao Distrito Federal legislar concorrentemente sobre: (...) XII previdência social, proteção e defesa da saúde; (...) $\S 1^{\circ}$ - No âmbito da legislação concorrente, a competência da União limitar-se-á a estabelecer normas gerais."

1164 Neste sentido: DALLARI, Sueli Gandolfi. Os estados brasileiros e o direito à saúde. São Paulo: HUCITEC, 1995, p.85-86.

1165 ALEXY, Robert. Teoria dos direitos fundamentais. Tradução de Virgílio Afonso da Silva. 2.ed. São Paulo: Malheiros, 2012, p.472-474.

${ }^{1166}$ De acordo com AITH, "as políticas de saúde e a prestação de serviços públicos de saúde devem sempre considerar, como diretriz básica, a necessidade de se institucionalizar mecanismos e procedimentos efetivos de participação da comunidade. A diretriz da participação da comunidade no âmbito do Estado Democrático de Direito brasileiro impõe uma gestão participativa na elaboração e definição da política de saúde, como na execução e controle dos serviços públicos de saúde". AITH, Fernando. A saúde como direito de todos e dever do Estado: o papel dos Poderes Executivo, Legislativo e Judiciário na efetivação do direito à saúde no Brasil. In: Direito Sanitário: Saúde e Direito, um Diálogo Possível. AITH, Fernando; SATURNINO, Luciana Tarbes Mattana; DINIZ, Maria Gabriela Araújo; MONTEIRO, Tammy Claret (organizadores). Belo Horizonte: ESP-MG, p. 82, 2012. 
cada uma das esferas da Federação: a Conferência de Saúde; e o Conselho de Saúde (artigo $1^{\mathrm{o}}$, incisos I e II). ${ }^{1167}$

As Conferências de Saúde são instâncias colegiadas, formadas por representantes de diversos segmentos sociais, visando avaliar a situação de saúde e propor diretrizes para a formulação da política de saúde nos níveis correspondentes. As Conferências de Saúde devem se reunir a cada quatro anos, sendo convocadas, de forma ordinária, pelo Poder Executivo ou, extraordinariamente, pela própria Conferência ou Conselho de Saúde (artigo $1^{\circ}$, parágrafo $1^{\circ}$ da Lei n. 8.142 , de 28 de dezembro de 1990). ${ }^{1168}$

Embora as Conferências Nacionais de Saúde existam desde os anos $40^{1169}$ do século vinte, somente a partir da Constituição Federal de 1988 passaram a assumir o caráter de espaço público que apresentam atualmente. Desde então, foram elaboradas seis Conferências Nacionais de Saúde: a 9a (1992), a 10ª (1996), a $11^{\mathrm{a}}$ (2000), a $12^{\mathrm{a}}$ (2003), a $13^{\mathrm{a}}$ (2007) e a 14 ${ }^{\mathrm{a}}$ (2011). Da $9^{\mathrm{a}}$ Conferência Nacional de Saúde o tema foi "Municipalização é o caminho". Da 10a " "Construção do modelo de atenção à saúde". Da 11'a "Efetivando o SUS: acesso, qualidade e humanização na atenção à saúde com controle

1167 “Art. $1^{\circ}$ O Sistema Único de Saúde (SUS), de que trata Lei n. 8.080, de 19 de setembro de 1990, contará, em cada esfera de governo, sem prejuízo das funções do Poder Legislativo, com as seguintes instâncias colegiadas: I - a Conferência de Saúde; e II - o Conselho de Saúde."

1168 “Art. $1^{\circ}(\ldots) \S 1^{\circ}$ A Conferência de Saúde reunir-se-á a cada quatro anos com a representação dos vários segmentos sociais, para avaliar a situação de saúde e propor as diretrizes para a formulação da política de saúde nos níveis correspondentes, convocada pelo Poder Executivo ou, extraordinariamente, por esta ou pelo Conselho de Saúde."

${ }_{1169}$ A $1^{\text {a }}$ Conferência Nacional de Saúde foi realizada em novembro de 1941, proposta por Gustavo Capanema com temática relativa à gestão e à administração dos serviços de saúde, à época em que os setores de educação e saúde eram de responsabilidade de um mesmo Ministério, o Ministério de Educação e Saúde (MES). As conferências subsequentes também refletiram a conjuntura histórica. Apesar da determinação legal de convocação a cada dois anos, a $2^{\mathrm{a}}$ Conferência Nacional de Saúde foi realizada apenas em 1950, no final do Governo Dutra, com o tema "Pontos de vista dominantes entre os Sanitaristas". A $3^{\text {a }}$ Conferência Nacional de Saúde ocorreu somente em 1963, formada por representantes do governo e voltada a analisar a situação sanitária e a reorganização do sistema de saúde. O golpe militar de 1964 inviabilizou a implementação das medidas propostas pela $3^{\mathrm{a}}$ conferência, mas suas deliberações estimularam os debates realizados por movimentos sociais a partir da década de 1970. A $4^{a}$ Conferência Nacional de Saúde, em 1967, a $5^{\text {a }}$ Conferência Nacional de Saúde, em 1975, a $6^{\text {a }}$ Conferência Nacional de Saúde, em 1977, e a $7^{\text {a }}$ Conferência Nacional de Saúde, em 1979, foram realizadas durante o regime militar, retomando o caráter de espaço de debate técnico, com a participação de especialistas nos temas debatidos e autoridades do Ministério da Saúde, do Ministério da Previdência Social e Assistência Social (MPAS) e dos estados e territórios. A $8^{\text {a }}$ Conferência Nacional de Saúde, conforme visto alhures, realizada em 1986, no período da Nova República, atende às necessidades expressadas pelos movimentos sociais de abertura do processo no espaço público, definindo os contornos das mudanças ao ampliar o espectro de atores envolvidos e explicitando em seu relatório as diretrizes para a reorganização do sistema. O temário da $8^{a}$ Conferência Nacional de Saúde abrangia os seguintes temas: saúde como direito; reformulação do Sistema Nacional de Saúde; e financiamento do setor. Os objetivos políticos de universalização do acesso à saúde e as diretrizes para a reorganização do sistema, previstos no relatório desta conferência, foram alcançados com a promulgação da Constituição Federal de 1988. BRASIL. Conselho Nacional de Secretários de Saúde. As Conferências Nacionais de Saúde: Evolução e perspectivas. Brasília: CONASS, 2009, p. 8-19. 
social". Da 12a "Saúde um direito de todos e um dever do Estado: a saúde que temos, o SUS que queremos". Da 13", "Políticas de Estado e desenvolvimento". E, da 14", "Todos usam o SUS! SUS na Seguridade Social - Política pública, patrimônio do povo brasileiro.”

Os Conselhos de Saúde consistem em órgãos colegiados, de caráter permanente e deliberativo, integrados por representantes do governo, dos prestadores de serviço, dos profissionais de saúde e dos usuários. Devem atuar na elaboração de estratégias e no controle da execução da política de saúde na instância correspondente, inclusive nos aspectos econômicos e financeiros. As decisões do Conselho de Saúde devem ser homologadas pelo chefe do Poder Executivo constituído em cada esfera do governo (artigo $1^{\circ}$, parágrafo $2^{\circ}$, da Lei n. 8.142, de 28 de dezembro de 1990). ${ }^{1170}$ A capacidade deliberativa dos conselhos é reduzida porque deve ser desenvolvida sem trazer prejuízo às funções do Poder Legislativo, com base na manutenção da separação e na harmonia entre os Poderes. ${ }^{1171}$

Os conselhos são instâncias de ação política na área da saúde, responsáveis pela articulação de ações estatais por meio do exercício da cidadania de diversos atores sociais, com o propósito de ampliar a participação popular e o controle da sociedade na gestão do Sistema Único de Saúde.

Tanto nos conselhos de saúde, quanto nas conferências de saúde a representação dos usuários será paritária em relação ao conjunto dos demais segmentos ${ }^{1172}$, garantindo que os usuários efetivamente tenham voz ativa nessas instâncias colegiadas, participando como atores e beneficiários das decisões estatais sobre políticas públicas de saúde (artigo $1^{\circ}$, parágrafo $4^{\circ}$ da Lei n. 8.142 , de 28 de dezembro de 1990). ${ }^{1173}$

As conferências e os conselhos de saúde consistem em instrumentos próconsensuais orgânicos, em que a participação popular é indireta, pois quem participa dos

1170 “Art. $1^{\circ}(\ldots) \S 2^{\circ} \mathrm{O}$ Conselho de Saúde, em caráter permanente e deliberativo, órgão colegiado composto por representantes do governo, prestadores de serviço, profissionais de saúde e usuários, atua na formulação de estratégias e no controle da execução da política de saúde na instância correspondente, inclusive nos aspectos econômicos e financeiros, cujas decisões serão homologadas pelo chefe do poder legalmente constituído em cada esfera do governo."

1171 Nos termos do artigo $2^{\circ}$ da Constituição Federal: “Art. $2^{\circ}$ São Poderes da União, independentes e harmônicos entre si, o Legislativo, o Executivo e o Judiciário".

1172 Os conselhos e as conferências de saúde se estruturaram pela participação plural definida na lei, com a garantia de participação de $50 \%$ de usuários e os outros $50 \%$ formados por gestores, prestadores de serviços e trabalhadores da área da saúde. FALEIROS, Vicente de Paula; SILVA, Jacinta de Fátima Senna; VASCONCELLOS, Luiz Carlos Fadel de; e SILVEIRA, Rosa Maria Godoy. A construção do SUS: histórias da Reforma Sanitária e do Processo Participativo. Brasília: Ministério da Saúde, 2006, p.21.

1173 “Art. $1^{\circ}(\ldots) \S 4^{\circ}$ A representação dos usuários nos Conselhos de Saúde e Conferências será paritária em relação ao conjunto dos demais segmentos." 
conselhos e das conferências de saúde são representantes dos usuários, ou seja, intermediários entre os cidadãos e a Administração. As normas de organização e funcionamento das conferências de saúde e dos conselhos de saúde serão definidas em regimento próprio, aprovadas pelo respectivo conselho (artigo $1^{\circ}$, parágrafo $5^{\circ}$, da Lei $n$. 8.142 , de 28 de dezembro de 1990). ${ }^{1174}$

O Conselho Nacional de Saúde, disciplinado pelo Decreto n. 5.839, de 11 de julho de 2006, é definido como órgão colegiado de caráter permanente e deliberativo, integrante da estrutura regimental do Ministério da Saúde, composto por representantes do governo, prestadores de serviço, profissionais de saúde e usuários, cujas decisões, consubstanciadas em resoluções, são homologadas pelo Ministro de Estado da Saúde (artigo $1^{\circ}$ ). É formado por quarenta e oito membros titulares, sendo cinquenta por cento de representantes de entidades e movimentos sociais de usuários do SUS; e cinquenta por cento de representantes de entidades de profissionais de saúde, representantes do governo, entidades de prestadores de serviços de saúde, do Conselho Nacional de Secretários de Saúde - CONASS, do Conselho Nacional de Secretários Municipais de Saúde - CONASEMS e de entidades empresariais com atividade na área de saúde $\left(\operatorname{artigo} 3^{\circ}\right) .{ }^{1175}$

O Decreto n. 5.839, de 11 de julho de 2006, estabelece o sistema eleitoral como forma para a escolha das entidades de usuários do Sistema Único de Saúde (SUS), das entidades de profissionais de saúde, da comunidade científica da área de saúde, das entidades de prestadores de serviços de saúde e das entidades empresariais com atividades na área de saúde que indicarão seus representantes para compor o Conselho Nacional de Saúde (artigo $4^{\circ}$ ). Ademais, prescreve regras para a eleição do Presidente do Conselho Nacional de Saúde (CNS), fixa ser de três anos o mandato de seus membros, permitida uma recondução $\left(\operatorname{artigos} 6^{\circ}\right.$ e $\left.7^{\circ}\right)$.

\footnotetext{
1174 “Art. $1^{\circ}(\ldots) \S 5^{\circ}$ As Conferências de Saúde e os Conselhos de Saúde terão sua organização e normas de funcionamento definidas em regimento próprio, aprovadas pelo respectivo conselho."

${ }^{1175}$ Nos termos do artigo $2^{\circ}$, do Decreto n. 5.839, de 11 de julho de 2006, o Conselho Nacional de Saúde tem competência para, dentre outras atividades: (i) atuar na formulação de estratégias e no controle da execução da Política Nacional de Saúde, na esfera do Governo Federal, inclusive nos aspectos econômicos e financeiros; (ii) estabelecer diretrizes a serem observadas na elaboração dos planos de saúde; (iii) elaborar cronograma de transferência de recursos financeiros aos Estados, ao Distrito Federal e aos Municípios, consignados ao Sistema Único de Saúde - SUS; (iv) - aprovar os critérios e os valores para remuneração de serviços e os parâmetros de cobertura de assistência; e (v) articular-se com o Ministério da Educação quanto à criação de novos cursos de ensino superior na área de saúde, no que concerne à caracterização das necessidades sociais.
} 
A estrutura do Conselho Nacional de Saúde (CNS) é reproduzida nos Estados e Municípios para que, como instrumentos democráticos participativos, sejam eficazes na elaboração, no acompanhamento da execução e na fiscalização do cumprimento das políticas públicas de saúde.

Os Conselhos Municipais de Saúde, os Conselhos Estaduais de Saúde e o Conselho Nacional de Saúde são centros de deliberação que viabilizam a manifestação de interesses e a participação dos cidadãos, por intermédio de representantes, nas discussões sobre a atuação do Estado, pressionando-o e fiscalizando-o. FALEIROS et al afirmam que as reuniões plenárias dos conselhos são canais que permitem a troca de experiências sobre a efetividade das ações e serviços de saúde em cada região e a realização do difícil processo de mediação entre Estado, sociedade e grupos de interesses ${ }^{1176}$. Afinal, estes órgãos colegiados atuam na formulação de estratégias e no controle da execução da política de saúde na instância correspondente, deliberando inclusive sobre os aspectos econômicos e financeiros.

Atualmente, consoante ALMEIDA, também se tem atribuído ao federalismo a função de garantir a democracia participativa, com a criação de múltiplos círculos de decisões políticas, nos quais o cidadão fica mais próximo do poder. ${ }^{177} \mathrm{Na}$ área da saúde, a descentralização permite que o sistema de participação popular seja amplo e capilarizado.

FALEIROS et al consideram que o movimento social unificado entre o local (municipal/regional), estadual e nacional torna viável a mediação dos interesses. A descentralização permite a consideração das particularidades municipais e estaduais e, ainda, a articulação de políticas nacionalmente integradas pelo Conselho Nacional de Saúde, a partir das fórmulas negociadas pelos movimentos sociais, e não apenas por técnicos e políticos. ${ }^{1178} 1179$

${ }^{1176}$ FALEIROS, Vicente de Paula; SILVA, Jacinta de Fátima Senna; VASCONCELLOS, Luiz Carlos Fadel de; e SILVEIRA, Rosa Maria Godoy. A construção do SUS: histórias da Reforma Sanitária e do Processo Participativo. Brasília: Ministério da Saúde, 2006, p.19-21.

1177 ALMEIDA, Fernanda Dias Menezes de. Competências na Constituição de 1988. 3 ed. São Paulo: Atlas, 2005, p. 44.

1178 A descentralização da gestão é condicionada por fatores de três ordens: (i) estrutural, abrangente da capacidade de gasto ou capacidade político-administrativa; (ii) institucional, relativa à força das instituições envolvidas nas políticas e programas; e (iii) de ação política, que compreende as relações entre os vários níveis de governo e as relações entre Estados e Municípios. É também necessário que haja um regime de colaboração entre os entes federativos para a compatibilização em termos de diretrizes, recursos orçamentários e gestão, garantindo-se maior eficácia na elaboração e execução das políticas públicas e na fiscalização de seu cumprimento. FALEIROS, Vicente de Paula; SILVA, Jacinta de Fátima Senna; 
A participação social na Administração compreende um conjunto de estratégias e operações de acompanhamento da formulação, gestão e execução de políticas públicas por parte da sociedade, consolidando a democracia participativa ao lado da democracia representativa burocrática. ${ }^{1180}$

A função estatal de dirimir controvérsias na esfera administrativa no contexto do Estado contemporâneo exige um novo estilo de agir da Administração Pública, centrado na paridade jurídica com os cidadãos, no estabelecimento de reciprocidade e na criação de instituições com o escopo de concretizar direitos dos administrados. As relações entre Administração e os cidadãos estabelecem um novo paradigma que valoriza a presença destes como interlocutores e destinatários da ação administrativa, chamando-os a com ela colaborar. ${ }^{1181}$

Ao Estado compete não apenas instituir e conferir eficácia aos canais de participação e interlocução com os indivíduos que participam dessas instâncias colegiadas, mas também manter com eles constante interação, formando vínculos firmes e duradouros. ${ }^{1182}$ Tais vínculos são considerados indispensáveis para atribuir legitimidade e efetividade às ações estatais, que vêm sendo amplamente desenvolvidas em espaços públicos de contínua interseção entre Estado e comunidade.

VASCONCELLOS, Luiz Carlos Fadel de; e SILVEIRA, Rosa Maria Godoy. A construção do SUS: histórias da Reforma Sanitária e do Processo Participativo. Brasília: Ministério da Saúde, 2006, p.26-27.

1179 A disseminação dos conselhos e conferências de saúde nas esferas estadual, municipal e distrital foi viabilizada devido à vinculação ao repasse de recursos federais, que a Lei n. 8.142, de 28 de dezembro de 1990, determina seja feito de forma regular e automática aos Estados, Distrito Federal e Municípios (artigos $3^{\circ}$ da Lei n. 8.142/90 e artigo 35 da Lei n. 8.080/90).

1180 FALEIROS et al observam que o controle social não se limita aos espaços públicos dos conselhos de saúde, mas também influi nos orçamentos, em um conjunto de articulações e movimentos que constroem novas agendas para os Poderes Executivo e Legislativo, mobilizando a sociedade nas várias conferências, em todos os níveis de governo, da base para o vértice. FALEIROS, Vicente de Paula; SILVA, Jacinta de Fátima Senna; VASCONCELLOS, Luiz Carlos Fadel de; e SILVEIRA, Rosa Maria Godoy. A construção do SUS: histórias da Reforma Sanitária e do Processo Participativo. Brasília: Ministério da Saúde, 2006, p.22-23.

${ }^{1181}$ MONCADA afirma que a paridade jurídica entre a Administração Pública e os particulares significa que a Administração, tal como estes, fica sujeita à observância da Constituição, das leis e a certos princípios de caráter axiológico, quais sejam, os da igualdade, da proporcionalidade, da justiça, da imparcialidade e da boa fé. Esta relação de tendencial igualdade decorre do reconhecimento dos cidadãos como titulares de direitos fundamentais, com aplicabilidade direta e imediata para além de consagrados. MONCADA, Luís S. Cabral de. A relação jurídica administrativa: para um novo paradigma de compreensão da atividade, da organização e do contencioso administrativo. Coimbra: Coimbra Editora, p. 21-23 e 74, 2009.

1182 OLIVEIRA, Gustavo Henrique Justino de; SCHWANKA, Cristiane. A administração consensual como a nova face da Administração Pública no século XXI: fundamentos dogmáticos, formas de expressão e instrumentos de ação. In: Revista de Direito do Estado - RDE, n. 10, p. 271-288, abril/junho. 2008. 
Cumpre observar que a principal tarefa da Administração passa a ser a composição de conflitos envolvendo interesses públicos e privados ${ }^{1183}$, incluindo os cidadãos definitivamente no processo de determinação das formas de atuação estatal na execução das políticas públicas de saúde, que deixam de ser atividades exclusivas do Estado, desenvolvidas por autoridades públicas, e passam a ser compreendidas como resultado de processos de ponderação de diversos interesses públicos e interesses privados.

Neste contexto, foi estabelecido um relacionamento mais estreito entre o Estado e a sociedade, baseado num intenso processo de participação, mediante a instituição de canais de defesa de interesses e debates, conflitos e consensos. Os conselhos de saúde estruturados nos três níveis de governo e o movimento pela saúde construíram uma rede de forças com os conselhos de gestores estaduais (Conselho Nacional de Secretários de Saúde CONASS) e municipais de saúde (Conselho Nacional de Secretários Municipais de Saúde CONASEMS).

Os conselhos de saúde consistem em instituições participativas inovadoras, porquanto implicam na organização da sociedade civil de forma diversa dos partidos políticos, permitindo que interesses públicos e interesses coletivos, próprios de cada segmento, possam emergir e serem inseridos no contexto da negociação política.

A participação popular nos conselhos de saúde ganha relevância como instrumento de democracia participativa, imbricada à atividade estatal de mediação e determinação do interesse público que se desenvolve nesses espaços públicos. Por meio desses canais, de grande capilaridade, a Administração pode absorver e internalizar as demandas oriundas da sociedade, tornando as políticas públicas e os programas de saúde melhor qualificados para satisfazê-las.

O Conselho Nacional de Saúde editou a Resolução n. 333, de 4 de novembro de $2003^{1184}$, com o objetivo de consolidar e fortalecer a participação da comunidade no âmbito do Sistema Único de Saúde (SUS), fixando diretrizes sobre a criação, a organização e o funcionamento dos conselhos de saúde. Dentre outros aspectos, recomenda: que a escolha dos representantes seja realizada pelos próprios seguimentos e entidades; que a composição seja de cinquenta por cento de representantes de usuários do SUS, vinte e

1183 OLIVEIRA, Gustavo Henrique Justino de; SCHWANKA, Cristiane. A administração consensual como a nova face da Administração Pública no século XXI: fundamentos dogmáticos, formas de expressão e instrumentos de ação. In: Revista de Direito do Estado - RDE, n. 10, p. 271-288, abril/junho. 2008.

${ }^{1184}$ A Resolução n. 333, de 04 de novembro de 2003, foi homologada pelo Ministro da Saúde, nos termos do Decreto de Delegação de Competência de 12 de novembro de 1991. 
cinco por cento de entidades de profissionais de saúde e vinte e cinco por cento de representantes do governo e de prestadores de serviços privados conveniados ou sem fins lucrativos; que a representação de órgãos ou entidades tenha como critério a representatividade, a abrangência e a complementaridade do conjunto de forças sociais no âmbito de atuação do Conselho de Saúde; e que o mandato dos conselheiros, a ser definido no Regimento Interno do Conselho, não coincida com o mandato do Governo Estadual, Municipal, do Distrito Federal ou do Governo Federal, sugerindo a duração de dois anos e a possibilidade de recondução dos conselheiros, a critério das respectivas representações.

Os parâmetros fixados pelo Conselho Nacional de Saúde na Resolução n. 333, de 4 de novembro de 2003, conquanto não vinculativos, significam avanços à participação social nos conselhos de saúde. Porém, ainda se verificam grandes dificuldades à efetividade da democracia participativa nessas instâncias políticas.

De fato, além da falta de cultura cívica no País, quatro problemas se destacam em relação à participação da comunidade nos conselhos de saúde: (i) a baixa representatividade de seus membros; (ii) a ausência de segurança jurídica decorrente da nomeação dos conselheiros por atos normativos infralegais, não se assegurando a necessária estabilidade para o desempenho das funções; (iii) a forma de escolha de seus membros; e (iv) o risco de "captura" dos membros do conselho por entidades privadas ou pelo Estado para a defesa de interesses privados, como, por exemplo, de indústria farmacêutica, interesses corporativos, clientelistas, ou da pessoa jurídica de direito público.

Portanto, a instituição de mecanismos de participação nem sempre representa uma condição suficiente para a realização de diálogos efetivos ao alcance de consensos. A Administração Pública e a sociedade devem encontrar meios adequados para superar os óbices a fim de que nesses espaços públicos haja democracia substantiva.

Por derradeiro, no plano infralegal, há diversos instrumentos normativos que tratam da participação social no Sistema Único de Saúde. Dentre eles, em razão da importância, cumpre examinar dois planos de ação governamentais que prevêem medidas coordenadas para a efetividade da participação social na área da saúde ${ }^{1185}$ : a Política Nacional de Gestão

\footnotetext{
1185 De acordo com BUCCI, política pública pode ser definida como "um programa ou quadro de ação governamental, porque consiste num conjunto de medidas articuladas (coordenadas), cujo escopo é dar impulso, isto é, movimentar a máquina do governo, no sentido de realizar algum objetivo de ordem pública ou, na ótica dos juristas, concretizar um direito." BUCCI, Maria Paula Dallari. O conceito de política pública em direito. In: Políticas públicas: reflexões sobre o conceito jurídico. BUCCI, Maria Paula Dallari (organizadora). São Paulo: Saraiva, 2006, p.14.
} 
Estratégica e Participativa do Sistema Único de Saúde (PARTICIPASUS) e a Política Nacional de Educação Popular em Saúde no âmbito do Sistema Único de Saúde (PNEPSSUS).

A Portaria n. 3.027, de 26 de novembro de 2007, do Ministério da Saúde aprovou a Política Nacional de Gestão Estratégica e Participativa do Sistema Único de Saúde (PARTICIPASUS), com o objetivo de orientar as ações de governo na promoção, na qualificação e no aperfeiçoamento da gestão estratégica e democrática das políticas públicas no âmbito do Sistema Único de Saúde (SUS) nas respectivas esferas de gestão.

A Política Nacional de Gestão Estratégica e Participativa do Sistema Único de Saúde (PARTICIPASUS) partiu da ideia de que os Municípios devem ser valorizados como espaços públicos que podem intensificar as redes de participação social na construção do modelo de atenção proposto para o Sistema Único de Saúde (SUS). A articulação cooperativa e solidária entre as gestões municipais e a gestão estadual conforma um modelo regionalizado, que representa a possibilidade concreta de construção da atenção integral à saúde. Para a consolidação do Sistema Único de Saúde (SUS), a formulação da política de saúde deve emergir dos espaços em que se aproximam a gestão descentralizada, o desenvolvimento da atenção integral à saúde e o fortalecimento da participação popular. ${ }^{1186}$

1186 A Portaria n. 2.979, de 15 de dezembro de 2011 do Ministério da Saúde dispõe sobre a transferência de recursos para a qualificação da gestão no Sistema Único de Saúde (SUS), especialmente para implementação e fortalecimento da Política Nacional de Gestão Estratégica e Participativa do Sistema Único de Saúde (PARTICIPASUS), com foco na promoção da equidade em saúde, e para a implementação e fortalecimento das Comissões Intergestores Regionais (CIR) e do Sistema de Planejamento do SUS (artigo $1^{\circ}$ ). Nos termos do artigo $2^{\circ}$ da referida portaria, fica instituído incentivo financeiro de custeio destinado aos Estados e ao Distrito Federal para implementação e fortalecimento da Política Nacional de Gestão Estratégica e Participativa do Sistema Único de Saúde (PARTICIPASUS), com foco na promoção da equidade em saúde. A aplicação deste incentivo financeiro deve conduzir aos seguintes resultados: (i) reafirmação da participação popular e do controle social na construção de um novo modelo de atenção à saúde, requerendo o envolvimento dos movimentos sociais, considerados atores estratégicos para a gestão participativa, por meio das seguintes ações: a) realização de encontros com gestores, trabalhadores da saúde, conselheiros de saúde e lideranças sociais que atuam nos movimentos de mulheres, negros(as), quilombolas, do campo e floresta, população de rua, juventude e lésbicas, gays, bissexuais, travestis e transexuais (LGBT) e ciganos sobre gestão participativa, controle social e políticas de promoção da equidade em saúde; b) apoio à formação de comitês, comissões e ou grupos temáticos nas Secretarias de Saúde que versem sobre a coordenação e a execução das políticas de promoção de equidade em saúde; c) produção de material informativo e educativo sobre as políticas de promoção de equidade em saúde; d) apoio a formação de espaços de deliberação, como fóruns e comissões, entre os Conselhos Municipais e Estadual de Saúde para a articulação do controle social e formação de conselheiros de saúde sobre gestão participativa, controle social e políticas de promoção de equidade em saúde; e) apoio à mobilização social e aos movimentos que apoiem a promoção da equidade em saúde; (ii) aperfeiçoamento dos atuais canais de participação social, criação e ampliação de novos canais de interlocução entre usuários e sistemas de saúde, e de mecanismos de escuta do cidadão, com o fortalecimento do Sistema Nacional de Ouvidoria e a estruturação da Ouvidoria Ativa, por meio das seguintes ações: a) 
Os componentes abrangidos pela Política Nacional de Gestão Estratégica e Participativa do Sistema Único de Saúde (PARTICIPASUS) são quatro: (i) a gestão participativa e o controle social no Sistema Único de Saúde (SUS); (ii) o monitoramento e avaliação da gestão do Sistema Único de Saúde (SUS); (iii) as ouvidorias do Sistema Único de Saúde (SUS); e (iv) a auditoria do Sistema Único de Saúde (SUS).

De acordo com a Política Nacional de Gestão Estratégica e Participativa do Sistema Único de Saúde, a gestão participativa do Sistema Único de Saúde (SUS) exige a instituição de mecanismos que viabilizem a manifestação e a deliberação do conjunto de atores sociais, incluindo os profissionais de saúde e a comunidade. É necessário ampliar os espaços públicos para o exercício do diálogo e da pactuação das diferenças, de forma a construir um conhecimento compartilhado sobre saúde, preservando a subjetividade e a singularidade presentes em cada indivíduo. Além disso, é preciso fortalecer o controle social sobre a saúde, mediante a criação de canais de comunicação entre o cidadão e a Administração e a atribuição do maior grau possível de publicidade aos atos do governo.

$\mathrm{O}$ monitoramento ${ }^{1187}$ e a avaliação de processos e resultados estão atrelados ao princípio da eficiência, que pode ser aferido com base em indicadores de estrutura, em especial no tocante aos recursos alocados.

Por sua vez, as ouvidorias do Sistema Único de Saúde consistem em instrumentos de participação social direta, pois permitem a comunicação dos usuários do sistema e da Administração sem intermediários.

As ouvidorias são ferramentas democráticas estratégicas para a promoção da cidadania em saúde e a produção de informações que subsidiem a tomada de decisão dos gestores nas três esferas de governo, contribuindo para o controle social e o fortalecimento do Sistema Único de Saúde. ${ }^{1188}$ Tais canais de comunicação têm por objetivo receber manifestações dos cidadãos, incluindo reclamações, denúncias, sugestões, elogios e

adoção de medidas de aferição de satisfação dos usuários do SUS; e b) realização de atividades de qualificação de ouvidores; e (iii) realização de atividades de interação entre o Sistema Nacional de Auditoria (SNA) e o controle social, possibilitando o acesso da sociedade às informações e aos resultados das ações de auditoria (artigo $3^{\circ}$ ).

${ }^{1187} \mathrm{O}$ monitoramento pode ser entendido como um sistema pelo qual é possível observar, medir e avaliar continuamente um processo ou fenômeno. É um processo sistemático e contínuo de acompanhamento dos indicadores de saúde e da execução das políticas, ações e serviços nesta área visando à obtenção de informações em tempo oportuno para subsidiar a tomada de decisão, a identificação, solução e redução de problemas, bem como a correção de rumos.

1188 BRASIL. Ministério da Saúde. Secretaria-Executiva. Subsecretaria de Planejamento e Orçamento. Plano Nacional de Saúde - PNS: 2012-2015. Brasília: Ministério da Saúde, 2011, p.63. 
solicitação de informações, bem como adotar as medidas que sejam eventualmente necessárias.

De acordo com o Plano Nacional de Saúde - PNS: 2012-2015, há 99.334 demandas registradas no sistema OuvidorSUS (dados absolutos do período de abril de 2006 a dezembro de 2010), considerando todas as demandas encaminhadas às redes e sub-redes do sistema. Desse total, 34.802 encontram-se pendentes, ou seja, ainda não receberam um parecer conclusivo da área responsável, demonstrando a fragilidade, a ausência de acesso à informação (publicidade e motivação) e a necessidade de aprimoramento do sistema de ouvidoria. $^{1189}$

Por fim, a auditoria ${ }^{1190}$ do Sistema Único de Saúde (SUS) é um instrumento de gestão que tem por finalidade o fortalecimento do Sistema Único de Saúde (SUS), contribuindo para a alocação e utilização adequada dos recursos, a transparência e a ética. Neste sentido, busca atuar de forma proativa por meio de auditorias de gestão, auditorias estratégicas e de cooperação técnica. ${ }^{1191}$

De outro prisma, a estreita ligação entre a educação, a participação popular e a saúde foi a base para o estabelecimento de responsabilidades sanitárias e atribuições da União na condução do processo permanente de aprimoramento e consolidação do Sistema Único de Saúde ${ }^{1192}$, para a instituição do Comitê Nacional de Educação Popular em Saúde

${ }^{1189} \mathrm{O}$ índice de resolubilidade é de $57 \%$ nos casos em que dependem de outras esferas de gestão (estadual ou municipal) e de apenas $85,09 \%$ quando dependem exclusivamente de resposta de áreas técnicas do Ministério da Saúde. Dessa forma, as demandas pendentes relativas aos casos em que são necessárias informações de outras esferas representam 43\%, que é um índice considerado elevado, e de quase $15 \%$ nos casos em que são essenciais somente informações de áreas técnicas do Ministério da Saúde. Os dados foram extraídos do Plano Nacional de Saúde 2012-2015. BRASIL. Ministério da Saúde. Secretaria-Executiva. Subsecretaria de Planejamento e Orçamento. Plano Nacional de Saúde - PNS: 2012-2015. Brasília: Ministério da Saúde, 2011, p.63.

${ }^{1190}$ A auditoria pode ser conceituada como o conjunto de técnicas que visa avaliar a gestão pública, de forma preventiva e operacional, conforme os aspectos da aplicação de recursos, dos processos, das atividades, do desempenho e dos resultados mediante a confrontação entre uma situação encontrada e um determinado critério técnico, operacional ou legal.

${ }^{1191}$ Os fatores que contribuem para que o Sistema Nacional de Auditoria (SNA) não tenha avanços com a celeridade necessária ao fortalecimento da gestão do Sistema Único de Saúde (SUS) são: a não-realização de concursos públicos para exercer as funções de auditor; o contingente reduzido de profissionais com qualificação em auditoria no Sistema Único de Saúde (SUS), o que demanda a formação de um novo perfil profissional para o setor; a carência de normatização que balize a operacionalização das auditorias pelo SNA; a falta de compreensão dos gestores do sentido da auditoria como ferramenta de gestão; e a falta de integração entre os componentes federal, estaduais/distrital e municipais. BRASIL. Ministério da Saúde. Secretaria-Executiva. Subsecretaria de Planejamento e Orçamento. Plano Nacional de Saúde - PNS: 20122015. Brasília: Ministério da Saúde, 2011.p.62.

1192 Portaria n. 2.362, de 5 de outubro de 2006, do Ministério da Saúde, que dispõe sobre o Termo de Compromisso de Gestão Federal, estabelece em seu anexo um conjunto de responsabilidades da União agrupadas por eixos, dos quais cumpre realçar o eixo 6, relativo à "educação na saúde", e o eixo 7, sobre 
$(\mathrm{CNEPS})^{1193}$ e para a elaboração da Política Nacional de Educação Popular em Saúde no âmbito do Sistema Único de Saúde (PNEPS-SUS). ${ }^{1194}$

A Política Nacional de Educação Popular em Saúde no âmbito do Sistema Único de Saúde (PNEPS-SUS) reafirma o compromisso com a universalidade, a equidade, a integralidade e a efetiva participação popular no Sistema Único de Saúde (SUS), estabelecendo um projeto de prática político-pedagógica que permeia as ações voltadas à promoção, proteção e recuperação da saúde, a partir do diálogo entre a diversidade de indivíduos, valorizando os saberes populares, a ancestralidade, o incentivo à produção

"participação e controle social". Nestes dois campos, são as seguintes responsabilidades da União: "6 RESPONSABILIDADES NA EDUCAÇÃO NA SAÚDE: 6.1 formular, promover e pactuar políticas de educação permanente em saúde, apoiando técnica e financeiramente estados e municípios no desenvolvimento das mesmas; 6.2 promover a integração de todos os processos de capacitação e desenvolvimento de recursos humanos à política de educação permanente, no âmbito da gestão nacional do SUS; 6.3 propor e pactuar políticas regulatórias no campo da graduação e da especialização das profissões de saúde; 6.4 articular e propor políticas de indução de mudanças na graduação das profissões de saúde; e 6.5 propor e pactuar com o sistema federal de educação, processos de formação de acordo com as necessidades do SUS, articulando os demais gestores na mesma direção." “7. RESPONSABILIDADES NA PARTICIPAÇÃO E CONTROLE SOCIAL: 7.1 apoiar o processo de mobilização social e institucional em defesa do SUS; 7.2 prover as condições materiais, técnicas e administrativas necessárias ao funcionamento do Conselho Nacional de Saúde, que deverá ser organizado em conformidade com a legislação vigente; 7.3 organizar e prover as condições necessárias à realização de Conferências Nacionais de Saúde; 7.4 apoiar o processo de formação dos Conselheiros de Saúde; 7.5 promover ações de informação e conhecimento acerca do SUS, junto à população em geral; 7.6 apoiar os processos de educação popular em saúde, com vistas ao fortalecimento da participação social do SUS; 7.7 apoiar o fortalecimento dos movimentos sociais, aproximando-os da organização das práticas da saúde e com as instâncias de controle social da saúde; e 7.8 formular e pactuar a política nacional de ouvidoria e implementar o componente nacional, com vistas ao fortalecimento da gestão estratégica do SUS."

1193 Portaria n. 1.256, de 17 de junho de 2009, do Ministério da Saúde, institui o Comitê Nacional de Educação Popular em Saúde (CNEPS) com os objetivos previstos em seu artigo $1^{\circ}$, a saber: (i) participar da formulação, acompanhar a implementação e a avaliação da Política Nacional de Educação Popular em Saúde no SUS; (ii) colaborar com a elaboração de estratégias de mobilização, a fim de garantir a construção democrática e descentralizada da Política Nacional de Educação Popular em Saúde no SUS; (iii) acompanhar os acordos negociados entre o Ministério da Saúde e os movimentos sociais referentes às práticas de Educação Popular em Saúde; (iv) apoiar os movimentos, as entidades e instituições visando o desenvolvimento da Educação Popular em Saúde; (v) contribuir para o fortalecimento da luta pelo direito à saúde e em defesa do SUS, por meio da participação popular, identificando, divulgando e promovendo novos canais de participação popular e controle social, assim como colaborando com os já instituídos conselhos e conferências; (vi) participar e colaborar com as iniciativas do Ministério da Saúde que visem à incorporação da Educação Popular em Saúde como prática democrática na construção de políticas públicas de saúde; (vii) apoiar e colaborar com a implementação do Programa Nacional de Inclusão Digital (PID) e com os processos de Educação Permanente para o Controle Social no SUS; (viii) contribuir, por meio dos princípios da Educação Popular em Saúde, com a construção das bases pedagógicas para a transformação das práticas de educação em saúde desenvolvidas no SUS, fortalecendo a autonomia da população e a relação fraterna e solidária entre gestores, profissionais e usuários dos serviços de saúde; e (ix) contribuir com as ações de extensão universitária, pesquisa e ensino das instituições e dos centros de ensino, que tenham a Educação Popular em Saúde como princípio ético na formação dos profissionais e educadores articulados com a realidade da população, em função da importância das práticas populares de saúde e da participação popular para a efetivação do SUS. O artigo $2^{\circ}$ desta portaria estabelece a composição do Comitê, formado por representantes, titulares e suplentes, de órgãos públicos, entidades e organizações não-governamentais, assegurando a participação popular indireta.

${ }^{1194}$ Portaria n. 2.761, de 19 de novembro de 2013, do Ministério da Saúde. 
individual e coletiva de conhecimentos e a inserção destes no Sistema Único de Saúde $\left(\operatorname{artigo} 2^{\circ}\right)$.

A Política Nacional de Educação Popular em Saúde no âmbito do Sistema Único de Saúde (PNEPS-SUS) é orientada pelos princípios do diálogo, da amorosidade, da problematização, da construção compartilhada do conhecimento, da emancipação e do compromisso com a construção do projeto democrático e popular (artigo $3^{\circ}$ ). Um dos eixos estratégicos da PNEPS-SUS ${ }^{195}$ consiste na participação, controle social e gestão participativa, que visa fomentar, fortalecer e ampliar o protagonismo popular, através do desenvolvimento de ações que envolvam a mobilização pelo direito à saúde e a qualificação da participação nos processos de formulação, implementação, gestão e controle social das políticas públicas (artigo $4^{\circ}$, parágrafo $1^{\circ}$ ).

O objetivo geral da Política Nacional de Educação Popular em Saúde no âmbito do Sistema Único de Saúde (PNEPS-SUS) é implementar a Educação Popular em Saúde no âmbito do SUS, contribuindo com a participação popular, com a gestão participativa, o controle social, o cuidado, a formação e as práticas educativas em saúde (artigo 5º. ${ }^{1196} 1197$

${ }^{1195} \mathrm{O}$ artigo $4^{\circ}$ da Portaria n. 2.761, de 19 de novembro de 2013 assim dispõe: “Art. $4^{\circ}$ São eixos estratégicos da PNEPS-SUS: I - participação, controle social e gestão participativa; II - formação, comunicação e produção de conhecimento; III - cuidado em saúde; e IV - intersetorialidade e diálogos multiculturais."

${ }^{1196}$ A Política Nacional de Educação Popular em Saúde no âmbito do Sistema Único de Saúde (PNEPS-SUS) tem os seguintes objetivos específicos, dentre outros: (i) a promoção do diálogo e a troca entre práticas e saberes populares e técnico-científicos no âmbito do SUS, aproximando os sujeitos da gestão, dos serviços de saúde, dos movimentos sociais populares, das práticas populares de cuidado e das instituições formadoras (artigo $6^{\circ}$, inciso I); (ii) o fortalecimento da gestão participativa nos espaços do SUS (artigo $6^{\circ}$, inciso II); (iii) o fortalecimento dos movimentos sociais populares, os coletivos de articulação social e as redes solidárias de cuidado e promoção da saúde na perspectiva da mobilização popular em defesa do direito universal à saúde (artigo $6^{\circ}$, inciso IV); (iv) o incentivo do protagonismo popular no enfrentamento dos determinantes e condicionantes sociais de saúde (artigo $6^{\circ}$, inciso V); (v) a contribuição para o desenvolvimento de ações intersetoriais nas políticas públicas referenciadas na Educação Popular em Saúde (artigo 6 ${ }^{\circ}$, inciso VIII); (vi) o apoio a ações de Educação Popular na Atenção Primária em Saúde, fortalecendo a gestão compartilhada entre trabalhadores e comunidades, tendo os territórios de saúde como espaços de formulação de políticas públicas (artigo $6^{\circ}$, inciso IX); (vii) a contribuição com a educação permanente dos trabalhadores, gestores, conselheiros e atores dos movimentos sociais populares, incorporando aos seus processos os princípios e as práticas da educação popular em saúde (artigo $6^{\circ}$, inciso X); e (viii) a garantia de participação popular no planejamento, acompanhamento, monitoramento e avaliação das ações e estratégias para a implementação da PNEPS-SUS (artigo $6^{\circ}$, inciso XI).

${ }^{1197}$ Para o atendimento destes objetivos, a Portaria n. 2.761, de 19 de novembro de 2013, do Ministério da Saúde, fixa as atribuições do Ministério da Saúde (artigo $7^{\circ}$ ), das Secretarias de Estado de Saúde (artigo $8^{\circ}$ ) e das Secretarias Municipais de Saúde (artigo $9^{\circ}$ ), os quais devem: incluir a Política Nacional de Educação Popular em Saúde no âmbito do Sistema Único de Saúde (PNEPS-SUS) em seus respectivos Planos de Saúde; estabelecer estratégias e ações de planejamento, monitoramento e avaliação da PNEPS-SUS com a participação popular; garantir financiamento para implementá-la; e promover a intersetorialidade entre as políticas públicas que apresentam interface com a PNEPS-SUS. O Ministério da Saúde deve apoiar tecnicamente as Secretarias Estaduais de Saúde na implementação da PNEPS-SUS, que, por sua vez, devem apoiar as Secretarias Municipais de Saúde (artigos $7^{\circ}$, inciso VI e $8^{\circ}$, inciso III, respectivamente). 
Os quadros de ação governamental previstos na Política Nacional de Gestão Estratégica e Participativa do Sistema Único de Saúde (PARTICIPASUS) e na Política Nacional de Educação Popular em Saúde no âmbito do Sistema Único de Saúde (PNEPSSUS) apresentam potencial para melhorar quantitativa e qualitativamente a participação da comunidade nos mecanismos pró-consensuais voltados ao planejamento, à execução e à fiscalização das ações e serviços de saúde prestados no âmbito do Sistema Único de Saúde (SUS), mas somente com o passar dos anos será possível avaliar se houve avanços em relação à participação popular e se foram alcançados os objetivos nelas fixados, além de incrementar a produção normativa em matéria de saúde.

Vistos os mecanismos de participação administrativa na área da saúde, convém apontar as vantagens decorrentes de sua prática. Dentre os efeitos positivos dos instrumentos de participação examinados, convém apontar os seguintes: (i) fortalecem o regime democrático por meio do processo constante de controle e cobrança do cumprimento dos deveres impostos ao Estado; (ii) garantem ao povo o direito (e o dever) de discutir e participar do processo de construção das decisões estatais em matéria de saúde; (iii) permitem o controle preventivo de legalidade e de legitimidade da ação administrativa; (iv) desenvolvem o sentimento de pertencimento do cidadão à sociedade e criam uma cultura de participação; (v) conferem legitimidade e confiança ao exercício da atuação administrativa; (vi) induzem ao aprimoramento das ações e serviços públicos de saúde; (vii) oferecem subsídios para a tomada da decisão administrativa mais adequada e justa; (ix) tornam o povo corresponsável pelas decisões relativas à concretização do direito à saúde; (x) aproximam o cidadão da Administração, estabelecendo uma relação firme e permanente de cooperação; e (xi) formam cidadãos conscientes acerca da importância de sua contribuição com o aprimoramento e ao funcionamento eficiente do Sistema Único de Saúde (SUS).

De outro lado, considerando as linhas de raciocínio desenvolvidas, a problemática relativa à efetividade da participação administrativa, e que também se verifica, de forma mais ampla, na intervenção do povo em qualquer esfera de poder estatal, envolve, dentre outros problemas, os seguintes: (i) a supremacia de grupos de pressão, dos segmentos mais organizados ou do poder econômico; (ii) a apatia política (falta de estímulo para a ação cidadã); (iii) a abulia política (desinteresse em participar da ação cidadã); (iv) a acracia política (não poder participar da ação cidadã); (v) a falta de tradição participativa e de 
cultura cívica; (vi) a ausência de informação e/ou de publicização suficiente; (vii) a tradição autoritária do País; (viii) a desconsideração dos argumentos e manifestações produzidas no processo de tomada de decisão, implicando numa participação meramente formal.

A participação da comunidade no âmbito do Sistema Único de Saúde (SUS) vem ganhando cada vez mais espaço, mediante a utilização de instrumentos já instituídos na ordem jurídica brasileira e a criação de novas institucionalidades normativas, como fontes de legitimação das decisões estatais e mecanismos de gestão das políticas públicas.

No entanto, os problemas relacionados à efetividade dos instrumentos participativos na área da saúde colocam o desafio de que sejam encontrados meios adequados para resolvê-los. Há um longo percurso a ser percorrido para o aprimoramento do processo democrático na área da saúde, que envolve não apenas medidas jurídicas, mas também medidas políticas.

Sob o prisma jurídico, se faz necessário o aperfeiçoamento de instituições e processos relativos à participação na Administração Pública. Sob o prisma político, é imperioso o fortalecimento da educação para o exercício da cidadania, de forma a ampliar o rol de atores sociais interessados em colaborar com a gestão do Sistema Único de Saúde (SUS), bem como o repasse de recurso públicos federais às esferas estaduais, municipais e à esfera distrital em montante compatível com a organização e funcionamento das respectivas instâncias participativas.

Contudo, a participação popular na área da saúde não pode se esgotar na criação de instrumentos formais e espaços públicos de discussão, por vezes insuficientes para que haja diálogo e, em consequência, consensualidade. É necessário o desenvolvimento de meios capazes de realizar a democracia sanitária substantiva. Para tanto, é imprescindível que haja maior representatividade daqueles que atuam em nome da comunidade e que esta atuação seja congruente com os interesses dos representados.

A determinação do interesse público a ser perseguido nas instâncias participativas deve ter como eixo o atendimento dos objetivos fundamentais do Estado de reduzir as desigualdades sociais e garantir a universalidade e a equidade em saúde, inseridos no projeto constitucional de construção de uma sociedade fraterna, pluralista, livre, justa e solidária. 


\section{CAPÍtUlO 5 - SOLUÇÃO CONSENSUAL DE CONFLITOS SANITÁRIOS NA ESFERA ADMINISTRATIVA}

O último capítulo do trabalho tem por fim discorrer sobre os mecanismos direcionados a solucionar os conflitos de interesses entre a Administração Pública e particulares, de forma consensual e na via administrativa.

Para que tal empreitada seja possível, no primeiro subitem é examinada a questão da conflituosidade existente nas relações entre a Administração Pública e particulares, bem como o processo administrativo como instrumento de garantia de direitos dos cidadãos.

O segundo subitem trata do crescimento do modelo de Administração consensual no Brasil, focando, sobretudo, a atuação administrativa voltada à solução de conflitos, fora da via jurisdicional, no tocante à concretização do direito a prestações materiais em saúde, e quais casos esta atuação pode configurar um autêntico módulo convencional.

Na sequência, o estudo se volta ao plano do Direito Administrativo aplicado, abordando o tema por meio da análise de mecanismos pró-consensuais procedimentais, que são formas institucionalizadas para resolver conflitos relativos à dimensão positiva do direito à saúde na esfera administrativa.

Por derradeiro, são analisadas as virtudes e os riscos resultantes da aplicação desses mecanismos no desempenho da função administrativa.

\subsection{A Administração Pública belicosa e o processo administrativo como instrumento pacificador de conflitos}

A explosão de litigiosidade entre os sujeitos públicos e privados é considerada um fenômeno decorrente das profundas transformações ocorridas na concepção de Estado e da expansão de suas intervenções nas esferas de liberdade e propriedade dos indivíduos.

A despeito do agigantamento da Administração Pública e da multiplicação de conflitos travados com a sociedade, de forma geral, os órgãos públicos não garantem de forma satisfatória o acesso à informação, carecem de transparência no desempenho de suas funções administrativas e têm dificuldade de atender de forma eficiente os pedidos administrativos formulados pelos cidadãos. 
A atuação ineficaz da Administração Pública, alongando a duração dos processos administrativos de maneira injustificada, acaba por deslocar o conflito para o Poder Judiciário, muitas vezes com o fim de procrastinar sua solução tanto quanto possível. Esta postura, mais do que incrementar o volume de ações judiciais promovidas em face do Estado, exprime o desrespeito da Administração aos direitos e garantias fundamentais dos cidadãos reconhecidos pela Constituição Federal. Aliás, como afirma AITH, enquanto o Poder Executivo não oferecer um sistema de saúde capaz de atender aos ditames constitucionais e legais, o Poder Judiciário continuará sendo provocado para proteger o direito à saúde de todos aqueles que legitimamente levarem ao seu conhecimento uma lesão ou ameaça de lesão ao direito à saúde, por força do princípio da separação dos Poderes consagrado no artigo $2^{\circ}$ da Constituição Federal. ${ }^{1198}$

No entanto, não apenas o Judiciário, mas também a Administração Pública deve dar tratamento adequado aos conflitos de interesses, instituindo mecanismos para solucioná-los conforme a ordem jurídica, de forma eficiente e justa.

O Estado não tem o monopólio da solução dos conflitos por meio da jurisdição. ${ }^{1199}$ O Direito admite outras maneiras pelas quais as partes podem buscar uma solução do conflito em que estejam envolvidas. ${ }^{1200}$

1198 AITH, Fernando. A emergência do Direito Sanitário como um novo campo do Direito. In: Estudos de Direito Sanitário: a produção normativa e saúde. ROMERO, Luiz Carlos; DELDUQUE, Maria Célia (organizadores). Brasília: Senado Federal: Subsecretaria de Edições Técnicas, p. 37, 2011.

1199 Adotando o conceito apresentado por NEVES, jurisdição pode ser entendida como "a atuação estatal visando a aplicação do direito objetivo ao caso concreto, resolvendo-se com definitividade uma situação de crise jurídica e gerando com tal solução a pacificação social.” NEVES, Daniel Amorim Assumpção. Manual de Direito Processual Civil. 4. ed. São Paulo: Método, 2012. p.3.

1200 Conforme NEVES, as outras formas de solução de conflitos são denominadas de equivalentes jurisdicionais ou de formas alternativas de solução dos conflitos. Há três espécies reconhecidas por nosso Direito: (i) autotutela; (ii) autocomposição; e (iii) arbitragem. A autotutela consiste, fundamentalmente, no sacrifício integral do interesse de uma das partes envolvida no conflito em razão do exercício da força pela parte vencedora. A solução de conflitos resultante do exercício da força não é uma forma privilegiada no Estado Democrático de Direito, sendo raras as previsões legais que admitem a autotutela. Esta é a única forma de solução alternativa de conflitos que pode ser amplamente revista pelo Poder Judiciário. Como exemplos, é possível mencionar a legítima defesa (artigo 188, I, do Código Civil) e o desforço imediato no esbulho (artigo 1210, $\S 1^{\circ}$, do Código Civil). A autocomposição é uma forma de solução de conflitos sem a interferência da jurisdição, fundada no sacrifício integral ou parcial do interesse das partes envolvidas no conflito mediante a vontade unilateral ou bilateral de tais sujeitos. É um excelente meio de pacificação social, pois inexiste no caso concreto uma decisão impositiva, valorizando-se a autonomia da vontade das partes na solução dos conflitos, por meio de negociação, conciliação e mediação. Enquanto na negociação as partes transacionam sem a intervenção de um terceiro, na conciliação e na mediação a busca da autocomposição ocorre com a interferência de um terceiro, que pode oferecer soluções fundadas em sacrifício recíproco de interesses (conciliação), ou apenas construir um diálogo entre as partes de forma que elas mesmas resolvam o conflito (mediação). A autocomposição é um gênero, do qual são espécies: (ii.1) transação; (ii.2) submissão; e (ii.3) renúncia. Na transação, há um sacrifício recíproco de interesses, pois as partes abdicam parcialmente suas pretensões, para atingir a solução do conflito. Na submissão e na renúncia o exercício de vontade é 
A solução de conflitos de interesse travados entre os particulares e a Administração Pública vem se colocando cada vez mais como uma das preocupações do Direito Administrativo, porém ainda são incipientes as formas de solução consensual de conflitos em âmbito administrativo.

Daí decorre a necessidade de abertura de canais que tornem a participação dos cidadãos na Administração Pública efetiva e continuada, de modo a desenvolver uma cultura participativa e de democratização do espaço público, tornando-o acessível a todos os interesses existentes na sociedade, num processo de republicização do Estado. ${ }^{1201}$

Segundo MARQUES NETO, a republicização significa o reconhecimento da existência de inúmeros interesses públicos e que a legitimidade da ação do poder político depende da capacidade de demonstração, em concreto, do porquê da ação desigual no sentido de privilegiar um ou outro interesse público em confronto. Mais ainda, o Estado republicizado pressupõe o reconhecimento pelo poder político da desigualdade entre os interesses de titulares que se embatem na sociedade, abarcando as diferenças em termos materiais, culturais, de representação e de articulação de interesses, que impõem uma mediação do poder político ativa e prospectiva, para a identificação e proteção dos interesses dos hipossuficientes. Mediação esta que, ainda, tem que ser compensatória, visto que a simples neutralidade não é suficiente para assegurar o respeito e a efetivação desses interesses juridicamente protegidos. ${ }^{1202}$

unilateral, pois a solução decorre de ato da parte que abre mão do exercício de um direito teoricamente legítimo. Na renúncia, o titular do pretenso direito dele abdica, enquanto na submissão o sujeito se submete à pretensão contrária, ainda que sua resistência fosse legítima. Embora consistam em espécies de autocomposição e, como tal, equivalentes jurisdicionais, podem ocorrer também durante o processo judicial. Neste caso, a submissão é considerada reconhecimento jurídico do pedido, ao passo que a transação e a renúncia mantêm a mesma nomenclatura. A verificação de sua ocorrência dá ensejo à extinção do processo com resolução do mérito, por sentença judicial homologatória da autocomposição (artigo 269, incisos II, III e V, do Código de Processo Civil). O Projeto de Lei do novo Código de Processo Civil (Projeto de Lei n. 6.025/05, apensado ao Projeto de Lei n. 8.046/10) prestigiou a conciliação e a mediação, com o propósito de incentivar as formas alternativas de solução de conflitos. Por fim, a arbitragem é a forma de solução de conflitos pela qual as partes escolhem um terceiro de sua confiança para resolver a controvérsia, que decidirá independentemente da vontade das partes. A Lei n. 9.307/96 disciplina esta forma de solução de conflitos relativos a direitos patrimoniais disponíveis. NEVES, Daniel Amorim Assumpção. Manual de Direito Processual Civil. 4. ed. São Paulo: Método, 2012. p.5-10.

1201 Como realça DI PIETRO, somente por meio da participação crescente dos cidadãos no processo de manifestação da Administração Pública será viável pensar numa perspectiva de republicização do Estado. DI PIETRO, Maria Sylvia Zanella. Participação popular na administração pública. Revista de Direito Administrativo, p. 26-39, 1993.

1202 MARQUES NETO, Floriano de Azevedo. Regulação estatal e interesses públicos. São Paulo: Malheiros, 2002.p. 179-180. 
A afirmação dos direitos fundamentais dos indivíduos na Constituição Federal determinou importantes desdobramentos práticos no tocante às relações recíprocas entre a Administração e os cidadãos ${ }^{1203} \mathrm{e}$, consequentemente, na atuação dos indivíduos no processo administrativo ${ }^{1204}$ para a defesa de seus direitos perante a Administração, sem prejuízo da possibilidade de buscar a tutela jurisdicional.

Como afirma MACHETE, as funções atuais do Direito Administrativo não se limitam a disciplinar a atuação da Administração Pública numa perspectiva defensiva ou garantística: cumpre-lhe assegurar a concretização e a realização das respectivas tarefas decorrentes da democratização do Estado de Direito, num posicionamento de paridade com os administrados. ${ }^{1205}$

No quadro do Estado Democrático de Direito o poder público se submete à lei e ao direito. O Direito Administrativo vincula-se à concepção de Estado de Direito, justamente porque está ao serviço da lei, estabelecendo normas que regulam as atividades da Administração. Este regramento da atividade estatal protege os direitos individuais em face do ente público, limitando o poder das autoridades. ${ }^{1206}$

$\mathrm{Na}$ atual sociedade pluralista, o processo administrativo funciona como estrutura capaz de viabilizar a participação institucionalizada dos cidadãos, favorecendo o controle social e, assim, a legalidade e a legitimidade da atividade administrativa.

A Administração prestadora tem o dever de garantir as posições jurídicas dos particulares, dentre as quais as decorrentes da dimensão positiva do direito à saúde. A utilização do processo administrativo com a função de garantia de direitos dos particulares,

1203 De acordo com MENEZES DE ALMEIDA, a dinâmica relação entre Administração Pública e os cidadãos é permanentemente influenciada por fatores políticos, sociais e econômicos, dentre outros aspectos do fenômeno humano. MENEZES DE ALMEIDA, Fernando Dias. Contrato Administrativo. São Paulo: Quartier Latin, 2012. p.338.

${ }^{1204}$ SILVA emprega a expressão "procedimento" em vez de "processo" para se referir à atuação dos sujeitos, sob o prisma do contraditório, ante a Administração. Nas suas palavras: “(...) o procedimento surge como o instrumento adequado para a conciliação do interesse público com os direitos dos indivíduos, pelo que é de exigir que ele tenha lugar, pelo menos, em todos os casos em que estejam em causa direitos fundamentais. Daí a tendência moderna para ligar o procedimento e os direitos fundamentais, acentuando a dimensão de garantia de procedimento contida nesses direitos. E a consideração de que os reflexos dos direitos fundamentais no procedimento vinculam tanto o legislador, que tem de constituir um procedimento efectivador dos direitos fundamentais, como a Administração, que tem de completar o direito do procedimento existente através de uma actuação conforme aos direitos fundamentais." SILVA, Vasco Manuel Pascoal Dias Pereira da. Em busca do acto administrativo perdido. Coimbra: Almedina, 2003. p. 212214.

${ }^{1205}$ MACHETE, Pedro. Estado de Direito Democrático e Administração paritária. Coimbra: Almedina, 2007, p.58-59.

1206 MEDAUAR, Odete. Direito administrativo moderno. 17. ed. São Paulo: Revista dos Tribunais, 2013.p.39. 
criando estabilidade e segurança jurídica, é uma decorrência da atuação da Administração Pública conforme os princípios e valores democráticos contidos na Constituição Federal.

Por certo, no Estado Democrático de Direito não se pode afirmar que o dever de promover o valor "justiça" caiba exclusivamente ao Judiciário, devendo necessariamente estar associado ao exercício de todas as funções do Estado. A realização de justiça de modo eficiente incumbe também à Administração.

A afirmação dos direitos fundamentais na Constituição Federal constitui base firme e estável para a atuação dos indivíduos perante a Administração. A demora ou o não atendimento de direitos individuais pela Administração significa afronta à Constituição. ${ }^{1207}$

A Administração deve apreciar o pedido e decidir em tempo oportuno, seja pelo deferimento, seja pelo indeferimento do pedido, para propiciar paz e justiça social de modo direto na esfera administrativa. O posicionamento da Administração em face do pleito formulado pelo cidadão deve ser claro e fundamentado, de sorte que o indivíduo esteja munido das informações necessárias caso queira buscar a satisfação de sua pretensão por outros meios. $^{1208}$

Tal postura importa em profundas mudanças das condutas administrativas de inércia ou negligência, movidas por má-fé ou não, no atendimento de direitos de cidadãos. MEDAUAR assevera que infelizmente são comuns comentários, em tom de jactância, do seguinte teor: "Se acha que têm direitos, vá procurá-los no Judiciário", como se a função

1207 Conforme MEDAUAR, a observância do princípio da razoável duração do processo administrativo propicia paz social, gera confiabilidade, atenua a sobrecarga do Poder Judiciário. Em suas palavras, "reconhecendo, de modo ágil, o direito das pessoas, quando for o caso, se reduziriam, por certo, as demandas perante o Judiciário, $80 \%$ (oitenta por cento) das quais envolvem omissões ou atos da Administração, sendo "campeões" os órgãos previdenciários e tributários." MEDAUAR, Odete. O princípio da razoável duração do processo administrativo. In: Atuais rumos do processo administrativo. MEDAUAR, Odete; SCHIRATO, Vitor Rhein (org.). São Paulo: Revista dos Tribunais, 2010. p.101-102.

${ }^{1208}$ Como exemplo de instrumento de consensualidade, modelo de respeito ao cidadão e de "Justiça na Administração", deve ser mencionado o projeto "Transação Extrajudicial Desburocratizada no Âmbito da Administração", vencedor na categoria advocacia da VII Edição do prêmio Innovare. Por meio da transação extrajudicial e com base na Responsabilidade Objetiva da Administração quanto a seus serviços, a Procuradoria Jurídica do Município de Marialva, no Paraná, busca prevenir litígios facilitando o acesso do cidadão lesado pelo poder público à indenização, em casos que envolvam exclusivamente direitos patrimoniais. Utilizando-se de instrumentos simples, a prática é desburocratizante, na medida em que exige apenas os elementos essenciais por parte do interessado para a comprovação de que há responsabilidade civil do Estado (conduta de agente público, dano e nexo de causa e efeito entre a conduta e o resultado lesivo). Desta forma, a Administração municipal procura reparar os danos causados por meio do processo administrativo, com celeridade, independentemente do pagamento de custas. Disponível em: $<$ www.premioinovare.com.br>. Consulta em 24/12/2013. 
administrativa pudesse permanecer alheia aos direitos consagrados pela ordem jurídica ou fosse mérito da Administração deixar de reconhecer direito dos administrados. ${ }^{1209}$

A desconsideração da existência de conflitos gera deletérias consequências para a própria Administração Pública. De um lado, a Administração deixa de cumprir seu dever de promover soluções justas de maneira racional e eficiente. E, de outro lado, macula sua credibilidade junto aos administrados.

Bem por isso, via de regra, apesar do custo e do tempo do processo, grande parte dos administrados prefere acionar o Poder Judiciário de plano, buscando a prolação de provimento jurisdicional ante a qualquer lesão a direito ou ameaça de lesão decorrente de conduta (comissiva ou omissiva) da Administração Pública. ${ }^{1210}$

De acordo com Pesquisa do Conselho Nacional de Justiça, a Administração Pública federal, estadual e municipal somadas respondem por $51 \%$ (cinquenta e um por cento) do total de processos em trâmite no Judiciário brasileiro. ${ }^{1211}$ Em relação às ações judiciais em que o pedido é de prestação material na área da saúde, segundo a pesquisa do Fórum Nacional do Judiciário para a Saúde, do Conselho Nacional de Justiça, divulgada em 2011, havia 240.980 (duzentos e quarenta mil novecentos e oitenta) processos com pedidos dessa natureza em trâmite perante o Judiciário brasileiro. ${ }^{1212}$

Portanto, é inegável que o Estado está envolvido em grande número de conflitos, tendo o dever de instituir mecanismos, em todas as esferas da Federação, voltados a pacificá-los de forma justa, eficaz, dialógica e menos custosa para a Administração e os administrados, mormente se considerada a essencialidade do direito à saúde para uma vida com qualidade.

Se a Administração Pública informar aos cidadãos sobre a possibilidade, os requisitos e as vantagens de requerer, na via administrativa, o fornecimento de prestações materiais em saúde e atuar de forma transparente e célere na apreciação dos pedidos,

1209 MEDAUAR, Odete. Direito administrativo moderno. 17. ed. São Paulo: Revista dos Tribunais, 2013.p.184.

${ }^{1210}$ A Constituição Federal prevê o princípio da inafastabilidade da tutela jurisdicional, conforme seu artigo $5^{\circ}$, inciso XXXV, que dispõe: "a lei não excluirá da apreciação do Poder Judiciário lesão ou ameaça a direito”. Conforme MEDAUAR, no Brasil o sistema adotado é de jurisdição una, segundo o qual o julgamento dos litígios em que a Administração é parte compete aos juízes e tribunais comuns, sendo admitidas varas especializadas (que não significam justiça especial), mas inseridas entre os órgãos de uma única ordem de jurisdição. MEDAUAR, Odete. Direito administrativo moderno. 17. ed. São Paulo: Revista dos Tribunais, 2013. p.439-440.

1211 Conselho Nacional de Justiça. Departamento de Pesquisas Judiciárias. Os cem maiores litigantes. Brasília, março/2011. p.14. Disponível em: <www.cnj.jus.br>. Acesso em: 20/12/2013.

1212 Todos os dados da pesquisa estão disponíveis em: <www.cnj.jus.br>. Consulta em 23/12/2013. 
provavelmente será suficiente para encorajar os particulares a optarem por requerer nesta esfera o atendimento do direito fundamental à saúde, após o qual, caso seja infrutífero, remanescerá o caminho da via judicial.

De acordo com a denominação atribuída por MEDAUAR, o processo administrativo apresenta três fases: (i) instrutória ou inicial, formada por atos que dão início ao processo administrativo, o qual pode ser desencadeado de ofício ou por iniciativa de interessados; (ii) preparatória, integrada pela colheita de todos os elementos fáticos e jurídicos necessários e relevantes para a tomada de decisão justa, correta quanto aos fatos e ao Direito, abrangendo atos e fatos relativos às provas, pareceres jurídicos e técnicos, relatórios, audiências públicas e alegações escritas; e (iii) decisória, na qual a autoridade administrativa (unipessoal ou em um colegiado) determina o teor do ato, emitindo e formalizando a decisão, bem como os elementos imprescindíveis à sua eficácia, tais como a notificação, publicação e eventualmente homologação ou aprovação, eis que todos são ínsitos à própria decisão. ${ }^{1213}$

Em relação à fase instrutória ou inicial, caso o processo administrativo seja instaurado mediante iniciativa do interessado, para a defesa de seus direitos ou interesses em face da Administração Pública, o fará com fundamento no direito de petição $(\mathrm{CF}$, art. $5^{\circ}$, XXXIV, alínea “a”). ${ }^{1214}$ Conforme prevê a Lei de Processo Administrativo federal, o recebimento e o processamento da petição pela Administração Pública são irrecusáveis, devendo o servidor orientar o interessado em relação ao suprimento de eventuais falhas (art. $6^{\circ}$, par. único, da Lei n. 9.784/99). ${ }^{1215}$

No tocante aos pedidos para recebimento de prestações materiais em saúde, em nível federal, a Administração Pública deve elaborar modelos e formulários para pretensões equivalentes. Conclui-se com isso que, em todos os órgãos e entidades federais

1213 MEDAUAR, Odete. Direito administrativo moderno. 17. ed. São Paulo: Revista dos Tribunais, 2013.p.193.

1214 “Art. $5^{\circ}$ Todos são iguais perante a lei, sem distinção de qualquer natureza, garantindo-se aos brasileiros e aos estrangeiros residentes no País a inviolabilidade do direito à vida, à liberdade, à igualdade, à segurança e à propriedade, nos termos seguintes: (...) XXXIV - são a todos assegurados, independentemente do pagamento de taxas: a) o direito de petição aos Poderes Públicos em defesa de direitos ou contra ilegalidade ou abuso de poder;"

1215 "Art. $6^{\circ} \mathrm{O}$ requerimento inicial do interessado, salvo casos em que for admitida solicitação oral, deve ser formulado por escrito e conter os seguintes dados: I - órgão ou autoridade administrativa a que se dirige; II identificação do interessado ou de quem o represente; III - domicílio do requerente ou local para recebimento de comunicações; IV - formulação do pedido, com exposição dos fatos e de seus fundamentos; V - data e assinatura do requerente ou de seu representante. Parágrafo único. É vedada à Administração a recusa imotivada de recebimento de documentos, devendo o servidor orientar o interessado quanto ao suprimento de eventuais falhas." 
(art. $1^{\circ}$, caput, da Lei n. 9.874/99) ${ }^{1216}$, públicos e privados, integrantes do Sistema Único de Saúde (SUS), deverão ser disponibilizados modelos ou formulários padronizados que contemplem os requisitos para requerer o fornecimento de medicamentos, insumos ou tratamentos de saúde (art. $7^{\circ}$, da Lei n. 9.874/99), ${ }^{1217}$ sendo recomendável que as demais unidades federativas adotem o mesmo procedimento. ${ }^{1218}$

A observância de um procedimento permite que todo administrado tenha iguais condições de acesso à Administração para postular a solução de controvérsias relativas a prestações materiais de saúde. Conforme BATISTA JÚNIOR, existindo procedimento preestabelecido, os administrados mais humildes não se sentirão intimidados nem ficarão na dependência de ter acesso privilegiado a autoridades com poder de decisão para discutir seus problemas concretos, o que, na prática, somente os ricos e poderosos conseguem ter. $^{1219}$

Embora não seja necessário buscar a via administrativa nem esgotá-la previamente ao ajuizamento de ação perante o Poder Judiciário $\left(\mathrm{CF} \text {, art. } 5^{\circ} \text {, inciso XXV }\right)^{1220}$, é possível vislumbrar, em tese, pelo menos quatro razões que podem implicar numa preferência dos cidadãos pela utilização do processo administrativo em detrimento do processo judicial, como instrumento de realização do direito à saúde, a saber: (i) o princípio do formalismo moderado, promovido por meio de ritos e formas simples, suficientes para propiciar um grau de certeza, segurança e respeito aos direitos dos sujeitos, bem como baseado na exigência de interpretação flexível quanto às formas, consideradas como meio para

1216 “Art. $1^{\circ}$ Esta Lei estabelece normas básicas sobre o processo administrativo no âmbito da Administração Federal direta e indireta, visando, em especial, à proteção dos direitos dos administrados e ao melhor cumprimento dos fins da Administração."

1217 A Lei de Processo Administrativo federal assim determina: "Art. $7^{\circ}$ Os órgãos e entidades administrativas deverão elaborar modelos ou formulários padronizados para assuntos que importem pretensões equivalentes".

1218 Em decorrência dos princípios da publicidade e da eficiência a que a Administração Pública direta e indireta nos três níveis da Federação se sujeita (CF, art. 37), além de publicadas na imprensa oficial, deveriam ser organizadas e disponibilizadas nos respectivos órgãos e entidades e também no site de cada um, listas que contivessem, de forma clara e em linguagem simples, ordenadas pelo nome da doença ou agravo à saúde, todos os medicamentos fornecidos em programas de assistência farmacêutica e todos os tratamentos oferecidos por hospitais e clínicas no âmbito do Sistema Único de Saúde (SUS), bem como o procedimento e os requisitos necessários para recebê-los. A ausência de acesso à informação organizada deixa grande parte da população brasileira à margem dos serviços públicos de saúde.

1219 BATISTA JÚNIOR, Onofre Alves. Transações administrativas: um contributo ao estudo do contrato administrativo como mecanismo de prevenção e terminação de litígios e como alternativa à atuação administrativa autoritária, no contexto de uma Administração Pública mais democrática. São Paulo: Quartier Latin, 2007, p. 550-551.

1220 “Art. $5^{\circ}$ (...) XXXV - a lei não excluirá da apreciação do Poder Judiciário lesão ou ameaça a direito;" 
alcançar as finalidades do processo ${ }^{1221}$ (artigo $2^{\circ}$, parágrafo único, inciso IX, art. $6^{\circ}$, parágrafo único, e artigo 22 , todos da Lei n. 9.784/99) ${ }^{1222}$; (ii) o princípio da razoável duração do processo, acrescido ao rol dos direitos fundamentais por meio da Emenda Constitucional n. 45, de 9 de dezembro de 2004 (CF, artigo 5º, inciso LXXVIII) ${ }^{1223}$, assegura a todos, no âmbito judicial e administrativo, que a decisão será tomada no menor tempo possível. Na esfera administrativa ${ }^{1224}$ este princípio está estreitamente vinculado ao princípio da eficiência, de observância obrigatória pela Administração Pública direta e indireta $(\mathrm{CF} \text {, art. 37, caput })^{1225}$ e, nos termos do artigo 69-A, da Lei n. 9.784/99, inserido pela Lei n. 12.008/2009, há hipóteses em que os processos administrativos terão prioridade na tramitação ${ }^{1226}$; (iii) a ausência de custas, inclusive em fase recursal $\left(\mathrm{CF}\right.$, art. $5^{\circ}$, inciso XXXIV, alínea "a" $1227{ }^{1228}$ e art. $2^{\text {o }}$, parágrafo único, inciso XI, da Lei n. 9.784/99) ${ }^{1229}$; e

1221 MEDAUAR, Odete. Direito administrativo moderno. 17. ed. São Paulo: Revista dos Tribunais, 2013.p.192.

1222 Nos termos da Lei n. 9.784/99: "Art. $2^{\circ}$ A Administração Pública obedecerá, dentre outros, aos princípios da legalidade, finalidade, motivação, razoabilidade, proporcionalidade, moralidade, ampla defesa, contraditório, segurança jurídica, interesse público e eficiência. Parágrafo único. Nos processos administrativos serão observados, entre outros, os critérios de: (...) IX - adoção de formas simples, suficientes para propiciar adequado grau de certeza, segurança e respeito aos direitos dos administrados;" "Art. $6^{\circ} \mathrm{O}$ requerimento inicial do interessado, salvo casos em que for admitida solicitação oral, deve ser formulado por escrito e conter os seguintes dados: (...) Parágrafo único. É vedada à Administração a recusa imotivada de recebimento de documentos, devendo o servidor orientar o interessado quanto ao suprimento de eventuais falhas."; e "Art. 22. Os atos do processo administrativo não dependem de forma determinada senão quando a lei expressamente a exigir."

${ }^{1223}$ O inciso LXXVIII, do artigo $5^{\circ}$, da Constituição Federal dispõe o seguinte: “Art. $5^{\circ}$ (...) LXXVIII - a todos, no âmbito judicial e administrativo, são assegurados a razoável duração do processo e os meios que garantam a celeridade de sua tramitação."

1224 Nos termos do artigo 49, da Lei de Processo Administrativo federal (Lei n. 9.784/99), após a instrução do processo administrativo, a Administração deverá decidir no prazo de 30 (trinta) dias, ressalvada a prorrogação por igual período, devidamente motivada, caso em que o processo deverá ser decidido em 60 (sessenta) dias, confira: "Art. 49. Concluída a instrução de processo administrativo, a Administração tem o prazo de até trinta dias para decidir, salvo prorrogação por igual período expressamente motivada."

1225 "Art. 37. A administração pública direta e indireta de qualquer dos Poderes da União, dos Estados, do Distrito Federal e dos Municípios obedecerá aos princípios de legalidade, impessoalidade, moralidade, publicidade e eficiência e, também, ao seguinte: (...)"

1226 “Art. 69-A. Terão prioridade na tramitação, em qualquer órgão ou instância, os procedimentos administrativos em que figure como parte ou interessado: I - pessoa com idade igual ou superior a 60 (sessenta) anos; II - pessoa portadora de deficiência, física ou mental; III - (vetado); IV - pessoa portadora de tuberculose ativa, esclerose múltipla, neoplasia maligna, hanseníase, paralisia irreversível e incapacitante, cardiopatia grave, doença de Parkinson, espondiloartrose anquilosante, nefropatia grave, hepatopatia grave, estados avançados da doença de Paget (osteíte deformante), contaminação por radiação, síndrome de imunodeficiência adquirida, ou outra doença grave, com base em conclusão da medicina especializada, mesmo que a doença tenha sido contraída após o início do processo. $\S 1^{\circ} \mathrm{A}$ pessoa interessada na obtenção do benefício, juntando prova de sua condição, deverá requerê-lo à autoridade administrativa competente, que determinará as providências a serem cumpridas. $\S 2^{\circ}$ Deferida a prioridade, os autos receberão identificação própria que evidencie o regime de tramitação prioritária."

1227 "Art. $5^{\circ}$ Todos são iguais perante a lei, sem distinção de qualquer natureza, garantindo-se aos brasileiros e aos estrangeiros residentes no País a inviolabilidade do direito à vida, à liberdade, à igualdade, à segurança e à propriedade, nos termos seguintes: (...) XXXIV - são a todos assegurados, independentemente do 
(iv) o princípio da oficialidade, segundo o qual cabe à Administração tomar todas as providências dirigidas ao andamento regular e contínuo do processo, independentemente da provocação dos sujeitos, para a realização de atos e providencias, inclusive quanto à instrução, no sentido de ordenar a coleta de elementos necessários ao esclarecimento de fatos pertinentes ao assunto $\operatorname{tratado}^{1230}$ (art. $2^{\circ}$, parágrafo único, XII, da Lei n. 9.784/99). ${ }^{1231}$

No contexto da democracia participativa o processo administrativo foi valorizado como instrumento de legitimação da ação do Estado, conferindo previsibilidade do agir administrativo e garantindo direitos dos indivíduos no processo de formação da decisão estatal. ${ }^{1232}$

Aliás, uma das funções do processo administrativo é exatamente a garantia de respeito aos direitos dos administrados ${ }^{1233}$, prestigiando, dentre outros, o respeito ao contraditório, à ampla defesa e à razoável duração do processo, aparecendo como instrumento privilegiado de proteção do cidadão perante o Estado. ${ }^{1234}$

pagamento de taxas: a) o direito de petição aos Poderes Públicos em defesa de direitos ou contra ilegalidade ou abuso de poder;"

${ }^{1228}$ De acordo com FERRAZ e DALLARI, todo processo administrativo rege-se pelo princípio da gratuidade, porquanto o direito de petição é uma garantia constitucional que viabiliza o direito de agir de qualquer pessoa, em defesa de seus direitos ou interesses, em face da Administração. FERRAZ, Sérgio; DALLARI, Adilson Abreu. Processo Administrativo. 2.ed. São Paulo: Malheiros, 2007.p.118.

${ }^{1229}$ A Lei de Processo Administrativo federal consagrou, dentre os critérios que deverão ser observados no processo administrativo, "a proibição de cobrança de despesas processuais, ressalvadas as previstas em lei" (artigo $2^{\circ}$, inciso XI, da Lei n. 9.784/99).

1230 MEDAUAR, Odete. Direito administrativo moderno. 17. ed. São Paulo: Revista dos Tribunais, 2013.p.191.

1231 “Art. $2^{\circ}$ A Administração Pública obedecerá, dentre outros, aos princípios da legalidade, finalidade, motivação, razoabilidade, proporcionalidade, moralidade, ampla defesa, contraditório, segurança jurídica, interesse público e eficiência. Parágrafo único. Nos processos administrativos serão observados, entre outros, os critérios de: (...) XII - impulsão, de ofício, do processo administrativo, sem prejuízo da atuação dos interessados;"

${ }^{1232}$ MOREIRA NETO, Diogo de Figueiredo. Novas tendências da Democracia: Consenso e Direito Público na Virada do Século - o caso Brasileiro. Revista Brasileira de Direito Público. Belo Horizonte, n. 3, ano 1. Outubro 2003. Disponível em: <http:/editoraforum.com.br>. Consulta em 20/12/2013. Sem página. Edição digital.

${ }^{1233}$ A finalidade de garantia do processo administrativo está expressamente prevista no artigo $1^{\circ}$, da Lei de Processo Administrativo federal, que assim dispõe: "Art. $1^{\circ}$ Esta Lei estabelece normas básicas sobre o processo administrativo no âmbito da Administração Federal direta e indireta, visando, em especial, à proteção dos direitos dos administrados e ao melhor cumprimento dos fins da Administração."

1234 Como afirma SILVA, não deixa de ser paradoxal a situação de que a noção clássica de ato administrativo, como ato de autoridade funcionalmente ligado ao exercício do Poder do Estado, agora aparece como instrumento privilegiado de proteção do cidadão, demonstrando quão inadequada era a concepção fundada em critérios autoritários e que confundia poderes jurídicos com poderes fáticos. SILVA, Vasco Manuel Pascoal Dias Pereira da. Em busca do acto administrativo perdido. Coimbra: Almedina, 2003. p. $458-460$. 
A participação dos cidadãos na Administração Pública também passou a ser assegurada e incentivada pelo Estado como técnica de decisão na elaboração de políticas públicas, visando maior efetividade na sua execução, pois tende a ser bem aceita se construída com a participação dos indivíduos e dos grupos da sociedade envolvidos, numa relação contínua e recíproca de comunicação.

Assim, o processo administrativo tornou-se o local de confluência e integração dinâmica dos sujeitos, que possibilita a participação do cidadão na Administração e uma melhor ponderação dos interesses públicos e privados envolvidos no caso para a tomada da decisão administrativa final. ${ }^{1235}$

Portanto, no Estado contemporâneo, as tarefas da Administração Pública compreendem: (i) a atuação por meio de ações e serviços realizados com qualidade e eficiência em benefício dos cidadãos; (ii) o reconhecimento célere de direitos dos cidadãos; (iii) o estabelecimento de mecanismos de participação administrativa que permitam a oitiva dos cidadãos anteriormente à manifestação de vontade estatal que possa lhes afetar; (iv) a mediação de interesses públicos e privados conflitantes; e (v) a institucionalização de práticas baseadas no consenso, negociação e conciliação de interesses. ${ }^{1236}$

\subsection{Os módulos convencionais e a implementação do direito fundamental à saúde}

O Direito Administrativo foi concebido como um modelo de organização jurídicopolítica do Estado Moderno, caracterizado pela concentração e delimitação do poder. ${ }^{1237} \mathrm{~A}$ legitimação do poder concentrado no Estado decorre da aceitação da ideia de renúncia de parte da liberdade individual para que seja feita a vontade geral, expressa na lei, com base no interesse público. A delimitação do poder é assegurada pela tripartição das funções especializadas do Estado em três Poderes: Legislativo, Executivo e Judiciário, bem como pela garantia de direitos individuais dos cidadãos. ${ }^{1238}$

\footnotetext{
1235 BATISTA JÚNIOR, Onofre Alves. Transações Administrativas. São Paulo: Quatier Latin. p. 188-194.

${ }^{1236}$ Neste sentido, conferir: OLIVEIRA, Gustavo Henrique Justino de. Participação Administrativa. In: A\&C Revista de Direito Administrativo e Constitucional, Belo Horizonte, ano 5, n. 20, p. 167-169, abril/junho, 2005.

${ }^{1237}$ MARQUES NETO, Floriano de Azevedo. Regulação estatal e interesses públicos. São Paulo: Malheiros, 2002.p.178

1238 SILVA, Vasco Manuel Pascoal Dias Pereira da. Em busca do acto administrativo perdido. Coimbra: Almedina, 2003. p. 15.
} 
O alargamento das tarefas do Estado Social, notadamente de protagonizar a efetivação de um extenso catálogo de direitos econômicos e sociais, aumentou a complexidade das relações entre a Administração Pública e os cidadãos, gerando a crise do modelo providencialista. Como afirma OLIVEIRA, a busca pela superação desta crise nas últimas duas décadas do século XX espraiou os clamores por uma redefinição dos fins e do modo de atuar do Estado. ${ }^{1239} 1240$

Nesse contexto, no Brasil, assim como em diversos outros países, foram adotados programas de reforma e modernização do Estado e, por extensão, da Administração Pública. A Reforma Administrativa representa um conjunto de medidas voltadas a modificar as estruturas, a organização, o funcionamento e os instrumentos da Administração Pública, com o objetivo de melhor capacitá-la para fazer frente aos novos fins do Estado e aos interesses da sociedade. ${ }^{1241}$

A realidade vivida pelo Estado contemporâneo indica que a fórmula tradicional que lhe confere o monopólio legítimo da coerção é insuficiente para enfrentar todos os desafios postos à Administração Pública, dos quais se destacam: a crise da lei como amálgama do consenso social; a fragmentação do interesse público; a multiplicidade de interesses que transcendem o interesse individual; o alargamento das demandas que cabem ao Estado Social prover; o aumento do controle social; e uma maior tensão por participação administrativa dos indivíduos e grupos.

No modelo tradicional de democracia formal, instituído nas sociedades monoclasse e biclasse, era suficiente o consenso formado na escolha dos agentes políticos, anteriormente à elaboração da lei e de forma abstrata, sem levar em consideração a vontade dos destinatários do ato. Porém, ao longo do tempo, este modelo foi superado por uma

1239 OLIVEIRA, Gustavo Henrique Justino de. Participação Administrativa. A\&C Revista de Direito Administrativo e Constitucional, Belo Horizonte, ano 5, n. 20, p. 167-168, abril/junho 2005. Disponível em: http://www.bidforum.com.br/. Acesso em: 18/12/2013.

${ }^{1240}$ Além de efetivar os direitos econômicos e sociais, que é dever do Estado Social, a Administração Pública do Estado contemporâneo deve garantir a realização dos direitos fundamentais, dentre os quais se encontra o direito fundamental à boa administração, associados a um conjunto de posturas, tais como a observância do contraditório em processos que digam respeito aos seus interesses e à efetiva reparação de danos que eventualmente sejam causados a si. OLIVEIRA, Gustavo Henrique Justino de; SCHWANKA, Cristiane. $A$ administração consensual como a nova face da Administração Pública no século XXI: fundamentos dogmáticos, formas de expressão e instrumentos de ação. In: Revista de Direito do Estado - RDE, n. 10, p. 271-288, abril/junho. 2008.

1241 OLIVEIRA, Gustavo Henrique Justino de. Participação Administrativa. A\&C Revista de Direito Administrativo e Constitucional, Belo Horizonte, ano 5, n. 20, p. 167-168, abr./jun. 2005. Disponível em: http://www.bidforum.com.br/. Acesso em: 18/12/2013. 
crescente busca pelo estabelecimento de mecanismos de consenso entre a Administração e os cidadãos.

Segundo MOREIRA NETO, a passagem para a sociedade pluriclasse, a revivescência do humanismo e, notadamente, o advento da Revolução das Comunicações tornaram os cidadãos mais esclarecidos e exigentes, estimulando a busca pela ampliação do consenso político acerca de quem deverá governar, para a escolha de políticas, de como deverão governar, dando ensejo à democracia substantiva. ${ }^{1242}$

No contexto do Estado contemporâneo, em que são extensas as tarefas da Administração e inúmeros os conflitos, o modelo de democracia substantiva vem a atender reivindicações de diversos grupos sociais para os quais importa alcançar um consenso mais amplo sobre a decisão na formulação de políticas públicas. ${ }^{1243} \mathrm{Na}$ realidade, uma decisão concertada pressupõe, em suma, o processo dinâmico, bilateral e iterativo da negociação. Por isso, na Administração consensual releva, em rigor, não o conteúdo da decisão, mas o modo ou processo de formação dela.

CHEVALLIER afirma que a governança vem sendo idealizada como meio de legitimação dos poderes estabelecidos e motor de mudança política. Este novo estilo de agir e de decidir, fundado na cooperação e na procura por adesão, determina a análise acerca da inflexão dos modos clássicos de exercício da autoridade caracterizada pela assimetria, desigualdade e unilateralidade. A governança apresenta basicamente dois fundamentos: (i) a eficácia da ação pública, baseada na informalidade e na flexibilidade; e (ii) a obtenção de compromissos e convencimento, por meio de estímulos. ${ }^{1244}$

No mesmo sentido, MOREIRA NETO associa a Administração consensual ou concertada ao aprimoramento da governabilidade e, assim, ao princípio da eficiência, uma vez que esta via de atuação permitiria o atendimento das demandas sociais e receberia a

1242 MOREIRA NETO, Diogo de Figueiredo. Novas tendências da Democracia: Consenso e Direito Público na Virada do Século - o caso Brasileiro. Revista Brasileira de Direito Público. Belo Horizonte, n. 3, ano 1. Outubro 2003. Disponível em: <http:/editoraforum.com.br>. Consulta em 20/12/2013. Sem página. Edição digital.

${ }^{1243}$ MOREIRA NETO, Diogo de Figueiredo. Novas tendências da Democracia: Consenso e Direito Público na Virada do Século - o caso Brasileiro. Revista Brasileira de Direito Público. Belo Horizonte, n. 3 , ano 1. Outubro 2003. Disponível em: <http:/editoraforum.com.br>. Consulta em 20/12/2013. Sem página. Edição digital.

${ }^{1244}$ CHEVALLIER, Jacques. A governança e o Direito. In: Revista de Direito Público da Economia- RDPE, Belo Horizonte, ano 3, n. 12, p. 129-146, outubro/dezembro 2005. 
colaboração ativa dos administrados em defesa das medidas consensualmente alcançadas. ${ }^{1245}$

É preciso assinalar que o princípio da eficiência impõe à Administração Pública a obrigação de realizar suas atribuições de forma rápida, com perfeição e rendimento, além de observar outras regras, como o princípio da legalidade. ${ }^{1246}$ De acordo com MODESTO, o princípio da eficiência pode ser definido como a exigência jurídica, imposta à Administração Pública e a todos os que lhe fazem as vezes, de atuarem de forma honesta, econômica e satisfatória na realização das finalidades públicas que lhe forem confiadas por lei, por ato ou contrato de Direito Público. ${ }^{1247}$

Embora o princípio da eficiência tenha sido acrescentado pela Emenda Constitucional n. 19/98 ao rol dos princípios de observância obrigatória pela Administração Pública, expressamente previsto no artigo 37, caput, da Constituição Federal de 1988, como adverte MODESTO, nunca existiu autorização constitucional para uma Administração ineficiente, contra produtiva ou negligente. Numa democracia representativa a boa gestão da coisa pública pode ser percebida como uma exigência inerente ao exercício da função administrativa e deve ser buscada nos limites estabelecidos pela lei, na justa proporção das necessidades coletivas. A eficiência é, pois, uma das faces materiais do princípio da legalidade. ${ }^{1248}$

No século XX, a abertura de canais entre a sociedade e o Estado para a realização dos anseios democráticos possibilitou a emergência da chamada Administração concertada, uma fórmula sintética designativa de módulos organizados e funcionais caracterizados por uma atividade consensual e negocial, empregada tanto para o desempenho da

1245 MOREIRA NETO, Diogo de Figueiredo. Mutações do direito administrativo. Rio de Janeiro: Renovar. 2000, p.41-43. No mesmo sentido: OLIVEIRA, Gustavo Henrique Justino de; SCHWANKA, Cristiane. $A$ administração consensual como a nova face da Administração Pública no século XXI: fundamentos dogmáticos, formas de expressão e instrumentos de ação. In: Revista de Direito do Estado - RDE, n. 10, p. 271-288, abril/junho. 2008.

1246 GASPARINI, Diogenes. Direito Administrativo. 13. ed., São Paulo: Saraiva, 2008, p.21-23.

${ }^{1247}$ MODESTO, Paulo. Notas para um debate sobre o princípio da eficiência. In: Revista Diálogo Jurídico, v. 1, n. 2, edição digital, maio, 2001. Disponível em: <www.direitopublico.com.br>. Consulta em 2/1/2014. ${ }^{1248}$ Nas palavras de MODESTO, "a função administrativa é sempre atividade finalista, exercida em nome e em favor de terceiros, razão pela qual exige legalidade, impessoalidade, moralidade, responsabilidade, publicidade e eficiência dos seus exercentes. O exercício regular da função administrativa, numa democracia representativa, repele não apenas o capricho e o arbítrio, mas também a negligência e a ineficiência, pois ambos violam os interesses tutelados na lei." MODESTO, Paulo. Notas para um debate sobre o princípio da eficiência. In: Revista Diálogo Jurídico, v. 1, n. 2, edição digital, maio, 2001. Disponível em: $<$ www.direitopublico.com.br>. Consulta em 2/1/2014. 
administração corrente e o desenvolvimento de projetos conjuntos com a iniciativa privada e entidades da Administração Pública, quanto para a solução de conflitos. ${ }^{1249}$

Muito embora não se possa afirmar que a "Administração consensual" ou "Administração concertada" se trate de um fenômeno novo no Direito Administrativo brasileiro, bastando mencionar o instituto da desapropriação amigável, previsto no artigo 10, do Decreto-Lei n. 3.365, de 21 de junho de $1941^{1250}$, apenas nos últimos trinta anos a consensualidade passou a ser considerada uma tendência da Administração Pública. Por certo, houve uma crescente edição de leis relativas a acordos administrativos ${ }^{12511252}$,

${ }^{1249}$ MOREIRA NETO, Diogo de Figueiredo. Novas tendências da Democracia: Consenso e Direito Público na Virada do Século - o caso Brasileiro. Revista Brasileira de Direito Público. Belo Horizonte, n. 3, ano 1. Outubro 2003. Disponível em: <http:/editoraforum.com.br>. Consulta em 20/12/2013. Sem página. Edição digital.

1250 "Art. 10. A desapropriação deverá efetivar-se mediante acordo ou intentar-se judicialmente, dentro de cinco anos, contados da data da expedição do respectivo decreto e findos os quais este caducará."

${ }^{1251}$ Embora não haja regulação minudente no Direito brasileiro acerca da competência dos órgãos e entidades administrativas para a realização de acordos administrativos, há diversas autorizações legais pontuais, dentre as quais é importante mencionar: a Lei n. 7.347, de 24 de julho de 1985, que disciplina a Lei da Ação Civil Pública, prescreve a possibilidade de que os órgãos públicos legitimados à sua propositura poderão tomar dos interessados "compromisso de ajustamento de sua conduta às exigências legais", mediante cominação de obrigações, atribuindo ao termo eficácia de título executivo extrajudicial (artigo $5^{\circ}$, parágrafo $6^{\circ}$ ); a Lei $n$. 12.529, de 30 de novembro de 2011, que estrutura o Sistema Brasileiro de Defesa da Concorrência e revogou, dentre outros, os artigos $7^{\circ}$, inciso VI, 14, inciso IX e 53, da Lei n. 8.884, de 11 de junho de 1994, que estabeleciam o "compromisso de cessação de prática", prevê a competência do Plenário do Tribunal Administrativo de Defesa Econômica para "aprovar os termos do compromisso de cessação de prática e do acordo em controle de concentrações, bem como determinar à Superintendência-Geral que fiscalize seu cumprimento" (art. $\left.9^{\circ}, \mathrm{V}\right)$ e do Presidente do Tribunal para "assinar os compromissos e acordos aprovados pelo Plenário" (art. 10, VII) e estabelece em seu artigo 85 as hipóteses em que o compromisso de cessação da prática sob investigação ou dos seus efeitos poderá ser tomado; a Lei n. 9.307, de 23 de setembro de 1996, que dispõe sobre a arbitragem, estipulando seu cabimento para dirimir litígios relativos a "direitos patrimoniais disponíveis" (art. 10); a Lei n. 11.079, de 30 de dezembro de 2004, que institui normas gerais para licitação e contratação de parceria público-privada no âmbito da Administração Pública e prevê a possibilidade de que o instrumento convocatório preveja "o emprego dos mecanismos privados de resolução de disputas, inclusive a arbitragem, a ser realizada no Brasil e em língua portuguesa, nos termos da Lei n. 9.307, de 23 de setembro de 1996, para dirimir conflitos decorrentes ou relacionados ao contrato". (art. 11, III); a Lei n. 8.987, de 13 de fevereiro de 1995, que dispõe sobre o regime de concessão e de permissão de serviços públicos e estabelece a possibilidade de que o contrato de concessão contenha previsão do emprego de "mecanismos privados para resolução de disputas decorrentes ou relacionadas ao contrato, inclusive a arbitragem, a ser realizada no Brasil e em língua portuguesa, nos termos da Lei n. 9.307, de 23 de setembro de 1996 (art. 23-A).

${ }^{1252}$ No concernente à solução de conflitos de interesses na via administrativa, é preciso mencionar a Câmara de Conciliação e Arbitragem da Administração Federal (CCAF) ${ }^{1252}$, criada pelo Ato Regimental n. 5, de 27 de setembro de 2007 e disciplinada pela Portaria n. 1.281, de 27 de setembro de 2007, com base no artigo $4^{\circ}$, inciso XI, da Lei Complementar n. 73, de 10 de fevereiro de 1993, que instituiu a Lei Orgânica da Advocacia-Geral da União (AGU), como unidade da Consultoria-Geral da União (CGU), que é, por sua vez, órgão de direção superior integrante da estrutura da Advocacia-Geral da União (AGU). A Câmara de Conciliação e Arbitragem da Administração Federal (CCAF) foi instituída com o objetivo de prevenir e solucionar os litígios que envolvam a União, suas autarquias, fundações, sociedades de economia mista e empresas públicas federais. A competência da Câmara de Conciliação e Arbitragem da Administração Federal (CCAF) foi ampliada e, conforme dispõe o Decreto n. 7.392, de 13 de dezembro de 2010, atualmente abrange as controvérsias entre entes e órgãos da Administração Pública Federal, bem como entre esses e a 
trabalhos acadêmicos ${ }^{1253}$ e o desenvolvimento de ações administrativas voltadas ao estabelecimento de instrumentos de consensualidade.

A instituição de mecanismos e canais de comunicação entre a Administração e os cidadãos permite uma participação administrativa cada vez mais intensa, bem como a prevenção e a composição de conflitos envolvendo interesses públicos e interesses privados. A partir do desenvolvimento de relações de cooperação e de uma cultura de diálogo, a Administração Pública se coloca como a primeira a observar a ordem jurídica e incentiva virtudes como a tolerância, a confiança e a boa-fé, construindo as bases ideais para estabelecer consensos com a sociedade. ${ }^{1254}$

De fato, a Administração passou a adotar, em cada vez mais alargados domínios da sua atuação e com uma frequência cada vez maior, formas de atuação "consensual” com os indivíduos, quer mediante a participação e a concertação com os particulares, quer

Administração Pública dos Estados, do Distrito Federal e dos Municípios. BRASIL. Câmara de Conciliação e Arbitragem da Administração Federal - CCAF: cartilha. 3. ed. Brasília: AGU, 2012, p.7. Trata-se de um instrumento relevante para canalizar e resolver de forma consensual, racional e dialógica os conflitos de interesses entre diversos órgãos e esferas da Administração Pública. Contudo, por ora, a competência da Câmara de Conciliação e Arbitragem da Administração Federal (CCAF) está limitada aos conflitos de interesses entre órgãos públicos, não incluindo as relações entre a Administração e os cidadãos, que são o foco de interesse deste trabalho.

${ }^{1253}$ Não seria possível apresentar um rol que exaurisse as obras e artigos acadêmicos publicados, porém cumpre mencionar os seguintes: MOREIRA NETO, Diogo de Figueiredo. Novas tendências da Democracia: Consenso e Direito Público na Virada do Século - o caso Brasileiro. Revista Brasileira de Direito Público. Belo Horizonte, n. 3, ano 1. Outubro 2003. Disponível em: <http:/editoraforum.com.br>; BATISTA JÚNIOR, Onofre Alves. Transações Administrativas. Um contributo ao estudo do contrato administrativo como mecanismo de prevenção e terminação de litígios e como alternativa à atuação administrativa autoritária, no contexto de uma Administração Pública mais democrática. São Paulo: Quartier Latin, 2007; OLIVEIRA, Gustavo Henrique Justino de; SCHWANKA, Cristiane. A administração consensual como a nova face da Administração Pública no século XXI: fundamentos dogmáticos, formas de expressão e instrumentos de ação. In: Revista de Direito do Estado - RDE, n. 10, p. 271-288, abril/junho. 2008; DALLARI, Adilson Abreu. Acordo para recebimento de crédito perante a Fazenda Pública. In: Revista de informação legislativa, v. 42, n. 165, p. 7-9, janeiro/março 2005; MENEZES DE ALMEIDA, Fernando Dias. Contrato Administrativo. São Paulo: Quartier Latin, 2012; PALMA, Juliana Bonacorsi de. Atuação administrativa consensual: estudo dos acordos substitutivos no processo administrativo sancionador. Dissertação (mestrado). Curso de Pós-Graduação em Direito. Área de Direito do Estado. Universidade de São Paulo. São Paulo, 2010.

${ }^{1254}$ Como afirma MOREIRA NETO, as relações de cooperação podem trazer benefícios às civilizações pautadas por relações de antagonismo e que tem na competição a mola do progresso. A cooperação é o tipo de relacionamento ideal numa civilização, uma vez que possibilita a coordenação de expressões de poder para alcançar fins comuns, e, assim, o desenvolvimento de virtudes sociais como a tolerância e a confiança, que possibilitam a concertação de vontades e o surgimento do consenso. MOREIRA NETO, Diogo de Figueiredo. Novas tendências da Democracia: Consenso e Direito Público na Virada do Século - o caso Brasileiro. Revista Brasileira de Direito Público. Belo Horizonte, n. 3, ano 1. Outubro 2003. Disponível em: $<$ http:/editoraforum.com.br>. Consulta em 20/12/2013. Sem página. Edição digital. 
mediante a generalização de formas de atuação contratuais, ainda quando estejam em causa atuações unilaterais. ${ }^{1255}$

A Administração consensual integra os cidadãos no próprio ciclo de formação da decisão, a qual deverá ser mais transparente, explicitada e negociada do que antes. A Administração habitua-se a procurar o consenso daqueles indivíduos que podem ser atingidos pelos efeitos da decisão. ${ }^{1256} \mathrm{O}$ fundamento da utilização do consenso na área da tradicional Administração imperativa resulta da estruturação das relações jurídicoadministrativas, em grande medida, a partir dos direitos individuais. ${ }^{1257}$

A abertura de canais democráticos na Administração Pública e a multiplicidade de atores sociais envolvidos provoca uma transformação no modo de produção do Direito Administrativo, visando a melhor eficácia da ação pública, com a cooperação de múltiplos atores sociais, o estabelecimento de relações de cooperação e a maior adesão dos cidadãos.

Como observa MEDAUAR, a consensualidade na Administração Pública vem sendo proposta como mecanismo de solução de conflitos não tanto devido aos seus méritos, mas em razão da percepção generalizada da insuficiência do sistema jurisdicional para solucionar, em tempo razoável, as ações que estão pendentes de apreciação e julgamento. ${ }^{1258}$

No entanto, não é este o enfoque do presente trabalho. A exigência de instituição de mecanismos voltados à solução consensual de conflitos na esfera administrativa, com vem sendo defendido neste trabalho, não decorre do fato de o Judiciário estar sobrecarregado de ações judiciais, mas de um dever autônomo que incumbe à Administração Pública democrática de prestar serviços públicos eficientes e concretizar os direitos sociais.

$\mathrm{Na}$ medida em que a Constituição passou a contemplar direitos econômicos e sociais, ampliando as tarefas do Estado, cumpre ao Direito Administrativo, instrumento por

1255 SILVA, Vasco Manuel Pascoal Dias Pereira da. Em busca do acto administrativo perdido. Coimbra: Almedina, 2003. p. 466-467.

1256 SILVA, Vasco Manuel Pascoal Dias Pereira da. Em busca do acto administrativo perdido. Coimbra: Almedina, 2003. p. 466-473.

${ }^{1257} \mathrm{O}$ acordo administrativo constitui, em suas diversas vertentes, o instrumento de ação da Administração consensual, motivo pelo qual esta também pode ser denominada Administração por acordos. OLIVEIRA e SCHWANKA sustentam que a noção de acordo é mais ampla do que a noção de contrato, consistindo o acordo em gênero do qual contrato é espécie. OLIVEIRA, Gustavo Henrique Justino de; SCHWANKA, Cristiane. A administração consensual como a nova face da Administração Pública no século XXI: fundamentos dogmáticos, formas de expressão e instrumentos de ação. In: Revista de Direito do Estado RDE, n. 10, p. 271-288, abril/junho. 2008.

1258 MEDAUAR, Odete. Administração Pública: do ato ao processo. In: Biblioteca Digital Fórum Administrativo - Direito Público. Belo Horizonte: Fórum. Ano 9, n. 100, junho 2009. Disponível em: $<$ http:/editoraforum.com.br>. Consulta em 23/12/2013. Sem página. Edição digital. 
excelência da intervenção estatal no domínio econômico e social, propiciar os instrumentos aptos a alcançar os ideais de igualdade e justiça social na via administrativa. ${ }^{1259}$

Conquanto o conceito de interesse público seja indeterminado, é possível reconstruir sua noção, dentro do contexto constitucional, para que possa ser adequadamente defendida a supremacia do interesse público como pilar do regime jurídico-administrativo. ${ }^{1260} \mathrm{Na}$ definição de BORGES, o interesse público consiste num somatório de interesses individuais coincidentes em torno de um bem da vida ao qual atribuem um valor, proveito ou utilidade de ordem moral ou material, que cada pessoa deseja adquirir, conservar ou manter em sua própria esfera de valores. Esse interesse tornase público quando compartilhado por um número significativo de pessoas, componentes de uma comunidade determinada, passando a ser também identificado como interesse de todo o grupo, ou, pelo menos, como um querer valorativo predominante da comunidade. ${ }^{1261} 1262$

Portanto, o interesse público que a Administração tem o dever de tutelar é o interesse do conjunto social qualificado pelo sistema normativo, ou seja, a dimensão pública dos interesses individuais, formada pela junção dos interesses majoritários dos membros da coletividade. Como ressalta MELLO, tendo o Estado sido concebido para a realização de interesses públicos, somente poderá defender seus próprios interesses

1259 TÁCITO, Caio. A Constituição e o Direito Administrativo. In: Revista de Direito Administrativo, Rio de Janeiro, n. 232, p.56-57, 2003.

${ }^{1260}$ Como observa Borges, o interesse público sempre foi ameaçado pelos donos do poder, tendo sido objeto de manipulação para a proteção de posições autoritárias, muitas vezes para acobertar "razões de Estado", quando não interesses menos nobres e, até, inconfessáveis. Desta forma, sob a pretensa independência de poderes, autoridades administrativas utilizaram ao logo dos tempos a noção de interesse público para obstar o controle de seus atos pelo Poder Judiciário. BORGES, Alice Gonzales. Supremacia do interesse público: desconstrução ou reconstrução? In: Revista Diálogo Jurídico, n. 15, Salvador, p. 2-3, janeiro/fevereiro/março de 2007.

${ }^{1261}$ BORGES, Alice Gonzales. Supremacia do interesse público: desconstrução ou reconstrução? In: Revista Diálogo Jurídico, n. 15, Salvador, p. 9, janeiro/fevereiro/março de 2007.

${ }^{1262}$ Para MARQUES NETO, a noção de interesse público deve ser vista à luz de novas perspectivas, que influenciam no significado dos princípios centrais do regime jurídico-administrativo: a supremacia do interesse público e a indisponibilidade deste. O princípio da supremacia do interesse público deve ser compreendido como a prevalência dos interesses públicos em relação aos interesses privados, devendo ser desdobrado em três subprincípios, aos quais a Administração Pública deve obediência: (i) a proibição do atendimento de interesses particularísticos (v.g., aqueles desprovidos de amplitude coletiva, transindividual); (ii) a obrigatoriedade de ponderação de todos os interesses públicos envolvidos no caso concreto; e (iii) a imprescindibilidade de explicação das razões de atendimento de um interesse público em detrimento dos demais. Por outro lado, a indisponibilidade expressa a irrenunciabilidade dos interesses públicos, ou seja, o dever do agente público, no exercício da função administrativa, de proteger e fazer prevalecer os interesses socialmente hipossuficientes. MARQUES NETO, Floriano de Azevedo. Regulação estatal e interesses públicos. São Paulo: Malheiros, 2002. p. 165. 
privados, como pessoa jurídica, quando coincidirem com a realização dos interesses públicos. ${ }^{1263}$

Por consequência, a alegação de violação ao interesse público deve ser verificada pelo conteúdo da decisão, tanto decorrente do exercício de poder unilateral da Administração, como decorrente de acordo de vontades. ${ }^{1264}$

O fenômeno da Administração consensual não abrange apenas a utilização de módulos convencionais pela Administração e particulares. ${ }^{1265}$

Contudo, a centralidade do presente estudo é a solução consensual de conflitos entre a Administração e particulares, relativos a prestações materiais de saúde (medicamento, tratamento, internação, realização de cirurgia, vaga em leito de hospital, transplante de órgãos etc.), ou seja, a função judicativa administrativa, como técnica de superação de conflitos. ${ }^{1266}$

Portanto, é imperioso fazer um corte para restringir a análise da Administração consensual no tocante à solução de conflitos de interesses sobre prestações estatais de saúde na via administrativa. ${ }^{1267}$

Aceito o corte realizado, importa verificar se, em quais condições, é possível que a Administração Pública, atuando de modo a cumprir sua função pública, possa agir de forma consensual ou concertada.

${ }^{1263}$ BANDEIRA DE MELLO, Celso Antônio. Curso de Direito Administrativo. 27 ed. São Paulo: Malheiros, 2010. p.61 e 66.

1264 MENEZES DE ALMEIDA, Fernando Dias. Contrato Administrativo. São Paulo: Quartier Latin, 2012. p.302.

${ }^{1265}$ Para MOREIRA NETO a concepção de Administração consensual abrange três funções: (i) função decisória administrativa; (ii) função executiva administrativa; e (iii) função judicativa administrativa. A função judicativa administrativa se refere tanto ao sentido de antecipar, como de compor conflitos. São exemplos desta categoria os acordos substitutivos, a conciliação, a mediação, a arbitragem, os ajustes de conduta e similares. Com base nessa classificação, nas duas hipóteses referidas há realização do interesse público, correspondendo, assim, à modalidade de consenso relativa à função judicativa administrativa. MOREIRA NETO, Diogo de Figueiredo. Novas tendências da Democracia: Consenso e Direito Público na Virada do Século - o caso Brasileiro. Revista Brasileira de Direito Público. Belo Horizonte, n. 3, ano 1. Outubro 2003. Disponível em: <http:/editoraforum.com.br>. Consulta em 20/12/2013. Sem página. Edição digital.

${ }^{1266}$ MOREIRA NETO, Diogo de Figueiredo. Novas tendências da Democracia: Consenso e Direito Público na Virada do Século - o caso Brasileiro. Revista Brasileira de Direito Público. Belo Horizonte, n. 3, ano 1. Outubro 2003. Disponível em: <http:/editoraforum.com.br>. Consulta em 20/12/2013. Sem página. Edição digital.

${ }^{1267}$ Sem que se pretenda analisar a participação da iniciativa privada no Sistema Único de Saúde, admitida de forma complementar, mediante contrato de direito público ou convênio, conforme dispõe o artigo 199, parágrafo $1^{\circ}$ da Constituição Federal, cumpre mencionar a possibilidade de utilização dos módulos convencionais de cooperação, tendo em vista a conjugação de esforços para o exercício de competências constitucionalmente atribuídas aos entes estatais e a consecução de um fim comum. Sobre os módulos convencionais de cooperação, conferir: MENEZES DE ALMEIDA, Fernando Dias. Contrato Administrativo. São Paulo: Quartier Latin, 2012.p.240-261. 
A partir da sistematização proposta MENEZES DE ALMEIDA ${ }^{1268}$, os verdadeiros módulos convencionais abrangem duas grandes categorias: (i) casos em que uma nova situação jurídica (subjetiva e objetiva) é criada, necessariamente a partir do acordo de vontades das partes envolvidas, que se subdivide em três blocos: módulos convencionais de cooperação, módulos convencionais de concessão e módulos convencionais instrumentais; e (ii) casos em que a Administração teria poder de decidir unilateralmente para criar uma nova situação jurídica, contudo decide substituir o exercício desse poder por um acordo de vontades, intitulados módulos convencionais substitutivos de decisão unilateral da Administração. ${ }^{1269}$

A primeira categoria enfocada por MENEZES DE ALMEIDA compreende três hipóteses em que a convenção é indispensável para a criação de situação jurídica, correspondendo à maioria dos módulos convencionais praticados pela Administração Pública em seu quotidiano. ${ }^{1270}$

Com efeito, a norma constitucional que reconhece o direito fundamental à saúde é de eficácia contida e aplicabilidade imediata $\left(\mathrm{CF}\right.$, art. $6^{\circ}$ e art. $\left.5^{\circ}, \S 1^{\circ}\right)$. Ao direito subjetivo a prestações materiais de saúde corresponde o dever objetivo do Estado de realizar ações e serviços de saúde, voltado "à redução do risco de doença e de outros agravos", bem como "ao acesso universal e igualitário às ações e serviços para sua promoção, proteção e recuperação" (CF, art. 196, caput). ${ }^{1271}$

Como visto alhures, o direito fundamental à saúde é um direito subjetivo que possui uma dimensão negativa, como direito de defesa do indivíduo perante agressões dos poderes públicos e de terceiros e, igualmente, uma dimensão positiva (normativa e

\footnotetext{
${ }^{1268}$ MENEZES DE ALMEIDA desenvolve a análise do fenômeno contratual constatado no Direito Positivo sob uma perspectiva histórica e evolutiva, e expõe as razões pelas quais a teoria do contrato administrativo, nos seus moldes tradicionais, deve ser revista e reformulada para se adequar ao contexto contemporâneo. A obra "Contrato Administrativo" corresponde à tese apresentada por MENEZES DE ALMEIDA em concurso de livre-docência, na Faculdade de Direito da Universidade de São Paulo, cujas provas ocorreram em fevereiro de 2011. Conforme nota do autor, o título atribuído à tese "Teoria do Contrato Administrativo: uma abordagem histórico-evolutiva com foco no Direito brasileiro" foi simplificado, com a finalidade de estabelecer uma comunicação mais adequada com o público em geral. MENEZES DE ALMEIDA, Fernando Dias. Contrato Administrativo. São Paulo: Quartier Latin, 2012.

${ }^{269}$ MENEZES DE ALMEIDA, Fernando Dias. Contrato Administrativo. São Paulo: Quartier Latin, 2012. p.236-240.

${ }_{1270}$ MENEZES DE ALMEIDA, Fernando Dias. Contrato Administrativo. São Paulo: Quartier Latin, 2012. p.238.

${ }^{1271}$ O artigo 196, caput, da Constituição Federal assim dispõe: "Art. 196. A saúde é direito de todos e dever do Estado, garantido mediante políticas sociais e econômicas que visem à redução do risco de doença e de outros agravos e ao acesso universal e igualitário às ações e serviços para sua promoção, proteção e recuperação."
} 
material), prioritariamente dirigida ao legislador, que deve criar as condições necessárias para a sua realização.

A eficácia imediata das normas que reconhecem os direitos fundamentais assegura a projeção do direito à saúde, desde logo, nas relações jurídico-administrativas, atribuindo aos indivíduos a possibilidade de sua invocação direta perante a Administração, sem prejuízo de sua exigência perante o Judiciário.

A prestação do serviço público de saúde configura um dever constitucional do Estado Social, imanente à função pública, de competência material comum de todos os entes da federação, do qual não podem se eximir (CF, art. 23, II). ${ }^{1272}$

Além da prestação de serviços públicos de saúde, a Lei n. 8.080/90 prevê incumbir à União, aos Estados, ao Distrito Federal e Municípios o dever de assegurar o funcionamento adequado do Sistema Único de Saúde (SUS), por meio de controle, avaliação e fiscalização permanente das ações e serviços de saúde, com a adoção de medidas eventualmente necessárias para que sejam corrigidas e aprimoradas, conforme preveem o artigo 15 , inciso $\mathrm{I}^{1273}$, o artigo 16 , inciso $\mathrm{XVII}^{1274}$, o artigo 17 , inciso $\mathrm{II}^{1275}$ e o artigo 18 , inciso I. ${ }^{1276}$

O Estado, destinatário do dever de proteção da saúde, em cumprimento à sua obrigação e em conformidade com as atribuições pactuadas entre os entes federativos, fica vinculado ao regular fornecimento dos medicamentos previstos em lista específica e à prestação de tratamento de saúde adequado e eficiente a todos os indivíduos que necessitarem, mediante políticas sociais e econômicas (art. 196, caput, da Constituição Federal).

De conseguinte, o atendimento pela Administração da pretensão material em saúde de um indivíduo não pode ser enquadrado nos módulos convencionais, uma vez que a situação jurídica decorre da Constituição Federal, das leis e das normas infralegais que

1272 A Constituição Federal prescreve em seu artigo 23, inciso II, o seguinte: “Art. 23. É competência comum da União, dos Estados, do Distrito Federal e dos Municípios: (...) II - cuidar da saúde e assistência pública, da proteção e garantia das pessoas portadoras de deficiência;",

1273 “Art. 15. A União, os Estados, o Distrito Federal e os Municípios exercerão, em seu âmbito administrativo, as seguintes atribuições: I - definição das instâncias e mecanismos de controle, avaliação e de fiscalização das ações e serviços de saúde;

1274 “Art. 16. A direção nacional do Sistema Único da Saúde (SUS) compete: (...) XVII - acompanhar, controlar e avaliar as ações e os serviços de saúde, respeitadas as competências estaduais e municipais;"

1275 Art. 17. À direção estadual do Sistema Único de Saúde (SUS) compete: (...) II - acompanhar, controlar e avaliar as redes hierarquizadas do Sistema Único de Saúde (SUS);"

1276 Art. 18. À direção municipal do Sistema de Saúde (SUS) compete: (...) I - planejar, organizar, controlar e avaliar as ações e os serviços de saúde e gerir e executar os serviços públicos de saúde;” 
regulamentam as ações e os serviços públicos de saúde no âmbito do Sistema Único de Saúde (SUS).

Não cabe à Administração convencionar a adoção de conduta à qual já está juridicamente vinculada. Uma convenção que preveja o dever do Estado de cumprir política pública de saúde já existente em relação a determinado indivíduo não representa autêntica opção pelo módulo convencional, mas mera submissão da atividade administrativa à ordem jurídica, com o reconhecimento do direito subjetivo a prestações positivas (materiais) do titular do direito à saúde.

Da mesma forma, a concordância do indivíduo em receber da Administração Pública tratamento diverso do que havia pedido em âmbito administrativo, mas que esteja incluído em algum programa, no âmbito do Sistema Único de Saúde (SUS), conforme os critérios estabelecidos em Protocolo Clínico e Diretriz Terapêutica (PCDT), não significa uma opção da Administração Pública pelo módulo convencional. Neste caso ocorre a renúncia do particular em relação à sua pretensão (e não do direito à saúde, que é indisponível), considerando a existência de alternativa terapêutica oferecida no âmbito do Sistema Único de Saúde (SUS).

Embora não configurem módulos convencionais propriamente ditos (o reconhecimento do direito subjetivo a prestações materiais em saúde pela Administração Pública e a concordância do particular em substituir o tratamento de saúde postulado, não oferecido no âmbito do Sistema Único de Saúde, por outro que seja oferecido), numa acepção ampla é possível considerar que nesses casos há um consenso. Isto porque se estabelece um acordo, entendido como expressão do consenso da Administração e do administrado, apto a reger harmoniosamente esta relação jurídico-administrativa, com o atendimento pelo Estado de uma demanda por prestação material de saúde. ${ }^{1277}$

Nos casos em que a prestação material postulada na via administrativa não faça parte de nenhuma política pública ou programa no âmbito do Sistema Único de Saúde (SUS) nem exista alternativa terapêutica para o tratamento, a Administração pode criar uma situação jurídica de vantagem ao particular, além das políticas econômicas e sociais

1277 De acordo com MENEZES DE ALMEIDA, o consenso integra a essência da figura do contrato e considera que o fenômeno da Administração consensual envolve, dentre outros aspectos, uma utilização mais intensa dos módulos convencionais. Porém, ressalva que "o espírito de consenso na ação administrativa vai muito além do uso do instrumento convencional propriamente dito". MENEZES DE ALMEIDA, Fernando Dias. Contrato Administrativo. São Paulo: Quartier Latin, 2012. p.340-341. 
de saúde existentes, por meio de um ato administrativo ampliativo ${ }^{1278}$, concedendo-lhe direitos subjetivos originários em duas hipóteses.

A primeira hipótese é aquela em que, embora exista política pública de saúde no âmbito do Sistema Único de Saúde (SUS), a Administração se compromete a fornecer uma prestação material de saúde diversa daquela contemplada nos programas disponíveis, devido a circunstâncias pessoais documentalmente comprovadas, por exemplo: características biológicas que comprometem a eficácia do tratamento; não apresentação de resposta adequada ao tratamento (refratariedade medicamentosa); ou a manifestação de reações alérgicas ao tratamento.

A segunda hipótese se refere à situação em que não existe política pública de saúde no âmbito do Sistema Único de Saúde (SUS) para a doença ou agravo que acomete o indivíduo, apesar de existir tratamento ou medicamento desenvolvido pela indústria farmacêutica, com registro da Agência Nacional de Vigilância Sanitária (ANVISA).

Nos dois casos, à luz do conjunto de circunstâncias concretas contidas no processo administrativo, como relatórios e pareceres técnicos (médicos, econômicos e financeiros), a Administração deverá avaliar e decidir motivadamente acerca do atendimento ou não da pretensão material de saúde.

Nesta avaliação, em se tratando de direito originário a prestações, um dos critérios a ser considerado deve se referir ao núcleo essencial do direito à saúde, ou seja, se o medicamento ou tratamento de saúde postulado é imprescindível à manutenção da vida do indivíduo em condições dignas.

Assim, caso haja o atendimento da prestação material de saúde buscada pelo cidadão no bojo do processo administrativo, este culminará com um ato administrativo ampliativo, consistente em uma decisão que alarga o círculo de ação jurídica de seu destinatário. 1279

1278 De acordo com MELLO, são atos ampliativos aqueles que aumentam a esfera de ação jurídica do destinatário, tais como, as concessões em geral, permissões, autorizações, admissões e licenças. MELLO, Celso Antônio Bandeira de. Curso de Direito Administrativo. 27. ed. São Paulo: Malheiros. 2010.p.425.

1279 Quanto aos resultados sobre a esfera jurídica dos administrados, MELLO classifica os atos administrativos em duas categorias: atos ampliativos e atos restritivos da esfera jurídica dos administrados. MELLO afirma a importância da distinção ante a bipartição de regimes aplicáveis a cada uma das categorias. Assim, destaca que a teoria da eficácia em relação aos atos ampliativos é distinta daquela aplicável aos atos restritivos da esfera jurídica dos administrados, não se aplicando em relação aos ampliativos nada do que se relaciona com a imperatividade, a exigibilidade ou a executoriedade. Da mesma forma, toda a temática concernente à participação da vontade do particular na formação de relações jurídico-administrativas somente se propõe em relação aos atos ampliativos. MELLO, Celso Antônio Bandeira de. Curso de Direito Administrativo. 27. ed. São Paulo: Malheiros. 2010.p.427. 
Uma vez decidido pela Administração, em última instância, de modo contencioso, acerca do direito subjetivo originário de um particular à prestação material em saúde, ocorrerá a chamada "coisa julgada administrativa", implicando, para a Administração, a definitividade dos efeitos da decisão. Trata-se de instituto que cumpre uma função de garantia de direitos dos administrados, atinente à segurança jurídica e à boa-fé na esfera administrativa. ${ }^{1280}$

A segunda categoria apresentada por MENEZES DE ALMEIDA, embora não seja propriamente nova, vem se tornando mais extensa na prática administrativa contemporânea. Nestes casos, a Administração possui, anteriormente, o poder de ação unilateral, mas decide substituir o exercício desse poder por um acordo de vontades, ou seja, em lugar da decisão administrativa unilateral, cria uma situação jurídica subjetiva, vinculando as partes envolvidas, por uma convenção. ${ }^{1281}$

No Direito Administrativo brasileiro, a Lei n. 9.784/99 (Lei de Processo Administrativo federal) não prevê a possibilidade de substituição de decisão administrativa unilateral por atos convencionais, o que certamente serviria como estímulo à celebração de acordos em substituição pela Administração.

A despeito disso, como observa MENEZES DE ALMEIDA, não se vislumbra uma vedação que possa ser colocada como regra, sendo possível a celebração desses acordos, pois a opção de decidir de modo consensual com o destinatário da decisão está implícita no poder de decidir de forma unilateral. ${ }^{1282}$

Um exemplo de módulo convencional empregado pela Administração Pública em substituição à sua decisão unilateral consiste no compromisso de ajustamento de conduta ao Direito, celebrado por meio de termo de ajustamento de conduta (TAC), previsto no artigo $5^{\circ}$, parágrafo $6^{\circ}$, da Lei n. 7.347 de 24 de julho de 1985 , que trata da ação civil pública. ${ }^{1283} 1284$

${ }^{1280}$ De acordo com MELLO, o fenômeno da "coisa julgada administrativa" só ocorre em relação aos atos ampliativos da esfera jurídica dos administrados. O ato administrativo torna-se irrevogável e irretratável, proibindo sua impugnação em juízo pela Administração, garantindo a estabilidade da decisão administrativa. Por outro lado, terceiros não estão impedidos de buscar a correção judicial do ato. MELLO, Celso Antônio Bandeira de. Curso de Direito Administrativo. 27. ed. São Paulo: Malheiros. 2010.p.427.

${ }^{1281}$ MENEZES DE ALMEIDA, Fernando Dias. Contrato Administrativo. São Paulo: Quartier Latin, 2012. p.297-298.

1282 MENEZES DE ALMEIDA, Fernando Dias. Contrato Administrativo. São Paulo: Quartier Latin, 2012. p.301-302.

${ }^{1283} \mathrm{O}$ artigo $5^{\circ}$, parágrafo $6^{\circ}$, inserido pelo artigo 113 , da Lei n. 8.078, de 11 de setembro de 1990 assim dispõe: "Art. 5' Têm legitimidade para propor a ação principal e a ação cautelar: I - o Ministério Público; II a Defensoria Pública; III - a União, os Estados, o Distrito Federal e os Municípios; IV - a autarquia, empresa 
Com efeito, os órgãos da Administração podem celebrar termo de ajustamento de conduta, ou figuras similares, no âmbito de processos administrativos, caso avaliem, no caso concreto, ser vantajoso substituir sua decisão unilateral, de tomar certa medida visando a aplicação de sanção a outra parte, por um acordo de vontades em que o infrator se comprometa a corrigir sua conduta, adequando-a ao Direito.

O compromisso de ajustamento de conduta é um instrumento de composição de controvérsias e de pacificação social, que pode ser celebrado diretamente pelas partes envolvidas na fase pré-processual, com a função precípua de prevenir a lide que se formaria, com a consequente propositura de ação civil pública. ${ }^{1285}$

Conquanto o grau de consensualidade por parte daquele que tem sua conduta ajustada seja mais restrito, na medida em que há uma ameaça iminente da tomada de uma decisão unilateral pela Administração, que pode vir a impor sanção, há implícito no termo de ajustamento de conduta (TAC) o sentido convencional substitutivo de decisão da Administração. ${ }^{1286}$

Não se impõe o compromisso, que é assumido de livre vontade. Ainda que o compromisso de ajustamento de conduta contenha obrigações dirigidas apenas ao compromitente, necessita de sua anuência expressa para produzir seus efeitos. ${ }^{1287}$

pública, fundação ou sociedade de economia mista; V - a associação que, concomitantemente: a) esteja constituída há pelo menos 1 (um) ano nos termos da lei civil; b) inclua, entre suas finalidades institucionais, a proteção ao meio ambiente, ao consumidor, à ordem econômica, à livre concorrência ou ao patrimônio artístico, estético, histórico, turístico e paisagístico. (...) $§ 6^{\circ}$ Os órgãos públicos legitimados poderão tomar dos interessados compromisso de ajustamento de sua conduta às exigências legais, mediante cominações, que terá eficácia de título executivo extrajudicial."

${ }^{1284}$ No subitem 4.2 deste trabalho se fez referência aos compromissos de ajustamento de conduta à lei, ou figuras similares, como exemplos de instrumentos pró-consensuais contratuais.

1285 FERNANDES, Rodrigo. Compromisso de ajustamento de conduta ambiental: fundamentos, natureza jurídica, limites e controle jurisdicional. Rio de Janeiro, São Paulo e Recife: Renovar, 2008. p.83-85.

${ }^{1286}$ MENEZES DE ALMEIDA afirma que nessas situações, muitas vezes, o conteúdo explícito nos termos de ajustamento de conduta (TAC) indica que se trata da imposição de uma conduta pela Administração a determinado sujeito submetido ao seu poder de exigir o cumprimento do Direito, não se verificando, expressamente, um resultado jurídico construído pela convenção. Porém, ao celebrar um termo de ajustamento de conduta, a Administração está, por acordo de vontades, optando por substituir sua decisão unilateral, cujo poder de edição, contudo, não renuncia. MENEZES DE ALMEIDA, Fernando Dias. Contrato Administrativo. São Paulo: Quartier Latin, 2012. p.303-304.

1287 Conforme FERNANDES, o compromisso de ajustamento de conduta é caracterizado pela consensualidade, pois nasce da livre proposta ou da aquiescência do compromitente com a obrigação advinda do órgão público tomador. Para FERNANDES é bastante remota a hipótese de o acordo estabelecer obrigações apenas para uma das partes, na medida em que a decisão pela atuação consensual do órgão tomador do compromisso, ainda que implícita, contém a obrigação dirigida ao Estado de não propositura da ação ou adoção de outras medidas coercitivas. FERNANDES, Rodrigo. Compromisso de ajustamento de conduta ambiental: fundamentos, natureza jurídica, limites e controle jurisdicional. Rio de Janeiro, São Paulo e Recife: Renovar, 2008. p.62-63 e 67-70. 
Portanto, com base nessas lições, é certo que a Administração pode celebrar compromisso de ajustamento de conduta ao Direito, no bojo de um processo administrativo sanitário, como alternativa à decisão unilateral de imposição de sanção decorrente do cometimento de infrações sanitárias. Por meio do termo de ajustamento de conduta (TAC), a Administração deverá estabelecer as condições de cumprimento das obrigações legais pelo compromitente (o modo e o prazo), mediante a adoção ou a abstenção de certas condutas.

Ante a dogmática dos modelos convencionais apresentada por MENEZES DE ALMEIDA, que acompanhamos no presente trabalho, somente estará configurado verdadeiro módulo convencional nas hipóteses em que a Administração opte por celebrar termo de ajustamento de conduta ao Direito, ou figuras similares, em sede de processo administrativo, o que configura um módulo convencional substitutivo de decisão unilateral da Administração. ${ }^{1288}$

\subsection{Mecanismos de solução consensual de conflitos relativos ao direito à saúde na esfera administrativa}

De todos os aspectos da Administração consensual, o que se coloca em destaque neste trabalho é a solução de conflitos entre a Administração Pública e os cidadãos na via administrativa, concernentes às prestações materiais de saúde (medicamentos, insumos, tratamentos, cirurgias, leito hospitalar etc.).

Neste tópico cabe ilustrar, mediante recurso a alguns exemplos, mecanismos de composição de conflitos, instituídos no Brasil, relativos a prestações materiais de saúde, analisando as repercussões de cada um.

5.3.1. Os instrumentos pró-consensuais procedimentais instituídos pela Coordenação das Demandas Estratégicas do SUS (CODES), da Secretaria de Estado da Saúde de São Paulo (SES/SP), e pela Procuradoria Geral do Estado de São Paulo (PGE/SP) $)^{1289}$

\footnotetext{
1288 MENEZES DE ALMEIDA, Fernando Dias. Contrato Administrativo. São Paulo: Quartier Latin, 2012. p.236-240.

${ }^{1289}$ As informações contidas neste subitem foram extraídas das seguintes fontes: NAFFAH FILHO, Michel; CHIEFFI, Ana Luiza; CORREA, Maria Cecília M.M.A. S-CODES: um novo sistema de informações sobre ações judiciais da Secretaria de Estado da Saúde de São Paulo. In: BEPA. Boletim Epidemiológico Paulista,
} 
A Secretaria de Estado da Saúde de São Paulo (SES/SP) criou a Coordenação das Demandas Estratégicas do SUS (CODES), em maio de 2007, com o objetivo de separar da Coordenadoria de Ciência, Tecnologia e Insumos Estratégicos de Saúde (CCTIES) o processamento e cumprimento de decisões judiciais no âmbito do Estado de São Paulo. A Coordenação das Demandas Estratégicas do SUS (CODES) não possui estrutura formal e está diretamente vinculada ao Gabinete do Secretário de Saúde.

Anteriormente à sua criação, em julho de 2005, a Coordenadoria de Planejamento de Saúde (CPS) já havia desenvolvido um sistema de controle jurídico (SCJ) com as finalidades de: (i) criar um canal de comunicação com o autor da ação judicial através de telegrama; (ii) identificar os produtos e suas quantidades a serem adquiridas para o atendimento das determinações judiciais; (iii) organizar a dispensação de produtos, assim como a comprovação de sua entrega através de recibos legíveis armazenados eletronicamente; e (iv) oferecer informações técnicas pertinentes para que a Procuradoria Geral do Estado pudesse elaborar a defesa no processo judicial.

Em 2008, a organização conquistada com o sistema de controle jurídico (SCJ) na capital foi expandida para o interior do Estado e com esta ampliação a Coordenação das Demandas Estratégicas do SUS (CODES) identificou a necessidade de um novo sistema que pudesse auxiliar na gestão de compras, no controle de estoques e administração dos almoxarifados, para o melhor atendimento das decisões judiciais. Assim, foi desenvolvido um novo sistema, denominado S-CODES, com três módulos: judicial, administrativo e relatórios.

No módulo judicial do S-CODES, em julho de 2010, estavam cadastradas 23.003 ações judiciais ativas, agrupadas por categorias (materiais, medicamentos, nutrição, outros itens e procedimentos), tendo sido apurado que o valor mensal despendido com o cumprimento das decisões judicias proferidas nestas ações judiciais era de $\mathrm{R} \$$ 57.038.981,90 (cinquenta e sete milhões, trinta e oito mil, novecentos e oitenta e um reais e noventa centavos).

v. 7, p. 18-30, 2010; relatório disponível no site <http://www.premiomariocovas.sp.gov.br/>; relatório de Atividades da Coordenação das Demandas Estratégicas do SUS (CODES) elaborado em julho de 2010 por Maria Cecília Marchese da Motta Azevedo Correa, nomeada para exercer as funções de Coordenação das Demandas Estratégicas do Sistema Único de Saúde (SUS), desde sua instituição, em 3 de maio de 2007 (Diário Oficial do Estado de São Paulo, Seção II, p. 61, de 03/05/2010, retificado em 05/05/2010, Seção II, p.61), juntado como anexo (n. 1); e site da Secretaria de Estado da Saúde de São Paulo: http://www.saude.sp.gov.br/. Consulta em: 31/12/2013. 
Por sua vez, o módulo administrativo do S-CODES, que é o foco de interesse deste trabalho, se refere ao atendimento dos cidadãos, para o fornecimento de prestações materiais em saúde na via administrativa.

A primeira experiência ocorreu em 2007, logo após o registro pela Agência Nacional de Vigilância Sanitária (ANVISA) de dois novos retrovirais, o Raltegravir e o Maraviroc para o tratamento de pessoas com AIDS (Síndrome da Imunodeficiência Humana). Em parceria com o Centro de Referência e Treinamento (CRT) DST/AIDS-SP, a Coordenação das Demandas Estratégicas do SUS (CODES) operacionalizou e cadastrou os indivíduos que apresentaram laudos médicos favoráveis e obtiveram decisão da Administração para receber os medicamentos. Em 2008, enquanto havia 8 (oito) indivíduos que recebiam o medicamento Maraviroc por ordem judicial, 98 (noventa e oito) recebiam por decisão administrativa e, em relação ao Raltegravir, 32 (trinta e dois) indivíduos recebiam por ordem judicial, ao passo que 274 (duzentos e setenta e quatro) recebiam os medicamentos por decisão administrativa. No total, havia 40 (quarenta) ordens judiciais e 372 (trezentos e setenta e duas) decisões administrativas sendo cumpridas.

Este modelo exitoso de atendimento na via administrativa, especificamente para Raltegravir e o Maraviroc, ocorreu até dezembro de 2008, visto que em janeiro de 2009 o Ministério da Saúde incorporou o medicamento Raltegravir no Programa Nacional de Doenças Sexualmente Transmissíveis (DST) e AIDS. ${ }^{1290}$

Em 11 de março de 2008, a Secretaria de Estado da Saúde de São Paulo (SES/SP), por meio da Coordenação das Demandas Estratégicas do SUS (CODES), e a Defensoria Pública do Estado de São Paulo ${ }^{1291}$ celebraram uma parceria, visando o esclarecimento dos

\footnotetext{
1290 No mesmo sentido, em julho de 2009, a Coordenação das Demandas Estratégicas do SUS (CODES) estabeleceu um plano de incorporação de 7 (sete) medicamentos oncológicos, com o mais alto nível de evidência, ainda não previstos nas tabelas do Ministério da Saúde, para que fossem fornecidos pela Secretaria de Estado da Saúde aos indivíduos com indicação clínica. Nesta época, os recursos públicos investidos em medicamentos oncológicos somavam 4,3 milhões. Em julho de 2010, com os novos medicamentos oncológicos dispensados na via administrativa, os investimentos passaram a ser de 22,3 milhões.

1291 A Constituição Federal assegura, em seu artigo 50, inciso LXXIV, que "o Estado prestará assistência jurídica integral e gratuita aos que comprovarem insuficiência de recursos;" Esta norma foi regulamentada pela Lei n. 1.060, de 5 de fevereiro de 1950, a qual estabelece normas para a concessão de assistência judiciária gratuita aos necessitados. De acordo com o artigo $4^{\circ}$ desta lei, terão direito aos benefícios da assistência judiciária aqueles que não puderem pagar os honorários de advogado e as custas do processo, sem prejuízo do sustento próprio ou de sua família, devendo declarar tal condição mediante simples afirmação, na própria petição inicial. No Estado de São Paulo, por força do disposto no artigo 10 do Ato das Disposições Transitórias da Constituição do Estado de São Paulo e da Lei Complementar n. 988, de 9 de janeiro de 2006, a assistência judiciária é prestada pela Defensoria Pública do Estado de São Paulo e pela Procuradoria de Assistência Judiciária, sendo esta órgão integrante da Procuradoria-Geral do Estado de São Paulo, nos termos do que dispõe a Lei Complementar n. 478, de 18 de julho de 1986.
} 
indivíduos acerca do funcionamento do Sistema Único de Saúde, especialmente da assistência farmacêutica para fins de recebimento de medicamentos na esfera administrativa.

Por meio deste instrumento pró-consensual, os indivíduos que não encontrassem o medicamento ou insumo padronizados no âmbito do Sistema Único de Saúde (SUS) no posto de saúde, ou que pretendessem receber medicamentos não padronizados, eram encaminhados para atendimento por servidores públicos da Secretaria de Estado da Saúde de São Paulo (SES/SP), no próprio prédio da Defensoria Pública do Estado de São Paulo. Neste atendimento, os farmacêuticos avaliavam as receitas médicas e buscavam localizar o medicamento ou insumo na rede pública, por meio do S-CODES e, caso disponível, encaminhavam os indivíduos para o local correto em que poderiam recebê-lo. Na hipótese do medicamento não padronizado no âmbito do Sistema Único de Saúde (SUS) também é avaliada a receita médica, a necessidade do medicamento ou insumo prescrito e a possibilidade de fornecimento na via administrativa.

Por conta desta iniciativa de solução extrajudicial de conflitos envolvendo pretensões materiais de saúde, a Defensoria Pública do Estado de São Paulo conseguiu reduzir em $80 \%$ (oitenta por cento) a propositura de ações judiciais, cujo pedido consistia no fornecimento de medicamentos e insumos de saúde. O sucesso do instrumento próconsensual adotado pela Defensoria Pública do Estado de São Paulo foi reconhecido com o primeiro lugar do prêmio Innovare (categoria Defensoria Pública).

A partir do segundo semestre de 2009, a Secretaria de Estado da Saúde de São Paulo (SES/SP) ${ }^{1292}$ celebrou contrato de gestão ${ }^{1293}$ com uma Organização Social de Saúde (OSS) para realizar o serviço de triagem farmacêutica e nutricional no Ambulatório Médico de Especialidades (AME) Maria Zélia, com abrangência para a Grande São Paulo.

Desde 2010, a triagem farmacêutica presta orientação a aproximadamente 400 (quatrocentas) pessoas por dia e recebe 50 (cinquenta) novos pedidos administrativos, os quais são analisados por Comitês Técnicos, orientados pela Coordenação das Demandas

\footnotetext{
1292 No âmbito do Estado de São Paulo, a Lei Complementar n. 846, de 4 de junho de 1998, dispõe sobre a qualificação de entidades como organizações sociais e dá outras providências.

$1293 \mathrm{O}$ contrato de gestão, previsto no parágrafo $8^{\circ}$, do artigo 37, da Constituição Federal de 1988, regulamentado pela Lei n. 9.637, de 15 de maio de 1998, também consiste em uma forma de expressão da Administração consensual, classificada por MENEZES DE ALMEIDA como módulo convencional de cooperação. MENEZES DE ALMEIDA, Fernando Dias. Contrato Administrativo. São Paulo: Quartier Latin, 2012, p.240-242 e 248-252. Para aprofundar o estudo desta temática, conferir: OLIVEIRA, Gustavo Henrique Justino de. Contrato de gestão. São Paulo: Revista dos Tribunais, 2008.
} 
Estratégicas do SUS (CODES). Os pedidos administrativos são avaliados individualmente por Comitês de Especialistas, que decidem conforme a Medicina baseada em evidências. Não são fornecidos na via administrativa: (i) medicamentos sem registro na Agência Nacional de Vigilância Sanitária (ANVISA); (ii) medicamentos com alerta na Farmacovigilância ${ }^{1294}$; e (iii) medicamentos sem indicação em bula (off-label). ${ }^{1295}$

Nas situações em que o pedido administrativo for negado, a Coordenação das Demandas Estratégicas do SUS (CODES) funciona como uma segunda instância, cabendolhe reavaliar a situação pela Comissão Farmacoterapeutica, ou por instituição equivalente, assim como por sua Diretoria Clínica. Nestes casos, se os médicos e farmacêuticos verificarem que há pertinência do medicamento ou insumo que está sendo reclamado para a moléstia que acomete o indivíduo, apesar de não padronizado no Sistema Único de Saúde (SUS), a pretensão poderá ser atendida na via administrativa, considerando as circunstâncias peculiares do caso, por meio de um ato ampliativo da esfera de ação jurídica do administrado.

Também é possível solicitar, na via administrativa ${ }^{1296}$, o fornecimento de medicamento, insumo ou nutrição enteral não padronizado no âmbito do Sistema Único de Saúde (SUS), em caráter de excepcionalidade, esgotadas as alternativas terapêuticas disponíveis. Neste caso, é importante que o indivíduo apresente literatura científica com forte nível de evidência que justifique sua utilização.

Conquanto o medicamento, insumo ou nutrição enteral solicitado não faça parte de nenhum programa de assistência farmacêutica do Sistema Único de Saúde (SUS), o Comitês Técnicos e a Coordenação das Demandas Estratégicas do SUS (CODES) avaliam o relatório médico e, se entenderem que a prestação material é necessária ao tratamento de

1294 De acordo com o glossário da ANVISA, "Farmacovigilância é a Ciência e as atividades relativas à detecção, avaliação, compreensão e prevenção de efeitos adversos ou outros problemas relacionados a medicamentos." O alerta pode ser: rápido, restrito ou de segurança. O alerta rápido é o alerta que deve ser feito de maneira urgente para iniciar um procedimento de recolhimento de um medicamento ou outros. Já o alerta restrito é o alerta que contém informações sobre a segurança de um medicamento e que é direcionado para grupos específicos de usuários ou instituições, devido a peculiaridades de uso ou administração de determinados medicamentos. Por sua vez, o alerta de segurança é o alerta que contém informações sobre a segurança de um medicamento e que são amplamente divulgados. Glossário do grupo de prevenção ao uso indevido de medicamentos. Disponível em: <http://anvisa.gov.br/>. Consulta em 31/12/2013.

1295 Uso off-label de medicamento compreende as situações em que o medicamento é utilizado em divergência com o que consta em sua bula. Embora se trate de medicamento registrado na ANVISA, há alguma divergência em relação à indicação, à faixa etária, ao peso, à dose, à frequência, à apresentação ou à via de administração. Disponível em: <http://anvisa.gov.br/>. Consulta em 31/12/2013.

1296 Os pedidos podem ser apresentados em um dos 17 (dezessete) Departamentos Regionais de Saúde (DSR) do Estado de São Paulo. 
saúde do indivíduo, a Administração pode decidir favoravelmente ao administrado, passando a fornecê-lo na via administrativa.

Em julho de 2010 foram computados 17.931 (dezessete mil novecentos e trinta e um) pedidos administrativos ativos, cujo montante mensal despendido totalizava $\mathrm{R} \$$ 30.803.047,93 (trinta milhões oitocentos e três mil quarenta e sete reais e noventa e três centavos).

Em 2011 foram atendidos 63.125 (sessenta e três mil cento e vinte e cinco) indivíduos, pessoalmente ou por telefone, tendo sido recebidas 13.556 (treze mil quinhentas e cinquenta e seis) solicitações de fornecimento de medicamentos e insumos de saúde. Em 2012 foram realizados 49.469 (quarenta e nove mil quatrocentos e sessenta e nove) atendimentos (pessoalmente ou por telefone), tendo sido recebidas 11.469 (onze mil quatrocentos e sessenta e nove) solicitações de fornecimento de medicamento ou insumo de saúde.

A iniciativa inovadora do Estado de São Paulo, concebida para enfrentar o problema da "judicialização da saúde pública" conseguiu obter sucesso na redução da litigiosidade e recebeu, com méritos, o prêmio Inovação em Gestão Pública pelos resultados alcançados $^{1297}$.

Porém, mais do que a redução de conflitos, a atividade desempenhada pela Coordenação das Demandas Estratégicas do SUS (CODES) e pela Procuradoria Geral do Estado de São Paulo (PGE/SP) demonstra que a Administração Pública também desempenha importante papel para a transformação da realidade social, assegurando a efetividade do direito à saúde e o melhor funcionamento do Sistema Único de Saúde (SUS).

Há quatro aspectos desse modelo de Administração consensual que merecem ser destacados: primeiro, o estabelecimento de canais de comunicação entre órgãos jurídicos e órgãos de saúde pública do aparelho estatal (Procuradoria Geral do Estado e Secretaria de Estado da Saúde) para o melhor desempenho de suas atribuições relativas à proteção, à recuperação e à promoção da saúde; segundo, a criação de mecanismos de diálogo entre a

\footnotetext{
${ }^{1297}$ A $5^{\text {a }}$ edição do Prêmio Mario Covas, relativa ao ciclo 2008, teve 25 projetos premiados, dentre os quais, na categoria inovação em gestão pública, foi vencedora "Uma parceria inovadora para fazer frente ao fenômeno da 'judicialização das Políticas Públicas de saúde' - a otimização da gestão pública”, de iniciativa da CODES - Coordenação de Demandas Estratégicas do Sistema Único de Saúde, da Secretaria de Estado da Saúde e PJ8 - $8^{\mathbf{a}}$ Subprocuradoria, da Procuradoria Geral do Estado. Todas as informações relativas ao prêmio, bem como os relatórios sobre cada um dos projetos estão disponíveis no site: <http://www.premiomariocovas.sp.gov.br/>. Consulta em: 30/12/2013.
} 
Administração e os cidadãos, por meio de instituições, órgãos públicos e colaboradores do Poder Público (Organização Social de Saúde), com o objetivo de prestar informações e receber pedidos administrativos; terceiro, a organização de informações numa base de dados rica e complexa, assim, por meio de um sistema informatizado, tornou-se o atendimento do cidadão na via administrativa mais célere e eficiente; e quarto, a realização de igualdade e justiça social, na medida em que o atendimento gratuito e descentralizado assegura a todos, sem discriminação, o acesso à assistência farmacêutica e nutricional, independentemente do pagamento de custas ou de representação por advogado.

\subsubsection{Os instrumentos pró-consensuais procedimentais instituídos pela Secretaria de Estado da Saúde de São Paulo (SES/SP) e pelos Juizados Especiais da Fazenda Pública (JEFAZ) ${ }^{1298}$}

O Estado de São Paulo e o Tribunal de Justiça do Estado de São Paulo celebraram termo de cooperação técnica, visando implementar o projeto "Triagem Farmacêutica no Juizado Especial da Fazenda Pública-JEFAZ" 1299, em 6 de novembro de 2012, nas duas Varas da Fazenda Pública da Capital (Fórum Hely Lopes Meirelles), com projeção de expansão para as demais Comarcas do Estado de São Paulo.

São três os principais objetivos do projeto "Triagem Farmacêutica no Juizado Especial da Fazenda Pública-JEFAZ”, a saber: (i) realizar a triagem farmacêutica para possível integração do indivíduo aos serviços e programas oficiais de assistência farmacêutica do Sistema Único de Saúde (SUS); (ii) informar ao paciente sobre a possibilidade de apreciação administrativa pela Secretaria do Estado da Saúde da solicitação de medicamentos, insumos médicos, hospitalares e dietas; e (iii) oferecer informações técnicas aos magistrados, para subsidiar a análise das solicitações do paciente.

\footnotetext{
${ }^{1298}$ As informações contidas neste tópico foram extraídas do Termo de Cooperação Técnica celebrado entre o Estado de São Paulo, pelo Secretário de Estado da Saúde, e o Tribunal de Justiça do Estado de São Paulo, representado por seu Presidente, juntado como anexo (n.2), e do Relatório de Atendimento do Serviço de Análise Pré-Processual JEFAZ - 2012, da Secretaria de Estado da Saúde de São Paulo, juntado como anexo (n.3).

${ }^{1299}$ A Lei n. 12.153, de 22 de dezembro de 2009, que dispõe sobre os Juizados Especiais da Fazenda Pública no âmbito dos Estados, do Distrito Federal e Municípios, estabelece ser sua competência processar, conciliar e julgar causas cíveis de interesse dos Estados, do Distrito Federal, dos Territórios e dos Municípios, até o valor de 60 (sessenta) salários mínimos (art. $2^{\circ}$, caput). De acordo com o artigo $8^{\circ}$ desta lei, "os representantes judiciais dos réus presentes à audiência poderão conciliar, transigir ou desistir nos processos da competência dos Juizados Especiais, nos termos e nas hipóteses previstas na lei do respectivo ente da Federação”.
} 
Em princípio, o atendimento consiste na realização de triagem farmacêutica ${ }^{1300}$ para prestar informações aos indivíduos sobre como obter judicialmente prestações materiais de saúde, disponibilizadas no Sistema Único de Saúde (SUS). Caso a pretensão do indivíduo seja fornecida no âmbito do Sistema Único de Saúde (SUS), os técnicos da Secretaria de Estado da Saúde de São Paulo (SES/SP) buscam integrá-lo aos serviços e programas oficiais de assistência farmacêutica. Também são atendidos aqueles indivíduos que já propuseram ação e obtiveram decisão judicial no sentido do fornecimento da pretensão postulada.

Na sequência, é elaborada uma planilha do atendimento, com dados do paciente, de sua solicitação, assim como as orientações e encaminhamentos fornecidos, documentando o atendimento efetuado e sua conclusão, para controle e disponibilização semanal destes registros aos Magistrados que atuam nos Juizados Especiais da Fazenda Pública (JEFAZ) e aos gestores da Secretaria de Estado da Saúde de São Paulo (SES/SP).

Da análise do relatório dos atendimentos realizados no setor de análise préprocessual e triagem farmacêutica, relativo ao primeiro mês de atividades, de 21 de novembro a 19 de dezembro de 2012, interessam a este trabalho os dados relativos à solução consensual dos conflitos fora da via jurisdicional.

Neste período, foram atendidos 35 (trinta e cinco) indivíduos, dos quais 32 (trinta e dois) não haviam proposto ação judicial e 3 (três) já tinham ajuizado ação e obtido decisão judicial que determinava o fornecimento da prestação material de saúde ao Estado. Após o atendimento, 31 (trinta e um) indivíduos decidiram não propor ação judicial, tendo sido o conflito solucionado administrativamente, de forma consensual.

Conquanto este mecanismo tenha sido concebido para diminuir a propositura de ações em face do Estado e não para ampliar a efetiva participação dos indivíduos na Administração Pública, a parceria entre o Estado de São Paulo e o Tribunal de Justiça do Estado de São Paulo mostra-se como mais um instrumento pró-consensual procedimental para a solução de conflitos sobre prestações materiais em saúde.

O projeto "Triagem Farmacêutica no Juizado Especial da Fazenda Pública-JEFAZ" também assegura maior transparência da atividade administrativa, permitindo o acesso

\footnotetext{
${ }^{1300}$ A equipe de trabalho é composta por técnicos da Secretaria de Estado da Saúde de São Paulo (SES/SP), que realizam a análise da documentação médica, e por auxiliar administrativo, que desempenha as funções de apoio operacional.
} 
amplo dos indivíduos às informações sobre o Sistema Único de Saúde (SUS), o que é pressuposto essencial para uma Administração democrática.

O estabelecimento deste canal de comunicação entre os técnicos da Secretaria de Estado da Saúde de São Paulo (SES/SP) e os cidadãos viabiliza a concretização do direito à saúde, por meio dos programas e serviços de assistência farmacêutica instituídos no Sistema Único de Saúde (SUS). Desta forma, o Estado reconhece o direito subjetivo a prestações materiais em saúde que lhe incumbe prover na via administrativa, conjugando racionalidade, equidade e eficiência.

Além disso, o projeto permite a composição de conflitos na esfera administrativa, o que garante uma Administração Pública democrática. Por fim, caso não seja viável obter uma solução consensual, remanesce a possibilidade de ajuizar ação judicial em face do Estado.

\subsubsection{Os instrumentos pró-consensuais procedimentais instituídos pelo Comitê Interinstitucional de Resolução Administrativa de Demandas da Saúde (CIRADS) ${ }^{1301}$}

Neste tópico serão abordados os instrumentos de ação criados pelo Comitê Interinstitucional de Resolução Administrativa de Demandas da Saúde-CIRADS, inicialmente desenvolvido no Estado do Rio Grande do Norte, com o objetivo de criar um ambiente de diálogo entre seus integrantes, para solucionar os conflitos sobre prestações em matéria de saúde na via administrativa.

O Comitê Interinstitucional de Resolução Administrativa de Demandas da Saúde (CIRADS) foi constituído em 22 de julho de 2009, por meio de acordo de cooperação técnica ${ }^{1302}$, celebrado entre a Procuradoria da União no Estado do Rio Grande do Norte (PU/RN), a Defensoria Pública da União no Estado do Rio Grande do Norte (DPU/RN), a Procuradoria Geral do Estado do Rio Grande do Norte (PGE/RN), a Procuradoria Geral do Município do Natal (PGMN/RN), a Secretaria de Estado da Saúde Pública (SESAP/RN) e a Secretaria Municipal de Saúde do Natal (SMS/Natal), com o apoio técnico do Ministério da Saúde. Em 26 de julho de 2010, foi assinado o Primeiro Termo Aditivo ao referido

\footnotetext{
${ }^{1301}$ As informações contidas neste tópico foram extraídas das seguintes fontes: documentos contidos no site da Advocacia-Geral da União: <http://www.agu.gov.br/>, consulta em 02/01/2014; relatórios contidos no site do prêmio Innovare: <http://www.premioinnovare.com.br/>, consulta em: 02/01/2014.

${ }^{1302} \mathrm{O}$ termo do acordo segue juntado como anexo (n.4).
} 
Acordo de Cooperação Técnica ${ }^{1303}$, para incluir a Defensoria Pública do Estado do Rio Grande do Norte (DPE/RN) no CIRADS.

O objeto do acordo consiste no estabelecimento de parceria entre os órgãos jurídicos e os órgãos do Poder Executivo federal, estadual e municipal, para a análise dos casos concretos em que os indivíduos hipossuficientes não tenham recebido o devido atendimento pelo Sistema Único de Saúde (SUS), a fim de identificar: (i) se a pretensão pode ser solucionada administrativamente, evitando a sua judicialização; e (ii) se é possível obter a conciliação na ação judicial já em curso. Em ambas as hipóteses é necessário verificar: (1) se a pretensão material (medicamentos, insumos, materiais e serviços de saúde) é oferecida no âmbito do Sistema Único de Saúde (SUS) e não foi prestada; e (2) se o médico indicou tratamento diverso daqueles oferecidos pelo Sistema Único de Saúde (SUS) e, em caso positivo, se pode ser substituído por algum tratamento disponível.

A operacionalização deste instrumento tem início com o atendimento aos indivíduos hipossuficientes realizado pela Defensoria Pública da União no Estado do Rio Grande do Norte (DPU/RN), ou pela Defensoria Pública do Estado do Rio Grande do Norte (DPE/RN). Neste atendimento prévio analisa-se se houve falha na prestação do serviço de saúde no âmbito do Sistema Único de Saúde (SUS), ou se o médico indicou tratamento diverso daqueles oferecidos no âmbito do Sistema único de Saúde (SUS). Na hipótese da resposta ser afirmativa, o caso é levado aos demais participantes do Comitê Interinstitucional de Resolução Administrativa de Demandas da Saúde (CIRADS) para pronunciamento, em reunião ${ }^{1304}$, sobre a possibilidade de solução consensual do conflito na via administrativa.

Se houver tratamento disponível no âmbito do Sistema Único de Saúde (SUS), a DPU/RN e a DPE/RN poderão enviar um questionário ao médico que prescreveu o tratamento acerca da possibilidade de substituição da prescrição pela alternativa terapêutica

${ }^{1303}$ O Primeiro termo aditivo ao acordo de cooperação técnica de 22 de julho de 2009 segue juntado como anexo (n.5).

${ }^{1304}$ As reuniões do Comitê Interinstitucional de Resolução Administrativa de Demandas da Saúde (CIRADS) são realizadas mensalmente, aprovando-se a ata da reunião anterior. Em cada uma das reuniões há uma pauta pré-estabelecida e as deliberações são todas repassadas por e-mail aos membros, através do CIRADSGRUPOS, com a fixação de prazo para a adoção das providências cabíveis. A título ilustrativo é juntada, como anexo (n.6), a Ata da 19 ${ }^{\text {a }}$ Reunião do Comitê Interinstitucional de Resolução Administrativa de Demandas da Saúde (CIRADS), realizada em setembro de 2010, na qual constam casos em que houve o reconhecimento do direito subjetivo de alguns indivíduos à prestação material em saúde, tanto na área da assistência farmacêutica (como, por exemplo, o pedido de fornecimento de cloridrato de donepezila, amidarona, sinvastatina e acetato de ciproterona), quanto no tocante à realização de exames (ressonância magnética e radioterapia). 
fornecida no âmbito do Sistema Único de Saúde (SUS), o qual, após respondido, será submetido ao Comitê Interinstitucional de Resolução Administrativa de Demandas da Saúde (CIRADS), para apreciação e deliberação sobre a viabilidade de atendimento.

Também constitui objetivo do Comitê Interinstitucional de Resolução Administrativa de Demandas da Saúde (CIRADS) a realização de debates e eventos para a discussão de temas concernentes à saúde ${ }^{1305}$, bem como a apresentação de propostas, perante as autoridades competentes, voltadas ao aperfeiçoamento do Sistema Único de Saúde (SUS).

Neste sentido, o projeto "Classe Hospitalar", que associa saúde e educação, foi concebido e implantado pelo Comitê Interinstitucional de Resolução Administrativa de Demandas da Saúde (CIRADS), beneficiando diversas crianças hospitalizadas. Nos termos da Ata da $15^{\text {a }}$ reunião do $\operatorname{CIRADS}^{1306}$, realizada em maio de 2010 , foi oficializada a instituição deste projeto, que consiste na instalação de salas de aula vinculadas à rede de ensino público, em hospitais públicos ou conveniados ao SUS, que abriguem crianças internadas, possibilitando o tratamento de saúde sem prejuízo do ensino básico. O projeto foi inicialmente implantado no Hospital Infantil Varela Santiago e, em seguida, no Hospital Infantil Maria Alice Fernandes. Em 2010 foi instalada mais uma classe hospitalar no Hospital Infantil Maria Alice Fernandes e, no ano de 2011, a Secretaria de Educação do Estado do Rio Grande do Norte instalou mais cinco classes hospitalares em Natal e a primeira no interior do Estado.

Embora não consista em solução de conflito em matéria de saúde, não se pode negar a importância do projeto "Classe Hospitalar", que assegura a realização do direito fundamental à educação das crianças, mediante aulas lecionadas às crianças internadas em hospitais públicos ou conveniados ao Sistema Único de Saúde (SUS).

De julho de 2009 até fevereiro de 2011 o Comitê Interinstitucional de Resolução Administrativa de Demandas da Saúde (CIRADS) recebeu 106 casos, dos quais 43 (quarenta e três) foram solucionados de forma consensual na via administrativa, 11 (onze) foram arquivados e 51 (cinquenta e um) não foram resolvidos administrativamente.

\footnotetext{
1305 Em 2010, o Comitê Interinstitucional de Resolução Administrativa de Demandas da Saúde (CIRADS) promoveu três eventos em parceria com outros órgãos públicos (administrativos ou judiciais) relacionados ao debate de questões relativas à saúde, a saber: o "1 Ciclo de Debates sobre Assistência Farmacêutica no SUS"; o "1 Ciclo de Debates sobre Oncologia no SUS"; e o "Seminário Classe Hospitalar".

${ }^{1306}$ A Ata segue juntada como anexo (n. 7).
} 
A importância do trabalho desempenhado pelo Comitê Interinstitucional de Resolução Administrativa de Demandas da Saúde (CIRADS) foi reconhecida com a menção honrosa, na categoria Advocacia, na VII edição do Prêmio Innovare, em 2010. Além disso, foi apontado como modelo a ser seguido pelo Ex-Ministro da Saúde, José Gomes Temporão, tendo sido criado um grupo de trabalho constituído pela Defensoria Pública da União e da Procuradoria Geral da União para a implantação do Comitê Interinstitucional de Resolução Administrativa de Demandas da Saúde (CIRADS) em todos os Estados da Federação. ${ }^{1307}$

Os trabalhos deste grupo convergiram para a celebração de um acordo de cooperação técnica ${ }^{1308}$ entre a Advocacia-Geral da União (AGU), o Ministério da Saúde (MS), o Ministério da Justiça (MJ), por intermédio da Secretaria de Reforma do Judiciário e da Defensoria Pública da União, o Conselho Nacional de Secretários de Saúde (CONASS) e o Conselho Nacional de Secretários Municipais de Saúde (CONASEMS), com o objetivo de buscar alternativas de resolução de conflitos tanto judiciais, como extrajudiciais envolvendo o Sistema Único de Saúde (SUS).

Dentre os fundamentos para a celebração do acordo, foram consideradas: (i) a fundamentalidade do direito à saúde; (ii) o reconhecimento do dever, pelo Estado brasileiro, de prover condições indispensáveis ao seu pleno exercício; (iii) a ligação umbilical entre o direito à saúde e o princípio da dignidade da pessoa humana; (iv) a necessidade de se abrirem espaços de consenso e se construírem soluções compartilhadas, inclusive pela via administrativa; (v) a necessidade de se prestigiar as políticas públicas existentes e a organização do Sistema Único de Saúde; e (vi) o interesse público primário consistente na prestação de serviços de saúde pública com qualidade e eficiência à população.

Tendo em vista a busca da solução administrativa dos conflitos sobre prestações materiais de saúde, os participantes do Comitê Interinstitucional de Resolução Administrativa de Demandas da Saúde (CIRADS) se comprometeram a dar primazia às políticas públicas já estabelecidas pelo Sistema Único de Saúde (SUS) sempre que for possível.

${ }^{1307}$ Portaria Conjunta PGU/DPU n. 1, de 20 de julho de 2010, publicada no D.O.U. de 22/07/2010, Seção 2, p. 46.

${ }^{1308}$ Publicado no Diário Oficial da União em 23 de março de 2012, Seção 3, e juntado como anexo (n.8). 
O Comitê Interinstitucional de Resolução Administrativa de Demandas da Saúde (CIRADS) consiste num modelo de Administração consensual, compreendido em sentido amplo, na área da saúde. Os instrumentos de ação utilizados permitem a busca do consenso, na via administrativa, para solucionar conflitos de interesses entre a Administração e indivíduos hipossuficientes, sobre o direito a prestações materiais de saúde, conforme as políticas públicas oferecidas no âmbito do Sistema Único de Saúde (SUS).

\subsection{A complementariedade do modelo de Administração consensual. As virtudes e os riscos deste modelo}

Apesar do crescimento do emprego de instrumentos de ação de Administração consensual nas últimas três décadas no Brasil, este modelo é complementar e não substitutivo do modelo de Administração imperativa.

A Administração Pública passou a conjugar a atuação autoritária com a atuação consensual, por meio de módulos convencionais, que se colocam como instrumentos para a satisfação do interesse público identificado no caso concreto. Não há substituição da atuação autoritária a partir da utilização de instrumentos de consenso. Conforme GONÇALVES, a Administração consensual limita-se a desempenhar um papel complementar do agir administrativo autoritário. ${ }^{1309} 1310$

Conforme MENEZES DE ALMEIDA, o modelo da Administração consensual deve ser considerado como instrumento de realização do Direito geral e não como um fim em si mesmo. Também não deve ser concebido como solução para todos os casos que se apresentam ao Estado no desempenho de sua função administrativa. ${ }^{1311}$ Isto porque, nem

\footnotetext{
1309 GONÇALVES, Pedro. Entidades privadas com poderes públicos: o exercício de poderes públicos de autoridade por entidades privadas com funções administrativas. Dissertação (doutorado). Curso de PósGraduação em Ciências Jurídico-Políticas. Universidade de Coimbra. Coimbra, 2005, p. 275-276.

1310 OLIVEIRA e SCHWANKA consideram que os instrumentos de ação da Administração consensual são preferenciais, e não unicamente alternativos, em detrimento da utilização de métodos estatais que veiculem unilateral e impositivamente obrigações para os cidadãos, empresas e organizações da sociedade civil. OLIVEIRA, Gustavo Henrique Justino de; SCHWANKA, Cristiane. A administração consensual como a nova face da Administração Pública no século XXI: fundamentos dogmáticos, formas de expressão e instrumentos de ação. In: Revista de Direito do Estado - RDE, n. 10, p. 271-288, abril/junho. 2008. 1311 MENEZES DE ALMEIDA, Fernando Dias. Contrato Administrativo. São Paulo: Quartier Latin, 2012. p.343 e 347 .
} 
sempre os acordos são capazes de assegurar a solução mais eficiente à satisfação do interesse público.

Ante a diversificação das formas do agir administrativo, cabe à Administração Pública optar pelo módulo imperativo ou pelo módulo convencional, a depender da maior efetividade do instrumento para a concreção das finalidades da lei. Assim, não é possível, em regra, ao particular exigir o modelo da Administração consensual.

Porém, excepcionalmente, em se tratando de situações equivalestes em que a Administração tenha escolhido o módulo convencional para uma delas, será possível requerer tratamento similar, baseado no princípio da igualdade ${ }^{1312}$, estabelecido no artigo $5^{\circ}$, caput, da Constituição Federal. ${ }^{1313}$

Em relação ao modelo da Administração imperativa, não se pode olvidar que a Administração, no exercício de suas funções, por realizar atividade voltada à realização de interesses da coletividade, recebe certas prerrogativas de potestade pública, conferidas pelo sistema normativo, tais como a imperatividade, exigibilidade, presunção de legitimidade e executoriedade de certas medidas urgentes ou previstas em lei. ${ }^{1314}$

Tendo em vista os interesses públicos que lhe incumbe proteger, a Administração dispõe de meios jurídicos peculiares a fim de que sua atuação possa objetivar, de forma eficaz, os escopos consagrados como próprios da coletividade. A justificação dos poderes conferidos à Administração está fundada na qualidade dos interesses que lhe incumbe prover, apresentando, pois, caráter instrumental. De acordo com MELLO, a utilização das prerrogativas conferidas à Administração só é legítima quando relacionadas com a proteção dos interesses públicos. ${ }^{1315}$

Assim, em determinadas situações, em razão do atributo da executoridade do ato administrativo, a Administração, por meios próprios, pode compelir materialmente o

\footnotetext{
${ }^{1312} \mathrm{O}$ valor de igualdade, sob o prisma do Direito Administrativo, significa impessoalidade no exercício da função administrativa, expressamente prevista no artigo 37, caput, da Constituição Federal, dentre os princípios norteadores da Administração Pública direta e indireta.

1313 “Art. $5^{\circ}$ Todos são iguais perante a lei, sem distinção de qualquer natureza, garantindo-se aos brasileiros e aos estrangeiros residentes no País a inviolabilidade do direito à vida, à liberdade, à igualdade, à segurança $\mathrm{e}$ à propriedade, nos termos seguintes: (...)"

${ }^{1314}$ MELLO, Celso Antônio Bandeira de. Curso de Direito Administrativo. 27. ed. São Paulo: Malheiros. 2010.p.417-422.

${ }^{1315}$ MELLO, Celso Antônio Bandeira de. Curso de Direito Administrativo. 27. ed. São Paulo: Malheiros. 2010.p.418.
} 
administrado ao cumprimento da obrigação que impôs, sem necessidade de recorrer ao Judiciário para satisfazer sua pretensão jurídica. ${ }^{1316}$

$\mathrm{Na}$ área da saúde, por exemplo, quando a Administração apreende um lote de medicamentos sem registro na Agência Nacional de Vigilância Sanitária (ANVISA) ou cujo prazo de validade se expirou ou, ainda, quando realiza a internação compulsória de uma pessoa acometida de doença infecto-contagiosa, em época de epidemia, a Administração pratica atos unilaterais, imperativos e exigíveis, com a prerrogativa de compelir materialmente o administrado a cumpri-lo, dada a necessidade de atendimento urgente do interesse público, consubstanciado na proteção da saúde pública.

Se a Administração não tiver poderes à sua disposição para concretizar os interesses públicos, na medida em que estes sejam necessários para satisfazê-los, conforme delineado na lei, teríamos um caos, uma sociedade anárquica e desorganizada, no qual os cidadãos seriam privados da segurança jurídica, que é um dos bens indispensáveis para a vida em sociedade. ${ }^{1317}$

Cumpre lembrar que, no Estado de Direito, não há poderes incondicionados e a Administração Pública deve sempre obedecer ao princípio da legalidade ${ }^{1318}$, entendido não somente como a sujeição à Constituição e à lei votada pelo Legislativo, mas também aos preceitos e aos valores que norteiam toda a ordem jurídica.

Para arrematar a abordagem científica do tema, é de rigor considerar, de forma breve, as principais virtudes e os riscos do modelo de Administração consensual.

O modelo da Administração consensual apresenta, basicamente, cinco virtudes, a saber: (i) incrementa a legitimidade da ação estatal com a participação dos cidadãos no processo de tomada de decisões administrativas; (ii) flexibiliza a atuação administrativa, na medida em que os mecanismos de consenso permitem uma maior adequação à realidade concreta; (iii) garante decisões de melhor qualidade, visto que respaldadas em suporte fático mais consistente; (iv) protege o administrador, que autolimita sua discricionariedade

1316 MELLO, Celso Antônio Bandeira de. Curso de Direito Administrativo. 27. ed. São Paulo: Malheiros. 2010.p.419.

1317 BORGES, Alice Gonzales. Supremacia do interesse público: desconstrução ou reconstrução? In: Revista Diálogo Jurídico, n. 15, Salvador, p. 2-3, janeiro/fevereiro/março de 2007.

${ }^{1318}$ De acordo com MEDAUAR, a compreensão do princípio da legalidade deve abranger a observância da lei formal, votada pelo Legislativo, bem como das bases valorativas decorrentes de um Estado Democrático de Direito, que é o modo de ser do Estado brasileiro, conforme prevê o artigo $1^{\circ}$, caput, da Constituição e, ainda, deve incluir a observância dos demais fundamentos e princípios de raiz constitucional. Além do mais, o princípio da legalidade obriga a Administração a cumprir normas que ela própria editou. MEDAUAR, Odete. Direito administrativo moderno. 17. ed. São Paulo: Revista dos Tribunais, 2013.p.139-140. 
em prol da consensualidade, eliminando ou reduzindo a possibilidade de conflito; e (v) atribui maior eficiência à atuação administrativa. ${ }^{1319}$

A primeira virtude decorre do desenvolvimento de relações jurídico-administrativas baseadas na cultura do diálogo, por meio da participação democrática dos cidadãos no processo de tomada de decisões administrativas. Devido à participação no processo, os cidadãos se comprometem com a decisão administrativa, a qual terá maior aceitação e efetividade social.

A segunda virtude assegura o emprego de métodos de atuação administrativa negociais, flexíveis, diversificados e adequados à situação específica.

A terceira virtude se refere à maior qualidade decisória, propiciada pela colaboração dos cidadãos, que trazem ao processo mais elementos para a tomada da decisão administrativa.

A quarta virtude da Administração consensual se refere à autolimitação da atuação discricionária do administrador, porquanto este deve considerar todos os fatores trazidos ao processo administrativo pelos interessados, exercendo uma ponderação dos interesses identificados, que deve ser explicitada na motivação do instrumento consensual.

Por fim, a quinta virtude é a eficiência da atuação estatal, que compreende a racionalidade e a otimização no uso dos meios, bem como a melhor qualidade dos resultados da atividade administrativa.

De outro lado, o modelo de Administração consensual também apresenta enormes riscos, que a partir de uma perspectiva ideológica do tema poderiam não ser abordados, sustentando-se sua defesa incondicionada com arrimo nas virtudes que o modelo apresenta.

Como ressalta MENEZES DE ALMEIDA, esta perspectiva ideológica justifica a adoção de cautelas, visto que a Administração consensual não estará necessariamente atuando em favor da liberdade e da democracia. ${ }^{1320}$

A liberdade, compreendida no contexto do Estado Democrático de Direito, é garantida, sobretudo, pelo princípio da legalidade. A legalidade, em sua dimensão material,

\footnotetext{
1319 OLIVEIRA, Gustavo Henrique Justino de; SCHWANKA, Cristiane. A administração consensual como a nova face da Administração Pública no século XXI: fundamentos dogmáticos, formas de expressão e instrumentos de ação. In: Revista de Direito do Estado - RDE, n. 10, p. 271-288, abril/junho. 2008; e MOREIRA NETO, Diogo de Figueiredo. Mutações do direito administrativo. Rio de Janeiro: Renovar, 2000, p. 37-48.

${ }^{1320}$ MENEZES DE ALMEIDA, Fernando Dias. Contrato Administrativo. São Paulo: Quartier Latin, 2012. p.343-344.
} 
valoriza os aspectos da generalidade e abstração da norma legal, que poderiam ser violados ante o agir arbitrário do governante. ${ }^{1321}$

Com fundamento nessas lições, o primeiro perigo da Administração consensual consiste na ruptura com a igualdade e com a objetividade asseguradas pelas regras gerais e abstratas e, em consequência, com a justiça que a impessoalidade da lei assegura. ${ }^{1322} \mathrm{O}$ princípio da impessoalidade é indissociavelmente ligado à ideia de legalidade material, e, como tal, fundamento do Estado de Direito.

O princípio da impessoalidade significa a atribuição de tratamento isonômico daqueles que se encontrarem na mesma situação e de tratamento diferenciado àqueles que se encontrarem em situação desigual. Em respeito aos princípios da isonomia e da publicidade impõe-se a ampla informação dos administrados acerca das soluções consensuais adotadas, possibilitando que todos os que estejam na mesma situação jurídica sejam tratados de forma equânime pela Administração.

De outro lado, no tocante à democracia, MENEZES DE ALMEIDA afirma que a participação dos cidadãos (destinatários do ato) no processo de elaboração do contrato é favorecida no modelo da Administração consensual. Contudo, para que o módulo convencional expresse o valor democrático, é necessário também que o instrumento de consensualidade seja produzido conforme o Direito geral, consistente nas normas gerais e abstratas previstas na Constituição e nas leis do Estado. ${ }^{1323}$

Conforme esta construção, o segundo perigo do modelo consensual de Administração se expressa na odiosa possibilidade de sobreposição de interesses individuais ou de determinados grupos aos interesses públicos, acarretando, assim, um desvirtuamento do caráter democrático deste modelo.

Posto isso, elididos os riscos acima aventados, o modelo de Administração consensual pode apresentar proveitosos canais de comunicação para a solução de conflitos entre os cidadãos e o Estado, constituindo um importante elemento legitimador da

${ }^{1321}$ MENEZES DE ALMEIDA, Fernando Dias. Contrato Administrativo. São Paulo: Quartier Latin, 2012. p.343-344.

${ }_{1322}$ Por esta razão, BATISTA JÚNIOR sustenta que somente a celebração de contratos de transação mediante autorização legal específica prestigia o princípio da legalidade, afastando qualquer tipo de discricionariedade. BATISTA JÚNIOR, Onofre Alves. Transações administrativas: um contributo ao estudo do contrato administrativo como mecanismo de prevenção e terminação de litígios e como alternativa à atuação administrativa autoritária, no contexto de uma Administração Pública mais democrática. São Paulo: Quartier Latin, 2007, p.546-547.

${ }^{1323}$ MENEZES DE ALMEIDA, Fernando Dias. Contrato Administrativo. São Paulo: Quartier Latin, 2012. p.346-347. 
Administração democrática, que pode representar um notável mecanismo que favorece a pacificação jurídica e a transformação social.

Com efeito, o Direito Administrativo deve ser um mecanismo útil para guiar a sociedade, com ênfase na elaboração das decisões públicas e em suas consequências no contexto fático. ${ }^{1324}$ Conforme o caso concreto, a Administração consensual poderá contribuir ativamente para o desenvolvimento social, a realização de direitos fundamentais e a promoção de justiça.

1324 SOLÉ, Juli Ponce. Procedimento administrativo, globalización y buena Administración. In: Derecho Administrativo global: organização, procedimento, control judicial. SOLÉ, Juli Ponce (coordenador). Madrid, Barcelona, Buenos Aires: INAP-Marcial Pons, 2010. p.87. 


\section{CONSIDERAÇÕES FINAIS}

A temática escolhida para a pesquisa objetivou estabelecer as estruturas necessárias ao exame dos mecanismos para a solução consensual de conflitos na via administrativa, sobretudo no tocante ao direito fundamental à saúde, que pressupõe o oferecimento de prestações materiais pelo Estado.

Muitos foram os temas abordados ao longo da pesquisa e embora não seja possível apresentar conclusões que os esgotem, uma vez que há diversas abordagens da temática que podem ser problematizadas, as considerações finais apresentadas na sequência condensam, sistematicamente, as principais ideias e posições aventadas no trabalho.

A partir da compreensão de que o problema atual em relação à eficácia dos direitos sociais não é mais o de fundamentá-los, e sim o de protegê-los, verificou-se que se trata de um problema político e, também, jurídico. As reflexões introdutórias relataram o quadro de exclusão e as dificuldades de acesso por grande parte das pessoas às ações e serviços de saúde no Brasil, suscitando algumas linhas de raciocínio para formular construções teóricas e práticas acerca dessa matéria.

O primeiro capítulo teve início com a ideia de que o Direito deve incorporar a problemática da justiça, considerando sua função instrumental de transformar a realidade a que pertence, rumo a uma sociedade com liberdade, igualdade e justiça. Analisou a consolidação do direito à saúde no Brasil no movimento de afirmação histórica dos Direitos Humanos e da criação de canais comunicacionais entre o Estado e a sociedade.

$\mathrm{O}$ estudo histórico-dialético dos direitos sociais está estreitamente ligado à insuficiência dos direitos de liberdade, afirmados no século XVIII, para a garantia de condições dignas e paritárias de vida às pessoas. Com o amadurecimento de novas exigências e de novos valores, como o de bem-estar e igualdade material, no final do século XIX e início do século XX, houve forte movimento popular para que os direitos sociais fossem introduzidos no texto constitucional, passando a ser garantidos através ou por meio do Estado.

Após o término da segunda Guerra Mundial iniciou-se um processo de busca do fortalecimento do Estado Democrático de Direito e de positivação dos direitos fundamentais, com base na dignidade da pessoa humana. Das lutas travadas pelo homem 
por sua própria emancipação e das transformações de condições de vida que essas reivindicações produzem, emergiram importantes avanços para a humanidade.

A Declaração Universal dos Direitos Humanos, de 1948, representa um sistema de valores reputados pela sociedade como bens de primeira grandeza, que merecem atenção especial do Direito. Nesta Declaração, a saúde foi indiretamente reconhecida como um direito decorrente do direito à vida. Ante a posição de que a Declaração deveria ser juridicizada para tornar-se obrigatória e vinculante no plano do Direito Internacional, foi elaborado o Pacto sobre Direitos Econômicos, Sociais e Culturais (PIDESC), que consagra com maior detalhamento os direitos ditos de segunda dimensão. O PIDESC foi incorporado ao ordenamento jurídico brasileiro pelo Decreto n. 591, de 6 de julho de 1992. $\mathrm{Na}$ esfera nacional, os direitos sociais somente foram reconhecidos como direitos fundamentais a partir da promulgação da Constituição Federal de 1988, com o objetivo expresso de atenuar, se não mesmo eliminar, as desigualdades sociais e econômicas.

Ainda no primeiro capítulo foi analisado o tratamento dado à saúde nas Constituições do Brasil anteriores à Constituição Federal de 1988, apresentando um panorama sobre o quadro sanitário da época. O processo de concepção e formação do Sistema Único de Saúde (SUS) teve grande significação histórica devido à forte mobilização popular em torno do Movimento pela Reforma Sanitária, que culminou com a encampação do modelo universalista e de atenção integral, colocando fim ao modelo privatista e meramente curativo até então existente no Brasil.

O segundo capítulo da pesquisa está centrado no estudo do direito à saúde à luz da Constituição Federal de 1988, na qual foi inserido pioneiramente no catálogo de direitos fundamentais. O direito à saúde é direito fundamental em sentido formal, vez que consagrado no Título II da Carta Magna como direito social (artigo $6^{\circ}$ ) e também é direito fundamental em sentido material, porquanto decorre de um consenso geral sobre a importância de se proteger, promover e recuperar a saúde.

A afirmação da saúde como direito fundamental na Constituição Federal de 1988 representou um marco para a consolidação do Direito Sanitário no Brasil. Isto porque, além de reconhecer a saúde como direito de todos e dever do Estado, previu uma seção específica dedicada à saúde, nos artigos 196 e 200 da Constituição Federal, orientando toda a regulamentação normativa que compõe o Direito Sanitário. 
Por se tratar de um bem essencial à realização plena do ser humano e à preservação da vida com dignidade e qualidade, a Constituição determina que as ações e serviços de saúde são de relevância pública, cabendo ao Estado dispor sobre sua regulamentação, fiscalização e controle. Prevê que sua execução deve ser feita diretamente ou por intermédio de terceiros e, também, por pessoa física ou jurídica de direito privado (artigo 197).

De acordo com o raciocínio desenvolvido no trabalho, o regime jurídico dos direitos fundamentais abrange, dentre outras características, a eficácia normativa reforçada da norma constitucional e a aplicabilidade direta e imediata, nos termos do que prescreve o artigo $5^{\circ}$, parágrafo $1^{\circ}$, da Constituição Federal. Embora o direito à saúde possa ser sindicado desde logo, apontou-se que a eficácia da norma que o assegura é de eficácia contida, sujeita a restrições previstas na legislação que o regulamenta, especialmente no tocante às prestações materiais oferecidas pelo Estado. Assim, o direito subjetivo a prestações materiais em saúde em face do Estado não é um direito absoluto, podendo incidir sobre ele algumas restrições, compreendidas na teoria da reserva do financeiramente possível, entendida numa acepção ampla. Por outro lado, de toda forma, deve ser resguardado o núcleo essencial do direito à saúde (teoria do mínimo existencial), o qual transcende os serviços básicos e abrange as prestações estatais imprescindíveis à manutenção de uma vida digna, com certa qualidade.

Conforme examinado no trabalho, a Constituição Federal dispõe que a competência material para cuidar da saúde é comum de todos os entes federados (artigo 23, II) e a competência legislativa é concorrente (artigo 24, IX e parágrafo $1^{\circ}$ ). Em seguida, estabelece originariamente um sistema de saúde público e universal, fundado na igualdade de acesso e na integralidade de cobertura, organizado em níveis crescentes de complexidade e de acordo com uma estrutura descentralizada e regionalizada, aberto à participação da comunidade e com permissão para a participação da iniciativa privada, de forma complementar.

Sobre a multifuncionalidade do direito fundamental à saúde consignou-se que a depender da função que o direto exerça, este pode gerar diversas posições jurídicas, a saber: (i) direito de defesa (negativa), relativo ao círculo de atividades individuais que está livre das ordens estatais, exigindo-se a abstenção do Estado e de terceiros; (ii) direito a prestações (positiva), nos casos em que se pressupõem uma intervenção positiva para sua 
concretização por parte do Estado. Nessa segunda hipótese, é possível exigir: (ii.1) prestações normativas ou jurídicas (direitos a prestações em sentido amplo, abrangentes dos direitos de participação na organização e no procedimento); e (ii.2) prestações materiais ou fáticas (direito a prestações em sentido estrito); e (iii) direito de participação da comunidade (ativa), assegurando a possibilidade de intervenção do indivíduo na elaboração, execução e fiscalização de políticas públicas de saúde.

As posições jurídicas subjetivas (dimensão subjetiva) para os indivíduos correspondem a deveres objetivos do ponto de vista do Estado (dimensão objetiva), diretamente vinculados à obrigação de adotar as medidas necessárias à concretização do direito à saúde, mediante políticas sociais e econômicas, com o fim de reduzir o risco de doenças e outros agravos à saúde, bem como de garantir o acesso universal e igualitário às ações e serviços para sua promoção, proteção e recuperação (artigo 196, caput).

A constitucionalização do Direito Administrativo provocou mudanças na Administração Pública devido à incidência de princípios de eficácia irradiante por todo o sistema jurídico. Tais mudanças repercutiram nas relações jurídico-adminsitrativas, com a valorização do cidadão e a busca pela realização dos direitos fundamentais.

O Estado Social foi criado a partir de uma inspiração de justiça, igualdade e liberdade. Ao ampliar de forma incomensurável suas tarefas e meios intervencionistas para estabelecer o equilíbrio na repartição dos bens sociais, o Estado Social passou a assegurar aos indivíduos garantias concretas que tendem a fazer prevalecer a concepção democrática de poder, vinculada à fruição dos direitos fundamentais.

A partir deste momento, as relações entre a Administração Pública e os indivíduos sofreram mutações, das quais foram destacadas: a Administração Pública volta-se para a coletividade, passando a conhecer melhor os problemas e as demandas sociais; a Administração não detém exclusividade no estabelecimento do interesse público, passando a admitir a participação dos indivíduos no processo de identificação dos interesses juridicamente tutelados; a Administração deixa de atuar como mera executora da lei em cada caso concreto, passando também a editar atos normativos; a Administração passa a desempenhar atividade compositiva de conflitos de interesses entre os indivíduos e a Administração.

Há uma ampla gama de normas infralegais que compõem o Direito Sanitário e que se organizam a partir das normas previstas na Constituição Federal. 
Verificou-se que o Direito Sanitário brasileiro tem como fonte direta a lei, considerada em sua acepção ampla, e como fontes indiretas a jurisprudência, os costumes e a doutrina. As fontes diretas compreendem todos os instrumentos normativos que contemplam normas jurídicas de Direito Sanitário, a começar pela Constituição Federal, no ápice do sistema normativo, além das leis complementares e ordinárias, dos decretos, das portarias e das resoluções.

O terceiro capítulo teve por fim analisar a estrutura normativa e o funcionamento do Sistema Único de Saúde (SUS), considerando os princípios reitores e os dois grandes objetivos para os quais foi instituído: (i) a redução do risco de doenças e de outros agravos; e (ii) o acesso universal e igualitário às ações e serviços para sua promoção, proteção e recuperação da saúde. O estudo partiu do modelo jurídico-constitucional para, em seguida, abordar os principais aspectos da legislação estruturante (Lei n. 8.080/90 e Lei n. 8.142/90) e das normas operacionais que regem o funcionamento do Sistema Único de Saúde (SUS).

Os contornos da tarefa do legislador de estruturar o Sistema Único de Saúde (SUS) foram fixados pela própria Constituição Federal que definiu, em seu artigo 198, caput, a noção de um sistema, ao dispor que "as ações e serviços públicos de saúde integram uma rede regionalizada e hierarquizada e constituem um sistema único (...)". E mais, determinou que este sistema fosse norteado pelas seguintes diretrizes: (i) descentralização, com direção única em cada esfera de governo; (ii) atendimento integral; (iii) prioridade para as atividades preventivas, sem prejuízo dos serviços assistenciais; e (iv) participação da comunidade (artigo 198, incisos I a III).

Em relação à integralidade de atendimento, consignou-se sua previsão como diretriz do Sistema Único de Saúde, que nos termos da Constituição Federal consiste em: oferecer "atendimento integral, com prioridade para as atividades preventivas, sem prejuízo das assistenciais" (artigo 198, inciso II). O Estado tem o dever de se programar de forma eficiente para realizar políticas sociais e econômicas voltadas à redução do risco de doenças e outros agravos, bem como prestar ações e serviços para a promoção, proteção e recuperação da saúde de todas as pessoas. Observou-se que a Lei n. 8.080, de 19 de setembro de 1990, prescreve em seu artigo $7^{\circ}$, inciso II, dentre os princípios do Sistema Único de Saúde, a noção de que a cobertura oferecida deve ser a mais ampla possível, com o oferecimento prioritário de medidas preventivas, sem deixar de prestar ações curativas, de proteção e promoção da saúde. 
Destacou-se que o princípio da integralidade de atendimento também abrange o dever de fornecer medicamentos, pois a assistência farmacêutica é indispensável para o tratamento de diversas doenças e agravos, tal como prevista na Lei n. 8.080/90 (alínea "d" do inciso I, do artigo $6^{\circ}$ ).

O estudo identificou que o Sistema Único de Saúde (SUS) adota o modelo de gestão por processos, conhecido por protocolos de atendimento médico, que objetiva padronizar as ações e serviços públicos de saúde, inclusive na área de assistência farmacêutica, como estratégia para atingir o melhor resultado no menor lapso temporal possível e com redução de custos, em conformidade com o que reza o princípio da eficiência. Ressaltou-se que a Lei n. 12.401, de 28 de abril de 2011, atribuiu nova redação à Lei n. 8.080, de 19 de setembro de 1990, incluindo o Capítulo VIII, que trata "da assistência terapêutica e da incorporação de tecnologia em saúde" no âmbito do Sistema Único de Saúde, em linha de compasso com a organização e o planejamento que também deve ser feito na área da saúde (artigos 19-M a 19-U).

Assim, foi definido que a "assistência terapêutica integral" consiste em dispensar medicamentos, consoante as diretrizes definidas em protocolos clínicos para a doença ou agravo à saúde a ser tratado, bem como ofertar procedimentos terapêuticos constantes de tabelas elaboradas pelo gestor federal no âmbito do Sistema Único de Saúde (artigo 19-M, da Lei n. 12.401/2011), conformando o direito subjetivo derivado a prestações.

Defendeu-se que, em regra, o direito à saúde é assegurado pelo direito subjetivo derivado às prestações contempladas pelas políticas de saúde delimitadas pelo Executivo e pelo Legislativo, em respeito aos princípios expressamente previstos na Constituição Federal, dentre os quais se encontram o princípio da separação dos Poderes (artigo $2^{\circ}$ ), os princípios que definem os objetivos maiores do Estado (artigo $3^{\circ}$ ), o princípio da isonomia (artigo $5^{\circ}$, caput), os princípios que regem a Administração Pública (artigo 37) e os princípios da ordem econômica (artigo 170). Em hipóteses excepcionais é possível que as políticas públicas de saúde não assegurem o "mínimo existencial” ou núcleo essencial do direito à saúde. Nesses casos, ante as necessidades do indivíduo, e devido ao tratamento de saúde oferecido pelo Sistema Único de Saúde ser para ele ineficaz (por circunstâncias pessoais), ou em virtude da existência de política pública para o tratamento de doença ou enfermidade específica, deve ser assegurado o direito subjetivo originário a prestações estatais (medicamentos, insumos, tratamentos, cirurgias, leito hospitalar etc.) adequadas, 
eis que, nesses casos, estas prestações configuram um patamar mínimo imprescindível para que se possa viver dignamente.

Apesar dos avanços com a implementação do Sistema Único de Saúde, procurou-se demonstrar a persistência de muitos problemas a serem equacionados, particularmente em razão do investimento de valores insuficientes na área da saúde no Brasil. A Lei Complementar n. 141/2012, que regulamentou a Emenda Constitucional n. 29/2000, previu os percentuais mínimos a serem aplicados anualmente em ações e serviços públicos de saúde pelos Estados, Distrito Federal e Municípios. Em relação à União, fixou a obrigação de aplicar, anualmente, em ações e serviços públicos de saúde, o montante correspondente ao valor empenhado no exercício financeiro anterior, acrescido, pelo menos, do percentual referente à variação nominal do Produto Interno Bruto (PIB) ocorrida no ano anterior ao da lei orçamentária, e caso haja variação negativa do Produto Interno Bruto (PIB), determina que seja aplicado o mesmo valor do exercício financeiro precedente. Há discussões sobre a constitucionalidade dessas normas, visto que não estabelecem um percentual mínimo a ser pago pelo ente federal.

A despeito disso, desde a aprovação da Emenda Constitucional n. 29/2000, a União vem reduzindo sua participação relativa no financiamento da saúde pública, muito embora 141 milhões de brasileiros (aproximadamente $73 \%$ da população) necessitem exclusivamente das ações e dos serviços públicos para a proteção, a promoção e a recuperação de sua saúde. As despesas públicas em saúde do Estado brasileiro, como proporção do Produto Interno Bruto (PIB), alcançam apenas 4,07\%, embora a Organização Mundial de Saúde (OMS) aponte o investimento de, no mínimo, 5\% a 6\% do PIB aos países que adotam sistemas universais de atendimento. Com baixos níveis de financiamento, o Estado continuará violando o direito à saúde, seja por não assegurar a universalidade de atendimento ou a integralidade de cobertura, seja por não representar uma melhoria na qualidade das ações e serviços de saúde.

Além do subfinanciamento da área da saúde, existem outros problemas relativos à efetividade desse direito, devido às desigualdades regionais, à participação da comunidade no Sistema Único de Saúde (SUS) e à ausência de adequado planejamento das ações e serviços de saúde.

Os instrumentos que permitem a participação da sociedade civil organizada no planejamento, execução e fiscalização das ações e serviços prestados pelo Sistema Único 
de Saúde (SUS) podem contribuir para legitimar a atividade administrativa e para que a Administração conheça as demandas da comunidade e aprimore a qualidade e a eficiência da prestação dos serviços públicos de saúde.

A segunda parte deste capítulo voltou sua atenção à questão da atividade planejadora do Estado frente aos novos e complexos desafios trazidos pela Constituição Federal de 1988, especialmente o reconhecimento da saúde como direito fundamental e do correlato dever do Estado de dar-lhe efetividade por meio de políticas econômicas e sociais.

O Estado tem o dever de planejar suas ações, como determina a Constituição Federal (artigo 174, caput), na medida em que somente uma gestão pública organizada e eficiente é compatível com o Estado de Direito Democrático e Republicano. A atuação planejadora do Estado é imprescindível para conduzir ao desenvolvimento social e econômico do País. Esta atividade está relacionada ao princípio da eficiência, pois oferece as ferramentas para avaliar o modo racional, oportuno e adequado para o exercício das funções estatais dirigidas à realização dos valores consagrados na Constituição Federal, sobretudo os direitos fundamentais.

Os resultados do planejamento (planos ou políticas públicas) devem observar os objetivos gerais do Estado (artigo 3º ) e os objetivos específicos (artigos 196 e 198) impostos aos órgãos estatais e à sociedade civil pela Constituição Federal. Ademais, como sucessão de atos e medidas encadeadas e dirigidas ao atendimento desses objetivos, concluiu-se que os planos afiguram-se imprescindíveis à eficiência e à racionalidade da atividade estatal, bem como à efetividade do direito à saúde (artigo $6^{\circ}$ da Constituição Federal). O planejamento e a gestão do Sistema Único de Saúde com a participação da comunidade permitem assegurar a integralidade do atendimento, a continuidade das políticas públicas e o aumento progressivo do investimento na área da saúde, com maior racionalidade e eficiência.

O quarto capítulo destinou-se a analisar a participação popular na Administração Pública em relação às atribuições do Sistema Único de Saúde (SUS). A participação administrativa do indivíduo expressa a dimensão ativa dos direitos fundamentais (status ativo), ligada à cidadania, e consiste na possibilidade de o indivíduo tomar parte nas decisões da Administração que poderão afetá-lo. 
De inicio, verificou-se que a democracia representativa articula povo e poder, cabendo ao povo escolher aqueles que o representam, enquanto aos escolhidos cabe deliberar em nome da coletividade, permitindo que a sociedade civil, que distribuiu o poder, possa também controlar o seu exercício. Se a atuação do poder público não obedecer aos princípios e valores consagrados em normas jurídicas que garantam a fidelidade política dessa atuação dos representantes, não há legitimidade democrática.

O modelo de democracia representativa se multiplicou no chamado Estado Liberal, inspirado pela ideia de manter uma relação de confiança entre representantes e representados, a que legitimaria esta fórmula de exercício do poder. Contudo, apenas no século XX foram estendidos os direitos de participação na vida política a todos os adultos com residência permanente em um País. No Estado Social de Direito os representados passaram a manifestar o anseio natural de participar das decisões coletivas sobre assuntos que possam repercutir sobre seus interesses políticos e, mais particularmente, administrativos. A adoção dos princípios próprios do Estado Democrático de Direito pela Constituição Federal de 1988 consistiu num significativo avanço com duas relevantes consequências: a sujeição do Estado à lei e ao Direito; e à participação popular na Administração Pública. Em razão da crise de representatividade e da falta de confiança do povo em seus representantes, passou-se a buscar formas de complementaridade entre a democracia representativa e a democracia participativa e, também, o fortalecimento da democracia participativa.

A cooperação e a conjugação de esforços do Estado e da sociedade para a discussão e a compreensão dos problemas de uma sociedade plural, permitem maior coincidência entre o conteúdo das decisões administrativas e as necessidades sociais e valorizam a busca pelo consenso.

Apresentou-se uma classificação dos mecanismos institucionalizados de participação administrativa em três grandes categorias: pró-consensuais procedimentais, pró-consensuais contratuais e pró-consensuais orgânicos.

Os instrumentos pró-consensuais procedimentais consistem naqueles que permitem a atuação do indivíduo junto à Administração Pública durante o processo que culminará com a tomada da decisão administrativa, sem perder seu caráter privado nem se incorporar ao órgão administrativo, tais como, o direito de ser ouvido, a enquete, a audiência pública e a consulta pública. 
Por sua vez, os instrumentos pró-consensuais contratuais são aqueles celebrados entre o poder público e o administrado (pessoa física ou jurídica), grupos de pessoas, entidades representativas de interesses ou instituições para viabilizar um acordo sobre o objeto discutido, podendo contemplar deveres para uma ou ambas as partes. São exemplos desses instrumentos pró-consensuais contratuais os mecanismos criados pela Administração Pública voltados a alcançar uma solução consensual de conflitos de interesses na esfera administrativa, como os compromissos de ajustamento de conduta à lei, ou figuras similares.

Já os instrumentos de participação pró-consensuais orgânicos são aqueles que viabilizam a atuação do particular em órgãos colegiados da Administração, com atividade contínua ou formados ad hoc para discutir matérias específicas. Os instrumentos de participação pró-consensuais orgânicos têm um viés de controle interno e preventivo da legalidade e legitimidade da atuação administrativa e podem ser utilizados por indivíduos ou grupos. São exemplos desta categoria: a participação popular em órgãos de consulta, em órgãos de decisão, a utilização do "ombudsman” e das ouvidorias.

Em seguida, foram estudados os pressupostos para a participação administrativa, tendo se concluído que além da estrutura jurídica organizada para seu exercício é imperiosa a presença de três fatores: a educação que prepare o indivíduo para o exercício da cidadania; o acesso à informação que garanta a plena transparência da atividade desenvolvida pela Administração Pública; e o processo administrativo conforme os princípios do Estado Democrático de Direito, que assegure ao administrado as mesmas garantias deferidas no processo jurisdicional, com a observância de parâmetros legais e axiológicos do ordenamento jurídico, numa perspectiva de legalidade material.

Em relação às novas tecnologias, concluiu-se que podem consistir numa ferramenta complementar de inclusão dos indivíduos na gestão pública, aliada a outras que considerem os fatores sociais, culturais e econômicos brasileiros, não sendo possível, por ora, substituir os meios tradicionais de publicidade da atividade administrativa pela informação eletrônica, sob pena de obstaculizar ou diminuir a necessária transparência da atividade administrativa, em prejuízo da democratização da Administração Pública.

O processo administrativo desponta como instrumento para o melhor cumprimento dos fins da Administração e de proteção dos direitos dos administrados. A atuação administrativa nas relações entre Administração Pública e cidadão deve ser cooperativa, 
isto é, a autoridade pública deve oferecer as informações necessárias e as condições materiais para que o indivíduo possa gozar dos direitos reconhecidos pelo ordenamento jurídico. Dentre outras finalidades, o processo administrativo tem por escopo proteger o administrado em face de outros administrados e da própria Administração, como instrumento de garantia de direitos, bem como executar o direito de forma justa.

O capítulo sobre a participação administrativa é concluído com o exame das normas previstas na ordem jurídica brasileira para operacionalizar a diretriz de participação da comunidade no Sistema Único de Saúde, prevista no artigo 198, inciso III, da Constituição Federal.

O fortalecimento da denominada "democracia sanitária" depende não apenas da atuação estatal, consistente em abrir espaços públicos de comunicação entre a Administração e a sociedade, que favoreçam o diálogo anteriormente à tomada da decisão administrativa, mas também da efetiva participação dos cidadãos de forma ativa e permanente colaborando com a Administração na elaboração, na execução, no controle de políticas públicas sanitárias, bem como na tomada de decisões relevantes em matéria de saúde.

A participação da comunidade na área da saúde foi prevista como princípio do Sistema Único de Saúde (SUS) na Lei 8.080/90 (artigo $7^{\circ}$, inciso VIII). Esta lei, com a redação alterada pela Lei n. 12.401, de 28 de abril de 2011, instituiu outros instrumentos participativos na Administração, os quais se referem ao processo de incorporação de tecnologia em saúde no Sistema Único de Saúde. E, ainda, a Lei n. 8.142/90, que dispõe sobre a participação da comunidade na gestão do Sistema Único de Saúde (SUS), determina a criação, em cada uma das esferas da Federação, de duas instâncias colegiadas: a conferência de saúde e o conselho de saúde (artigo $1^{\circ}$. I e II), devendo a composição em ambos os órgãos colegiados ser paritária entre representantes do governo, prestadores de serviço, profissionais de saúde e usuários (artigo $1^{\circ}$, parágrafo $4^{\circ}$ ).

Portanto, atualmente há mecanismos institucionalizados de participação social no Sistema Único de Saúde: as conferências de saúde e os conselhos de saúde. Nesses espaços públicos deve ser assegurado um amplo debate com a sociedade acerca do conteúdo do direito à saúde e das decisões a serem tomadas na formulação e execução de políticas públicas de saúde. Além disso, o Poder Executivo em diversas esferas da Federação vem incrementando a utilização de instrumentos pró-consensuais como a audiência pública e a 
consulta pública, a fim de que a população participe efetivamente da elaboração de políticas públicas de saúde e da definição das normas jurídicas em matéria de saúde.

O desafio que se coloca é o de examinar se esses mecanismos expressam, de fato, a participação da comunidade na efetivação do direito à saúde. Concluiu-se ser necessário melhorar a qualidade da democracia sanitária nos mecanismos institucionalizados e recrudescer os canais de participação popular e controle social no Sistema Único de Saúde (SUS).

O quinto capítulo do trabalho foi dedicado ao exame da conflituosidade existente nas relações entre a Administração Pública e indivíduos quanto ao direito a prestações materiais em saúde, bem como da necessidade de promover mudanças na forma de atuação estatal quanto à solução desses conflitos na via administrativa. O desempenho das tarefas de composição e solução de conflitos pela Administração impõe a execução do Direito Positivo e a realização de justiça também na via administrativa.

A afirmação constitucional dos direitos fundamentais dos indivíduos determinou importantes desdobramentos na relação jurídico-administrativa, sobretudo na participação dos indivíduos na Administração Pública, favorecendo a utilização do processo administrativo como instrumento eficiente para a garantia de seus direitos perante a Administração, além da possibilidade de buscar a tutela da pretensão perante o Poder Judiciário.

Anotou-se que há um crescimento de instrumentos jurídicos que permitem a atividade consensual empregada para o desempenho da administração corrente, o desenvolvimento de projetos conjuntos do Estado com a iniciativa privada, bem como para a solução de conflitos, conformando um modelo de Administração consensual ou concertada, que passa a expressar uma forma complementar ao modelo de Administração imperativa.

Presente o corte temático proposto, a Administração consensual foi examinada em sua finalidade de solucionar conflitos de interesses atinentes às prestações materiais de saúde na via administrativa.

Lembra-se aqui, como de resto afirmado ao longo do trabalho, que o estudo teve como foco a Administração consensual com o fim de dirimir controvérsias não devido ao Judiciário estar assoberbado com o volume de demandas por prestações materiais de saúde, mas sim do dever que incumbe à Administração de instituir mecanismos aptos à realização 
dos direitos fundamentais e dos objetivos do Estado, estabelecidos pelo artigo $3^{\circ}$ da Constituição Federal, notadamente de: “construir de uma sociedade livre, justa e solidária”; "garantir o desenvolvimento nacional"; "reduzir as desigualdades sociais e regionais"; e "promover o bem de todos"

Com respaldo na doutrina, foi apresentada a sistematização dos módulos convencionais de ação da Administração consensual, buscando-se identificar se os instrumentos pró-consensuais de solução de conflitos podem ser enquadrados em tais figuras. Verificou-se que a composição do conflito na via administrativa, decorrente do atendimento da prestação material de saúde, não configura um autêntico módulo convencional, visto que a situação jurídica (dever do Estado de fornecer prestações materiais) decorre da Constituição Federal, da Lei n. 8.080/90 e dos demais instrumentos normativos que estabelecem a proteção e a promoção da saúde.

Conquanto o atendimento pela Administração da demanda por prestação material em saúde (ou o fornecimento de alternativa terapêutica) não configure um autêntico módulo convencional, observou-se que é possível considerar a existência de um consenso nesses casos, numa acepção ampla. Isto porque a Administração e o indivíduo estabelecem um acordo, no sentido da concordância em pacificar o conflito, com o atendimento célere da pretensão material para a efetivação do direito fundamental à saúde.

Nas hipóteses em que a prestação material postulada na via administrativa não faça parte de nenhuma política pública ou programa no âmbito do Sistema Único de Saúde (SUS) nem exista alternativa terapêutica para o tratamento, concluiu-se que, presentes determinadas circunstâncias fáticas, a Administração pode criar uma situação jurídica de vantagem ao particular, além das políticas econômicas e sociais de saúde existentes, por meio de um ato administrativo ampliativo, concedendo-lhe direitos subjetivos originários.

O reconhecimento do direito à saúde pela Administração, com o oferecimento da prestação material e a solução consensual do conflito assegura mais do que a concretização do direito fundamental à saúde: garante o respeito à dignidade humana; assegura a realização de justiça na via administrativa; e promove igualdade material e justiça social.

Ainda com base na dogmática dos modelos convencionais, concluiu-se que o termo de ajustamento de conduta (TAC), previsto no artigo $5^{\circ}$, parágrafo $6^{\circ}$, da Lei n. 7.347 de 24 de julho de 1985, que trata da ação civil pública, consiste em autêntico módulo 
convencional empregado pela Administração Pública em substituição à sua decisão unilateral.

Na sequência, o estudo se dirigiu ao plano do Direito Administrativo aplicado para examinar alguns instrumentos pró-consensuais procedimentais já instituídos no Brasil para solucionar conflitos sanitários na esfera administrativa.

O estudo desses instrumentos pró-consensuais procedimentais para dirimir conflitos relativos à dimensão positiva do direito à saúde na via administrativa pode gerar proveitosos avanços quanto ao cumprimento, pela Administração, do compromisso de garantir a efetivação do direito à saúde, de forma individual e coletivamente, numa perspectiva de paz e justiça na sociedade.

Com efeito, é imprescindível a adoção de cautelas para que os instrumentos de Administração consensual não sejam utilizados em nome da democracia e da eficiência como ameaças letais à lei em sentido material e à impessoalidade, sob pena de desvirtuarem os fins democráticos do Estado de Direito.

Por outro prisma, foram apresentadas as virtudes dos mecanismos consensuais, destacando-se seu caráter instrumental à realização do Direito geral e à transformação da realidade social, por meio da promoção do bem-estar social e da igualdade material.

A Administração pode (e deve) desempenhar um papel de protagonista no tocante à pacificação de conflitos sanitários, instituindo mecanismos que viabilizem a concretização célere do direito do direito fundamental à saúde por meio de prestações materiais, pelo menos no tocante ao núcleo essencial desse direito, com a garantia das condições minimamente adequadas para uma vida digna e com qualidade.

A intervenção do Estado Social para a concretização do direito fundamental à saúde em sua dimensão positiva gera, progressivamente, a justa distribuição de bens, assegurando uma situação equitativa de oportunidades, sem a qual os cidadãos não poderiam ser considerados livres e iguais.

Portanto, embora o tema mereça discussões mais amplas, é possível concluir que os instrumentos pró-consensuais procedimentais, desenvolvidos para solucionar controvérsias na via administrativa podem auxiliar o Estado Social e Democrático de Direito no cumprimento de seu dever de realização do direito fundamental à saúde de forma equânime, eficiente e justa. 


\section{REFERÊNCIAS BIBLIOGRÁFICAS}

AITH, Fernando. Curso de Direito Sanitário: a proteção do direito à saúde no Brasil. São Paulo: Quartier Latin, 2007.

A emergência do Direito Sanitário como um novo campo do Direito. In: Estudos de Direito Sanitário: a produção normativa e saúde. ROMERO, Luiz Carlos; DELDUQUE, Maria Célia (organizadores). Brasília: Senado Federal: Subsecretaria de Edições Técnicas, p. 13-40, 2011.

A saúde como direito de todos e dever do Estado: o papel dos Poderes Executivo, Legislativo e Judiciário na efetivação do direito à saúde no Brasil. In: Direito Sanitário: saúde e direito, um diálogo possível. AITH, Fernando; SATURNINO, Luciana Tarbes Mattana; DINIZ, Maria Gabriela Araújo; MONTEIRO, Tammy Claret (organizadores). Belo Horizonte: Escola de Saúde Pública do Estado de Minas Gerais ESPMG, p. 73-105, 2010.

ALEXY, Robert. Teoria dos direitos fundamentais. Tradução de Virgílio Afonso da Silva. 2.ed. São Paulo: Malheiros, 2012.

ALFONSO, Luciano Parejo. Los actos administrativos consensuales em el Derecho Español. In: Revista de Direito Administrativo e Constitucional, Belo Horizonte, ano 3, n.13, p.11-43, julho/setembro 2003.

ALMEIDA, Fernanda Dias Menezes de. Competências na Constituição de 1988. 3.ed. São Paulo: Atlas, 2005.

ALVES, Sandra Mara Campos. Democracia participativa e a consulta pública na Agência Nacional de Saúde Suplementar. In: Temas atuais de direito sanitário. Maria Célia Delduque (organizadora), v.1, Brasília: CEAD/FUB, p. 45-63, 2009.

AMARAL, Gustavo. Saúde direito de todos, saúde direito de cada um: reflexões para a transição da práxis judiciária. In: O CNJ e os desafios da efetivação do direito à saúde. NOBRE, Milton Augusto de Brito; SILVA, Ricardo Augusto Dias da (coordenadores). Belo Horizonte: Fórum, p 81-115, 2011.

ANDRADE, Cássio Cavalcante. Direito educacional: interpretação do direito constitucional à educação. Belo Horizonte: Fórum, 2010.

ANTUNES, Euzébio Henzel; GONÇALVES, Janaína Barbier. Redução da judicialização e efetivação das políticas públicas sob o enfoque do planejamento e gestão sistêmicos. In: Revista da Procuradoria-Geral do Estado. Procuradoria-Geral do Estado do Rio Grande do Sul, v.31, n. 67, Porto Alegre: PGE, p.9-23, 2010. 
BACELLAR FILHO, Romeu Felipe. Reflexos da constitucionalização do Direito Administrativo: pessoa, processo, procedimento e contrato administrativo. In: Revista Argentina del Régimen de la Administración Pública, v. XXXV, p. 171-186, 2013.

BAHIA, Ligia. As contradições entre o SUS universal e as transferências de recursos públicos para os planos e seguros privados de saúde. In: Ciência \& Saúde Coletiva edição digital, v. 13, n.5, p. 1.385-1.397, 2008. Disponível em: <http://www.scielo.br/>.

BARCELlOS, Ana Paula de. A Eficácia dos Princípios Constitucionais: dignidade da Pessoa Humana. 3.ed. Rio de Janeiro: Renovar, 2011.

BARROS, Sérgio Resende de. A difusão dos Direitos Humanos Fundamentais. In: Direitos fundamentais coletivos e difusos: questões sobre a fundamentalidade. KIM, Richard Pae; BARROS, Sérgio Resende; KOSAKA, Fausto Kozo Matsumoto (coordenadores). São Paulo: Verbatim, p. 37-45, 2012.

BARROSO, Luís Roberto. Curso de Direito Constitucional contemporâneo: os conceitos fundamentais e a construção do novo modelo. São Paulo: Saraiva, 2009.

Da falta de efetividade à judicialização excessiva: Direito à saúde, fornecimento gratuito de medicamentos e parâmetros para a atuação judicial. In: Revista da Procuradoria-Geral do Estado. Procuradoria-Geral do Estado do Rio Grande do Sul, v.31, n.66, p.89-114, julho/dezembro 2007.

BASTOS, Celso Ribeiro; MARTINS, Ives Gandra. Comentários à Constituição do Brasil: promulgada em 5 de outubro de 1988, v.8: arts. 193 a 232. 2.ed. São Paulo: Saraiva, 2000.

BATISTA JÚNIOR, Onofre Alves. Transações administrativas: um contributo ao estudo do contrato administrativo como mecanismo de prevenção e terminação de litígios e como alternativa à atuação administrativa autoritária, no contexto de uma Administração Pública mais democrática. São Paulo: Quartier Latin, 2007.

BENEVIDES, Maria Victoria de Mesquita. A cidadania ativa: referendo, plebiscito e iniciativa popular. São Paulo: Ática, 1991.

BERTOLLI FILHO, Cláudio. História da Saúde Pública no Brasil. 3. ed. São Paulo: Ática, 1999.

BITTAR, Eduardo Carlos Bianca; ALMEIDA, Guilherme Assis de. Curso de Filosofia do Direito. 4.ed. São Paulo: Atlas, 2005.

BOBBIO, Norberto. A era dos direitos. Tradução de Carlos Nelson Coutinho, nova ed. Rio de Janeiro: Elsevier, 2004.

O futuro da Democracia: uma defesa das regras do jogo. Tradução de Marco Aurélio Nogueira. 6.ed. Rio de Janeiro: Paz e Terra, 1986.

BONAVIDES, Paulo. Curso de Direito Constitucional. 22. ed. São Paulo: Malheiros, 2008. 
. Ciência Política. 17.ed. São Paulo: Malheiros, 2010.

- Teoria Constitucional da Democracia Participativa: por um Direito Constitucional de luta e resistência, por uma nova hermenêutica, por uma repolitização da legitimidade. 3. ed. São Paulo: Malheiros, 2008.

Teoria Constitucional da Democracia Participativa: por um Direito Constitucional de luta e resistência: por uma nova hermenêutica; por uma repolitização da legitimidade. 3.ed. São Paulo: Malheiros, 2008.

. Do estado liberal ao estado social. 5 ed. Belo Horizonte: Del Rey, 1993.

BORGES, Alice Gonzales. Reflexões sobre a judicialização de políticas públicas. In: Revista Brasileira de Direito Público, ano 7, n. 25, Belo Horizonte: Editora Fórum, p.9-44, abril/junho 2009.

. Supremacia do interesse público: desconstrução ou reconstrução? In: Revista Diálogo Jurídico, n. 15, Salvador, p. 1-23, janeiro/fevereiro/março de 2007.

BRASIL. Conselho Nacional da Indústria-Instituto Brasileiro de Opinião Pública e Estatística (CNI-IBOPE). Pesquisa: retratos da sociedade brasileira: saúde pública. Brasília: CNI, 2012.

BRASIL. Conselho Nacional de Secretários de Saúde. Legislação Estruturante do SUS. Coleção Para Entender a Gestão do SUS, v.13. Brasília: CONASS, 2011.

BRASIL. Conselho Nacional de Secretários de Saúde. Sistema Único de Saúde. Coleção Para Entender a Gestão do SUS, v. 1. Brasília: CONASS, 2011.

BRASIL. Conselho Nacional de Secretários de Saúde. O Financiamento da Saúde. Coleção Para Entender a Gestão do SUS, v. 2. Brasília: CONASS, 2011.

BRASIL. Conselho Nacional de Secretários de Saúde. Assistência Farmacêutica no SUS. Coleção para entender a gestão do SUS, v.7. Brasília: CONASS, 2011.

BRASIL. Conselho Nacional de Secretários de Saúde. As Conferências Nacionais de Saúde: Evolução e perspectivas. Brasília: CONASS, 2009.

BRASIL. Ministério da Saúde. Conselho Nacional de Saúde. Relatório Final da $13^{\mathrm{a}}$ Conferência Nacional de Saúde: Saúde e Qualidade de vida: políticas de estado e desenvolvimento. Brasília: Editora do Ministério da Saúde, 2008.

BRASIL. Conselho Nacional de Secretários de Saúde. SUS: avanços e desafios. Brasília. CONASS, 2007c.

BRASIL. Controladoria-Geral da União. Ouvidoria-Geral da União. Orientações para implantação de uma unidade de ouvidoria: rumo ao sistema participativo. 5.ed. Coleção OGU. Brasília: Controladoria-Geral da União, 2012. 
BRASIL. FUNASA. 100 anos de saúde pública. FUNASA em revista. Ministério da Saúde. n. 1. Janeiro de 2004. Disponível no site da Fundação Nacional da Saúde, em: $<$ http://www.funasa.gov.br>.

BRASIL. Ministério da Saúde. Secretaria-Executiva. Secretaria de Planejamento e Orçamento. Plano Nacional de Saúde- PNS: 2012-2015. Brasília. 2011. Disponível em: $<$ http://bvsms.saude.gov.br>.

BRASIL. Ministério da Saúde. Política Nacional de Atenção às Urgências. Ministério da Saúde. 3 ed. Série E. Legislação de Saúde. Brasília: Editora do Ministério da Saúde, 2006.

BRASIL. Ministério da Saúde. Secretaria de Vigilância em Saúde. Departamento de Vigilância Epidemiológica. Diretrizes nacionais para prevenção e controle de epidemias de dengue. Brasília: Ministério da Saúde, 2009.

BRASIL. Ministério da Saúde. Secretaria de Vigilância em Saúde. Programa Nacional de Controle da Dengue: amparo legal à execução das ações de campo - imóveis fechados, abandonados ou com acesso não permitido pelo morador. 2. ed. Brasília: Ministério da Saúde, 2006.

BRASIL. Ministério da Saúde. Secretaria-Executiva. Secretaria de Planejamento e Orçamento. Plano Nacional de Saúde - PNS: 2012-2015. Brasília, 2011.

BUCCI, Maria Paula Dallari. Fundamentos para uma teoria jurídica das políticas públicas. São Paulo: Saraiva, 2013.

O conceito de política pública em direito. In: Políticas públicas: reflexões sobre o conceito jurídico. BUCCI, Maria Paula Dallari (organizadora). São Paulo: Saraiva, p.149, 2006.

BULOS, Uadi Lammmêgo. Constituição Federal anotada. 10.ed. São Paulo: Saraiva, 2012.

CAMMAROSANO, Márcio. A Divisão Constitucional de Competências e a Cooperação Federativa na Prestação de Serviços Municipais de Saneamento Básico. In: Estudos sobre o marco regulatório de saneamento básico no Brasil. OLIVEIRA, José Roberto Pimenta Oliveira. DAL POZZO, Augusto Neves (organizadores). Belo Horizonte: Editora Fórum, p. 143-153, 2011.

CAMPELLI, Magali Geovana Ramlow; CALVO, Maria Cristina M. O cumprimento da Emenda Constitucional n. 29 no Brasil. In: Caderno de Saúde Pública, Rio de Janeiro, n. 23, p.1613-1623, julho de 2007.

CANOTILHO, José Joaquim Gomes. O Estado adjetivado e a teoria da Constituição. In: Revista da Procuradoria-Geral do Estado. Procuradoria-Geral do Estado do Rio Grande do Sul, v. 25, n. 56, p.25-40, 2012.

Estudos sobre Direitos Fundamentais. Coimbra: Coimbra Editora, 2004. 
2003.

Direito Constitucional e Teoria da Constituição. 7. ed. Coimbra: Almedina, Direito Constitucional. 6 ed. Coimbra: Editora Almedina. 1993.

CARVALHO, Luísa Maria Torres de; PEREIRA, EANES DELGADO BARROS. Morbidade Respiratória em Crianças Fumantes Passivas. In: Jornal Brasileiro de Pneumologia, v. 28, p. 8-14, 2002.

CARVAlHO FILHO, José dos Santos. Manual de Direito Administrativo. 21.ed. Rio de Janeiro: Lumen Juris, 2009.

CHEVAlLIER, Jacques. O Estado Pós-Moderno. Tradução de Marçal Justen Filho. Coleção Fórum Brasil-França de Direito Público, v.1. Belo Horizonte: Fórum. 2009.

. A governança e o Direito. In: Revista de Direito Público da Economia- RDPE, Belo Horizonte, ano 3, n. 12, p. 129-146, outubro/dezembro 2005.

CINTRA, Antônio Carlos de; GRINOVER, Ada Pellegrini; DINAMARCO, Cândido Rangel. Teoria Geral do Processo. 22.ed. São Paulo: Malheiros. 2006.

CLÈVE, Clèmerson Merlin. O direito e os direitos: elementos para uma crítica do direito contemporâneo. 3.ed. Belo Horizonte: Fórum, 2011.

A Constituição completa 20 anos. In: Revista Internacional de Direito e Cidadania, v. 2, p. 45-47, 2009.

O cidadão, a administração pública e a nova Constituição. In: Revista de Informação Legislativa. Brasília, ano 27, n. 106, p. 81-98, abril/junho 1990.

COMPARATO, Fábio Konder. Rumo à justiça. São Paulo: Saraiva, 2010.

Ensaio sobre o juízo de constitucionalidade de políticas públicas. In: Revista de informação legislativa, v. 35, n. 138, p. 39-48, abril/junho de 1998.

CONSELHO FEDERAL DE MEDICINA. Demografia Médica no Brasil: cenários e indicadores de distribuição, v. 2. SCHEFFER, Mário (coordenador); CASSENOTE, Alex; BIANCARELLI, Aureliano (pesquisadores). São Paulo: Conselho Regional de Medicina do Estado de São Paulo, 2013.

CONSELHO FEDERAL DE PSICOLOGIA. A regulação dos serviços de saúde mental no Brasil: inserção da Psicologia no Sistema Único de Saúde e na Saúde Suplementar. Brasília: CFP, 2013.

CONSELHO NACIONAL DE JUSTIÇA. Departamento de Pesquisas Judiciárias. Os cem maiores litigantes. Brasília, março/2011. Disponível em: <www.cnj.jus.br>. 
DAHL, Robert A. Poliarquia: Participação e Oposição. Tradução de Celso Mauro Paciornik. São Paulo: Editora da Universidade de São Paulo, 2005 (Clássicos 9).

DALlARI, Adilson Abreu. Viabilidade da Transação entre o Poder Público e Particular. In Revista Trimestral de Direito Público, v. 36. São Paulo: Malheiros, 2001.

DALLARI, Dalmo de Abreu. Estado de Direito e direitos fundamentais. In: Estudos de Direito Público em homenagem a Celso Antônio Bandeira de Mello. FIGUEIREDO, Marcelo; PONTES FILHO, Valmir (organizadores). São Paulo: Malheiros, p. 217-231, 2008.

Elementos de Teoria Geral do Estado. 2.ed. São Paulo: Saraiva, 1998.

DALLARI, Sueli Gandolfi. Direito Sanitário: fundamentos, teoria e efetivação. In: Direito Sanitário: saúde e direito, um diálogo possível. AITH, Fernando; SATURNINO, Luciana Tarbes Mattana; DINIZ, Maria Gabriela Araújo; MONTEIRO, Tammy Claret (organizadores). Belo Horizonte: Escola de Saúde Pública do Estado de Minas Gerais ESPMG, p.43-71, 2010.

O conteúdo do direito à saúde. In: O Direito achado na rua: introdução crítica ao direito à saúde. COSTA, Alexandre Bernardino; SOUSA JÚNIOR, José Geraldo; DELDUQUE, Maria Célia; OLIVEIRA, Mariana Siqueira de Carvalho; DALLARI, Sueli Gandolfi (organizadores), v.4, Brasília: CEAD/UnB, p.91-101, 2009.

A participação popular e o Direito à saúde no Sistema Nacional de Saúde Brasileiro. Revista de Direito Sanitário, v. 6, n. 1/2/3, p. 10-13, São Paulo, 2005.

Os Estados brasileiros e o direito à saúde. São Paulo: Editora Hucitec, 1995.

O papel do município no desenvolvimento de políticas de saúde. In: Revista de Saúde Pública, São Paulo, v. 25, n. 5, p. 401-405, out./1991.

DALLARI, Sueli Gandolfi; NUNES JÚNIOR, Vidal Serrano. Direito Sanitário. São Paulo: Editora Verbatim, 2010.

DAVIES, Ana Carolina Izidório. Saúde pública e seus limites constitucionais. São Paulo: Editora Verbatim, 2012.

DI PIETRO, Maria Sylvia Zanella. Cobrança de tarifa independentemente da conclusão do mecanismo de tratamento do esgoto: exame dos aspectos de constitucionalidade e legalidade. In: Revista de Direito Administrativo \& Constitucional. Belo Horizonte, ano 13, n. 53, p. 233-263, julho/setembro 2013.

Direito Administrativo. 23. ed. São Paulo: Atlas, 2010.

- Participação popular na Administração Pública. In: Revista de Direito Administrativo, Rio de Janeiro, p. 26-39, janeiro/março 1993. 
500 anos de direito administrativo brasileiro. In: Revista dos Tribunais, v. 926, p. 56-77, 2012.

DOWBOR, Monika. Enfrentando os desafios da representação em espaços participativos. DOWBOR, Monika; HOUTZAGER, Peter (coordenadores.). São Paulo: CEBRAP: IDS, 2008.

DUARTE, Luciana Gaspar Melquíades. Possibilidades e limites do controle judicial sobre as políticas públicas de saúde: um contributo para a dogmática do direito à saúde. Belo Horizonte: Editora Fórum, 2011.

ESCOREL, Sarah; NASCIMENTO, Dilene Raimundo do; EDLER, Flavio Coelho. As origens da reforma sanitária e do SUS. In: Lima, Nísia Trindade; Gerschman, Silvia; Edler, Flavio Coelho. Saúde e democracia: história e perspectivas do SUS. Rio de Janeiro, Fiocruz, p.59-81, 2005.

ESTADÍSTICAS SANITARIAS MUNDIALES: una instantánea de la salud mundial. Organización Mundial de la Salud. 2012. Disponível em: <http://www.who.int/>.

FAGUNDES, Miguel Seabra. O controle dos atos administrativos pelo Poder Judiciário. 8.ed. atualizada por Gustavo Binenbojm. Rio de Janeiro: Editora Forense, 2010.

FALEIROS, Vicente de Paula; SILVA, Jacinta de Fátima Senna; VASCONCELLOS, Luiz Carlos Fadel de; e SILVEIRA, Rosa Maria Godoy. A construção do SUS: histórias da Reforma Sanitária e do processo participativo. Brasília: Ministério da Saúde, 2006.

FERNANDES, Rodrigo. Compromisso de ajustamento de conduta ambiental: fundamentos, natureza jurídica, limites e controle jurisdicional. Rio de Janeiro, São Paulo e Recife: Renovar, 2008.

FERRAZ, Sérgio; DALLARI, Adilson Abreu. Processo Administrativo. 2.ed. São Paulo: Malheiros, 2007.

FERREIRA FILHO, Manoel Gonçalves. Direitos humanos fundamentais. 14.ed. São Paulo: Saraiva, 2012.

FIGUEIREDO, Mariana Filchtiner. Algumas notas sobre a eficácia e efetividade do direito fundamental à saúde no contexto constitucional brasileiro. In: Boletim do Instituto de Saúde. Direito à Saúde. v.12. n. 3, p. 220-226, dezembro de 2010.

Direito Fundamental à Saúde: parâmetros para sua eficácia e efetividade. Porto Alegre: Livraria do Advogado, 2007.

FREITAS, Juarez. Discricionariedade Administrativa e o Direito Fundamental à Boa Administração Pública. São Paulo: Malheiros, 2007. 
GABARDO, Emerson. A eficiência no desenvolvimento do Estado brasileiro: uma questão política e administrativa. In: Princípios de Direito Administrativo: legalidade, segurança jurídica, impessoalidade, publicidade, motivação, eficiência, moralidade, razoabilidade, interesse público. MARRARA, Thiago (organizador). São Paulo: Atlas, p.327-351, 2012.

GADELHA, Maria Inêz Pordeus. Escolhas públicas e protocolos clínicos: o orçamento, as renúncias necessárias e os novos projetos de leis. In: O CNJ e os desafios da efetivação do direito à saúde. NOBRE, Milton Augusto de Brito Nobre; SILVA, Ricardo Augusto Dias da (coordenadores). Belo Horizonte: Fórum, p.345-352, 2011.

GASPARINI, Diogenes. Direito Administrativo. 13. ed., São Paulo: Saraiva, 2008.

GAUDIN, Jean-Pierre. Gouverner par contrat: l'action publique en question. Paris: Presses de Sciences Politiques, 1999.

GONÇALVES, Pedro. Entidades privadas com poderes públicos: o exercício de poderes públicos de autoridade por entidades privadas com funções administrativas. Dissertação (doutorado). Curso de Pós-Graduação em Ciências Jurídico-Políticas. Universidade de Coimbra. Coimbra, 2005.

GROSS, Alexandre Felix. Atuação do STF na efetivação do direito à saúde no Brasil: perspectivas da judicialização entre escassez e políticas públicas. In: Revista do Tribunal Regional Federal da Primeira Região, Brasília: TRF 1ª Região, ano 24, n.3, março/2012.

GROTTI, Dinorá Adelaide Musetti. A participação popular e a consensualidade na Administração Pública. In: Revista de Direito Constitucional e Internacional. Volume 10, n.39, p.132-144, abril/junho 2002.

HABERMAS, Jürgen. Direito e Democracia: entre facticidade e validade. Tradução de Flávio Beno Siebeneichler, v. II, Rio de Janeiro: Tempo brasileiro, 1997.

Soberania popular como procedimento. In: Revista Novos Estudos Cebrap. Tradução de Márcio Suzuki. São Paulo: CEBRAP, v. 26, p. 100-113, março, 1990.

. Escritos sobre moralidad y eticidad. In: Paidós- I.C.E. da I.C.E. da Universidade Autônoma de Barcelona. Tradução de Manuel Jiménez Redondo. Pensamento Contemporâneo 17. Barcelona: Paidós-I.C.E. da I.C.E. da Universidade Autônoma de Barcelona, 1998.

IARC. Scientific Publication n. 161. Air Pollution and Cancer. STRAIF, Kurt; COHEN, Aaron; SAMET, Jonathan (editores). eISBN 978-92-832-2161-6. Disponível em: $<$ http://www.iarc.fr>.

JELLINEK, Georg. Teoría General del Estado. Fondo de Cultura Económica. Trad. y prólogo de Fernando de los Ríos. México: FCE, 2000. 
LUNA, Ana Claudia Vergamini. Direitos sociais: controle jurisdicional de políticas públicas, limites e possibilidades. Dissertação (Mestrado). Curso de Pós-Graduação em Direito. Universidade de São Paulo. São Paulo, 2012.

MACHETE, Pedro. Estado de Direito Democrático e Administração paritária. Coimbra: Almedina, 2007.

MACHADO, Jónatas E.M.; RAPOSO, Vera Lúcia. Direito à saúde e qualidade dos medicamentos: proteção dos dados de ensaios clínicos numa perspectiva de direito brasileiro, comparado e internacional. Coimbra: Almedina, 2010.

MACHADO, Roberto; LOUREIRO, Ângela; LUZ, Rogério; MURICY, Kátia. Danação da norma: a medicina social e constituição da psiquiatria no Brasil. Série saber e sociedade. Rio de Janeiro: Edições Graal, 1978.

MÂNICA, Fernando Borges. A complementaridade da participação privada no SUS. In: Revista Brasileira de Direito da Saúde, v. 2, Brasília: CMB, p. 34-54 janeiro/julho de 2012.

Participação privada na prestação de serviços públicos de saúde. Tese (doutorado). Curso de Pós-Graduação em Direito. Área de Direito do Estado. Universidade de São Paulo. São Paulo, 2009.

Teoria da Reserva do Possível: Direitos Fundamentais a Prestações e a Intervenção do Poder Judiciário na Implementação de Políticas Públicas. In: Revista Brasileira de Direito Público, Belo Horizonte, ano 5, n. 18, p.169-186, julho/setembro de 2007.

MARQUES, Silvia Badim; e DALLARI, Sueli Gandolfi. Garantia do direito social à assistência farmacêutica no estado de São Paulo. In: Revista Saúde Pública. v. 41, n. 1. São Paulo. Fevereiro, p.101-107, 2007.

MARQUES NETO, Floriano de Azevedo. Regulação estatal e interesses públicos. São Paulo: Malheiros, 2002.

- Os grandes desafios do controle da Administração Pública. In: Nova Organização Administrativa Brasileira. Belo Horizonte: Fórum, p. 195-225, 2009.

Público e privado no setor de saúde. In: Revista de Direito Público da Economia-RDPE, Belo Horizonte, ano 3, n.9, p.105-154, jan./mar. 2005.

MARRARA, Thiago. Breve intróito: por que ainda falar de princípios? In: Thiago Marrara (organizador). Princípios de direito administrativo. São Paulo: Atlas, p. 15-18, 2012.

O conteúdo do princípio da moralidade: probidade, razoabilidade $e$ cooperação. In: Princípios de Direito Administrativo: legalidade, segurança jurídica, impessoalidade, publicidade, motivação, eficiência, moralidade, razoabilidade, interesse público. MARRARA, Thiago (organizador). São Paulo: Atlas, p.159-179, 2012. 
- Direito Administrativo e novas tecnologias. In: Revista de Direito Administrativo, v. 256, p. 225-251, 2011.

A atividade de planejamento na Administração Pública: o papel e o conteúdo das normas previstas no anteprojeto da Nova Lei de Organização Administrativa. In: Revista Brasileira de Direito Público, v. 34, p.1-30, 2011.

. As fontes do Direito Administrativo e o princípio da legalidade. In: Supremacia do interesse público e outros temas relevantes do Direito Administrativo. São Paulo: Atlas. p. 230-260, 2010.

MARRARA, Thiago e NUNES, Lydia Neves Bastos Telles. Reflexões sobre o controle das políticas de saúde e de medicamentos. In: Direito à vida e à saúde: impactos orçamentário e judicial. BLIACHERIENE, Ana Carla; DOS SANTOS, José Sebastião. São Paulo: Atlas, p. 79-96, 2010.

MARTINS JÚNIOR, Wallace Paiva. Transparência administrativa: publicidade, motivação e participação popular. 2.ed. São Paulo: Saraiva, 2010.

MEDAUAR, Odete. Direito Administrativo moderno. 17. ed. São Paulo: Revista dos Tribunais, 2013.

. O Direito Administrativo em evolução. São Paulo: Revista dos Tribunais, 1992.

O princípio da razoável duração do processo administrativo. In: Atuais rumos do processo administrativo. MEDAUAR, Odete; SCHIIRATO, Vítor Rhein (organizadores). São Paulo: Revista dos Tribunais, p. 99-107, 2010.

Administração Pública: do ato ao processo. In: Biblioteca Digital Fórum Administrativo - Direito Público. Belo Horizonte: Fórum, ano 9, n. 100, junho 2009. Disponível em: <http:/editoraforum.com.br>.

1993.

. A processualidade no direito administrativo. São Paulo: Revista dos Tribunais, . O direito administrativo em evolução. São Paulo: Revista dos Tribunais, 1992.

MELlO, Celso Antônio Bandeira de. Curso de Direito Administrativo. 27. ed. São Paulo: Malheiros, 2010.

Conteúdo Jurídico do princípio da Igualdade. 3 ed. São Paulo: Malheiros, 2005.

MENEZES DE ALMEIDA, Fernando Dias. Contrato Administrativo. São Paulo: Quartier Latin, 2012.

Princípio da impessoalidade. In: Princípios de Direito Administrativo: legalidade, segurança jurídica, impessoalidade, publicidade, motivação, eficiência, 
moralidade, razoabilidade, interesse público. MARRARA, Thiago (organizador). São Paulo: Atlas, p.109-118, 2012.

Considerações sobre a "Regulação" no Direito Positivo Brasileiro. In: Revista de Direito Público da Economia (RDPE). Belo Horizonte, ano 3, v. 12, edição digital, outubro/dezembro 2005.

MIRAGEM, Bruno. A nova Administração Pública e o Direito Administrativo. São Paulo: Editora Revista dos Tribunais, 2011.

MIRANDA, Ciro Carvalho. Dissertação (mestrado). Fornecimento Gratuito de Medicamento pelo Poder Público e Protocolos Clínicos: poder regulamentar do Ministério da Saúde e adequação do exercício do direito fundamental. Instituto Brasiliense de Direito Público. Brasília, 2010.

MIRANDA, Jorge. Manual de Direito Constitucional. Parte IV: Direitos Fundamentais. 3.ed. Coimbra: Coimbra Editora. 2000.

MODESTO, Paulo. Participação popular na administração pública: mecanismos de operacionalização. In: Revista Diálogo Jurídico. Salvador: Centro de Atualização Jurídica (CAJ), v.1, n. 7, outubro, 2001. Disponível em: <http://www.direitopublico.com.br>. Consulta em 17/12/2013.

Notas para um debate sobre o princípio da eficiência. In: Revista Diálogo Jurídico, v. 1, n. 2, edição digital, maio, 2001. Disponível em: $<$ www.direitopublico.com.br>.

MONCADA, Luís S. Cabral de. A relação jurídica administrativa: para um novo paradigma de compreensão da atividade, da organização e do contencioso administrativo. Coimbra: Coimbra Editora, 2009.

MOREIRA NETO, Diogo de Figueiredo. Curso de Direito Administrativo: parte introdutória, parte geral e parte especial. 15. ed. Rio de Janeiro: Editora Forense, 2009.

. Novas tendências da Democracia: Consenso e Direito Público na Virada do Século - o caso Brasileiro. In: Revista Brasileira de Direito Público, n. 3, ano 1, edição digital, outubro 2003. Belo Horizonte: Editora Fórum. Disponível em: $<$ http:/editoraforum.com.br>.

Mutações do direito administrativo. Rio de Janeiro: Renovar. 2000.

NAFFAH FILHO, Michel; CHIEFFI, Ana Luiza; CORREA, Maria Cecília M.M.A. SCODES: um novo sistema de informações sobre ações judiciais da Secretaria de Estado da Saúde de São Paulo. In: BEPA. Boletim Epidemiológico Paulista, v. 7, p. 18-30, 2010.

NASCIMENTO, Amauri Mascaro. Curso de Direito do Trabalho: história e teoria geral do direito do trabalho: relações individuais e coletivas do trabalho. 19. ed. São Paulo: Saraiva, 2004. 
NEVES, Daniel Amorim Assumpção. Manual de Direito Processual Civil. 4. ed. São Paulo: Método, 2012.

NOHARA, Irene Patrícia. Direito Administrativo. 3. ed. São Paulo: Atlas, 2013.

NOHARA, Irene Patrícia; MARRARA, Thiago. Processo Administrativo: Lei n. 9.784/99 comentada. São Paulo: Atlas, 2009.

NOTA TÉCNICA n. 012, de 2013-CONOF/CD. Núcleo de Saúde da Consultoria de Orçamento e Fiscalização Financeira da Câmara dos Deputados (CONOF/CD). Financiamento da saúde: Brasil e outros países com cobertura universal. A participação estatal no financiamento de saúde e a situação do Sistema Único de Saúde-SUS. Disponível na biblioteca digital da Câmara dos Deputados: < http://bd.camara.leg.br>.

NOTA TÉCNICA n. 014/2012. Núcleo de Saúde da Consultoria de Orçamento e Fiscalização Financeira da Câmara dos Deputados (CONOF/CD). Regulamentação da Emenda Constitucional n. 29, de 2000 (piso constitucional de aplicação em saúde): análise das principais inovações trazidas pela Lei Complementar n. 141, de 13 de janeiro de 2012, que regulamentou a Emenda Constitucional n. 29, de 2000. Disponível na biblioteca digital da Câmara dos Deputados: < http://bd.camara.leg.br>.

OLIVEIRA, Aline Albuquerque Sant'Anna de. Direito à saúde: conteúdo, essencialidade e monitoramento. In: Revista CEJ, Brasília, ano XIV. v. 48. p.92-100, Janeiro/março 2010.

OLIVEIRA, Ana Maria Caldeira; IANNI, ZÖLLNER, Aurea Maria; DALLARI, Sueli Gandolfi. Controle social no SUS: discurso, ação e reação. In: Ciência e Saúde Coletiva (Impresso), v. 18, p. 2329-2338, 2013.

OLIVEIRA, Gustavo Henrique Justino de. Contrato de gestão. São Paulo: Revista dos Tribunais, 2008.

Participação Administrativa. In: A\&C Revista de Direito Administrativo e Constitucional, Belo Horizonte, ano 5, n. 20, p. 167-194, abr./jun. 2005. Disponível em: $<$ http://www.bidforum.com.br/>.

Direito Administrativo democrático. Belo Horizonte: Fórum, 2010.

OLIVEIRA, Gustavo Henrique Justino de; MÂNICA, Fernando Borges. Parcerias na saúde: reflexões sobre a Emenda Constitucional n. 51/2006 e a Lei federal n. 11.350/2006. Belo Horizonte: Editora Fórum, 2009.

OLIVEIRA, Gustavo Henrique Justino de; HOHMANN, Ana Carolina C. A lei federal de saneamento básico e os serviços públicos de limpeza urbana. In: Fórum Administrativo, Belo Horizonte, ano 7, n. 73, edição digital, março 2007.

OLIVEIRA, Gustavo Henrique Justino de; SCHWANKA, Cristiane. A administração consensual como a nova face da Administração Pública no século XXI: fundamentos 
dogmáticos, formas de expressão e instrumentos de ação. In: Revista de Direito do Estado - RDE, n. 10, p. 271-288, abril/junho. 2008.

ORGANIZAÇÃO PAN-AMERICANA DA SAÚDE - ORGANIZAÇÃO MUNDIAL DA SAÚDE (OPAS-OMS). Brasília: Organização Pan-Americana da Saúde, 2011.

ORGANIZAÇÃO PAN-AMERICANA DA SAÚDE - ORGANIZAÇÃO MUNDIAL DA SAÚDE (OPAS-OMS). O acesso aos medicamentos de alto custo nas Américas: contexto, desafios e perspectivas. Brasília: Organização Pan-Americana da Saúde; Ministério da Saúde; Ministério das Relações Exteriores, 2009.

PAIXÃO, Hugo Rosa da. Os espaços públicos de controle e intervenção social. In: Revista CEJ, Brasília, Ano XIV, n. 51, p. 66-75, out./dez. 2010.

PEREZ, Marcos Augusto. A Administração Pública democrática: institutos de participação popular na Administração Pública. Belo Horizonte: Editora Fórum, 2004.

PICININ, Juliana de Almeida. Saneamento básico, implantação gradual e modicidade da tarifa. In: Fórum Administrativo, Belo Horizonte, ano 11, n. 125, p.9-19, julho 2011.

PIVETTA, Saulo Lindorfer. Direito fundamental à saúde: regime jurídico-constitucional, políticas públicas e controle judicial. Dissertação (mestrado). Curso de Pós-Graduação em Direito. Área de Direito do Estado. Universidade Federal do Paraná. Curitiba, 2013.

PIOVESAN, Flávia. Temas de Direitos Humanos. 6. ed. São Paulo: Saraiva, 2013.

Justiciabilidade dos direitos sociais e econômicos: desafios e perspectivas. In: Direitos fundamentais sociais. CANOTILHO, J.J.Gomes; CORREIA, Marcus Orione Gonçalves; CORREIA, Érica Paula Barcha (coordenadores). São Paulo: Saraiva, p. 53-69, 2010 .

Saraiva, 2006.

Direitos humanos e o Direito Constitucional internacional. 7.ed. São Paulo:

PIRES, Luís Manuel Fonseca. O Estado Social e Democrático e o Serviço Público: um breve ensaio sobre liberdade, igualdade e fraternidade. Belo Horizonte: Fórum, 2011.

POLÍTICAS DE SAÚDE NO BRASIL: um século de luta pelo direito à saúde, realizado pela Secretaria de Gestão Estratégica e Participativa, do Ministério da Saúde, em parceria com a Organização Pan-Americana da Saúde - OPAS e a Universidade Federal Fluminense - UFF (documentário). Ano de produção: 2006.

PORTELA, Paulo Henrique Gonçalves. Direito Internacional Público e Privado. 3. ed. Bahia: Jus PODIVM. 2011.

POZZA, Carla. Controle Judicial das políticas públicas no Estado constitucional. In: Revista da Procuradoria-Geral do Estado. Procuradoria-Geral do Estado do Rio Grande do Sul, v.31, n. 67. Porto Alegre: PGE, p.41-68, 2010. 
PUPIN, Ricardo Lorenzi. Os direitos fundamentais sociais como elementos necessários de transformação e efetivação do Estado Democrático. In: Direitos fundamentais coletivos e difusos: questões sobre a fundamentalidade. KIM, Richard Pae; BARROS, Sérgio Resende; KOSAKA, Fausto Kozo Matsumoto (coordenadores). São Paulo: Verbatim, p. 71-100, 2012.

RESENDE, Rodrigo Eugênio Matos. A regulamentação da Emenda Constitucional 29: esperança ou decepção para o financiamento da saúde pública? In: Revista de Direito da Procuradoria Geral do Estado de Goiás. Goiás: CEJUR. v. 26, p. 59-81, 2011.

REY, Luís. Dicionário de termos técnicos de medicina e saúde. 2.ed. Rio de Janeiro: Guanabara Koogan, 2008.

ROCHA, Julio Cesar de Sá da. Direito da saúde: Direito Sanitário na perspectiva dos interesses difusos e coletivos. 2.ed. São Paulo: Atlas, 2011.

ROPER, Jon. The complete illustrated guide to the presidents of America. Londres: Lorenz books, 2009.

ROUSSEAU, Jean Jacques. Contrato Social. Versão original: 1762. Tradução de Rolando Roque da Silva. Edição eletrônica: Ridendo Castigat Moraes. 2002 Disponível em: $<$ http://www.cfh.ufsc.br>. Consulta em: 9 de setembro de 2013.

SALLES, Carlos Alberto de. A arbitragem na solução de controvérsias contratuais da Administração Pública. Tese (livre docência). Curso de Pós-Graduação em Direito. Área de Direito Processual Civil. Universidade de São Paulo. São Paulo, 2010.

SANTOS, Boaventura de Sousa. Para uma revolução democrática da justiça. 3.ed. São Paulo: Cortez, 2011.

SANTOS, Lenir. SUS: regionalizando a descentralização- região de saúde como imposição constitucional ou como ato de vontade dos entes federativos? In: Boletim de Direito Administrativo (BDA), p.1396-1407, Dezembro 2012.

SARLET, Ingo Wolfgang. A titularidade simultaneamente individual e transindividual dos direitos sociais analisada à luz do exemplo do direito à proteção e promoção da saúde. In: $\mathrm{O}$ CNJ e os desafios da efetivação do direito à saúde. NOBRE, Milton Augusto de Brito Nobre; SILVA, Ricardo Augusto Dias da (coordenadores). Belo Horizonte: Fórum, p.120126, 2011.

Segurança social, dignidade da pessoa humana e proibição de retrocesso: revisitando o problema da proteção dos direitos fundamentais sociais. In: Direitos fundamentais sociais. CANOTILHO, J.J.Gomes; CORREIA, Marcus Orione Gonçalves; CORREIA, Érica Paula Barcha (coordenadores). São Paulo: Saraiva, p. 71-109, 2010. 
Os direitos fundamentais, sua dimensão organizatória e procedimental $e$ o direito à saúde: algumas aproximações. Revista de Processo. Revista de Processo. São Paulo: Revista dos Tribunais, v. 175, ano 34, p.9-33, agosto de 2009.

SARLET, Ingo Wolfgang; FIGUEIREDO, Mariana Filchtiner. Algumas considerações sobre o direito fundamental à proteção e promoção da saúde aos 20 anos da Constituição Federal de 1988. In: Revista de Direito do Consumidor n. 67, p. 125-172, 2008.

Reserva do possível, mínimo existencial e direito à saúde: algumas aproximações. In: Direitos Fundamentais, orçamento e "reserva do possível". SARLET, Ingo Wolfgang; TIMM, Luciano Benetti (organizadores). Porto Alegre: Livraria do Advogado, p.11-53, 2008.

SARLET, Ingo Wolfgang; MARINONI, Luiz Guilherme; MITIDIERO, Daniel. Curso de Direito Constitucional. 2. ed. São Paulo: Revista dos Tribunais, 2013.

SCAFF, Fernando Facury. A efetivação dos direitos sociais no Brasil: garantias constitucionais de financiamento e judicialização. In: A eficácia dos Direitos Sociais. SCAFF, Fernando Facury; ROMBOLI, Roberto; REVENGA, Miguel (coordenadores). São Paulo: Quartier Latin, 2010.

SCHIER, Paulo Ricardo. Ensaio sobre a constitucionalização do Direito Administrativo no contexto brasileiro: complexidade do processo In: Direito Público sem fronteiras. SILVA, Vasco Pereira da; SARLET, Ingo Wolfgang (coordenadores). Lisboa: Instituto de Ciências Jurídico-Políticas, p. 217-264, 2011.

SCHIRATO, Vitor Rhein. O processo administrativo como instrumento do Estado Democrático de Direito e da Democracia. In: Atuais rumos do processo administrativo. MEDAUAR, Odete; SCHIRATO, Vitor Rhein (organizadores). São Paulo: Editora Revista dos Tribunais, p. 9-51, 2010.

SCHMIDT-ASSMANN, Eberhard. La teoría general del derecho administrativo como sistema: objeto y fundamentos de la construcción sistemática. Madrid-Barcelona: INAPMarcial Pons, 2003.

SERRANO, Mônica de Almeida Magalhães. O Sistema Único de Saúde e suas diretrizes constitucionais. 2.ed. São Paulo: Verbatim, 2012.

SILVA, Francisco Livanildo da. O Direito à saúde e a Política Nacional de Atenção Oncológica: uma análise a partir da crescente judicialização dos medicamentos antineoplásicos. Dissertação (mestrado). Universidade Federal do Rio Grande do Norte. Pós-Graduação em Direito. Natal, 2012.

SILVA, Gilberto Fonte Boa da; SILVA, Mauro Lúcio da. A Lei Complementar n. 141/2012 e o gestor público da saúde. Rio de Janeiro: COSEMS RJ, 2012.

SILVA, José Afonso da. Aplicabilidade das normas constitucionais. 7.ed. São Paulo: Malheiros, 2008. 
2000.

Curso de Direito Constitucional Positivo. 17 ed. São Paulo: Melhoramentos,

SILVA, Vasco Manuel Pascoal Dias Pereira da. Em busca do acto administrativo perdido. Coimbra: Almedina, 2003.

SILVA, Virgílio Afonso. Direitos Fundamentais: conteúdo essencial, restrições e eficácia. São Paulo: Malheiros, 2009.

Interpretação constitucional e sincretismo metodológico. In: Interpretação constitucional. SILVA, Virgílio Afonso da. São Paulo: Malheiros, p. 115-143, 2010.

SOLÉ, Juli Ponce. Procedimento administrativo, globalización y buena Administración. In: Derecho Administrativo global: organização, procedimento, control judicial. SOLÉ, Juli Ponce (coordenador). Madrid, Barcelona, Buenos Aires: INAP-Marcial Pons, p.79$190,2010$.

SOUZA, Luciane Moessa de. Meios consensuais de solução de conflitos envolvendo entes públicos e a mediação dos conflitos coletivos. Tese (doutorado). Universidade Federal de Santa Catarina. Pós-Graduação em Direito na área de Direito, Estado e Sociedade. Florianópolis, 2010.

SOUZA, Maria de Lourdes de; FERREIRA, Luiz Alberto Peregrino Ferreira; REZENDE, Vanessa Murta; BRANCO, Marisa Lucena Branco (organizadores). A saúde e a inclusão social nas fronteiras. Florianópolis: Fundação Boiteux, 2008. Disponível em: $<$ http://bvsms.saude.gov.br $>$.

SOUZA, Vagner Pereira de; PIVA, Teresa Cristina de Carvalho. A Peste Bubônica no Rio de Janeiro e o Instituto Soroterápico Federal. In: Scientiarum Historia IV. Rio de Janeiro: Congresso de Historia das Ciências e das Técnicas e Epistemologia, p. 701-707, 2011. Disponível em: < http://www.hcte.ufrj.br>. Consulta em 10/12/2013.

SOUZA NETO, Cláudio Pereira de. Teoria constitucional e democracia deliberativa: um estudo sobre o papel do direito na garantia das condições para a cooperação na deliberação democrática. Rio de Janeiro: Renovar, 2006.

STEDMAN. Dicionário Médico. 27 ed. Tradução de Stedman's Medical Dictionary. COANA, Claudia; ARAÚJO, Claudia Lucia Caetano de; FIGUEIREDO, José Eduardo Ferreira de; BARBOSA, Liane Oliveira Mufarrej; VOEUX, Patricia Lydie. AZEVEDO, Maria de Fátima (supervisora), Rio de Janeiro: Guanabara Koogan, 2003.

SUNDFELD, Carlos Ari. Direito Administrativo para Céticos. São Paulo: Malheiros Editores, 2012.

Fundamentos de Direito Público. 4.ed. São Paulo: Malheiros, 2009. 
Processo Administrativo: um diálogo necessário entre o Estado e cidadão. In: Revista de Direito Administrativo \& Constitucional, Belo Horizonte, n. 23, p. 39-51, 2006.

Vigilância epidemiológica e direitos constitucionais. In: Programa Nacional de Controle da Dengue: amparo legal à execução das ações de campo - imóveis fechados, abandonados ou com acesso não permitido pelo morador. Ministério da Saúde, Secretaria de Vigilância em Saúde. 2. ed. Série C. Projetos, Programas e Relatórios. Brasília: Ministério da Saúde, p.99-120, 2006.

STRECK, Lenio Luiz. Hermenêutica jurídica e(m) crise: uma exploração hermenêutica da construção do Direito. Porto Alegre: Livraria do Advogado, 1999.

TÁCITO, Caio. A Constituição e o Direito Administrativo. In: Revista de Direito Administrativo, n. 232, Rio de Janeiro, p.53-58, abril/junho 2003.

TIMM, Luciano Benetti. Direito à saúde e a maneira mais eficiente de prover direitos fundamentais: uma perspectiva de direito e economia? In: O CNJ e os desafios da efetivação do direito à saúde. NOBRE, Milton Augusto de Brito Nobre; SILVA, Ricardo Augusto Dias da (coordenadores). Belo Horizonte: Fórum, p.255-272, 2011.

TORRES, Ricardo Lobo. O Minimo Existencial e os Direitos Fundamentais. In: Revista de Direito Administrativo, n. 177, p. 20-49, julho/setembro 1989.

VALLE, Vanice Regina Lírio do. Controle social: promovendo a aproximação entre Administração Pública e cidadania. In: Brasil. Tribunal de Contas da União. Prêmio Serzedello Corrêa 2001. Monografias vencedoras: Perspectivas para o Controle Social e a Transparência da Administração Pública. Brasília: TCU, Instituto Serzedello Corrêa, p.75139, 2002.

VENTURA, Deisy de Freitas Lima. Uma visão internacional do direito à saúde. In: Série O Direito achado na rua: introdução crítica ao direito à saúde. COSTA, Alexandre Bernardino; SOUSA JÚNIOR, José Geraldo; DELDUQUE, Maria Célia; OLIVEIRA, Mariana Siqueira de Carvalho; DALLARI, Sueli Gandolfi (organizadores), v.4. Brasília: CEAD/UnB, p. 77-101, 2009.

VIEIRA, Oscar Vilhena. A desigualdade e a subversão do Estado de Direito. In: Estado de direito e o desafio do desenvolvimento. VIEIRA, Oscar Vilhena; DIMOULIS, Dimitri (organizadores). São Paulo: Saraiva, p.207-232, 2011.

WANNMACHER, Lenita. Tratamento Medicamentoso Antitabagismo. In: Boletim da Organização Pan-Americana de Saúde. v. 4, Brasília, p. 1-6, março de 2007.

WEICHERT, Marlon Alberto. Saúde e Federação na Constituição Brasileira. Rio de Janeiro: Lumen Juris, 2004. 


\begin{abstract}
ANEXOS
ANEXO 1 - Relatório de Atividades da Coordenação das Demandas Estratégicas do SUS (CODES) elaborado em julho de 2010.

ANEXO 2 - Termo de Cooperação Técnica celebrado entre o Estado de São Paulo e o Tribunal de Justiça do Estado de São Paulo.

ANEXO 3 - Relatório de Atendimento do Serviço de Análise Pré-Processual JEFAZ 2012, da Secretaria de Estado da Saúde de São Paulo.

ANEXO 4 - Acordo de cooperação técnica de constituição do Comitê Interinstitucional de Resolução Administrativa de Demandas da Saúde (CIRADS), de 22 de julho de 2009.

ANEXO 5 - Termo aditivo ao acordo de cooperação técnica de 22 de julho de 2009, celebrado para incluir a Defensoria Pública do Estado do Rio Grande do Norte (DPE/RN) no CIRADS.

ANEXO 6 - Ata da 19 ${ }^{a}$ Reunião do Comitê Interinstitucional de Resolução Administrativa de Demandas da Saúde (CIRADS), realizada em setembro de 2010.

ANEXO 7 - Ata da 15ª reunião do Comitê Interinstitucional de Resolução Administrativa de Demandas da Saúde (CIRADS), realizada em maio de 2010.

ANEXO 8 - Acordo de cooperação técnica celebrado entre a Advocacia-Geral da União (AGU), o Ministério da Saúde (MS), o Ministério da Justiça (MJ), o Conselho Nacional de Secretários de Saúde (CONASS) e o Conselho Nacional de Secretários Municipais de Saúde (CONASEMS), com o objetivo de buscar alternativas de resolução de conflitos envolvendo o Sistema Único de Saúde (SUS).
\end{abstract}




\section{Relatório de Atividades}

\section{Coordenação das Demandas Estratégicas do SUS - CODES}




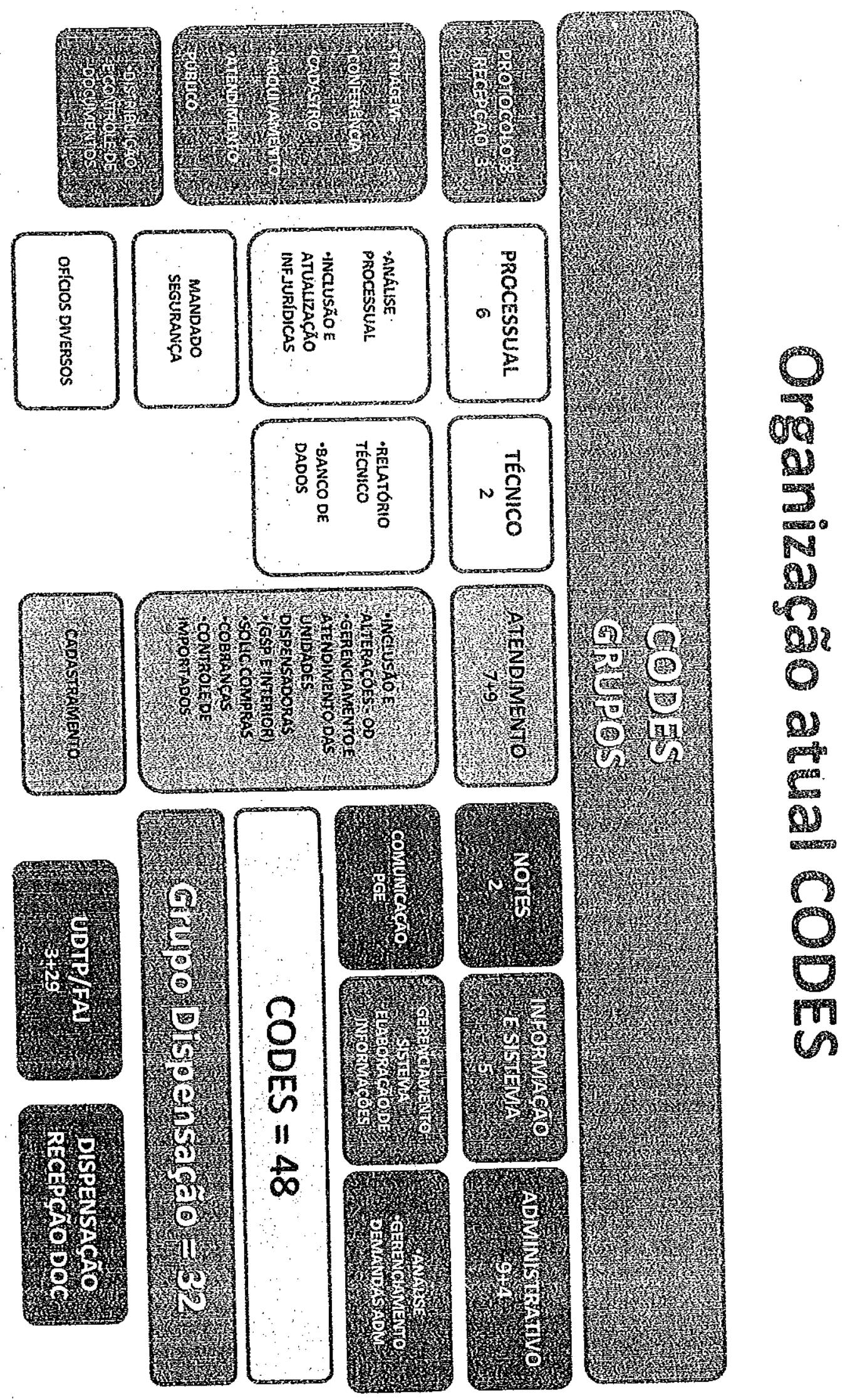




\section{CODES - Coordenação das Demandas Estratégicas do SUS}

Julho/2010

- "Criada" em maio/2007 (anexo 1) com o objetivo de separar da CCTIES o processamento e cumprimento das Ações Judiciais. Não tem estrutura formal e é vinculada diretamente ao Gabinete do Secretário.

\section{AÇÕES JUDICIAIS}

\section{BREVE HISTÓRICO}

Em julho/2005, com o objetivo "organizar" as Ações Judiciais" da Capital, foi implantado pela CCTIES o Sistema de Controle Jurídico (SCJ), desenvolvido pela Coordenadoria de Planejamento de Saúde (CPS). Esta nova forma de organização permitiu:

1. Criar um canal de comunicação com o autor da AJ através de telegrama, encerrando "definitivamente" a prática dos pacientes perambulando e advogados gritando pelos corredores da Secretaria;

2. Identificar os produtos e suas quantidades a serem adquiridos para o atendimento das determinações judiciais;

3. Organizar a dispensação dos produtos, assim como: a comprovação de sua entrega através de recibos legíveis e confiáveis armazenados eletronicamente no SCJ;

4. Oferecer informações técnicas pertinentes para a Procuradoria Geral do Estado (inicialmente $\mathrm{PJ}-2$ e posteriormente $\mathrm{PJ}-8$ ), elaborar a defesa do Estado 
Em janeiro/2007 foi implantado, pela Coordenação Geral de Administração (CGA) no Sistema de Controle de Protocolo/Prodesp numeração processual específica (0300) para as Ações Judiciäis a fim de garantir institucionalmente uma entrada única e com a celeridade necessária para este tipo de demanda.

A organização conquistada com o SCJ na Capital, só foi ampliada ao interior do Estado em 2008. Com a expansão foi identificada a necessidade de um novo sistema que pudesse efetivamente auxiliar a gestão das compras, controle dos estoques e administração dos almoxarifados, visando a racionalidade do recurso público no atendimento das determinações judiciais.

No final de 2008, o Secretário autorizou o desenvolvimento do novo sistema pela CPS. Optou-se então por um sistema modular; nos moldes daquele desenvolvido e implantado na Central de Transplantes de São Paulo.

O novo sistema foi denominado S-CODES.

Em julho/2009, o Secretário decide incorporar dois novos profissionais ao seu Gabinete para prestar as informações nos Mandados de Segurança (a semelhança daquelas prestadas a PJ-8) e determina que os localiza fisicamente no CODES, $1^{\circ}$ andar do prédio sede.

Cumprem esta tarefa atualmente Dr. Guilherme Monti Martins e Dr. Eduardo Seixas Armani. 


\section{IMPLANTAÇÃO DO S-CODES}

Seu primeiro módulo (JUDICIAL) foi implantado no $1^{\circ}$ semestre/2010. Atualmente estão em desenvolvimento os módulos "Administrativo" e "Relatórios".

Houve a necessidade de revisão de todas as AJ que se encontravam no SCJ. Foram cadastradas 45.201 nos 58 meses (entre julho/2005 a abril/2010), com uma média diária de 26 novas ações a serem cumpridas isoladamente pela Secretaria e/ou solidaria com a União e Municípios.

\section{PROdutos DO S-CODES}

3.1. Descrição das informações registradas em 31/05/2010:

$\Rightarrow$ Demandas cadastradas: 23.003 Ações Judiciais

$\Rightarrow$ Total de itens dispensados: 65.060: (média de 2,83 por Demanda)

$\Rightarrow$ Distribuição dos itens por categoria:

- Medicamentos: $66,1 \%$ (43.040 itens)

- Materiais: $30,5 \%$

- Nutrição: $3,2 \%$

- Outros: $0,2 \%$

$\Rightarrow$ Dos Medicamentos:

- Grupo A - Ap.Digestivo/Metabolismo: 34,7\%

- Grupo C - S.Cardiovascular: $17,8 \%$

- Grupo N - S.Nervoso: 14,1\%

- Grupo L - Antineoplásicos/lmunomoduladores: 10,3\%

- Grupo B - Sangue: 4,6\%

- Grupo M - Musculoesquelético: $4,5 \%$

- Outros: $14 \%$ 
$\Rightarrow$ Os mais freqüentes de cada grupo:

$\checkmark$ GRUPO A:

- Insulinas: 9.598

\begin{tabular}{|c|c|c|}
\hline Análogas: & $\begin{array}{l}\text { Glargina: } 36,1 \% \\
\text { Detemir: } 6,9 \%\end{array}$ & $\begin{array}{l}\text { Lispro: } 23,5 \% \\
\text { Asparte: } 21,4 \%\end{array}$ \\
\hline Padronizadas: & NPH: $7,4 \%$ & \\
\hline Outras: & $4,7 \%$ & \\
\hline
\end{tabular}

- Metformina: 718

- Omeprazol: 458

- Vitaminas + Minerais: 288

- Vitaminas Isoladas: 306

$\checkmark$ GRUPO B:

- Ácido acetilsalicílico: 850

- Clopidrogrel: 653

- Varfarina: 104

$\checkmark$ GRUPO C:

- Sinvastatina: 529

- Losartana: 407

- Enalapril: 388

- Anlodipino: 269

- Espironolactona: 245

$\checkmark$ GRUPO N:

- Metilfenidato: 576 (Ritalina)

- Oxcarbazepina: 276

- Gabapentina: 240

- Clonazepam: 225

- Aripiprazol: 198

$\checkmark$ GRUPO L:

- Adalimumabe: 790

- Infliximabe: 564

- Etanercepte: 526

- Rituximabe: 274

- Bevacizumabe: 192

$\checkmark$ GRUPO M:

- Teriparitida: 336

- Glicosamina + condroitina: 268

- Ácido zoledrônico: 264

- Alendronato de Sódio: 150

- Baclofeno: 136 
$\Leftrightarrow$ Situação dos medicamentos mais freqüentes nas determinaçồes judiciais em relação a sua presença nos Programas de Assistência Farmacêutica e/ou similares (31/05/2010)

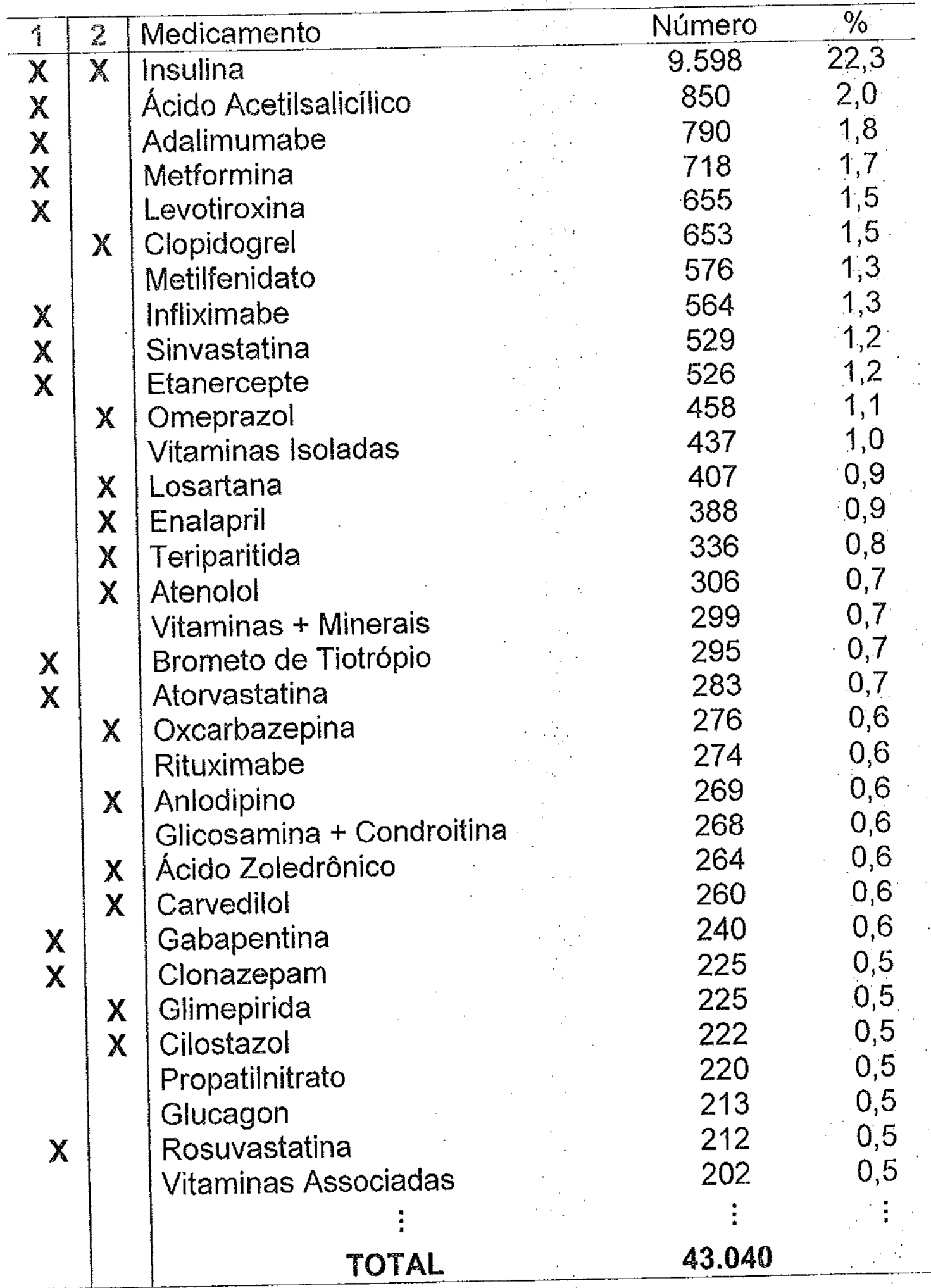

\footnotetext{
Fonte: S-CODES
}

1 Programas de Assistência Farmacêutica do SUS

2 Similar Terapêutico 


\subsection{Algumas funcionalidades (pen-drive):}

1. Previsão de compras:

As demandas judiciais estão reunidas por unidade dispensadora $e$ status (anexo 2). É possível abri-las numa listagem como a gerada em 30/07/2010, com a estimativa de consumo mensal de todos os produtos (medicamentos, materiais, nutrição, outros itens) para atendimento e previsão das compras. Seus custos podem ser resumidos na tabela abaixo:

\begin{tabular}{|c|c|c|}
\hline 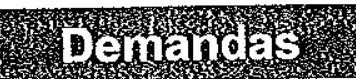 & oatgonas & 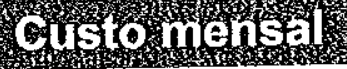 \\
\hline \multirow{5}{*}{$\begin{array}{c}\text { Judiciais } \\
\text { (ativas 24.267) }\end{array}$} & Materiais & $2.838 .936,20$ \\
\hline & Medicamentos & $51.836 .793,90$ \\
\hline & Nutrição & $2.361 .198,12$ \\
\hline & Outros itens & $2.053,68$ \\
\hline & Procedimentos* & - \\
\hline \multicolumn{2}{|c|}{ Judiciais - Total } & $57.038 .981,90$ \\
\hline
\end{tabular}

Fonte: S-CODES

* Atendimento único (cadeira de rodas) ou contrato de atendimento (Home-Care).

\section{Gestão dos estoques - CRS (exceto Grande São Paulo)}

Foi definido na implantação do S-CODES um almoxarifado para cada DRS, de 2 a 17. Por solicitação da Coordenadoria de Regiões de Saúde (CRS) o CODES propôs a movimentação dos almoxarifados já implantados (exceto os DRS's de Ribeirão Preto, Marília e Registro) de forma a otimizar as próximas compras.

Foram necessários os seguintes passos: 
1. Autonomia dos estoques (4.005 produtos) por Departamento Regional de Saúde;

2. Movimentação proposta baseada nos critérios:
a. estoque com autonomia $>8$ meses: ESTOQUE DOADOR

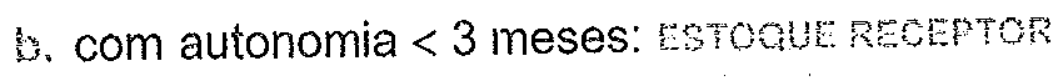

3. Resultado da movimentação do quadro anterior foi: 775 Estoouss afesptokes alcançaram a autonomia $>3$ meses e o valor "poupado" foi de $R \$ 2.233 .186,11$ e permitiu gerar as planilhas de aquisição por DRS.

4. Após esta movimentação temos as planilhas de compra total da CRS, assim como de cada DRS. A consolidação das planilhas de aquisição permite estimar um custo total de $R \$$ 28.321.996,31 (há a informação da CRS que nos meses de junho e julho foram disponibilizados $R \$ 12.632 .043,00$ para compras de produtos de ação judicial).

Os almoxarifados das DRS's de Ribeirão Preto, Marília e Registro só foram informatizados na primeira semana de agosto.

\subsection{Outras aplicações:}

As tabelas iniciais do módulo judicial do S.CODES, como a do anexo 3 , permitem demonstrar de forma simples que a aquisição das 16 apresentações (determinadas judicialmente) de ácido acetilsalicílico geram uma despesa mensal de $\mathrm{R} \$ 3.745,18$, quando estas mesmas prescrições poderiam ser atendidas com o produto padronizado pelo SUS, ácido acetilsalicílico de $100 \mathrm{mg}$, por R $\$ 380,92 / \mathrm{mês}$. 


\section{ATENDIMENTO DAS AçõES JUDICIAIS}

\subsection{Capital}

A entrega dos produtos para atender as AJ foi transferida do Centro de Saúde Vila Mariana para a UD Tenente Pena em dezembro/2009, \& passou a ser operada pela OSS Seconci. A média diária de atendimentos em julho/2010 foi de 308 .

\subsection{Interior}

Todos os DRS's foram treinados para reproduzir o mesmo modelo de atendimento, assim como o armazenamento eletrônico dos recibos no S-CODES.

Foi solicitado a não emissão de recibos manuais (especialmente os impossiveis de comprovar atendimento) 


\section{ATENDIMENTO ADMINISTRATIVO}

\section{BREVE HISTÓRICO}

O desafio do atendimento das necessidades dos pacientes tem sido enfrentado de diversas formas pela Secretaria.

Na gestão iniciada em 2003, uma das primeiras opções foi a de desenvolver "Protocolos Estaduais" tendo em vista a peculiar inércia do Ministério da Saúde.

Iniciamos por formatar uma proposta para o atendimento dos diabéticos insulino-dependentes, no quesito insumos para controle da glicemia que, após a pactuação na CIB em maio/2005 desencadeou a primeira Ata de Registro de Preço feita por uma Secretaria Estadual para uso municipal.

Vários "protocolos estaduais" foram elaborados e publicados e além de outros estudos evidenciando que a estratégia a ser adotada poderia ser um "canal administrativo" para o atendimento de necessidades específicas de grupos de pacientes.

A primeira experiência nesta modalidade foi feita com relação aos novos anti-retrovirais registrados no país pela ANVISA e não incorporados de imediato pelo Programa Nacional de AIDS (PNAIDS), o resultado deste descompasso gerou verdadeiras "epidemias" de AJ.

Em 2007, foram cadastradas no SCJ na Capital 96 Ações de uma vez, para o fornecimento do medicamento Darunavir. 
Nos últimos dias de 2007, dois novos anti-retrovirais foram registrados pela ANVISA, Raltegravir e Maraviroc. No sentido de evitar "novas epidemias" de AJ e em especial com a evidência clínica da indicação destes medicamentos para pacientes multifalidos, o Secretário autorizou a utilização do "novo modelo" em parceria com o CRT-AIDS. Todas as indicações foram avaliadas por Comitê Técnico e coube ao CODES operacionalizar o cadastramento dos pacientes autorizados (neste momento passamos a utilizar o SCJ também para cadastrar os pacientes com autorização administrativa) e 0 fornecimento dos medicamentos.

O Ministério da Saúde incorporou no PNAIDS e adquiriu medicamento Raltegravir a partir de janeiro de 2009.

O resultado deste "novo modelo" de atendimento administrativo em 2008 foi:

\begin{tabular}{|c|c|c|c|}
\hline 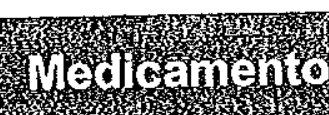 & 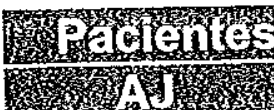 & 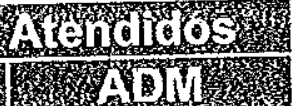 & (2) \\
\hline Maraviroc & 8 & 98 & 106 \\
\hline Raltegravir & 32 & 274 & 306 \\
\hline (8) & 9 & 11 & 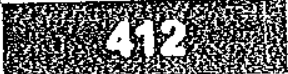 \\
\hline
\end{tabular}

O custo deste atendimento foi exclusivamente pelo do Tesouro Estadual.

\section{Defensoria pública da CAPITAL}

Em março/2008, após inúmeras tentativas de esclarecimento da atuação do SUS e da Assistência Farmacêutica oferecida à população e sem nenhum resultado prático, foi pactuado um 
atendimento dos "assistidos" da Defensoria Pública da Capital (Av. Liberdade, $n^{\circ} 32$ ) pelos farmacêuticos do CODES, duas vezes por semana, no sentido de orientá-los a procurar o local resolutivo.

Claro ficou desde o inicio desta atuação que um dos maiores fornecedores de clientes a Defensoria Pública da Capital é a Secretaria Municipal de Saúde de São Paulo (SMS-SP), com:

a) prescrições cujo atendimento poderia ser a própria unidade;

b) prescrições a serem encaminhadas para as Farmácias Estaduais (de medicamentos excepcionais, como eram chamadas nesta época);

c) "prescrições sociais" de alimentos, fraldas, produtos de higiene etc.

Ao longo desta "parceria" observamos:

2.1. Em $13 / 03 / 2008$, site da Defensoria Pública do Estado é exaltado o início da "parceria" (anexo 4).

2.2. DOE $29 / 05 / 2009$ é publicado Comunicado orientando e considerando o "sucesso e efetividade" (anexo 5).

2.3. DOE 23/12/2009, "Defensoria é reconhecida e premiada em concurso nacional", diz o texto: "A iniciativa extrajudicial da Defensoria Pública do Estado de São Paulo reduziu em cerca de $80 \%$ o número de ações judiciais para esta finalidade" (remédio e outros produtos não localizados na rede pública), o que the rendeu o primeiro lugar do Prêmio Innovare (categoria Defensoria Pública)" (anexo 6). 
Evidentemente foi motivo de orgulho para o Estado de São Paulo receber tal honraria, no entanto na prática a atuação da Def́ensoria Pública tem abandonado esta "parceria" (???).

Recentemente, em reunião com o Secretário da Justiça, a nova Defensora Chefe, Chefe de Gabinete de Estado da Saúde, foi apresentado este quadro desgastante, como pode "ser exemplificado pela relação das Ações Judiciais propostas pelos defensores da Capital e em especial de Osasco (anexo 7).

\section{Ministério Público EstaduAl}

A Coordenação do CODES participou durante o ano de 2009, a convite do Centro de Apoio Operacional das Promotorias de Justiça Cíveis e de Tutela Coletiva, do assim chamado CAO-Civel Itinerante. O Centro de Apoio promoveu reuniões em todas as Regionais do MPE, discutindo com os Promotores por dois dias, vários temas, entre eles o SUS e a Asșistência farmacêutica. Em todas as reuniões foi possível convidar o Diretor da DRS correspondente a Regional do MPE para participar do evento.

Nestas reuniões ficou evidenciada a necessidade de um canal ágil que responda as duvidas de acesso a medicamentos e outros serviços aos Promotores do MPE e a população.

Com relação aos promotores foi acordado que o Assessor do Promotor Geral de Justiça, Dr. Reynaldo Mapelli Jr., encaminha por e-mail a Coordenação do CODES apenas as dúvidas do dia-a-dia.

Com relação a população, profissionalizamos 0 atendimento desenvolvido na Defensoria Pública, conforme descrito a seguir. 


\section{TRIAGEM FARMACEUTICA}

No segundo semestre de 2009, o Secretario autorizou que uma OSS (SPDM) operasse o Pedido Administrativo (Serviço de Triagem Farmacêutica e Nutricional) no AME Maria Zélia, com abrangência para a Grande São Paulo (anexo 8).

Atualmente a Triagem Farmacêutica orienta cerca de 400 pessoas por dia e recebe 50 novos pedidos administrativos, que são analisados por Comitês Técnicos sob a coordenação do CODES,

Tabela - Custo das demandas administrativas

\begin{tabular}{|c|c|c|}
\hline Den & 6atogor & 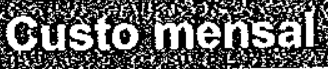 \\
\hline \multirow{5}{*}{$\begin{array}{c}\text { Administrativas } \\
\text { (ativas 17.931) }\end{array}$} & Materiais & $243.104,47$ \\
\hline & Medicamentos & $30.465 .467,43$ \\
\hline & Nutrição & $94.476,03$ \\
\hline & Outros itens & - \\
\hline & Procedimentos & - \\
\hline \multicolumn{2}{|c|}{ Administrativas - Total } & $30,803,047,93$ \\
\hline
\end{tabular}

Fonte: SCJ

\section{HOSPITAIS DE ENSINO}

Em reunião realizada em junho/2009 com todos os Hospitais de Ensino do Estado de São Paulo o Secretario pediu que apresentássemos a situação das AJ originadas com receitas dos $\mathrm{HE}$ e "combinou" que a partir de julho faria mensalmente o desconto de $1 / 6$ do valor das AJ propostas no $1^{\circ}$ semestre de 2009. O impacto desta proposta pode ser visualizado a seguir. 


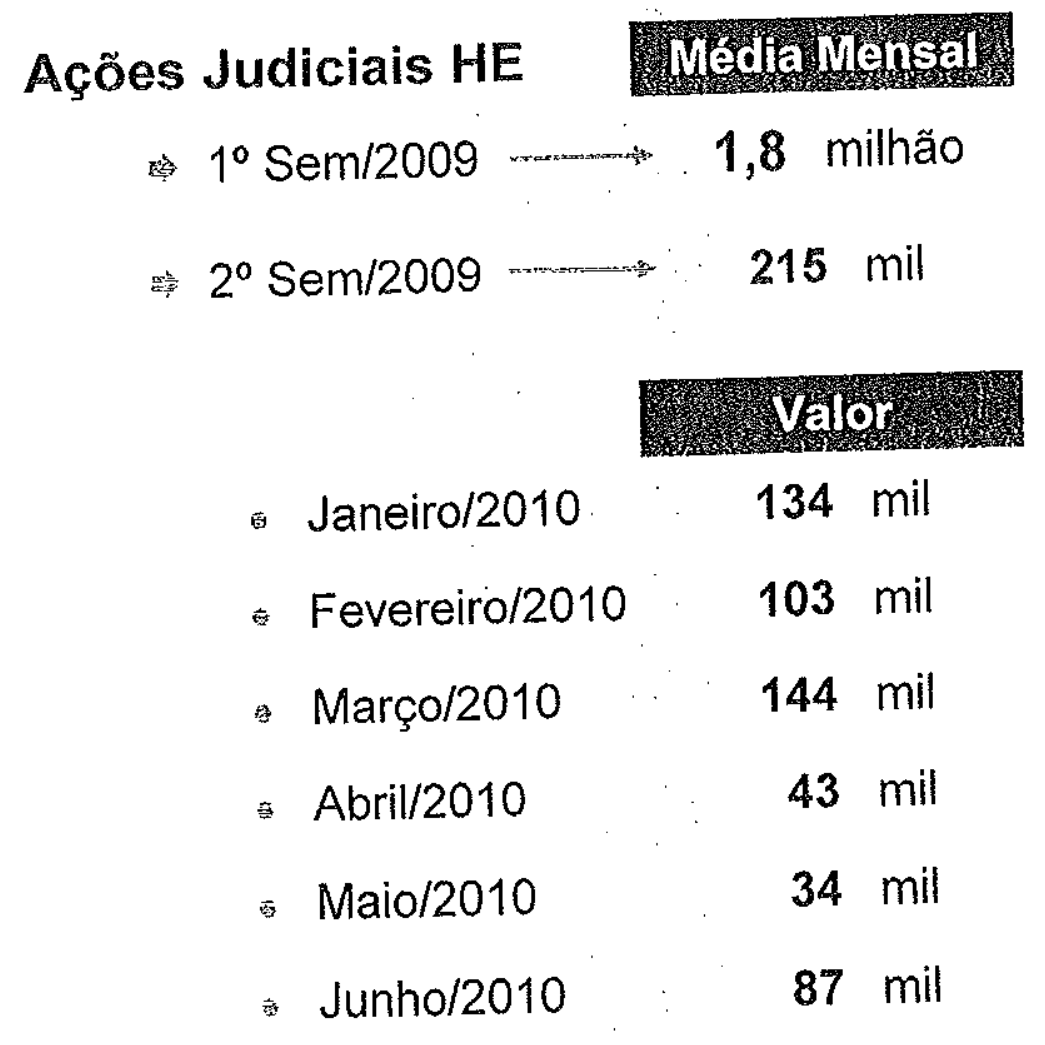

Pactuamos na ocasião que o CODES seria o canal para solicitações administrativas de situações peculiares e devidamente avaliadas pela Comissão Farmacoterapeutica (ou equivalente da instituição) assim como pela Diretoria Clínica. Também para estas solicitações valem as regras do pedido administrativo:

- Avaliação individual por Comitê de Especialistas da justificativa médica;

- Medicina baseada em envidência é o fio condutor

- Não é fornecido:

- Medicamento sem ANVISA

- Medicamento com alertas na Farmacovigilância

- Sem indicação em bula ("off label") 


\section{OUTRAS MEDIDAS:}

Resolução SS 126

A análise dos receituários juntados as ações judiciais e solicitações administrativas mostrou um cenário desalentador! A maior parte das receitas não contém dados básicos pertinentes para ser chamada de prescrição médica: $90 \%$ não contem data, $20 \%$ não têm nome completo do paciente etc. Diante deste quadro o Secretário publicou a Resolução SS 126, de 13 de agosto de 2009, que disciplina as prescrições médicas no âmbito do Estado (anexo 9).

\section{ATUALIZAÇÃO dO PORTAL:}

\# Com o intuito de manter atualizados os inúmeros parceiros, o CODES tem buscado junto aos órgãos da Secretaria, as alterações da Assistência Farmacêutica e atualizações dos atendimentos, garantindo com a CPS o item AF do portal da SES atualizado.

http:/www. saude sp.gov.br/content/assistencia farmaceutica.mmp

\section{NOVOS ONCOLÓGICOS}

Após algumas discussões infrutíferas com o Ministério da Saúde (INCA) e evidencias clínicas demonstrada pelos nossos Serviços de Oncologia, alem da constatação que uma ONG criou uma linha de montagem para AJ de medicamentos oncológicos (com ou sem indicação clínica), o Secretário decidiu por estabelecer um plano de incorporação de medicamentos oncológicos não previstos ainda pelas Tabelas do Ministério da Saúde. 
Em junho/2009 o gasto mensal com os novos oncológicos era de $R \$$ 4,3 milhões. Pactuamos em meado de 2009, SES / ICESP e 15 Serviços de Oncologia de Hospitais de Ensino (CACONs e UNACONs) os 7 medicamentos com nível de evidência $A$, a serem fornecidos pela Secretaria com sua indicação clínica (anexo 10).

Em julho de 2010 o valor mensal dispensado para atender administrativamente os medicamentos oncológicos foi de $\mathrm{R} \$ 22,3$ milhões.

É preciso esclarecer que o Ministério da Saúde vem acenando desde 2009 com a incorporação de alguns destes medicamentos na tabela do SUS e novamente o assunto é tratado da forma habitual pelo MS... .

Junto, folha final da versão preliminar da Nota Técnica do CONASS elaborada em 30/07/2010, com as propostas apresentadas pelo ilustre Secretário da SAS (anexo 11), onde MAIS UMA VEZ as incorporações de novos medicamentos ficaram para "a próxima negociação" e os demais "não serão incorporados agora". 


\section{SituAÇÃo ATUAL / PENDÊnCIAS}

Julho/2010

1. Definir atuação dos DRS's com relação a Triagem Farmacêutica, apoio as Regionais da PGE e Atendimento Administrativo.

2. Definir proposta feita à CCTIES para que todo medicamento $\checkmark$ especializado negado, se transforme em administrativo (especialmente agora com a recente implantação do Juizado Especial da Fazenda Pública).

3. Definir se outras ações judiciais deverão ser cadastradas e acompanhadas pelo S-CODES, como por exemplo, ACP. Outros

procedimentos de assistência à saúde, como por exemplo, câmara hiperbárica, etc..

4. S-CODES / Implantar o Módulo Administrativo que se encontra em ambiente de teste, durante o mês de setembro. O desenvolvimento e implantação do Módulo Relatórios deverá ocorrer até o final de 2010.

5. Novos projetos administrativos em andamento:

5.1. Nova modalidade de entrega dos medicamentos oncológicos (parceria Sírio Libanês / convênio):

- Medicamentos de infusão administrativos (início previsto agosto/2010);

medicamentos de infusão judiciais (setembro/2010);

* Medicamentos orais/Nárzea do Carmo (8.439 cadastrados no SCJ). 
5.2. Ampliar o tratamento para degeneração macular (com aplicação intra-ocular) para alguns Hospitais de Ensino do interior, no modelo Unifesp.

6. Recomendação $n^{\circ} 31$ do Conselho Nacional de Justiça, de 30 de março de 2010 que "Recomenda nos Tribunais a adoção de medidas visando a melhor subsidiar os magistrados e demais operadoras do direito, para assegurar maior eficiência na solução das demandas judiciais envolvendo a assistência a saúde".

Foram iniciadas as conversas preliminares para uma atuação com as Escolas (da Magistratura, da Defensoria Pública Estadual e Federal, e a do Ministério Público Estadual), com os Centros de Apoio (como o CAJUFA (Juízes da Fazenda Pública da Capital) e o CADIP, Centro de Apoio do Direito Público do Tribunal de Justiça de São Paulo.

7. Resumo do movimento do mês de julho cadastrado no S-CODES e SCJ.

\section{Entradas:}

$\Rightarrow$ AJ $637\left\{\begin{aligned} 84 & \text { Capital (31 DPESP) } \\ 573 & \text { Interior }\end{aligned}\right.$

$\Rightarrow$ ADM $414\left\{\begin{aligned} 309 & \text { Capital } \\ 95 & \text { Oncológicos (todo Estado) } \\ 9 & \text { Interior } \\ 1 & \text { CRT - AIDS }\end{aligned}\right.$

\section{Atendimentos:}

$\Rightarrow$ UD Tenente Pena: Módia diária $\begin{cases}\text { AJ } & 308 \\ \text { ADM } & 400\end{cases}$ 


\section{CUSTOS ATUAIS COM AS DEMANDAS \\ ADMINISTRATIVAS E JUDICIAIS (30/07/2010)}

\begin{tabular}{|c|c|c|}
\hline Demandas & Categorla & Gusto Menst \\
\hline \multirow{5}{*}{$\begin{array}{l}\text { ADMINISTRATIVAS ** } \\
\text { (Ativas 17.931) }\end{array}$} & Materiais & $243.104,47$ \\
\hline & Medicamentos & $30.465 .467,43$ \\
\hline & Nutrição & $94.476,03$ \\
\hline & Outros Itens * & $-\quad \quad \quad$ \\
\hline & Procedimento * & - \\
\hline 7an & $\mathrm{TAl}$ & 30.803047 .93 \\
\hline
\end{tabular}

\begin{tabular}{|c|c|c|}
\hline Demandas & Categorta & Custo Mensal \\
\hline \multirow{4}{*}{$\begin{array}{l}\text { JUDICIAIS *** } \\
\text { (Ativas } 24.267 \text { ) }\end{array}$} & Materiais & $2.838 .936,20$ \\
\hline & Medicamentos & $51.836 .793,90$ \\
\hline & Nutrição & 2.361 .198 \\
\hline & Outros Itens & $2.053,6$ \\
\hline & edimentos & - \\
\hline
\end{tabular}

\section{Total RS}

87.842 .02988

* Atendimento único ou contrato de atendimento.

** Tempo de tratamento conhecido

*** Em geral tempo indeterminado / medicamentos e produtos de marca /

Não foi incluido no custo médio gastos com escolas , Home Care, etc...

Fonte: S-CODES e SCJ 


\section{TERMO DE COOPERACC̃̃O TÉCNICA}

Pelo presente instrumento, o Estado de São Paulo, neste ato representado pelo Senhor Secretário de Estado da Saúde, Doutor Giovanni Guido Cerri, e - Tribunal de Justiça do Estado de São Paulo, neste ato representado por seu Presidente, Desembargador Ivan Ricardo Garisio Sartori,

Considerando:

- a Saúde como o direito de todos e dever do Estado, garantido mediante políticas sociais e econômicas que visem à redução do risco de doença e de outros agravos e ao acesso universal e igualitário às ações e serviços para sua promoção, proteção e recuperação, prevista na Carta Magna;

- a Audiência Pública no 4, realizada em 2009 pelo Supremo Tribunal Federal, na qual foram discutidas questões relevantes da judicialização da saúde; 
- a importância na difusão e divulgação das diretrizes e implementações dos Programas de Saúde estabelecidos no País, bem como das políticas existentes, da organização do Sistema Púbico Brasileiro de saúde e do gerenciamento do Sistema Único de Saúde-SUS;

RESOLVEM celebrar o presente Termo de Cooperação, visando implementar o Projeto "Triagem Farmacêutica no Juizado Especial da Fazenda Pública - JEFAZ", mediante as cláusulas e condições a seguir articuladas:

\section{Introducão:}

O Projeto "Triagem Farmacêutica no Juizado Especial da Fazenda Pública - JEFAZ", consiste na análise da documentação médica por técnicos da Secretaria do Estado da Saúde de Sao Paulo (SES-SP) junto às Varas do Juizados Especiais da Fazenda Pública (JEFAZ), para fornecer orientacão ao paciente, sobre os Programas Oficiais de Assistência Farmacêutica existentes no SUS e sobre os Protocolos Clínicos da Secretaria Estadual de Saúde, assim como outras vias regularmente disponibilizadas para a assistência à saúde.

O Projeto também prevê a disponibilização de informacões técnicas para auxiliar os magistrados na formação de um juízo de valor quanto à apreciação das questões clínicas nas ações relativas à saúde. 
Deste modo, visa o Projeto "Triagem Farmacêutica no Juizado Especial da Fazenda Pública - JEFAZ", a diminuição de ações judiciais desnecessárias, o incremento no uso racional de medicamentos com maior segurança e efetividade, reinserindo o paciente no SUS, o quanto possível.

\section{Objetivos:}

1. Realizar triagem farmacêutica para possível reintegração do paciente aos Servicos e Programas Oficiais de Assistência Farmacêutica do SUS; com escopo de evitar a propositura de medidas judiciais desnecessárias,

2. Informar ao paciente sobre a possibilidade da apreciação administrativa pela Secretaria do Estado da Saúde, da solicitação de medicamentos, insumos médicos hospitalares e dietas,

3. Oferecer informações técnicas aos magistrados, para subsidiar a análise das solicitações do paciente;

\section{Justificativas:}

Na Audiência Pública № 4, realizada pelo Supremo Tribunal Federal para discutir as questões relativas às demandas judiciais que objetivam 0 fornecimento de prestações de saúde, diante do grande número de demandas envolvendo a assistência à saúde em tramitação no Poder Judiciário brasileiro, agravado pela constatação de carência de informações clínicas prestadas aos magistrados a respeito dos problemas de saúde enfrentados pelos autores dessas demandas, assim como o representativo dispêndio de recursos 
públicos decorrente desses processos judiciais e o reclamo dos gestores para que sejam ouvidos antes da concessão de provimentos judiciais de urgência; foi considerada a necessidade de propor medidas que visem a aperfeiçoar a prestação jurisdicional em matéria de assistência à saúde.

Considerando ainda, que os medicamentos e tratamentos utilizados no Brasil dependem de prévia aprovação pela ANVISA, na forma do art. 12 da Lei 6.360/76 c/c a Lei 9.782/99, as quais objetivam garantir a saúde dos usuários contra práticas com resultados ainda não comprovados ou mesmo contra aquelas que possam ser prejudiciais aos pacientes; justifica-se a implantação do Projeto "Triagem Farmacêutica no Juizado Especial da Fazenda Pública JEFAZ", como proposta de contribuição para efetivação do direito à saude.

\section{Responsabilidades das partes:}

O presente Projeto JEFAZ é elaborado em caráter de estrita cooperação, não gerando qualquer ônus financeiro entre os partícipes, observando-se as regras estabelecidas nos seus anexos I e II, podendo ser rescindido a qualquer tempo por quaisquer dos partícipes, com antecedência de 30 (trinta) dias.

E, por estarem os partícipes justos e de acordo, firmam o presente convênio denominado "Projeto JEFAZ", o Estado de São Paulo, representado por seu Secretário de Estado da Saúde, Dr. Giovanni Guido Cerri, o Tribunal de Justiça do Estado de São Paulo, representado por seu Presidente, Desembargador Ivan Ricardo Garisio Sartori, em (três) vias de igual teor. 


\section{SECRETARIA DE ESTADO DA SAÚDE}

Coordenação de Demandas Estratégicas do SUS-CODES

Gabinete do Secretário

São Paulo, 06 de novembro de 2012.

Des. Ivan Ricardo Garisio Sartori

Presidente do Tribunal de Justiça

do Estado de São Paulo

Des. Samuel Alves de Melo Júnior

Presidente da Câmara de Direto Público

Tribunal de Justiça do Estado São Paulo
Dr. Giovanni Guido Cerri

Secretário de Estado da Saúde

de São Paulo

Dr. Reynaldo Mapelli Júnior

Chefe de Gabinete

Secretaria Estado da Saúde

de São Paulo

Dr. Elival da Silva Ramos

Procurador Geral do Estado

de São Paulo
Dra. Eloisa de Sousa Arruda

Secretária de Estado da Justiça

e da Defesa da Cidadania 


\section{Relatório de Atendimento \\ Serviço de Analise Pré Processual Triagem Farmacêutica JEFAZ - 2012}

\section{Apresentação}

O Projeto "Triagem Farmacêutica no Juizado Especial da Fazenda Pública - JEFAZ" consiste na análise da documentação médica por técnicos da Secretaria do Estado da Saúde de São Paulo (SES-SP) junto às Varas do Juizados Especiais da Fazenda Pública (JEFAZ), para fornecer orientacão aos pacientes, sobre os Programas Oficiais de Assistência Farmacêutica existentes no SUS e sobre os Protocolos Clínicos da Secretaria Estadual de Saúde, assim como outras vias regularmente disponibilizadas para a assistência à saúde.

O Projeto Jefaz foi implantado em 21 de novembro de 2012 nas duas Varas da Fazenda Pública da Capital, com projeção de expansão para demais Comarcas do Estado de São Paulo.

\section{Equipe de Trabalho}

A equipe de trabalho é composta por farmacêuticas que realizam o atendimento de triagem farmacêutica e auxiliar administrativo, que realiza $o$ apoio operacional ao Projeto, nas dependências do Fórum Hely Lopes Meirelles, de segunda às sextas feiras, no horário das 13:00 às 18:00 horas.

\section{Fluxo de trabalho}

O serviço de Analise Pré Processual Triagem Farmacêutica realiza o atendimento de pacientes que buscam junto às duas Varas dos Juizados Especiais da Fazenda Pública (JEFAZ) da capital, informações de como obter judicialmente o acesso de itens ou serviços disponibilizados ou não no SUS. São atendido também autores oriundos de determinação judicial expedida. 


\section{Secretaria de Estado da Saúde de São Paulo}

\section{Análise Pré Processual Triagem Farmacêutica - JEFAZ}

O atendimento consiste em realizar a triagem farmacêutica para possível reintegração do paciente aos Serviços e Programas Oficiais de Assistência Farmacêutica do SUS.

Conforme a análise dos dados da solicitação, é informado ao paciente e ao Magistrado, a possibilidade do acesso (ou não) pelas vias disponibilizadas pela Secretaria do Estado da Saúde, à exemplo da Solicitação Administrativa, consoante Resolução SS-54, de 11-05-2012, e outras vias regularmente disponibilizadas para a assistência à saúde.

Durante 0 atendimento, é realizado o preenchimento de uma planilha com dados do paciente, de sua solicitação, assim como as orientações e encaminhamentos fornecidos, documentando o atendimento efetuado e sua conclusão, para controle e disponibilização destes registros aos Magistrados do Juizado Especial da Fazenda Pública-SP e gestores da Secretaria de Estado da Saúde - SP, semanalmente.

\section{Indicadores}

Foram analisados os dados dos atendimentos realizados no setor de Análise Pré - processual Triagem Farmacêutica de 21/11/2012 à 19/12/2012 com ênfase nas seguintes dimensões do projeto: origem da indicação para atendimento, tipo de solicitação recebida, encaminhamentos realizados, status do atendimento, judicialização da demanda após atendimento. 


\section{RESULTADOS}

Tabela 1- Status de finalização do atendimento realizado.

\begin{tabular}{|l|l|}
\hline Status & No de atendimento \\
\hline Finalizados & 24 \\
\hline Orientados & 6 \\
\hline Em andamento & 5 \\
\hline Total & 35 \\
\hline
\end{tabular}

Fonte: Atendimentos realizados JEFAZ 2012

Gráfico - 1

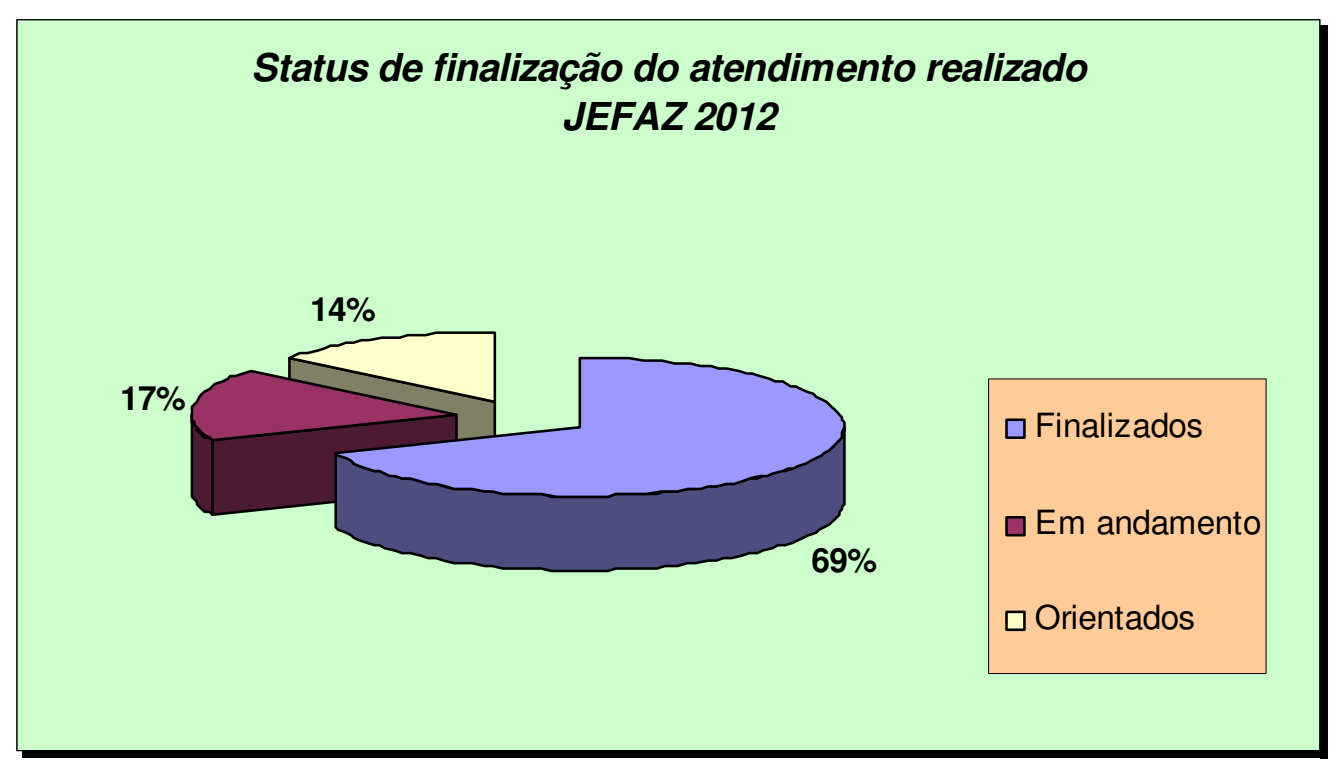


Secretaria de Estado da Saúde de São Paulo Análise Pré Processual Triagem Farmacêutica - JEFAZ

Tabela 2- Indicação para o atendimento

Origem

Protocolo de triagem judicial

Determinação judicial

Total

Atendimentos realizados JEFAZ 2012

\section{Gráfico - 2}

\section{№ de atendimentos}

32

03

35

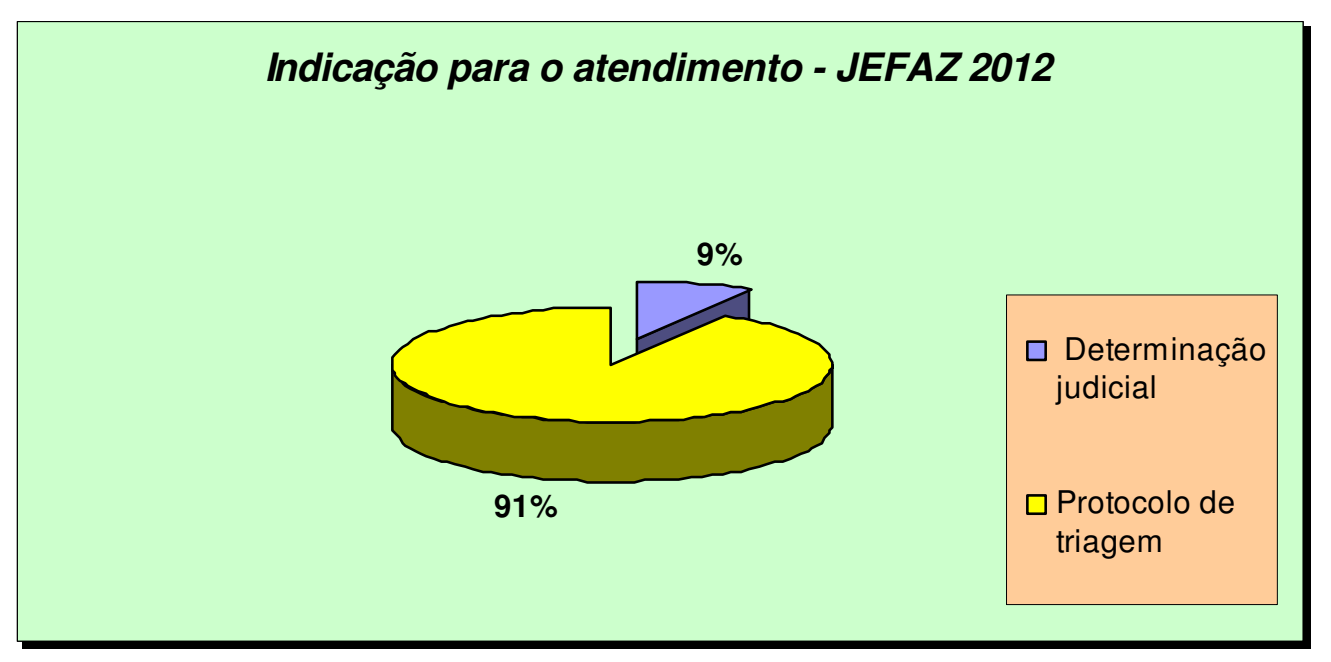


Tabela 3- Tipo de solicitação recebida

\begin{tabular}{|l|l|}
\hline Tipo de solicitação & No de atendimento \\
\hline Medicamento & 21 \\
\hline Procedimento & 10 \\
\hline Nutrição & 3 \\
\hline Material & 1 \\
\hline Total & 35 \\
\hline Fonte: Atendimentos realizados JEFAZ 2012 \\
\hline
\end{tabular}

\section{Gráfico - 3}

Tipo de solicitação recebida - JEFAZ 2012

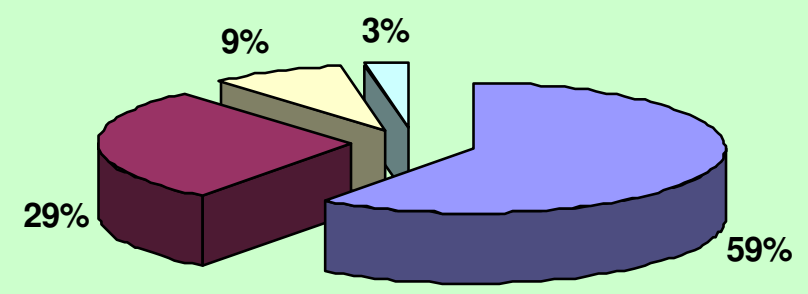

$\square$ medicamento

$\square$ procedimento

$\square$ nutrição

$\square$ material 
Secretaria de Estado da Saúde de São Paulo

Análise Pré Processual Triagem Farmacêutica - JEFAZ

Tabela 4- Encaminhamento dos atendimentos realizados

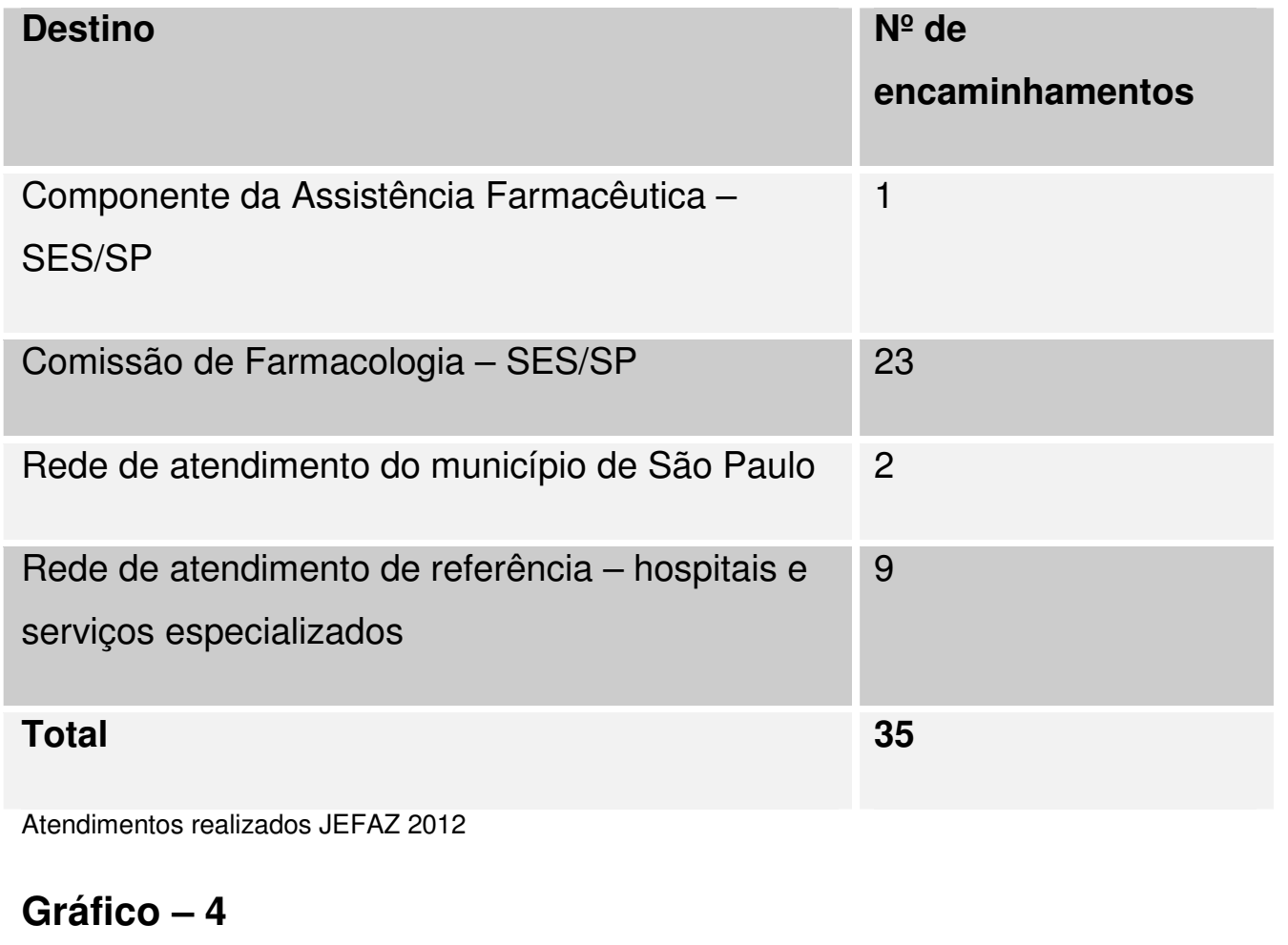

\section{Encaminhamento realizado - JEFAZ 2012}

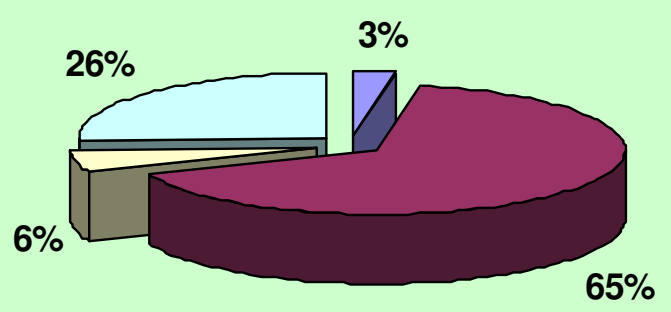

\begin{tabular}{|l|}
\hline$\square$ Assistência \\
Farmacêutica \\
$\square$ Comissão \\
Farmacologia \\
$\square$ Rede de atendimento \\
do município de São \\
Paulo \\
$\square$ Rede de referencia \\
de atendimento - \\
Hospitais
\end{tabular}


Tabela 5 - Judicialização após atendimento.

\begin{tabular}{|l|l|}
\hline Situação & № de atedimentos \\
\hline Não judicializados & 31 \\
\hline Judicializados após atendimento & 1 \\
\hline Ação já em andamento & 3 \\
\hline Total & 35 \\
\hline
\end{tabular}

Atendimentos realizados JEFAZ 2012

Gráfico- 5

Jucidialização após atendimento - JEFAZ 2012

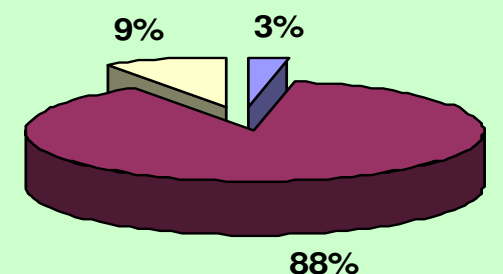

Judicializado após atedimento

$\square$ Não judicializado

$\square$ Ação em andamento 


\section{SECRETARIA DE ESTADO DA SAÚDE}

Coordenação de Demandas Estratégicas do SUS-CODES

Gabinete do Secretário

\section{ANEXO I}

\section{Áreas envolvidas:}

Secretaria de Estado da Saúde - SES/SP

Tribunal de Justiça do Estado de São Paulo - TJ/SP- Varas do Juizado Especial da Fazenda Publica - SP capital

\section{Infraestrutura:}

\begin{tabular}{|c|c|}
\hline \multirow{2}{*}{ Local } & $\begin{array}{r}\text { Juizado Especial da Fazenda Pública - JEFAZ } \\
\text { Fórum da Vara da Fazenda Pública }\end{array}$ \\
& $\begin{array}{c}\text { Viaduto Dona Paulínia, no 80- São Paulo-SP } \\
\text { Horário de } \\
\text { funcionamento }\end{array}$ \\
\hline $\begin{array}{c}\text { Demanda } \\
\text { Estimada }\end{array}$ & De segunda a sexta feira $12: 00$ às 18:00 hs \\
\hline
\end{tabular}

\section{Área física / equipamentos}

\begin{tabular}{|c|c|c|}
\hline Especificação & Equipamentos/mobiliário & Quantidade \\
\hline $\begin{array}{c}\text { Sala de espera com } \\
\text { lugar reservado para } \\
\text { deficiente físico }\end{array}$ & Cadeiras & 10 \\
\hline $\begin{array}{c}\text { Sala de avaliação com } \\
\text { lugar reservado para } \\
\text { deficiente físico }\end{array}$ & $\begin{array}{c}\text { Computador modelo Pentium 4 com } \\
2 \text { GHZ de processador, 2 GB de } \\
\text { memória RAM e HD de 80 GB, } \\
\text { sistema operacional Windows Vista }\end{array}$ & 02 \\
\hline
\end{tabular}




\begin{tabular}{|c|c|c|}
\hline & Fax/ copiadora & 01 \\
\cline { 2 - 3 } & Impressora laser conectada a rede & 01 \\
\cline { 2 - 3 } & $\begin{array}{c}\text { Link Intragov } \\
\text { Telefone com acesso a ligações } \\
\text { externas }\end{array}$ & 01 \\
\cline { 2 - 3 } & $\begin{array}{c}\text { Cadeiras } \\
\text { Mesas }\end{array}$ & 04 \\
\hline
\end{tabular}

\section{Recursos humanos}

\begin{tabular}{|c|c|c|}
\hline Equipe Técnica & Quantidade & Contratação \\
\hline Farmacêutico & 01 & SES \\
\hline Auxiliar de farmácia & 01 & SES \\
\hline
\end{tabular}

\section{$\underline{\text { Responsabilidades }}$}

\begin{tabular}{|c|c|c|}
\hline \multirow{2}{*}{ Discriminação } & \multicolumn{2}{|c|}{ Responsabilidade } \\
\cline { 2 - 3 } & SES & TJ \\
\hline Área física & & $\mathrm{x}$ \\
\hline Equipamentos / mobiliário & & $\mathrm{x}$ \\
\hline Manutenção & & \\
\hline Recursos humanos & $\mathrm{x}$ & \\
\hline Gestão da equipe técnica & $\mathrm{x}$ & \\
\hline
\end{tabular}




\section{SECRETARIA DE ESTADO DA SAÚDE}

Coordenação de Demandas Estratégicas do SUS-CODES Gabinete do Secretário

TRIBUNAL DE JUSTIC

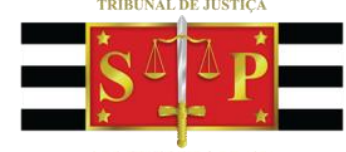

PODER JUDICIÁRIO

tRIBUNAL DE JUSTIÇA dO ESTADO DE SÃo PAULO

\begin{tabular}{|c|c|c|}
\hline Manutenção & & $\mathrm{x}$ \\
\hline Link Intragov & & $\mathrm{x}$ \\
\hline Telefone com acesso a ligações externas & $\mathrm{x}$ & \\
\hline
\end{tabular}

\section{Método}

Descrição operacional

\begin{tabular}{|c|c|}
\hline Agente & Operação \\
\hline $\begin{array}{c}\text { Colaborador } \\
\text { do TJSP }\end{array}$ & $\begin{array}{l}\text { 1. Recepcionar e encaminhar o paciente com os } \\
\text { documentos médicos (receita médica e exames) e } \\
\text { documentos pessoais para a triagem farmacêutica }\end{array}$ \\
\hline $\begin{array}{l}\text { Oficial Adm } \\
\quad \text { (SES) }\end{array}$ & $\begin{array}{l}\text { 1.1. Recepcionar o paciente } \\
\text { 1.2. Conferir a documentação recebida } \\
\text { 1.3. Consultar os bancos de dados da SES para verificar } \\
\\
\text { se existem outras solicitações administrativas e/ou } \\
\text { judiciais do paciente }\end{array}$ \\
\hline $\begin{array}{l}\text { Farmacêutico } \\
\qquad \text { (SES) }\end{array}$ & $\begin{array}{l}\text { 1.1. Analisar a receita médica em relação aos requisitos } \\
\text { legais, medicamento prescrito e a patologia do } \\
\text { paciente } \\
\text { Realizar Avaliação Farmacêutica das prescrições de } \\
\text { medicamentos pertencentes aos Programas Oficiais de } \\
\text { Assistência Farmacêutica: } \\
\text { 2.1.a) Entregar a documentação necessária ao paciente } \\
\text { para requerer o medicamento prescrito no Componente da } \\
\text { Assistência Farmacêutica correspondente, } \\
\text { 2.1.b) Orientar o paciente como obtê-lo no local mais } \\
\text { próximo da sua residência }\end{array}$ \\
\hline
\end{tabular}




\section{SECRETARIA DE ESTADO DA SAÚDE}

Coordenação de Demandas Estratégicas do SUS-CODES

Gabinete do Secretário

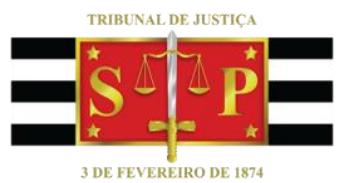

PODER JU DICIÁ RIO
TRIBUNAL DE JUSTIÇA DO ESTADO DE SÃo PAULO

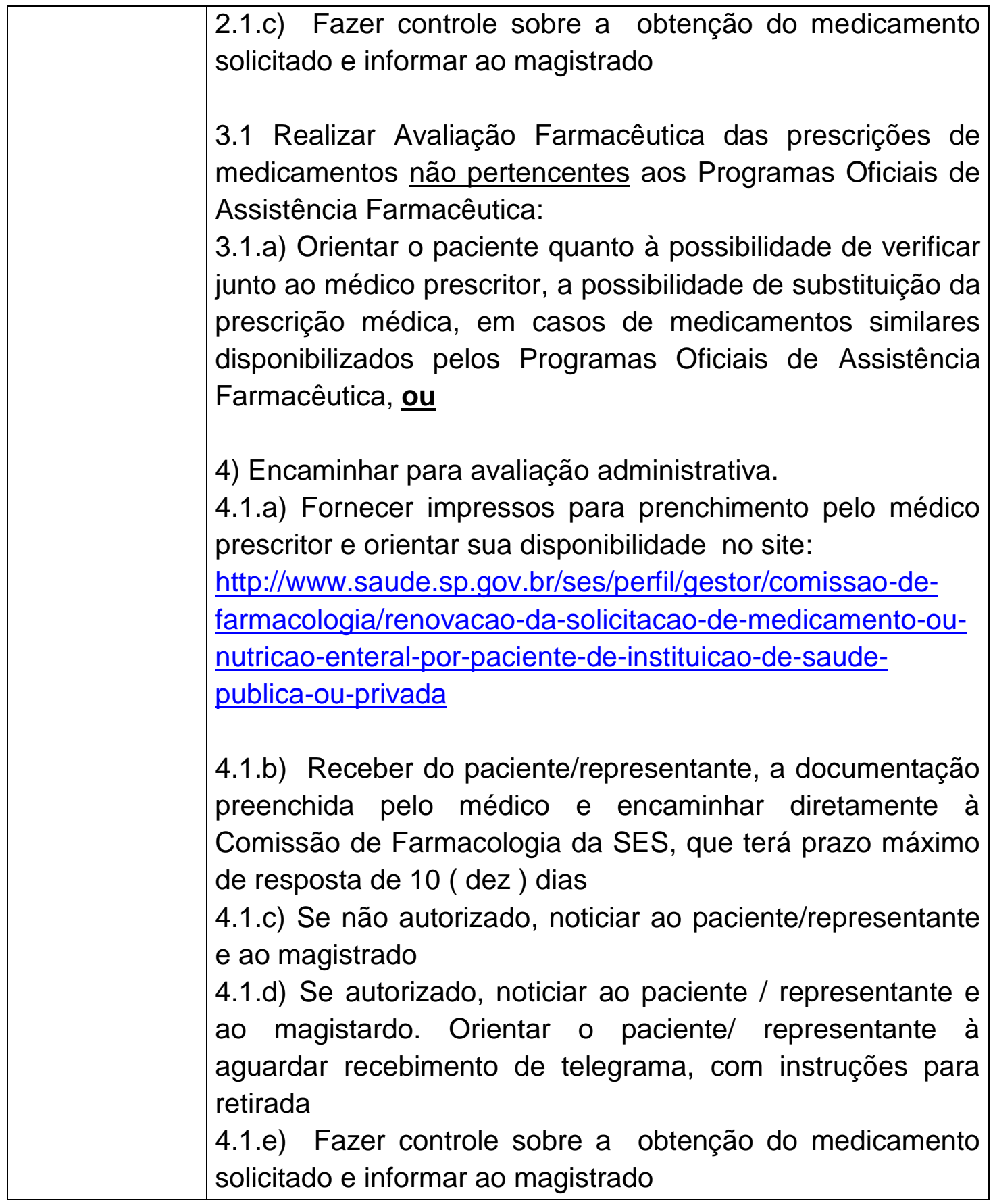




\title{
SECRETARIA DE ESTADO DA SAÚDE
}

Coordenação de Demandas Estratégicas do SUS-CODES

Gabinete do Secretário

\author{
PODER JUDICIÁRIO
}

TRIBUNAL DE JUSTIÇA DO ESTADO DE SÃO PAULO

\section{ANEXO II}

\section{Fluxograma de atendimento}

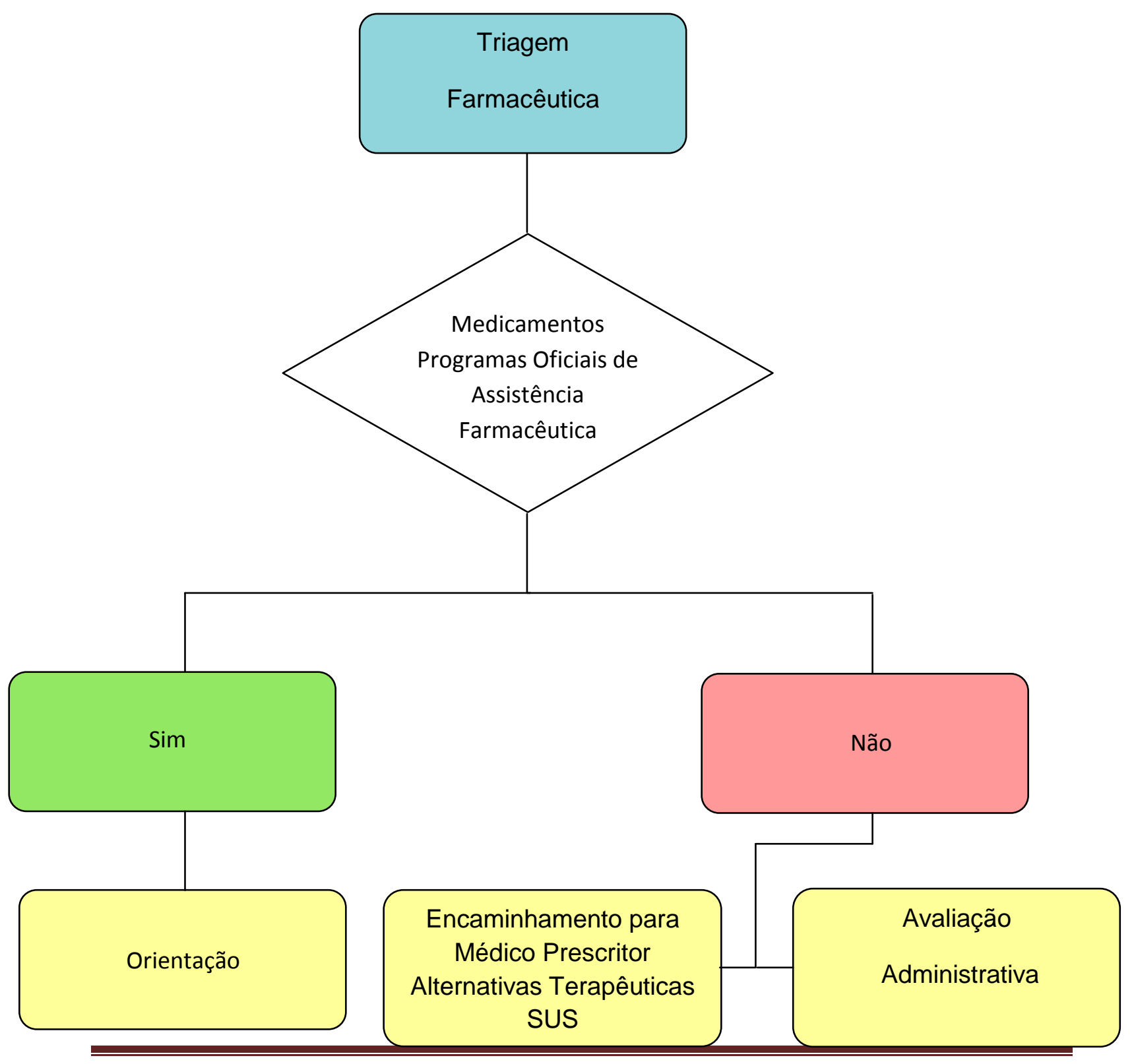

Projeto - Triagem Farmacêutica no Juizado Especial da Fazenda Pública - JEFAZ 
Acordo de Cooperação Técnica que, entre si, celebram a Defensoria Pública da União no Estado do Rio Grande do Norte - DPU/RN, a Procuradoria da União no Estado do Rio Grande do Norte - PU/RNAGU, a Procuradoria Geral do Estado do Rio Grande do Norte - PGE/RN, a Procuradoria Geral do Município do Natal - PGMN/RN, a Secretaria de Estado da Saúde Pública - SESAP/RN e a Secretaria Municipal de Saúde do Natal - SMS/Natal, visando a solucionar, administrativamente, Demandas envolvendo questões de saúde ligadas ao Sistema único de Saúde - SUS.

A Defensoria Pública da União no Estado do Rio Grande do Norte, doravante denominada DPU/RN, com sede na Rua Deodoro da Fonseca, 601, Cidade Alta, Natal/RN, neste ato representada pelo Defensor Público Chefe da União, Dr. WAGNER RAMOS KRIGER; a Procuradoria da União no Estado do Rio Grande do Norte, doravante denominada PU/RN-AGU, com sede na Avenida Brancas Dunas, 565, Ed. Aquarius Center, Candelária, Natal/RN, neste ato representada pelo Procurador-Chefe da União, Dr. NIOMAR DE SOUSA NOGUEIRA; a Procuradoria Geral do Estado do Rio Grande do Norte, doravante denominada PGE/RN, com sede na Avenida Afonso Pena, 1155, Tirol, Natal/RN, neste ato representada pelo ProcuradorGeral do Estado, Dr. FRANCISCO DE SALES MATOS; a Procuradoria Geral do Município do Natal/RN, doravante denominada PGMN/RN, com sede na Rua Vigário Bartolomeu, 542, Cidade Alta, Natal/RN, neste ato representada pelo Procurador-Geral do Município de Natal, Dr. BRUNO MACEDO DANTAS; a Secretaria de Estado da Saúde Pública,
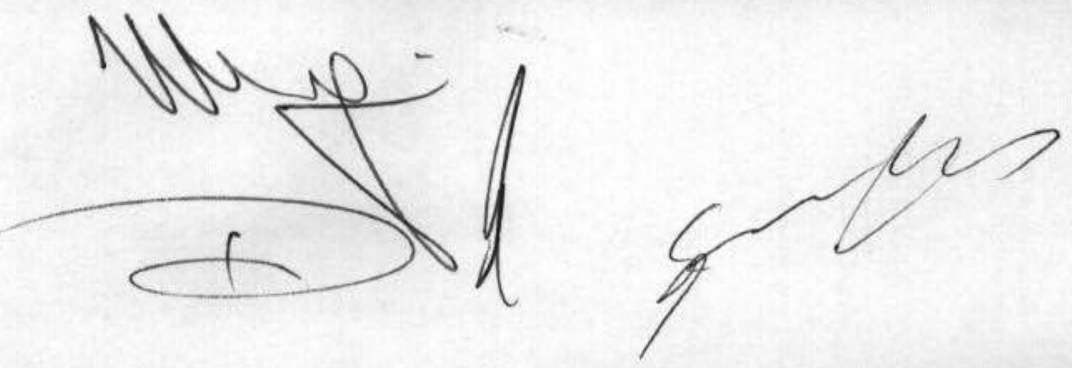
doravante denominada SESAP/RN, com sede na Avenida Deodoro da Fonseca, $730,8^{\circ}$ andar, Centro, Natal/RN, neste ato representada pelo Secretário de Estado da Saúde Pública, Dr. GEORGE ANTUNES DE OLIVEIRA; e a Secretaria Municipal de Saúde do Natal, doravante denominada SMS/Natal, com sede na Rua João Pessoa, 634, Ed. Ducal, $15^{\circ}$ Andar, Cidade Alta, Natal-RN, neste ato representada pela Secretária de Saúde do Município do Natal, Dra. ANA TÂNIA LOPES SAMPAIO; considerando o mútuo interesse das partes e, ademais,

Considerando a crescente judicialização das questões de saúde envolvendo o SUS;

Considerando a necessidade de se abrir um canal de discussões sobre as questões de saúde entre os diversos entes públicos envolvidos com as demandas judiciais;

Considerando a necessidade de se fazer uma advocacia preventiva de litígios nas questões de saúde, bem como a conveniência de se buscar conciliação nas questões de saúde já judicializadas;

Considerando que a saúde é um direito fundamental do ser humano, reconhecido pelo Estado brasileiro, o qual deve prover as condições indispensáveis ao seu pleno exercício;

Considerando o fato de que o SUS é financiado com recursos públicos do orçamento da seguridade social, da União, dos Estados, do Distrito Federal e dos Municípios;

Considerando que é interesse público primário prestar um serviço de saúde pública de qualidade e eficiente à população;

Considerando a urgência na prestação dos serviços de saúde à população;

Considerando que é um dos princípios do SUS o direito à informação, às pessoas assistidas, sobre sua saúde; e

Considerando a necessidade de se efetivar as políticas públicas de saúde já existentes e reconhecidas como direito dos assistidos,
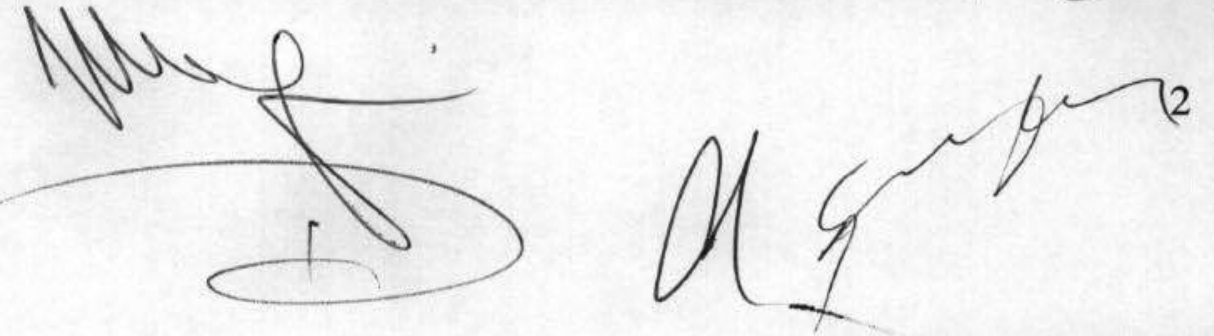
RESOLVEM, celebrar o presente ACORDO DE COOPERAÇÃO TÉCNICA, doravante denominado ACORDO, elaborado em conformidade com o art. 116 da Lei 8.666, de 21 de junho de 1993, e legislação correlata, de acordo com as cláusulas e condições a seguir:

\section{CLÁUSULA PRIMEIRA - DO OBJETO}

O presente ACORDO tem por objeto o estabelecimento de parceria entre a DPU/RN, a PU/RN-AGU, a PGE/RN, a PGMN/RN, a SESAP/RN, e a SMS/Natal, para análise, por meio do Comitê Interinstitucional de Resolução Administrativa de Demandas da Saúde - CIRADS, ora constituído, doravante denominado de CIRADS, dos casos concretos em que o assistido pelo Sistema Único de Saúde (SUS) não tenha recebido o devido atendimento pelo referido sistema, a fim de identificar tanto os casos em que o pleito pode ser atendido administrativamente, evitando a sua judicialização, quanto aqueles em que se pode obter conciliação em ações judiciais já em curso, nas hipóteses em que o tratamento de saúde (fornecimento de medicamentos, insumos, materiais e serviços de saúde) esteja previsto no âmbito do SUS e não tenha sido prestado, bem como naquelas hipóteses em que, por algum motivo, o médico indicou tratamento diverso dos que são oferecidos pelo SUS.

Parágrafo Primeiro - O CIRADS será composto por Defensores Públicos da União, Advogados da União, Procuradores do Estado do Rio Grande do Norte, Procuradores do Município do Natal/RN, servidores públicos da Secretaria de Estado da Saúde Pública e servidores públicos da Secretaria Municipal de Saúde do Natal/RN, designados pelas respectivas autoridades competentes, sendo um titular e dois suplentes por órgão público.
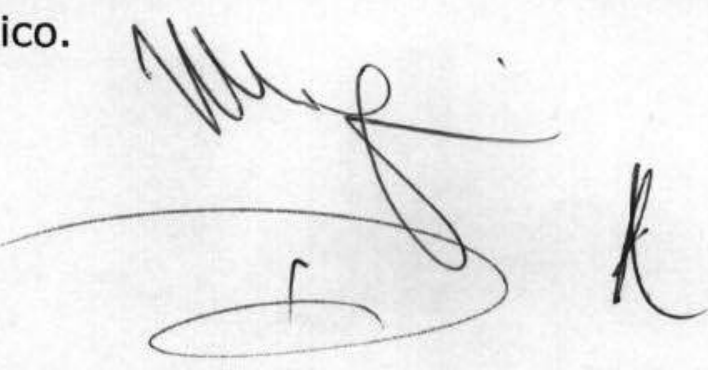
Parágrafo Segundo - Poderão participar, ainda, como auxiliares eventuais ou permanentes do CIRADS, médicos, farmacêuticos, assistentes sociais, psicólogos, juristas, servidores públicos com envolvimento na área de saúde e outros, de comum acordo entre os componentes do CIRADS.

Parágrafo Terceiro - Constitui objetivo do CIRADS, também, a apresentação de propostas, perante as autoridades competentes, tendentes ao aperfeiçoamento do SUS.

\section{CLÁUSULA SEGUNDA - DA EXECUÇÃo}

O CIRADS exercerá suas funções por meio de reunião mensal, a ser realizada, preferencialmente, na última quarta-feira do mês, ou em outra periodicidade ou data que melhor se adequar aos objetivos do comitê, em local a ser previamente definido, tudo de comum acordo entre os participantes.

Parágrafo Primeiro - Serão submetidos ao CIRADS os casos em que a DPU/RN, ao realizar a prestação de assistência jurídica ao cidadão, constatar a possibilidade de ter havido falha na prestação do serviço de saúde, por não ter sido oferecido o tratamento de saúde previsto no âmbito do SUS, bem como nas hipóteses em que o médico tiver indicado tratamento diverso daqueles oferecidos pelo SUS.

Parágrafo Segundo - O Defensor Público da União exporá as razões fáticas e jurídicas pelas quais considera que a negativa na prestação do tratamento de saúde deveria ser revista e, em seguida, os demais participantes do CIRADS terão a palavra para pronunciamento.
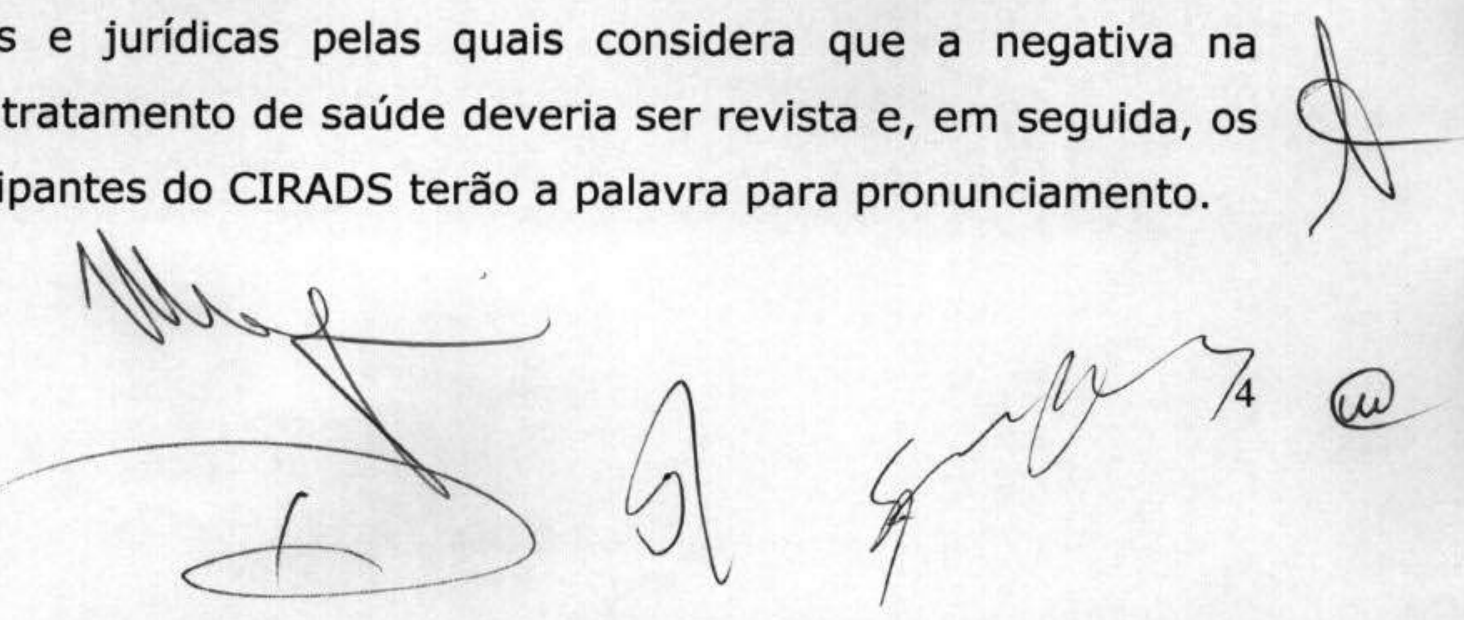
Parágrafo Terceiro - Será designado um membro do CIRADS ou servidor dos respectivos órgãos componentes para funcionar como secretário da sessão, o qual registrará, em ata, todas as discussões e deliberações.

Parágrafo Quarto - A fim de otimizar o funcionamento do CIRADS, a DPU/RN deverá enviar, imediatamente ao atendimento jurídico ao assistido, por e-mail a ser indicado pelos demais participantes, todos os elementos de fato e de direito relativos ao caso específico, especialmente o receituário médico e os exames de que disponha.

Parágrafo Quinto - A DPU/RN poderá enviar questionário, aprovado pelo CIRADS, ao médico que prescreveu o tratamento, o qual, após respondido, deverá ser submetido ao CIRADS, para apreciação e deliberação sobre a viabilidade de atendimento.

Parágrafo Sexto - O CIRADS se valerá de sua experiência decorrente da análise dos casos concretos para formular, perante as autoridades competentes, sugestões de aperfeiçoamento do SUS.

\section{CLÁUSULA TERCEIRA - DA COORDENAÇÃO}

O CIRADS terá um Coordenador, que o representará perante o público externo e organizará as suas atividades, bem como um Subcoordenador, que substituirá o Coordenador em suas ausências, ambos pertencentes aos quadros funcionais dos órgãos públicos Participantes, os quais serão eleitos por um período de 02 (dois) anos.
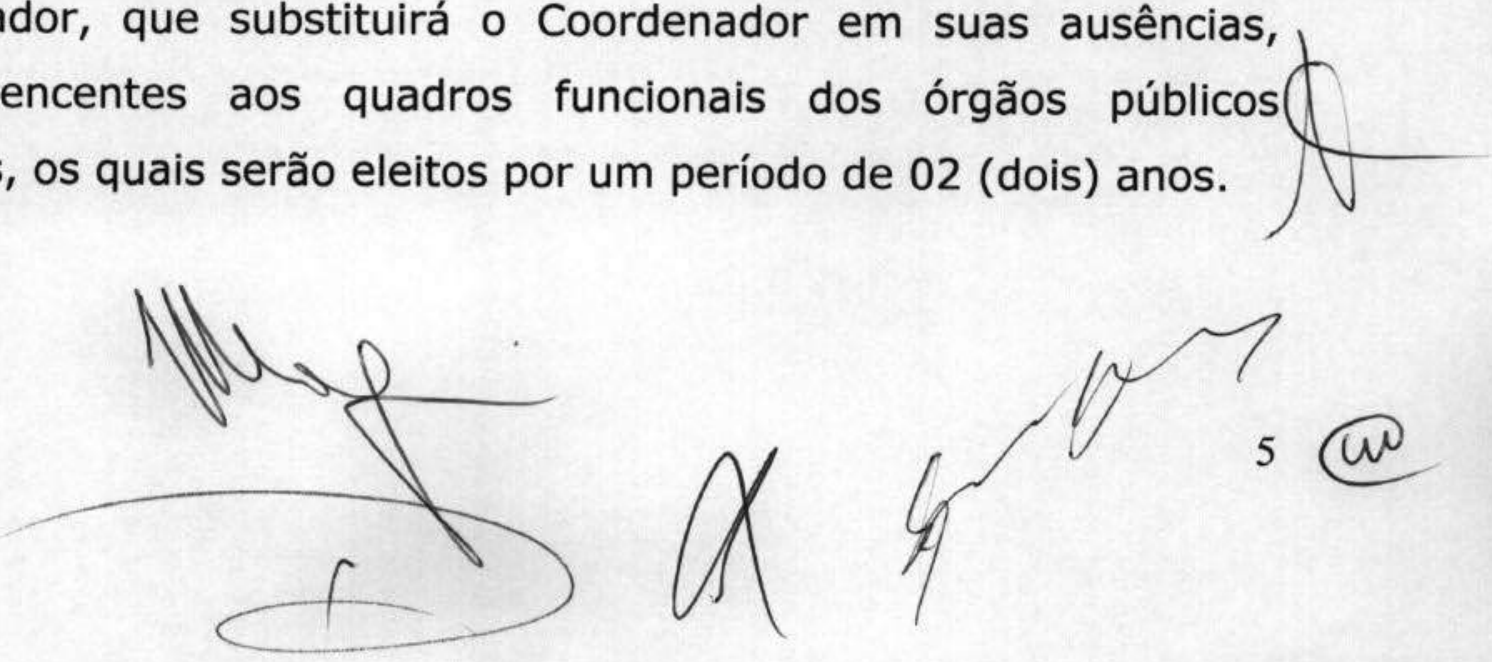


\section{CLÁUSULA QUARTA - DAS OBRIGAÇÕES DOS PARTICIPANTES}

Para a implementação das ações previstas no presente Acordo são estabelecidas as seguintes obrigações:

\section{I - DAS OBRIGAÇÕES COMUNS:}

a) atuar em parceria com os demais membros do comitê, participando do planejamento, do acompanhamento e da avaliação das ações objeto deste Acordo;

b) fazer-se representar em todas as reuniões do CIRADS;

c) dividir as informações obtidas sobre o caso concreto com todos os membros do CIRADS;

d) disponibilizar e-mail para receber e enviar as comunicações do CIRADS, devendo comunicar aos demais Participantes eventual mudança de conta;

e) submeter à apreciação do CIRADS as demandas de saúde já ajuizadas em que se tenha verificado a viabilidade de conciliação;

f) manter sigilo da identidade dos cidadãos que pleiteiam os serviços de saúde, podendo-se divulgar os casos analisados e resolvidos, porém, sem fornecer elementos que possam identificar os assistidos;

g) zelar pelo acesso restrito às reuniões, não se fazendo acompanhar por pessoas que não tenham ligação com os casos de saúde tratados;

h) promover discussões, debates, seminários e audiências públicas para fins de estudo e apresentação de sugestões, objetivando melhorar a qualidade e eficiência dos serviços de saúde pública oferecidos à população;
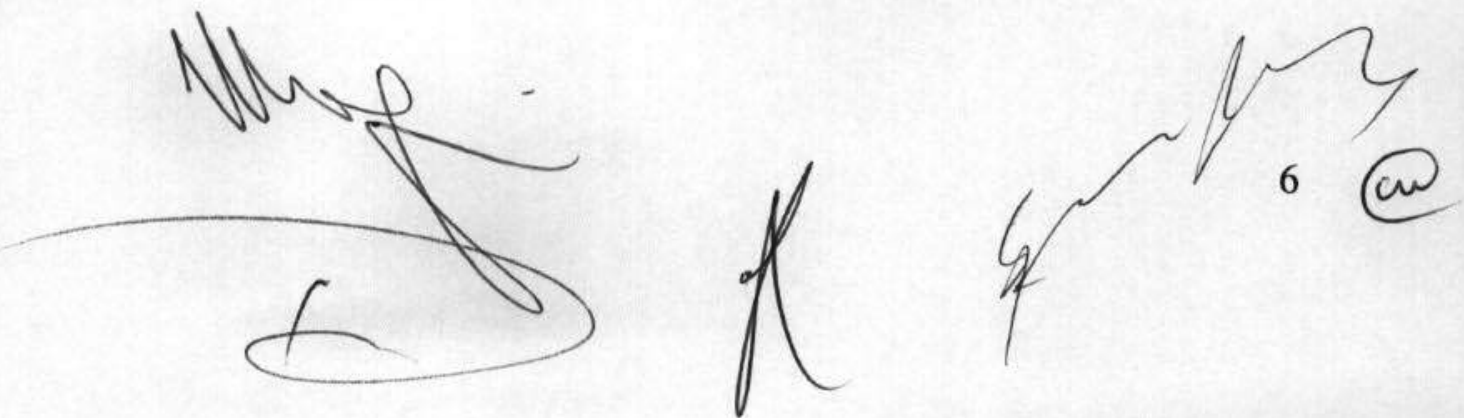
i) procurar alternativas para melhorar o atendimento do SUS, promovendo a integração entre autoridades públicas e apresentando sugestões a serem encaminhadas aos órgãos públicos competentes para avaliação e adoção de medidas tendentes a aperfeiçoar o sistema;

j) viabilizar a participação de pessoas ligadas à área da saúde que possam contribuir para os bons trabalhos do CIRADS; e

k) informar ao CIRADS possíveis irregularidades praticadas no âmbito do SUS.

\section{II - DA DPU/RN:}

a) proceder à análise prévia dos casos a serem submetidos ao CIRADS;

b) divulgar as ações do CIRADS no âmbito da DPU;

c) disponibilizar o acesso, através do envio de e-mail para os demais membros, a todos os elementos de fato e de direito colhidos no atendimento ao assistido; e

d) envidar esforços no sentido submeter ao CIRADS, previamente à judicialização, as demandas da saúde.

\section{III - DA PU/RN-AGU:}

a) proceder à análise prévia dos casos submetidos ao CIRADS;

b) divulgar as ações do CIRADS no âmbito da AGU;

c) diligenciar, perante o Ministério da Saúde, no sentido de colher subsídios técnicos acerca dos casos concretos tratados no CIRADS, bem como informações gerais de interesse do CIRADS; e

d) disponibilizar o acesso, através do envio de e-mail para demais membros, a todas as informações obtidas do Ministério da Saúde.
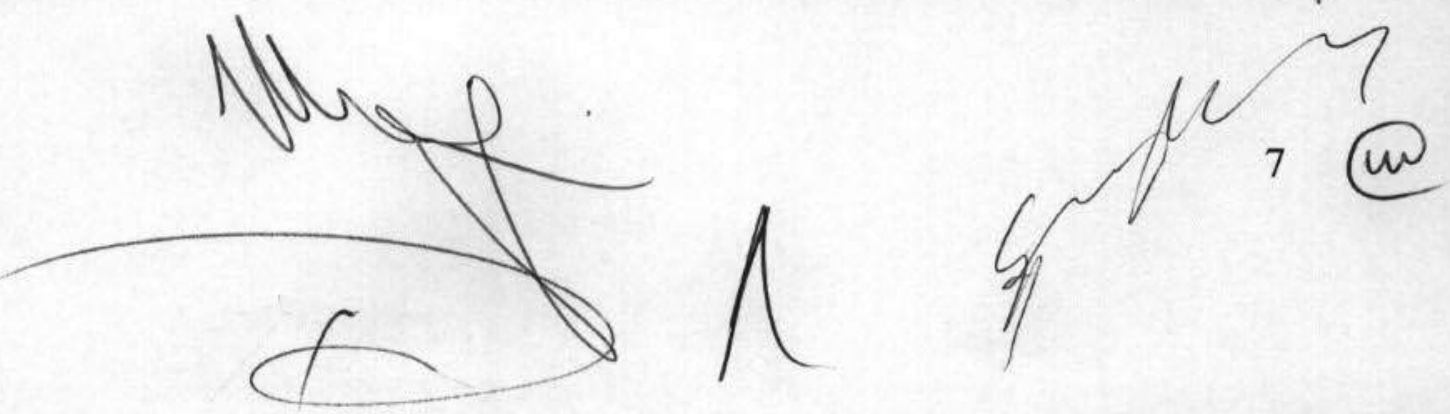


\section{IV - DA PGE/RN:}

a) proceder à análise prévia dos casos submetidos ao CIRADS;

b) divulgar as ações do CIRADS no âmbito da PGE/RN; e

c) disponibilizar o acesso, através do envio de e-mail para os demais membros, a todas as informações referentes aos casos concretos tratados no CIRADS.

\section{V - DA PGMN/RN:}

a) proceder à análise prévia dos casos submetidos ao CIRADS;

b) divulgar as ações do CIRADS no âmbito da PGMN/RN;

c) disponibilizar o acesso, através do envio de e-mail para os demais membros, a todas as informações referentes aos casos concretos tratados no CIRADS; e

\section{VI - DA SESAP/RN:}

a) proceder à análise prévia dos casos submetidos ao CIRADS;

b) divulgar as ações do CIRADS no âmbito da SESAP/RN;

c) disponibilizar o acesso, através do envio de e-mail para os demais membros, a todas as informações referentes aos casos concretos tratados no CIRADS;

d) prestar a assistência técnica necessária ao esclarecimento das dúvidas surgidas; e

e) implementar os compromissos de atendimento ao usuário assumidos no âmbito do CIRADS.
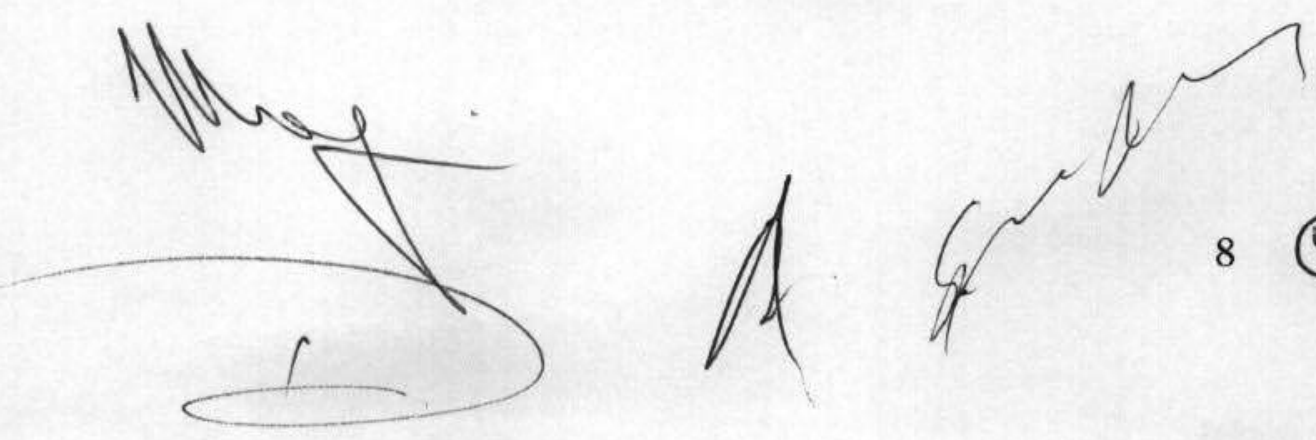


\section{VII - DA SMS/Natal:}

a) proceder à análise prévia dos casos submetidos ao CIRADS;

d) divulgar as ações do CIRADS no âmbito da SMS/Natal;

c) disponibilizar o acesso, através do envio de e-mail para os demais membros, a todas as informações referentes aos casos concretos tratados no CIRADS;

d) prestar a assistência técnica necessária ao esclarecimento das dúvidas surgidas; e

e) implementar os compromissos de atendimento ao usuário assumidos no âmbito do CIRADS.

\section{CLÁUSULA QUINTA - DA OPERACIONALIZAÇÃO}

Este Acordo deverá ser executado fielmente pelos Participantes, de acordo com as cláusulas pactuadas e a legislação pertinente, respondendo cada qual pelas conseqüências de sua inexecução ou execução parcial.

\section{CLÁUSULA SEXTA - DOS RECURSOS}

As atividades objeto deste Acordo não gerarão obrigações de natureza financeira para quaisquer dos Participantes, que se comprometem a arcar, respectivamente, com eventuais custos que advierem de sua execução.
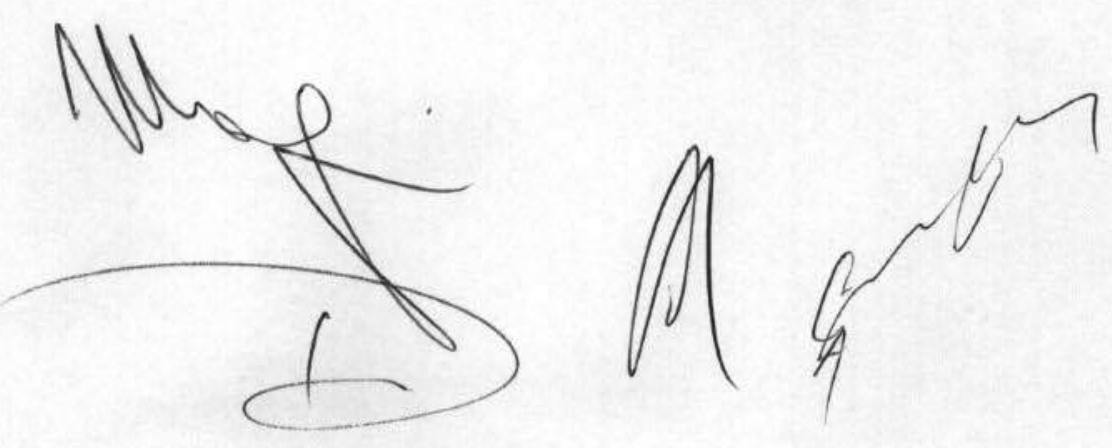


\section{CLÁusula sÉtima - DA ALTERAÇÃo, DA denúNCIA E DA RESCISÃo}

Este Acordo poderá ser alterado, por meio de termo aditivo, ou denunciado por quaisquer dos Participantes, mediante notificação prévia, com antecedência mínima de trinta dias, ou rescindido por descumprimento de quaisquer de suas cláusulas ou por força de norma que o torne inexeqüível.

Parágrafo Único - É permitido o ingresso no CIRADS, por meio de termo aditivo, de novos órgãos públicos com demandas ligadas à área da saúde.

\section{CLÁUSULA OITAVA - DA VIGÊNCIA}

O presente Acordo terá vigência por prazo indeterminado, a contar da data de sua assinatura.

\section{CLÁUSULA NONA - DA PUBLICAÇÃo}

A PU/RN-AGU, a SESAP/RN e a PGMN/RN providenciarão a publicação do extrato correspondente ao presente Acordo, respectivamente, no Diário Oficial da União, no Diário Oficial do Estado do Rio Grande do Norte e no Diário Oficial do Município do Natal, até o quinto dia útil do mês seguinte ao de sua assinatura.

\section{CLÁUSULA DÉCIMA - dOS CASOS OMISSOS}

Os casos omissos serão resolvidos de comum acordo pelos Participantes.

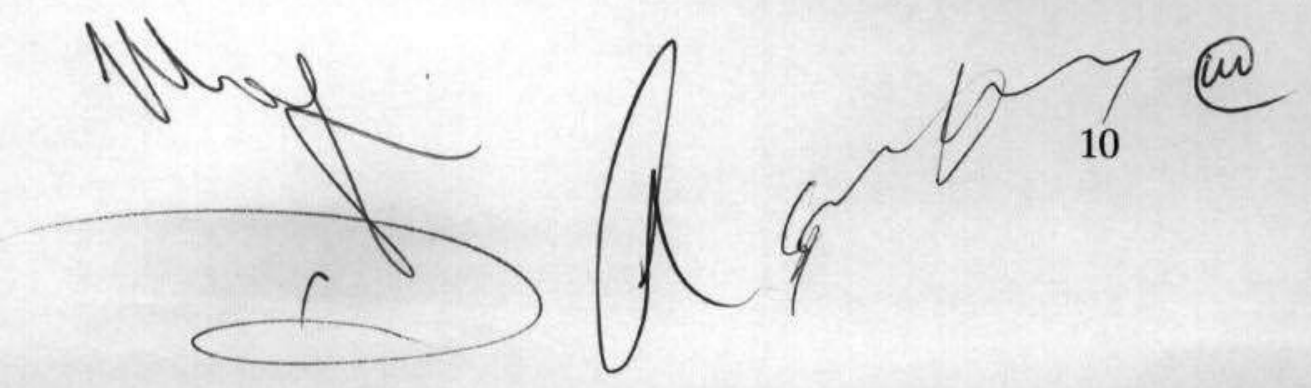




\section{CLÁUSULA DÉCIMA PRIMEIRA - DO FORO}

As questões decorrentes da execução deste Acordo, que não possam ser dirimidas administrativamente, serão processadas e julgadas no Foro da Justiça Federal, Seção Judiciária do Rio Grande do Norte.

E, por estarem os Participantes justos e acordados em suas intenções, firmam, entre si, o presente instrumento, elaborado em 06 (seis) vias de igual teor e forma, na presença das testemunhas abaixo nomeadas.

Natal/RN, 22 de julho de 2009.

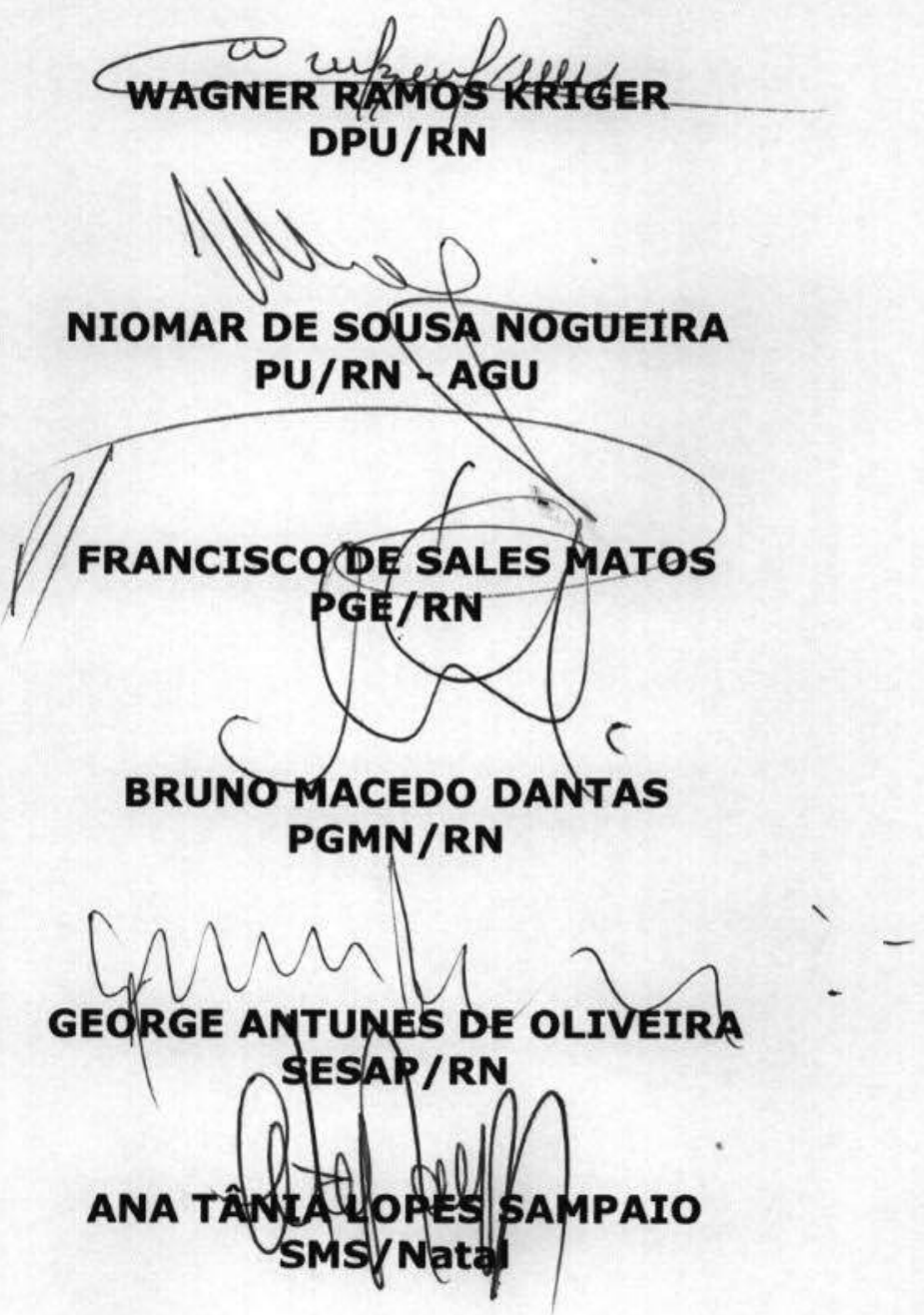




\section{Primeiro Termo Aditivo ao Acordo de}

Cooperação Técnica de 22/07/2009 que, entre si, celebram a Defensoria Pública da União no Estado do Rio Grande do Norte - DPU/RN, a Procuradoria da União no Estado do Rio Grande do Norte - PU/RNAGU, a Procuradoria Geral do Estado do Rio Grande do Norte - PGE/RN, a Procuradoria Geral do Municipio do Natal - PGMN/RN, a Secretaria de Estado da Saúde Pública - SESAP/RN, a Secretaria Municipal de Saúde do Natal - SMS/Natal e a Defensoria Pública do Estado do Rio Grande do Norte - DPE/RN, objetivando a inclusão da Defensoria Pública do Estado do Rio Grande do Norte ao Comitê Interinstitucional de Resolução Administrativa de Demandas da Saúde - CIRADS, que visa solucionar, administrativamente, demandas envolvendo questões de saúde ligadas ao Sistema Único de Saúde - SUS.

\section{A Defensoria Pública da União no Estado do Rio Grande do} Norte, doravante denominada DPU/RN, com sede na Av. Alexandrino de Alencar, 663, Alecrim, Natal/RN, neste ato representada pelo Defensor Público-Chefe Substituto, Dr. JOSÉ ARRUDA DE MIRANDA PINHEIRO; a Procuradoria da União no Estado do Rio Grande do Norte, doravante denominada PU/RN-AGU, com sede na Avenida Brancas Dunas, 565, Ed. Aquarius Center, Candelária, Natal/RN, neste ato representada pelo Procurador-Chefe da União Substituto, Dr. CÁSSIO RÊGO DE CASTRO; a Procuradoria Geral do Estado do Rio Grande do Norte, doravante denominada PGE/RN, com sede na Avenida Afonso Pena, 1155, Tirol, Natal/RN, neste ato representada pelo
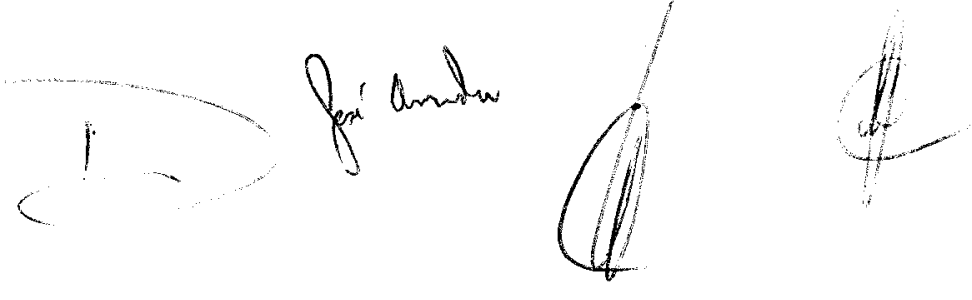
Procurador-Geral do Estado, Dr. LUIZ ANTÔNIO MARINHO; a Procuradoria Geral do Município do Natal/RN, doravante denominada PGMN/RN, com sede na Rua Vigário Bartolomeu, 542, Cidade Alta, Natal/RN, neste ato representada pelo Procurador-Geral do Município do Natal, Dr. BRUNO MACEDO DANTAS; a Secretaria de Estado da Saúde Pública, doravante denominada SESAP/RN, com sede na Avenida Deodoro da Fonseca, 730, $8^{\circ}$ andar, Centro, Natal/RN, neste ato representada pelo Secretário de Estado da Saúde Pública, Dr. GEORGE ANTUNES DE OLIVEIRA; a Secretaria Municipal de Saúde do Natal, doravante denominada SMS/Natal, com sede na Rua João Pessoa, 634, Ed. Ducal, $15^{\circ}$ Andar, Cidade Alta, Natal-RN, neste ato representada pelo Secretário de Saúde do Município do Natal, Dr. THIAGO BARBOSA TRINDADE; e a Defensoria Pública do Estado do Rio Grande do Norte, doravante denominada de DPE/RN, com sede na Avenida Duque de Caxias, com a Rua Tavares de Lima, 102/104, Ribeira, Natal/RN, neste ato representada pelo Defensor Público-Geral do Estado, Dr. PAULO AFONSO LINHARES; considerando o mútuo interesse das partes e, ademais,

Considerando o disposto no Parágrafo Único da Cláusula Sétima do Acordo de Cooperação Técnica de 22/07/2009, doravante denominado de ACORDO; e

Considerando a necessidade de ampliar o acesso dos cidadãos ao Comitê Interinstitucional de Resolução Administrativa de Demandas da Saúde - CIRADS,

RESOLVEM celebrar o presente PRIMEIRO TERMO ADITIVO AO ACORDO DE COOPERAÇÃO TÉCNICA DE 22/07/2009, doravante denominado PRIMEIRO TERMO ADITIVO AO ACORDO, elaborado em conformidade com o art. 116 da Lei 8.666, de 21 de junho de 1993, el legislação correlata, de acordo com as cláusulas e condições a seguir:
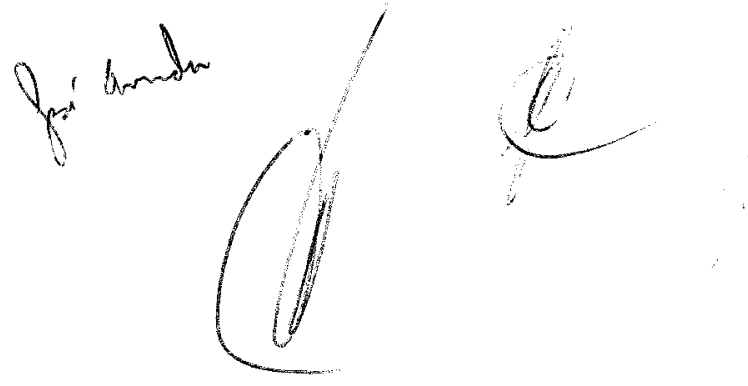


\section{CLÁUSULA PRIMEIRA - DO OBJETO}

O presente PRIMEITO TERMO ADITIVO AO ACORDO tem por objeto a inclusão da DPE/RN na parceria já existente entre a DPU/RN, a PU/RN-AGU, a PGE/RN, a PGMN/RN, a SESAP/RN, e a SMS/Natal, que constituiu o Comitê Interinstitucional de Resolução Administrativa de Demandas da Saúde - CIRADS, doravante denominado de CIRADS, com os objetivos previstos na Cláusula Primeira do Acordo de Cooperação Técnica de 22/77/2009, promovendo as alterações nas Cláusulas do referido ACORDO, na forma abaixo:

\section{CLÁUSULA SEGUNDA - DA ALTERAÇÃo DA CLÁUSULA PRIMEIRA}

O "caput" e o Parágrafo Primeiro da Cláusula Primeira - Do objeto - referente ao ACORDO são alterados, ficando com a redação abaixo transcrita:

"O presente ACORDO tem por objeto o estabelecimento de parceria entre a DPU/RN, a PU/RN-AGU, a PGE/RN, a PGMN/RN, a SESAP/RN, a SMS/Natal, e a DPE/RN, para análise, por meio do Comitê Interinstitucional de Resolução Administrativa de Demandas da Saúde - CIRADS, ora constituído, doravante denominado de CIRADS, dos casos concretos em que o assistido pelo Sistema Único de Saúde (SUS) não tenha recebido o devido atendimento pelo referido sistema, a fim de identificar tanto os casos em que o pleito pode ser atendido administrativamente, evitando a sua judicialização, quanto aqueles em que se pode obter conciliação em ações judiciais já em curso, nas hipóteses em que o tratamento dę saúde (fornecimento de medicamentos, insumos, materiais e serviços de

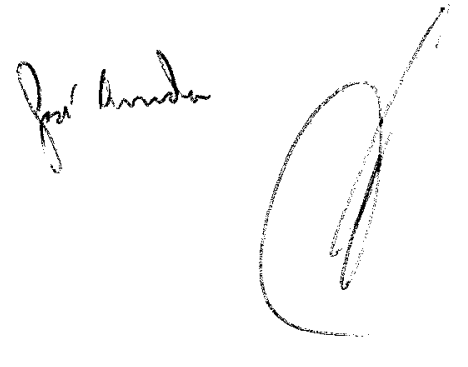


saúde) esteja previsto no âmbito do SUS e não tenha sido prestado, bem como naquelas hipóteses em que, por algum motivo, o médico indicou tratamento diverso dos que são oferecidos pelo SUS.

Parágrafo Primeiro - O CIRADS será composto por Defensores Públicos da União, Advogados da União, Procuradores do Estado do Rio Grande do Norte, Procuradores do Município do Natal/RN, servidores públicos da Secretaria de Estado da Saúde Pública, servidores públicos da Secretaria Municipal de Saúde do Natal/RN e por Defensores Públicos do Estado do Rio Grande do Norte, designados pelas respectivas autoridades competentes, sendo um titular e, no mínimo, dois suplentes por órgão público.

\section{$(\ldots)$.}

\section{CLÁUSULA TERCEIRA - DA ALTERAÇÃO DA CLÁUSULA SEGUNDA}

Os Parágrafos Primeiro, Segundo, Quarto e Quinto da Cláusula Segunda - Da Execução - referente ao ACORDO são alterados, ficando com a redação abaixo transcrita:

"Parágrafo Primeiro - Serão submetidos ao CIRADS os casos em que a DPU/RN ou a DPE/RN, ao realizar a prestação de assistência jurídica ao cidadão, constatar a possibilidade de ter havido falha na prestação do serviço de saúde, por não ter sido oferecido o tratamento de saúde previsto no âmbito do SUS, bem como nas hipóteses em que/o médico tiver indicado tratamento diverso daqueles oferecidos pelo SUS.
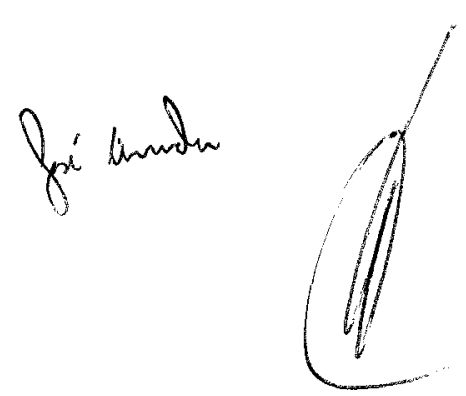
Parágrafo Segundo - O Defensor Público da União ou o Defensor Público do Estado do Rio Grande do Norte exporá as razões fáticas e jurídicas pelas quais considera que a negativa na prestação do tratamento de saúde deveria ser revista e, em seguida, os demais participantes do CIRADS terão a palavra para pronunciamento.

\section{(...).}

Parágrafo Quarto - A fim de otimizar o funcionamento do CIRADS, a DPU/RN ou a DPE/RN deverá enviar, imediatamente ao atendimento jurídico ao assistido, para o e-mail dos demais membros do CIRADS, todos os elementos de fato e de direito relativos ao caso específico, especialmente o receituário médico e os exames de que disponha.

Parágrafo Quinto - A DPU/RN ou a DPE/RN poderá enviar questionário, aprovado pelo CIRADS, ao médico que prescreveu o tratamento, o qual, após, respondido, deverá ser submetido ao CIRADS, para apreciação e deliberação sobre a viabilidade de atendimento.

\section{(..)."}

\section{CLÁUSULA QUARTA - DO ACRÉSCIMO À CLAÚSULA QUARTA}

A Cláusula Quarta - Das Obrigações dos Plarticipantes - referente ao ACORDO é acrescida do item VIII, abaixo:
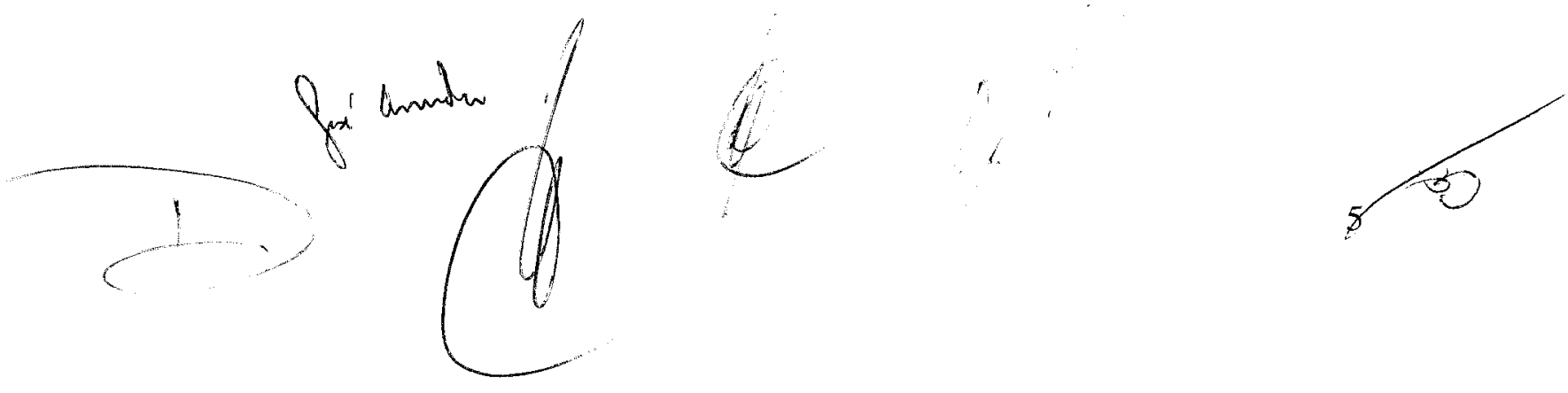


\section{"VIII - DA DPE/RN:}

a) proceder à análise prévia dos casos a serem submetidos ao CIRADS;

b) divulgar as ações do CIRADS no âmbito da DPE/RN;

c) disponibilizar o acesso, através do envio de e-mail para os demais membros, a todos os elementos de fato e de direito colhidos no atendimento ao assistido; e

d) envidar esforços no sentido submeter ao CIRADS, previamente à judicialização, as demandas da saúde."

\section{CLÁUSULA QUINTA - DA RATIFICAÇÃO}

Ficam ratificadas todas as demais Cláusulas e condições pactuadas no ACORDO, que não tenham sido atingidas pelo presente PRIMEIRO TERMO ADITIVO AO ACORDO.

\section{CLÁUSULA SEXTA - DA PUBLICAÇÃo}

A PU/RN-AGU, a SESAP/RN e a PGMN/RN providenciarão a publicação do extrato correspondente ao presente PRIMEIRO TERMO ADITIVO AO ACORDO, respectivamente, no Diário Oficial da União, no Diário Oficial do Estado do Rio Grande do Norte e no Diário Oficial do Município do Natal, faté o quinto dia útil do mês seguinte ao de sua assinatura.

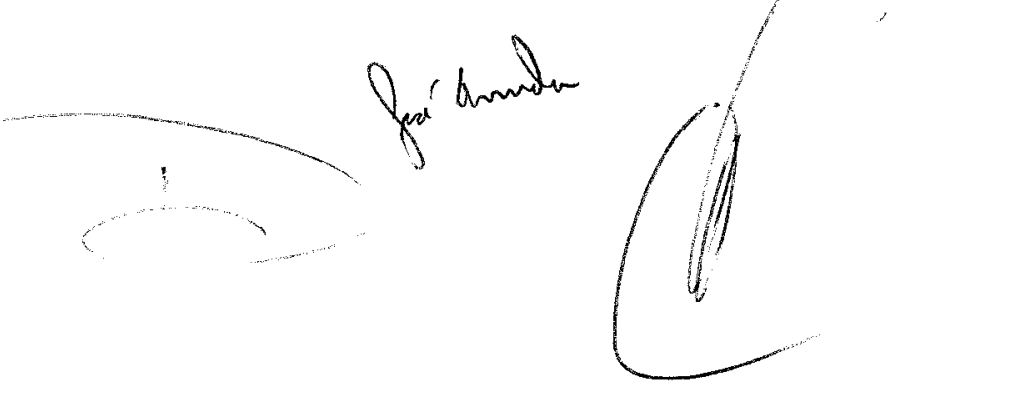


$E$, por estarem os Participantes justos e acordados em suas intenções, firmam, entre si, o presente instrumento, elaborado em 07 (sete) vias de igual teor e forma, na presença das testemunhas abaixo nomeadas.

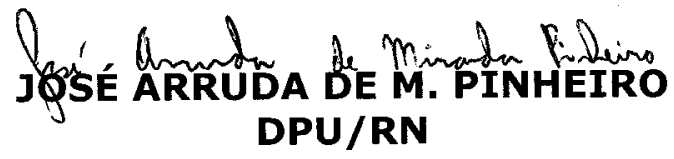
DPU/RN
Natal/RN, 26 de julho de 2010.

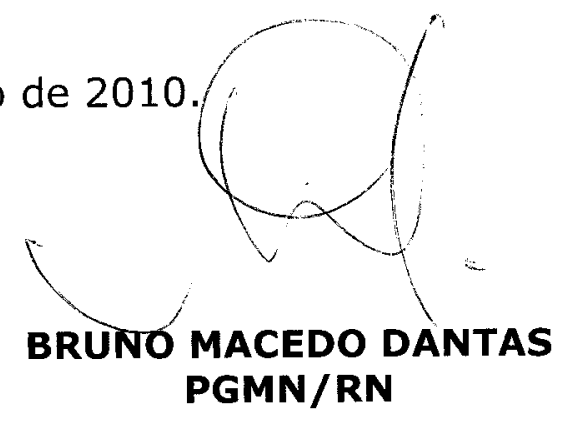

GEORGE ANTUNES DE OLIVEIRA SESAP/RN

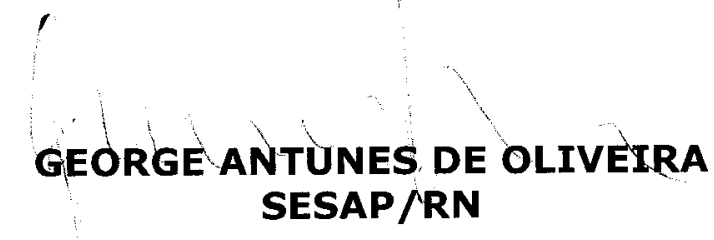

Testemunhas:

01)

CPF:

02)

CPF: 


\title{
CIRADS
}

Comitê Interinstitucional de Resolução Administrativa de Demandas da Saúde

\author{
ATA DA $19^{a}$ REUNIÃO DO COMITÊ INTERINSTITUCIONAL DE \\ RESOLUÇÃO ADMINISTRATIVA DE DEMANDAS DA SAÚDE - CIRADS
}

Aos 15 (quinze) dias do mês de setembro de dois mil e dez, na sede da Procuradoria da União no Estado do Rio Grande do Norte, foi realizada a $19^{\mathrm{a}}$ reunião do Comitê Interinstitucional de Resolução Administrativa de Demandas da Saúde - CIRADS, com a participação do Advogado da União Thiago Pereira Pinheiro; da Diretora da UNICAT Dra. Maria José de Souza Pieretti; da Defensora Pública Federal Elisângela Santos de Moura; das Defensoras Públicas do Estado Cláudia Carvalho Queiroz e Fabrícia Conceição Gomes Gaudêncio, do Procurador do Município do Natal/RN Erick Alves Pessôa; da representante do Setor de Demandas Judiciais da Secretaria Estadual de Saúde Dra. Larissa Dantas de Carvalho; da representante da SMS/NatalDRAC Dra. Mônica Nunes de Miranda Collier; das responsáveis pelo Setor de Assistência Farmacêutica da SMS/Natal Dra. Carla Regina de Farias e Dra. Leila Costa de Queiroz Cavalcanti dos Anjos. ITENS DA PAUTA: 1) aprovaçãe da ata da $18^{a}$ reunião do CIRADS; 2) análise dos casos já encaminhados ao CIRADS; 3) outros assuntos levados ao CIRADS pelos demais integrantes. DELIBERAÇÕES: 1) aprovada a ata da $18^{\mathrm{a}}$ reunião do CIRADS; 2) S.K.F.B. - FRALDAS DESCARTÁVEIS - a SMS-Natal havia informado que poderia fornecer as fraldas descartáveis tamanho P. A DPE-RN irá verificar com a assistida a situação do cumprimento da decisão judicial e enviará uma resposta para o CIRADSGRUPOS sobre a possibilidade de acordo; E.B.S. - VITRECTOMIA - o caso foi solucionado judicialmente; S.L.P.S. - RESSECÇÃO DE VALVULA URETRAL POSTERIOR - o caso foi solucionado judicialmente. A SMS/Natal-DRAC irá informar qual o equipamento necessário para a realização desta cirurgia; J.M.O. URETROTOMIA INTERNA - o paciente está aguardando a realização da cirurgia no Hospital Universitário Dr. Onofre Lopes. A DPU/RN solicitou que o Diretor do HOUL seja oficiado para esclarecer o motivo da demora na realização das cirurgias de URETROTOMIA INTERNA; M.G.M.P. - BOTTON DE SILICONE - o SUS não oferece este produto que é importado dos Estados Unidos da América; S.N.S. BRONCOFIBROSCOPIA - a SMS/NATAL-DRAC informou que o exame é realizado no Hospital Universitário Dr. Onofre Lopes, porém, há necessidade da
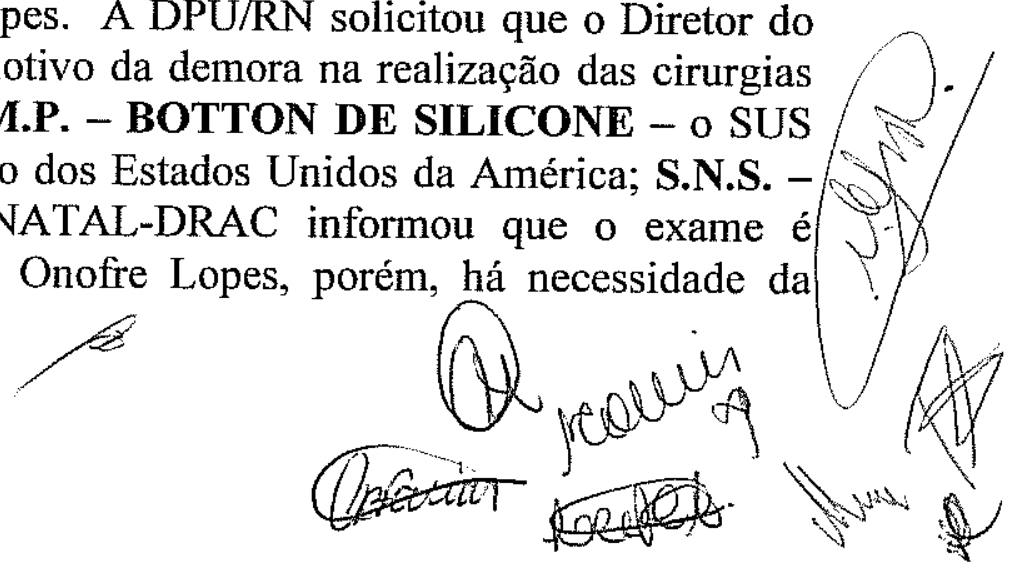
aquisição de uma pinça especial para a realização do referido exame. O Coordenador do CIRADS irá oficiar o Diretor do HUOL acerca da solução do problema. A SESAP/RN irá verificar a possibilidade de realizar o exame na rede pública estadual, de forma que no prazo de 05 (cinco) dias úteis dará uma resposta por meio do CIRADSGRUPOS; H.P.A.O. - EXAME DE ENDOSCOPIA POR VIDEOCÁPSULA - o exame é novo e não é realizado pelo SUS, de forma que o feito foi judicializado e será retirado do CIRADS; R.R.P. - REVASCULARIZAÇÃo DISTAL NO MEMBRO INFERIOR - a SESAP/RN irá verificar como está o andamento da realização destas cirurgias e encaminhará uma resposta sobre o caso específico ao CIRADSGRUPOS no prazo de 05 (cinco) dias úteis; E.V.L. QUESTRAN LIGHT EM PÓ - a UNICAT informou que este medicamento não está disponibilizado nos programas de Assistência Farmacêutica do SUS; A.C.F. ESTUDO DE DNA - este exame ainda não é realizado na rede local de saúde; M.L.V.C. - DUO TRAVATAN - a Assistência Farmacêutica da SMS-Natal informou que o medicamento está em processo de compra e há uma previsão, segundo o Setor de Compras, que o mesmo seja disponiblizado na rede num prazo de 07 (sete) dias úteis. Assim que a medicação estiver disponivel será enviado um aviso para o CIRADSGRUPOS; J.A.C.F. - VITRECTOMIA - o assistido está aguardando a cirurgia no Hospital Universitário Dr. Onofre Lopes; M.E.L.F. CLORIDRATO DE DONEPEZILA - a UNICAT forneceu o medicamento ao assistido (CASO SOLUCIONADO); A.R.B. - AMIODARONA e SINVASTATINA - a Assistência Farmacêutica da SMS/Natal informou que o medicamento SINVASTATINA está disponível na rede municipal de saúde e será fornecido ao assistido no PROSUS, em quantidade suficiente por 06 (seis) meses. O Setor de Assistência Farmacêutica da SMS-Natal irá verificar se o medicamento AMIODARONA está disponível para dispensação na rede municipal de saúde, de forma que encaminhará uma resposta no prazo de 05 (cinco) dias úteis para o CIRADSGRUPOS (CASO PARCIALMENTE SOLUCIONADO); J.U.S. RESSONÂNCIA MAGNÉTICA, RADIOTERAPIA E ACETATO DE CIPROTERONA - a DPU/RN informou que houve uma alteração no tratamento e o assistido está sendo atendido pela LIGA NORTE-RIOGRANDENSE CONTRA O CÂNCER. A UNICAT fornece o ACETATO DE CIPROTERONA para o tratamento de HIRSUTISMO (CASO SOLUCIONADO); 3) a DPU/RN solicitou que se formasse um Grupo de Trabalho para discutir a implantação de uma Política Estadual de Nutrição (dietas especiais); a Dra. Maria José de Souza Pieretti (coordenadora), a Dra. Federal Elisângela Santos de Moura, a Dra. Cláudia Carvalho Queiroz, Dra. Larissa Dantas de Carvalho e a Dra. Mônica Nunes de Miranda Collier irão contactar profissionais para discutir o assunto em uma reunião específica do CIRADS para formar um grupo de técnicos com objetivo de fomentar esta Política Pública Estadual de Nutrição; a DPU/RN solicitou que os membros do CIRADS fizessem uma vistoria no HOUL para verificar como está o funcionamento das cirurgias de VITRECTOMIA; o Coordenador do CIRADS irá agendar a visita com o Diretor do HUOL, bem como irá agendar uma reunião específica para tratar deste assunto com o Diretor do HUOL e os Secretários de Saúde do Estado e do Município do Natal; a DPE/RN solicitou que as respostas no CIRADSGRUPOS fossem enviadas no prazo máximo de 05 (cinco) dias úteis; a próxima reunião do CIRADS ficou marcada para o 
dia 06/10/2010, às 14h30min, na sede da PURN-AGU. Nada mais havendo a tratar, deu-se por encerrada a presente reunião.

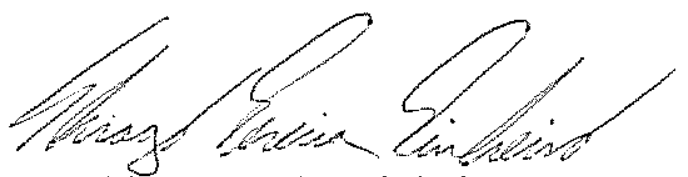

Thiago Pereira Pinheiro

Advogado da União

Coordenador do CIRADS

Parlar Regina de facias

Carla Regina de Farias

Responsável pelo Setor de Assistência

Farmacêutica da SMS/Natal

Sulvacotadeb.e. Aujos Leila Costa de Queiroz C. dos Anjos Representante do Setor de Assistência

Farmacêutica da SMS/Natal

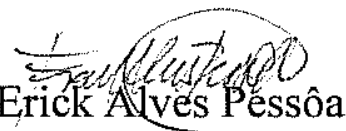

Procurador do Municipio do Natal

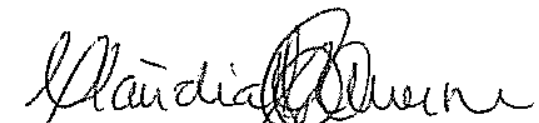

Cláudia Caryahno Queiroz

Defensora Pública do Estado

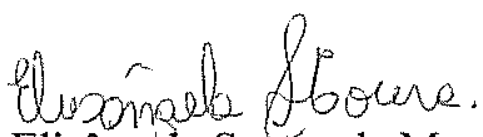

Elisângela Santós de Moura

Defensora Pública Federal
Fabricia Conceição Gomes Gaudêncio

Defensora Pública do Estado

Hónica) dest Coelleir

Mônica Nunes de Miranda Collier Representante da SMS/Natal-DRAC

loaviss santos de candle Larissa Dantas de Carvalho Representante do Setor de Demandas Judiciais da SESAP/RN 


\section{CIRADS}

\section{Comitê Interinstitucional de Resolução Administrativa de Demandas da Saúde}

\section{ATA DA $15^{a}$ REUNIÃO DO COMITÊ INTERINSTITUCIONAL DE RESOLUÇÃO ADMINISTRATIVA DE DEMANDAS DA SAÚDE - CIRADS}

Aos 11 (onze) dias do mês de maio de dois mil e dez, na sede da Procuradoria da União no Estado do Rio Grande do Norte, foi realizada, em caráter extraordinário, a $15^{\text {a }}$ reunião do Comitê Interinstitucional de Resolução Administrativa de Demandas da Saúde - CIRADS, com a participação do Advogado da União Francisco Livanildo da Silva, da Defensora Pública da Uniāo Elisângela Santos de Moura, das representantes da SMS/Natal-DRAC Dra. Maria da Saudade de Azevedo e Dra. Mônica Nunes de Miranda Collier, do responsável pelo Setor de Demandas Judiciais da SESAP/RN Dr. Sidney Domingos de Souza, além da participação, em caráter especial, do Secretário Adjunto de Estado da Saúde Pública Dr. José Fernandes Neto, e, como convidados, da Dr $^{\mathrm{i}}$. Lana do Monte Paula Brasil, Diretora-Geral do Hospital Pediátrico Maria Alice Fernandes, da Dr ${ }^{a}$ Agueda Maria Trindade, Diretora Técnica do Hospital Infantil Varela Santiago, Simone Maria da Rocha, mestranda da UFRN e pesquisadora na área de pedagogia, além de outras pessoas ligadas ao assunto que acompanharam as autoridades de saúde e educação presentes, objetivando discutir a implantação do Projeto "Classe Hospitalar" no Estado do Rio Grande do Norte:

Aberta a reuniáo pelo Advogado da União Francisco Livanildo da Silva, representante da Procuradoria da Uniāo no CIRADS, este fez uma sucinta explanação acerca do CIRADS, destacando seus objetivos na área da conciliação administrativa em torno da saúde pública e, em seguida, esclareceu que a representante da Defensoria Pública da União no Rio Grande do Norte no CIRADS, Dr ${ }^{\text {a }}$ Elisângela Santos de Moura, havia trazido ao comitê o Projeto "Classe Hospitalar", que consiste na instalação de salas de aula vinculadas à rede de ensino público em hospitais públicos ou conveniados ao SUS, que abriguem crianças internadas para tratamento médico, de forma que estas possam recuperar a sua saúde sem prejuízo do ensino regular, solicitando apoio para a sua oficial implementação, inicialmente, no Hospital Infantil Varela Santiago. Eis o motivo desta reuniäo específica.

Na ocasião, as pedagogas Simone Rocha e Christianne Néry realizaram uma explanação sobre a equipe pedagógica do Hospital Infantil Varela, o qual possui um trabalho de acompanhamento pedagógico às crianças internadas naquele nosocômio, porém sem qualquer reconhecimento pelo sistema de ensino oficial. Ressaltou-se que a implantação da denominada "Classe Hospitalar", além de ser um direito constitucionalmente assegurado pelo artigo 205 da Constituição Federal de 1988, foi regulamentada pela Resolução $\mathrm{CNE} / \mathrm{CEB}$ n. ${ }^{\circ}$ 02/2001, da Câmara de Educação Básica do Conselho Nacional de Educação, e pela Resolução n. ${ }^{\circ}$ 01/2003, do Conselho Estadual de Educação/RN.

Em seguida, a $\operatorname{Dr}^{\mathrm{a}}$ Agueda falou sobre a importância e os efeitos benéficos às crianças internadas no Hospital Infantil Varela Santiago após a implantação do trabalho desenvolvido pelas pedagogas acima referidas. No seu ver, 
quando possuem acompanhamento escolar, as crianças sentem-se mais motivadas para o tratamento de saúde, inclusive, com enorme expectativa quando se aproxima o horário marcado para as aulas.

Logo após, a Drit Lana Brasil expôs que a direçāo do Hospital Pediátrico Maria Alice Fernandes sempre teve interesse em desenvolver um trabalho voltado para a educação dos pacientes ali internados. Segunda ela, procurou-se a Secretaria de Educaçăo do Estado, nāo tido obtido êxito, contudo. Ressaltou-se haver interesse da direçāo do hospital em apoiar a implantação do Projeto "Classe Hospitalar" naquele nosocômio.

Assim, após as discussōes sobre o tema, foi aceita a proposta do CIRADS de formação de um Grupo de Trabalho composto por representantes das Secretarias Estaduais e Municipais de Saúde e Educaçāo, da Direçăo dos Hospitais Infantis Varela Santiago e Maria Alice Fernandes, da PURN-AGU e da DPU/RN, que contará com a colaboração das pedagogas Simone Rocha e Christianne Nery, para, inicialmente, oficializar a "Classe Hospitalar" já existente no Hospital Infantil Varela Santiago e implantar a "Classe Hospitalar" no Hospital Maria Alice Fernandes, ambos nesta Capital. Cada órgão presente comprometeu-se a indicar o nome de um ou mais membros para compor o Grupo de Trabalho. Assim, após a indicaçāo dos nomes, o Coordenador do CIRADS convocará a todos para a primeira reunião com o grupo constituído.

Nada mais havendo a tratar, deu-se por encerrada a presente reunião.

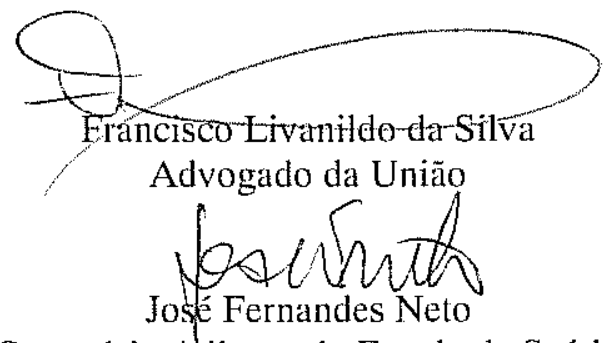

Secretário Adjunto do Estado da Saúde Pública

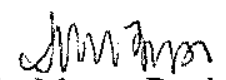

Lana do Monte Paula Brasil

Diretora-Geral do Hospital Pediátrico Marial Alice Fernandes

Simone Maria der Rocha

Mestranda da UFRN

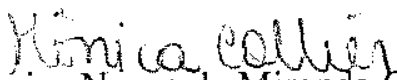

Mônica Nunes de Miranda Collier Representante da SMS/Natal-DRAC

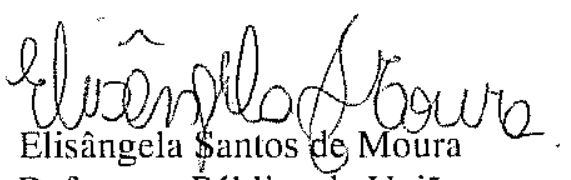

Defensora Pública da União

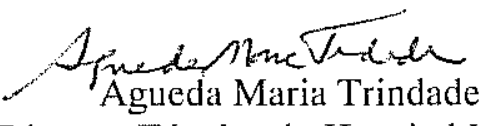

Diretora Técnica do Hospital Infantil Varela Santiago

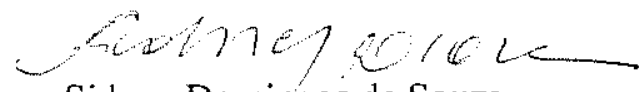

Sidney Domingos de Souza

Responsável pelo Setor de Demandas Judiciais da SESAP/RN

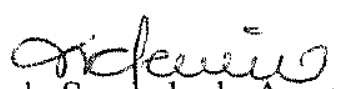

Maria da Saudade de Azevedo Representante da SMS/Natal-DRAC 


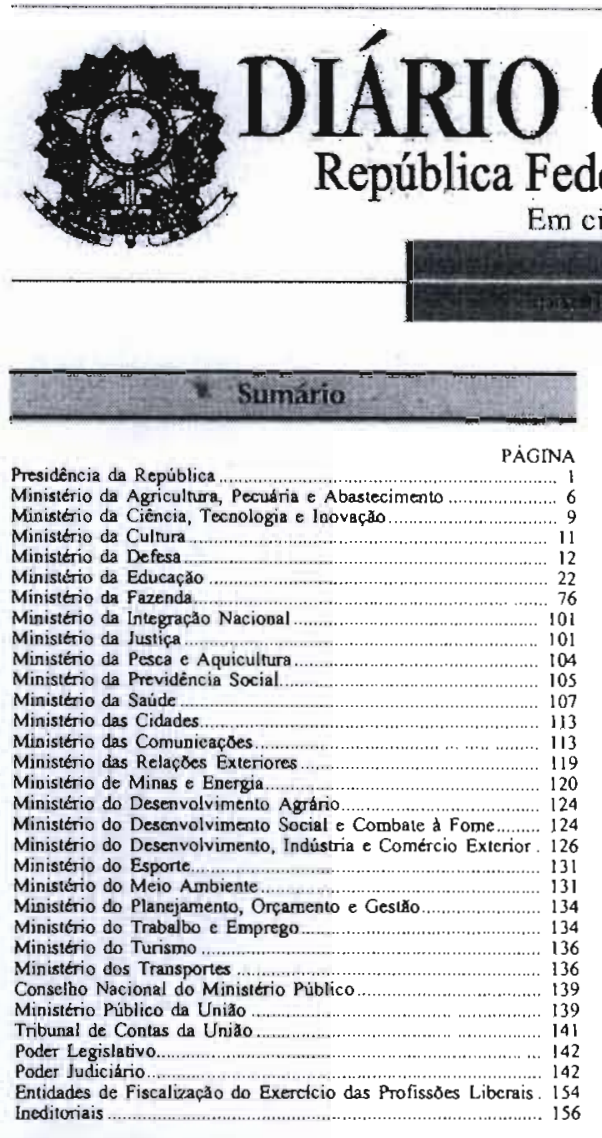

Presidencía da Republica.

SECRETARIA-GERAL

SECRETARIA EXECUTTVA

SECRETARLA DE AOMINISTRAÇÄO

EXTRATO DE TERMO ADITIVO N* 2/2012 - UASG 110001

Número do Contrato: 111/2010. No Processo: 00140000110201057. NEXIGLBCDDADE N $N^{\circ} 8 / 2010$ Contratante: PRESIDENCLA DA REPUBLLICA -CNPJ Contratado: 00082024000137. Contratado : COMPANHLA DE SANEAMENTO AMBIENTAL DO DISTRTTO FEDERAL. Objeto: Prorrogaçăo do prazo de vigencía ale 25 de maio de 2013. Fundamento Legal: Inciso II do art. 57 da Lei n" 8.666/93. Vigência: 25/05/2012 a 25/05/2013. Data de Assinatura $21 / 03 / 2012$

(SICON - 22/03/2012) 110001-00001-2012NE800014

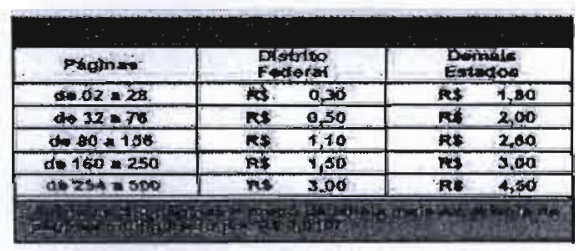

OFICIAL DA UNIÃO

Federativa do Brasil - Imprensa
Em circulação desde $1^{\circ}$ de outubro de 1862

\section{coz de mavo} GABINETE DE SEGURANÇA INSTITUCIONAL

\author{
AVISO DE REVUGACÁ̃O
}

Fica revogada a lıcilaçăo supracitada, seferente ao processo $N^{\circ} 00044000386201112$. Objeto: Pregðo Elerrónico-Seleça c c contrataça de empresa para prestaça dos servicos de suporte técnico na siçăa subscriçóses de licenças do software Red Hal Enterprise Linux Server, para servidores.

$$
\text { MARIA DE FATISAR CAMPOS OLIVEHRA }
$$

(STDEC - 22/03/2012) 110001-00001-2012NE800014

ADVOCACIA-GERAL DA UNIÃO

ESCOLA DA ADVOCACLA-GERAL DA UNLÃO VICTOR NUINES LEAL

EXTRATO DE CONTRATO N: $13 / 2012$ - IAASG 110156

No PTocesso: 00590001478201115. DISPENSA No 1/2012 Conm tante: ADVOCACIA GERAL DA UNIAO -CNPJ Contratado 00114090000141 . Contratado : CONSELHO CULTURAL THOMAS JEFFERSON Objeto: Contrataça de cmpresa especializada para for capacilaça de 200 (duzentos) servidorcs e membros da AdvocaciGeral da Uniðo. Fundamento Legal: Lei $\pi^{\circ} 8666 / 93$. Vigéncia 12/03/2012 a 11/03/2013. Valor Tolal: RS236.000,00. Fone: $100000000-2012$ NE800019 Fonte: $100000000-2012$ NE80002

(SICON - 22/03/2012) 110161-0000!-2012NE800691

SECRETARIA-GERAL DE ADMINISTRAÇÃO

$$
\begin{gathered}
\text { EXTRATO DE INEXIGIBILIDADE DE LICITACAOO } \\
N^{\circ} \text { YIZOI2 - UASG } 110156
\end{gathered}
$$

No Processo: 00590000135201214 Objeto: Paricipaçăo de servi dores e membros das Carciras Juridicas no Seminário Nacional sob
Obras e Servicos de Engenharia do Plancjamento e Julgamento Licitaçăo até a Fiscalização dos Contratos. Tolal de ltens Licitados 00001 . Fundamento Legal: Art. 25 . Inciso II da Lei $n^{\circ} 8.666 \mathrm{~d}$ 21/06/1993. Justificativa: Capacitaçà de servidores Declaraça â Inexigibilidade en 22/03/2012. JULLANA SAHIONE MAYRINK NEIVA. Direlora da Escola da Advocacia-geral da Uniajo. Ra

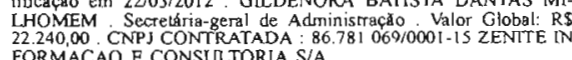

(SIDEC - 22/03/2012) 11016I-00001-2012NE800691

DIRETORLA DE GESTÃO DE PESSOAS

SUPERINTENDÊNCIA DE ADMINISTRACÃO NO DISTRTTO FEDERAL

EXTRATO DE ACURDO DE COOPERAÇOO TECNICA

Espécie: Acordo de Cooperaça to Técnica que entre sı celebram ADVOCACIA-GERAL DA UNIĀO (AGU), O MONISTERTO DA SAUDE (MS), o MINISTERIO DA JUSTICA (M), por intermédio da Secretaria de Reforma do Judiciáno e da Defensonia Pública DE (CONASS) E O CONSELHO NACIONAL DE SECRETARLOS MUNICIPAIS DE SAUDE (CONASEMS). Objeto: O presenie ACORDO tem por objeto o estabelecimento de parceria entre a AGU MS, O MJ, por inlermédio da DPU e da Secretaria de Reforma do Judiciano, CONASS $e$ o CONASEMS, por mero de junçáo de saúde com a busca de alternativas de resoluçes de conflitos tanto judiciais, como extrajudiciais, que envolvem o Sistems Único de
Saude - SuS. Vigencia: 09/11/2011 a 08/11/2013 Data da assinalura

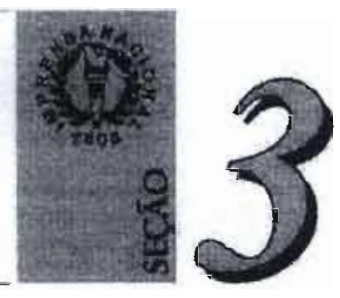

12

09/11/2011. Assinam: LUIS DNACIO LUCENA ADAMS - Advo gado-Geral da Uniăo, ALEXANDRE ROCHA SANTOS PADILHA Minisiro de Estado da Saude, JOSE EDUARDO CARDOSO - M Mistro dc Eslado da Justica, MARCELO VIELRA DE CAMPOS DE MORAES E CORDOVA - Defensor Püblico-Geral Fuderal, BEA TRIZ FICLEIREDO DOBASHI - Presidente do Consclho Nacion de Secrét́rios de Saude e ANTOONIO CARLOS FIGUEIREDO NARDl - Presidente do Conselho Nacional de Secretários Municipais de Saúde.

EXTRATO DE. TERMO ADITIVO N ${ }^{\circ}$ 32012 - UASS, 110061 Numcro do Conirato: 00001/2009, subrogado pelaUASG: 110061 COORDENACAO-GERAL DE SERVCOS

DISPENSA No $11 / 2009$ Contralante: ADVOCACIA GERAL DA INTA -CPF Contratado. 12301213234. Contralado. MARIA ISA BEL. DA SILVA PIRES SOARESObjeto: Promogar o prazo de vigencis por mais 12 (doze) meses. Fundamento Legal: Lei $8.666 / 93$ Vigèncla: $12 / 03 / 2012$ a 11/03/2013. Valor Total: R\$282.234,84. For te: 100000000 - 2012NE800183. Data de Assinatura: 11/03/2012.

(SICON - 22/03/2012) 110161-00001-2012NE800691 AVISO DE, REVOGACAO DISPENSA DE LICITAC ÄO N $\mathbf{N}^{n} 19 / 2012$

Fica revogada a Dispensa de Licitaça supra citada referenle ao processo $N^{\mathrm{N}} 004280017522011$

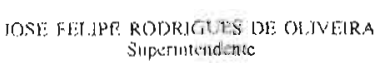

(SIDEC - 22203/2012) 110161-00001-2012NE800691

SUPERINTENDÊNCLA DE ADMINISTRAC̄̃̃O EM SÃO PAULO

EXTRATU DE CONTRATO Nं $1 / 2012$ - U/ASG 11009

No Processo: 00589000026201236. PREGÃO SISPP N' 20/2011 Conratante: SUPPERNTENDENCIA DE ADMINISTRACĀO NO ESTADO DE SAO PAULO CNPJ Conlra!ado: 71208516000174. Conralado: COMPANHIA DE TELECOMUNICAÇOES DO BRASIL CENTRAL. Objeto. Contrataçà de pessoa juridica para prestaçâo de
Scrviços Telefónico Fixa-Comutado nas modalidades Longa Distância Nacional - LDN com ligaçdes fixo-fixo (D1, D2, D3 e D4) e fixomovel (VC2 e VC3) Fundarnento Legal: Lei $8666 / 93$ e demais legislaçà correlata. Vigencia. I2/03/2012 a 1203/2013. Valor Total: นนra: $12 / 03 / 2012$.

(SICON - 22/03/2012) 110061-00001-2012NE800691

\section{SECRETARLA DE POLÍTICAS} PARA AS MULHERES

EXIRATO DE CONTHATO N" G/2012 - UASC; 201021

No Processo: 00036000206201274. DISPENSA No 3/2012 Contratante: SECRETARIA DE POLITICAS PARA AS MULHERES

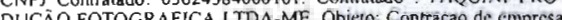
De serviros de rolografia com producoo folografica te digual das fetos produzidas, com boa execucaodas fotos contratadas, segundo bricfing as-5escoria de comunicacao e com a presenca do segundo bricfing da as-sessoria de comunicacao e com a presenca do gência: 20/03/2012 a 20/04/2012. Valor Total: R\$2 300,00. Fontc: 100000000 - 2012NE800031. Data de Assinatura: 20/03/2012. (SICON - 22/03/2012) 


\section{ACORDO DE COOPERAÇÃO TÉCNICA}

Acordo de Cooperação Técnica que, entre si, celebram a Advocacia-Geral da União (AGU), o Ministério da Saúde (MS), o Ministério da Justiça (MJ), por intermédio da Secretaria de Reforma do Judiciário e da Defensoria Pública da União, o Conselho Nacional de Secretários de Saúde (CONASS) e o Conselho Nacional de Secretários Municipais de Saúde (CONASEMS), com o objetivo de fomentar a solução administrativa de demandas de saúde envolvendo o Sistema Único de Saúde (SUS).

A ADVOCACIA-GERAL DA UNIÃO, inscrita no CNPJ/MF sob o nº 00394411000885 , com sede no Setor de Autarquia Sul, Quadra 3, Lote 5/6, Ed. Multi Brasil Corporate, Brasília-DF, CEP 70.610-460, doravante denominada AGU, neste ato, representada por seu titular, o Advogado-Geral da União LUIIS INÁCIO ADAMS, CPF n 465.336.800-72 o MINISTÉRIO DA SAÚDE, inscrito no CNPJ/MF sob o no 00.394.544/0002-66, situado na Esplanada dos Ministérios, Bloco "G", CEP. 70.058-901, Brasília-DF, doravante denominado MS, representado neste ato por seu titular, Ministro ALEXANDRE ROCHA SANTOS PADILHA, CPF nº 131.926.798-08, o MINISTÉRIO DA JUSTIÇA, inscrito no CNPJ/MF sob o nํ 00394494/0072-20, situado na Esplanada dos Ministérios, Bloco "T", CEP. 70.064-900, Brasília-DF, doravante denominado MJ, representado neste ato por seu titular, Ministro JOSÉ EDUARDO CARDOZO, CPF no 021.604.318-26, e com a interveniência tanto da SECRETARIA DE REFORMA DO JUDICIÁRIO, situada na Esplanada dos Ministérios, Bloco "T", sala 324, CEP. 70.064-900, Brasília-DF, neste ato representada pelo Secretário de Reforma do Judiciário Interino, Dr. MARCELO VIEIRA DE CAMPOS, CPF no 151.223.768-08, assim como da DEFENSORIA PÜBLICA DA UNIÃO, inscrita no CNPJ/CGC sob o n00.375.114/0001-16, com sede no Setor Bancário Sul, Quadra 01, Bloco H, Lote 26, Edifício Sede, Brasília-DF, CEP 70.070100, doravante denominada DPU, neste ato representada por seu titular, DEFENSOR PÚBLICOGERAL FEDERAL, HAMAN TABOSA DE MORAES E CÓRDOVA, CPF nº 762.813.611-72 -, o CONSELHO NACIONAL DE SECRETÁRIOS DE SAÚDE, inscrito no CNPJ/MF sob o nº 00.718.205/0001-07, situado no Setor de Autarquias Sul, Quadra 1, Bloco N, 14º andar, sala 1.404, Ed. Terra Brasilis, CEP. 70.070-010, Brasília-DF, doravante denominado CONASS, representado neste ato por sua Presidente, BEATRIZ FIGUEIREDO DOBASHI, CPF no 200.639.381-20, o CONSELHO NACIONAL DE SECRETÁRIOS MUNICIPAIS DE SAÚDE, inscrito no CNPJ/MF sob o n33484825-0001-88, situado na Esplanada dos Ministérios, Bloco G, Anexo B, sala 144, CEP. 70058900, Brasilia-DF, doravante denominado CONASEMS, representado neste ato por seu Presidente, ANTÔNIO CARLOS FIGUEIREDO NARDI, CPF no 061.827348-41, considerando o mútuo interesse das partes e, ademais,

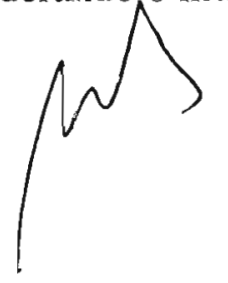


Considerando que a saúde é um direito fundamental do ser humano, albergado pela Declaração Universal dos Direitos Humanos e reconhecido pelo Estado brasileiro, o qual deve prover as condições indispensáveis ao seu pleno exercício;

Considerando que a proteção do direito à saúde está umbilicalmente ligada à observância do princípio da dignidade da pessoa humana;

Considerando a crescente judicialização das questões de saúde envolvendo o Sistema Único de Saúde (SUS) e o representativo dispêndio de recursos públicos decorrente dos processos judiciais;

Considerando a necessidade de se abrir um canal de discussões sobre as questões de saúde entre os diversos entes públicos envolvidos com as demandas judiciais;

Considerando "a importância de se abrirem espaços de consenso e de se construírem soluções compartilhadas, inclusive pela via administrativa." (Min. Gilmar Mendes no encerramento da Audiência Pública-Saúde);

Considerando as reiteradas reivindicações dos gestores para que sejam ouvidos antes da concessão de provimentos judiciais de urgência e a necessidade de se prestigiar sua capacidade gerencial, as políticas públicas existentes e a organização do Sistema Único de Saúde;

Considerando que é interesse público primário prestar um serviço de saúde pública de qualidade e eficiente à população;

Considerando o disposto na Portaria Interministerial $n^{\circ} 001 / 2010$, celebrada entre a Procuradoria-Geral da União e a Defensoria Pública da União, publicada no DOU, Seção 2, p. 46, do dia 22 de julho de 2010, que cria Grupo de Trabalho Interinstitucional a fim de estudar fórmulas que propiciem a expansão dos Comitês Interinstitucionais de Resolução Administrativa de Demandas da Saúde- CIRADS e dá outras providências; e

Considerando o Termo de Cooperação Técnica n 108/2009, celebrado entre o Conselho Nacional de Justiça, o Ministério da Saúde, o Tribunal de Contas da União, a Advocacia-Geral da União, o Conselho Federal da Ordem dos Advogados do Brasil, a Agência Nacional de Vigilância Sanitária, o Colégio dos Procuradores-Gerais dos Estados e do Distrito Federal, a Associação Nacional dos Defensores Públicos, o Conselho Nacional dos Secretários de Saúde e o Conselho Nacional de Secretarias Municipais de Saúde, que cria o compromisso de aperfeiçoamento do SUS em busca de racionalização de custos e diminuição de ações no âmbito da saúde,

RESOLVEM celebrar o presente ACORDO DE COOPERAÇÃO TÉCNICA, doravante denominado ACORDO, elaborado em conformidade com o art. 116 da Lei 8.666, de 21 de junho de 1993, e legislação correlata, nos termos das cláusulas e condições a seguir:

\section{CLÁUSULA PRIMEIRA - DO OBJETO}

O presente ACORDO tem por objeto o estabelecimento de parceria entre a AGU, o MS, o MJ, por intermédio da DPU e da Secretaria de Reforma do Judiciário, o CONASS e o CONASEMS, por meio de junção de esforços visando à redução do ajuizamento de demandas na área da saúde, com a busca de alternativas de resoluções de conflitos tanto judiciais, como extrajudiciais, que envolvem o Sistema Único de Saúde- SUS.

\section{CLÁUSULA SEGUNDA - DOS OBJETIVOS}

O principal objetivo deste ACORDO é a busca da conciliação administrativa, com a redução do número de demandas judiciais que envolvem o Sistema Único de Saúde. 
possível, dar:

Para a consecução desse objetivo, os participantes comprometem-se a, sempre que

I - primazia às políticas públicas já estabelecidas pelo SUS, buscando, antes do ajuizamento de demanda judicial, a resolução do conflito diretamente com os gestores locais do SUS; e

II - prevalência às formas de resolução administrativas de conflitos, fomentando iniciativas neste sentido, a exemplo do que já ocorre no Estado do Rio Grande do Norte, com o êxito na instalação do Comitê Interinstitucional de Resolução Administrativa de Demandas de Saúde CIRADS, premiado com a menção honrosa na VII Edição do Prêmio INNOVARE.

\section{CLÁUSULA TERCEIRA - DAS COMPETÊNCIAS DOS PARTICIPANTES}

Compete aos participantes, em conjunto e no âmbito de suas respectivas competências, a adoção das medidas administrativas e normativas necessárias à consecução dos objetivos do presente ACORDO, especialmente:

\section{I - À AGU:}

a) incentivar a implementação dos Comitês Interinstitucionais de Resolução Administrativa de Demandas de Saúde- CIRADS, pelo pais;

b) proceder à análise prévia dos casos submetidos a esses Comitês, sempre na busca de soluções administrativas para as demandas na área da saúde;

c) diligenciar, perante o Ministério da Saúde, no sentido de colher subsídios técnicos acerca dos casos concretos tratados, bem como informações gerais de interesse do CIRADS;

II - A DPU:

a) incentivar a implementação dos Comitês Interinstitucionais de Resolução Administrativa de Demandas de Saúde- CIRADS, pelo país;

b) proceder à análise prévia dos casos a serem submetidos ao CIRADS;

c) divulgar as ações do CIRADS no âmbito da DPU;

d) disponibilizar o acesso, através do envio de e-mail para os demais membros do CIRADS ou por outro sistema tecnológico desenvolvido para essa finalidade, a todos os elementos de fato e de direito colhidos no atendimento do assistido; e

e) envidar esforços no sentido de submeter ao CIRADS, previamente à judicialização, as demandas da saúde;

III - Ao MJ, por intermédio da Secretaria de Reforma do Judiciário:

a) promover a articulação e cooperação com os Poderes Executivos Estadual ou Municipal, e com as instituições que compõem o Poder Judiciário;

b) realizar estudos e diagnósticos sobre a judicialização do direito à saúde, e sobre mecanismos de resolução extrajudicial;

IV - Ao MS:

a) divulgar e fomentar a instalação dos Comitês Interinstitucionais de Resolução Administrativa de Demandas de Saúde- CIRADS pelo país;

b) prestar assistência técnica necessária ao esclarecimento de dúvidas surgidas;

c) implementar os compromissos de atendimento ao assistidos assumidos no âmbito do CIRADS;

d) promover a articulação e cooperação com o Executivo Estadual pu Municipal, no âmbito do SUS;

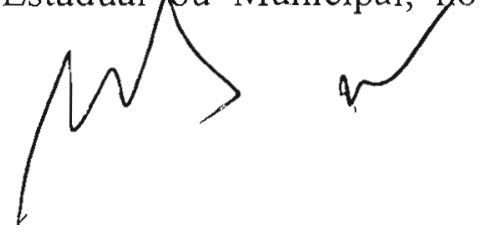


e) viabilizar a participação de pessoas ligadas à área da saúde que possam contribuir para os bons trabalhos dos Comitês;

V - Ao CONASS:

a) empreender esforços no sentido de divulgar e fomentar a instalação dos Comitês Interinstitucionais de Resolução Administrativa de Demandas de Saúde- CIRADS junto às Secretarias de Saúde dos Estados; e

\section{VI - AO CONASEMS:}

a) empreender esforços no sentido de divulgar e fomentar a instalação dos Comitês Interinstitucionais de Resolução Administrativa de Demandas de Saúde- CIRADS junto às Secretarias de Saúde dos Municípios.

\section{CLÁUSULA QUARTA - DOS RECURSOS}

Não haverá transferência voluntária de recursos entre os participantes para a execução do presente ACORDO. As despesas necessárias à plena consecução do objeto acordado, tais como: serviços de terceiro, pessoal, deslocamentos, comunicação entre os órgãos e outras que se fizerem necessárias, correrão por conta de dotações específicas constantes nos orçamentos de cada órgão.

\section{CLÁUSULA QUINTA - DA OPERACIONALIZAÇÃO}

O presente ACORDO deverá ser executado fielmente pelos Participantes, de acordo com as cláusulas pactuadas e a legislação pertinente, respondendo cada qual pelas consequências de sua inexecução ou execução parcial.

\section{CLÁUSULA SEXTA - DA ALTERAÇÃO, DA DENÚNCIA E DA RESCISÃO}

Este ACORDO poderá ser alterado, por mútuo consentimento, por meio de termo aditivo, exceto quanto ao seu objeto, ou denunciado por quaisquer dos Participantes, mediante notificação escrita prévia, com antecedência mínima de sessenta dias, ou rescindido por descumprimento de quaisquer de suas cláusulas ou por força de norma que o torne inexequível.

\section{CLÁUSULA SÉTIMA - DA VIGÊNCIA}

O ACORDO terá eficácia a partir da data de sua assinatura e vigência de 24 (vinte e quatro) meses, podendo ser prorrogado automaticamente, exceto se houver manifestação em contrário, nos termos da lei.

\section{CLÁUSULA OITAVA - DA PUBLICAÇÃO}

A AGU providenciará a publicação do extrato correspondente ao presente ACORDO no Diário Oficial da União, até o quinto dia útil do mês seguinte ao de sua assinatura, bem como o CONASS e o CONASEMS providenciarão a sua publicação nos respectivos meios de comunicação oficial. 


\section{CLÁUSULA NONA - DO FORO}

As questões decorrentes da execução deste ACORDO, que não possam ser resolvidas administrativamente, serão dirimidas originariamente pela Seção Judiciária do Distrito Federal.

Em assim sendo, por estarem acordados, os participantes firmam o presente ACORDO, redigido em 7 (sete) vias de igual teor e forma, para que surta seus efeitos jurídicos.

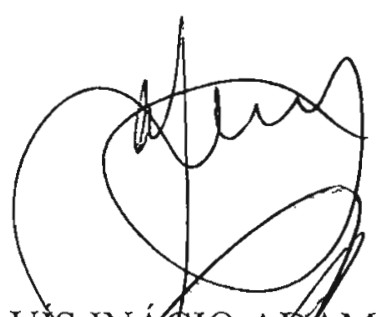

LUIS INÁLIO AWAMS

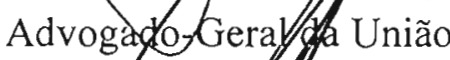

JOSÉ EDY YO OCARDOZO

Ministro questado da Justiça

Defensor Público-Geral Federal

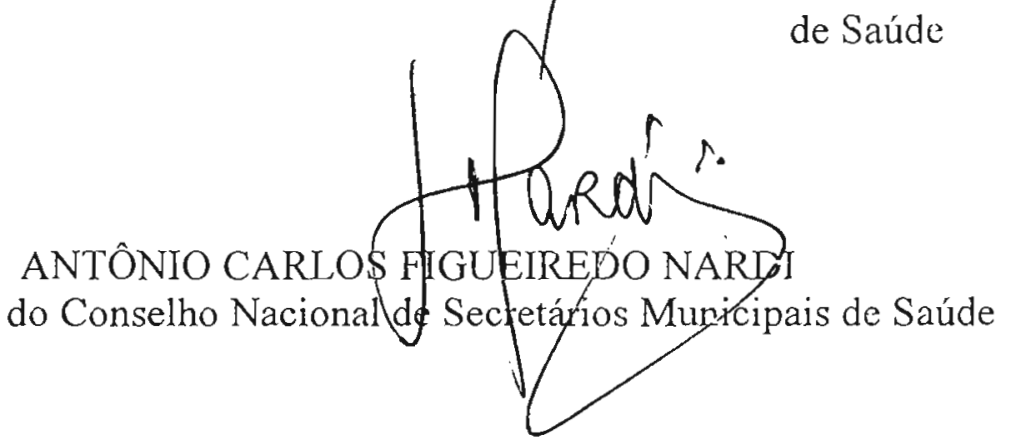
HAMAN TABOSA DE MORAES E CÓRDOVA
ANTÔNIO CARLOS FIGUEIRED́O NARDI

Presidente do Conselho Nacional de Secretários de Saúde
BEATRIZ FIGUEIREDO DOBASHI

ALEXANDRE ROCHA SANTOS PADILHA Ministro de Estado da Saúde

MARCDILO VIEIRA DE CAMPOS Secyelúrio de Reforma do Judiciário Interino

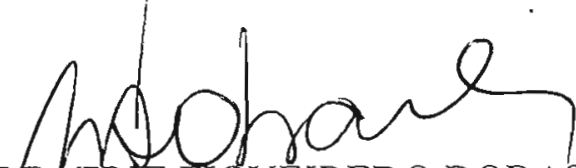
$T$ (

Presidente do Conselho Nacionald dy 